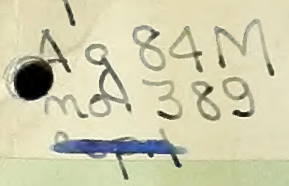

\title{
FOREST RESOURCES of the
}

Douglas-Fir

Region
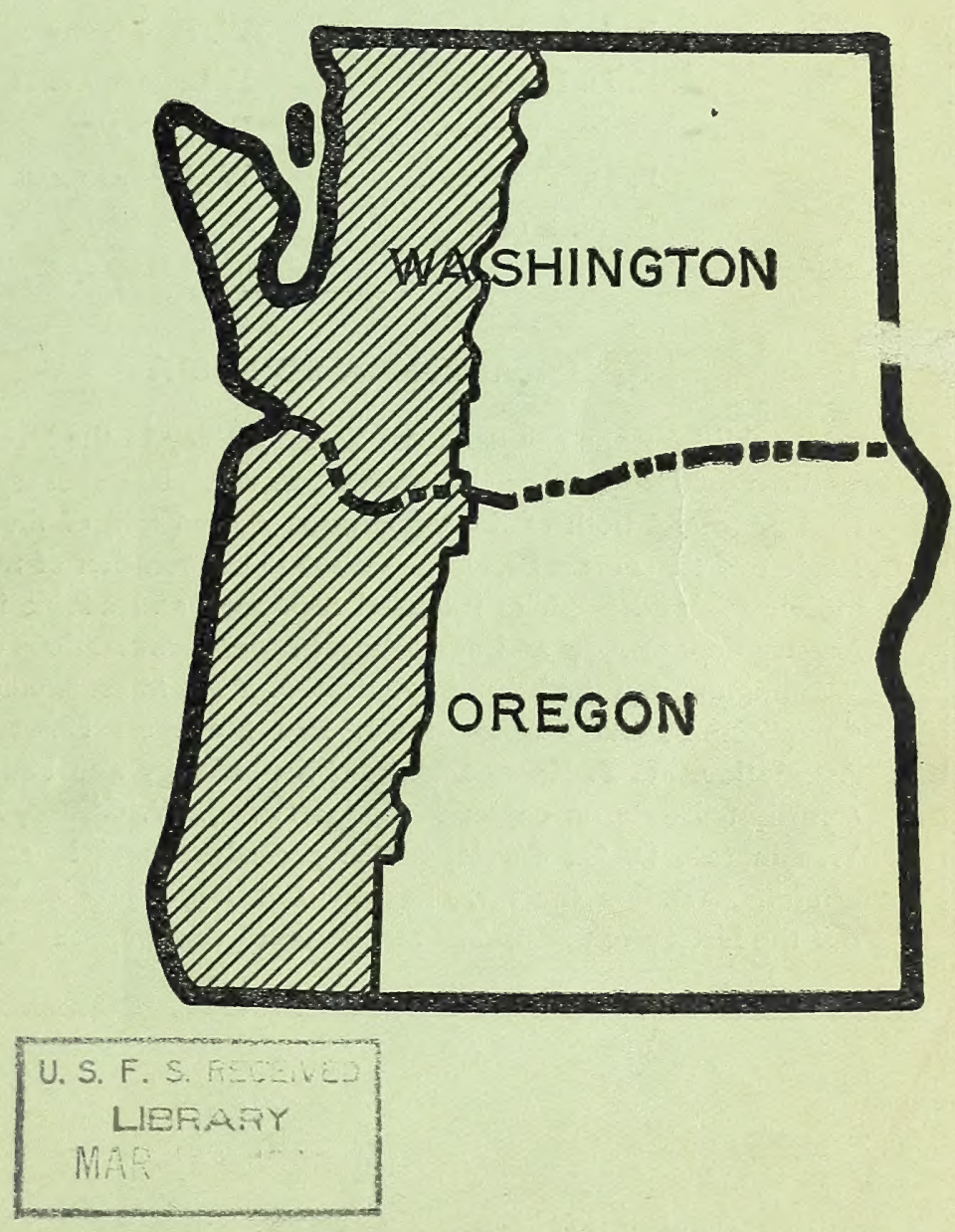

FOREST SERVICE

United States Department of Agriculture

Miscellaneous Publication No. 389 


\section{Historic, archived document}

Do not assume content reflects current scientific knowledge, policies, or practices. 
FOREST SURVEY STAFF

Pacific Northwest Forest Experiment Station

H. J. ANDREws, in charge 1930-38

R. W. Cowlin, in charge 1938-
W. H. Bolles
D. N. Matthews
P. A. Briegleb
W. H. MEYER
E. D. Buell
F. L. Moravets
H. M. Johnson
P. N. Pratt
P. D. KEMP
W. J. WAKEMAN
C. W. KLINE

\section{ACKNOWLEDGMENT}

In publishing the results of the Forest Survey in the Douglas-fir region credit must be given to the efficient service of temporary and assigned field personnel both of the experiment station and of the North Pacific Region of the Forest Service. Valuable cooperation of numerous other individuals and agencies included assistance and advice from the State forestry departments and agricultural experiment stations of Oregon and Washington, and the helpful cooperation of the forest protective organizations, commercial cruising firms, and the West Coast Lumbermen's Association. F. P. Keen, Bureau of Entomology and Plant Quarantine, contributed data on depletion by insects. J. W. Girard, Forest Service, Washington, D. C., developed the procedure used in adjusting timber cruises. As station director, Thornton T. Munger gave leadership throughout the history of the project and directed the preparation of the report. 
UNITED STATES DEPARTMENT OF A GRIGUTURE Miscellaneous publiCAtion No. 389 WAShington, D. C., DECEMBER I940

\title{
Forest Resources
}

\section{of the Douglas-Fir Region}

\author{
म2. एक \\ by H. J. ANDREWS and \\ R. W. COWLIN, senior forest economists \\ PACIFIC NORTHWEST FOREST AND RANGE EXPERIMENT STATION \\ FOREST SERVICE
}

UNITED STATES GOVERNMENT PRINTING OFFICE • WASHINGTON ・ I94

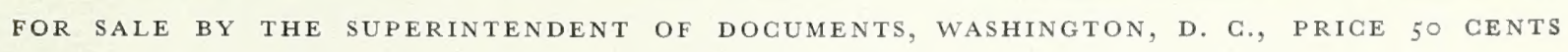




\section{The Forest Survey}

TFFECTIVE rehabilitation and constructive management of this country's forest resources require not only protection against neglect and destruction but, with equal urgency, provision for permanent and wise use. Intelligent forest land use planning must be based upon reliable facts as to location, area, and condition of existing and prospective forest land, supply of timber and other forest products, forest depletion and forest growth, and production and consumption of forest products. This necessity for dependable and comprehensive data is now being translated into action through the provisions of the McSweeney-McNary Forest Research Act of 1928, authorizing a Nationwide forest survey. The Forest Service was directed by the Secretary of Agriculture to conduct the survey.

The fivefold purpose of the Forest Survey is: (1) To make an inventory of the extent and condition of forest lands and of the present supply of timber and other forest products on these lands; (2) to ascertain the rate at which this supply is being increased through growth, and the potential growth on forest areas; (3) to determine the extent of depletion of the forests through cutting and through loss from fire, insects, disease, wind throw, and other causes; (4) to determine the present consumption and the probable future trend in requirements for timber and other forest products; and (5) to analyze and correlate these findings with other economic data, as an aid in the formulation of private and public policies for most effective and rational use of land suitable for forest production.

These investigations are conducted in each forest region of the United States by the regional forest experiment station of the Forest Service. In Oregon and Washington they are conducted by the Pacific Northwest Forest and Range Experiment Station, with headquarters at Portland, Oreg.

It is planned to publish the results of this investigation, as they become available, in a series of reports applying to large forest areas such as districts, regions, and States. It is expected that the information presented in these reports for large geographic units will facilitate more intensive studies of small areas. 


\section{Contents}

Survey findings in brief

The Douglas-fir region

Major phases of survey

Methods and specifications

specifications . . . . . . . . .

Standards of measurement . . . . 7

Species and size classification . . . 7

Type definitions and type mapping . 8

Nonforest types . . . . . . . . 8

Woodland types . . . . . . . 9

Timberland types . . . . . . 9

Miscellaneous types . . . . 10

Classifications . . . . . . . 10

Ownership classes . . . . 10

Other classifications . . . . . 11

Forest inventory. . . . . . . . 13

Types and areas . . . . . . . 14

Nonforest land . . . . . . 18

Conifer sawlog types. . . . . 19

Conifer types less than sawlog size . 22

Deforested lands . . . . . . 25

Woodland and noncommercial forests . . . . . . 26

Hardwood forests . . . . . 26

Forest site quality . . . . . 28

Timber volume . $\quad . \quad$. . . . . . 28

Saw-timber volume . . . . 29

Economic availability . . . . 35

Cubic volume . . . . . . 37

Ownership of forest resources . . . 38

Private ownership . . . . . 38

National-forest ownership . . . 38

State ownership . . . . . . 40

County ownership . . . . . 41

Municipal ownership . . . . 41

Indian ownership . . . . . 41

Revested grant lands. . . . . 41

Other Federal lands . . . . . 42

Depletion . . . . . . . . 43

Cutting depletion. . . . . . . 43

Sawlog production . . . . . 45
Depletion--Continued.

Cutting depletion-Continued.

Forest fuel wood . . . . . . 46

Forest pulpwood . . . . . . 47

Other minor timber products . . 49

Fire depletion . . . . . . . . 49

Depletion from other causes. . . . 51

Assumed future depletion . . . . 52

Forest growth . . . . . . . . . 54

Kinds of growth calculation made . . 55

Current annual growth . . . . . 56

Realizable mean annual growth. . . 58

Results of computation . . . . 58

Interpretation of results . . . . 60

Potential annual growth . . . . 60

Comparison of current, realizable, and potential growth . . . . 62

Trends in future forest increment . . 62

If present forest practice continues. $\quad 62$

If forest practice becomes more intensive . . . . . 63

If selective cutting is widely employed . . . . . . 64

Summary . . . . . . . . 65

Forest protection . . . . . . . 66

Protection on Federal lands . . . . 66

Protection on State, county, and private lands . . . . . 67

Future hazard conditions . . . . 68

Land use . . . . . . . . . 70

Agriculture . . . . . . . 70

Present use of land for agriculture.... . . . 70

Trends in agricultural land use . 72

Relation of agricuỉture to forests . 72

Forest land use . . . . . . . 74

Status of cut-over land . . . . . 74

Timber production . . . . 74

Production of commodities other than timber . . . . . 75 
Land use-Continued.

Status of cut-over land-Continued.

Soil and watershed protection . . 75

Recreation . . . . . . 76

Wildlife production and use. . . 77

Grazing . . . . . . 77

Forest problem areas . . . . 80

Forest industries . . . . . . . . 81

Conditions in the industries. . . 81

Development. . . . . . 81

Integration . . . . . . 82

Investments . . . . . . 82

Labor . . . . . . . 82

Production . . . . . . . 83

Markets . . . . . . . 83

Logging . . . . . . . 85

Types of organization . . . 85

Methods . . . . . . 86

Transportation . . . . . 87

Lumber manufacture . . . . . 88

Sawmills . . . . . 89

Transportation and markets . . 91

Sawmill byproducts . . . . . 92

Other wood-using industries. . . . 93

Pulp and paper manufacture . . 93

Shingle manufacture. . . . . 94

Veneer and plywood manufacture. $\quad 96$

Wood preserving. . . . . 96

Secondary wood-using industries . 96

Future timber supplies in relation to industrial development . . . . . 97

Major forest districts . . . . . . 97

Puget Sound district. . . . 98

Grays Harbor-Willapa Bay district. 99

Columbia River district . . . 99

Willamette River district . . . 100

Oregon coast district . . . 100

South Oregon district . . . . 100

Future depletion and inventories . . 101

Sawlogs . . . . . . . 104

Pulpwood . . . . . . 109

Plywood . . . . . . 112

Poles and piling . . . . . . 112

Fuel . . . . . . . 113

Hardwoods . . . . . 114

Forest-land management problems . . . 115

Uses of forest land other than for timber production . . . . . 115

Future agricultural expansion . . 115

Forage production . . . . 115

Recreation . . . . . 116
Forest-land management problems-Con.

Uses of forest land-Continued.

Wildiife . . . . . . . 119

Sustained-yield forest management . 119

Forest-land ownership . . . . . 122

Stable ownership essential to continuous-production management

Factors influencing liquidation of private ownership . . . . .

Areas favorable for private ownership

Current trend to county ownership .

Integration of public lands and policies desirable.

Public-acquisition programs

A regional forest program . . . . . 135

Future situation if present trends continue

136

Stabilizing forest-land ownership . . 136

Public acquisition of forest land . 137

Public regulation of forest-land use . 139

Methods of cutting . . . . 139

Slash disposal . . . . . . 139

Sustained yield . . . . . . 139

Restriction of cutting . . . . 139

Forest protection . . . . . . 139

Reforestation of denuded lands . . 140

Forest research. . . . . . 140

Forestry extension and forestry education. . . . 141

The public responsibility . . . 141

Management of public forest land . 141

Improvements . . . . . . 141

Legislation . . . . . 142

The private owners' responsibility . . 142

Control of overproduction . . . 142

Logging practice . . . . . 142

Utilization of minor species . . . 142

Manufacturing practice . . . . 142

Industrial expansion. . . . 143

Road development . . . . 143

Sustained-yield management . . 143

Conclusions . . . . . . . 144

Literature cited . . . . . . 145

Appendix . . . . . . . . 146

Inventory methods and sources. . . 146

Depletion-study methods and sources . 148

Periodic saw-timber growth . . . 150

Method of computing realizable mean annual growth. . . . . 150

Supplemental tables . . . . . 152 


\section{Survey Findings in Brief}

$\mathrm{T}$ HE highest service that forests of the Douglas-fir region can render is in support and stabilization of communities dependent on them. Included are, not only the people and investments in forest industries, but also those in farms, stores, banks, garages, schools, transportation, and various industries. Forests support in one way or another about half the population of the region. To redeem this enormous responsibility for service, forests must furnish a permanent annual harvest of material equal at least to present production. This will require sustained-yield forest practice, including acceptance of the responsibilities of permanent ownership.

The major problem therefore is to bring about promptly the adoption of a system of managing oldgrowth and second-growth forests for the continuous production of high-quality material while there is yet sufficient growing stock to do so without calamitous dislocation of people and industry.

A factual resume of the findings of the Forest Survey, as presented in detail in subsequent pages of this publication, is as follows: ${ }^{1}$

1. The forest is an integral part of the farm economy of the Douglas-fir region. Forests furnish fuel, fence posts, and other products essential to farm management and rural life. Forest products are important crops to many farmers. Forest industries afford part-time employment to many farmers and support, directly and indirectly, approximately half the population of the region.

2. The Douglas-fir region produces 30 percent of the lumber, 90 percent of the shingles, and 23 percent of the wood pulp produced in the United States, depending chiefly upon outside markets.

3. The major forest problem in the Douglas-fir region is the necessity for instituting a system of managing old-growth forests for continuous production. This means that clear cutting over vast areas, which has resulted in large areas of nonstocked cut-over land, must be halted.

4. The Douglas-fir region has 29 million acres of forest land, amounting to 82.6 percent of its total land area. Of this, 26.1 million acres, or 90 percent, was classified in the forest survey as commercial conifer.

5. Conifer types of saw-timber size occupy more than 14.5 million acres, of which 11.6 million is old growth and 2.9 million second growth. Second-growth conifer types less than saw-timber size occupy 7 million acres. Deforested burns, old nonrestocked cut-overs, and recent cut-overs total 4.4 million acres.

${ }^{1}$ Forest survey progress releases on the Douglas-fir region issued by the Pacific Northwest Forest and Range Experiment Station previous to the publication of this major report are: (1) Forest statistics in separate form for Clallam, Clark, Cowlitz, Grays Harbor, Island, Jefferson, King, Kitsap, Lewis, Mason, Pacific, Pierce, San Juan, Skagit, Skamania, Snohomish, Thurston, Wahkiakum, and Whatcom Counties, Wash., and for Benton, Clackamas, Clatsop, Columbia, Coos, Curry, Douglas, Hood River, Jackson, Josephine, Lane, Lincoln, Linn, Marion, Multnomah, Polk, Tillamook, Washington, and Yamhill Counties, Oregon. 1934. [Mimeographed.] (2) Forest Resources of the Douglas-Fir Region. Forest Res. Notes No. 13.1934. [Mimeographed.] (3) Pulpwood Resources of Western Oregon and Western Washington. Forest Res. Notes No. 17. 1935. [Mimeographed.] (4) Forest Growth in the Douglas-Fir Region. Forest Res. Notes No. 20. 1936. [Mimeographed.] (5) Timber Volume and Type Acreage on the National Forests of the North Pacific Region. Forest Res. Notes No. 22. 1937. [Mimeographed.] (6) Detailed forest type maps of each of the above listed 38 counties. Scale 1 inch equals 1 mile. Blue line print form. 1934. (7) State type maps-Douglas-fir region covered by four sheets, NW Washington, SW Washington, NW Oregon, SW Oregon. Scale $1 / 4$ inch $=1$ mile. 1936. [Lithographed.] The Pacific Northwest Station has also cooperated with the State of Washington in the following recent publication: Cowlin, R. M., and Morets, F. L., FOREsT resources of Washington. Wash. Dept. of Conserv. and Development, Olympia. 44 pp., illus. 
6. More than 3 million acres of forest land in the Douglas-fir region was cut over prior to 1920 and in 1933 had not been put to other use; of this total, in 1933, 28 percent was well stocked with second-growth trees, 36 percent was medium stocked, 15 percent was poorly stocked, and 21 percent was nonstocked. In the period 1920-33 more than 2 million acres was cut over, of which at the end of the period 12 percent was well stocked with reproduction, 17 percent was medium stocked, 29 percent was poorly stocked, and 42 percent was nonstocked. Of the total area of cut-over land in the region, 50 percent is satisfactorily restocked and 50 percent is either nonstocked or only poorly stocked.

7. The region's saw-timber stand totals 546 billion board feet, log scale, all but 4 billion of which is conifers. Douglas-fir, the leading species, totals 331 billion feet, and is followed by western hemlock with 105 billion board, feet. Other important species are western redcedar, Sitka spruce, and silver fir.

8. It was estimated that only a little more than half the saw-timber volume could profitably be logged under the conditions that prevailed during the period 1925-29.

9. The regional total of cubic volume in trees 6 inches and larger in breast-height diameter is 129 billion cubic feet; species eminently suitable for pulp manufacture make up 39 billion cubic feet, or 30 percent.

10. More than 53 percent of the commercial forest land and approximately 48 percent of the saw-timber volume in the Douglas-fir region are privately owned, and 30 percent of the commercial forest land and 37 percent of the saw-timber volume are within the national forests. The remaining 17 percent of the land and 15 percent of the volume are in other forms of public ownership or owned by Indians.

11. Current annual depletion of saw timber from all causes is estimated to total about 8.3 billion board feet, of which 7.9 billion board feet is cutting depletion.

12. Sawlog production in the Douglas-fir region during 1925-33 averaged 7.4 billion board feet, of which 5.4 billion feet was Douglas-fir, 1 billion feet western hemlock, 0.6 billion feet western redcedar, 0.3 Sitka spruce, and 0.1 billion other species.

13. Current losses of saw timber by fire, excluding catastrophes such as the Tillamook fire of 1933 , amount to a quarter of a billion board feet annually. The area burned over annually averages more than 250,000 acres, including large areas of second growth. Killing of second growth seriously endangers future saw-timber supplies.

14. Current annual growth in the Douglas-fir region totals approximately 2.4 billion board feet. Potential annual growth under intensive forest practice is approximately 8.2 billion board feet.

15. The supply of old-growth Douglas-fir within economically feasible transportation distance of the Puget Sound and Grays Harbor districts will be practically exhausted within two decades if the present rate of depletion continues.

16. The supply of pulp timber is sufficient to maintain the existing rate of wood-pulp production indefinitely if reasonable forest practice is observed and if the volume of pulp species used in lumber manufacture is not increased.

17. In order to stabilize economic life in this region sustained-yield forest management should be instituted as soon as possible. The ultimate sustained-yield capacity of the region under reasonably intensive forest management is estimated at 8 billion board feet per year; during the transition period, under optimum conditions, a cut of about $61 / 2$ billion per year is allowable.

18. In the Puget Sound, Grays Harbor, and Columbia River districts the annual cuts allowable under a sustained-yield budget were exceeded during 1933, a year of comparatively low production. Progressive overcutting of the southern districts will bring about conditions similar to those in the north.

19. Most of the forest land that should be used for continuous production could, through concerted action by industry and government, be put under sustained-yield management within 25 to 50 years.

20. With an enlarging acreage of cut-over land and a growing use of the forests by the public for recreation, the Douglas-fir region is facing an increasingly difficult problem of forest-fire protection. 


\section{The Douglas-Fir Region}

the stand, western hemlock and other species in-

$\mathrm{T}$

HE Douglas-fir region, which includes those parts of Oregon and Washington west of the summit of the Cascade Range, was selected as the place to begin the Nation-wide forest survey (fig. 2). Extending 480 miles from north to south and varying in width from 100 to about 150 miles, this region has an area of more than 35 million acres, of which 29 million acres, or 83 percent, is forest land. Its long littoral exposure subjects most of it to humid westerly winds; its climate is characterized by equable temperatures, except in the high mountains, and moderate to heavy precipitation. Climatic conditions are particularly favorable to conifer forest growth, and the region is noted for the luxuriance and density of its forest vegetation

The forests of this region are almost exclusively conifer, and Douglas-fir (Pseudotsuga taxifolia) is the. predominating tree, forming 60 percent or more of the stand on more than half the forest land (fig. 1). Important species commonly associated with Douglas-fir are western hemlock (T suga heterophylla), western redcedar (Thuja plicata), Sitka spruce (Picea sitchensis), Pacific silver fir (Abies amabilis), and noble fir (A. nobilis). Exceptions to the predominance of Douglas-fir are found in the forests on the cool, humid western slopes of the Coast Ranges and the Olympic Mountains known as the fog belt, where western hemlock and Sitka spruce are the outstanding species and Douglas-fir is occasionally entirely lacking. Again, on the higher slopes of the Cascade Range and the Olympic Mountains and occasionally on those of the Coast Ranges, the stands are made up principally of western hemlock, Pacific silver fir, noble fir, mountain hemlock (Tsuga mertensiana), and western white pine (Pinus monticola). Latitudinally also, toward the cooler, northern extreme of the regicn, Douglas-fir forms a smaller percentage of creasing in frequency; and on the dry exposures of the interior valleys and foothills of southern Oregon, Douglas-fir gives way to ponderosa pine ( $P$. ponderosa).

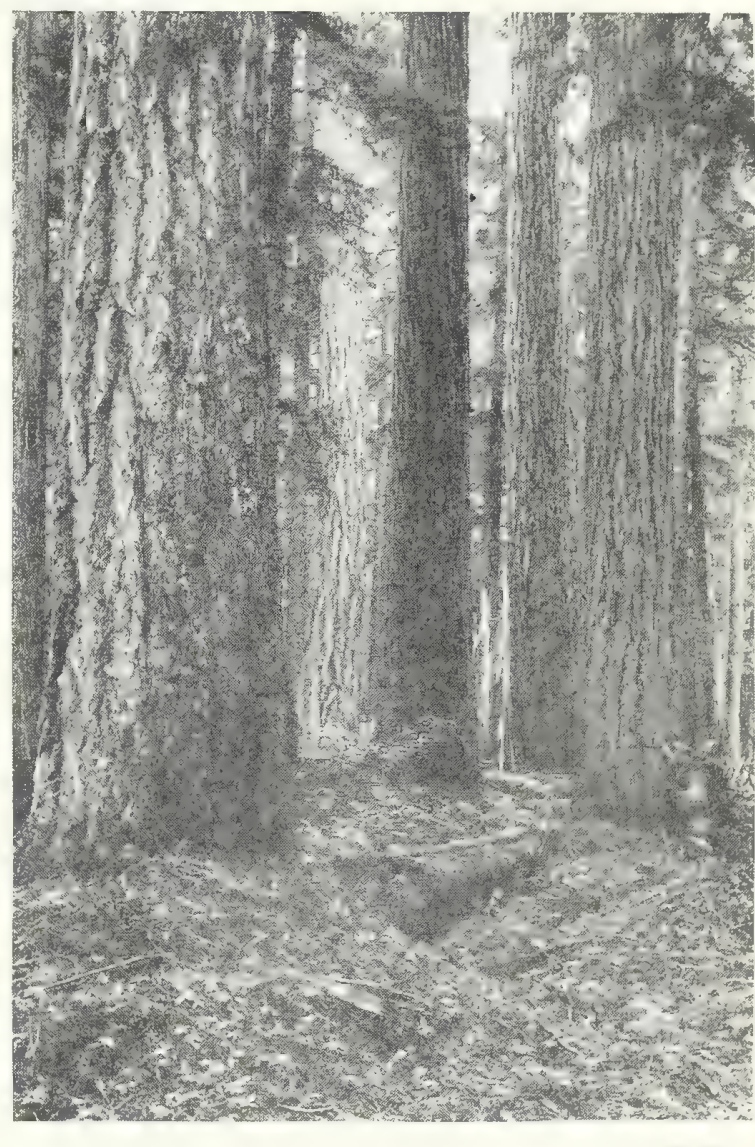

F 325601

Figure 1.-Saw-timber stand of old-grozeth Douglas-fir near the Columbia River in western Washington averaging more than 40 inches in diameter and having a gross volume of about 125,000 board feet per acre. The trees in the picture measure from 5 to 6 feet in diameter. 


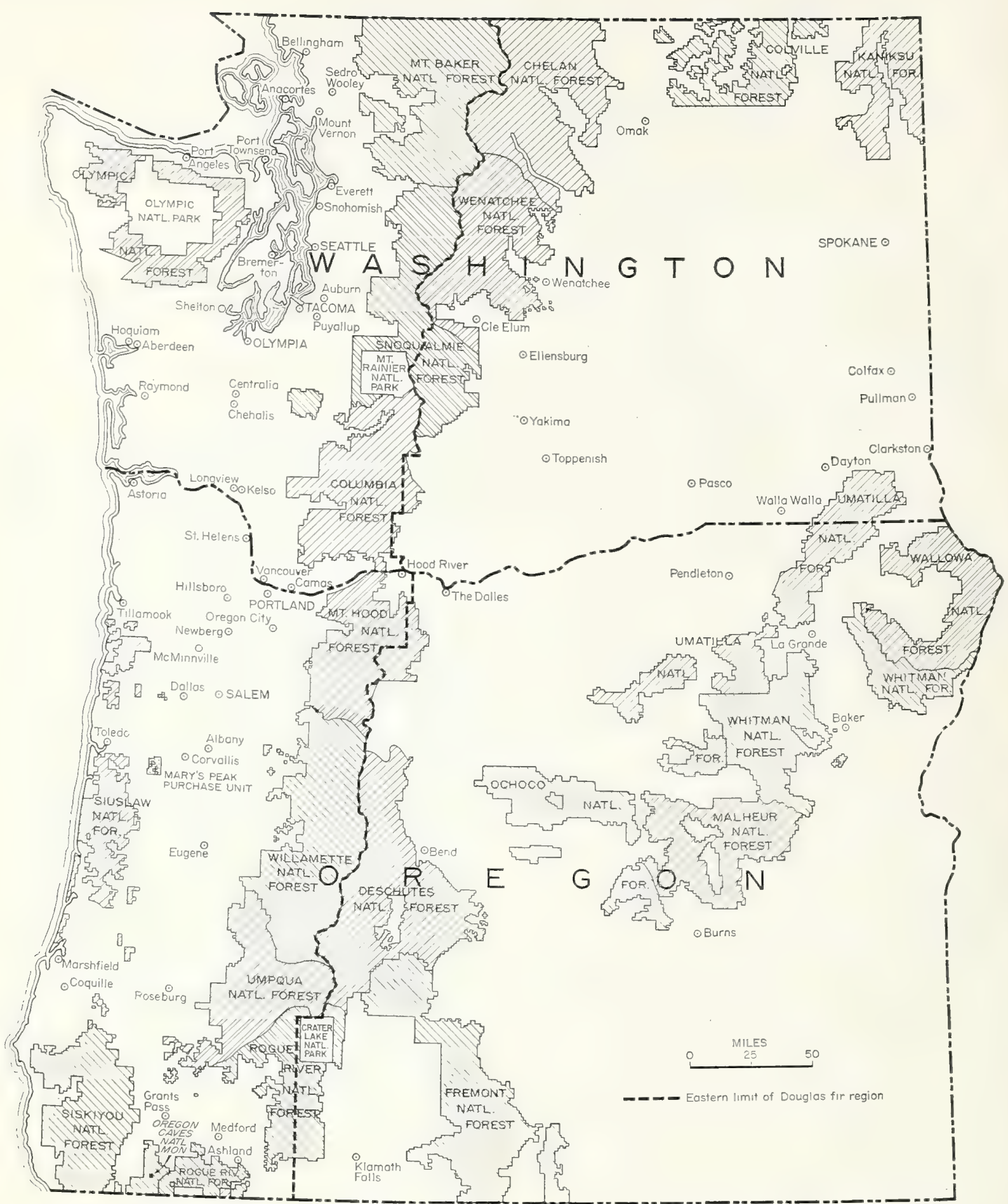

FIGURE 2.-Map of Oregon and Washington showing Douglas-fir region, national forests, parks, monuments, and principal cities 


\section{Major Phases of Survey}

in-

$\mathrm{T}$ HE major phases of the Douglas-fir survey were four - the inventory phase, the study of forest depletion, estimates of forest growth, and a determination of present and future timber requirements. An analysis of this information for the purpose of developing principles and policies to make the forests contribute most in services regionally and nationally leads inevitably into a consideration of land use planning, future supplies of timber in relation to industrial development and requirements, and forest management. Although the requirements phase is discussed here only for the region, the subject is much broader than this; it is planned to integrate it with similar information from other regions for publication later as a report on forest-products requirements for the whole country.

The inventory phase of the forest survey was undertaken first in the spring of 1930. Its principal purposes were to obtain:

1. Volume of the present timber stands, by species and by ownership class.

2. Areas of the several types, by ownership class.

3. Areas of the immature-conifer types by age class and degree of stocking.

4. Maps showing location of each of the forest types.

5. A classification of timber stands according to economic availability for logging.

6. A classification of forest area according to site quality.

The existence of considerable information, particularly on the merchantable timber areas which comprise about half of the 29 million acres in the Douglas-fir region, made it practicable to rely on checking and compiling the information already available from public or private cruises, maps, and reports. This was supplemented with field examinations of all remaining areas.
The work of the inventory phase was conducted in four steps: (1) Collection of all existing information, (2) checking and adjusting to a common standard all usable existing timber estimates, (3) field examination of areas not covered by usable information, (4) compilation of data collected. ${ }^{2}$

The immediate object of the depletion phase of the forest survey was to determine the quantity and kind of timber annually removed by cutting or killed by fire, wind throw, insects, disease, and all other causes; in short, the extent and character of the drain on the forest capital. The ultimate object was to obtain data needed for an analysis that would determine the trends of depletion and growth, present and potential, and the net result of the two trends.

Depletion as considered in this study does not include ordinary endemic losses due to such causes as diseases, surface fires, wind throw, and insects. Such normal losses have been allowed for in the construction of the yield tables used in calculating growth. Depletion as here considered involves only timber killed or removed by logging, by fires that kill entire stands, by windstorms of major intensity, and by insect epidemics.

To estimate the rate and quantity of current and potential growth in the forests of this region would be simple if rates of growth were constant for all conditions. Instead, they vary among individual trees according to species, age, and dominance; among individual forest stands according to type, site, average age, and stocking; and among aggregates of stands according to the growth character-

2 The organization of the field work and the detailed procedure involved in each of these four steps are described in the Appendix, p. 146. 
istics of individual stands. Stands more than 160 years of age were considered as a whole to have no present net growth. Although some stands above this age are increasing in merchantable volume, others are actually losing in merchantable volume; thus in these older stands losses due to mortality and to decay approximately balance growth. Stands not more than 160 years of age were classed as growing stands. For all these stands growth computations were made.

Four conceptions of rate of growth were considered: Current annual growth, realizable mean annual growth, potential annual growth, and periodic growth. These terms as used in this report are defined as follows:

Current annual growth is the volume increase that took place in 1933.

Realizable mean annual growth is (1) mean annual growth from 1933 to 2032 of existing stands, or to dates earlier than 2032 for those areas which it is assumed will be depleted before that date, plus (2) mean annual growth on portions of areas now deforested or to be deforested that presumably will restock before 1952. These calculations were made for each of the three decades from 1933 to 1962.

Potential annual growth is the average quantity of timber that can be grown annually if all the commercial conifer forest land produces 75 percent of full capacity.

Periodic growth is growth within a given periodin this study, 10 years. It was estimated for each of the three decades from 1933 to 1962 . On the basis of these estimates and of assumptions as to future depletion, future inventories at 10-year intervals during that period were estimated.

The requirements phase of the forest survey consisted of a determination of present and prospective requirements for wood products of the Douglasfir region. Estimates of the quantities of these products needed in the future cannot be made solely on the basis of needs within the region. Interchange of products between regions necessitates determination of future requirements on a national basis.

Obviously, this region with its enormous forest resources and comparatively sparse population can supply its requirements for practically all kinds of forest products indefinitely. The only wood products consumed in this region that must be imported are small amounts of hardwood material such as flooring and interior finish, and articles manufactured of woods not grown in this region, such as certain kinds of furniture and implement handles. The principal sources of these items are eastern and southern United States, the Philippine Islands, South America, and Central America. 


\section{Methods and Specifications}

\section{Standards of Measurement}

I T WAS necessary to fix standards of measurement of the volume of standing timber, so that estimates would be stable and could be correlated with estimates for other regions and adjusted to meet changing economic conditions. Standards were defined that conformed as far as practical with generally accepted concepts of utilization practices appropriate to current conditions. Inventory, growth, and depletion data are given in board feet, log scale in the body of this report. Lumber-tally equivalents are found in the appendix.

Timber-volume estimates were made in board feet, $\log$ scale, according to the Scribner Decimal $\mathrm{C}$ rule, and in cubic feet. The board-foot estimates included only the stems of living trees that would make at least one log meeting the following specifications: Conifers other than ponderosa pine and sugar pine, 32 feet long, 12 inches in diameter inside bark at the small end; ponderosa pine and sugar pine, 16 feet long, 10 inches in diameter inside bark at the small end; hardwoods, 8 feet long, 10 inches in diameter inside bark at the small end. Practically, this amounts to making the minimum specification for conifers other than these two pines the 16-inch diameter class ( 15.1 to 17.0 inches d. b. h. $)^{3}$ and that for ponderosa pine, sugar pine, and hardwoods the 12-inch diameter class (11.1 to 13.0 inches d. b. h.)

Allowance was made in the volume estimates for decay, defects, and such breakage as is inevitable in logging. In other words, the estimates are for the net volume usable in saw-timber operations under good utilization practices.

${ }^{3}$ "D. b. h." signifies diameter at breast height ( $41 / 2$ feet above average ground level) outside bark.
Probably the standards of utilization employed in the survey estimates are slightly more intensive for the more valuable species, and considerably so for the less valuable species, than the average utilization standards of present-day saw-timber operators, owing chiefly to the inclusion of trees as small as the 16-inch diameter class.

Cubic-foot volume was computed for the sound wood of stems only, from stump to 4-inch tip inside bark, limb wood and bark excluded, of all trees of or above the 6 -inch (5.1 to 7.0 inches) diameter class.

The estimates cover all timber areas, including farm woods, outside the platted limits of municipalities.

In order to obtain satisfactory estimates of volume of standing timber it was necessary to have for each of the commercial saw-timber species an accurate volume table that could be applied throughout the region. Investigation and check of the existing tables showed that some of them could be used as they were and others could be made usable by adjustment and extension to include larger trees, but that for some species new tables would have to be made. Volume tables used for the principal species are described in the appendix.

\section{Species and Tree-Size Classification}

An estimate of total volume of living timber was made and recorded separately for every species that usually attains saw-timber size and character and that was present in commercial types in quantity measurable according to survey standards. Also, an estimate of total volume of dead timber was made and recorded for Port Orford white-cedar (Chamaecyparis lawsoniana), western redcedar, and Alaska yellow-cedar (C. nootkatensis). (Owing to their durability and resistance to decay, dead trees 
of these species have commercial value and are logged.) In some cases, separate estimates were made for certain size and age classes of timber of a single species; in some, estimates were combined for pairs of species having similar dendrological and structural characteristics.

Species that usually do not attain saw-timber size in the Douglas-fir region include Pacific yew (Taxus brevifolia) and some hardwoods.

Table 1 lists the species (27), ${ }^{4}$ classes, and diameter ranges for which volume was recorded, with the symbols adopted for convenience in referring to them. As applied to Douglas-fir here and elsewhere in this report, "old growth" and "second growth" are relative terms distinguishing between the older timber and the younger, more rapid-growing timber. Likewise, "large" and "small" are used here as relative terms distinguishing between larger and smaller timber of a given type or species.

\section{Type Definitions and Type Mapping}

In primitive forests of the Douglas-fir region certain fairly definite major species associations and innumerable minor associations may be observed. Fire, cutting, and land settlement have added to the complexity of forest-cover conditions, and consequently to the difficulty of defining types. Each forest type recognized in this survey had to have some significance in forest management. Types had to be within practical limits in number, and type definitions had to be such that types could be determined from office records, such as timber cruises, and could easily be recognized in the field and indicated on field maps. A type scheme that had already been adopted by the Forest Service for intensive surveys partly fulfilled the requirements. On this foundation a scheme was finally evolved that stood the test of 4 years' field use with few changes.

The forest-cover and land-use types recognized in the forest survey of the Douglas-fir region ${ }^{5}$ follow:

\section{Nonforest Types}

No. 2. Nonforest land other than agricultural, including (1) barren areas too rocky, deficient in soil, or exposed to support a cover of either trees,

\footnotetext{
4 Italic numbers in parentheses refer to Literature Cited, p. 145.

${ }^{5}$ Numbers preceding types relate to series of types listed for the entire Northwest.
}

TABLE 1.- Species and diameter classes for which volume was recorded

CONIFERS

\begin{tabular}{|c|c|c|}
\hline Name and class & Symbol & $\begin{array}{c}\text { Breast- } \\
\text { height } \\
\text { diameter } \\
\text { range }\end{array}$ \\
\hline $\begin{array}{l}\text { Douglas-fir (Pseudotsuga taxifolia): } \\
\text { Large old growth }\end{array}$ & DA & $\begin{array}{l}\text { Inches } \\
40+\end{array}$ \\
\hline Small old growth & $\mathrm{DB}$ & $22-40$ \\
\hline Large second growth & $\mathrm{DC}$ & $22-40$ \\
\hline \multirow{2}{*}{\multicolumn{3}{|c|}{ Sitka spruce (Picea sitchensis): }} \\
\hline & & \\
\hline Large & $\mathrm{SA}$ & $24+$ \\
\hline Small .. & SB & $16-24$ \\
\hline Engelmann spruce $(P \text {. engelmannii })_{\ldots} \ldots$ & ES & $16+$ \\
\hline \multicolumn{3}{|l|}{ Western hemlock (Tsuga heterophylla): } \\
\hline Large & $\mathrm{HA}$ & $20+$ \\
\hline Small $\ldots . . .$. & НВ & $16-20$ \\
\hline Mountain hemlock ( $T$. mertensiana) & $\mathrm{MH}$ & $16+$ \\
\hline \multicolumn{3}{|l|}{ Western redcedar (Thuja plicata): } \\
\hline Live__... & $\mathrm{C}$ & $16+$ \\
\hline Dead & $\mathrm{KC}$ & $16+$ \\
\hline \multicolumn{3}{|l|}{$\begin{array}{l}\text { Port Orford white-cedar (Chamaecyparis lawsoni- } \\
\text { ana): }\end{array}$} \\
\hline Live & $\mathrm{PC}$ & $16+$ \\
\hline Dead & KPC & $16+$ \\
\hline \multicolumn{3}{|l|}{ Alaska yellow-cedar (C. nootkatensis): } \\
\hline California incense-cedar (Libocedrus decurrens) & IC & $16+$ \\
\hline \multicolumn{3}{|l|}{$\begin{array}{l}\text { Ponderosa pine (Pinus ponderosa) and Jeffrey } \\
\text { pine }(P \text {. jeffreyi): }\end{array}$} \\
\hline Large & YA & $22+$ \\
\hline Small... & YB & $12-22$ \\
\hline Sugar pine ( $P$. lambertiana) & sP & $12+$ \\
\hline $\begin{array}{l}\text { Western white pine }(P \text {. monticola }) \text { and whitebark } \\
\text { pine }(P \text {. albicaulis })\end{array}$ & $\mathrm{W}$ & $16+$ \\
\hline $\begin{array}{l}\text { Lodgepole pine ( } P \text {. contorta latifolia }) \text {, shore pine } \\
(P \text {. contorta }) \text {, and knobcone pine }(P \text {. attenuata })\end{array}$ & LP & $16+$ \\
\hline $\begin{array}{l}\text { White fir (Abies concolor) and grand fir ( } A \text {. } \\
\text { grandis) }\end{array}$ & WF & $16+$ \\
\hline $\begin{array}{l}\text { Noble fir }(A . \text { nobilis }) \text { and Shasta red fir }(A, \text { mag- } \\
\text { nifica shastensis })\end{array}$ & NF & $16+$ \\
\hline Pacific silver fir (A. amabilis) & A & $16+$ \\
\hline Alpine fir (A. lasiocarpa) & $\mathrm{AF}$ & $16+$ \\
\hline $\begin{array}{l}\text { Western larch (Larix occidentalis) and alpine lareh } \\
(\text { L. lyallii) }\end{array}$ & WL & $16+$ \\
\hline Redwood (Sequoia sempervirens) & $\mathrm{R}$ & $16+$ \\
\hline
\end{tabular}

BROADLEAF TREES

\begin{tabular}{l|c|c} 
Red alder (Alnus rubra) & RA & $12+$ \\
Oregon white oak (Quercus garryana) & OO & $12+$ \\
Canyon live oak (Q. chrysolepis) & CLO & $12+$ \\
California black oak (Q. kelloggii) & CO & $12+$ \\
Tanoak (Lithocarpus densifora) & TO & $12+$ \\
Northern black cottonwood (Populus trichocarpa & & \\
hastata) and quaking aspen (P. tremuloides) & BC & $12+$ \\
Bigleaf maple (Acer macrophyllum) & OM & $12+$ \\
Pacific madrone (Arbutus menziesii) & MAD & $12+$ \\
Oregon ash (Fraxinus oregona) & ASH & $12+$ \\
California laurel (Umbellularia californica) & $12+$ \\
Golden chinquapin (Castanopsis chrysophylla) & CH & $12+$ \\
Western paper birch (Betula papyrifera occiden- & & \\
talis) and northwestern paper birch (B. papyri- & & \\
fera subcordata) &
\end{tabular} 
shrubs, or herbs; (2) grass, sagebrush, and brush areas on which the principal present vegetation is either grass, herbs, brush, shrubs, or sagebrush; and (3) cities, towns, and unmeandered water surfaces. ${ }^{6}$ No. 3. Agricultural land, including (1) areas cleared or cultivated for agricultural use, including pasture; and (2) stump pasture, logged-off or burned-off land from which stumps or snags have not been removed, now part of an operating farm unit and devoted chiefly to grazing. Usually, on such an area some attempt has been made to propagate forage plants by seeding or repeated burning.

\section{Woodland Types}

No. 4. Oak-madrone woodland, consisting of approximately 60 percent or more of any species of oaks (including tanoak) or madrone or any combination of these.

No. 53 2. Ponderosa pine woodland, in which ponderosa pine predominates and on which the trees are scattered, singly or in clumps, and form a very thin stand. Individual trees may or may not be of merchantable size and form.

\section{Timberland Types}

Nos. 6, 7, 8, 9, and 10. Douglas fir: A forest containing approximately 60 percent or more, by volume, of Douglas fir - the characteristic forest west of the summit of the Cascade Range. The five Douglas-fir types, differentiated by the sizes into which most of the volume falls, are (6) large old growth, 42 inches d. b. h. and more; (7) small old growth, 22 to 40 inches; (8) large second growth, 22 to 40 inches (coarse-grained timber yielding only a small percentage of the upper grades of lumber); (9) small second growth, 6 to 20 inches; (10) seedlings and saplings, mostly less than 6 inches.

Nos. 11, 12, and 13. Sitka spruce: A forest containing 50 percent or more, by volume, of Sitka spruce, rarely in pure stands, usually in mixture with Douglas-fir, western hemlock, and western redcedar. The three Sitka spruce types are (11) large, 26 inches d. b. h. and more; (12) small, 6 to 24 inches; (13) seedlings and saplings, mostly less than 6 inches.

Nos. 14, 15, and 16. Western hemlock: A forest containing 50 percent or more, by volume, of

${ }^{6}$ Bodies of water that have not been surveyed by the General Land Office and that consequently are included in the official totals of land area. western hemlock with varying quantities of Douglasfir, western redcedar, Pacific silver fir, and Sitka spruce. The three western hemlock types are (14) large, 20 inches d. b. h. and more; (15) small, 6 to 20 inches; (16) seedlings and saplings, mostly less than 6 inches.

No. 17. Western redcedar, large: A forest containing approximately 40 percent or more, by volume, of western redcedar, in which most of the volume is in trees more than 24 inches d. b. h.

No. 18. Port Orford white-cedar, large: A forest in which 20 percent or more of the volume is in Port Orford white-cedar trees more than 30 inches d. b. h., with varying quantities of Douglas-fir white fir, western redcedar, western hemlock, Sitka spruce, and hardwoods.

No. 19. "Cedar," small: A forest in which western redcedar 24 inches or less in d. b. h. or Port Orford white-cedar 30 inches d. b. h. or less, or both, compose 40 percent or more, by volume, of the dominant stand, with some or considerable quantities of western hemlock, Sitka spruce, or Douglas-fir, or of two or all three of these species.

Nos. 20, 20A, 21, and 22. Ponderosa and sugar pine. The four types are (20) large ponderosa pine, in which the predominating trees are the so-called yellow pine, about 22 inches d. b. h. or more (about 150 or 200 years old or older), in which no material part of the stand has been cut; (20A) large sugar pine, containing 20 percent or more, by volume of sugar pine, never in pure stands, usually in mixture with Douglas-fir, ponderosa pine, or white fir, in which most of the volume is in trees 22 inches d. b. h. or more. (This type was mapped only outside the boundaries of national forests.) (21) Small ponderosa pine in which most of the trees are less than about 22 inches in diameter (less than 150 or 200 years old), either on an old burn or on an area that has been selectively cut, and in which the volume in trees 12 inches d. b. h. or more is ordinarily at least 1,000 board feet per acre; (22) ponderosa pine seedlings, saplings, and poles, on an old burn or on heavily cut-over land, most of the trees being less than 12 inches d. b. h. and the stand of larger trees, if any, amounting to less than 1,000 board feet of saw timber per acre,

Nos. 23 and 24. Fir-mountain hemlock: The two fir-mountain hemlock types are (23) large, in which most of the dominant trees are 16 inches 
d. b. h. or more and of saw-timber character (mature stands not of this character are ordinarily included in the subalpine type); (24) small, most dominants less than 16 inches d. b. h., usually a young stand on an old burn.

Nos. 25 and 26. Lodgepole pine: A forest containing at least 50 percent, by volume, of lodgepole pine or knobcone pine, often pure. The two types are determined by the size of 50 percent or more of the dominant trees: (25) Large, 12 inches d. b. h. and more; (26) small, less than 12 inches.

Nos. 27 and 28. White fir-larch-Douglas-fir: A mixed forest of greatly varied composition, consisting of two or more of the five species western larch, white fir, Douglas-fir, ponderosa pine, and lodgepole pine, in which ponderosa pine constitutes not more than 40 percent of the stand; limited to the range of western larch and prevalent on north and other cool slopes within the ponderosa pine zone. The two types are determined by the size of the trees representing most of the volume: (27) Large, 20 inches d. b. h. and more; (28) small, less than 20 inches.

Nos. 29 and 30. White fir: Usually a mixed forest within the range of ponderosa pine and sugar pine, containing 50 percent or more, by volume, of grand fir or white fir. The two types are determined by the size of most of the dominant trees: (29) Large, more than 20 inches d. b. h. or 150 years in age; (30) small, less than 20 inches or 150 years.

No. 31. Hardwood: A hardwood forest, either pure or mixed, consisting predominately of one or more species other than oaks or madrone.

No. 32. Redwood: A forest containing approximately 80 percent or more, by volume, of redwood, usually with some Douglas-fir and some Pacific madrone, tanoak, and other hardwoods.

No. 33. Subalpine: A forest at the upper limits of tree growth, usually unmerchantable because of poor form and small size, the principal components being alpine fir, mountain hemlock, Shasta red fir, lodgepole pine, whitebark pine, western white pine, and alpine larch.

\section{Miscellaneous Types}

No. 34. This number was used as a prefix to type numbers to denote areas clean cut prior to 1920 or selectively cut at any time.
No. 35. Nonrestocked cut-over: An area cleancut prior to 1920 on which less than 10 percent of the 13.2-foot squares are stocked, not put to other than forest use.

No. 36. Recent cut-over: An area clean-cut since the beginning of 1920, regardless of the status of regeneration.

No. 37. Deforested burn: Land not cut over on which the stand has been killed by fire and that is less than 10 percent restocked.

No. 38. Noncommercial rocky: An area of any species of timber within the range of commercial timber and below the range of the subalpine type that is too rocky, too steep, or too sterile to produce a stand of commercial size, density, and quality; ordinarily the stand averages less than 5,000 board feet per acre.

The scale decided on for type mapping was 1 inch to the mile. A larger scale would have led to excessive detail and made the cost more than was contemplated; a smaller one would not have provided sufficient space for the field examiner to record data of the desired completeness. Obviously, areas only a few acres in extent could not be mapped on the adopted scale. It was decided that all 40-acre or larger areas of commercial forest land - that is, land now bearing or capable of producing forests of commercial character-and agricultural land should be mapped, but that for noncommercial-forest land, barrens, etc., the minimum should be several hundred acres. Hardwood types, owing to their infrequent occurrence, usually as "shoestrings" along creek and river bottoms, were mapped if occupying areas as large as 20 acres. These limits are fixed not absolutely but merely as a guide. In all cases the field examiner was allowed to exercise his judgment. If he could conveniently map a farm or a patch of conifer timber as small as 20 or 30 acres without slowing down the work he was at liberty to do so; if he was mapping an area low in values and difficult of access he was allowed to generalize more than if mapping an area of high values and easy access.

\section{Classifications}

\section{Owenership Classes}

Separation of forest type and volume data according to ownership was considered particularly im- 
portant because of the high timber values involved and the large quantities of timberland in various classes of public ownership. Its usefulness has been emphasized by economic developments since the inception of this project. The subject of forestland ownership is being carefully studied by economists, foresters, legislators, public officials, and the lumber industry. The break-down in private forest-land ownership (22) is a cause of particular concern and the subject of many studies.

Ownership statistics were taken from the best public records available. It is recognized that ownership is constantly changing and that the totals given for individual ownership classes probably fail in many cases to coincide with statistics from other sources. Both forest land and intermingled nonforest land were classified as to ownership. No distinctions were attempted as to the ownership of large bodies of agricultural land; they were all arbitrarily classified as privately owned. As applied to forest land, the ownership classification was as follows:

Private. All privately owned forest property, including farm woods.

State, available for cutting.

State, reserved from cutting.

County. Forest property deeded to the county. (Tax-delinquent land not deeded to the county is classified as private.)

Municipal. Includes all municipally owned forest property outside the platted limits of municipalities.

Indian. Includes both tribal lands and trust allotments.

Revested land grant. Includes Oregon \& California Railroad and other land grants that have reverted to Federal ownership whether classified as timber, agricultural, or power withdrawals.

Federal other than national forest and revested land grant. Includes national parks, military reservations, unappropriated public domain and miscellaneous.

National forest, available for cutting.

National forest, reserved from cutting.

National forest, State selection.

The term "reserved from cutting" as applied to State or national-forest land denotes areas unavailable for cutting because of statute, proclamation, or policy. Most land so classed had been officially dedicated to watershed protection, to recreational use, or as national-forest primitive areas on which primitive conditions are to be maintained so far as possible for recreational purposes. The term "available for cutting" means that there was no legal or formal prohibition on timber cutting; it does not imply the presence of timber ready for cutting or, in fact, of any timber at all.

National-forest areas designated as State selection areas are lands in the north Puget Sound unit that have been designated for exchange with the State of Washington in order to enable the State to consolidate scattered land holdings.

\section{Other Classifications}

For convenience and facility of analysis and discussion, the region was arbitrarily divided into 11 units (figs. 3 and 4). So far as was practical, the units were compact areas homogeneous as to eco-

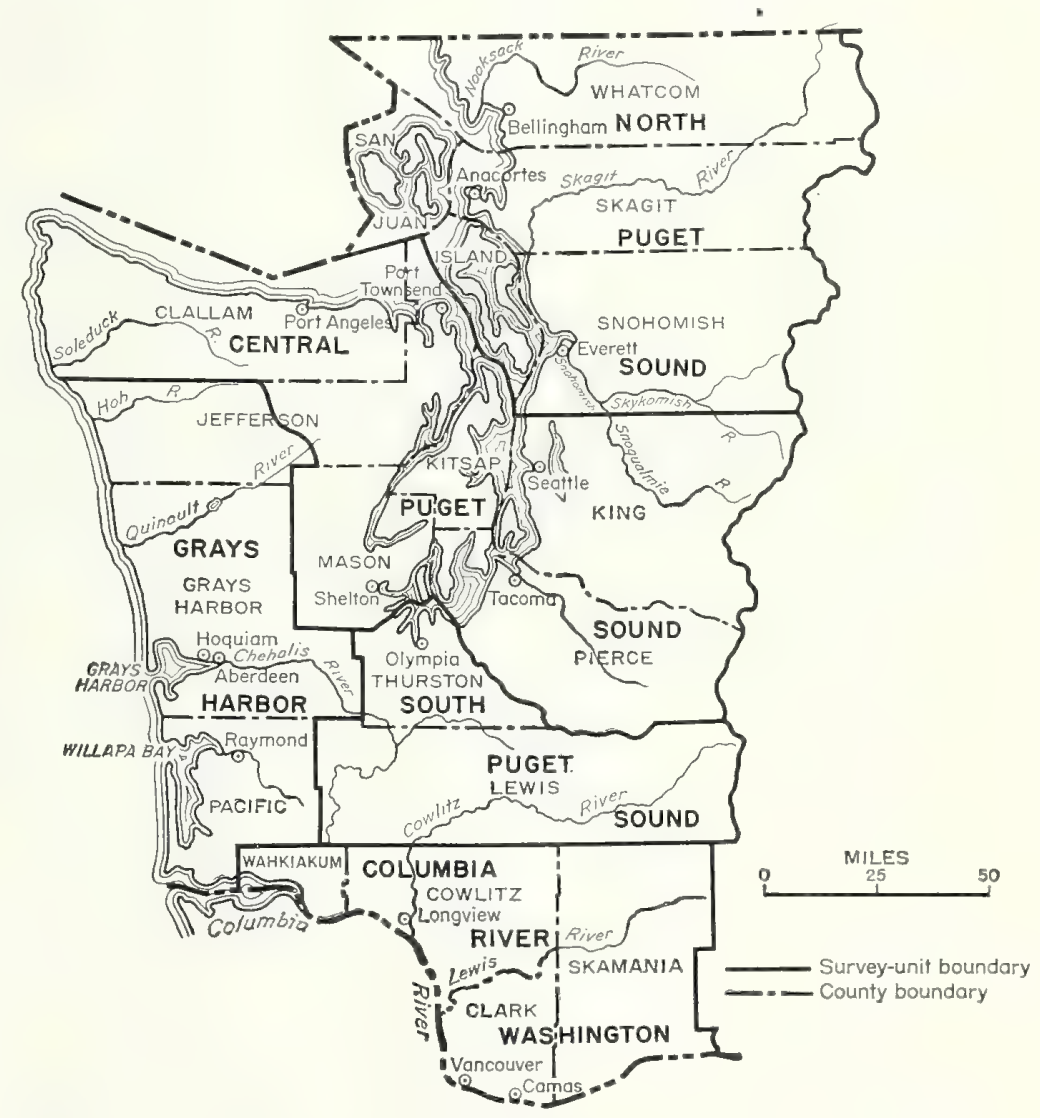

FIGURE 3.-Map of western Washington showing survey units, counties, and important drainages. 


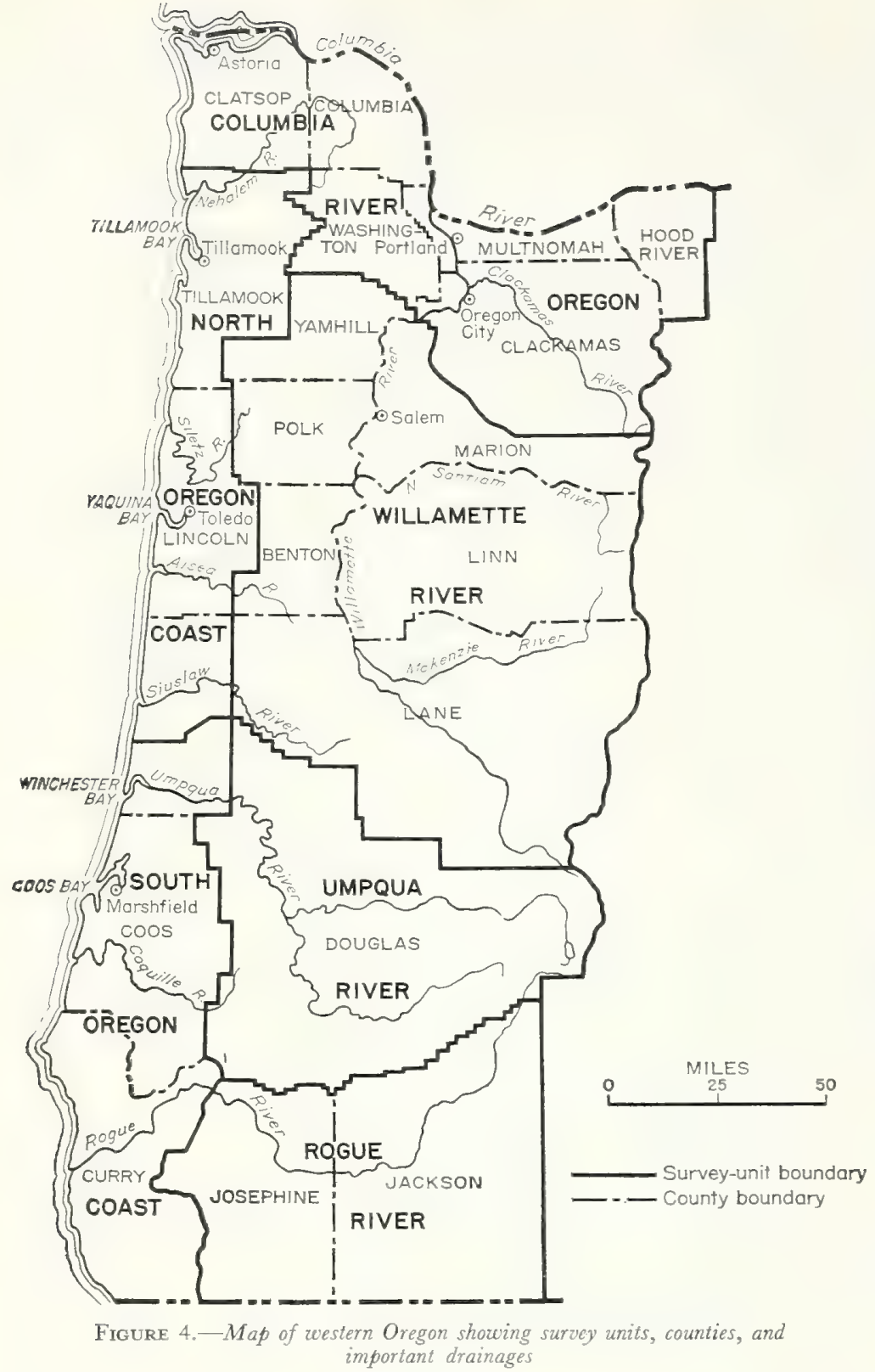

to economic availability. Class I includes timber that according to estimate could profitably be logged under the production and marketing conditions that prevailed during the period 1925-29; class II, timber that under those conditions could be logged at a loss of not more than $\$ 5$ per 1,000 board feet; and class III, all other timber.

In order to calculate growth and volume of immature conifer stands, most of these stands were classified according to age, in 10-year classes, and according to density, in three degrees of stocking. If an area were 70 - to 100-percent covered, according to the stocked-quadrat method of measurement (explained in the appendix), it was classified as well stocked; if 40 to 69 percent, medium stocked; if 10 to 39 percent, poorly stocked; and if less than 10 percent, nonstocked.

The term "site quality" denotes the forest-productive capacity of an area, determined by the composite effect of all climatic and soil conditions. Site-quality classifications based on height of dominant and codominant trees at a given age have been adopted for the Douglasfir type and the ponderosa pine type.

The classification for Douglas-fir consists of five classes and that for ponderosa pine of six classes; in each case, the highest class is designated I. The Douglas-fir classification was employed for all forest-cover types in the region except ponderosa

nomic influences and industrial conditions. In most cases unit boundaries were made to coincide with county lines, so that data could be assembled by counties. It was impossible to establish absoIutely self-contained units.

Saw timber was ranked in three classes according pine, lodgepole pine, subalpine, oak-madrone, hardwood, and noncommercial rocky. The ponderosa pine classification was used for all ponderosa pine types except woodland. Land occupied by the other types listed was not classified by site quality. 
$\mathrm{U}$ NDOUBTEDLY the most important natural resource of the Douglas-fir region is its forest land, which comprises 29 million acres of the total land area of 35 million acres. Forest land composes approximately 85 percent of western Washington and 81 percent of western Oregon. Approximately 27 million acres is classified as commercial forest land. Although exceeded in forest area by nearly every other important forest region, in the United States, the Douglas-fir region, owing to the large size of its trees and the density of its forest stands, far exceeds any one of them in saw-timber volume. The total stand of saw timber at time of estimate was 546 billion board feet, log scale.

Puget Sound, which penetrates to the heart of western Washington (see type maps at end of report) was formerly surrounded by magnificent forests of old-growth Douglas-fir and western redcedar. Ease of logging and transportation attracted lumbermen to lands bordering the sound as early as the middle of the nineteenth century. Grays Harbor and Willapa Bay, on the coast of western Washington, offered almost equally attractive opportunities for forest exploitation. Practically all the old-growth Douglas-fir forests of western Washington were within 30 to 40 miles of navigable waterways. Now western Washington, particularly in the vicinity of Puget Sound and Grays Harbor, is characterized by vast expanses of cut-over land largely barren of conifer growth. The remaining old-growth Douglas-fir stands in western Washington are principally in the eastern parts of Cowlitz and Lewis Counties. Extensive virgin forests of western hemlock, Sitka spruce, and western redcedar occur along the Washington coast, and on the upper slopes of the Cascade

$224146^{\circ}-40-2$
Range throughout western Washington occur extensive bodies of old-growth western hemlock and balsam fir-mountain hemlock. Large areas in the Olympic Mountains and the Cascade Range in northwestern Washington are occupied by subalpine and other noncommercial forests, or are barren of tree growth chiefly because of altitude.

There are few extensive bodies of developed agricultural land in western Washington. The two largest are at the northern and southern extremes, in western Whatcom County near the Canadian border and in Clark County on the Columbia River.

The forest cover of western Oregon (see foresttype maps at end of report) differs materially in pattern from that of western Washington. Logging has removed the virgin timber from extensive areas in extreme northwestern Oregon, but almost unbroken stands of old-growth Douglas-fir cover the lower slopes and foothills of the Cascade Range practically the length of the State. Scattered throughout this timber belt are comparatively small bodies of second growth on old burns, small deforested burns, and cut-over areas. At higher elevations, reaching to the summit of the Cascade Range, is a mixture of western hemlock, balsam fir-mountain hemlock, noncommercial forests, and barrens. In parts of southwestern Oregon ponderosa pine types predominate.

In the Coast Range of Oregon the virgin Douglasfir forests are broken by extensive even-aged secondgrowth forests varying in age from 40 to 80 years. These are the result of several large fires that burned during the middle of the nineteenth century. Scattered throughout the Coast Range are a number of fairly large deforested burns, and in 
the northwest is the great Tillamook burn, where roughly 380 square miles was deforested in 1933.

Between the Cascade Range and the Coast Range in the north half of western Oregon is the fertile Willamette Valley, shaped like a cornucopia. It contains more than 4,000 square miles, of which by far the greater part is farmed. Dotted throughout the valley are small woodlands. Other large agricultural areas in western Oregon are the Umpqua River and Rogue River Valleys.

Throughout the Coast Range and Cascade Range of both States, ribbons of farm land, and hardwoods border the lower stream courses.

\section{Types and Areas}

The areas of the individual forest-cover and landuse types recognized in the survey are given in table 2 by ownership class, together with a summary by broad groups of types. Table 3 presents type areas by forest-survey units. Figure 5 compares acreages in the several generalized type classes and ownership classes.

TABLE 2.-Area of all types in the Douglas-fir region, by ownership class, 1933

INDIVIDUAL TYPES

\begin{tabular}{|c|c|c|c|c|c|c|c|c|c|c|c|c|}
\hline \multirow{3}{*}{ Type name and No. } & \multirow{3}{*}{ Private } & \multicolumn{2}{|c|}{ State } & \multirow{3}{*}{ County } & \multirow{3}{*}{$\begin{array}{c}\text { Muni- } \\
\text { cipal }\end{array}$} & \multicolumn{6}{|c|}{ Federally owned or managed } & \multirow{3}{*}{ Total } \\
\hline & & & & & & \multirow[b]{2}{*}{ Indian } & \multirow[b]{2}{*}{$\begin{array}{c}\text { Revest- } \\
\text { ed land } \\
\text { grants }\end{array}$} & \multicolumn{3}{|c|}{ National forest } & \multirow[b]{2}{*}{ Other? } & \\
\hline & & $\begin{array}{l}\text { Avall- } \\
\text { able for } \\
\text { cutting }\end{array}$ & $\begin{array}{l}\text { Reserv- } \\
\text { ed from } \\
\text { eu!tio: }\end{array}$ & & & & & $\begin{array}{l}\text { Avail- } \\
\text { able for } \\
\text { cutting }\end{array}$ & \begin{tabular}{|} 
Resers- \\
ed from \\
cutting
\end{tabular} & $\begin{array}{l}\text { State } \\
\text { selec- } \\
\text { tion }\end{array}$ & & \\
\hline & $\begin{array}{l}1,000 \\
\text { acres }\end{array}$ & $\begin{array}{l}1,000 \\
\text { acres }\end{array}$ & $\begin{array}{l}1,000 \\
\text { acres }\end{array}$ & $\begin{array}{l}1,000 \\
\text { acres }\end{array}$ & $\begin{array}{l}1,000 \\
\text { acres }\end{array}$ & $\begin{array}{l}1,000 \\
\text { acres }\end{array}$ & $\begin{array}{l}1,000 \\
\text { acres }\end{array}$ & $\begin{array}{l}1,000 \\
\text { acres }\end{array}$ & $\begin{array}{l}1,000 \\
\text { acres }\end{array}$ & $\begin{array}{l}1,00 n \\
\text { acres }\end{array}$ & $\begin{array}{l}1,000 \\
\text { actes }\end{array}$ & $\begin{array}{l}1,000 \\
\text { actes }\end{array}$ \\
\hline Nonforest land other than agricultural (2) $\ldots$ & 549. 2 & 13.9 & 0.5 & 9.9 & 7.9 & 4. 2 & 39.1 & 435.0 & 193. 1 & 4. 3 & 197. 9 & $1,455.0$ \\
\hline Agricultural (3) & $4,611.5$ & 12.3 & 1.9 & 17.1 & 1.8 & 5.8 & 12.0 & 1.9 & & & 6. 2 & $4,670.5$ \\
\hline Oak-madrone woodland (4) ....... & 224. 7 & 1.3 & $\left({ }^{3}\right)$ & 6.4 & .8 & .4 & 46.2 & 67.9 & & & 16. 6 & 364.3 \\
\hline \multicolumn{13}{|l|}{ Douglas-fir: } \\
\hline Large old growth (6) & $2,157.5$ & 115. 5 & 1.4 & 25.3 & 5.3 & 7.8 & 313.6 & 607.5 & 35.1 & .3 & 30.1 & $3,299.4$ \\
\hline Small old growth (7) & 921.6 & 22.5 & .7 & 36.0 & 7.0 & .8 & 589.9 & $1,905,2$ & 29.5 & & 52.1 & $3,565.3$ \\
\hline Large second growth (8) ..... & $1,425.4$ & 57. 9 & 1. 2 & 45.3 & 1. 7 & 7. 9 & 339.3 & 728.0 & 1.7 & & 33.2 & 2. 641.6 \\
\hline Small second growth (9) ...... & $2,416.2$ & 127.6 & 5.0 & 121.1 & 8.6 & 15. 6 & 243.4 & 597.1 & 26.1 & & 131.5 & $3,692.2$ \\
\hline Seedlings and saplings $(10)$ & 1.291 .3 & 61.2 & .5 & 71.3 & 25.8 & 5.4 & 57.8 & 527.9 & 37.3 & & 32.0 & $2,110.5$ \\
\hline \multicolumn{13}{|l|}{ Sitka spruce: } \\
\hline Large (11) & 135.6 & 10.5 & .4 & 2.5 & .2 & 9.7 & & 25.2 & 1.1 & & 4. 6 & 189.8 \\
\hline Small (12) & 41. 2 & .5 & .1 & 2.5 & 1 & 4 & . & 2.2 & & & .6 & 47. 6 \\
\hline Seedlings and saplings (13) & 10.2 & .3 & $\ldots$ & .6 & (3) & (3) & & .9 & & & (3) & 12.0 \\
\hline \multicolumn{13}{|l|}{ Western hemlock: } \\
\hline Large (14) & 976.1 & 212.8 & .4 & 22.5 & 10.8 & 51.6 & 4.3 & 871.7 & 50.1 & 1. 2 & 45.7 & $2,247.2$ \\
\hline Small $(15) \ldots \ldots$ & 284.4 & 14.0 & $\ldots$ & 14.1 & 4.4 & 1.0 & .5 & 33.8 & 2.6 & & 11. 2 & 366.0 \\
\hline Seedlings and saplings $(16)$ & 179.8 & 27.4 & .1 & 14.8 & 2.0 & .6 & .5 & 14. 6 & 2.0 & & 1.5 & 243.3 \\
\hline Western redcedar, large (17) . . . & 192.5 & 49.4 & .1 & 3.9 & .8 & 62.5 & .5 & 71.3 & 6.3 & .5 & .9 & 388.7 \\
\hline Port Orford white-cedar, large (18) & 27.4 & .1 & $\ldots$ & .1 & - n... & & 5.6 & 5.5 & & & $(3)$ & 38.7 \\
\hline "Cedar," small (19) .............. & 23.4 & .5 & 3 & .9 & (3) & & .1 & .6 & & & $-\ldots$ & 25.8 \\
\hline \multicolumn{13}{|l|}{ Ponderosa pine: } \\
\hline Large (20) & 92.6 & 1.5 & (3) & 6.5 & .2 & & 100.5 & 85.0 & & & 7.2 & 293.5 \\
\hline Small $(21)$ & 42.2 & .1 & $\cdots$ & 5. 2 & .1 & & 17.5 & 10. 3 & & & 3.7 & 79.1 \\
\hline Seedlings and saplings (22) & 88.6 & .9 & $\ldots$ & 10. 6 & .7 & & 36.5 & 7.5 & & & 8.4 & 153. 2 \\
\hline Sugar pine, large $(20 \mathrm{~A})$ & 51.3 & --- & $\ldots$ & 5.8 & $\ldots$ & & 36.3 & 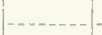 & & & 4.4 & 97.8 \\
\hline \multicolumn{13}{|l|}{ Fir-mountain hemlock: } \\
\hline Large (23) & 208. 2 & 67.0 & .5 & 3.1 & 8.7 & 5.5 & 8.01 & $1,130.7$ & 85.9 & .4 & 91.3 & $1,609.3$ \\
\hline Small $(24)$ & 22.9 & $-\cdots$ & --- & .8 & .1 & $-\ldots-$ & 3.5 & 212.8 & 31.4 & & 2.4 & 273.9 \\
\hline \multicolumn{13}{|l|}{ Lodgepole pine: } \\
\hline Large (25) & 1.5 & & & & & $\left({ }^{3}\right)$ & & 1.6 & & & $\left({ }^{3}\right)$ & 3.1 \\
\hline Small $(26)$ & 33.1 & 1.0 & .5 & 1.5 & (3) & & .3 & 227.2 & 4.2 & & 2.1 & 269.9 \\
\hline White fir-Iarch-Douglas-fir: & & & & & & & & & & & & \\
\hline large (27) & .1 & & & - & & & & 30.4 & 7.0 & & .1 & 37.6 \\
\hline Snall $(28) \ldots$ & 2,2 & & $--\infty \mid$ & .2 & & & & 22.7 & 5.8 & & & 30.9 \\
\hline
\end{tabular}


TABLE 2.-Area of all types in the Douglas-fir region, by ownership class, 1933-Continued

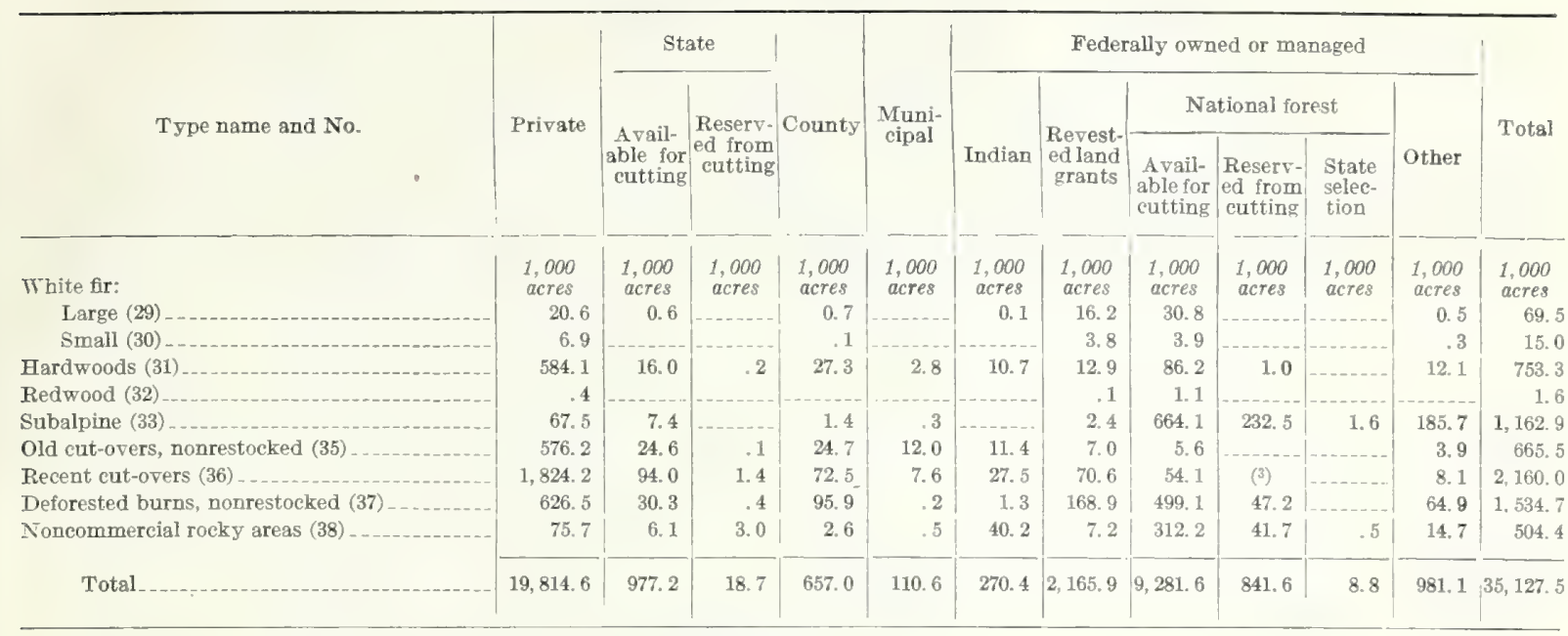

\section{GENERALIZED TYPES}

\begin{tabular}{|c|c|c|c|c|c|c|c|c|c|c|c|c|}
\hline Nonforest land (2 and 3) & $5,160.7$ & 26. 2 & 2.4 & 27.0 & 9.7 & 10.0 & 51.1 & 436. 9 & 193.1 & 4.3 & 204.1 & 6.125 .5 \\
\hline Hardwood timber (31) & 584.1 & 16.0 & .2 & 27.3 & 2.8 & 10.7 & 12.9 & 86.2 & 1.0 & & 12.1 & 753.3 \\
\hline $\begin{array}{l}\text { Conifer saw- } \log \text { timber }(51 / 2,46,7,8,11,14,17 \text {, } \\
18,20,20 \mathrm{~A}, 23,27,29 \text {, and } 32)\end{array}$ & $6,229.4$ & 537.8 & 4. 7 & 155.1 & 34.8 & 145.9 & $1,433.6$ & $5,492,4$ & 216.7 & 2.4 & 275.1 & $14,527.9$ \\
\hline $\begin{array}{l}\text { Conifer timber smaller than saw-log size }(9,12 \text {, } \\
15 \text {, and 21): }\end{array}$ & & & & & & & & & & & & \\
\hline On cut-over areas & $1,020.5$ & 23.0 & 1.1 & 39.8 & 8.3 & 10.3 & 8.6 & & & & 7.6 & 1.119.2 \\
\hline On old burns & $1,763.5$ & 119.2 & 4.0 & 103. I & 4. 9 & 6.7 & 252.8 & 643.4 & 28.7 & & 139.4 & $3,065.7$ \\
\hline Total ..... & $2,784.0$ & 142.2 & 5. 1 & 142.9 & 13.2 & 17.0 & 261.4 & 643.4 & 28. 7 & 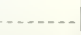 & 147.0 & $4,184.9$ \\
\hline $\begin{array}{l}\text { Conifer timber, seedling and sapling }(10,13 \text {, } \\
16 \text {, and } 22) \text { : }\end{array}$ & & & & & & & & & & & & \\
\hline On cut-over areas & $1,190.7$ & 53.0 & .3 & 67.0 & 26.6 & 5.5 & 8.3 & 25.5 & 1.5 & & 9.9 & 1.388 .3 \\
\hline On old burns & 379.2 & 36.8 & .3 & 30.3 & 1.9 & .5 & 86.5 & 525.4 & 37.8 & $\ldots$ & 32.0 & $1,130.7$ \\
\hline Total - & 1.569 .9 & 89.8 & .6 & 97.3 & 28.5 & 6.0 & 94.8 & 550.9 & 39.3 & & 41.9 & $2,519.0$ \\
\hline $\begin{array}{l}\text { Conifer timber, small mixed types }(19,24,28 \text {, } \\
\text { and } 30) \text { : }\end{array}$ & & & & & & & & & & & & \\
\hline On cut-over areas & 20.5 & .4 & .2 & .7 & --- & & .1 & .8 & .4 & & & 23.1 \\
\hline On old burns & 34.9 & .1 & .1 & 1.3 & .1 & $\ldots$ & 7.3 & 239.2 & 36.8 & & 2.7 & 322.5 \\
\hline Total . & 55.4 & .5 & .3 & 2.0 & .1 & . & 7.4 & 240.0 & 37,2 & & 2.7 & 345.6 \\
\hline Noncommercial $\left(4,5 \frac{1}{2}, 425,26,33\right.$, and 38$) \ldots$ & 404. 2 & 15.8 & 3. 5 & 12. 3 & 1.7 & 40.6 & 58.2 & $1,273.0$ & 278.4 & 2.1 & 221.3 & $2,311.1$ \\
\hline $\begin{array}{l}\text { Recent cut-overs (36) } \\
\text { old cut-overs, nonrestocked, and deforested- }\end{array}$ & $1,824.2$ & 94.0 & 1.4 & 72.5 & 7. 6 & 27.5 & 70.6 & 54.1 & (3) & & 8. 1 & $2,160.0$ \\
\hline burn types (35 and 37$)$ & $1,202.7$ & 54.9 & .5 & 120.6 & 12. 2 & 12. 7 & 175.9 & 504.7 & 47. 2 & & 68.8 & $2,200.2$ \\
\hline Total & $19,814,6$ & 977.2 & 18. 7 & 657.0 & 110.6 & 270.4 & $2,165.9$ & $9,281.6$ & 841.6 & 8.8 & 981.1 & $35,127.5$ \\
\hline
\end{tabular}

3 Less than 50 acres.

46,510 acres of type $51 / 2$ in Josephine County, Oreg., is classified here as noncommercial. 
TABLE 3.-Area of all types in the Douglas-fir region, by State and forest-survey unit, 1933

\begin{tabular}{|c|c|c|c|c|c|c|c|}
\hline \multirow[b]{2}{*}{ Type name and No. } & \multirow[b]{2}{*}{$\begin{array}{c}\text { Region } \\
\text { total }\end{array}$} & \multicolumn{6}{|c|}{ Western Washington } \\
\hline & & $\begin{array}{l}\text { North } \\
\text { Puget } \\
\text { Sound }\end{array}$ & $\begin{array}{l}\text { Central } \\
\text { Puget } \\
\text { Sound }\end{array}$ & $\begin{array}{l}\text { South } \\
\text { Puget } \\
\text { Sound }\end{array}$ & $\begin{array}{l}\text { Grays } \\
\text { Harbor }\end{array}$ & \begin{tabular}{|c|} 
Columbia \\
River, \\
Wash- \\
ington
\end{tabular} & Total \\
\hline & $\begin{array}{l}1,000 \\
\text { acres }\end{array}$ & $\begin{array}{l}1,00 n \\
\text { actes }\end{array}$ & $\begin{array}{l}1,000 \\
\text { acres }\end{array}$ & $\begin{array}{l}1,000 \\
\text { acres }\end{array}$ & $\begin{array}{l}1,000 \\
\text { acres }\end{array}$ & $\begin{array}{l}1,000 \\
\text { acres }\end{array}$ & $\begin{array}{l}1,000 \\
\text { acres }\end{array}$ \\
\hline Nonforest land other than agricultural (2) ... & $1,455.0$ & 467.3 & 370.0 & 22.6 & 89.7 & 58.9 & $1,008.5$ \\
\hline Agricultural (3) & $4,670.5$ & 450.9 & 343.5 & 257.0 & 79.4 & 284.5 & $1,415.3$ \\
\hline Oak-madrone woodland (4) & 364.3 & .1 & 2.2 & .3 & .3 & .1 & 3.0 \\
\hline \multicolumn{8}{|l|}{$\begin{array}{l}\text { Ponderosa pine woodland }(51 / 2) \ldots \\
\text { Dounglas-fir: }\end{array}$} \\
\hline Douglas-fir: & & & & & & & \\
\hline Large old growth $(6) \ldots$ & $3,299.4$ & 143.9 & 285.0 & 367.0 & 186.2 & 296.2 & $1,278.3$ \\
\hline Small old growth $(\bar{\tau}) \ldots \ldots$ & $3,565.3$ & 59.6 & 306.9 & 24.0 & 11.8 & 20.1 & 422.4 \\
\hline Large second growth (8) & $2,641.6$ & 120.2 & 152. 2 & 252.6 & 39.1 & 166.7 & 730.8 \\
\hline Small second growth $(9) \ldots$ & $3,692.2$ & 310.3 & 525.6 & 232.5 & 51.7 & 347.7 & $1,467.8$ \\
\hline Seedlings and saplings (10) _. & $2,110.5$ & 230.7 & 549.6 & 224.2 & 108.9 & 232.1 & $1,345.5$ \\
\hline \multicolumn{8}{|l|}{ Sitka spruce: } \\
\hline Large (11) & 189.8 & 1.5 & 25.7 & & 69.3 & 1.8 & 98.3 \\
\hline Small (12) & 47.6 & .9 & (1) & & 9.2 & 3.9 & 14.0 \\
\hline Seedlings and saplings (13) & 12.0 & & & & 1.3 & & 1.3 \\
\hline \multicolumn{8}{|l|}{ Western hemlock: } \\
\hline Large (14) & $2,247.2$ & 420.8 & 587.3 & 84.7 & 676.8 & 136.7 & $1,906.3$ \\
\hline Small (15) & 366.0 & 46.5 & 58.9 & 3.5 & 125.8 & 29.6 & 264.3 \\
\hline Seedlings and saplings (16) & 243.3 & 28.2 & 85.0 & 1. 2 & 85.3 & 11.9 & 211.6 \\
\hline Western redcedar, large (17) $\ldots \ldots$ & 388.7 & 129.6 & 63.3 & 3.1 & 171.3 & 8.8 & 376.1 \\
\hline Port Orford white-cedar, large (18) & 38.7 & & & & & & 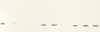 \\
\hline "Cedar," small (19) . & 25. 8 & 9.5 & 1.6 & & 6.8 & 1.0 & 18.9 \\
\hline \multicolumn{8}{|l|}{ Ponderosa pine: } \\
\hline Large (20) & 293.5 & & & & & 5. 0 & 5.0 \\
\hline Small (21) & 79.1 & & .8 & & & & .8 \\
\hline Seedlings and saplings (22) ... & 153.2 & & & & & & \\
\hline Sugar pine, large $(20 \mathrm{~A}) \ldots$ & 97.8 & & & & & & ... \\
\hline \multicolumn{8}{|l|}{ Fir-mountain bemlock: } \\
\hline Large (23) & $1,609.3$ & 325.5 & $250 . \epsilon$ & 105.6 & 169.0 & 142.6 & 993.3 \\
\hline Small (24) & 273.9 & 20.6 & 25.5 & 22.2 & .2 & 84.8 & 153.3 \\
\hline \multicolumn{8}{|l|}{ Lodgepole pine: } \\
\hline Large (25) & 3. 1 & & .2 & & (1) & & .2 \\
\hline Small $(26)$ & 269.9 & 6. 0 & 4.2 & .8 & 2.3 & 13.3 & 26.6 \\
\hline \multicolumn{8}{|l|}{ White fir-larch-Douglas-fir: } \\
\hline Large $(2 \pi) \ldots$ & 37.6 & & & & & 14.9 & 14.9 \\
\hline Small (28) & 30.9 & & & & & 9.9 & 9.9 \\
\hline \multicolumn{8}{|l|}{ White fir: } \\
\hline Large (29) & 69.5 & .4 & & 1.6 & (1) & & 2.0 \\
\hline Small $(30)$ & 15.0 & .5 & .1 & & & 1.0 & 1.6 \\
\hline Hardwoods (31) & 753.3 & 134. 2 & 102. 2 & 35.5 & 60.9 & 20.4 & 353. 2 \\
\hline Redwood (32) $\ldots$ & 1.6 & & & & & & \\
\hline Subalpine (33) & $1,162.9$ & 590.5 & 341.6 & 37.8 & 74.1 & 47.9 & $1,091.9$ \\
\hline Old cutorers (35) & 665.5 & 149.8 & 202.6 & 28.0 & 62.5 & 82.9 & 525.8 \\
\hline Recent cut-overs (36) & $2,160.0$ & 205.8 & 483.2 & 294.9 & 323.9 & 133.2 & 1.441 .0 \\
\hline Deforested burns, nonrestocked (37) ... & $1,534.7$ & 73.8 & 63.1 & 16. 7 & 6. 2 & 206.0 & 365.8 \\
\hline Noncommercial rocky areas $(38) \ldots$ & 504.4 & 116.8 & 79.1 & 11.7 & 63.3 & 30.7 & 301.6 \\
\hline Total_-_... & $35,127.5$ & $4,043.9$ & $4,910.0$ & $2,027.5$ & $2,475.3$ & $2,392.6$ & $15,849.3$ \\
\hline
\end{tabular}

1 Less than 50 acres. 
TABLE 3.-Area of all types in the Donglas-fir region, by State and forest-survey unit, 1933-Continued

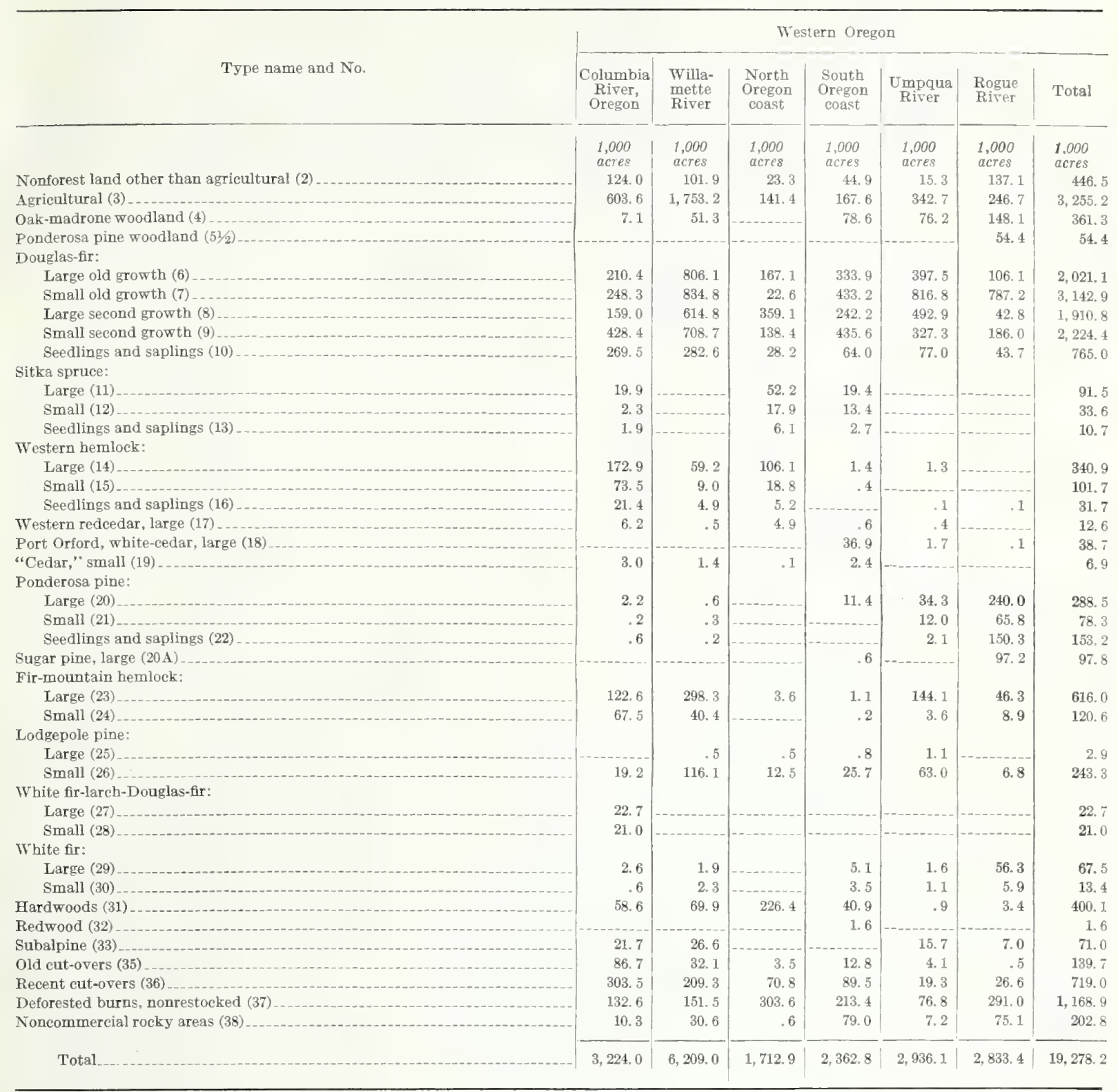

\footnotetext{
${ }^{1}$ Less than 50 acres.
} 


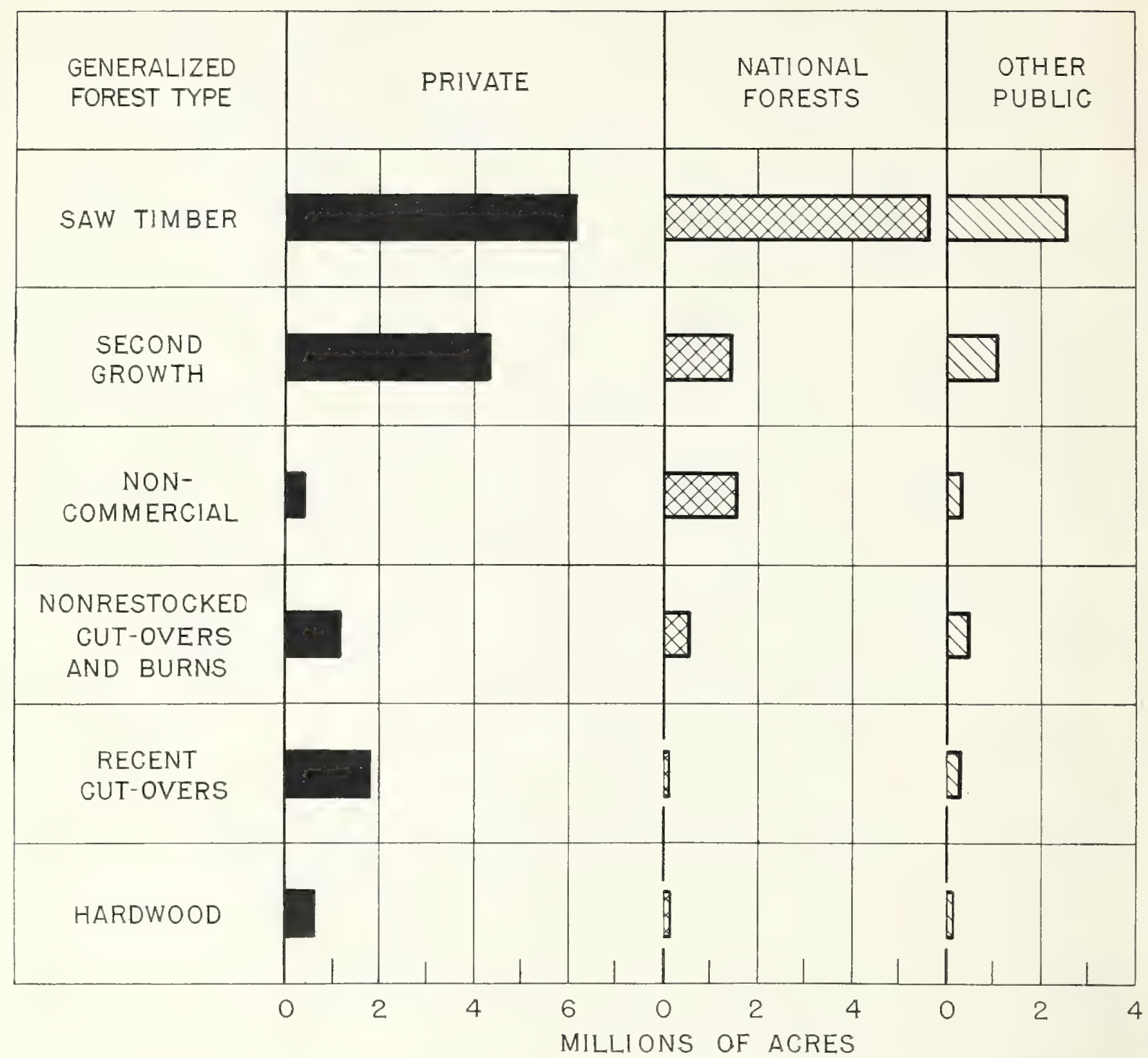

FIGURE 5.-Areas of generalized forest types in western $W$ ashington and western Oregon, by ownership class.

\section{Nonforest Land}

The "agricultural land" category takes in cultivated fields and orchards and also stump pasture, included in operating farm units, on which operators are making definite efforts to improve the forage by clearing, seeding, fencing, or other measures (fig。6). It does not include the large acreage of cut-over land that is used as free range by neighboring farmers. This land is grazed casually and, in many instances, in trespass. Usually no attempt is made to convert it to permanent pasture. It is not an uncommon practice to burn this type of land in an attempt to improve the grazing. Most of the $4 \frac{1}{2}$ million acres classed as agricultural was orginally forested and is capable of again growing forests if not devoted to other use.

The "nonforest land other than agricultural" is chiefly land that will not support tree growth, because of soil, climate, or topography. It includes sand beaches, rock barrens, swamps, mountain meadows, roads, and urban and industrial sites. Of the $1 \frac{1}{2}$ million acres in this class more than twothirds is in Washington, where the Cascade Range 
is more rugged and has a more severe climate than in Oregon.

\section{Conifer Sawlog Types}

The conifer saw-timber types occupy 14.5 million acres, or more than 40 percent of the region's total land area and more than 50 percent of its forest land. Practically all the saw-timber volume in the region occurs in the types making up this group. The average stand per acre of these types approximates 35,000 board feet. Figure 7 shows the extent of saw-timber stands contrasted with that of secondgrowth stands. About 60 percent of the saw-timber type area is in Oregon and 40 percent in Washington.

\section{OLD-GROWTH DOUGLAS-FIR}

Nearly all the cutting in this region has taken place in old-growth Douglas-fir forests, chiefly in type 6 stands averaging more than 40 inches d. b. h. It is estimated that before logging began old-growth Douglar-fir timber covered about 14 million acres. Of the 6.9 million acres remaining, three-quarters is in western Oregon.

Old-growth stands in western Washington are predominantly mixed; in western Oregon predomi- nantly pure. In the region as a whole they average about 80 percent Douglas-fir. The most common associates are western hemlock, western redcedar, Pacific silver fir, and noble fir. The understory consists usually of western hemlock, western redcedar, bigleaf maple, and red alder. The alder is generally limited to the stream courses. Along the larger rivers northern black cottonwood is found. Tree species much less commonly present in these types are Sitka spruce along the coast, Pacific yew, western chokecherry (Prunus virginiana demissa), and in southern Oregon ponderosa pine, sugar pine, Port Orford white-cedar, golden chinquapin, tan oak, California laurel, and Pacific madrone.

The underbrush of these types is characteristically dense and luxuriant. Salal (Gaultheria shallon), vine maple (Acer circinatum), salmonberry (Rubus spectabilis), Oregon-grape (Odostemon aquifolium), and devils club (Fatsia horrida) are the most common brush species.

Stand volume per acre ranges from 10,000 to more than 175,000 board feet and averages about 60,000 board feet for the large old growth and 40,000 board feet for small old growth. Douglas-fir sawlog-size trees range in diameter from 16 to more than 100 inches.

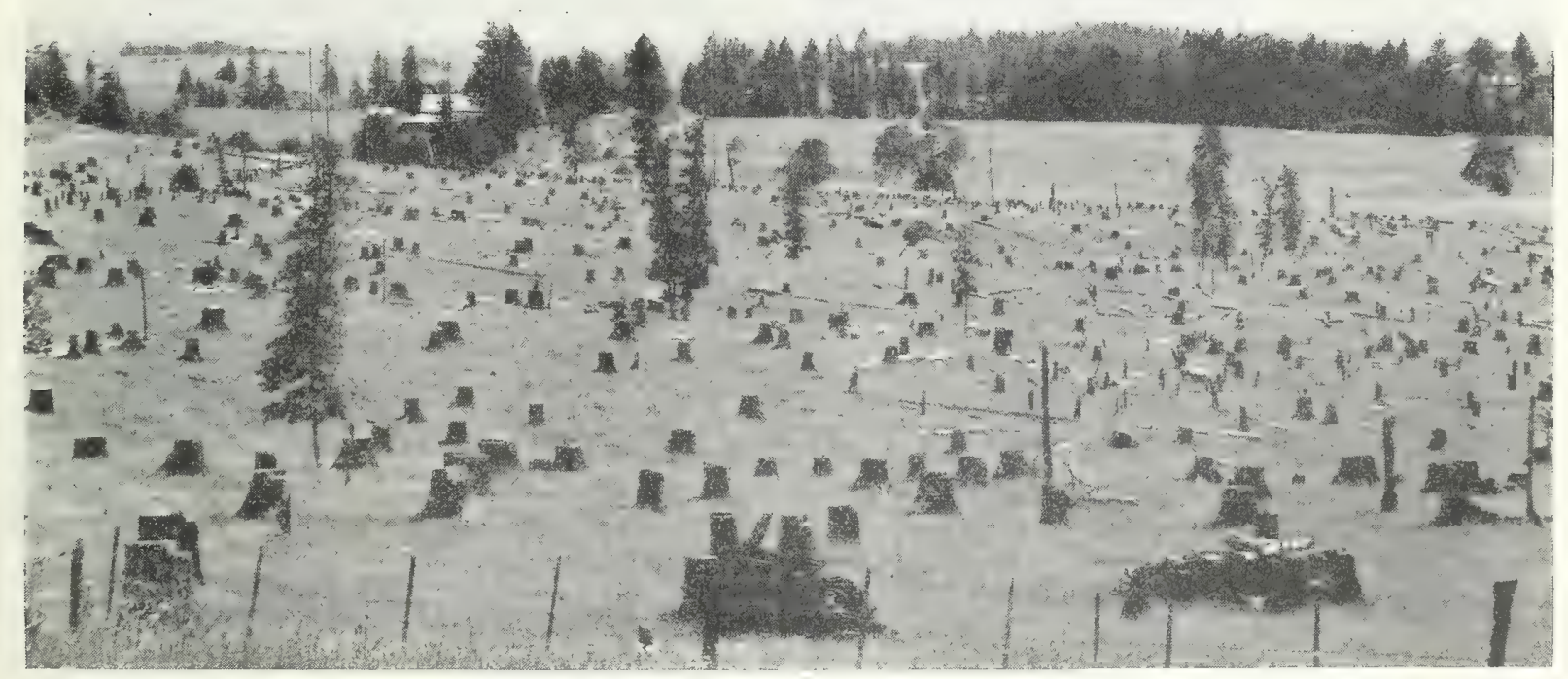

Figure 6.- Siump pasture, classified in the survey as agricultural and definitely out of forest production. In background, patches of forest such as are found throughout the Willamette Valley and other large agricultural areas in the Douglas-fir region. 
Large old growth occurs on better sites and usually at lower elevations than the smaller type. Small old growth is common in the Cascade Range of Oregon but seldom occurs in the Coast Range except in southern Oregon. It is found along the west shores of Puget Sound and on Hood Canal, a district of comparatively low precipitation and gravelly soil.

A very large proportion of the original area of large old growth was privately owned, and after three decades of large-scale logging about twothirds of the present area is privately owned. Most of the small old growth is on national-forest land, little of which has been cut over.

DOUGLAS-FIR SECOND-GROWTH SAW TIMBER

About 28 percent of the total Douglas-fir sawtimber type area is occupied by second growth (type 8), nearly three-quarters of it in western Oregon.

Second-growth saw-timber stands are nearly all even-aged. Most of them range from about 90 to 160 years. On the better sites and in the more open stands Douglas-fir trees reach a breast-high diameter of 20 inches as young as 60 years and 40 inches by 120 years. As a general rule, however, Douglasfir even on sites I and II does not attain a 40-inch d. b. h. if the stand is closed until it reaches the age of 150 years, after which growth slows down.

These stands occur chiefly on old burns. They are usually pure averaging for the region as a whole between 85 and 90 percent Douglas-fir. Volume per acre ranges from 10,000 to 125,000 board feet and averages about 45,000 feet. A very considerable amount of logging is taking place in this type, principally to supply logs to small mills

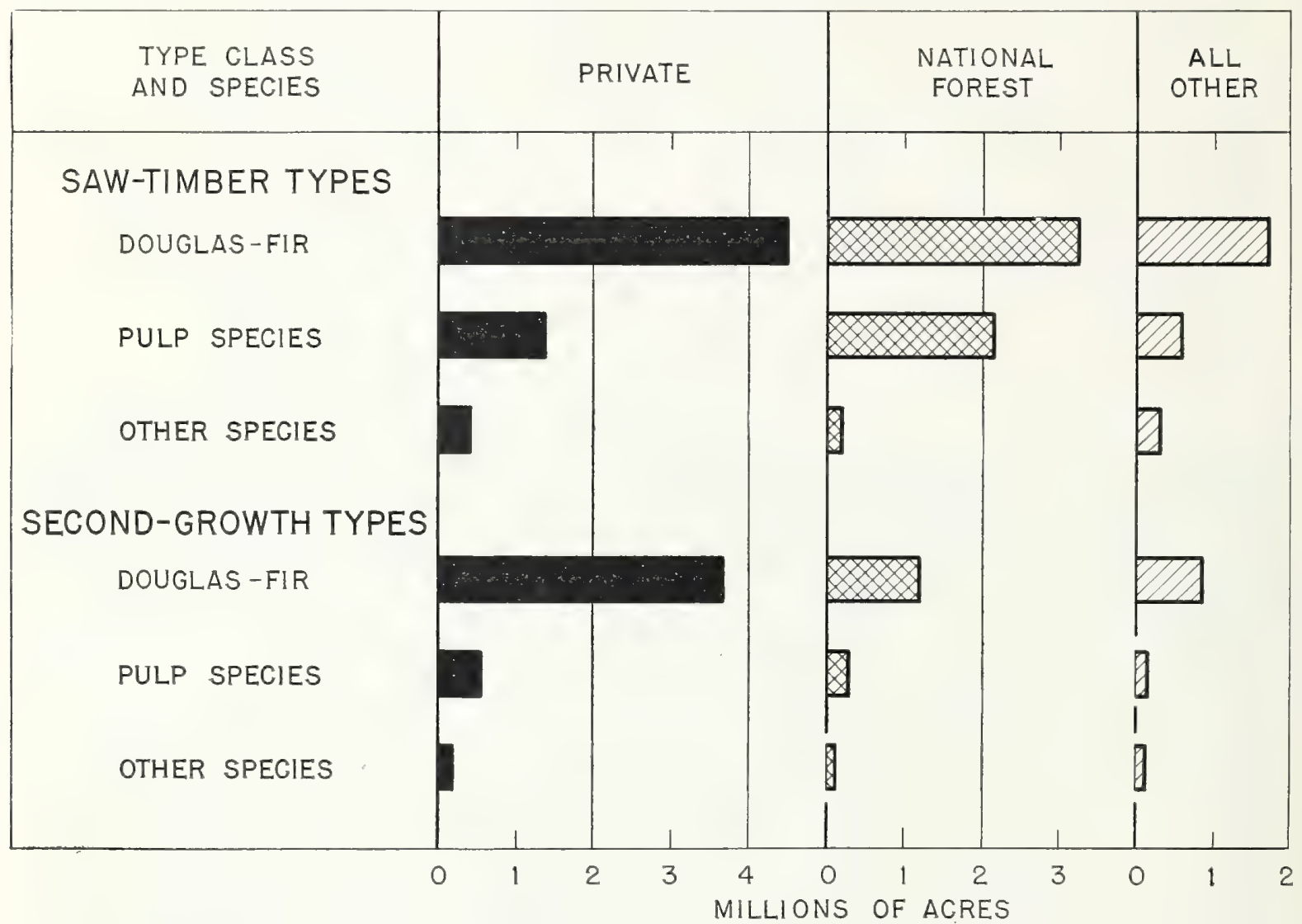

FIGURE 7.-Areas of saw-timber and second-growth types in the Douglas-fir region, by ownership class. 
cutting railroad ties. Most of the pole and piling material produced in the region is derived here. The comparative accessibility of a large portion of the area accounts for much of the premature logging of these young stands.

\section{MISCELLANEOUS SAWLOG TYPES}

Of the other sawlog types the most important is western redcedar (17), occurring almost exclusively in western Washington, in low, moist situations, rarely in pure stands. Much of the early logging in the Puget Sound district was in this type, and logging in it is still extensive.

The large Port Orford white-cedar type (18) occupies less than 39,000 acres, all in southwestern Oregon. The stands are seldom pure, the usual associate being Douglas-fir. Because of its high stumpage value this type has been actively exploited in recent years. Most of the cutting has taken only the "cedar."

Next in importance to the "cedar" types are the large ponderosa and sugar pine types (20 and 20A). These are practically restricted to the Rogue River and Umpqua River units, where they have considerable commercial importance. Their stand volume is usually much less than that of the types previously discussed, ranging from about 5,000 to 30,000 board feet per acre and averaging about 15,000 feet.

The large white fir-larch-Douglas-fir type (27) is unimportant west of the Cascade divide, and the redwood type (32) is restricted to a few acres in extreme southwestern Oregon.

\section{PULPWOOD TYPES}

The pulpwood types are composed of the large spruces, hemlocks, and balsam firs, which at present find their chief use for this purpose.

Of these types, which occupy in all 4.1 million acres, large western hemlock (type 14) is the most widespread, since it is found at practically all elevations within the range of commercial forest growth (sea level to about 4,000 to 5,000 feet elevation) and almost throughout the length of the region (fig. 8). Eighty-five percent of its area, however, is in two large belts in western Washington extending the length of the State, one a coastal belt about 20 miles wide and the other along the

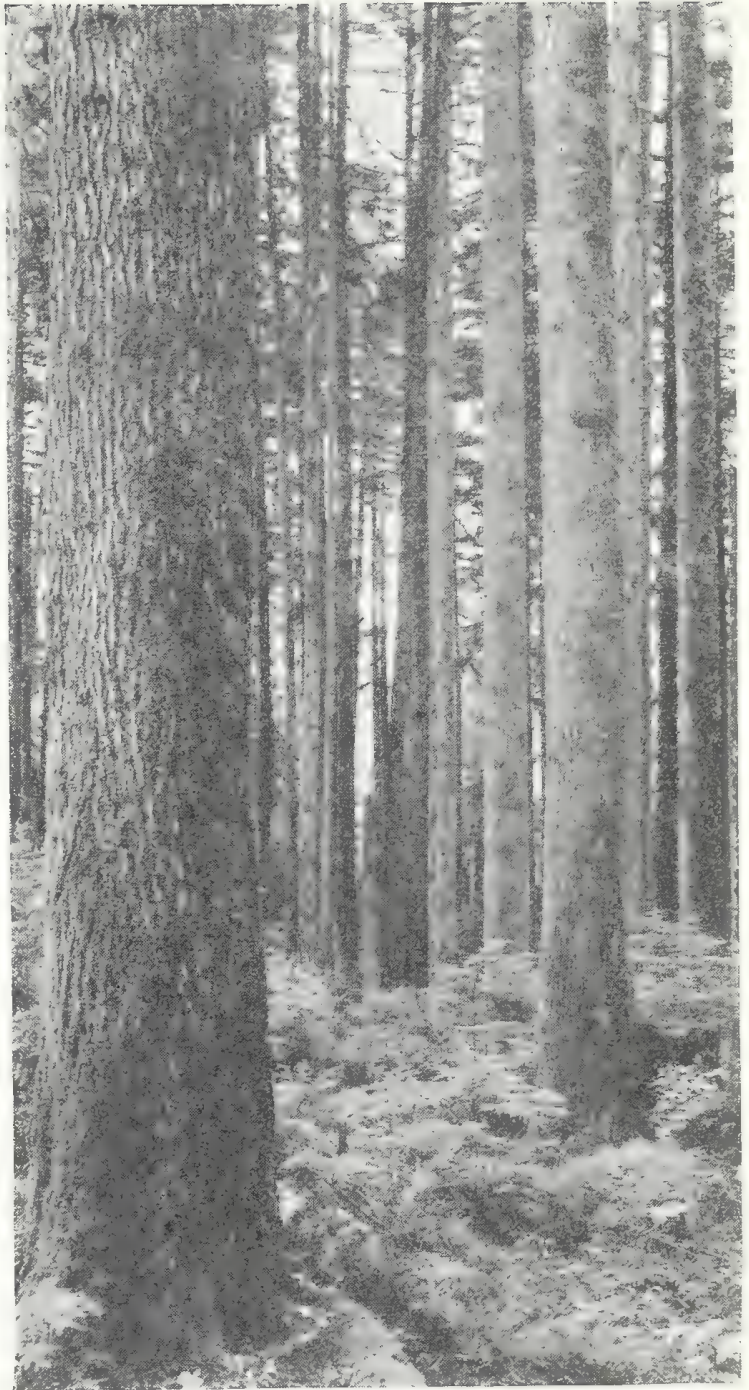

F320956

Figure 8.-Western hemlock, the Douglas-fir region's chief pulp species, extensive stands of which occur along the coast and on the upper slopes of the Cascade Range. The region has 105 billion board feet of this species

upper slopes of the Cascade Range between the Douglas-fir and balsam fir-mountain hemlock zones. The type has been little exploited except at the low elevations accessible to tidewater. Some stands are as much as 40-percent Douglas-fir and are logged primarily for that species.

The next most prevalent pulpwood type is the large fir-mountain hemlock (type 23), the principal constituents of which are Pacific silver fir, noble fir, Shasta red fir, mountain hemlock, western hem- 
lock, and Engelmann spruce. This type occurs commonly at the higher elevations of the Cascade Range and Olympic Mountains and occasionally at the extreme elevations of the Coast Range. Because of its comparative inaccessibility and the unsuitability of its constituent species for sawlogs, it has little present commercial value and practically no logging is taking place in it. Future exploitation will probably be almost exclusively for pulpwood.

The larger Sitka spruce type (11) occurs only in a coastal belt rarely more than 10 miles wide. The common associates are western hemlock, western redcedar, and Douglas-fir. Although its acreage is relatively small, this type has been logged extensively for sawlogs and pulpwood. During the
World War much of the type 11 area was partially logged for airplane spruce.

White fir (type 29) occurs on a small area only. More than three-quarters of the area is in southern Oregon. The remainder is principally in stream bottoms in small patches rarely exceeding 80 acres. Large white fir is occasionally cut for pulpwood by farmers and woodcutters.

\section{Conifer Types Less Than Sawlog Size}

Immature stands consisting chiefly of trees below sawlog size cover 7 million acres. The continued growth of these stands and their protection against fire and premature cutting are most essential for the future saw-timber supply. Table 4 and figure 9 show their area, by age and stocking.

TABLE 4.--Area of certain immature conifer forest types in the Douglas-fir region, by age class and degree of stocking, 1933

\begin{tabular}{|c|c|c|c|c|c|c|c|c|c|}
\hline Type and age class (years) & $\begin{array}{l}\text { Good } \\
\text { stocking }\end{array}$ & $\begin{array}{l}\text { Medium } \\
\text { stocking }\end{array}$ & $\begin{array}{l}\text { Poor } \\
\text { stocking }\end{array}$ & $\begin{array}{c}\text { All stock- } \\
\text { ings }\end{array}$ & Type and age class (years) & $\begin{array}{l}\text { Good } \\
\text { stocking }\end{array}$ & $\begin{array}{l}\text { Medium } \\
\text { stocking }\end{array}$ & $\begin{array}{c}\text { Poor } \\
\text { stocking }\end{array}$ & $\begin{array}{l}\text { Ail stock- } \\
\text { ings }\end{array}$ \\
\hline Douglas fir, small second & & & & & Western hemlock, small: & 1,000 acres & 1,000 acres & $\mid 1,000$ acres $\mid$ & 1,000 acres \\
\hline growth: & 1,000 actes & 1,000 acres 1 & 1,000 acres & 1,000 acres & $20 \ldots \ldots$ & 14.3 & 9.3 & .3 & 23.9 \\
\hline 20 & 60.9 & 88. 7 & 24.6 & 174.2 & $30 \ldots \ldots$ & 60.4 & 44.0 & 4. 3 & 108.7 \\
\hline 30 & 348.9 & 385.2 & 72.8 & 806.9 & $40 \ldots \ldots$ & 51.2 & 28.3 & 2.3 & 81.8 \\
\hline 40 & 395,4 & 424.6 & 85.4 & 905.4 & $50 \ldots \ldots$ & 16.5 & 11.6 & .9 & 29.0 \\
\hline 50 & 277.3 & 273.5 & 63.2 & 614.0 & $60 \ldots$ & 15.0 & 16.8 & 2.8 & 34.6 \\
\hline $60 \ldots$ & 206.4 & 312.4 & 58.4 & 577.2 & $70 \ldots \ldots \ldots$ & 21.2 & 13. 9 & 5.2 & 40.3 \\
\hline $50 \ldots$ & 190.6 & 198.8 & 24.8 & 414. 2 & $80 \ldots$ & 5.5 & 7.2 & 3.1 & 15.8 \\
\hline $80 \ldots \ldots \ldots$ & 43.0 & 57.4 & 20.5 & 120.9 & $90 \ldots \ldots$ & .8 & 1.1 & .2 & 2.1 \\
\hline $90 \ldots$ & 24.8 & 18.8 & 1.2 & 44. 8 & $100 . \ldots$. & 5.7 & 23.1 & 1,0 & 29.8 \\
\hline $100 \ldots$ & 10.1 & 19.1 & 5.4 & 34.6 & Total & 190. 6 & 155.3 & 20.1 & 366.0 \\
\hline Total.................... & $1,557.4$ & $1,778,5$ & 356.3 & $3,692.2$ & Western hemlock, seedlings and | & & & & \\
\hline $\begin{array}{l}\text { Douglas-fir, seedlings and sap- } \\
\text { lings: }\end{array}$ & & & & & $\begin{array}{c}\text { saplings: } \\
10\end{array}$ & 128,6 & 57.7 & 21.2 & 207.5 \\
\hline $10 \ldots$ & 392.2 & 586.7 & 363.5 & $1,342.4$ & $20 \ldots$ & 15.7 & 10.4 & .7 & 26.8 \\
\hline $20 \ldots$ & 291.2 & 283.8 & 63.4 & 638.4 & $30 \ldots$ & 5.0 & 1.1 & & 6. 1 \\
\hline $30 \ldots \ldots$ & 81.1 & 41.1 & 5.3 & 127.5 & $40 \ldots \ldots$ & 1.3 & .4 & & 1.7 \\
\hline $40 \ldots$ & 1.7 & .1 & $\ldots-$ & 1.8 & $50 \ldots \ldots \ldots$ & .4 & .2 & & .6 \\
\hline 50 & .3 & .1 & . & .4 & $60 \ldots$ & (1) & - & .4 & .4 \\
\hline Total & 766.5 & 911.8 & 432.2 & 2.110 .5 & $70 \ldots$ & (1) & .2 & -..- & .2 \\
\hline Sitka spruce, small: & & & & & Total & 151.0 & 70.0 & 22.3 & 243.3 \\
\hline $20 \ldots \ldots$ & 1.0 & 2.3 & & 3.3 & "Cedar," small: & & & & \\
\hline $30 \ldots$ & 5.1 & 5.2 & .3 & 10.6 & 10 & 2.7 & 2. 6 & 6.1 & 11.4 \\
\hline $40 \ldots$ & 7.6 & 5.3 & .2 & 13. 1 & $20 \ldots$ & 2.9 & 1.7 & .8 & 5.4 \\
\hline 50 & .5 & $\therefore 3$ & .1 & .9 & $30 \ldots \ldots \ldots$ & .8 & .5 & .2 & 1.5 \\
\hline $60, \quad \ldots$ & 6.1 & 5.9 & 1.3 & 13.3 & $40 \ldots$ & 2.3 & .9 & .2 & 3.4 \\
\hline $70 \ldots$ & - & (1) & .2 & .2 & $50 \ldots$ & .6 & 1.0 & .6 & 2.2 \\
\hline $80 \ldots$ & .9 & 1. 3 & 3.2 & 5.4 & $60 \ldots \ldots$ & ... & .3 & (1) & .3 \\
\hline $90 \ldots \ldots$ & -..... & .3 & & .3 & $70 \ldots \ldots$ & $\ldots$ & (1) & & (1) \\
\hline $100 \ldots$ & $\ldots$ & .5 & (1) & .5 & $80 \ldots \ldots$ & .2 & .1 & (1) & .3 \\
\hline Total $\ldots$ & 21.2 & 21.1 & 5.3 & 47.6 & $100 \ldots \ldots$ & .5 & .8 & $\ldots$ & 1.3 \\
\hline $\begin{array}{l}\text { Sitha spruce, seedlings and sap- } \\
\text { lings: }\end{array}$ & & & & & Total & 10.0 & 7. 9 & 7.9 & 25.8 \\
\hline Iings: & .6 & 2.7 & 3.8 & 7.1 & Ponderosa pine, small: 2 & & & & \\
\hline 20 & .6 & 3.4 & .1 & 4.1 & $20 \ldots \ldots \ldots \ldots$ & $\because$ & $\cdots$ & .1 & .1 \\
\hline $30 \ldots$ & .1 & .7 & $\ldots$ & .8 & $30 \ldots$ & 1 & .4 & ..... & .5 \\
\hline Total & 1.3 & 6.8 & 3.9 & 12.0 & $50 \ldots$ & $\begin{array}{l}1.2 \\
2.0\end{array}$ & $\begin{array}{l}2.4 \\
3.6\end{array}$ & $\begin{array}{l}2.9 \\
2.0\end{array}$ & $\begin{array}{l}6.5 \\
7.6\end{array}$ \\
\hline
\end{tabular}

1 Less than 50 acres.

2780 acres of type 21 in Pierce County, Wash., is omitted from this table, as it was classified as uneven-aged. 
TABLE 4.-Area of certain immature conifer forest types in the Douglas-fir region, by age class and degree of stocking, 1933-Continued

\begin{tabular}{|c|c|c|c|c|c|c|c|c|c|}
\hline Type and age class (years) & $\begin{array}{l}\text { Good } \\
\text { stocking }\end{array}$ & $\begin{array}{l}\text { Medium } \\
\text { stocking }\end{array}$ & $\begin{array}{l}\text { Poor } \\
\text { stocking }\end{array}$ & $\begin{array}{l}\text { All stock- } \\
\text { ings }\end{array}$ & Type and age class (years) & $\begin{array}{l}\text { Good } \\
\text { stocking }\end{array}$ & $\begin{array}{l}\text { Medium } \\
\text { stocking }\end{array}$ & $\begin{array}{c}\text { Poor } \\
\text { stocking }\end{array}$ & $\begin{array}{l}\text { All stock- } \\
\text { ings }\end{array}$ \\
\hline Ponderosa pine, small-Con. & 1,000 acres 1 & 1,000 acres & 1,000 acres 1 & 1,000 acres & White-fir - larch - Douglas - fir, & & & & \\
\hline $60 . \ldots$ & 3.3 & 24.3 & 12,3 & 39.9 & small: & 1,000 acres $\mid 1$ & 1,000 acres & 1,000 acres 1 & 1,000 acres \\
\hline $70 \ldots \ldots+1$. & 1.2 & 10.2 & 5.2 & 16. 6 & 10 & $\mid-(-n-1)$ & 1. 1 & & 1.1 \\
\hline 80 & 1. 6 & 2.5 & 1.0 & 5.1 & $20 \ldots$ & 2.4 & 4.0 & 1.3 & 7.7 \\
\hline $90 \ldots$ & .3 & .6 & -1.--- & .9 & $30 \ldots$ & 5.6 & 4.1 & & 9.7 \\
\hline $100 \ldots$ & ..... & & 1.1 & 1.1 & $40 \ldots$ & 1.4 & & & 1.4 \\
\hline & & & & & $50 \_\quad \ldots$ & 7.2 & & & 7.2 \\
\hline \multirow[t]{2}{*}{ Total } & 9.7 & 44.0 & 24.6 & 78.3 & $60 \ldots$ & 3.8 & & & 3.8 \\
\hline & $=$ & $=$ & $=$ & $=$ & Total & 20.4 & 9.2 & 1.3 & 30.9 \\
\hline $\begin{array}{l}\text { Ponderosa pine, seedlings and } \\
\text { saplings: }\end{array}$ & & & & & White fir, small: & & & & \\
\hline $10 \ldots \ldots$ & .2 & 1.9 & 1.0 & 3.1 & 10 & 1.3 & .3 & .4 & 2.0 \\
\hline 20 & 2.7 & 9.9 & 5.4 & 18.0 & $20 \ldots \ldots \ldots$ & .4 & .4 & .1 & .9 \\
\hline 30. & 2.8 & 18.8 & 5.3 & 26.9 & $30 \ldots \ldots$ & .9 & .8 & & 1. 7 \\
\hline 40 & 12.4 & 46.5 & 13.3 & 72.2 & $40 \ldots \ldots \ldots$ & .1 & 1.7 & .1 & 1.9 \\
\hline $50 \ldots$ & 2.2 & 4.3 & 3.4 & 9.9 & $50 \ldots \ldots$ & .3 & 1.4 & .6 & 2.3 \\
\hline $60 \ldots \ldots \ldots$ & 4.9 & 15.0 & 2.8 & 22.7 & $60 \ldots \ldots$ & 1.4 & 1. 3 & $-\cdots$ & 2. 7 \\
\hline \multirow{2}{*}{$80 \ldots \ldots \ldots$} & .2 & 1 & .1 & .4 & $70 \ldots \ldots$ & .7 & .2 & .1 & 1.0 \\
\hline & 25.4 & 965 & 313 & & $90 \ldots$ & -- & & .1 & $\therefore 1$ \\
\hline & 20.4 & 90.0 & 31.5 & 153.2 & $100 \ldots \ldots$ & .4 & 1.3 & -- & 1. 8 \\
\hline \multirow{3}{*}{$\begin{array}{c}\text { Fir-mountain hemlock, small: } \\
10 \\
20\end{array}$} & & & -1 & $==-$ & Total & 5. 5 & 8.1 & 1.4 & 15.0 \\
\hline & 11. 3 & 13. 9 & 34.1 & 59.3 & Total, all types: & & & & \\
\hline & 45. 1 & 46.1 & 9.1 & 100.3 & 10 & 536.9 & 666.9 & 430.1 & $1,633.9$ \\
\hline $30 \ldots$ & 25.7 & 15.9 & 3.3 & 44.9 & $20 \ldots \ldots$ & 437. 2 & 460.0 & 105.9 & $1,003.1$ \\
\hline $40 \ldots$ & 14.1 & 2. 0 & 1.8 & 17.9 & $30 \ldots$ & 536.5 & 517,8 & 91.5 & $1,145.8$ \\
\hline 50 & 7.3 & 1.0 & .1 & 8.4 & $40 \ldots$ & 488.7 & 512.2 & 106.2 & $1,107.1$ \\
\hline $60 \ldots$ & 1.2 & 6.7 & .9 & 8.8 & 50 & 314.6 & 297.0 & 70.9 & 682.5 \\
\hline $70 \ldots$ & 7.0 & $\cdots+$ & -- & 7.0 & $60 \ldots$ & 242.1 & 382.7 & 78.9 & 703.7 \\
\hline $80 \ldots \ldots \ldots$ & 8.4 & 4.8 & $-\cdots$ & 13.2 & $70 \ldots$ & 220.7 & 223.3 & 35.5 & 479.5 \\
\hline $90 \ldots$ & .3 & - ..... & $-\ldots \ldots$ & .3 & $80 \ldots$ & 59.8 & 74.1 & 27.9 & 161.8 \\
\hline \multirow[t]{3}{*}{100} & 1.0 & 12.8 & - & 13.8 & $90 \ldots$ & 26,2 & 20.8 & 1.5 & 48.5 \\
\hline & & & & - & 100 & 17.7 & 57.6 & 7.5 & 82.8 \\
\hline & 121.4 & 103.2 & 49.3 & 273.9 & Total & $2,880,4$ & $3,212.4$ & 955.9 & $7,048.7$ \\
\hline
\end{tabular}

\section{DOUGLAS-FIR SECOND GROWTH}

The small second-growth (9) and seedling and sapling (10) types occupy a total of 5.8 million acres including some of the most favorably located and productive forest land in the region. Stands of these types are almost always even-aged. They are usually pure, averaging from 80 to 90 percent Douglas-fir in the region as a whole.

The small second-growth Douglas-fir occupies 3.7 million acres, mostly old burns. The stands, 6 to 20 inches d. b. h., range from 20 to 120 years in age; on poor sites many stands reach 100 years. Less than half the small second-growth stands are well stocked (table 4). As a general rule those growing on old burns are better stocked than those growing on cut-over land, because practically all cut-over land has been burned over at least once and much of it several times.
The stands on cut-over lands occur chiefly on areas that were logged in the early days of the lumber industry and that are easily accessible from industrial centers. Topography usually permitted cheap logging. Undoubtedly these areas will be logged again before many of the more remote oldgrowth areas. They are being logged already in a small way for poles, piling, fuel wood, and sawlogs. This premature clear cutting of small second growth is a short-sighted practice, but from present indications it will increase. Approximately twothirds of the area involved is privately owned, chiefly by farmers and other local small holders. Such owners usually do not have the resources to carry timber for long periods. How to introduce forest-management practice in these second-growth stands is one of the critical forest problems in this region. 


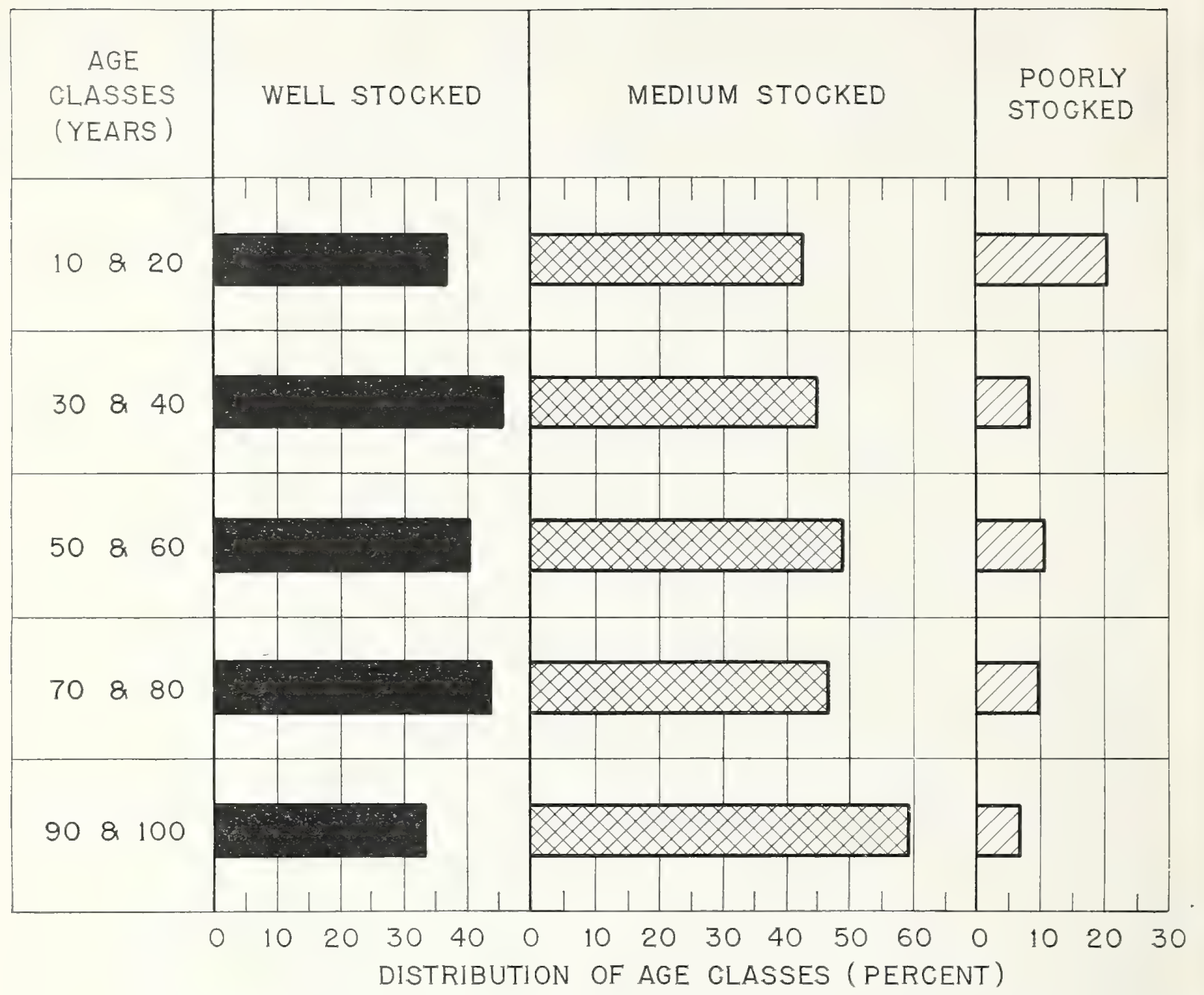

FIGURE 9.- Age class and stocking of immature conifer stands in western Washington and western Oregon

The seedling and sapling stands (less than 6 inches in d. b. h.) range from 1 to about 30 years in age and cover 2.1 million acres; those on a few thousand acres of poor land are as old as 50 years. Roughly half the area of this type has been cut over (fig. 10). The condition of these stands is far from satisfactory; only a little more than a third of the area is well stocked.

\section{SECOND-GROWTH PULPWOOD}

Second-growth Sitka spruce (types 12 and 13) occupies about 60,000 acres. Usually it occurs as mixed stands near the coast and ranges in age from 1 to 100 years. The stands occupy very productive sites, their stocking averages better than that of second-growth Douglas-fir stands, and their yields are higher.

The western hemlock types (15 and 16) are the most important of the second-growth types other than Douglas-fir, and have a total area of 609,000 acres. The stands are usually even-aged and pure in composition. Age, stocking, and site being equal, higher yields are obtained from western hemlock second growth than from Douglas-fir second growth. There has been little cutting on these stands, although in the past few years small areas have been logged from pulpwood.

Balsam fir-mountain hemlock less than 16 inches d. b. h. (type 24) covers 274,000 acres, practically all of which is on old burns at high elevations on 
the national forests. The stands are usually mixed. White fir second growth (type 30) occurs only in small scattered patches.

\section{OTHER SMALL SECOND-GROWTH TYPES}

Second-growth "cedar" (type 19) usually occurs in mixture with Douglas-fir and western hemlock, and seldom occurs in sufficient proportion to be a type. The ponderosa pine second-growth types (21 and 22) are concentrated in the Rogue River unit and are of considerable importance there. Small white fir (28) is confined to the Columbia River units.

\section{Deforested Lands}

More than a tenth of the total forest-land area of the region has been deforested by fire alone or by fire following logging and is now nonproductive.

\section{NONRESTOCKED CUT-OVERS}

Nonrestocked lands cut over before 1920 (type 35) constitute one of the most acute land-use problems in the region. They total 666,000 acres, or about
21 percent of the total area cut over prior to 1920. Approximately 79 percent of the acreage of this type is in western Washington, concentrated in the vicinity of Puget Sound, Grays Harbor, and the Columbia River. Most of it is within 15 miles of one or another of the industrial centers, Seattle, Tacoma, Everett, Portland, and Aberdeen. It formerly supported fine stands of virgin timber, and is very accessible. The present cover consists of shrubs and herbs with a few broadleaf trees and an occasional conifer. Much of the area is covered with bracken. Part of it is grazed, but too intermittently to be considered pasture land. The present condition of this land is not the result of logging alone; most of it, since being cut over, has been burned several times.

In 1934 about 87 percent of this land was private, 4 percent county-owned, and 4 percent Stateowned. (See table 2.) Since then a considerable acreage has been forfeited to the counties for unpaid taxes, and a much larger acreage has become tax delinquent. Instability of ownership adds to the problem that this land presents, and in many

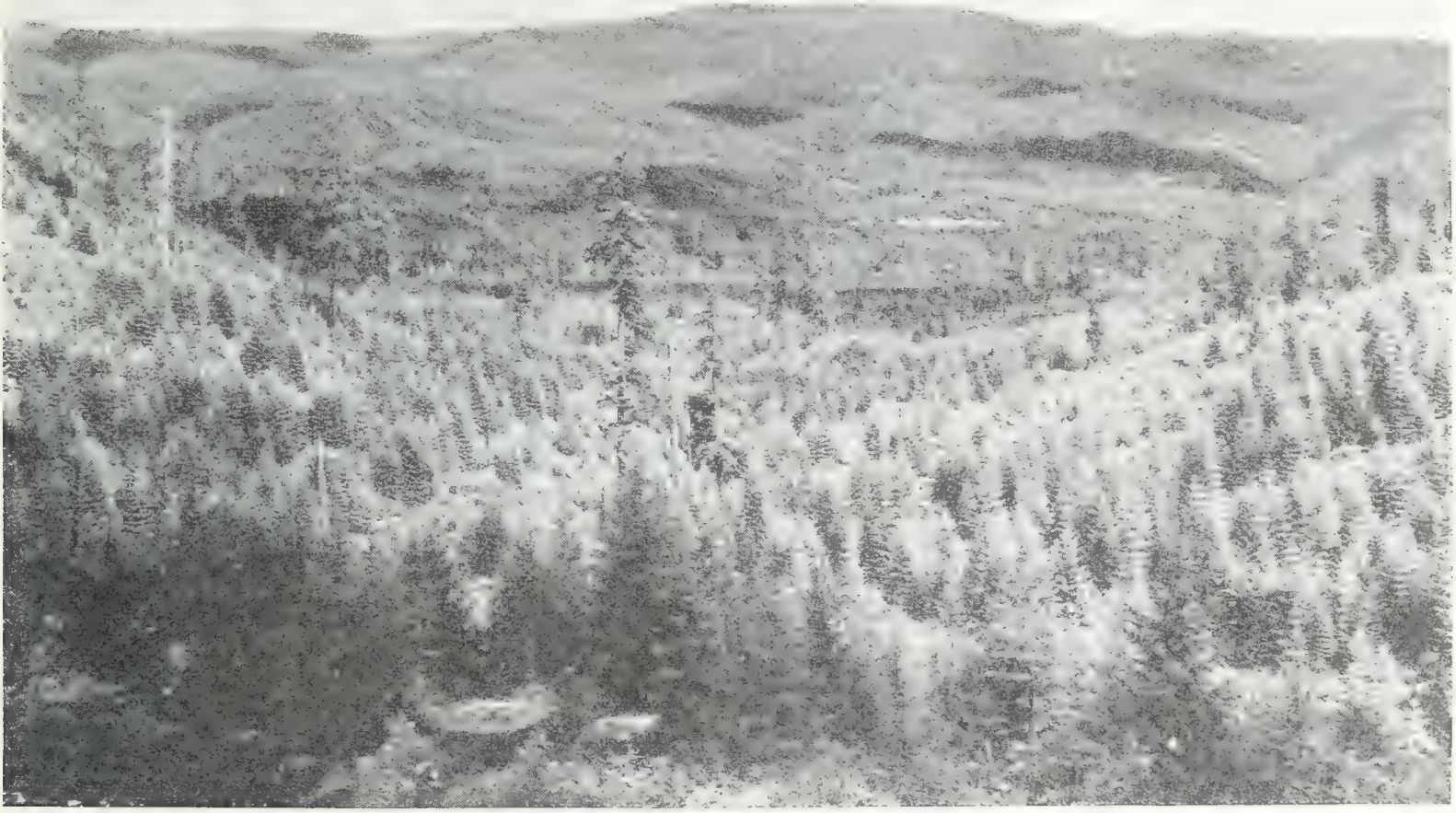

Figure 10.-Clear-cut area in western Oregon that restocked satisfactorily with Douglas-fir about 10 years ago, as a result of adequate seed supply and fire protection. Similar stands were found on more than a million acres of cut-over land in the region. 
cases responsibility for its care and protection is evaded by its owners. Remedial measures to correct this and other critical forest problems are discussed later in the report.

\section{RECENT CUT-OVERS}

Lands that have been cut over since the beginning of 1920 (type 36) total 2,160,000 acres (fig. 11), two-thirds of which is in western Washington. It is all easily accessible, and most of it is near the great waterways of the region, Puget Sound and the Columbia River. In 1934 approximately 84 percent was privately owned and 3 percent countyowned. The county-owned portion has increased greatly since then, and much more has become tax delinquent.

Less than a third of the recently logged land is satisfactorily restocked. Results of a linear survey of the land logged in the 4-year period 1920-23 show that 12 percent of that land is well stocked, 17 percent is medium stocked, 29 percent is poorly stocked, and 42 percent is nonstocked. Since 1923 the seed crops have been poor. It may be assumed that lands logged later than 1923 are in poorer condition than those logged earlier.

The recent cut-over type includes not only some of the most accessible forest land in the region but also some of that having the greatest potential productivity. This potential productivity has been greatly impaired by present practices, which if they continue will bring the forest resources of the region far below what they would have been had this land been permitted to restock promptly and fully. The first and urgently needed step in restoring these lands to a fair degree of productivity is to give them more intensive fire protection.

\section{DEFORESTED BURNS}

The deforested cut-over lands have yielded at least one crop, but $1 \frac{112}{2}$ million acres of land (type 37) has been deforested by fire without having yielded a crop. (A comparatively small percentage of the trees killed by fire have been salvaged.) Part of this area has been burned several times, and each succeeding fire lessened the chance of natural restocking. Part will regenerate naturally in time, but a large part must be planted if it is to become productive without undue delay. A portion has been burned so severely that the in- herent productive capacity of the soil has been considerably reduced by exposure to the elements, and now supports a scanty cover of weeds and shrubs.

Many of the present deforested burns, particularly those in the Oregon Coast Range, supported some of the finest stands in the region. Some areas such as the Tillamook and Wolf Creek burns of 1933 may restock naturally, but had not had time to do so when the survey data were collected. There are other large deforested areas where the original forest was noncommercial or inaccessible.

\section{Woodland and Noncommercial Forests}

Approximately 8 percent of the total forest land in the region, 2,311,000 acres, is woodland and noncommercial forests. Although lands of these classes are not suitable or available for commercial production of timber products, they are valuable for other uses. They protect the headwaters of streams, conserving soil and water, they furnish grazing for stock, and contribute much to the region's scenic attractions. Oak-madrone woodland (type 4) is occasionally cut for cordwood and is extensively grazed. The other types forming this group are lodgepole pine (types 25 and 26), subalpine forests (type 33), and noncommercial rocky areas (type 38).

\section{Hardwood Forests}

Broadleaf or hardwood forests occur infrequently and are very much less important than conifer stands. Less than 3 percent of the forest area in the region is occupied by hardwood forests (type 31) other than oak-madrone woodland. Hardwoods occur mainly on the moist stream-bottom lands; extensive continuous hardwood forests are lacking. The more important broadleaf stands occur in the valleys and on the lower slopes of the Oregon Coast Range and in the vicinity of Puget Sound. The most common species is red alder. It often forms pure forests by seeding in on conifer sites after fire and acts as a rapid-growing temporary cover for the seedling conifers. This dominance persists for a few decades, but ultimately the alder is overtopped by the conifers (fig. 12). Red alder reaches optimum development on the bottom lands and well watered sections of the western slope of the 


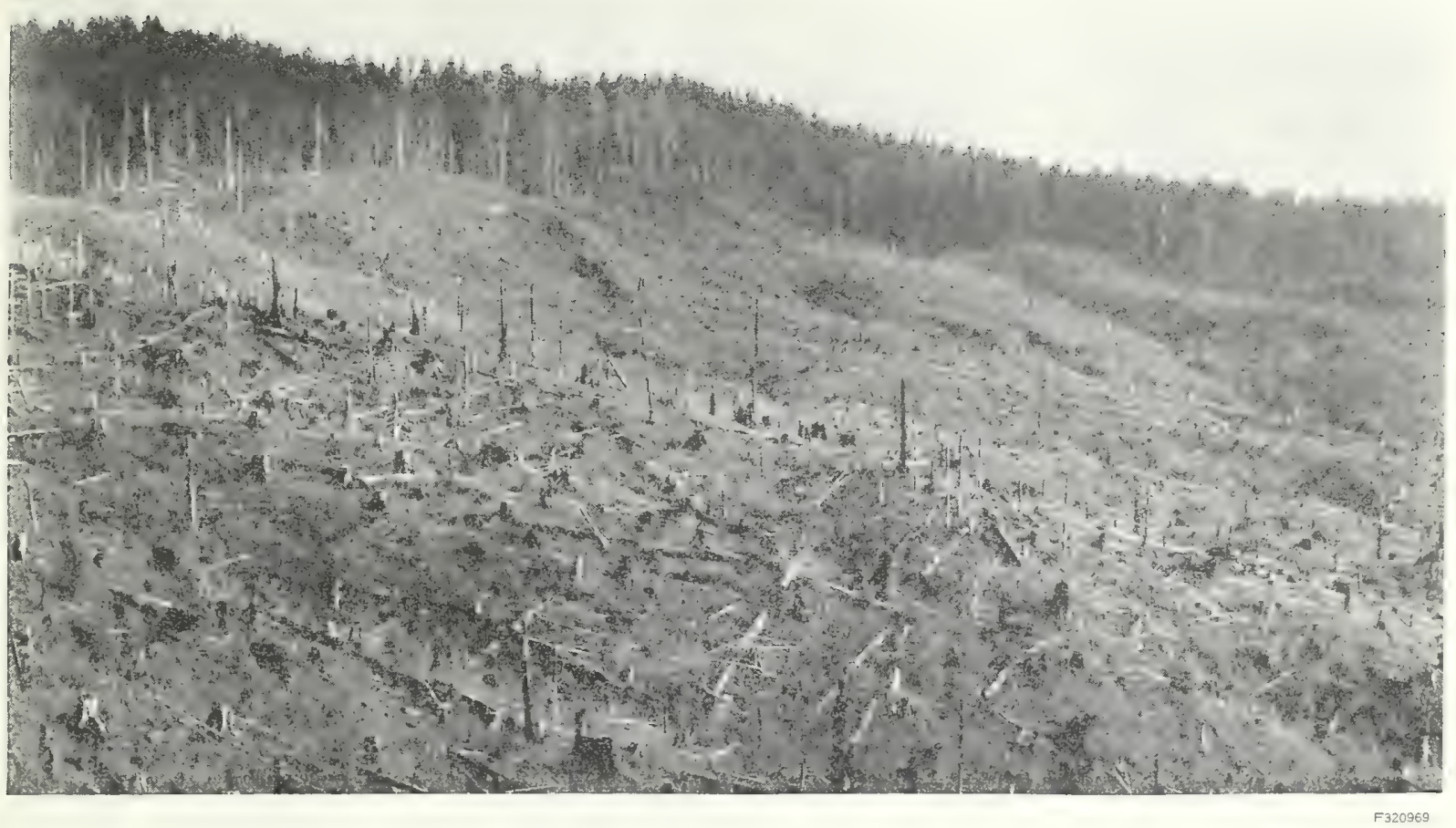

FIGURE 11.-Example, in western Oregon, of the 2,160,000 acres clear-cut in the Douglas-fir region in 1920-33. Most of this total has been slash burned, and much of it has been accidentally reburned. According to forest-survey findings, probably 12 percent of it is well stocked, 17 percent medium stocked, 29 percent poorly stocked, and 42 percent nonstocked.

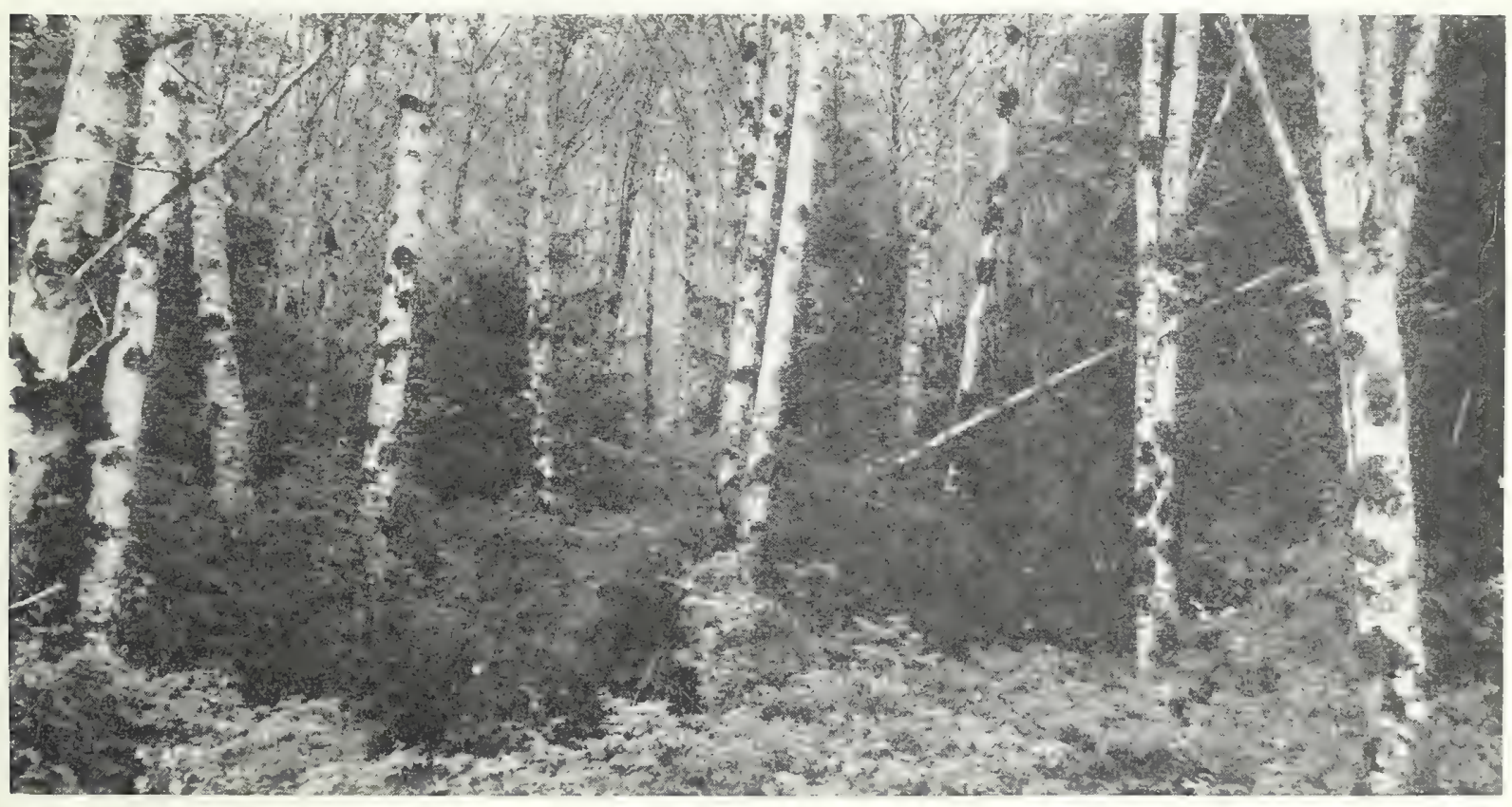

FIGURE 12.--Red alder, the principal hardwood species of the Douglas-fir region. In such stands, which are cut for sawlogs and fuelwood, the conifer understory may be expected eventually to overtop the alder. 
Coast Range in Oregon. Other important broadleaf trees are bigleaf maple, northern black cottonwood, California laurel, and Oregon ash. Bigleaf maple occurs more commonly in mixture or as an understory tree in conifer stands than in pure stands. Northern black cottonwood often forms pure stands on the banks of the larger rivers, on gravel bars, and on river islands.

\section{Forest Site Quality}

The distribution of the 26 million acres of commercial conifer forest land by site-quality classes (p. 12), as in table 5, indicates the relative growth capacity of the region. The Douglas-fir site classification was applied to all this area except about 748,000 acres for which the ponderosa pine classification was used. The area of Douglas-fir site quality I has been greatly reduced by conversion of forest lands to nonforest uses, and by deterioration of lands that were logged at an early period and have been burned frequently. Land of this site class occurs principally on the flats and lower slopes of the Coast Range of southwestern Washington and northwestern Oregon and in the Cascade Range north of the Cowlitz River. It is rarely found in southern Oregon.

The 28 percent of commercial areas in Douglasfir site class II is common to the Coast Range and the lower elevations of the Cascade Range, except in southern Oregon.

Douglas-fir site class III is the most common in this region, including areas of the coarser, shallow soils on mountain slopes. In western Oregon, 46 percent of the total commercial conifer forest land is in this site class and 39 percent in western Washington.

Douglas-fir site class IV includes the areas of shallow, coarse soil with much exposed rock and the drier exposures on the upper slopes of the Cascade Range. Little land of this site class is found in the Coast Range except in southwestern Oregon.

More than a million acres is of site class $\mathrm{V}$, the lowest in the Douglas-fir classification. Class V includes the land bordering subalpine and other noncommercial areas, gravel bars along streams, swampy areas, and exposed rocky ridges. By far
TABLE 5.-Land areas in the Douglas-fir region, forest land areas, and commercial conifer areas, by site-quality class 1

\begin{tabular}{|c|c|c|c|c|}
\hline $\begin{array}{l}\text { Kind of forest and } \\
\text { site-quality class }\end{array}$ & \multicolumn{2}{|c|}{ Total area } & $\begin{array}{l}\text { Area } \\
\text { in } \\
\text { forest } \\
\text { land }\end{array}$ & $\begin{array}{l}\text { Area } \\
\text { in com- } \\
\text { mercial } \\
\text { conifers }\end{array}$ \\
\hline \multicolumn{5}{|l|}{ Commercial conifer: } \\
\hline Douglas-fir: & Acres & Percent & Percent & Percent \\
\hline Class $I_{-\ldots}$ & 520,398 & 1.48 & 1. 79 & 1.99 \\
\hline Class II & $7,224,513$ & 20.57 & 24.91 & 27. 64 \\
\hline Class III. & $11,131,223$ & 31.69 & 38. 38 & 42. 59 \\
\hline Class IV. & $5,424,108$ & 15. 44 & 18. 70 & 20.75 \\
\hline Class V... & $1,086,121$ & 3.09 & 3. 75 & 4. 16 \\
\hline Total . & $25,386,363$ & 72.27 & 87.53 & 97.13 \\
\hline \multicolumn{5}{|l|}{ Ponderosa pine: } \\
\hline Class I & 23,602 & .07 & .08 & .09 \\
\hline Class II_... & 159,781 & .45 & .55 & .61 \\
\hline Class III... & 378,357 & 1.08 & 1. 31 & 1. 45 \\
\hline Class IV ................ & 169,111 & .48 & .58 & .65 \\
\hline Class V..... & 14,657 & .04 & .05 & .06 \\
\hline Class VI $\ldots \ldots . . . . .$. & 2,217 & .01 & .01 & .01 \\
\hline Total _. & 747.725 & 2.13 & 2.58 & 2.87 \\
\hline Total commercial conifer & $26,134,088$ & 74.40 & 90.11 & 100.00 \\
\hline Lodgepole pine & 273,064 & .78 & .94 & \\
\hline Noncommercial rocky.... & 504,355 & 1.43 & 1. $7 \pm$ & 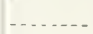 \\
\hline Subalpine & $1,162,882$ & 3. 31 & 4. 01 & \\
\hline Oak-madrone & 364,299 & 1.04 & 1. 26 & ... \\
\hline Hardwood ........ & 556,712 & 1.58 & 1.92 & \\
\hline Pine woodland... & 6,510 & .02 & .02 & \\
\hline Total... & $2,867,822$ & 8.16 & 9.89 & \\
\hline Ail forest types & $29,001,910$ & 82.56 & 100.00 & \\
\hline Nonforest types.......... & 6.125 .539 & 17.44 & -no- & \\
\hline Grand total - & $35,12 \bar{i}, 449$ & 100.00 & & \\
\hline
\end{tabular}

1 Deforested areas, types 35,36 , and 37 , were classified as to site on the basis of original type. For definition of site-quality classes see p. 12.

the greater part of this land is in the Cascade Range and in southwestern Oregon.

Areas of all six of the site classes commonly used in classifying ponderosa pine land were found in this region. The ponderosa pine land in the Douglas-fir region averages about class III, whereas that in eastern Oregon and eastern Washington averages about class IV.

\section{Timber Volume}

The quantity, kind, economic availability, and ownership of the timber of the Douglas-fir region are matters of national as well as regional importance. The largest remaining stand of old-growth timber in the United States is here. According to 
conservative estimates the national total of sawtimber volume is 1,764 billion board feet lumber tally, and the national total volume of all trees, both saw timber and smaller, is 519 billion cubic feet. This region's saw-timber volume, converted to lumber tally, ${ }^{7}$ is approximately 628 billion board feet, or 36 percent of the national total, and its cubic timber volume is 129 billion feet, or 25 percent of the national total. The way in which this enormous volume, particularly its old-growth component, is cut and marketed will influence forest management in every other forest region of the United States. Under current economic conditions, only about half of this volume is available for exploitation.

\section{Saw-Timber Volume}

All but a small volume of material cut is derived from trees of sawlog size. All the lumber, shingles, and plywood, practically all the pulpwood, and a large proportion of the fuel wood, piling, and other timber products are cut from trees of sawlog size.

Nearly half the total volume of the 24 conifer and 12 hardwood species of the region's saw timber is privately owned (table 7)-including more than half the volume of the more valuable species and size classes, such as large old-growth Douglas-fir, Sitka spruce, and Port Orford white-cedar. The next largest portion is on the national forests. Of the 546 billion board feet of all timber, only 4 billion is hardwood. Western Oregon has 55 percent of the total volume and 70 percent of the Douglas-fir volume (table 6).

\section{DOUGLAS-FIR}

Douglas-fir exceeds in total saw-timber volume any other tree species in this country. It attains its best development in western Oregon and Washington and in British Columbia. In size of individual trees and density of stands it is exceeded only by the sequoias. In its physical and mechanical properties Douglas-fir wood is well adapted for a multitude of uses and is pre-eminent for many structural purposes. It is marketed the world over. The principal uses are structural timbers, dimension and yard lumber, flooring, doors, factory lumber, veneer, plywood, piling, and ties.

7 Saw-timber volume is shown in lumber tally in the Appendix, p. 162.
Douglas-fir constitutes approximately 61 percent of the saw-timber volume of this region. In spite of the concentration of logging in the old-growth types, nearly 44 percent of the remaining Douglasfir volume (331.4 billion board feet) is in oldgrowth trees more than 40 inches in d. b. h.; and of this, nearly half is in the four most southerly Oregon survey units, the Willamette River, Umpqua River, south Oregon coast, and Rogue River. This size class includes the fine-grained, slowgrowing "yellow fir" from which is produced by far the greater part of the region's output of clear lumber, veneer, and plywood. Approximately 62 percent of this volume in the region is privately owned. Of the 54.6 billion board feet of this class

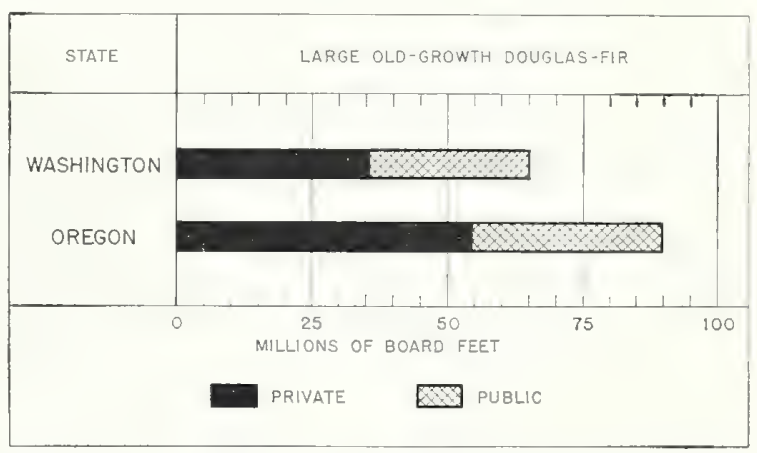

Figure 13.--In both Washington and Oregon nearly two-thirds of the valuable "yellow fir," or large old-growth Douglas-fir, is in private ownership.

of timber in western Washington, 65.1 percent is privately owned (fig. 13); of the 89.9 billion board feet in western Oregon, 60.8 percent is privately owned.

Almost a third of the total Douglas-fir volume is in the class of slower-growing, small old-growth trees (22 to 40 inches in d. b. h.). Although it produces some clear lumber, this class as a rule is much inferior in quality to large old growth. Most of its volume is in the Cascade Range in Oregon, at higher elevations and on poorer sites than the larger class. Less than a third of it is privately owned, and more than half is on the national forests.

The small old-growth stumpage, all factors other than size being equal, usually sells for a lower price than that of the larger class; but much of this which is most accessible brings a premium for conversion to piling and structural timbers. Small old-growth timber seldom produces peeler-grade logs; this is 
TABLE 6.- Folume of timber log scale, Scribner rule, in the Douglas-fir region, by species, State, and forest-survey unit, 1933 [In million board feet-i. e., 000,000 omitted]

\begin{tabular}{|c|c|c|c|c|c|c|c|}
\hline \multirow[b]{2}{*}{ Species } & \multirow[b]{2}{*}{$\begin{array}{l}\text { Total for } \\
\text { region }\end{array}$} & \multicolumn{6}{|c|}{ Western Washington } \\
\hline & & $\begin{array}{l}\text { North } \\
\text { Puget } \\
\text { Sonnd }\end{array}$ & $\begin{array}{l}\text { Central } \\
\text { Puget } \\
\text { Sound }\end{array}$ & $\begin{array}{l}\text { South } \\
\text { Puget } \\
\text { Sound }\end{array}$ & $\begin{array}{l}\text { Grays } \\
\text { Harbor }\end{array}$ & $\begin{array}{c}\text { Colum- } \\
\text { bia River }\end{array}$ & Total \\
\hline \multicolumn{8}{|l|}{ Douglas-fir: } \\
\hline Large old growth & $144,456,4$ & $5,208.1$ & 14. 243.3 & 12.461 .7 & $8,912.0$ & $13,735.3$ & $54,560.4$ \\
\hline Small old growth & $101,378.5$ & $2,104.6$ & 10.131 .7 & $4,099.8$ & $1,031.0$ & 2.584 .9 & $19,952.0$ \\
\hline Large second growth & $68,271.5$ & $2,139.6$ & 3. 233.7 & 8. 029.0 & $1,115.2$ & 4.653 .3 & $19,170.8$ \\
\hline Small second growth & $17,246.6$ & 544.3 & $1,456.0$ & $1,246.3$ & 166. 5 & 2.306 .6 & $5,719.7$ \\
\hline \multicolumn{8}{|l|}{ Western hemlock: } \\
\hline Large & $91,651.6$ & $12,335.2$ & $24,917.1$ & $6,034.6$ & $19,906.6$ & $6,525.9$ & $69,719.4$ \\
\hline Small .... & $12,908,2$ & $1,921.5$ & $2,404.5$ & $1,016.3$ & $3,879.4$ & $1,031.5$ & $10,253.2$ \\
\hline \multicolumn{8}{|l|}{ Sitka spruce: } \\
\hline Large ..... & $10,828.7$ & 124.2 & $1,848.2$ & 68.7 & $3,939.4$ & 227.7 & $6,208.2$ \\
\hline Small & 856.9 & 11.0 & 9.9 & & 463.9 & 35.8 & 520.6 \\
\hline Western redcedar, live & $24,659.3$ & $5,308.9$ & $5,203.2$ & $2,169.0$ & $5,666.5$ & $1,744.5$ & $20,092.1$ \\
\hline \multicolumn{8}{|l|}{ Port Orford white-cedar: } \\
\hline $\begin{array}{l}\text { Lire . } \\
\text { Dead . }\end{array}$ & $\begin{array}{r}1,174.0 \\
24.8\end{array}$ & & & & & & \\
\hline Alaska yellow-cedar, lire & 547.7 & 150.9 & 259.5 & 85.7 & 20.8 & 18. 6 & 535,5 \\
\hline California incense-cedar, live & $1,788.5$ & & & & & & \\
\hline Other "cedar", dead. & $1,064.8$ & 430.8 & 106.6 & 95.7 & 314.7 & 21.2 & 969.0 \\
\hline \multicolumn{8}{|l|}{ Balsam firs: } \\
\hline White and grand & $6,385.3$ & 34.8 & 43.2 & 294,4 & 354,2 & 138. 7 & 865.3 \\
\hline Noble and Shasta red.. & $8,676.6$ & .9 & 951.1 & 791.7 & 21.5 & 994.0 & $2,759.2$ \\
\hline Pacific silver & $32,924.5$ & $7,911,7$ & $8,972.2$ & $2,410.5$ & $6,759.3$ & $3,829.5$ & 29.883 .2 \\
\hline Alpine & 99. 0 & 4.2 & 25.1 & 4.2 & & (1) & 33.5 \\
\hline \multicolumn{8}{|l|}{ Ponderosa and sugar pine: } \\
\hline Large ponderosa (and Jeffrey) & $4,491.9$ & (1) & & & & 98.4 & 98.4 \\
\hline Small ponderosa (and Jeffrey) & 449.5 & & 2.3 & & & & 2.3 \\
\hline Sugar. & $3,553.1$ & & $\ldots . .$. & .... & & & 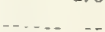 \\
\hline \multicolumn{8}{|l|}{ Other conifers: } \\
\hline Engelmann spruce_. & 223.0 & .1 & .5 & 1.4 & & 32.0 & 34.0 \\
\hline Mountain hemlock & $5,390.3$ & 612.3 & 444,6 & 199.7 & 56.5 & 80.3 & $1,393.4$ \\
\hline Western white (and whitebark) pine & $2,819.5$ & 184.7 & 523. 1 & 162.0 & 139.5 & 488.4 & $1,497.7$ \\
\hline Lodgepole (and knobcone) pine & 81.3 & .2 & 4.5 & 2 & .4 & .4 & 5.7 \\
\hline Redwood & 57.4 & & & & & & \\
\hline Western larch & 126.7 & & & & & 26.5 & 26,5 \\
\hline \multicolumn{8}{|l|}{ Hardwoods: } \\
\hline Red alder & $2,050.5$ & 96.2 & 148.8 & 38.0 & 173.0 & 97.7 & 553.7 \\
\hline Bigleaf maple & 735.2 & 44. 3 & 33.0 & 121.0 & 39.1 & 8.9 & 246.3 \\
\hline Black cottonwood (and aspen) & 273.5 & 63,4 & 26. 1 & 11.5 & 13. 1 & 29.0 & 143.1 \\
\hline Oregon white oak & 88.3 & & & & & & \\
\hline California black oak.... ...... & 63.6 & & (N) & & & & - \\
\hline Canyon live oak & 3. 3 & & ... & & & & \\
\hline Tanoak ............... & 439.5 & & & & $\ldots . . . .$. & & - \\
\hline Madrone ... & 247.1 & & - . & & & & \\
\hline Oregon ash & 45.4 & .2 & 3.2 & 6.9 & & 1.3 & 11.6 \\
\hline California laurel & 58.8 & & & $\ldots . .$. & & & \\
\hline Chinquapin & 66.9 & & & & & & \\
\hline Western and northwestern paper birch. & 2 & 2 & ...... & & & (n) & .2 \\
\hline Total & $546,207.9$ & $39,232.3$ & $74,991.4$ & $39,348.3$ & $52,972,6$ & $38,710.4$ & $245,255,0$ \\
\hline
\end{tabular}

1 Less than 50,000 board feet. 
TABLE 6. - Volume of timber, log scale, Scribner rule, in the Douglas-fir region, by species and ownership class, 1933-C Continued [In milion board feet-i. e. 000,000 omitted]

\begin{tabular}{|c|c|c|c|c|c|c|c|}
\hline \multirow[b]{2}{*}{ Species } & \multirow[b]{2}{*}{$\begin{array}{c}\text { Colum- } \\
\text { bia River }\end{array}$} & \multicolumn{6}{|c|}{ Western Oregon } \\
\hline & & $\begin{array}{l}\text { Willa- } \\
\text { mette } \\
\text { Rirer }\end{array}$ & $\begin{array}{l}\text { North } \\
\text { Oregon } \\
\text { coast }\end{array}$ & $\begin{array}{c}\text { Umpqua } \\
\text { River }\end{array}$ & $\begin{array}{l}\text { South } \\
\text { Oregon } \\
\text { coast }\end{array}$ & $\begin{array}{l}\text { Rogue } \\
\text { River }\end{array}$ & Total \\
\hline \multicolumn{8}{|l|}{ Douglas-fir: } \\
\hline Large old growth .... & $10,373.0$ & $35,783.0$ & $8,033.7$ & $16,240.8$ & $15,198.6$ & $4,266.9$ & $89,896,0$ \\
\hline Small old growth & $9,889.1$ & $29,729.8$ & $1,713.2$ & $22,516.4$ & $8,425.6$ & $9,152.4$ & $81,426,5$ \\
\hline 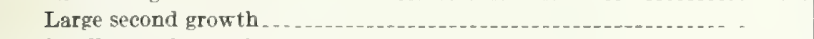 & $3,732.6$ & $16,018.6$ & $8,421.3$ & $12,394.1$ & $7,533.8$ & $1,000.3$ & $49,100,7$ \\
\hline Small second growth... ... & 966. 7 & $3,796.5$ & 599.6 & $3,029.8$ & $2,276.4$ & 857.9 & $11,526.9$ \\
\hline \multicolumn{8}{|l|}{ Western hemlock: } \\
\hline Large . . . . . . & $7,311.1$ & $8,370.9$ & $4,458.5$ & 812.9 & 905.2 & 73. 6 & $21,932.2$ \\
\hline Small & $1,085.9$ & 929. 3 & 466.1 & 90.5 & 75.0 & 8. 2 & $2,655.0$ \\
\hline \multicolumn{8}{|l|}{ Sitka spruce: } \\
\hline Large. . . . . & $1,216.9$ & 6.1 & $2,114,6$ & & $1,282.9$ & & $4,620.5$ \\
\hline Small & 21. 0 & .2 & 261.4 & & 53.7 & & 336.3 \\
\hline \multicolumn{8}{|l|}{ Western redcedar: } \\
\hline Live........ & $1,070.8$ & $1,879.0$ & 723.7 & 487.3 & 406.4 & & $4,567.2$ \\
\hline Dead & 9.8 & 14.5 & 32.7 & 18.8 & 19. 2 & 8 & 95.8 \\
\hline Port Orford white-cedar: & . & & & & & & \\
\hline Lire................ & $\therefore$ & & & 90.9 & $1,050.5$ & 32.6 & $1,174.0$ \\
\hline Dead & $\ldots$ & ...... & & -.... & 24.8 & & 24.8 \\
\hline Alaska yellow-cedar, live & 5.6 & 6.2 & & 4 & ....- & & 12. 2 \\
\hline California incense-cedar, live & - ..... & 208.2 & & 917.7 & 2.4 & 660.2 & 1, 788. 5 \\
\hline \multicolumn{8}{|l|}{ Balsam firs: } \\
\hline White and lowland white... & 297.5 & 590.0 & 2.8 & $1,380.3$ & 599.0 & $2,650,4$ & $5,520.0$ \\
\hline 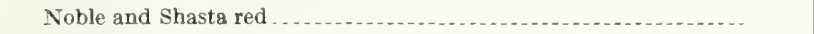 & $1,589.7$ & $1,735.5$ & 348.4 & $1,033.2$ & 26.1 & $1,184.5$ & $5,917.4$ \\
\hline Pacific silver & $1,655.1$ & $1,148.6$ & 136.4 & 101.2 & & & $3,041.3$ \\
\hline Alpine & 38.4 & 27.0 & & .1 & & & 65. 5 \\
\hline \multicolumn{8}{|l|}{ Ponderosa and sugar pine: } \\
\hline Large ponderosa (and Jeffrey) & 55.8 & 67.7 & & 737.7 & 27.4 & $3,504.9$ & $4,393,5$ \\
\hline Small ponderosa (and Jeffrey) & & 2. 2 & & 34.8 & 2.8 & 407.4 & 447.2 \\
\hline Sugar & $-\ldots---1$ & 168. 2 & & $1,110.4$ & 147.1 & $2,127.4$ & $3,553.1$ \\
\hline \multicolumn{8}{|l|}{ Other conifers: } \\
\hline Engelmann spruce......... & 130.7 & 43.8 & & .4 & 1.1 & 13. 0 & 189.0 \\
\hline Mountain hemlock & 692.6 & $2,484.1$ & & 819.7 & $-\ldots$ & .5 & $3,996.9$ \\
\hline Western white (and whitebark) pine... & 236.1 & 474.2 & .5 & 357.2 & .5 & 253. 3 & $1,321.8$ \\
\hline Lodgepole (and knobcone) pine & 6.5 & 63.3 & .2 & 3.0 & 1.8 & .8 & 75.6 \\
\hline Redwood & $\ldots$ & -...... & & $\cdots$ & 57.4 & & 57.4 \\
\hline Western larch. & 99.3 & .9 & & & & & 100.2 \\
\hline \multicolumn{8}{|l|}{ Hardwoods: } \\
\hline Red alder ............ & 56.4 & 115.4 & 961.6 & 57.2 & 305.9 & .3 & $1,496.8$ \\
\hline Bigleaf maple & 32.8 & 242.3 & 15. 3 & 75.6 & 122.7 & .2 & 488.9 \\
\hline Black cottonwood (and aspen) & 53.6 & 71.5 & ............. & .3 & .9 & 4. 1 & 330. 4 \\
\hline Oregon white oak... & 1. 2 & 22.5 & & 45.8 & 2.8 & 16. 0 & 88.3 \\
\hline California black oak $\quad \ldots$. & $-\ldots$ & ........ & .......... & 30.4 & 5.4 & 27.8 & 63.6 \\
\hline Canyon live oak ... . . . . & .. & $\ldots$ & $\ldots$ & .. & .3 & 3.0 & 3.3 \\
\hline Tanoak . . . . . & $\ldots$ & - & & & 433.6 & 5.9 & 439.5 \\
\hline 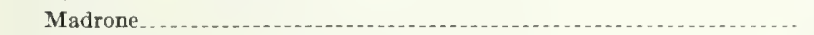 & ....... & $\ldots . . .$. & $\ldots$. & 214.3 & 26.3 & 6.5 & 247.1 \\
\hline Oregon ash. & 5.4 & 25. 7 & ........ & 1.7 & .2 & .8 & 33.8 \\
\hline California laure] & ............... & ...... & & $\ldots$ & 58.8 & $\ldots$ & 58.8 \\
\hline Chinquapin & $\ldots$ & $-\ldots . .$. & & 53.4 & 12. 7 & .8 & 66.9 \\
\hline \multicolumn{8}{|l|}{ Western and northwestern paper birch } \\
\hline Total. . & $40,633.6$ & $104,025.2$ & $28,290.0$ & $62,656.3$ & $39,087.3$ & $26,260.5$ & $300,952.9$ \\
\hline
\end{tabular}


TABLE 7.-Volume of timber, log scale, Scribner rule, in the Douglas-fir region, by species and ownership class, 1933

[In million board feet-i, e. 000,000 omitted]

\begin{tabular}{|c|c|c|c|c|c|c|c|c|c|c|c|c|}
\hline \multirow{3}{*}{ Species } & \multirow{3}{*}{$\begin{array}{c}\text { Privately } \\
\text { owned }\end{array}$} & \multicolumn{2}{|c|}{ State owned } & \multirow{3}{*}{ County } & \multirow{3}{*}{$\begin{array}{c}\text { Muni- } \\
\text { cipal }\end{array}$} & \multicolumn{6}{|c|}{ Federally owned or managed } & \multirow{3}{*}{ Total } \\
\hline & & \multirow[b]{2}{*}{$\begin{array}{l}\text { Avail- } \\
\text { able }\end{array}$} & \multirow{2}{*}{$\begin{array}{c}\text { Re- } \\
\text { served }\end{array}$} & & & \multirow{2}{*}{ Indian } & \multirow{2}{*}{$\begin{array}{l}\text { Re- } \\
\text { served } \\
\text { grant } \\
\text { land }\end{array}$} & \multicolumn{3}{|c|}{ National forest } & \multirow[b]{2}{*}{ Other ${ }^{1}$} & \\
\hline & & & & & & & & $\begin{array}{c}\text { Avail- } \\
\text { able }\end{array}$ & $\begin{array}{c}\text { Re- } \\
\text { served }\end{array}$ & $\begin{array}{l}\text { State } \\
\text { selec- } \\
\text { tion }\end{array}$ & & \\
\hline \multicolumn{13}{|l|}{ Douglas-fir: } \\
\hline Large old growth & $90,233.7$ & $4,776.8$ & 42.0 & 828.0 & 242.7 & 255.4 & $15,813.4$ & $28,909.4$ & $1,940.7$ & 19.6 & $1,394.7$ & $144,456.4$ \\
\hline Small old grow th & $31,225.7$ & $1,259.1$ & 12.9 & 474.5 & 246.9 & 31.1 & $11,028,8$ & $55,195.9$ & 876.8 & .8 & $1,026.0$ & $101,378.5$ \\
\hline Large second growth... & $34,334.7$ & $1,593,9$ & 35.2 & 701,3 & 31.5 & 107.5 & $9,740.8$ & $21,223,4$ & 81.2 & .6 & 421.4 & $68,271.5$ \\
\hline Small second growth & $11,012.3$ & 740.4 & 14.6 & 309.8 & 26.7 & 43.1 & $2,290.8$ & $2,536.2$ & 3.3 & .2 & 269.2 & $17,246.6$ \\
\hline \multicolumn{13}{|l|}{ Western hemlock: } \\
\hline Large & $45,340.4$ & $7,482.0$ & 20.8 & 613.2 & 378. 6 & $1,385.8$ & $1,135.4$ & $31,406.4$ & $1,614,2$ & 20.1 & $2,254.7$ & $91,651,6$ \\
\hline Small & $6,790.3$ & $1,026.7$ & 2.4 & 112.2 & 16. 1 & 122.9 & 125.4 & $4,317.0$ & 229.8 & 2.2 & 163.2 & $12,908,2$ \\
\hline \multicolumn{13}{|l|}{ Sitka spruce: } \\
\hline Large..... & $7,934,1$ & 752.1 & 10. 2 & 98.6 & 8.8 & 461.9 & .1 & $1,357.4$ & 65.6 & .2 & 139.7 & $10,828.7$ \\
\hline Small & 702.3 & 31.1 & .8 & 15.4 & .2 & 55.7 & & 42.8 & & & 8. 6 & 856.9 \\
\hline \multicolumn{13}{|l|}{ Western redcedar: } \\
\hline Live........ & $12,926.2$ & $2,339.1$ & 8.7 & 171.1 & 65.9 & $1,183.3$ & 518.1 & $6,751,8$ & 471.1 & 13.6 & 210.4 & $24,659.3$ \\
\hline Dead _........... & 423.0 & 118.8 & $-\cdots$ & 4.5 & 2.3 & 197.9 & 10.2 & 298.7 & 6. 3 & 2. 2 & .9 & $1,064.8$ \\
\hline Port Orford white-cedar: & & & & & & & & & & & & \\
\hline Live . ...... ... & 789.3 & 1.6 & .3 & 5.9 & .1 & 1.4 & 186. 1 & 187.6 & .1 & & $\cdot 1.6$ & $1,174.0$ \\
\hline Dead ... . . . . . & 22.2 & 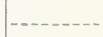 & -...- & $(2)$ & -... & $\ldots$ & 2.0 & .6 & $-\ldots-$ & & -...-. & 24.8 \\
\hline Alaska yellow-cedar, live & 89.7 & 5.2 & $-\cdots$ & .2 & 1 & $\ldots$ & 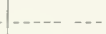 & 350.0 & 14.4 & 1.4 & 86.7 & 547. 7 \\
\hline California incense-cedar, live & 759.3 & .5 & $\left({ }^{2}\right)$ & 23.5 & .6 & .8 & 458. 4 & 539.1 & $(2)$ & & 6. 3 & $1,788.5$ \\
\hline Balsam firs: & & & & & & & & & & & & \\
\hline White and grand & $2,241.7$ & 60.6 & .3 & 26. 9 & 1.9 & 6.8 & $1,016.5$ & $2,998.1$ & 16.1 & & 16.4 & $6,385.3$ \\
\hline Noble and Shasta red. & $2,082.7$ & 179. 6 & 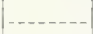 & 15.5 & 59.7 & $(2)$ & 179.4 & $5,647.9$ & 387.8 & & 124.0 & $8,676.6$ \\
\hline Pacific silver & $8,276.0$ & $3,150.7$ & 10.6 & 123.8 & 273.6 & 446.9 & 2.1 & $17,882.2$ & $1,054.7$ & 13.9 & 1.690 .0 & $32,924,5$ \\
\hline Alpine & 11. 7 & & -..... & .1 & -..--- & - n-.-- & -...- & 51. 6 & 30.9 & & 4.7 & 99.0 \\
\hline Ponderosa and sugar pine: & & & & & & & & & & & & \\
\hline Large ponderosa (and Jeffrey) & $1,613.5$ & 7.9 & .1 & 77.9 & 6.0 & & $1,749.5$ & 978.3 & 1.1 & & 57.6 & $4,491.9$ \\
\hline Small ponderosa (and Jeffrey) ........ & 196.5 & 1.4 & (2) & 15.5 & .8 & 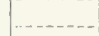 & 144.3 & 76. 7 & ....... & & 14. 3 & 449.5 \\
\hline Sugar & $1,001.4$ & 4.3 & $(2)$ & 42.9 & .7 & $(2)$ & $1,066.1$ & $1, \frac{14}{x} .5$ & $\left({ }^{2}\right)$ & & 23.2 & $3,553.1$ \\
\hline Other conifers: & & & & & & & & & & & & \\
\hline Engelmann spruce & 3.9 & & & & & & & 181.8 & 37.3 & & & -223.0 \\
\hline Mountain hemlock & 201.7 & 20.7 & & 1.4 & .2 & -...- & .1 & $4,775.4$ & 287.6 & 1,1 & 102.1 & $5,390.3$ \\
\hline Western white (and whitebark) pine & 323.9 & 97.0 & $-\ldots$ & 3.6 & 15.1 & 280 & 18.0 & $2,151.7$ & 69.5 & .5 & 112.2 & $2,819.5$ \\
\hline Lodgepole (and knobcone) pine..... & 4. 1 & & .2 & $\left({ }^{2}\right)$ & & & & 74.3 & 2.7 & & $(2)$ & 81.3 \\
\hline Redwood $\ldots$ & 16.0 & & & & & & & 41.4 & ....... & & & 57.4 \\
\hline Western larch & .7 & $\ldots$ & $\ldots$ & (2) & - & & & 108.4 & 17.4 & & .2 & 126. 7 \\
\hline Hardwoods: & & & & & & & & & & & & \\
\hline Red alder & $1,059.2$ & 54.0 & .7 & 43.2 & .9 & 52.9 & 102.6 & 707.3 & 5. 7 & .1 & 23: 9 & $2,050.5$ \\
\hline Bigleaf maple & 550.4 & 24.1 & .3 & 7.0 & .8 & 5.0 & 122.1 & 21,0 & .7 & .2 & 3,6 & 735.2 \\
\hline Black cottonwood (and aspen) & 214.3 & 4,5 & $\left({ }^{2}\right)$ & 6. 0 & $\left({ }^{2}\right)$ & 4.5 & $\left({ }^{2}\right)$ & 34.4 & 5.7 & & 4. 1 & 273. 5 \\
\hline Oregon white oak & 69.9 & .7 & $(2)$ & 1.2 & .1 & .1 & 9.5 & 4,5 & & & 2.3 & 88.3 \\
\hline California black oak .... & 36.0 & .4 & ....- & 1.1 & .1 & .1 & 13.0 & 11.4 & & & 1.5 & 63. 6 \\
\hline Canyon live oak & .5 & .1 & & 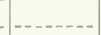 & & -..- & $\left({ }^{2}\right)$ & 2.7 & & & - & 3.3 \\
\hline Tanoak & 136. 0 & .6 & .3 & 3.8 & - n & 1.4 & 1.6 & 290.5 & & & 5. 3 & 439.5 \\
\hline Madrone........ & 134.4 & 1. 0 & (2) & 5.5 & $\left({ }^{2}\right)$ & .3 & 98.0 & 5. 7 & & & 2.2 & 247.1 \\
\hline Oregon ash & 43.8 & .3 & & $\left({ }^{2}\right)$ & $(2)$ & (2) & 1.0 & $\left({ }^{2}\right)$ & & & .3 & 45.4 \\
\hline California laurel & 41.9 & .5 & $\left({ }^{2}\right)$ & 1.0 & $\left({ }^{2}\right)$ & .1 & 14.3 & .5 & & & .5 & 58.8 \\
\hline Chínquapin & 37.5 & .3 & (2) & 1.4 & (2) & .1 & 26.6 & .5 & & & .5 & 66.9 \\
\hline $\begin{array}{l}\text { Western and northwestern paper } \\
\text { birch }\end{array}$ & & & & & & & & .2 & & & & .2 \\
\hline Total & $260,880.9$ & $23,736.0$ & 160.4 & $3,736.0$ & $1,380.4$ & $4,393.0$ & $45,874.2$ & $190,577.3$ & $7,220.7$ & 76. 7 & $8,172,3$ & $3 \mid 546,207.9$ \\
\hline
\end{tabular}

1 Of the 8,172 million board feet in the class "Other federal," 6,389 million board feet is included in Rainier National Park and Mount Olympus National Monument and is therefore not available for cutting.

2 Less than 50,000 board feet. 
one of the principal reasons why the larger class is valued higher.

Large second-growth trees (22 to 40 inches d. b. h.) contain slightly more than a fifth of the total Douglas-fir volume. These trees are rarely more than 150 to 175 years old and are fast-growing. Their wood is typically coarse-grained and of a reddish color that has given them the name "red fir." Of the total volume, 65 percent is in the Willamette River, north Oregon coast, south Oregon coast, and Umpqua River survey units, the result of fires that burned over large areas in all four units around 1800. Considerable quantities of trees of this class are now being cut, particularly in the Willamette River unit, where a number of small mills are in operation. The principal products manufactured are ties, dimension lumber, and common boards.

Small second-growth trees (16 to 20 inches d. b. h.) contain about 5 percent of the total Douglas-fir volume. These trees, usually not regarded by lumbermen as suitable for saw timber, are occasionally cut for sawlogs, poles, and piling, and fuel wood.

\section{WESTERN HEMLOCK}

All factors considered, western hemlock is next in importance to Douglas-fir. Nearly a fifth of the total saw-timber volume of the region is western hemlock. More than three-quarters of this is in western Washington. Western hemlock produces a wood having many good properties, but lacking the specialty qualities which bring high prices for Sitka spruce, western redcedar, and Port Orford white-cedar. It is of more extensive occurrence and more general use than these species. The prejudice of consumers against eastern hemlock has been extended to western hemlock, despite the superiority of the western species, and has resulted in discrimination against western hemlock lumber in eastern and midwestern markets. The wood of this tree is light, straight-grained, fairly soft and easy to work, odorless when dry, and nonresinous. It is used for common boards and dimension, box shook, and flooring; also extensively for paper pulp. Hemlock bark has a high tannin content, and there is a possibility that it will be used more extensively for tannin extraction.

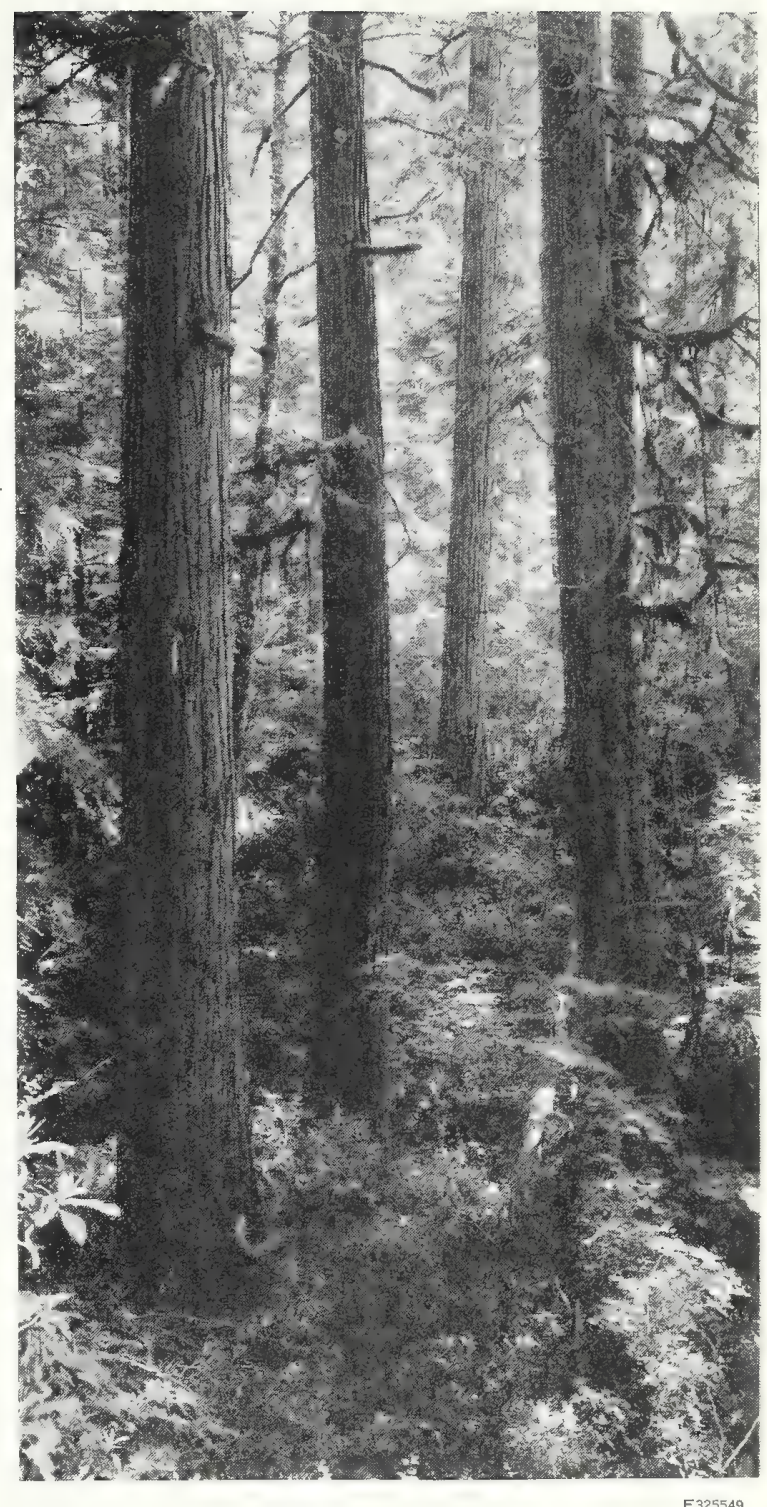

Figure 14.-Port Orford white-cedar, a very valuable species found only in southwestern Oregon and the extreme northwestern part of California. Principal products are battery separators, venetian blinds, and veneers. The volume of the existing stands totals about 1.2 billion board feet

\section{SITKA SPRUCE}

The wood of Sitka spruce is exceedingly valuable for special uses. It is comparatively light in weight, easy to work, tough, and nonresinous. During the World War it was used extensively for airplane construction. At present it is used principally for box 
shook, ladder stock, basket and crate veneers, and paper pulp. It is suitable for building lumber but is not used so extensively for that purpose as Douglas-fir. Because of its comparatively limited occurrence it will probably be used less for lumber than for specialty products and paper pulp.

\section{WESTERN REDCEDAR}

Western redcedar is one of the most important commercial species in the region. Its wood is light and soft and splits easily, and the heartwood is extremely resistant to decay. The principal use of western redcedar is for shingles. It is used also for shakes, sills, siding, interior trim, molding, posts, piling, and poles. The saw-timber stand is less than 25 billion board feet, of which more than 81 percent is in western Washington.

\section{PORT ORFORD WHITE-CEDAR}

Port Orford white-cedar (fig. 14) brings higher stumpage prices than any other forest tree of the region, owing to the intrinsic excellence of the wood and to its scarcity. The wood is valued highly for veneer stock, interior finish, boat construction, pattern stock, ties, block flooring, interior trim, and airplane construction. It is most widely used for specialty veneer products such as battery separators and venetian blinds. It is light in weight, straightgrained, easily worked, and exceedingly durable. It is in great demand abroad, particularly in Japan, and is exported in large quantities as logs, cants, and manufactured products. The region's total stand of this useful species is only 1.2 billion board feet, all located in the southwestern corner of Oregon.

\section{BALSAM FIRS}

The balsam firs, with a total volume of 48 billion board feet, include Pacific silver fir, noble fir, Shasta red fir, grand fir, white fir, and alpine fir, none of which is now utilized to any great extent. Noble fir is generally considered to be superior to the other balsam firs for lumber, and is cut in small quantities each year. Sometimes this tree has been called "larch" by lumbermen, and its products have masqueraded under that misnomer. It is used for siding, interior finish, shop lumber, and box shooks. Pacific silver fir and grand fir are utilized in small quantities, chiefly as pulpwood.
Alpine fir and Shasta red fir occur in nonoperable locations, and there is little immediate prospect of their utilization. All the balsam firs are well adapted to the manufacture of wood pulp, and will probably be used more extensively for that purpose in the future. Pacific silver fir leads them all in volume, with 32.9 billion board feet.

\section{PONDEROSA AND SUGAR PINES}

Ponderosa pine and sugar pine are much less important here than in other western forest regions, chiefly because of limited quantity. In the Rogue River unit they are more important in lumber manufacture than Douglas-fir; elsewhere in this region they are not important. The wood of these two species is used chiefly for sash and doors, box shook, common boards, and interior finish.

\section{OTHER CONIFERS}

The other conifers shown in table 6 are commercially unimportant here, because they occur in inaccessible locations or in insufficient quantities or because their wood is of poor quality. Engelmann spruce and mountain hemlock are suitable for pulpwood but are largely inaccessible. Western white pine, an important timber tree in other regions, is likewise found chiefly in the mountains beyond the reach of present lumbering operations. Redwood is so limited in occurrence in Oregon as to have little economic importance.

\section{HARDWOODS}

The hardwoods are of minor importance in this region. Red alder composes more than half the total hardwood volume. The wood of this tree is fine-grained, light, and relatively strong. It is used for furniture manufacture, turnery, and fuel.

Next in importance among the hardwoods is bigleaf maple, used in furniture manufacture, for veneer, and for fuel wood. Small quantities of maple burls have been exported to Europe. A large part of the bigleaf maple volume is in understory trees in conifer saw-timber types and under present practice is destroyed when the conifers are logged.

Northern black cottonwood is used in small quantities as pulpwood and for excelsior and cooperage. The oaks are used for fuel wood and in small quantities for cooperage and handle stock. 


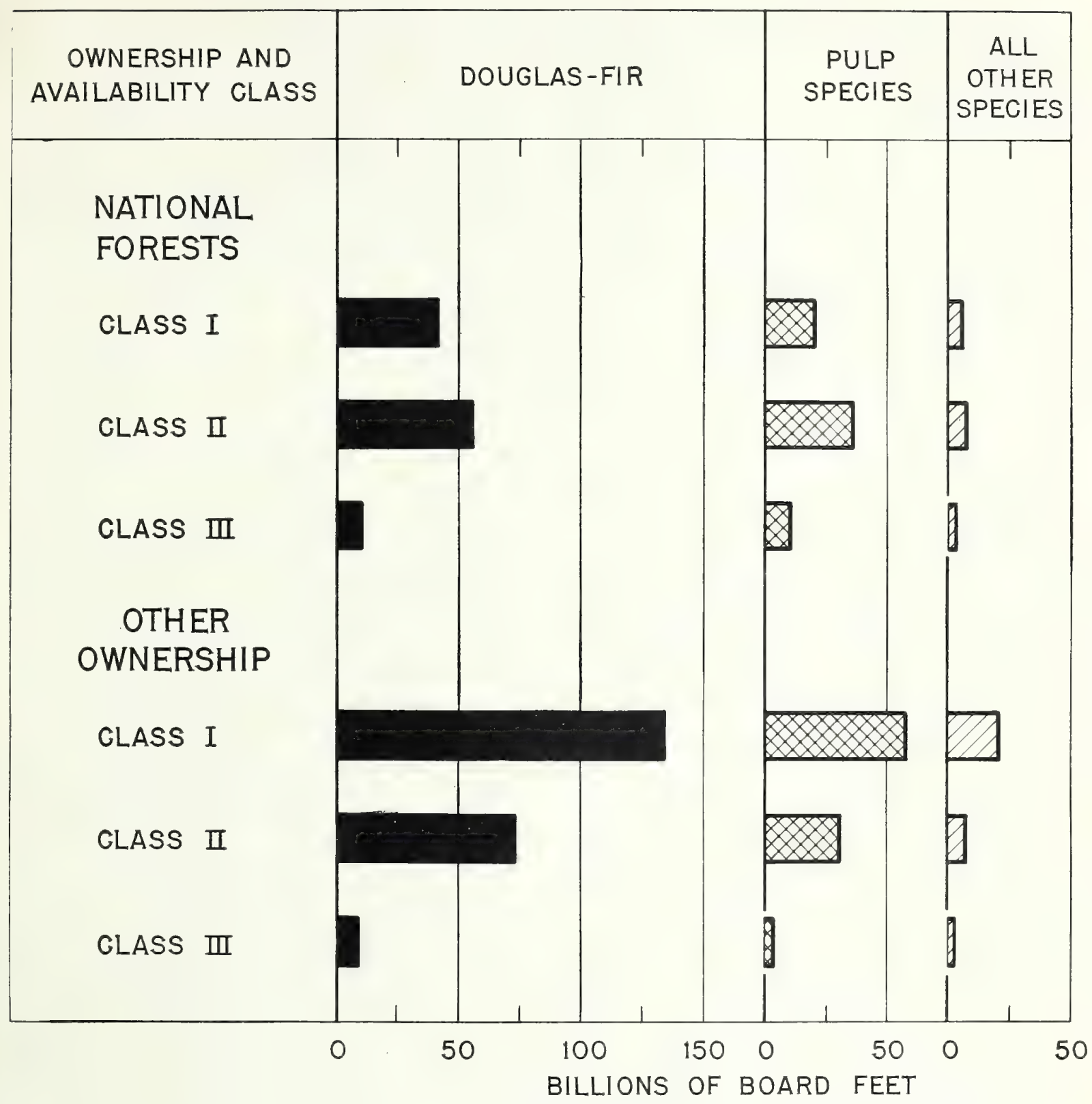

FIGURE 15.-Economic availability of saw timber in the Douglas-fir region, by species and by ownership and availability classes

California laurel is used in the manufacture of novelties. The other species are rarely used for any purpose.

\section{Economic Availability}

A large part of the timber easily accessible to tidewater has been cut. The large water bodies,
Puget Sound and Columbia River, have a great influence on economic availability, as already defined, and are chiefly responsible for the concentration of cutting in large continuous areas in western Washington and northwestern Oregon. Other factors being equal, timber within feasible transportation distance of these waterways ranks highest in economic availability. Other factors 
TABLE 8.--Economic availability classification of nonreserved saw timber in the Douglas-fir region, by ozenership, forest-survey unit, and species class 1

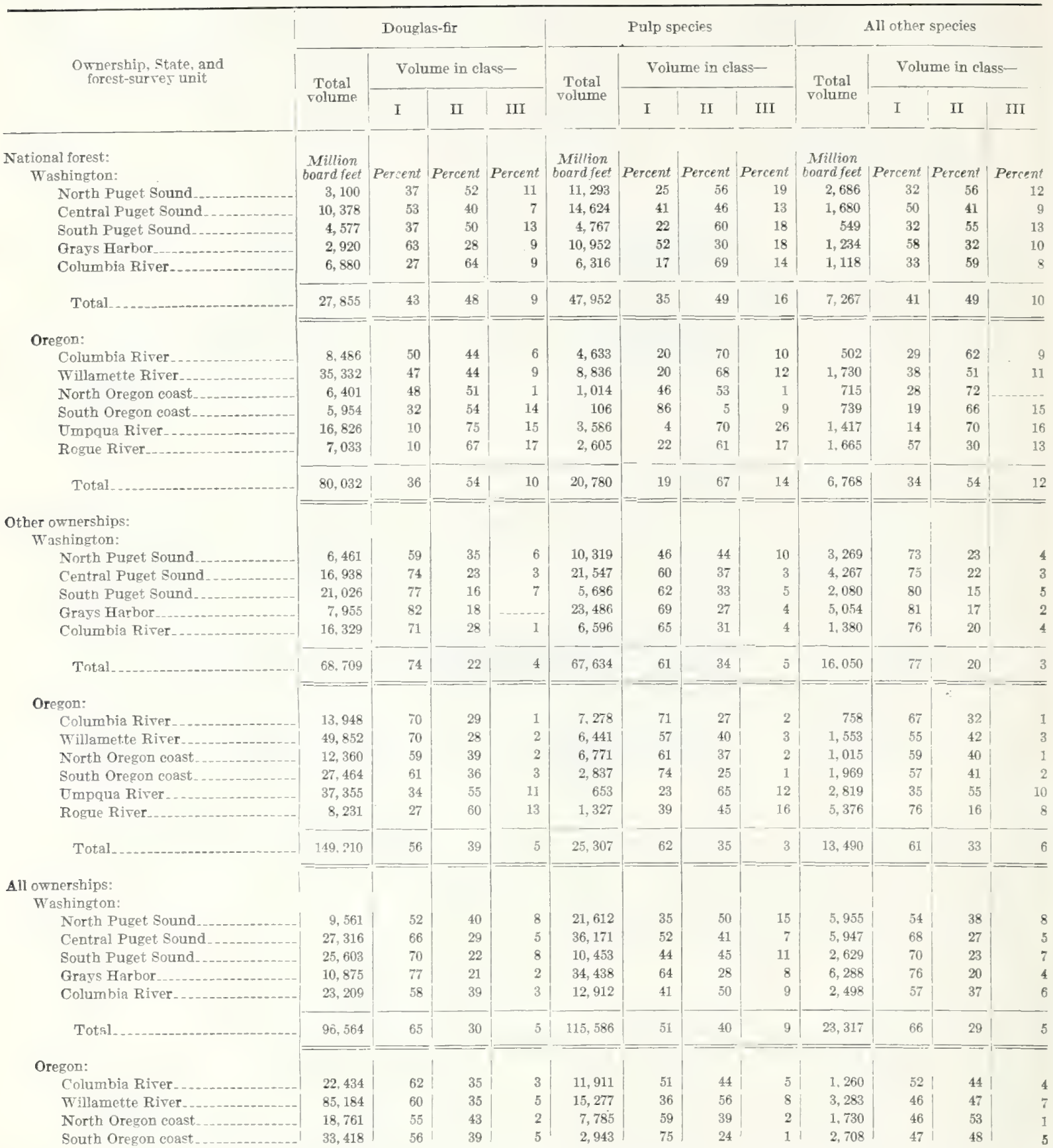

1 The economic arailability classification, based on estimate, is as follows: I, timber that could profitably be logged under the conaitions that prevailed during the period 1925-29; II, timber that under $1925-29$ conditions could be logged at a loss of not more than $\$ 5$ per M board feet; III, all other timber. "Nonreserved" means unaffected by any legal or formal prohibition on timber cutting. 
TABLE 8.-Economic availability classification of nonreserved saw timber in the Douglas-fir region, by ounership, forest-survey unit, and species class-Continued

\begin{tabular}{|c|c|c|c|c|c|c|c|c|c|c|c|c|}
\hline \multirow{3}{*}{$\begin{array}{l}\text { Ownership, State, and } \\
\text { forest-survey unit }\end{array}$} & \multicolumn{4}{|c|}{ Douglas-fir } & \multicolumn{4}{|c|}{ Pulp species } & \multicolumn{4}{|c|}{ All other species } \\
\hline & \multirow{2}{*}{$\begin{array}{l}\text { Total } \\
\text { volume }\end{array}$} & \multicolumn{3}{|c|}{ Volume in class- } & \multirow{2}{*}{$\begin{array}{l}\text { Total } \\
\text { volume }\end{array}$} & \multicolumn{3}{|c|}{ Volume in class- } & \multirow{2}{*}{$\begin{array}{c}\text { Total } \\
\text { rolume }\end{array}$} & \multicolumn{3}{|c|}{ Volume in class- } \\
\hline & & I & II & III & & $\mathbf{I}$ & II & III & & I & II & III \\
\hline $\begin{array}{l}\text { All ownerships_Continued. } \\
\text { Oregon-Continued. } \\
\text { Umpqua River } \\
\text { Rogue River }\end{array}$ & $\begin{array}{c}\text { Million } \\
\text { board fopt } \\
54,181 \\
15,264\end{array}$ & $\begin{array}{r}\text { Percent } \\
27 \\
22\end{array}$ & $\begin{array}{r}\text { Percent } \\
61 \\
63\end{array}$ & $\begin{array}{r}\text { Percent } \\
12 \\
15\end{array}$ & \begin{tabular}{|} 
Mullion \\
board feet \\
4,239 \\
3,932
\end{tabular} & $\begin{array}{r}\text { Percent } \\
7 \\
28\end{array}$ & $\begin{array}{r}\text { Percent } \\
69 \\
55\end{array}$ & $\begin{array}{r}\text { Percent } \\
24 \\
17\end{array}$ & $\begin{array}{l}\text { Million } \\
\text { board feet } \\
4,236 \\
7,041\end{array}$ & $\begin{array}{r}\text { Percent } \\
28 \\
72\end{array}$ & $\begin{array}{r}\text { Percent } \\
60 \\
19\end{array}$ & $\begin{array}{r}\text { Percent } \\
12 \\
9\end{array}$ \\
\hline Total & 229.242 & 49 & 44 & 7 & 46,087 & 43 & 49 & 8 & 20,258 & $52 \mid$ & 40 & 8 \\
\hline $\begin{array}{l}\text { Summary: } \\
\text { National forest } \\
\text { Other ownerships. }\end{array}$ & $\begin{array}{l}107,887 \\
217.919\end{array}$ & $\begin{array}{l}38 \\
62\end{array}$ & $\begin{array}{l}52 \\
34\end{array}$ & $\begin{array}{r}10 \\
4\end{array}$ & $\begin{array}{l}68,732 \\
92,941\end{array}$ & $\begin{array}{l}30 \\
62\end{array}$ & $\begin{array}{l}54 \\
34\end{array}$ & $\begin{array}{r}16 \\
4\end{array}$ & $\begin{array}{l}14,035 \\
29,540\end{array}$ & $\begin{array}{l}37 \\
70\end{array}$ & $\begin{array}{l}52 \\
26\end{array}$ & $\begin{array}{r}11 \\
1\end{array}$ \\
\hline All ownerships & 325,806 & 54 & 40 & 6 & 161,673 & 48 & 43 & 9 & 43,575 & 59 & 34 & 7 \\
\hline
\end{tabular}

influencing availability are topography, density of stand, size and quality of timber, species, and to a lesser extent proximity to common-carrier railroads. Broadly classified as to economic availability in table 8 and figure 15, the nonreserved saw timber of the region is divided into three species groupsDouglas-fir; pulp species, including the hemlocks, spruces, and balsam firs; and all other-and two kinds of ownership - national forest and all other.

In general the economic availability of saw timber is greater for western Washington than for western Oregon and is greater for other ownerships than for national forest. It is higher for Douglasfir than for the pulp species, both in western Oregon and in western Washington. On Oregon lands outside the national forests, however, it is less for Douglas-fir than for the pulp species. The reason is that a large part of the Douglas fir on these lands is in remote locations in the southern part of the State and is poor in quality, whereas by far the greater part of the pulp-species volume is at low and comparatively accessible locations in the coastal belt.

The "all other species" group has a total stand of 44 billion feet, mostly "cedar." Generally speaking the "cedars", exclusive of Alaska yellow-cedar, are more accessible than Douglas-fir and the pulpwood species. They occur usually at lower elevations and on ground more favorable for logging. Ponderosa pine and sugar pine, also, are in the main relatively accessible. As a result the all-otherspecies group ranks highest in economic availability.
This classification should not be considered precise or permanent. Developments in logging equipment and methods, such as increased use of crawler tractors and motortrucks, change from clear cutting to some sort of partial cutting, construction of new railroads, or improvement of certain harbors to accommodate sea-going vessels, would alter the status of large quantities of standing timber. Development of new uses and markets for some of the so-called minor species would upset the classification. As depletion advances the relative availability of the remaining timber will change.

\section{Cubic Volume}

Comparisons of the timber volumes of different forest regions can be made accurately only in cubic feet, because the board-foot unit of measure is not precise and varies greatly with relative size of timber and with utilization standards. Total cubic volume in this region, given in table 9 by ownership class and species, is 129.5 billion cubic feet. Of this total 101 billion feet is in sawlog-size (16 inches d. b. h. or more) trees, 7 billion feet is in understory (less than 16 inches d. b. h.) trees in conifer saw-timber stands, 18.5 billion feet is in conifer second-growth stands, and 3 billion feet is in hardwood stands. The first three categories include small quantities of hardwood volume and the last includes some conifer volume.

Sawlog-size timber constitutes a much larger percent of the cubic timber volume in the Douglas-fir region than in other forest regions of the United 
States (22), because of the preponderance of oldgrowth saw timber in this region. The Douglas-fir region excels every other forest region of the United States in total cubic volume, but not by so large a margin as in saw-timber volume.

Measurement of the entire stand in cubic units is particularly important in considering pulpwood supplies, ${ }^{8}$ although only a small part of the pulpwood at present consumed in this region is cut from trees of less than sawlog size. Under prevailing logging methods and the economic conditions now existing, it is unprofitable to remove understory trees and they are usually destroyed in logging.

Cubic measure is useful also in considering the capital stock available to produce future growth.

\section{Ownership of Forest Resources}

The large areas of idle forest land and the disorderly exploitation of forest resources in the Douglas-fir region have resulted partly from the ownership pattern. Ownership has been so diffused and public responsibility so neglected that no coordinated policy of forest-land use has been put into effect. Future condition of the forest resources depends even more on this factor. In order to produce the greatest social and economic benefits, the forest resources must be so managed that they will be permanently productive; and the type of management accorded forest land is governed largely by ownership. Stabilization of ownership is prerequisite to sustained-yield management of forest lands.

\section{Private Ownership}

More than 53 percent of the commercial forest land and approximately 48 percent of the sawtimber volume in the Douglas-fir region is privately owned. In general, the privately owned forest land is more accessible and the privately owned saw timber is of better quality than that in public ownership. Between 56 and 57 percent of the timber in economic-availability class I is privately

\footnotetext{
8 The pulpwood resources of this region are analyzed in detail in Pulpwood Resources of Western Oregon and Western Washington, Forest Research Notes No. 17, Pacific Northwest Forest Experiment Station. (Mimeographed.) 1935.
}

owned. Roughly 6.2 million acres of conifer timber of sawlog size remains. Included in the acreage of private commercial forest lands is 1.8 million acres of recently cut-over land (type 36), about half of which is nonrestocked, and 1.2 million acres of old nonrestocked cut-over land and deforested burns. Conifer second growth occupies 4.4 million acres of private land, of which about half is cut over and half is old burns. Practically all the second growth on cut-over areas and a considerable part of that on old burns is more accessible than the existing sawlog-size timber.

By far the greater part of the privately owned forest land in the region is owned by either lumber, timber, pulp-manufacturing, or land companies, railroads, or individuals other than farmers.

The conception of forest land as a resource to be managed on a sustained-yield basis has attained scant realization among private forest owners here. Beset by adverse economic factors, nearly all private owners are directing their efforts toward early liquidation of their standing timber. Cut-over lands, second-growth lands, and other lands not supporting saw timber, with few exceptions, are held either for speculation, as a protection to adjoining saw timber, to protect rights of way, or through inertia on the part of the owner. Very little land of this character is being managed by the owners for continuous production of forest crops.

Until recent years many timber owners confidently expected to dispose of much of their cutover land to settlers. Recent economic events and a growing realization that most of the remaining uncleared cut-over land is not suitable for agriculture have done much to dispel these hopes.

\section{National-Forest Ownership}

The national forests were originally created from the public domain and consist, generally speaking, of lands that up to the time of their withdrawal had not been considered desirable for private investment. They have been slightly augmented by exchange and in other ways. As depletion of private timber progresses, national-forest timber becomes more valuable.

The national-forest timber is managed under sustained-yield policies, and cutting on each oper- 
TABLE 9.-Cubic volume of timber, in the Douglas-fir region, by species and ownership class

[In millions of cubic feet-i. e. 000,000 omitted]

\begin{tabular}{|c|c|c|c|c|c|c|c|c|c|c|c|c|}
\hline \multirow{3}{*}{ Species } & \multirow{3}{*}{ Private } & \multirow{2}{*}{\multicolumn{2}{|c|}{ State }} & \multirow{3}{*}{ County } & \multirow{3}{*}{$\underset{\text { nicipa] }}{\text { Mu- }}$} & \multicolumn{6}{|c|}{ Federally owned or managed } & \multirow{3}{*}{ Total } \\
\hline & & & & & & \multirow{2}{*}{ Indian } & \multirow{2}{*}{$\begin{array}{c}\text { Revested } \\
\text { land } \\
\text { grants }\end{array}$} & \multicolumn{3}{|c|}{ National forest } & \multirow[b]{2}{*}{ Other } & \\
\hline & & $\begin{array}{l}\text { A vail- } \\
\text { able }\end{array}$ & $\begin{array}{c}\text { Re- } \\
\text { served }\end{array}$ & & & & & $\begin{array}{l}\text { A vail- } \\
\text { able }\end{array}$ & $\begin{array}{c}\text { Re- } \\
\text { served }\end{array}$ & $\begin{array}{l}\text { State } \\
\text { selec- } \\
\text { tion }\end{array}$ & & \\
\hline Douglas-fir & $39,503.4$ & 1.990 .8 & 33.9 & 843.2 & 142.8 & 133.9 & $8,396.4$ & $24,789.4$ & 662.3 & 3.7 & 692.4 & $77,192,2$ \\
\hline Sitka spruce & $1,813.1$ & 331.2 & 2.5 & 35.5 & 5.1 & 99.1 & 9.5 & 295.2 & 11.5 & .1 & 30.6 & $2,633,4$ \\
\hline Engelmann spruce & 1.2 & $\mid-\ldots . . .+1$ & & $\left({ }^{2}\right)$ & 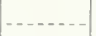 & & & 43.4 & 9.5 & $-\ldots$ & -...... & 54,1 \\
\hline Western hemlock & $12,416.1$ & $1,696.6$ & 6.8 & 228.0 & 94.0 & 350.5 & 359.9 & 8,4068 & 463.6 & 4.9 & 322.3 & 24.349 .5 \\
\hline Mountain hemlock ........... & 50.5 & 4.8 & $\ldots-$ & .3 & .1 & (n) & $\left({ }^{2}\right)$ & $1,171.4$ & 72.9 & .3 & 11.1 & $1,311.4$ \\
\hline Western redcedar, live & $3,189.0$ & 533.1 & 2.4 & 55.4 & 23.2 & 256.6 & 144.7 & $1,558.7$ & 114.8 & 2.9 & 41.7 & $5,922.5$ \\
\hline Alaska yellow-cedar, live & 22.2 & 1.3 & $\ldots$ & .1 & (2) & -.... & -.... & 99.6 & 3.5 & .3 & 14.1 & 141.1 \\
\hline California incense-cedar, live & 213.3 & 1.0 & $(2)$ & 10.2 & .4 & .2 & 127.1 & 135.9 & $\left({ }^{2}\right)$ & & 5.7 & 493.8 \\
\hline \multicolumn{13}{|l|}{ Port Orford white-cedar: } \\
\hline Live & 182.1 & 3. 2 & .2 & 2.2 & .1 & 4 & 42.6 & 40.7 & $\left({ }^{2}\right)$ & & 1.9 & 273.4 \\
\hline 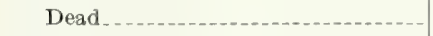 & 4. 5 & ...... & ..... & $(2)$ & $\ldots$ & 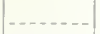 & .4 & .1 & & & & 5.0 \\
\hline Other dead "cedar"-_- & 89.3 & 25.0 & $-\ldots$ & 1.0 & .5 & 42.4 & 2.1 & 63.7 & 1.5 & .5 & .2 & 226.2 \\
\hline Ponderosa pine & 552.0 & 4. 1 & (2) & 42.9 & 2.4 & $\left({ }^{2}\right)$ & 446.0 & 262.7 & 1.1 & $-\ldots$ & 36.8 & 1.348 .0 \\
\hline Sugar pine & 219.1 & 2. 2 & (2) & 12.5 & .4 & (2) & 206. 9 & 261.6 & (2) & - & 8.2 & 711). 9 \\
\hline Western white (and whitebark) pine & 75.7 & 22.4 & $\ldots$ & .9 & 3.6 & 5.6 & 4. 3 & 528,6 & 17.1 & .1 & 17.0 & 675.3 \\
\hline Lodgepole pine & 37.0 & 1. 0 & .3 & 1.3 & $\left({ }^{2}\right)$ & $\left({ }^{2}\right)$ & .5 & 283.3 & 3.2 & $\ldots$ & 1. 7 & 328.3 \\
\hline White fir and grand fir...... & 648.6 & 25.0 & .2 & 12.5 & 1. 3 & 2.7 & 326.2 & 867.5 & 13.6 & .1 & 11.4 & 1.909 .1 \\
\hline Noble fir and Shasta red fir...... & 441.3 & 35.7 & .2 & 3.4 & 11.9 & $(2)$ & 39.6 & $1,257.1$ & 93.5 & & 26.4 & 1.909 .1 \\
\hline Pacific silver fir. & $1,735.0$ & 640.1 & 2,2 & 27.0 & 56.1 & 91.6 & 1.5 & $4,167.8$ & 244.1 & 2.8 & 185. 2 & $7,153.4$ \\
\hline Alpine fir & 8.1 & 1.0 & $\ldots$ & .2 & .2 & .2 & .2 & 39.5 & 9.4 & (2) & 1.8 & 60.6 \\
\hline Western larch & .6 & 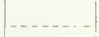 & . & 1 & $\cdots$ & $\ldots$ & -- & 45.8 & 4.0 & & .1 & 50. 6 \\
\hline Redwood $\ldots$ & 3. 1 & & & & ... & & & 8.2 & ... & & & 11.3 \\
\hline YeW & 4.8 & .2 & (2) & .2 & $(2)$ & .1 & 1.6 & 5.1 & .2 & & -1 & 12. 3 \\
\hline Red alder & 917.5 & 34,2 & .4 & 53.6 & 3.1 & 24.1 & 39.1 & 285.1 & 2.9 & (2) & 22.3 & $1,382.3$ \\
\hline Northern black cottonwood_... & 169. 6 & 2.8 & $\left({ }^{2}\right)$ & 3.0 & 1.0 & 2.9 & 1.2 & 5.1 & 1.1 & & 1.2 & 187.9 \\
\hline Oregon white oak & 161.4 & .8 & (2) & 4. 7 & .3 & .5 & 6.3 & 6.8 & & & 4.9 & 18.5. 7 \\
\hline California black oak & 43.3 & .6 & $-\ldots$. & 4.0 & .3 & $\left({ }^{2}\right)$ & 3.5 & 4.3 & & & 4.6 & 60.6 \\
\hline Tanoak ................. & 33.3 & .5 & .1 & 1.1 & $\ldots$ & .4 & 2.9 & 95.4 & & & 4.1 & 137.8 \\
\hline Canyon live oak . . & .3 & $(2)$ & $\cdots$ & (2) & & -.... & .2 & .8 & & & $(2)$ & 1.3 \\
\hline Bigleaf maple & 348.2 & 11.7 & 1 & 9.1 & 1.5 & 4.5 & 31.9 & 43.7 & 1.0 & (2) & 3.5 & 455.2 \\
\hline Ash & 46.1 & .3 & (2) & .4 & .1 & .1 & .9 & 3.6 & & & .3 & 51.8 \\
\hline Western and northwestern paper birch... & 2.1 & .2 & & .2 & - & .1 & - n & .2 & & & .1 & 2.9 \\
\hline California laurel & 19.1 & 1.7 & (2) & .5 & $(2)$ & .1 & 4. 6 & 4. 6 & & & .3 & 30.9 \\
\hline Madrone & 65.4 & .8 & $\left({ }^{2}\right)$ & 3. 6 & .2 & .2 & 33.5 & 42.5 & & & 4.1 & 150.3 \\
\hline Chinquapin & 14.9 & .6 & & .6 & $(2)$ & $\left({ }^{2}\right)$ & 10.3 & 8.4 & & & .2 & 35.0 \\
\hline Total & $63,031,2$ & $5,372.9$ & 49.3 & $1,357.7$ & 348.6 & $1,016.2$ & $10,243.9$ & $44,832,6$ & $1,730.8$ & 15.7 & $1,454,3$ & 129.453 .2 \\
\hline
\end{tabular}

${ }_{1}^{1}$ Including all sound wood in stems of all living trees and all standing dead trees 5.1 inches d. b. h. and larger from stump to 4 -inch tip inside bark, excluding bark and limb wood.

${ }^{2}$ Less than 50,000 cubic feet.

ating unit is restricted to the maximum specified in the working plan. Sales contracts and administrative measures provide for adequate protection of existing growing stock and for regeneration, thus assuring a perpetual supply that should promote stability of manufacturing plants and permanence of communities.

A policy of conservative disposal and a lack of market demands have tended to keep actual cutting far below the indicated sustained-yield capacity on most of the national forests of the region. In no year of the history of these national forests has the total quantity of timber cut from them equalled the total permitted by the working plans. Owing to the inaccessibility of some of the national-forest timber, it may be a long time before the cut reaches the quantity permissible; certainly, however, as the supply of private timber lessens there will be more demand for logging of national-forest timber.

The total area of the national forests in this region is a little over 10 million acres, of which 94 percent is forest land. Of the total forest land, 6 
percent is classed as noncommercial. The national forests form 35 percent of the region's total forest land and 30 percent of its commercial forest land. They contain 37 percent of its total saw-timber volume. In contrast, they contain only about 24 percent of the timber in availability class $I$ and their Douglas-fir percentage is smaller than that of the other ownership classes. Approximately 73 percent of the commercial forest land in the national forests supports stands of saw-timber size and 19 percent supports conifer second-growth stands, almost all of which occur on old burns. Only a small percentage of the commercial forest land is deforested.

The national forests, in common with other public lands, are not subject to any kind of local taxation. By statutory provision, however, 25 percent of all receipts derived from the sale or use of the resources of each national forest are transferred to the State or States containing the national forest, for expenditure on the public schools and public roads of the county or counties in which the forest is situated. When any national forest is in more than one State or county the distributive share to each from the proceeds of such forest shall be proportional to its area therein. Also, 10 percent of all national-forest receipts are made available for expenditure for construction and maintenance of roads and trails within the national forests of the States in which the funds originated. In addition, direct appropriations are made by Congress each year for road and trail construction on lands within the national forests. Substantial sums are spent each year for the protection, administration, and improvement of these public forests, whose resources of timber, forage, water, recreation, etc., are largely used by and are of much benefit to the national as well as the local population.

In this region, up to and including 1935, more than $\$ 9,000,000$ had been realized from the sale of national-forest products and approximately $\$ 2,250,000$ of national-forest receipts had been paid to the two States for distribution to the counties.

\section{State Ownership}

Forest lands in the Douglas-fir region owned by Oregon and Washington total nearly a million acres, of which about 16,000 acres is reserved for specific purposes such as State parks. The sawtimber volume in State ownership totals 23.9 billion board feet, of which 160 million feet is on reserved lands. The lands were granted by the Federal Government to the States to finance education and internal improvements. Oregon disposed of the greater part of her lands years ago, but Washington retained most of hers and is now profiting thereby. In the Douglas-fir region Washington owns 853,293 acres of forest land supporting 23.2 billion board feet of standing timber, and Oregon owns 113,968 acres supporting 0.7 billion board feet.

The common-school lands originally granted to the States comprised sections 16 and 36 in each township, and thus were badly scattered. This dispersion of the State forest lands has been one obstacle to their effective management. In western Oregon most of the remaining State lands have now been consolidated into one block called the Elliott State Forest. This was effected by exchanging scattered State lands for national-forest and Oregon \& California Railroad revested grant lands. This block is now almost entirely occupied by secondgrowth Douglas-fir stands. Although there are no statutory provisions for its management, the State Board of Forestry expects to manage it on a sustained-yield basis.

In western Washington the State is acquiring through exchange of scattered areas for nationalforest land, two comparatively large blocks of mature timber. One of these is on the west side of the Olympic Peninsula and the other is in the northern Cascade Range. In 1933 the Washington Legislature enacted a law reserving from sale all State timberland on the Olympic Peninsula area with the intention of creating a sustainedyield forest. Subsequently the constitutionality of certain provisions of the act was challenged by the Washington commissioner of public lands. The legislature failed to appropriate funds for the operation of a sustained-yield forest, and so far no cutting has taken place on the area. No corresponding law has been enacted concerning areas in the Cascade Range. Other large blocks of State forest are being established through acquisition of cutover land by donation from counties and by purchase from private owners. Payment to the private owners is made in State utility bonds. 


\section{County Ownership}

The counties of the Douglas-fir region owned nearly 630,000 acres of forest land in 1933, all acquired by tax foreclosure. Most of this area is either deforested or in second growth; however, more than 155,000 acres is occupied by stands of saw-timber size. In Oregon the area of countyowned land has increased greatly since 1933. Table 10 shows the increase in county-owned land in 8 of the 19 western Oregon counties, by forest cover type. In Washington, moratoria on tax foreclosures have prevented large increases in county-owned land. However, these moratoria have now expired and foreclosure proceedings are under way in a number of counties.

Tillamook is the one county that has declared a policy of retaining at least part of its county-owned forest lands. This county received some forest land as a gift and plans to retain it as a park. Furthermore, it has announced its intention to retain for forest purposes other lands acquired by foreclosure. There is no statutory basis for establishing permanent county forests in either Oregon or Washington, and a change in county administration could result in reversal of Tillamook County's present practices.

Generally speaking, the Oregon counties have no long-term program for handling their lands and are trying to pass them back into private ownership by sale. A few have sold stumpage of pole, tie, and saw-timber size without selling the land. Some of these stumpage sales have been on a contract basis and have brought extremely small returns. Obviously it is not probable that tax-reverted lands can be successfully reestablished in private ownership, except in a few cases, unless economic conditions change materially.

\section{Municipal Ownership}

Approximately 100,000 acres of forest land in the Douglas-fir region is owned by municipalities. Almost all this land is retained as a protection to domestic water supplies. None of it is owned and managed primarily for the purpose of timber production. In addition to this municipal land about 135,000 acres of national-forest land has been set aside for the protection of watersheds supplying domestic water to municipalities. An example of
TABLE 10.-Increase in county-owned forest land through tax delinquency during 1933-36 in 8 western Oregon counties

\begin{tabular}{|c|c|c|c|c|}
\hline \multirow{2}{*}{ Generalized type } & \multirow[b]{2}{*}{1933} & \multirow[b]{2}{*}{1936} & \multicolumn{2}{|c|}{ Increase } \\
\hline & & & 1933 & 1936 \\
\hline Conifer saw timber.... & $\begin{array}{r}\text { Acres } \\
76,480\end{array}$ & $\begin{array}{c}\text { Acres } \\
219,019\end{array}$ & $\begin{array}{r}\text { Acres } \\
142,539\end{array}$ & $\begin{array}{r}\text { Percent } \\
186\end{array}$ \\
\hline Conifer second growth & 78,052 & 159,999 & 81,947 & 105 \\
\hline Cut-overs and burns & 85,907 & 188,598 & 102,691 & 120 \\
\hline Noncommercial forests...... & 3,308 & 3.842 & 534 & 16 \\
\hline Hardwood forests........ & 6,871 & 12,792 & 5,921 & 86 \\
\hline Total & 250,618 & 584,250 & 333,632 & 133 \\
\hline
\end{tabular}

this is the Bull Run watershed on the Mount Hood National Forest, from which Portland draws its supply.

\section{Indian Ownership}

Indians own approximately 260,000 acres of forest land and 4.4 billion feet of saw timber in the Douglas-fir region. The region contains one large reservation, the Quinault, and a number of smaller ones. A small portion of the Indian-owned land consists of trust allotments. Timber on the Quinault and Makah Reservations is being sold and cut under management of trained foresters employed by the Office of Indian Affairs of the Department of the Interior. More than half the Indians' forest land supports stands of saw-timber size. Unusually large percentages of their timber are western redcedar, western hemlock, and Sitka spruce.

\section{Revested Grant Lands}

Most important of all forest-ownership classes other than private and national forest are the revested Oregon \& California Railroad and Coos Bay Wagon Road grants, all of which are in Oregon. These include well over 2 million acres of forest land and nearly 46 billion board feet of saw timber.

The original grant to the Oregon \& California Railroad, which later became a part of the Southern Pacific Railway system, consisted of the oddnumbered sections within a 20 -mile-wide strip on each side of the right-of-way, and an indemnity strip 10 miles wide on each side. This line ran from Portland, Oreg, to the California boundary. The grant contained specific provisions regarding the 
disposal of these lands by the grantee. A similar grant was made to the Coos Bay Wagon Road Co. for a much smaller area. The terms of both grants were violated and the Government brought suit against the companies in Oregon maintaining that the intent of the grants was being frustrated. The grant lands still unsold were declared forfeit and in 1916 were revested in the Federal Government by an act of Congress that provided for their classification and disposal. Land classified as agricultural (all tracts having less than 300,000 board feet of saw timber per 40 acres, regardless of suitability for farming) were opened to homestead entry. A very large part of this land was strictly forest land, with no agricultural potentialities. The timber on lands classed as timberland was made subject to public sale upon application. After the timber was removed these lands were opened to homestead entry. In 1934 they were temporarily closed to entry, by Executive order. A small acreage of land valuable principally for water-power development has been withdrawn and placed under the jurisdiction of the Federal Power Commission. The large remaining acreage is administered by the Department of the Interior. Until recently, authority and funds for the proper protection and management of the lands were not provided. Their checkerboard distribution was another obstacle to satisfactory management. In 1937 the Seventy-fifth Congress passed an act providing for sustainedyield management, under the jurisdiction of the Department of the Interior, of the portion of these lands classified as timberlands. The law provides for classifying the lands more suitable for agricultural use than for forestry purposes and restoring them to homestead entry.
The original act and subsequent legislation have provided for certain minimum payments to the Southern Pacific Railroad for its equities, to the counties in lieu of taxes, to the State for school purposes, and to the United States Reclamation Fund. Payments to the railway company, which were completed about 1927, and to the counties have exceeded receipts by millions of dollars.

\section{Other Federal Lands}

Other Federal lands include national parks, national monuments, unappropriated public domain, military reservations, lighthouse reservations, and some other Federal lands of small extent. The total area of forest land in this ownership category is about 775,000 acres. The largest and most important units are the Mount Olympus National Monument ${ }^{9}$ and Mount Rainier National Park, both administered by the National Park Service. Next in importance, probably, is the public domain, which is scattered in small isolated parcels the length of the region.

The total volume of saw timber on "other Federal lands" is more than 8 billion board feet. Slightly more than 3 billion board feet is on the Mount Olympus National Monument, and nearly the same quantity is on the Mount Rainier National Park. No cutting is allowed on either of these areas. Practically all the remaining volume is for one reason or another unavailable for commercial exploitation.

\footnotetext{
${ }^{9}$ Subsequent to the forest survey inventory, Congress created in 1938 the Olympic National Park containing the Mount Olympus National Monument, formerly part of the Olympic National Forest.
} 
O ONE now knows, or will ever know, what the volume of timber in the Douglas-fir region was before the coming of the white man. It is therefore quite impossible to compare the volume of the present stand with that of prehistoric times and thus compute the depletion that has resulted from the activities of civilization. It is certain that the primeval forest was far from carrying, on every acre, the maximum volume of a fully stocked, mature forest. Fires, windstorms, insects, and diseases had always taken their toll and kept certain areas understocked or temporarily stripped of large living timber. But it must be assumed that before the interference of man the forests of the region maintained from decade to decade and century to century a generally constant volume; that the natural agencies of depletion were constantly at work but were substantially in equilibrium with growth.

Since the region has been settled and industrial activity begun there has been great acceleration of depletion, particularly by cutting and fire, and the natural equilibrium has been upset. Though forests are a renewable resource, so active has been the harvesting of mature timber that the regrowth has not been able to keep pace, and depletion of the forest capital has resulted. It appears now that the saw-timber volume of the Douglas-fir region is being depleted about four times as fast as it is being replaced by growth.

The current annual depletion of saw timber from all causes is estimated to approximate 8.3 billion board feet. It should be remembered that the depletion considered here includes only that caused by man and by epidemics and catastrophes, not the normal losses that take place in any forest in a virgin state; normal losses due to causes such as scattered wind throw, decay, incidental insect killing, surface fires, and suppression in crowded stands had been allowed for in the preparation of the growth and yield tables used in the survey. Nor does it include material unutilized in logging, as is explained later.

The principal agent in this 8.3 billion board foot annual gross reduction in the forest inventory is cutting, which has been active at an accelerating rate in recent decades. Fire, also, is an important cause of forest destruction, particularly in secondgrowth stands; it is far more destructive than can be measured in terms of volume of timber killed. Forest-destructive agents of secondary significance in this particular region are insects and wind throw.

\section{Cutting Depletion}

The statistics of depletion from cutting herein given include only material actually removed from the woods as a result of harvesting operations; they do not include sound material left in the woods, because the inventory statistics and the growth calculations included only the usable part of the tree wherever the board-foot unit of measure was employed. A study of logging waste in the Douglas-fir region made by the Forest Service in 1926-27 (6), along with information obtained by the survey, formed the basis for adjusting gross volume and growth figures to volume actually removed in logging. The results of this study indicate that nearly $1 \frac{1}{2}$ billion board feet of sawlogs were left in the woods after logging in 1926 when the total sawlog production amounted to about 10 billion board feet. 
TABLE 11.-Annual output of timber products in the Douglas-fir region, by State and forest-survey unit I

MATERIAL ${ }^{2}$ CUT FROM TREES OF SAW-TIMBER SIZE

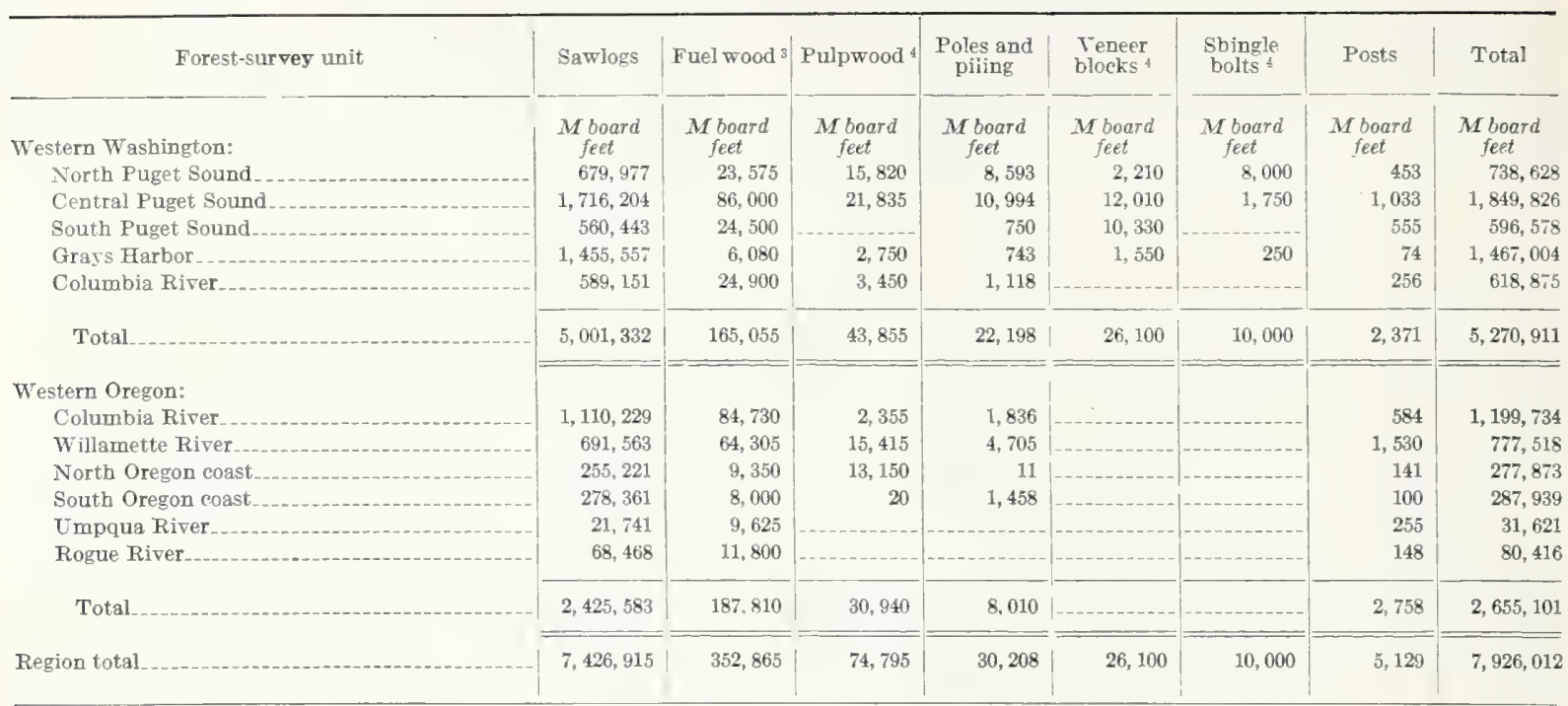

MATERIAL CUT FROM TREES OF LESS THAN SAW-TIMBER SIZE

\begin{tabular}{|c|c|c|c|c|c|c|c|c|}
\hline Forest-survey unit & Fuel wood & Pulpwood & $\begin{array}{l}\text { Poles and } \\
\text { piling }\end{array}$ & Posts & $\begin{array}{l}\text { Mine } \\
\text { timbers }\end{array}$ & $\begin{array}{c}\text { Hewed } \\
\text { ties }\end{array}$ & $\begin{array}{l}\text { Exrelsior } \\
\text { bolts }\end{array}$ & Total \\
\hline $\begin{array}{l}\text { Western Washington: } \\
\text { North Puget Sound.... }\end{array}$ & $\begin{array}{l}M \text { cubic } \\
\text { feet } \\
\quad 6,022\end{array}$ & $\begin{array}{c}M_{\text {iubic }} \\
\text { feet } \\
3,026\end{array}$ & $\begin{array}{l}M_{\text {feet }}{ }_{548} \\
\end{array}$ & $\begin{array}{l}M_{\text {feet }}{ }_{133} \\
{ }_{13}\end{array}$ & $\begin{array}{l}M_{\text {feet }} \text { cubic } \\
\quad 82\end{array}$ & $\begin{array}{l}M_{\text {feet }} \text { cubic } \\
\end{array}$ & $M_{\text {feet }}$ cubic & $\begin{array}{l}M \text { cubic } \\
\quad \text { feet } \\
\quad 9,855\end{array}$ \\
\hline Central Puget Sound. & 11,617 & 774 & 1,437 & 283 & 699 & 113 & 180 & 15,103 \\
\hline South Puget Sound.... & 2,115 & $-\ldots$ & 910 & 95 & 200 & 36 & & 3,356 \\
\hline Grays Harbor & 3,683 & 345 & 868 & 22 & $-\ldots$ & 14 & & 4,932 \\
\hline Columbia River & 2,268 & 271 & 1,488 & 52 & $\ldots$ & 23 & & 4,102 \\
\hline Total_...... & 25,705 & 4,416 & 5,251 & 585 & 981 & 230 & 180 & 37,348 \\
\hline Western Oregon: & & & & & & & & \\
\hline Columbia River & 10,078 & 771 & 473 & 170 & & & 45 & 11,537 \\
\hline Willamette River & 13,726 & 1,397 & 475 & 240 & 69 & & 180 & 16,087 \\
\hline North Oregon coast_... & 2,489 & 423 & 125 & 14 & & & & 3,051 \\
\hline South Oregon coast & 2,065 & 10 & 383 & 22 & 30 & 42 & & 2. 552 \\
\hline Umpqua River & 2,745 & & 16 & 22 & & & & 2,783 \\
\hline Rogue River & 2,970 & & & 55 & & & & 3,025 \\
\hline Total & 34,073 & 2,601 & 1,472 & 523 & 99 & 42 & 225 & 39,035 \\
\hline Region total & 59,778 & 7,017 & 6,723 . & 1,108 & 1,080 & 272 & 405 & 76,383 \\
\hline
\end{tabular}

1 Data for sawlog production are averages for the period 1925-33, other data are for 1930 only.

2 Figures given are log scale, based on Scribner rule.

3 In addition to the quantities of material shown uncer this heading, considerable quantities of slabs, edgings, mill waste, and sawdust were sold as fuel.

"In addition to the quantities shown under these headings, some sawlogs were used for manufacture of paper pulp, veneers, panels, plywood, and shingles. 
The survey of cutting depletion covered the material removed from the forest for different uses, not only as sawlogs but also as minor timber products, such as fuel wood, poles, piling, posts, veneer blocks, shingle bolts, pulpwood, mine timbers, hewed ties, and excelsior bolts. Sawlogs were classified by species and geographical unit; the minor timber products were classified by item, species, and geographical unit, and according to whether the material was cut from trees of saw-timber size (16 inches d. b. h. or more) or from smaller trees. The results were expressed in board feet for the saw-timber size and in cubic feet for the smaller trees. The average annual timber production in the Douglas-fir region is shown in table 11 by State and survey unit.

The total volume of material cut from trees of sawlog size annually during the period 1925-33 averaged 7.9 billion board feet. The area clearcut annually during that period amounted to roughly 165,000 acres. By far the greater part of the cutting, in terms of area, was in large oldgrowth Douglas-fir. Cutting is heaviest in the north Puget Sound, central Puget Sound, Grays Harbor, and Columbia River, Oreg., units.

\section{Sawlog Production}

Sawlogs comprise about 95 percent of the total cutting depletion. The average annual sawlog production during the period 1925-33 of 7.4 billion board feet, log scale, is distributed by species for each unit in western Oregon and western Washington in table 12. During the first part of this period annual sawlog production increased, but beginning with 1930 it declined rapidly, so that in the 4 years 1930-33 it was little more than half as much as in 1925-29.

More than two-thirds of the region's total output of sawlog volume during 1925-33 was produced in Washington. Douglas-fir composed 83 percent of the sawlog production in Oregon, and 68 percent of that in Washington. Other leading species, in order, were western hemlock, western redcedar, and Sitka spruce.

By far the greater part of the sawlog production6,592 million board feet annually-took place on private land. The remaining 835 million board feet was distributed, in million board feet, as follows: national-forest lands, 255, Oregon \& California Railroad revested grant lands, 245; State lands (all in Washington), 175; and Indianowned lands, 160. This volume on public or Indian lands was all cut by private concerns to which the stumpage had been sold.

Water transportation has been a significant factor in the development of the lumber industry in the Douglas-fir region. The units leading in saw$\log$ production are, in order, the central Puget

TABLE 12.-Average annual sawlog production, log scale, in the Douglas-fir region in 1925-33, by State, forest-survey unit, and species

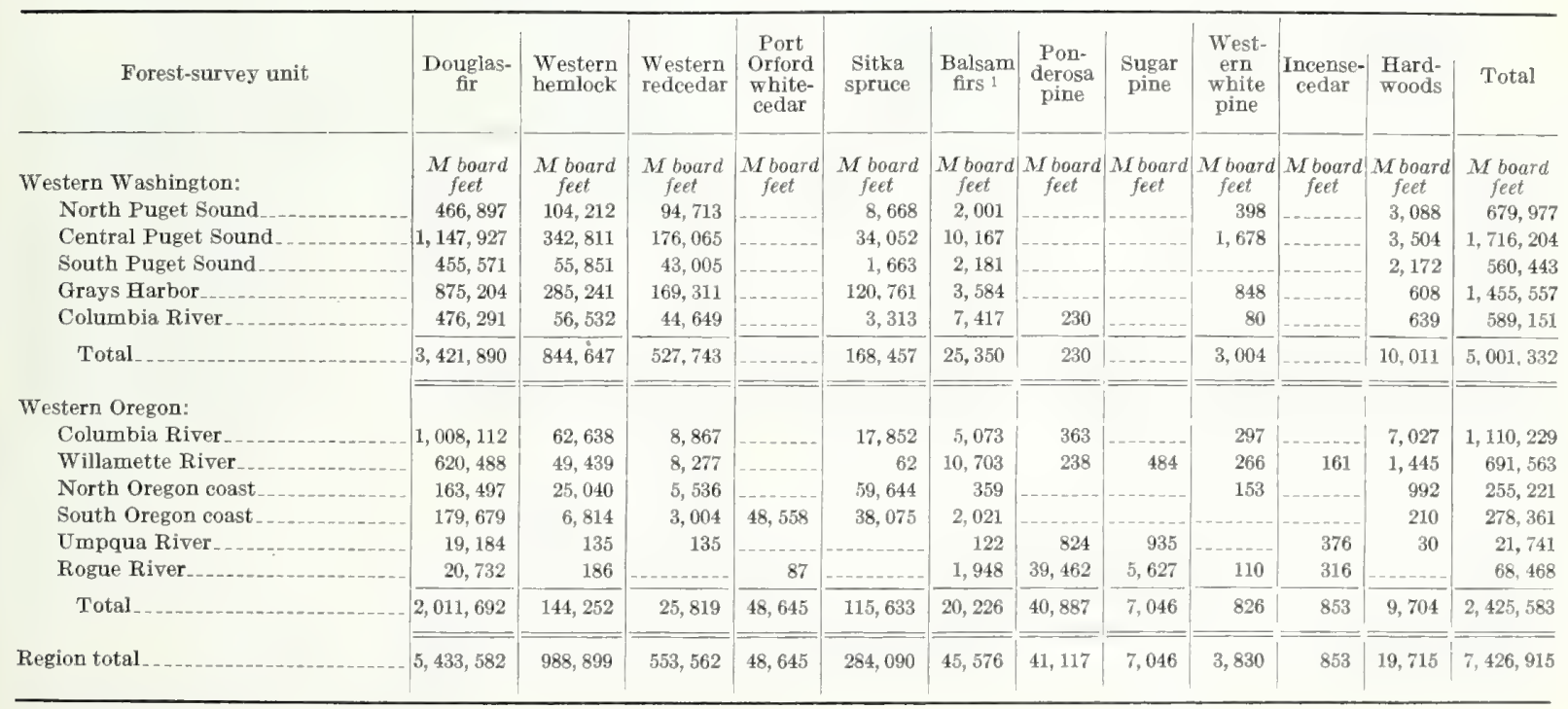

1 Including all species of Abies.

$224146^{\circ}-40-4$ 
Sound, Grays Harbor, Columbia River Oregon, Willamette River, and north Puget Sound. All these except the Willamette River unit are readily accessible to tidewater, and are characterized by cheap water transportation of logs. In the Willamette River unit comparatively few logs are transported by water and most of the sawlog production is done by logger manufacturers, whose mills are usually located within a relatively short distance of the woods operation.

The earliest logging operations in the region were in the vicinities of Puget Sound and the Columbia River. In the Columbia River district logging began in a small way more than a century ago. Supplies of saw timber in these units are still large but are being depleted rapidly, particularly in the some Oregon counties. In Washington, logging in this district has been greatly stimulated of late by the establishment of large mills at Longview. Continued large-scale logging has greatly depleted the accessible privately owned saw timber in the Puget Sound district-nearly to exhaustion in the counties east of the Sound. In Grays Harbor County, the comparatively easy logging ground and dense stands of high-quality timber invited early operation. This county outranked all others in the region in aggregate sawlog production from 1925 to 1933 , although cutting declined rapidly in the latter part of the period and in 1933 was exceeded by that of Cowlitz County.

In all units except the Rogue River, where ponderosa pine ranks first, Douglas-fir is the leading species in log production, ranging from 91 percent of the total in the Columbia River, Oreg., unit to 60 percent in the Grays Harbor unit. In the central Puget Sound and Grays Harbor units western hemlock constitutes about 20 percent of the total production; in the other units, much less. Western redcedar forms 14, 12, and 10 percent of the total log production in the north Puget Sound, Grays Harbor, and central Puget Sound units. Sitka spruce production is significant only in the Grays Harbor, south Oregon coast, and north Oregon coast units. Port Orford white-cedar logs are produced only in the south Oregon coast unit, where they form 17 percent of the total sawlog production. Practically all the ponderosa pine logs are produced in the Rogue River unit.
Not all the sawiogs produced are used in the manufacture of lumber. A considerable proportion of the western hemlock and Sitka spruce logs and practically all the white fir logs produced in 1925-33 were used to manufacture wood pulp. Some Douglas-fir and Sitka spruce logs were used in veneer manufacture. Most of the western redcedar logs were used for shingles.

\section{Forest Fuel Wood}

The cutting of forest trees of both saw-timber and smaller size for fuel, usually into split cordwood dimensions, is a factor in the depletion of growing stock. Forest fuel wood, as indicated by the 1930 production listed in table 13, constitutes about three-quarters of the volume of all the so-called minor timber products. In 1930 western Oregon produced 55 percent of the regional total, although it had but 41 percent of the region's population. Practically all the forest fuel wood is consumed locally, and the principal markets are the urban localities. The wood is trucked to consuming centers for distances up to 40 or 50 miles. The Columbia River, Oreg., and Willamette River, the most populous of the Oregon units, lead in fuel-wood production. In Multnomah County, Oreg., in which Portland is situated, 29 percent of the volume of all the trees of saw-timber size felled in the period studied was converted into forest fuel wood, together with 97 percent of the material cut from smaller trees. The chief reasons for western Oregon's greater fuel-wood production are: (1) A larger percentage of the population of western Oregon than of that of western Washington is rural or resident in small communities, and in the Douglas-fir region these population classes use wood as fuel almost exclusively; (2) the forest stands suitable for fuel wood near large cities are more nearly exhausted in western Washington; (3) coal mined near Seattle and other Puget Sound cities competes with forest fuel in local urban markets.

In western Oregon by far the greater part of the forest fuel wood is Douglas-fir; oak is next in importance, followed by red alder. In western Washington, the central Puget Sound unit, the most populous, produces roughly half the total output of forest fuel wood, and almost all the forest fuel wood produced is Douglas-fir. 
Considerable quantities of mill waste such as slabs, trimmings, hogged fuel, and sawdust, also, are used for industrial and domestic fuel. The use of mill waste for fuel is discussed more fully later.

\section{Forest Pulpwood}

Second in importance among the minor timber products is forest pulpwood-material cut in the woods. This is usually in 4-foot lengths, peeled and stacked in round or split form. During 1930, approximately 75 million board feet of forest pulpwood was cut from trees of saw-timber size and 7 million cubic feet from smaller trees (table 14). This is but a small part of the total material used in the manufacture of wood pulp in this region, other sources being sawlogs and sawmill waste.

Approximately 60 percent of the total forest pulpwood was produced in western Washington, most of it western hemlock. In western Oregon the leading species was grand fir, practically all of it cut and used in the Willamette River unit.

TABLE 13.-Production of forest fuel wood in the Douglas-fir region during 1930, by State, forest-survey unit, and species 1 MATERIAL 2 CUT FROM TREES OF SAW-TIMBER SIZE

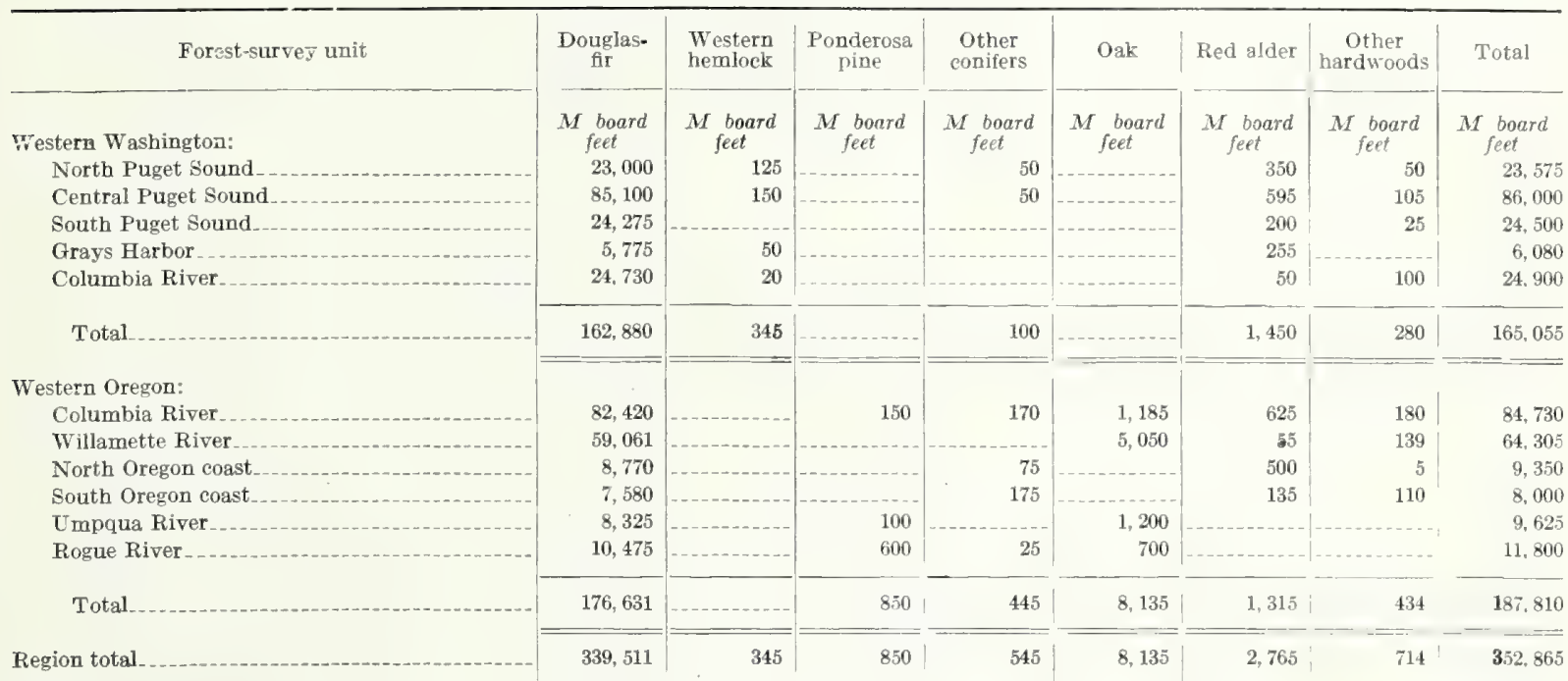

MATERIAL CUT FROM TREES OF LESS THAN SAW-TIMBER SIZE

\section{Western Washington: \\ North Puget Sound \\ Central Puget Sound. \\ South Puget Sound. \\ Grays Harbor \\ Columbia River \\ Total}

Western Oregon:

Columbia River

Willamette River

North Oregon coast

South Oregon coast

Umpqua River.

Rogue River

Total

Region total

\begin{tabular}{|c|c|c|c|c|c|c|c|}
\hline $\begin{array}{l}M_{\text {feet }} \text { cubic } \\
5,616\end{array}$ & $\begin{array}{c}M \text { cubic } \\
\text { feet }\end{array}$ & $\begin{array}{c}M \text { cutic } \\
\text { feet }\end{array}$ & $\underset{\text { feet }}{M \text { cubic }}$ & $\begin{array}{c}M \text { cubic } \\
\text { feet }\end{array}$ & $\begin{array}{l}\text { M cubic } \\
\text { foet } \\
384\end{array}$ & $\begin{array}{l}\text { Mr cubic } \\
\text { feet } \\
17\end{array}$ & $\begin{array}{l}M \text { cubic } \\
\text { feet } \\
\quad 6,023\end{array}$ \\
\hline 11,354 & 4 & & & & 259 & & 11,617 \\
\hline 1,987 & & & & & 119 & 9 & 2,115 \\
\hline 2,742 & 46 & & & & 894 & & 3,682 \\
\hline 2,232 & & & 13 & & 23 & & 2,268 \\
\hline 23,931 & 50 & . & 19 & & 1,679 & 26 & 25,705 \\
\hline 9,748 & & 27 & 9 & 150 & 103 & 42 & 10,079 \\
\hline 11,650 & & & & 2,067 & 9 & & 13,726 \\
\hline 2,149 & & & 32 & & 304 & 4 & 2,489 \\
\hline 1,897 & & & 61 & 6 & 51 & 50 & 2,065 \\
\hline 2,223 & & 18 & & 486 & & 18 & 2,745 \\
\hline 2,592 & & 171 & & 135 & & 72 & 2,970 \\
\hline 30,259 & & 216 & 102 & 2,844 & 467 & 186 & 34,074 \\
\hline 54,190 & 50 & 216 & 121 & 2,844 & 2,146 & 212 & 59,779 \\
\hline
\end{tabular}

\footnotetext{
1 In addition to the quantities of material shown here, considerable quantities of slabs, edgings, mill waste, and sawdust were sold for fuel.

Figures given are log scale, based on Scribner rule; 1,000 board feet is approximately equivalent to 130 cubic feet.
} 
TABLE 14.-Production of forest pulpwood 1 in the Douglas-fir region during 1930, by State, forest-survey unit, and species

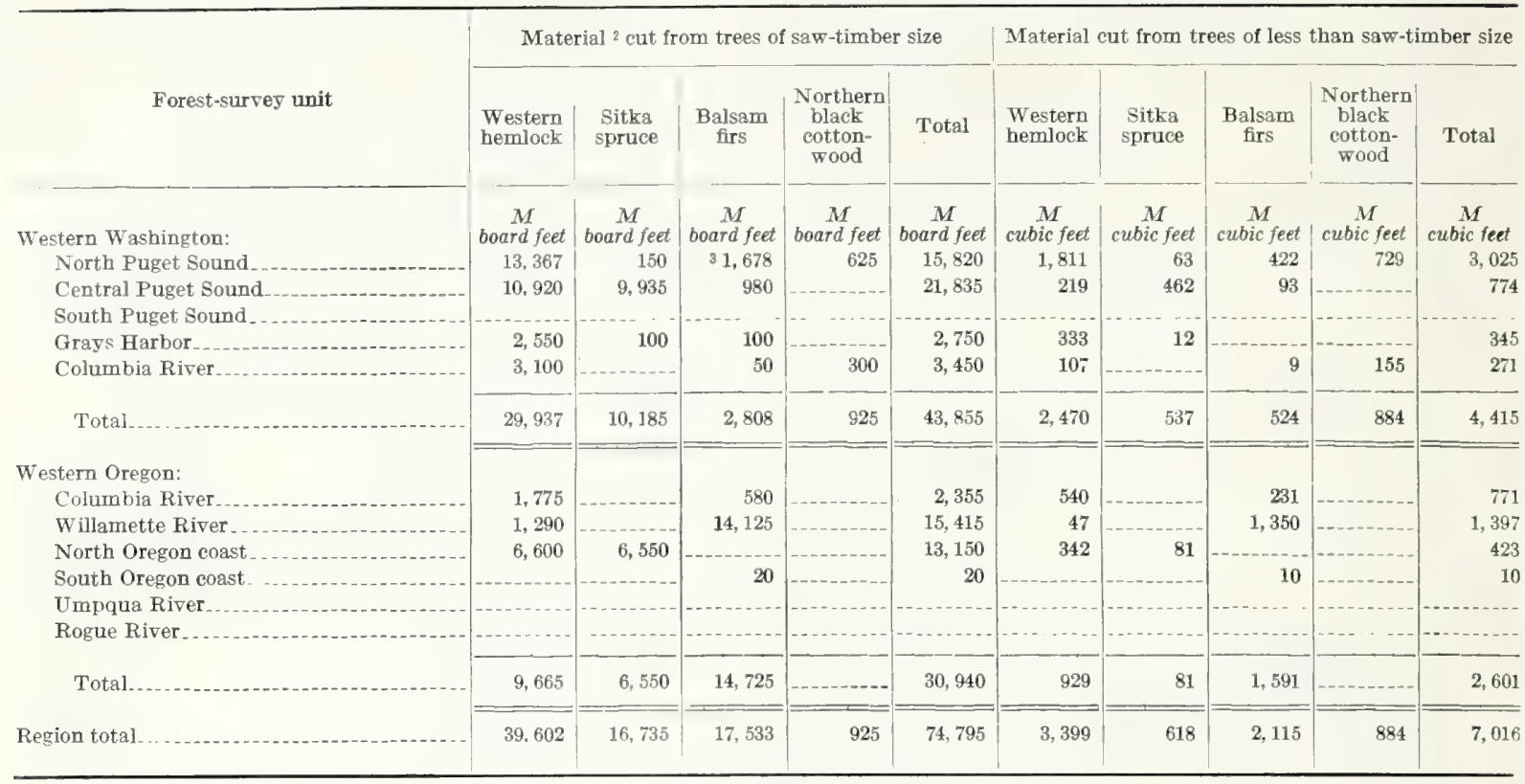

I In addition to the quantities of material shown here, some sawlogs were used to manufacture wood pulp.

2 Figures given are log scale, based on Scribner rule.

3 Includes 50,000 board fert of Douglas-fir.

TABLE 15.-Production of poles and piling in the Douglas-fir region during 1930, by State, unit, and species

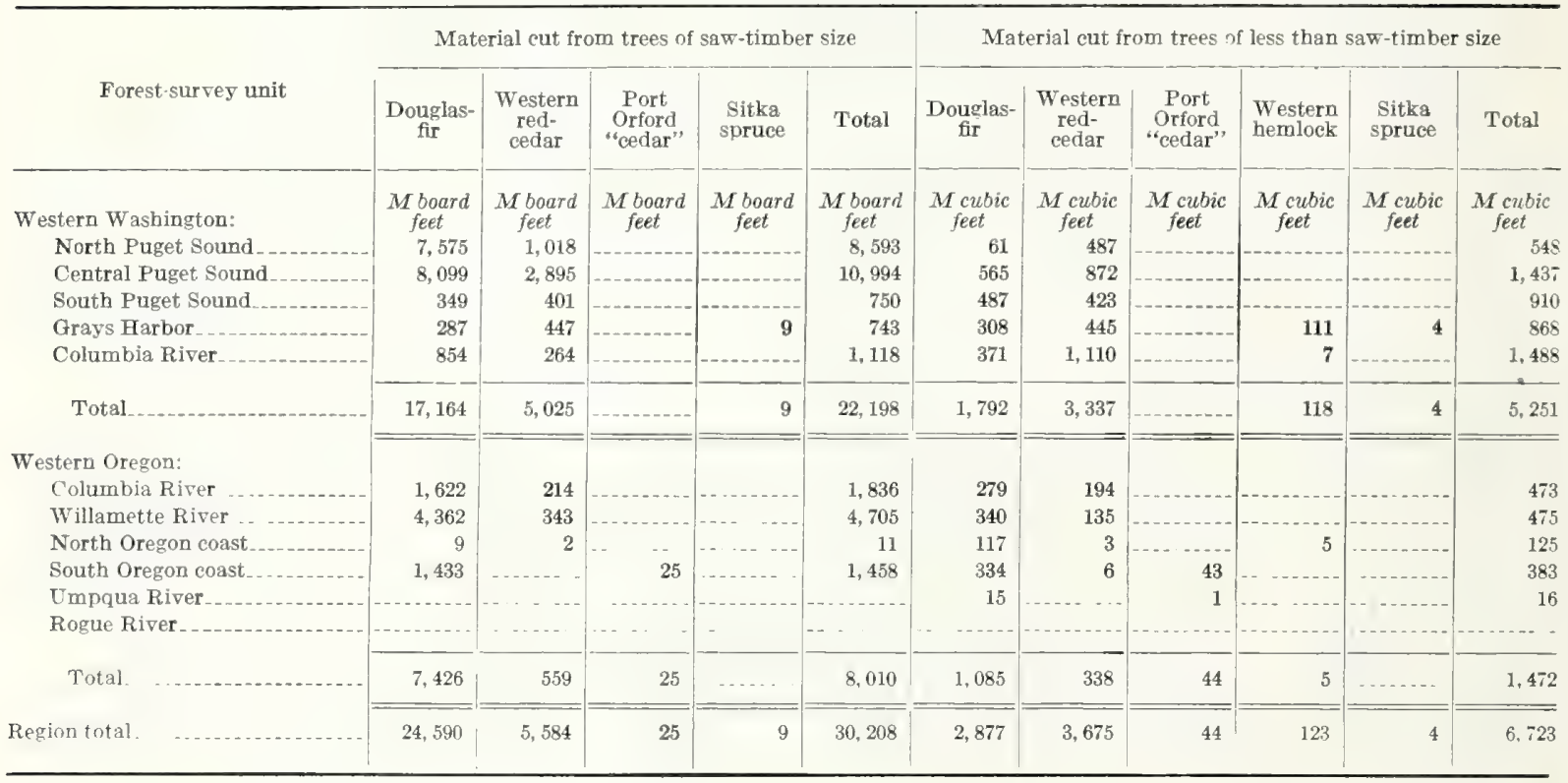


Production of forest pulpwood is usually an individual enterprise of farmers and local woodsmen. With few exceptions the producers haul the pulpwood to market by truck, and production is commonly restricted to areas within 40 or 50 miles of the pulp mills. Production increased considerably for 2 or 3 years after 1930, when unemployment among woods workers was at its height. Since then it has declined and the data for 1930 are probably representative of the average forest pulpwood production of recent years.

\section{Other Minor Timber Products}

Of the poles and piling produced in the region in 1930, as given in table 15, western Washington's annual production was three times that of western Oregon. Well over half the total was Douglas-fir, and nearly all the remainder western redcedar poles.

Veneer-block and shingle-bolt production during 1930 is shown in table 16. Practically all the veneer blocks were Douglas-fir. All the shingle bolts were western redcedar, and 80 percent of them were produced in the north Puget Sound unit. There was no reported production of veneer blocks or shingle bolts in western Oregon in 1930. This apparently means that western Oregon's veneer plants and shingle mills operated on logs exclusively.

The production of hewed ties, excelsior bolts, and mine timbers in 1930 is given in table 17. All the hewed ties produced in western Washington in 1930

TABLE 16.-Production of veneer blocks and shingle bolts, during 1930, by forest-survey unit and species 1

[In thousands board feet, $\log$ scale-i. e. 000 omitted]

\begin{tabular}{|c|c|c|c|c|c|c|}
\hline \multirow[b]{2}{*}{ Forest-survey unit } & \multicolumn{5}{|c|}{ Veneer blocks } & \multirow[b]{2}{*}{$\begin{array}{l}\text { Shingle } \\
\text { bolts, } \\
\text { western } \\
\text { redcedar }\end{array}$} \\
\hline & $\begin{array}{l}\text { Doug- } \\
\text { las-fir }\end{array}$ & $\begin{array}{l}\text { Sitka } \\
\text { spruce }\end{array}$ & $\begin{array}{c}\text { North- } \\
\text { ern } \\
\text { black } \\
\text { cotton- } \\
\text { wood }\end{array}$ & $\begin{array}{l}\text { Other } \\
\text { hard } \\
\text { woods }\end{array}$ & Total & \\
\hline North Puget Sound & 2,200 & & $\ldots$ & 10 & 2,210 & 8,000 \\
\hline Central Puget Sound- & 11,060 & 150 & 700 & 100 & 12,010 & 1,750 \\
\hline South Puget Sound.- & 10,025 & & 200 & 105 & 10,330 & $-\ldots$ \\
\hline Grays Harbor...... & 1,000 & 550 & & & 1,550 & 250 \\
\hline Columbia River. & -..... & & & & & \\
\hline Total & 24,285 & 700 & 900 & 215 & 26,100 & 10,000 \\
\hline
\end{tabular}

1 No production of veneer blocks and shingle bolts was reported for 1930 in western Oregon. All material was eut from trees of saw-timber size.
TABLE 17.-Production of hewed ties, excelsior bolts, and mine timbers during 1930, in cubic feet of solid wood by forest-survey unit and species

\begin{tabular}{|c|c|c|c|}
\hline Forest-survey unit & $\underset{\substack{\text { Hewed ties, } \\
\text { Douglas- } \\
\text { fir }}}{ }$ & $\begin{array}{l}\text { Excelsior bolts, } \\
\text { northern } \\
\text { black cotton- } \\
\text { wood }\end{array}$ & $\begin{array}{l}\text { Mine tim- } \\
\text { bers, Doug- } \\
\text { las-fir }\end{array}$ \\
\hline $\begin{array}{l}\text { Western Washington: } \\
\text { North Puget Sound_. }\end{array}$ & $\begin{array}{r}\text { M cubic feet } \\
\mathbf{4 4}\end{array}$ & $M$ cubic feet & $\begin{array}{r}M \text { cubic feet } \\
82\end{array}$ \\
\hline Central Puget Sound & 113 & 180 & 699 \\
\hline South Puget Sound & 36 & & 200 \\
\hline Grays Harbor & 14 & & \\
\hline Columbia River & 23 & & \\
\hline Total & 230 & 180 & 981 \\
\hline $\begin{array}{l}\text { Western Oregon: } \\
\text { Columbia River }\end{array}$ & & 45 & \\
\hline Willamette River & & 180 . & 69 \\
\hline North Oregon coast & & & \\
\hline South Oregon coast.- & ${ }^{1} 42$ & & 29 \\
\hline Umpqua River & & & \\
\hline Rogue River........ & --- & $\cdots-\cdots$ & \\
\hline Total & 142 & 225 & 98 \\
\hline Region total & 272 & 405 & 1,079 \\
\hline
\end{tabular}

1 Port Orford white-cedar.

were reported as Douglas-fir and all those in western Oregon as Port Orford white-cedar. Excelsior bolts, produced in the central Puget Sound unit in Washington and the Willamette River and Columbia River units in Oregon, were all reported to be of northern black cottonwood. All the mine timbers produced were reported as Douglas-fir, and most of them were cut in the central Puget Sound unit, where coal mining is an important industry.

It was difficult to obtain accurate data on post production, since approximately 85 percent of all posts produced are cut either by individual farmers for their own use or by small operators. In the totals for 1930, as reported in table 18, nearly equal quantities were produced in western Oregon and in western Washington, nearly all of them of western red cedar.

\section{Fire depletion}

Trees killed directly by fire and not salvaged usually constitute but a small percentage of the annual depletion of saw-timber volume in the Douglas-fir region. This percentage, however, is not the full measure of the destructiveness of fire; unfortunately, fire reduces future timber supplies 
TABLE 18.- Production of round and split posts in the Douglasfir region during 1930, by State, forest-survey unit, and species

MATERIAL OUT FROM TREES OF SAW-TIMBER SIZE

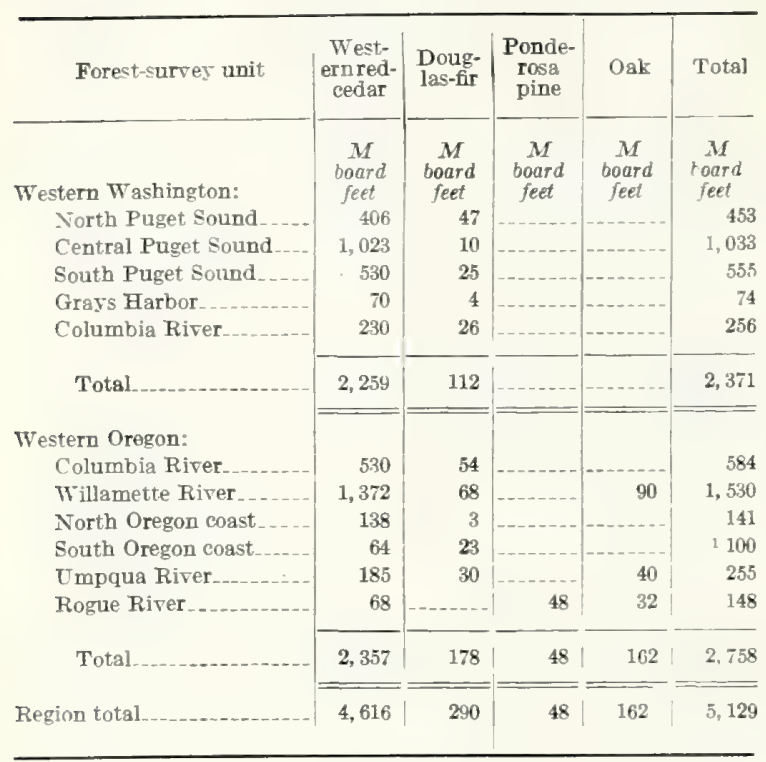

MATERIAL CUT FROM TREES OF LESS THAN SAW-TIMBER SIZE

\begin{tabular}{|c|c|c|c|c|c|}
\hline $\begin{array}{l}\text { Western Washington: } \\
\text { North Puget Sound..... }\end{array}$ & $\begin{array}{c}M \\
\text { cubic } \\
\text { feet } \\
133\end{array}$ & $\underset{\text { cubic }}{M}$ & $\begin{array}{c}M \\
\text { cutbic } \\
\text { feet }\end{array}$ & $\begin{array}{c}M \\
\text { cubic } \\
\text { feet }\end{array}$ & $\begin{array}{c}M \\
\text { cuthic } \\
\text { feet } \\
\quad 133\end{array}$ \\
\hline Central Puget Sound & 282 & & & & 282 \\
\hline South Puget Sound & 96 & & & & 96 \\
\hline Grays Harbor & 23 & & & & 23 \\
\hline Columbia River.... & 52 & & & & 52 \\
\hline Total .. & 586 & & & & 586 \\
\hline Western Oregon: & & & & & \\
\hline Columbia Rirer........ & 169 & & & 1 & 170 \\
\hline Willamette Rirer....... & 219 & & & 20 & 239 \\
\hline North Oregon coast ..... & 14 & & & & 14 \\
\hline South Oregon coast & 18 & 1 & & & 222 \\
\hline Umpqua River........ & 15 & & $\cdots$ & 8 & 23 \\
\hline Rogue River & 31 & $-\ldots$ & 3 & 18 & 255 \\
\hline Total ..... & 466 & 1 & 3 & 471 & 523 \\
\hline Region total & 1,052 & 1 & 3 & 47 & 1,109 \\
\hline
\end{tabular}

Includes $13 \mathrm{M}$ board feet of other species,

${ }^{2}$ Includes $3 \mathrm{M}$ board feet of other species.

by destroying young stands, delaying and preventing forest regeneration on cut-over land, and reducing the productivity of forest soils. In the present study of fire depletion, the gross area burned over annually was recorded by type, site, and unit and the net loss of saw-timber volume was recorded by type and unit. Such records were compiled and analyzed for the period 1924-33 for nationalforest land and for 1926-30 for all other land. The records used did not include any catastrophic fires, such as the Tillamook fire of 1933 which covered more than 240,000 acres and killed 10 billion feet of some of the finest timber in the region, practically all on private land. If such a catastrophe had been included in a study of a period as short as 5 or 10 years and for an area as small as a survey unit, the averages would have been distorted. In estimating future fire depletion it was assumed that a catastrophic fire would occur once in 30 years and a separate allowance was made for such losses. Estimates of the average acreage burned annually in the Douglas-fir region are given by generalized type for national-forest land and all other land in table 19. Saw-timber losses, confined to conifer saw-timber types, are, in $\mathbf{M}$ board feet, as follows.

National-forest land.............. 93, 790 Other land ................ 178, 613

Total. 272,403

Negligible volumes of saw timber were lost by fire in types $9,12,15,19,21,24$, and 28 ; fire reports customarily include them in saw-timber types or ignore them.

The 24,000 acres of national-forest land burned over annually in $1924-33$ is 0.24 percent of the total forest area of the national forests in the region. The net acreage was considerably less than this, since some fires reduce the stocking without completely destroying the stand. For example, in old-growth Douglas-fir stands (types 6 and 7) field study indicated that for each 100 acres burned over the net loss was equivalent to complete destruction of the stand on only 40 acres.

Approximately 30 percent of the acreage burned over annually was occupied by saw-timber stands, whereas nearly 56 percent of the total area of national-forest land in the region is occupied by such stands. A much higher proportion of the Douglas-fir seedling and sapling areas, of recently cut-over land, of old deforested burns, and of the noncommercial types is burned over annually than of saw-timber areas, for these types have a higher hazard than saw timber and older second growth. The seedling, sapling, and recent cut-over types, in particular, are highly inflammable. The non- 
commercial types commonly occur at the higher elevations, where they are exposed to lightning, the principal cause of fires on the national forests.

The annual loss by fire of saw-timber volume on national forests is 0.047 percent of the total national-forest saw timber. Very little of the firekilled timber on national forests is salvaged, because of inaccessibility to logging operations or because the quantity killed on any one area is too small to justify salvage logging.

Outside the national forests the 229,000 acres burned over annually during 1926-30 averaged 1.2 percent of the total. The average annual volume loss, not including material salvaged, was 179 million board feet, or 0.051 percent of the total saw-timber stand outside the national forests. Acreage burned over is considerably greater than on the national forests, largely because causative agents are more numerous, climate at the lower altitudes is more unfavorable, and the highly inflammable cut-over land types are more prevalent. Volume losses would be proportionately much greater than on the national forests if salvaged timber had been included. Considerable firekilled timber was salvaged on other lands. On national forests practically none was salvaged.

More than one-third of the annual burned acreage is recently cut-over land (type 36 ). During 1920-32 approximatly 165,000 acres was cut over annually, and each year more than half as much cut-over land was burned over accidentally, even after the intentional slash-disposal broadcast burning customarily practiced in western Oregon and Washington. Nearly a fourth of the total burned acreage was of stands of Douglas-fir seedlings and saplings (type 10). Areas of this type were burned over at the rate of 3.2 percent annually. These two types usually occur in the vicinity of active logging operations and are exposed to fire from slash burning of adjacent areas and from many other causes. Moreover, they are highly inflammable. Undoubtedly, also, they are given less effective protection than timber of sawlog size.

\section{Depletion From Other Causes}

Depletion from catastrophic or abnormal causes other than cutting and fire is not of great con-
TABLE 19.- Estimated annual averages ${ }^{1}$ of gross forest-land area covered by fire in the Douglasufir region

\begin{tabular}{|c|c|c|c|}
\hline Type group and type No. & $\begin{array}{l}\text { Na- } \\
\text { tional } \\
\text { forests }\end{array}$ & $\begin{array}{l}\text { Other } \\
\text { land }\end{array}$ & $\begin{array}{c}\text { All } \\
\text { land }\end{array}$ \\
\hline Conifer saw timer $(6,7,8,11,14,17,18,20$, & Acres & Acres & Acres \\
\hline $20 \mathrm{~A}, 23,27$, and 32$)$ & 7,356 & 35,631 & 42,987 \\
\hline Conifer second growth, small $(9,12,15$, and 21$)$ & 1,120 & 20,157 & 21,277 \\
\hline $\begin{array}{l}\text { Conifer seedlings and saplings }(10,13,16 \text {, and } \\
\text { 22) }\end{array}$ & 5,886 & 53,725 & 59,611 \\
\hline Conifer second growth, small $(19,24$, and 28$)$ & 968 & 231 & 1,199 \\
\hline Noncommercial $(4,51 / 2,26,33$, and 38) $\ldots$ & 3,135 & 7,808 & 10,943 \\
\hline Recent cut-over areas (36) & 1,039 & 83,797 & 84,836 \\
\hline $\begin{array}{l}\text { Old-cut-over areas, nonrestocked, and pre- } \\
\text { viously deforested burns ( } 35 \text { and } 37 \text { ) }\end{array}$ & 4,172 & 25,894 & 30,066 \\
\hline Hardwood timber $(31)$ & 34 & 2,203 & 2,237 \\
\hline Nonforest land (2 and 3) - & & & \\
\hline & 23,710 & 229,446 & 253,156 \\
\hline
\end{tabular}

For national-forest lands, fire-loss data were averaged for the period 1924-33, for other land, data are for 1926-30.

sequence in this region. Losses caused by natural phenomena such as landslides, avalanches, floods, or sand-dune movement do not form a total meriting separate consideration and are moreover exceedingly difficult to appraise on a region-wide and annual basis. Although at present there are no disease epidemics in the Douglas-fir region of such a scale as to cause extraordinary losses, the presence of white pine blister rust in sugar-pine stands of southern Oregon threatens serious future losses. It has been explained already that the current small losses inevitably occurring from endemic diseases and normal insect activity, from surface fires, from scattered wind throw, and from overcrowding in growing stands are allowed for in the preparation of growth and yield tables. The only such factors requiring separate mention are insects and wind throw.

The only forest-insect species causing material losses in the region are the hemlock looper (Ellopia fiscellaria var. lugubrosa Hulst.) and Sitka spruce aphis (Aphis abietina Walk.) in the spruce-hemlock stands near the coast, and the Douglas-fir beetle (Dendroctonus pseudotsugae Hopk.) in the Douglas-fir forests. Timber losses due to insects are not serious in the Douglas-fir region as compared with the ponderosa pine region of eastern Oregon, for example. The most destructive of the insects in this region is the hemlock looper, which becomes epidemic periodically. In 1889-91 a severe outbreak of this insect occurred in southwestern 
Clatsop County, Oreg., and in Pacific County, Wash., but no estimate of the loss from this outbreak was ever made. During the period 1918-21 another epidemic took place in Tillamook County, estimated to have killed 500 million board feet of standing timber on an area of approximately 27,000 acres. Fire followed the insects on much of this area, adding to the damage. The most recent epidemic was one in 1929-31 in Pacific County, Wash., which the Bureau of Entomology and Plant Quarantine estimated covered about 52,000 acres and caused the loss of approximately 165 million board feet of standing timber, practically all western hemlock. Control measures are credited with hastening the termination of this epidemic

The native Douglas-fir bark beetle is commonly found in freshly felled or fire-killed trees, but occasionally this insect increases abnormally on burns and cut-over areas and attacks neighboring green timber, causing considerable damage. These outbreaks are usually of short duration and small extent. The annual damage to spruce by the aphis is usually small, although heavier infestations occur periodically. The Bureau of Entomology and Plant Quarantine estimates that during the period 1921-30 the abnormal forest drain due to epidemics of the hemlock looper and other insects averaged 80 million board feet per year.

Abnormal losses from wind throw are difficult to estimate for a period as short as a decade, because they occur only sporadically and are likely to be catastrophic. The loss in the Olympic blowdown of January 1921 is estimated at 5 billion board feet, but there had probably been no storm damage like it for at least 75 years in this region. Losses averaging about 30 million board feet per year were reported for western Oregon in the decade 1920-29. In April 1931 several hundred million feet of timber was reported to have been wind thrown during one storm, which did its greatest damage on the Mount Hood and Willamette National Forests in Oregon. In October 1934 a windstorm of unusual severity in western Washington caused loss estimated at more than 300 million board feet, practically all on State and private lands in King, Pierce, Skagit, and Snohomish Counties. Fortunately a considerable part of this volume is salvable and it is therefore not considered as depletion.
On the basis of such records and evidence as were available regarding windstorms, the quantity of saw timber blown down, including both bodies of timber and scattered trees, was estimated to average 150 million board feet per year. It was further estimated that half of this fallen timber either was so scattered as not to affect total growth or would in the future be salvaged. If so, the net loss from wind throw was 75 million board feet annually.

\section{Assumed Future Depletion}

Undoubtedly all agents responsible for depletion in recent years will continue to be active in the future. By far the most important of the probable causes of future depletion is cutting. Beginning with 1933, the date of the inventory, the rate of depletion by cutting, fire, insects, and wind throw was estimated for each of three decades, 1933-42, 1943-52, and 1953-62. The estimates are shown in table 20 .

TABLE 20.-Assumed future average annual forest depletion in the Douglas-fir region

\begin{tabular}{|c|c|c|c|}
\hline Find of depletion and 10 -year period & $\begin{array}{c}\text { National } \\
\text { forests }\end{array}$ & $\begin{array}{l}\text { Other } \\
\text { land }\end{array}$ & Tota] \\
\hline Cutting: & $\begin{array}{c}\text { Million } \\
\text { board feet }\end{array}$ & $\begin{array}{c}\text { Million } \\
\text { board feet }\end{array}$ & $\begin{array}{l}\text { Million } \\
\text { board feet }\end{array}$ \\
\hline $1933-42$ & 215 & 6,785 & 7,000 \\
\hline $1943-52$ & 498 & 7,502 & 8,000 \\
\hline $1953-62$ & 831 & 6,169 & 7,000 \\
\hline \multicolumn{4}{|l|}{ Other: } \\
\hline $1933-42$ & 242 & 507 & 749 \\
\hline $1943-52 \ldots$ & 231 & 324 & 555 \\
\hline $1953-62$ & 199 & 240 & 439 \\
\hline \multicolumn{4}{|l|}{ Total: } \\
\hline $1933-42$ & 457 & 7,292 & 7,749 \\
\hline $1943-52 \ldots$ & 729 & 7,826 & 8,555 \\
\hline $1953-62 \ldots$ & 1,030 & 6.409 & 7,439 \\
\hline
\end{tabular}

During the period 1925-33, the annual depletion by cutting of material of saw-timber size averaged approximately 7.9 billion board feet. It was considerably higher at the beginning of the period, but declined rapidly after 1929. A gradual increase over the cutting rate of the 3 years $1930-32$ is anticipated during the decade 1933-42, but it is expected that the average for this period will be less than that for the period 1925-33. Therefore, it was estimated that the net annual depletion by cutting for 1933-42 would average 7 billion board feet. 
It was thought that in the decade 1943-52, as a result of reduction of timber supplies in other forest regions, a greater proportion of the national lumber requirements would be supplied by this region. Furthermore, increase in the population of the West should increase local lumber consumption and result in increased markets. Considering these and other factors, it was estimated that annual cutting depletion for the decade 1943-52 would average 8 billion board feet.

In view of the tendency of national population to become stable and the trend toward decreased per capita consumption of lumber, it was anticipated that by about 1950 national lumber consumption would again decline. By this time the eastern and southern forest regions, close to the large centers of population, should have increased their forest productivity so as to be more nearly self-sufficient, thus limiting the market in the East for lumber from the Pacific coast. An annual depletion by cutting of 7 billion feet was assumed for the decade 1953-62.

Assumptions as to future losses from fire were based on past rates of loss adjusted to meet changes in inventories. The net area burned annually per 100,000 acres was computed for each type. After analyzing these data, it was decided to combine the types into 10 groups and assign a net annual rate of loss per 100,000 acres, exclusive of that caused by catastrophes, to each group (table 50). Next, on the assumption that one such catastrophe as the great Tillamook fire of 1933 might be expected each 30 years and that it would destroy on the average approximately 150 million feet of timber on about 4,500 acres annually, catastrophe loss rates were computed for the saw-timber types and added to the rates previously calculated for ordinary fire losses.

A future net loss from wind throw of 75 million board feet annually was assumed and was converted to an acreage basis by using average-stand-per-acre figures for the types in which such loss occurs, derived from inventory check-cruise data. The result was about 1,400 acres per year. The future loss from the hemlock looper was assumed to be 60 million board feet, or 1,200 acres annually. This loss will probably occur exclusively in the hemlock saw-timber type (type 14).

Future depletion from cutting as shown in table 20 for the entire region was prorated to individual survey units on the basis of past cutting and amount of saw timber available for future cutting in the units. The total future cut assumed for each unit was prorated to type groups and the acreage cut of each type group calculated for national-forest land and other land separately. Average volume per acre as determined for each type group from inventory check-cruise data was used to estimate future cutting depletion. In so doing allowance was automatically made for logging waste.

Acreage depletion from fire, wind throw, and insect losses, computed as previously explained for each of the three decades, was converted to boardfoot volume, by use of stand-per-acre values computed separately for each unit's national-forest land and other land. These estimates were combined with cutting estimates for corresponding decades to give the total assumed future depletion from all causes (table 50). They were later used in conjunction with growth data to estimate inventories for 1943, 1953, and 1963. 
HEN conclusions had been reached regarding the extent of the forest capital of the Douglas-fir region and the rate at which it is being depleted, the next step in the survey was to calculate the rates at which this forest capital is being and might be replenished by growth.

In general, the forest stands of the region may be divided into two categories - those in which there is net volume growth and those in which growth is offset by mortality and decay. It was assumed in the survey that net increment in stands between the ages of 160 and 300 years is balanced by net loss in older stands, and estimates of growth were therefore restricted to stands not more than 160 years of age (2).

Because most of the growing stands are evenaged, growth in all stands was calculated on the basis of growth in even-aged stands and average ages were assigned to the small areas of uneven-aged stands.

Briefly, growth was calculated by applying rates to areal statistics of type, age, stocking, and site obtained in the inventory phase of the survey. Classification of forest lands and stands by these variables is described in pages 14 to 38 .

Table 21 shows what percent of the 11 million acres of growing stands in the region is occupied by each of five type groups. The conifer stands total

${ }_{10} \mathrm{~W} . \mathrm{H}$. Meyer devised the methods used in computing growth values and directed the computational work. P. A. Briegleb is the author of the text of this section. Previous publications presenting results of the growth phase of the forest survey are (1) the station's Forest Research Notes No. 17, Pulpwood Resources of Western Oregon and Western Washington, which includes some growth data for stands of pulpwood types, and (2) its Forest Research Notes No. 20, Forest Growth in the Douglas-Fir Region, which gives detailed growth statistics by broad ownership class for each unit and county of the region and briefly discusses the growth study and its results.
TABLE 21.-Composition of growing stands, in terms of total area occupied

\begin{tabular}{|c|c|c|}
\hline Type group & $\begin{array}{l}\text { Conifer } \\
\text { types }\end{array}$ & All types \\
\hline Douglas-fir & $\begin{array}{l}\text { Percent } \\
\quad 85.2\end{array}$ & $\begin{array}{l}\text { Percent } \\
76.5\end{array}$ \\
\hline Spruce-hemlock & 9. 2 & 8. 3 \\
\hline Ponderosa pine & 1.9 & 1.7 \\
\hline Other conifers & 3. 7 & 3.4 \\
\hline $\begin{array}{l}\text { Total conifers } \\
\text { Hardwood }\end{array}$ & 100.0 & 89.9 \\
\hline Grand total _. & & 100.0 \\
\hline
\end{tabular}

nearly 9 acres to 1 of hardwoods, and approximately 85 percent of them, by area, are of types in which Douglas-fir predominates.

Growth rates derived from standard Douglas-fir yield tables (12) were applied to all growing conifer stands, in the belief that application of these rates to stands of types other than Douglas-fir would lead to adequate, conservative estimates. Findings of the recently completed study of spruce-hemlock yield in the region (13) indicate that spruce-hemlock forests (fig. 16) usually produce materially greater volumes than would be estimated by use of the Douglas-fir yield tables. Because of the relatively small extent of growing spruce and hemlock stands, however, the procedure employed resulted in no serious underestimate of forest growth in the region as a whole. Analysis of results of the recently completed study of ponderosa pine yield (14) indicates that application of the Douglas-fir growth rates as modified for survey use to ponderosa pine stands has resulted in estimates satisfactory for the present purpose.

For application to actual stands the yield-table growth rates were reduced by the ratios of actual 
stocking (p. 10) to normal stocking. ${ }^{11}$ According to results of previous investigations $(12,15)$, understocked stands tend to approach normality, at a relatively slow rate where understocking is due principally to holes or gaps in the stand, and at a relatively rapid rate where it is due principally to wide spacing of the trees. Understocking in the forests as mapped in the survey is due primarily to the presence of gaps in the stands too small to be mapped on the scale adopted, and only secondarily to wide spacing of trees. The fact that no allowance was made for improvement of stocking with time contributes another element of conservatism to the growth estimates.

The growth rates used for the hardwood types were derived from an empiric yield table based on field sampling done as a part of the forest survey of Lewis County, Wash.

The growth rates used are rates of net growth; that is, they represent stand increment due to growth of merchantable-sized trees and to the passing of small trees into the merchantable-size class minus volume lost through normal tree mortality. Because the yield tables from which the rates were derived show only volume in living trees at 10 -year age intervals, they do not include the growth in trees that under present practices are lost through suppression but that could be utilized through intermediate cuttings and thinnings. Hence, intensive forest management would result in realization of growth greater than is indicated by the survey calculations.

\section{Kinds of Growth Calculation Made}

In this project four kinds of volume growth calculation were made: (1) Current annual growth, the annual increment of stands in their present condition; (2) realizable mean annual growth, an approximation of the growth that will actually occur in the future under forest practice as maintained in the past; (3) potential annual growth,

\footnotetext{
11 A normal stand, or fully stocked stand, is one that, so far as any practical consideration is involved, utilizes its site completely, that is, represents the full productive capacity of the land on which it is growing. Normality of stand is determined not only by number of trees per acre but also by spacing of trees. The condition referred to as normal stocking is not maximum stocking.
}

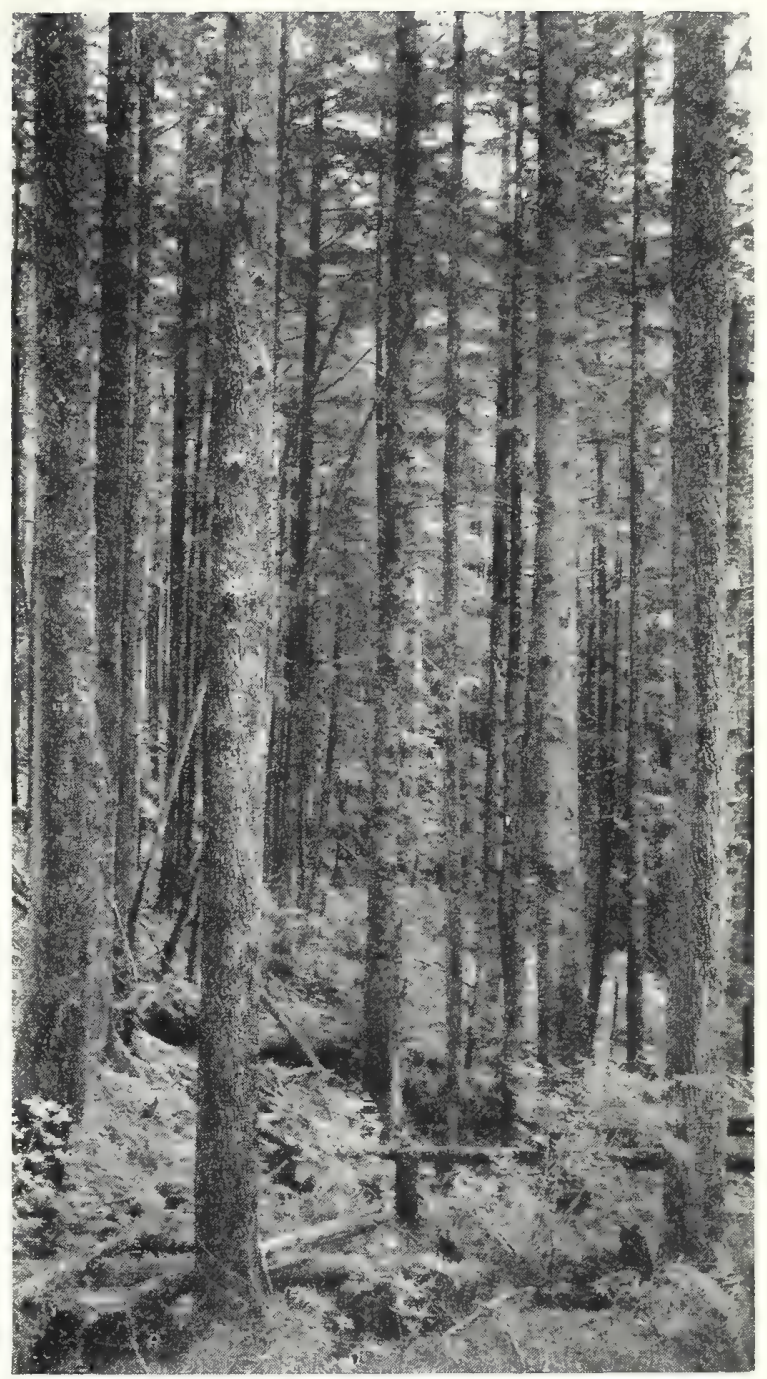

FigurE 16.-Second-growth western hemlock and Sitka spruce stand approximately 80 years of age. This type is found only within a few miles of tidewater

the average annual growth that could be obtained on the whole of the region's commercial forest land through intensive forest practice; and (4) periodic growth, the estimated growth within a given interval - in this study, 10 years. The predominance of conifers in the forests of the region has been previously pointed out. Although 10 percent of the growing stands are hardwood, less than 2 percent of the total area of forest land is true hardwood site and only a little more than 1 percent oakmadrone woodland site. In addition, much of the hardwood site is considered potential agricultural 
land and probably considerable portions of such land will be shifted from forest to farm use in the future. Consequently, in the growth phase the hardwood stands were considered only in the current growth calculation. Results of the periodic growth calculation, made in order to estimate board-foot timber inventories as of the years 1943, 1953, and 1963, are not discussed here but are included on page 150 .

In the growth phase as in the inventory phase, volume estimates were made in cubic feet and in board feet (for detailed specifications see p. 7). Periodic growth was computed on the basis of the current board-foot utilization standard only, as a means of estimating future board-foot inventories. In anticipation of more intensive forest utilization in the future, realizable and potential annual growth were also computed according to another standard, board feet for all trees 11.1 inches d. b. h. or more estimated in 16-foot logs to 8-inch top, Scribner rule. Boardfoot growth rates were reduced 5 percent for breakage and defect.

\section{Current Annual Growth}

Estimates of current annual growth, the annual increment of stands in their present condition, were based on acreages of growing types as found in 1933. This is the only one of the four kinds of growth calculation that does not involve estimates of future changes in condition and extent of forests. An estimate of current annual growth should not be used as a basis for any estimate of volume at a future time; it cannot remain valid for more than a short period. It does not show the potential productivity of the land, and it does not show the growth realizable over long periods such as are involved in management plans for large forest areas.

Current annual growth in the region totals 917 million cubic feet, or 2.4 billion board feet, Scribner $\log$ scale, of which 886 million cubic feet or 2.3 billion board feet is occurring in conifer stands (table 22).

Immature conifer stands occupy 9.9 million acres, or 38 percent of the commercial conifer forest land of the region. In cubic feet their annual increment amounts to only 0.66 percent of the region's total conifer timber stand; in board feet, only 0.42 percent.

Western Oregon, having a greater acreage of rapid-growing immature stands than western Washington, is producing 56 percent of the region's cubic-foot growth and 62 percent of its board-foot growth.

The three Puget Sound units contain 30 percent by area of the conifer second growth in the region and have 22 percent of the region's annual conifer board-foot growth and 28 percent of its cubic-foot growth. The two Oregon coast units, though containing only 14 percent of the region's conifer second-growth area and having approximately a commensurate amount of its current cubic-foot growth (16 percent), have 25 percent of its boardfoot growth. This is due to the relatively large proportion of sawlog-size stands among the growing forests on the Oregon coast, there being great areas of advance second-growth timber now about 80 years old.

Table 23 shows the species distribution of current annual growth in conifer stands. For the region as a whole, approximately three-quarters of the growth is of Douglas-fir and about one-fifth is of the pulpwood species. Notable departures from the regional averages are found in the Grays Harbor unit, where nearly two-thirds of the growth is of pulpwood species and less than one-third is of Douglas-fir. In the Rogue River unit, other species (in this instance principally ponderosa pine) are making more than one-third of the total current growth, both in cubic feet and in board feet.

The growing stands as a whole compare favorably in physical accessibility with the virgin stands of the region that are now being logged; but because their quality is, in general, much poorer, they are lower in current economic availability. However, the immature stands are growing rapidly in volume and in value and should not be logged at this time. Of greater import than their current economic availability is their potential availability. It is estimated that approximately 90 percent of such stands as a whole is either economically or potentially available.

Very little of the current net increment is being added to the large or clear stems that provide the 
bulk of the current sawlog production. Of the total net board-foot growth in the region one-third is in stands less than 22 inches d. b. h., approximately one-half in stands 22 to 30 inches d. b. h., and less than one-fifth on trees 32 or more inches d. b. h.

Survey data indicate that current annual growth is about 28 percent of total annual depletion of trees of sawlog size. However, such a direct comparison may be misleading in a region of extensive virgin forests in which growth is offset by mortality and decay. Such a rate of cutting in excess of growth may be justified until the large area of mature and overmature timber stands is converted to growing stands. The present growth of the region's forests would have been much less if extensive old-growth stands had not been destroyed by fire about the middle of the last century and replaced by thrifty growing stands which are now

TABXE 22.-Current annual growth ${ }^{1}$ in the Douglas-fir region, 1933

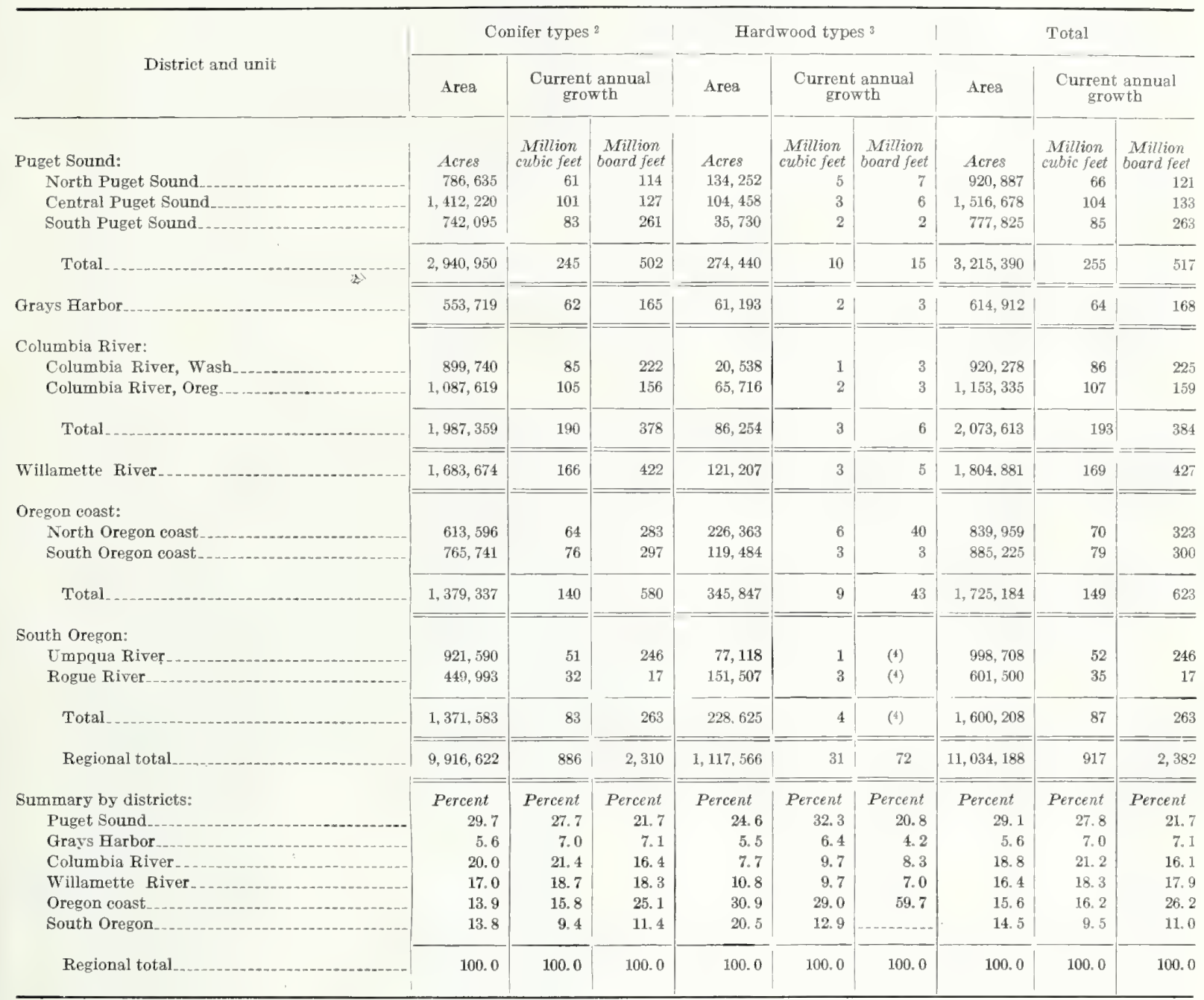

1 Growth in cubic feet is shown for the portion of the stem of all trees 5.1 hnches $\mathrm{d} . \mathrm{b} . \mathrm{h}$. or more between the stump and a top 4 inches in diameter inside bark, exelusive of bark and limb wood. Growth of conifers in board feet is shown for all trees $15.1 \mathrm{inches} d$. b. b. or more, estiraated in 32 -foot logs to 12-inch top, Scribner rule. Growth of hardwoods in board feet is shown for all trees 11.1 inches d. b. h. or more, estimated in 8 -foot logs to 10 -inch top, Scribner rule.

2 Data are shown only for stands 160 years or less in age, on commercial conifer forest land.

3 Data shown are totals for hardwood timberland (type 31) and oak-madrone woodland (type 4). Data for north Oregon coast include 182,060 acres of potential conifer forest land temporarily occupied by hardwoods, and those for south Oregon coast include 14,520 acres of such land.

Less than $1 / 2$ million board feet. 
TABLE 23. - Species distribution of current annual growth in conifer stands 1 of the Douglas-fir region

CUBIC-FOOT GROWTH

\begin{tabular}{|c|c|c|c|}
\hline Unit & $\begin{array}{c}\text { Douglas- } \\
\text { fir }\end{array}$ & $\begin{array}{c}\text { Balsam firs, } \\
\text { hemlocks, } \\
\text { and spruces }\end{array}$ & $\begin{array}{l}\text { "Cedars" } \\
\text { and other } \\
\text { species }\end{array}$ \\
\hline Puget Sound units: & Percent & Percent & Percent \\
\hline North Puget Sound & 66 & 27 & 7 \\
\hline Central Puget Sound & 74 & 22 & 4 \\
\hline South Puget Sound.................. & 88 & 9 & 3 \\
\hline Total & 77 & 19 & 4 \\
\hline 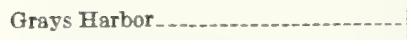 & 31 & 63 & 6 \\
\hline Columbia River units: & & & \\
\hline Columbia River. Wash & 78 & 21 & 1 \\
\hline Columbia River, Oreg & 73 & 26 & 1 \\
\hline Total _. & 75 & 24 & 1 \\
\hline Willamette Rirer. & 82 & 17 & 1 \\
\hline Oregon coast units: & & & \\
\hline North Oregon coast............ & 77 & 22 & 1 \\
\hline South Oregon cosst & 82 & 11 & 7 \\
\hline Total & 80 & 16 & 4 \\
\hline South Oregon units: & & & \\
\hline Cmpqua Rirer.-. & 88 & 6 & 6 \\
\hline Rogue River & 57 & 6 & 37 \\
\hline Total & 76 & 6 & 18 \\
\hline Region arerage & 75 & 21 & 4 \\
\hline
\end{tabular}

BOARD-FOOT GROWTH

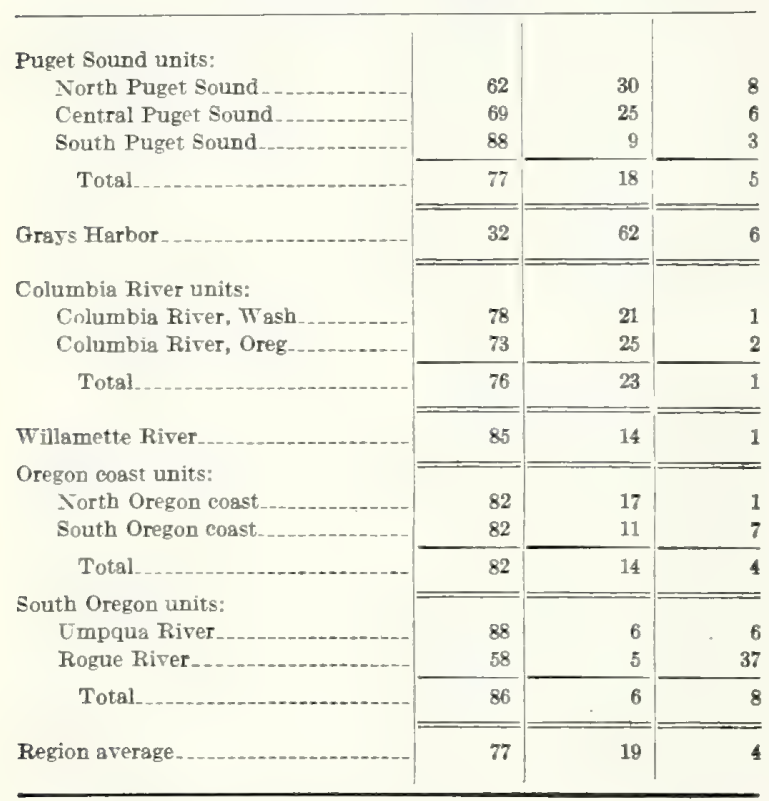

I On commercial conifer forest land. producing most of the board-foot growth. As the old-growth timber is harvested and replaced by young stands, growth will increase. More significant are the comparisons between depletion and realizable mean annual growth and between depletion and potential annual growth.

It is particularly significant, however, that the timber depletion of the region is principally in the high-quality material and that the volume being added by growth is of relatively poor quality. Hence the spread between current growth and depletion is much greater on a value than on a volume basis. In this connection it should be borne in mind that the successful application of selective timber management might greatly increase the average quality of the net volume increment.

Hardwood stands occupy 1.1 million acres and are making an annual growth of 31 million cubic feet or 72 million board feet. These totals each represent 3 percent of the region's total current growth.

\section{Realizable Mean Annual Growth}

The computation of realizable growth assumes a uniform rate of growth to assumed age at depletion. It prorates and credits the estimated growth of every stand, whether present or prospective, to the whole of its estimated life.

Although the concept of realizable mean annual growth is not entirely new, the present technique for computing such growth, which is explained in detail in the Appendix, is original and the term "realizable mean annual growth" is believed to have been used for the first time in connection with the growth phase of the forest survey of this region.

\section{Results of Computation}

If the present trends of depletion by cutting, fire, and other factors continue and if cutting and other depletion factors affect forest conditions in the future in the same manner as they have in the past, the realizable mean annual growth in the region for the decade that began with 1933 amounts to 733 million cubic feet or 3.3 billion board feet. The expected conversion of additional areas to secondgrowth conditions increases the realizable mean annual growth for the decade 1943-52 to 953 million cubic feet or 3.9 billion board feet. Further 
expected conversion from nongrowing to growing types increases the estimated annual growth for the decade 1953-62 to 1,060 million cubic feet or 4.1 billion board feet. Detail for the various units is given in table 24. Improved forest management could further increase realizable mean annual growth considerably.

Realizable growth in board feet for the decade 1933-42 is greater than current growth for every unit except the Umpqua River unit, and for the region as a whole is 43 percent greater. In the
Umpqua River unit current board-foot growth is greater than realizable growth for the first decade because in 1933 many of the growing stands were at an age at which current annual growth in board feet was greater than the average annual increment for the assumed life of the stands. In following decades, as more nongrowing old-growth timber stands are assumed to be converted to growing stands, realizable growth increases and exceeds current growth in this unit as well as in the others. The same explanation applies to the fact that cur-

TABLE 24.-Realizable mean annual growth ${ }^{1}$ of conifers of indicated diameter range in the various survey units of the Douglas-fir region, by decades

\begin{tabular}{|c|c|c|c|c|c|c|c|c|c|}
\hline \multirow{2}{*}{ Unit } & \multicolumn{3}{|c|}{$5.1+$ inches d. b. $\mathrm{h}$. } & \multicolumn{3}{|c|}{$11.1+$ inches $\mathrm{d} . \mathrm{b} . \mathrm{h}$} & \multicolumn{3}{|c|}{$15.1+$ inches d. b. h } \\
\hline & $1933-42$ & $1943-52$ & $1953-62$ & $1933-42$ & $1943-52$ & $1953-62$ & $1933-42$ & $1943-52$ & $1953-62$ \\
\hline Puget Sound units: & $\begin{array}{l}\text { Million } \\
\text { cubic feet }\end{array}$ & $\begin{array}{l}\text { Million } \\
\text { cubic feet }\end{array}$ & $\begin{array}{l}\text { Million } \\
\text { cubic feet }\end{array}$ & $\begin{array}{c}\text { Million } \\
\text { board feet }\end{array}$ & $\begin{array}{l}\text { Million } \\
\text { board feet }\end{array}$ & $\begin{array}{l}\text { Million } \\
\text { board feet }\end{array}$ & $\begin{array}{l}\text { Million } \\
\text { board feet }\end{array}$ & $\begin{array}{l}\text { Million } \\
\text { board feet }\end{array}$ & $\begin{array}{l}\text { Million } \\
\text { board feet }\end{array}$ \\
\hline North Puget Sound & 56 & 72 & 79 & 336 & 413 & 442 & 213 & 254 & 266 \\
\hline Central Puget Sound & 100 & 140 & 154 & 515 & 705 & 780 & 309 & 401 & 435 \\
\hline South Puget Sound & 66 & 88 & 102 & 418 & 527 & 594 & 314 & 378 & 409 \\
\hline Total & 222 & 300 & 335 & 1,269 & 1,645 & 1,816 & 836 & 1,033 & 1,110 \\
\hline Grays Harbor & 59 & 84 & 98 & 354 & 485 & 550 & 261 & 344 & 377 \\
\hline Columbia River units: & & & & & & & & & \\
\hline Columbia River, Wash & 74 & 94 & 103 & 462 & 562 & 599 & 328 & 380 & 394 \\
\hline Columbia River, Oreg........... & 90 & 119 & 128 & 541 & 675 & 711 & 344 & 418 & 433 \\
\hline Total $\ldots \ldots$ & 164 & 213 & 231 & 1,003 & 1,237 & 1,310 & 672 & 798 & 827 \\
\hline Willamette River..... & 118 & 142 & 162 & 797 & 906 & 980 & 559 & 613 & 6442 \\
\hline Oregon coast units: & & & & & & & & & \\
\hline North Oregon coast 3 & 53 & 71 & 79 & 402 & 491 & 511 & 316 & 370 & 378 \\
\hline South Oregon coast 3 & 58 & 73 & 82 & 427 & 489 & 530 & 343 & 377 & 396 \\
\hline Total & 111 & 144 & 161 & 829 & 980 & 1,041 & 659 & 747 & 774 \\
\hline South Oregon units: & & & & & & & & & \\
\hline Umpqua River.... & 37 & 42 & 45 & 288 & 307 & 316 & 240 & 248 & 250 \\
\hline Rogue River & 22 & 28 & 28 & 135 & 153 & 153 & 79 & 86 & 86 \\
\hline Total & 59 & 70 & 73 & 423 & 460 & 469 & 319 & 334 & 336 \\
\hline Regional total & 733 & 953 & 1,060 & 4,675 & 5,713 & 6,166 & 3,306 & 3,869 & 4,066 \\
\hline Summary hy distriets: & Percent & Percent & Percent & Percent & Percent & Percent & Percent & Percent & Percent \\
\hline Puget Sound & 30.3 & 31.5 & 31.6 & 27. 2 & 28.8 & 29.5 & 25.3 & 26. 7 & 27.3 \\
\hline Grays Harbor & 8. 0 & 8.8 & 9.2 & 7. 6 & 8.5 & 8. 9 & 7.9 & 8.9 & 9. 3 \\
\hline Columbia River. & 22.4 & 22.4 & 21.8 & 21.5 & 21.6 & 21.2 & 20.3 & 20.6 & 20.3 \\
\hline Willamette River. & 16.1 & 14.9 & 15.3 & 17.0 & 15.9 & 15.9 & 16.9 & 15.9 & 15. 8 \\
\hline Oregon coast & 15.1 & 15.1 & 15.2 & 17.7 & 17.2 & 16.9 & 19.9 & 19.3 & 19.0 \\
\hline South Oregon & 8.1 & 7.3 & 6.9 & 9.0 & 8.0 & 7.6 & 9.7 & 8.6 & 8. 3 \\
\hline Regional total & 100.0 & 100.0 & 100.0 & 100.0 & 100.0 & 100.0 & 100.0 & 100.0 & 100.0 \\
\hline
\end{tabular}

1 Growth that, according to the calculations deseribed in the text, may be expected if growth and depletion trends revealed by the survey continue through the designated period. Growth shown for trees 15.1 inches d. b. h. or more was calculated by estimating volumes in 32 -foot logs to 12 -inch top, by Scribner rule. That shown for trees 11.1 inches d. b. h. or more was calculated by estimating volumes in 16-foot logs to 8-inch top, by Scribner rule.

${ }^{2}$ Data exelude growth on 182,060 acres of potential conifer forest land temporarily occupied by hardwoods (type 31 ).

${ }^{3}$ Data exclude growth on 14,520 acres of potential conifer forest land temporarily occupied by hardwoods (type 31 ). 
rent cubic-foot growth is greater in every unit than realizable cubic-foot growth for the first decade and that realizable growth in cubic feet gradually increases, exceeding current growth in the second decade in all but four units and in the third decade in all but three units. In the Rogue River unit, realizable growth in board feet is approximately. the same in the third decade as in the second. It was assumed that in this unit greater depletion of stands increasing, rapidly in board-foot volume would occur in the third decade.

\section{Interpretation of Results}

Where extensive areas of very young growing stands and nongrowing virgin stands are involved, as in the Douglas-fir region, this type of growth computation clearly demonstrates that even without any marked increase in the intensiveness of forestry practice, future forest growth may be expected to exceed current growth as of 1933 by a considerable margin.

The next logical question is, What value can realizable growth be expected to approach? The detailed computation was carried forward only three decades because to have carried it further would have involved great additional labor and highly speculative assumptions regarding depletion and standards of forest practice and utilization, but an appraisal was made of the end result of similar computations for decades succeeding 1963.

The computation of realizable mean annual growth, if carried forward, would lead to estimates of growth for approximately 100 -year rotation on 80 percent of the commercial forest sites at a stocking of 55 percent of normal. Hence an approximation of its end result may be extrapolated by applying normal yield table rates for the commercial conifer forest sites under the stated assumption regarding stocking. This operation indicates an ultimate value of 4.5 billion board feet at the current standard of measurement and one of 7.4 billion board feet at the more intensive standard used in these growth calculations.

\section{Potential Annual Growth}

Potential annual growth is the average annual increment that could be obtained on the whole of the region's commercial forest land through intensive forestry practice. It could be achieved only after years of careful and effective forest-land management. As here computed potential growth does not represent the maximum increment obtainable; the theoretical ultimate value of increment has been substantially reduced ( 25 percent) to allow for a certain amount of understocking and nonuse of forest land believed inevitable. In computing it all the commercial conifer forest land was assumed to be occupied by immature stands, averaging 75 percent of normal stocking, with all age classes up to technical rotation age, approximate age of maximum mean annual growth, equally represented. Stocking in excess of this adjusted standard can be found throughout the region's natural forests, uniformly over areas of several thousand acres. The mean annual growth rate for each site-quality class was multiplied by the corresponding acreage, and the sum of the resulting products is the estimated potential annual growth ${ }^{12}$ (table 25).

Lands in the region capable of producing commercial conifer forests total about 26.1 million acres. These lands have the capacity to produce annually, under intensive sustained-yield forest management, 2.8 billion cubic feet of wood. Expressed in board-measure content of sawlogs from trees 15.1 inches d. b. h. or larger, the potential annual growth totals 8.2 billion board feet, log scale, Scribner rule; in board-measure content of all trees 11.1 inches $\mathrm{d}$. b. h. or larger, it comes to 12.6 billion board feet, log scale, Scribner rule. Of the region's total potential growth, 28 percent is contained in the three Puget Sound units and 16 percent in the two Columbia River units.

Areas of site-quality classes I and II include less than one-third of the region's commercial conifer forest land; but nearly one-half of its potential forest productivity (fig. 17). Less than one-tenth of the region's growth capacity is in site-quality classes IV and V, even though lands of these classes compose more than one-quarter of the commercial conifer forest land area.

Almost one-third of the commercial forest land in the region is within national forests; but because of relatively low site quality, these national-forest

iv The rates used in making these calculations, and the corresponding approximate rotation ages, are shown in table 55. 
TABLE 25.--Potential annual growth 1 of conifers of indicated diameter range in the Douglas-fir region, by survey units

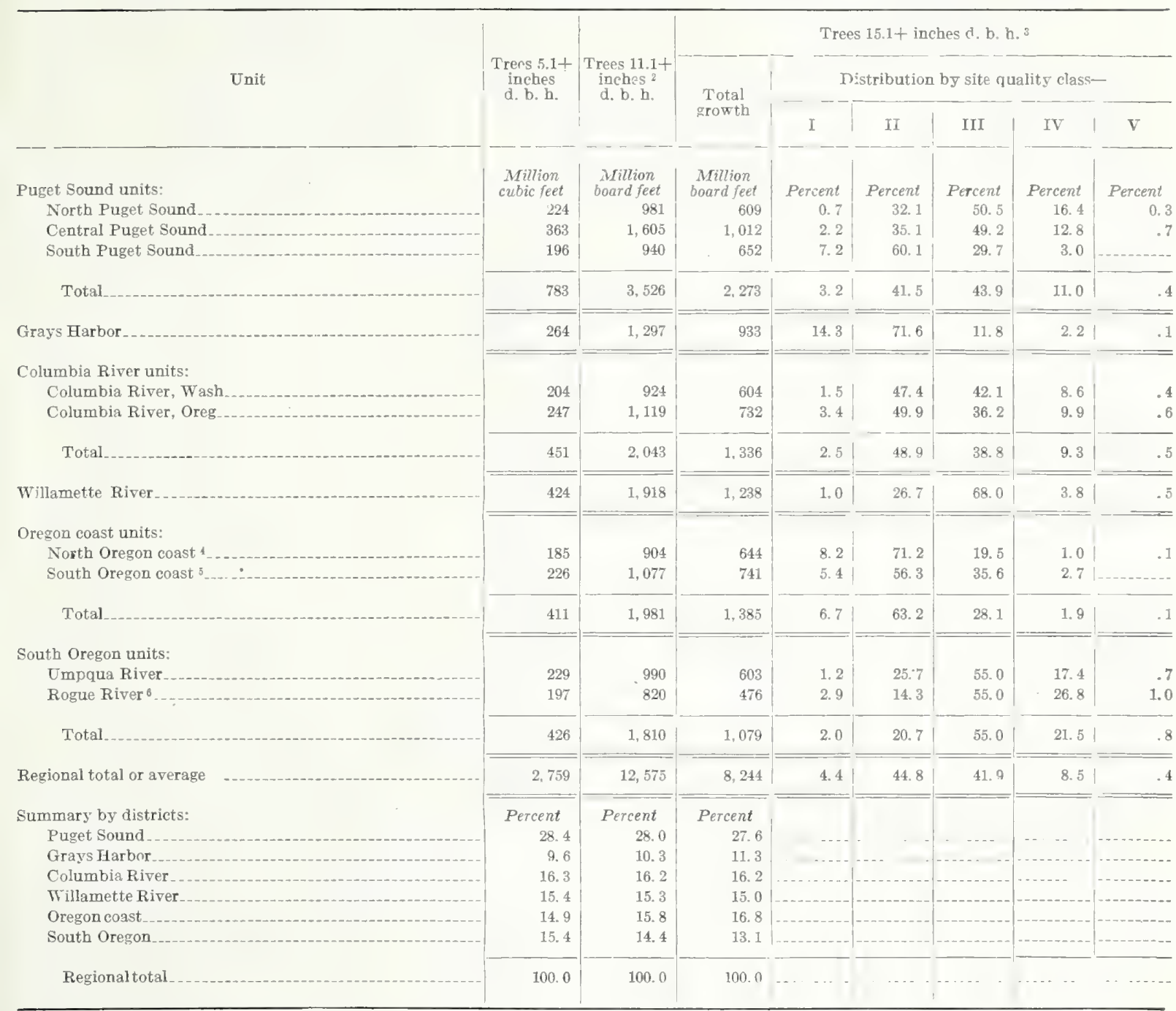

1 On commercial conifer land. Calculat ed at annual grow th rates shown in table 22

${ }^{2}$ Grow th estimated by Scribner rule in 16 -foot logs to 8 -inch top.

3 Growth estimated by Scribner rule in 32-foot logs to 12-inch top.

4 Data include growth on 182,060 acres of potential conifer forest land temporarily occupied br hardwoods (type 31 ).

3 Data include growth on 14,520 acres of potential conifer forest land temporarily occupied by hardwoods (type 31 ).

${ }^{6}$ Data exclude growth on 6.510 acres of pine woodland (type $51 / 2$ ) considered noncommercial forest land. 
lands have little more than one-fifth of the region's potential forest productivity.

Forest lands reserved from cutting have about 3 percent of the timber-growth capacity of the region. Additional withdrawal of forest lands from commercial use may be anticipated, and all such closure will correspondingly decrease the effective growth capacity of the region. The extent of this decrease is of course dependent upon the area and character of the lands withdrawn.

The species-group distribution of current annual growth as shown in table 23 is some indication of that of potential growth. Under prevailing methods of forest management and for the region as a whole, probably about three-fourths of the potential growth can be assigned to Douglas-fir and onefifth to the pulpwood species. These proportions could of course be materially altered by changes in forest management. Clear-cutting favors Douglasfir, while partial cutting tends to increase the percent of western hemlock, western redcedar, the balsam firs, and other tolerant species in the stand.

\section{Comparison of Current, Realizable, and Potential Growth}

Comparison of the growth calculations described is facilitated by table 26 .

In 1933, growing stands occupied 38 percent of the total commercial conifer land. The increment in such stands, however, was but 32 percent of the potential growth in cubic measure and 28 percent of that in board measure. This discrepancy between increment and area involved is due partly to differences in age-class distribution, but principally to the lower average stocking of current immature stands (62 percent of normal) compared with that assumed for the potential growth calculation (75 percent of normal). Differences in site on the areas involved are slight; the average site on the area that supported growing stands in 1933 is virtually equivalent to that of the entire commercial conifer area.

Although the end result of realizable growth is based on 80 percent of the commercial conifer land, the calculated end increments are but 55 to 59 percent of corresponding potential increments. This is due principally to the lower average stock-
TABLE 26. - Comparison of current annual, realizable mean annuai, and potential annual conifer growth in the Douglas-fir region

\begin{tabular}{|c|c|c|c|c|}
\hline \multirow[b]{2}{*}{$\begin{array}{l}\text { Kind of annual growth cal- } \\
\text { culation and period }\end{array}$} & \multirow[b]{2}{*}{$\begin{array}{l}\text { Area in- } \\
\text { volved }\end{array}$} & \multicolumn{3}{|c|}{ Increment or trees- } \\
\hline & & $\begin{array}{l}\text { 5.1+ } \\
\text { inches } \\
\text { d. b. h. }\end{array}$ & $\begin{array}{c}11.1+ \\
\text { inches } \\
\text { d. b. h. . }\end{array}$ & $\begin{array}{l}\text { 15.1+ } \\
\text { inche } \\
\text { d. b. b. ? }\end{array}$ \\
\hline & $\begin{array}{c}\text { Thousand } \\
\text { actes }\end{array}$ & $\begin{array}{l}\text { Million } \\
\text { cubic feet }\end{array}$ & $\begin{array}{c}\text { Miltion } \\
\text { board feet }\end{array}$ & $\begin{array}{l}\text { Million } \\
\text { board fert }\end{array}$ \\
\hline Current, 1933 & 9,917 & 886 & 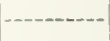 & $2,3 \mathbf{1 0}$ \\
\hline Realizable: & & & & \\
\hline $1933-42$ & 12,132 & 733 & 4,675 & 3,306 \\
\hline $1943-52$ & 13,195 & 953 & 5,713 & 3,869 \\
\hline $1953-62$ & 14,193 & 1,060 & 6. 166 & 4,066 \\
\hline End values. & 20,907 & 1,575 & 7,400 & 4,500 \\
\hline Potential___. & 26,134 & 2,759 & 12,575 & 8,244 \\
\hline $\begin{array}{l}\text { Summary in terms of poten- } \\
\text { tial values: } \\
\text { Current, }\end{array}$ & $\begin{array}{r}\text { Percent } \\
38\end{array}$ & $\begin{array}{r}\text { Percent } \\
32\end{array}$ & Percent & $\begin{array}{r}\text { Percent } \\
28\end{array}$ \\
\hline Realizable (end values) _- & 80 & 57 & 59 & 55 \\
\hline
\end{tabular}

1 Calculated by estimating volume in 16 -foot logs to 8-inch top, by Scribner rule.

2 Calculated by estimating rolume in 32-foot logs to 12-inch top, by Scribner rule.

ing, 55 percent of normal, assumed for the realizable increment in contrast with the 75 percent of normal stocking on which the potential growth calculation is based. Slight differences are also due to the rotations assumed. For the realizable calculation a constant 100 -year rotation was assumed, while the potential-growth calculation is based on technical rotations (table 55).

Under ideal forestry practice all the forest land in the region should be supporting either virgin or growing stands. However, of the area not now occupied by virgin stands, only 70 percent is supporting growing stands of one sort or another, and for this area as a whole current growth is but 58 percent of the potential in cubic measure and 51 percent in board measure. Opportunity for increasing forest growth in the region is therefore obvious.

\section{Trends in Future Forest Increment}

\section{If Present Forest Practice Continues}

If forest practice neither improves nor declines, annual growth may be expected to increase gradually from 2.3 billion board feet as of 1933 toward a maximum of 4.5 billion board feet. The rate of this increase and the date at which the maximum 
may be attained are of course dependent on the rate at which cutting proceeds, the type of stands in which it is concentrated, and the effectiveness of fire protection.

\section{If Forest Practice Becomes More Intensive}

The maximum average annual growth attainable under present standards of utilization and intensiveness of forest practice ( 4.5 billion board feet) is but little more than half the annual volume depletion the forests of the region have undergone in the recent past. Thus, the extent to which growth can be increased through improved forest practice will be a controlling factor in determining the level at which forest industry can be continuously maintained, assuming reasonable stability of demand.

By increasing the rotation assumed for realizable mean annual growth (100 years for all sites) to the technical rotation ages (ranging from 100 to 200 years, depending on site), the end value of realizable growth, based on a 55-percent stocking of 80 percent of commercial conifer sites, would be increased from 4.5 to 4.8 billion board feet. Obviously growth could be further increased by extending the timbered area and raising stocking to a greater percentage, through increased efficiency of fire control, seeding and planting of devastated sites, interplanting on poorly stocked sites, and adoption of logging methods that will insure prompt and adequate regeneration for cut-over areas. By increasing the average stocking of forest sites, mean annual increment for the region could be increased to the estimated potential annual total of 8.2 billion board feet, which assumes average stocking of all forest sites at 75 percent of normal, the estimated maximum attainable over extensive areas.

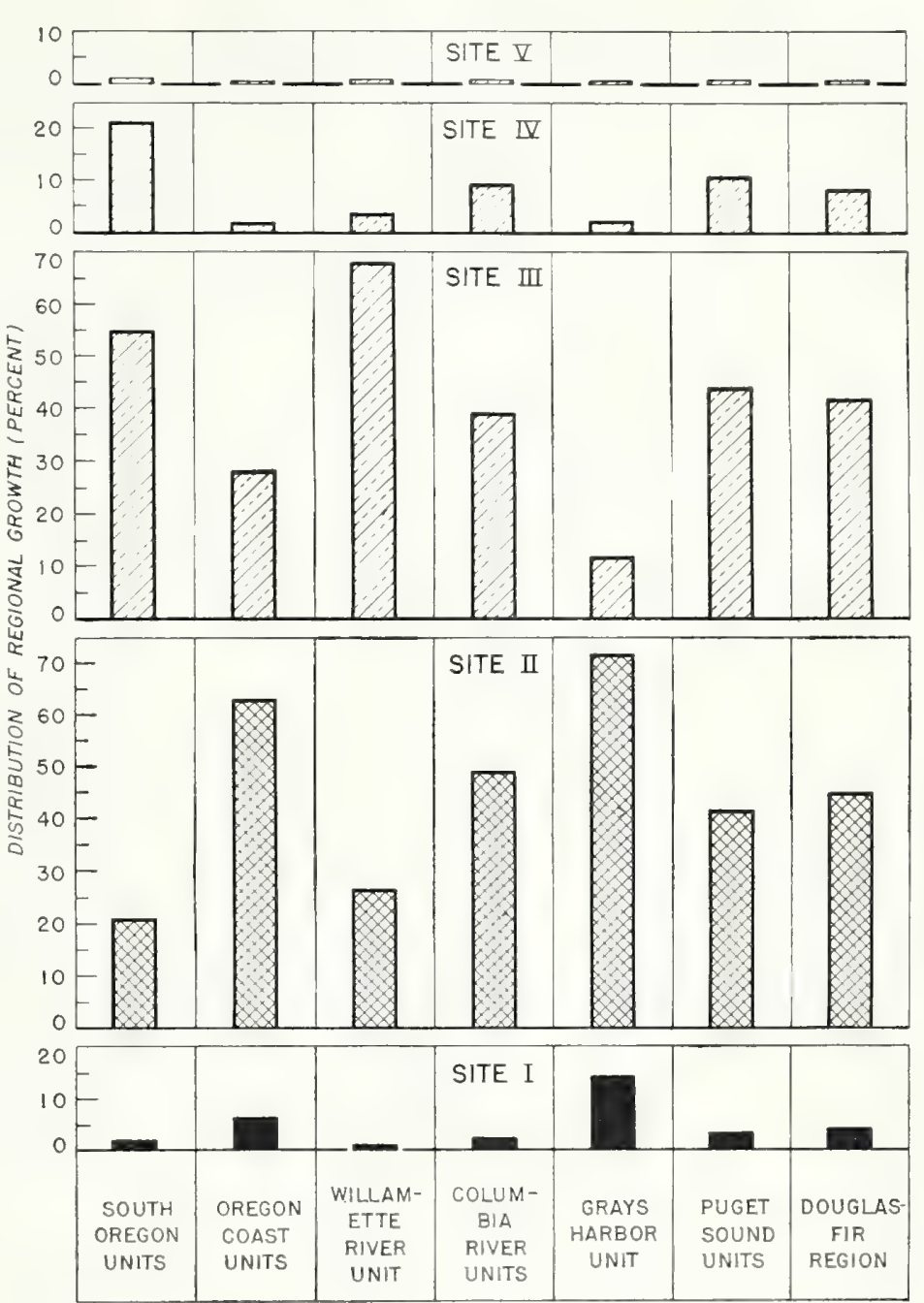

FIGURE 17.-Distribution of potential annual conifer growth (by Scribner rule, in 32-foot logs to 12-inch top) of trees 15.1 inches $d$. b. ho or more on commercial forest land in the Douglas-fir region, by survey unit and site class

From the foregoing computations of board-foot growth it is obvious that if the more intensive forest practice and higher standard of utilization were adopted, about 50 percent more material could be obtained from growing stands than is obtained under the present standard. The reductions in technical rotation age that would be effected by this change are indicated in table 55.

Under existing market conditions, increased yields through utilization of material cut in thin- 
ning operations can be realized economically only in extraordinary cases. They are dependent upon standards of utilization much more intensive than the prevailing average, and at present possible only on a few of the most accessible operations near adequate pulpwood, piling, or fuel-wood markets. The extent to which yield can be increased when opportunity is afforded for thinnings varies with utilization standard or type of product, as well as with site quality and with age and density of stands. Analysis of the normal mortality rates of Douglasfir stands reveals that ultimately increase in yield resulting from thinnings may approximate onethird of the cubic-foot yields shown in the published tables.

\section{If Selective Cutting Is Widely Employed}

A revolution in logging methods is now taking place in the Douglas-fir region. The steamdonkey, high-lead method, which is associated with clear cutting, is giving way to the crawlertractor method, which facilitates selection in cutting. If selective cutting came into practice on a wide scale as a result of this change in logging procedure, the total increment in succeeding stands would probably be somewhat different from that assumed in this discussion, which applies specifically to the even-aged second-growth stands that develop after clear cutting. Whether the increment of a given forest would be greater or less, or of improved quality, and whether the species composition would be altered, would depend largely on what kind of selective cutting was practiced. Changes in prospective growth that might be brought about by substitution of different kinds of selective cutting for clear cutting are as follows:

\section{AREA-SELECTION CUTTING}

If the selective cutting were predominantly in the nature of area selection, no material change in potential growth would be effected. In the long run, the growth on a series of patches clear cut in an operation of this sort would be about the same as that on a continuous clear-cut area of the same acreage. The proximity of an adequate seed supply, almost always assured under this system, would favor prompt, denser, and more uniform regeneration.

\section{ZERO-MARGIN CUTTING OR "CREAMING"}

If the selective cutting were predominantly zeromargin cutting, which takes all the trees of positive value and leaves the trees of minus value, the results of the change would probably vary widely. In some stands, such as the decadent even-aged Douglas-fir occurring on much of the privately owned forest land, such cuttings would frequently leave only defective and malformed trees, or suppressed trees of inferior species, which might produce little or no net growth and would be likely to cast too much shade to permit establishment of reproduction of desirable species; in this case less usable increment would become available than following clear cutting and full restocking. In other kinds of stands - for example, certain twostory stands-zero-margin selection would remove only scattered veterans and leave well-stocked, thrifty stands; in such cases, growing stock that would otherwise have been wasted would be preserved and many years' growth would be saved. In the many kinds of stands intermediate between these two, substitution of zero-margin selection would probably have widely varying effects on growth.

\section{LIGHT, FREQUENT CUTTING}

If the selective cutting prevailingly took the form of light cuts made at relatively short intervals and leaving well-distributed stands of thrifty treessuch cutting as is consistent with continuous forest management and is now being practiced experimentally in certain forest types-the reserve stand could be expected to produce a mean annual volume increment comparable in amount and greatly superior in quality to that of a normal forest composed of even-aged stands. To the extent, therefore, that this was done, selective cutting could be expected to result in greater realizable growth, particularly board-foot growth, over the whole forest area in the succeeding few decades than the method assumed in this report.

\section{SECONDARY CONSIDERATIONS}

Under selective cutting the fire hazard might be considerably different from what it is under clear cutting. If the selective cutting were light it might make possible better fire control: if heavy, it might 
have the opposite effect. Fire is the most potent factor in causing understocking and preventing satisfactory growth after logging.

Every managed forest having normal distribution of age classes, whether composed of even-aged stands or of uneven-aged stands, would probably produce about the same volume of wood per acre, site for site, under a selective-cutting as under a clear-cutting system of management, except as standards of utilization or the practicability of thinnings might vary. Under selective cutting the product would, however, average higher in quality. For example, the supply of high-quality old growth would be exhausted much less quickly and more of such timber would be produced. This should result in better utilization and therefore in greater net utilizable growth. Selective cutting might also result in utilization, through thinnings, of much material that would otherwise be lost. On the other hand, it might result in a higher percentage of tolerant species in the stand.

It may be concluded that widespread substitution of selective cutting for clear cutting would affect the volume and value increment on some areas favorably, on others unfavorably, and on others not at all. For the region as a whole, the effect of the change would depend on what type of selection predominated. If liquidation remained a controlling factor, the change would probably not alter materially the growth estimates herein presented. If large areas were carefully selectively logged under a system of light cuts at frequent intervals, realizable growth measured in board feet during the next few decades should substantially exceed the estimates presented.

\section{Summary}

Under prevailing methods of management the forests are being depleted of high-quality volume, the comparatively small volume being added by growth is of relatively poor quality, and no material improvement in quality of forest growth can be anticipated. Such increase in volume increment as may be expected without change in forest practice is small in comparison with that needed to support forest industries continuously at present levels. Although at the present time and for the region as a whole the relation of cut to permanent production capacity is apparently fairly rational it decidedly is not so for individual units. Cutting has been irregularly distributed, the best-quality stands and the most accessible stands being taken first. In several units, notably the Grays Harbor, Puget Sound, and Columbia River units, the present rate of cutting exceeds that allowable under sustained-yield management, while in Oregon outside of the Columbia River unit an increased cut could be sustained. 


\section{Forest Protection}

$\rightarrow$

$\mathrm{T}$

HE forests of the Douglas-fir region are particularly subject to devastating fires-more so than those of most of the other forest regions of the United States (fig. 18). The dry summer climate, the predominance of resinous trees, and the great volume of inflammable material all combine to create an acute fire hazard. During the past 25 years this hazard has increased greatly. The area of the inflammable types, such as cut-over land, has become much larger. Increases in mileage of roads, in motor travel, and in population, and the opening of hitherto inaccessible areas to settlers have added to the number of forest users and thus increased the possibilities of fires starting. Increased logging has left great areas of hazardous debris exposed to the drying effect of sun and wind. Lightning storms, as well as human activity in many forms, are ever present to start fires. In critical weather a spark from a logging engine, a landclearing operation, or the cigarette of a passer-by is sufficient to account for a major conflagration. Under these circumstances systematic fire protection is essential both to prevent fires which human agencies start and to hold to a minimum the damage that fire may do.

Organized fire protection has made great progress in the Douglas-fir region in the last two decades. Presumably, all forest land in the region is now protected against fire. Formerly, saw-timber areas were protected intensively while cut-over land received very little protection. In the past few years, however, particularly since the establishment of the Civilian Conservation Corps, protection of all lands has been strengthened considerably.

Federal, State, and private protective agencies cooperate closely, and together are responsible for the protection of all forest lands. Where there is a commingling of lands differing in ownership, cooperative agreements provide for division of the area and the assumption of responsibility for protection of each division by a single agency.

\section{Protection on Federal Lands}

The Forest Service is responsible for the protection of national-forest lands, amounting to about 91/2 million acres in the Douglas-fir region. In both States the Forest Service has contracted with the State foresters with fire-patrol associations for protection of isolated parcels of national-forest land intermingled with private land.

Steady progress has been made in fire protection on the national forests of this region in recent years, through increased facilities, better planning, and training of personnel in organization and technique. Since 1931 the aid received through the Civilian Conservation Corps and other emergency programs has been applied in construction of new roads and trails to make the national forests more accessible and reduce the time required to reach fires; construction and betterment of guard stations and telephone lines to increase the efficiency of fire detection and "smoke chasing"; building of many miles of firebreaks through old burns; and reduction of hazards along roads and in especially dangerous areas. Also, the C. C. C. has furnished a mobile fire-fighting force which can be organized and trained, held in readiness, and quickly transported to fires in organized units. As a result, fires have been attacked more intensively and effectively than is possible where pick-up labor only is available. 


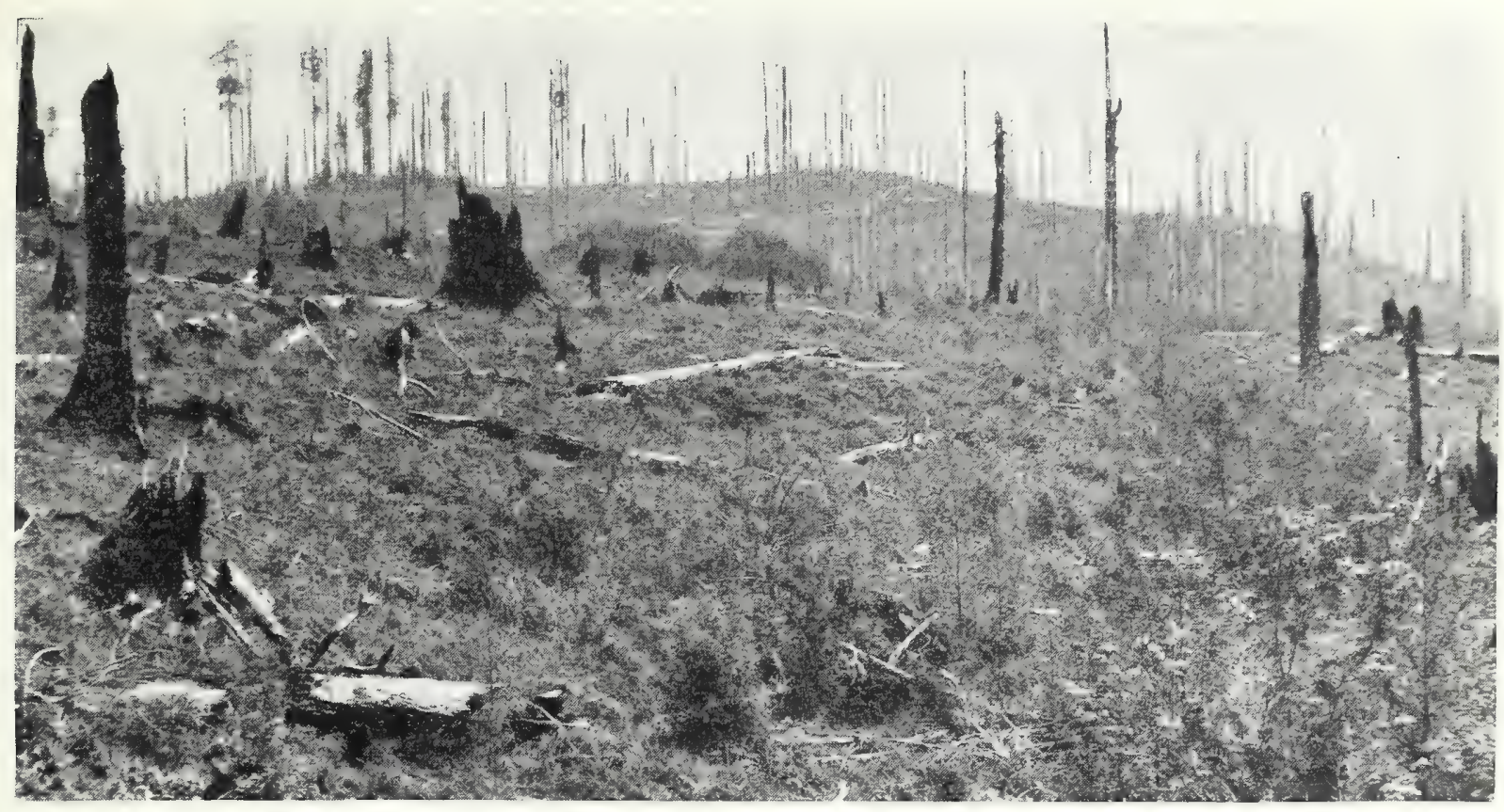

F 325521

FIGURE 18. - The fire that killed the forest stand on this area has been followed by a series of fires that have prevented restocking. Areas of similar history within the Douglas-fir region total more than $1 \frac{1}{2}$ million acres

The National Park Service is responsible for protecting the national parks and monuments. Generally speaking, the fire problem is not so acute on these lands as on the national forests. A large part of the area of the parks and monuments is nonforest land, or noncommercial forest land at high elevations where the fire season is comparatively short and the hazard not high. Indian lands are protected by the Indian Service. The protective organizations of these bureaus are similar to that of the Forest Service.

\section{Protection on State, County, and Private Lands}

Oregon and Washington both have progressive forest-fire codes providing for protection of privately owned forest lands, as well as laws requiring every owner of forest land to provide protection therefor. If an owner does not protect his land, the State forester does so and the cost is assessed against the property on the county tax rolls. Both States have compulsory slash-disposal laws. Oregon has a law enabling the Governor to close forest areas to entry during critical fire weather, and this has been invoked several times even when it meant postponement of the hunting season. In Washington, hazardous areas may be closed or other restrictions applied thereon by the director of conservation and development. Oregon also has an operator's permit law that gives the State forester authority to shut down logging operation during periods of high fire hazard, and a law requiring snag felling. Washington law authorizes the supervisor of forestry to close logging, land-clearing, or other industrial operations during periods of extreme fire hazard.

The organization of fire-protective agencies is essentially alike in the two States. On private lands, associations of timber owners have been formed to protect holdings of members. In Washington one such association functions over all territory west of the Cascade Range. Western Oregon has 11 associations, each of which covers a certain area, in some cases less than a county. Several timber companies maintain their own patrols. The Forest Service by contractual agreement with the associations and States protects practically all the 
State, county, and private lands within nationalforest boundaries and a large acreage of lands adjacent to national forests. Other private lands, State lands, and county lands are protected by the State except in King County, Wash., which retains its own fire warden, paying his salary and expenses from county funds. In both States the work of the associations and private patrols is inspected by State officials to see that adequate protection is given. In some cases the State contracts with an association for the protection of tax-roll land within the association's territory.

The States receive funds for fire protection from private owners through county tax rolls, through direct appropriation by their legislatures, and from the Federal Government. The Federal contribution under the Clarke-McNary Act has been an important factor in developing and maintaining fire protection of private lands. In 1936 the share of Clarke-McNary funds distributed to western Oregon was approximately $\$ 70,000$ and to western Washington about $\$ 65,000$. In recent years C. C. C. work has accelerated the progress of fire protection on private and State lands.

Expenditures for fire control on private and State lands in the last 10 or 15 years have ranged approximately from 3 to 5 cents per acre per year. They are generally conceded to be insufficient to obtain adequate protection of all types of forest land. The large proportion of cut-over land and other highly inflammable types on the areas protected by the State foresters increases greatly the cost of protection. In Oregon, the State forester (5) estimates that it would cost approximately 10 cents per acre per year to restrict the annual burn to 0.15 percent of the total forest area. Annual losses in both States have been many times that figure, but in 1936 and 1937 are reported to have been approximately 0.15 to 0.2 percent. Protection efforts on private lands are generally concentrated on merchantable timber, with much less attention to cutover and second-growth land.

One of the most serious problems facing the State forest-protective agencies is the rapidly increasing area of county-owned and tax-delinquent lands, which they are required to protect if the counties so elect. The State may charge the counties for such services but cannot force collection, and many counties are in arrears.
A few years ago the private associations became less active in Oregon, but they were revived by the passage of the so-called tithing act. This act provides that 10 percent of State taxes collected, including the forest-fire-patrol tax, be paid into the State general fund to be used in defraying expenses of general State administration. The timber owners, loath to see 10 percent of the money paid for fire-patrol purposes diverted, rejoined the associations. Unquestionably the scope and activities of the fire-patrol associations will diminish as more land is cut over and the volume of private saw timber decreases. Eventually, fire protection will probably be administered entirely by the States and the Federal Government. There is persistent demand for increased subvention by the Federal Government.

In respect to other enemies, the Douglas-fir region is more fortunate than in its war against fire, and protective measures against them are accordingly of relatively minor importance. Measures for conrol of hemlock looper infestations were first tried in this region during the epidemic of 1929-31. The infested areas were dusted with calcium arsenate from an airplane. The expense was shared by private owners and the State of Washington. The State acted principally as a landowner, since a large part of the timber involved was Stateowned. There are no annual expenditures for protection against either insects or disease in this region except those of the Federal Government for research in forest-insect and disease control conducted by the Bureau of Entomology and Plant Quarantine and the Bureau of Plant Industry. The former bureau has done some experimental work in the control of white pine blister rust. This problem is not serious in the Douglas-fir region, as the susceptible species (the five-needled pines) are relatively unimportant here.

\section{Future Hazard Conditions}

In the past few years logging methods in the Douglas-fir region have been revolutionized, and the end is not yet. In 1930 motortrucks hauled only a few hundred million feet of logs in this region. At present, it is estimated, trucks haul 2 million feet per day in the lower Columbia River 
region alone. It is alleged that in the 3 years 1934-36 there has been a greater shift to the use of tractors in Douglas-fir logging than there was in the 14 years 1920-33. There will still be considerable railroad and donkey-engine logging, but trucks and tractors will continue to be substituted where they are superior. The use of tractors and trucks for logging, regardless of intensity of cut, will have marked effects upon the problems of slash-hazard abatement and forest protection, some beneficial, some otherwise. For example: (1) Since logging with tractors does not knock down so much nonmerchantable material as donkeyengine logging, it leaves less combustible debris on the ground and leaves this debris rather well shaded by residual trees. (2) Disposal of slashings by broadcast burning is more dangerous and less effective after tractor logging than after absolute clear cutting, because the residual trees are likely to be killed and become snags. (3) The tractor trails and truck roads will be of some value as firebreaks and as means of ingress in case of accidental fire. (4) Absence of steam logging and railroad engines removes one flagrant cause of fires. (5) Tractor and truck logging distributes the slash hazard over a wider area than do railroad and donkey-engine logging. (6) If accidental fires are prevented, tractor-logged areas have a better chance than clear-cut areas to be quickly reclothed and shaded with woody vegetation and the fire hazard diminished.

Use of trucks and tractors has expanded the operable timber area in the region, owing largely to the fact that it makes possible the opening up of timber tracts with a far smaller capital investment than would be necessary for railroad and donkeyengine equipment. Past procedure resulted for the most part in large, continuous expanses of cut-over land, the fronts of which were extended by each year's cutting.

If protective measures are not adapted to the changing situation, the shift to truck and tractor logging may increase fire hazard. If areas logged selectively are broadcast burned, then hazard will be greater than that of clear-cut and broadcastburned areas, because of the killing of reserve trees. Where the slash hazard would not be materially reduced by burning and a useful reserve stand would be killed thereby, very intensive protection must be substituted. This will be facilitated in the case of very lightly logged areas by the relatively small quantity of debris and by the shade resulting from the reservation of large numbers of trees.

In view of the wide range in cutting methods and types of machinery, it would be unwise to adopt any inflexible method of slash disposal but rather to vary the method to fit local conditions. 
A century ago, before agricultural development of the Pacific Northwest began, approximately 33 million acres, or 94 percent, of western Oregon and western Washington was forested. Nearly half the nonforested land was level or rolling prairies and meadowland in the lower valleys. The open land suitable for agriculture was all preempted shortly after the arrival of the first settlers. The building of transcontinental railroads-largely between 1880 and 1890-brought an influx of settlers from the East and Middle West and immigrants from Europe. Clearing of forest land for agriculture then started in earnest. At the same time lumbering developed as an industry and cut-over land became available for agricultural settlement. In all, about $33 \frac{1}{2}$ to 4 million acres of forested land has been transformed into agricultural land, either by land clearing alone or by logging and subsequent clearing.

The remaining forests have been altered considerably by man's work. About $5 \frac{1}{2}$ million acres has been logged and not put to other use, and a large part of this is not satisfactorily restocked. Several extremely large fires and numerous smaller fires directly traceable to human causes have devastated vast areas. Second-growth stands are growing on extensive areas of logged-off land and old burns.

\section{Agriculture}

\section{Present Use of Land for Agriculture}

Agricultural land, as defined by the forest survey, consists of cultivated and pasture land, including stump pasture but excluding woodland or forest land in farm ownership. It totals approximately $4,700,000$ acres, about 70 percent of which is in western Oregon. It is estimated that more than half the farms in this region have some of their acreage in forest land.

The most extensive body of agricultural land in this region is in the Willamette Valley, in northwestern Oregon. This is a broad alluvial valley, interrupted occasionally by low rolling hills, about 120 miles in length and 50 miles in width at its widest point, containing about 2 million acres of agricultural land. Its soils are chiefly recent alluvial and old valley fill. The hill soils are residual, originating from both basaltic and sedimentary material.

The agricultural lands in the Umpqua River and Rogue River Valleys, in southwestern Oregon, the only other large bodies of farm land in western Oregon, total about half a million acres. The remaining agricultural land in western Oregon occurs as small areas on flood plains and bottom lands of the larger streams.

The most important agricultural areas in western Washington are the Cowlitz and Chehalis Valleys, the west half of Clark County, and the flood plains and alluvial valleys of the larger streams flowing into Puget Sound, such as the Nooksack, Skagit, Snohomish, Duwamish, and Puyallup Rivers. None of these compare in extent with the Willamette Valley, but they include some extremely productive land.

The total area in farm ownership in the Douglasfir region was nearly 7 million acres in 1934, according to the Bureau of the Census. Of this total approximately 2 million acres was classified as cropland, $3 \frac{1}{2}$ million acres as pasture land, more than three-fourths of a million acres as woodland not pastured, and nearly half a million acres as building sites, farmyards, roads, or wasteland. 
In addition to the woodland not pastured, 2 million acres of the pasture land was classed as woodland pasture, making a total of nearly 3 million acres of woodland in farm ownership. Much of this, however, is stump land supporting only a sparse stand of second-growth conifers or hardwoods; on the other hand, a considerable part of the area classed as woodland pasture is well forested and is only intermittently used for grazing. Since only about $4 \frac{3}{4}$ million acres was classified by the survey as agricultural, it can be seen that only a small portion of the woodland pasture was classed in the survey as agricultural; the remainder was considered forest land. Not all the forest land in farm ownership can be considered as farm woods, or woods managed in conjunction with agricultural land; some of it is entirely unrelated to the farm operation and is merely timberland adjacent to farms that is being held until the timber can be logged. Many a farm in the Douglas-fir region consists of a few acres of tillable bottom land and a large area of mountainous forest land. Such a farm is only a place of residence for the owner, producing not more than enough for family consumption. This type of farmer obtains a cash income from woods work and regards his forest land as a timber investment to be liquidated whenever possible.

There were nearly 100,000 farms in the Douglasfir region in 1934, according to the Bureau of the Census. The average farm contained 70 acres: 21 acres of cropland, 5 acres of plowable pasture, 21 acres of woodland pasture, 10 acres of other pasture, 8 acres of woodland not pastured, and 5 acres of land classified as miscellaneous.

The Bureau of the Census classified 22 percent of the farms as dairy farms, 19 percent as abnormal, 16 percent as general farms, 14 percent as poultry farms, 11 percent as fruit farms, 7 percent as selfsufficing farms, and 11 percent as either grain, crop specialty, truck, animal specialty, or stock farms. It is significant that such a large percent was classed as abnormal farms, a category comprising five subtypes-institutions, part-time farm, boarding and lodging farms, forest-product farms, and horse farms. In this group the part-time farms and forest-product farms are probably the most important and numerous. The part-time farm is defined as one where "the operator spent 150 days or more off the farm, in other than farm work, or reported an occupation other than farmer, provided the value of products did not exceed $\$ 750 . "$ Many of the part-time farmers were employed in forest industries. The forest-product farm is defined as one "where value of forest products sold represented 50 percent or more of the total value of all products of the farm." This type of farm is common in the Douglas-fir region.

The most recent population census, that of 1930, showed that in this region the rural farm population amounted to 316,778 , or 16.8 percent of the total population. For the same year persons classed as gainfully employed in agriculture numbered 103,643 , which is 12.7 percent of the regional total of persons gainfully employed in all occupations.

TABLE 27.-Acreage of improved farm land and of farm woods, number of farms, and average size of farms in the Douglas-fir region 1 , in stated years

\begin{tabular}{|c|c|c|c|c|c|c|c|c|c|}
\hline & \multirow[t]{2}{*}{ Year } & \multicolumn{2}{|c|}{ Land in farms } & \multirow{2}{*}{$\begin{array}{c}\text { Farms } \\
--- \\
\text { Number } \\
15,819\end{array}$} & \multirow{2}{*}{$\begin{array}{c}\begin{array}{c}\text { A verage } \\
\text { size of } \\
\text { farms }\end{array} \\
\begin{array}{c}\text { Acres } \\
254.7\end{array}\end{array}$} & \multicolumn{2}{|c|}{ Farm land 2 improved } & \multicolumn{2}{|c|}{$\begin{array}{c}\text { Farm land in farm } \\
\text { woods }^{3}\end{array}$} \\
\hline $1880_{-}$ & & $\begin{array}{c}\text { Acres } \\
4,028,421\end{array}$ & $\begin{array}{r}\text { Percent } \\
11.6\end{array}$ & & & $\begin{array}{c}\text { Acres } \\
1,958,037\end{array}$ & $\begin{array}{r}\text { Percent } \\
48.6\end{array}$ & $\begin{array}{c}\text { Acres } \\
1,793,678\end{array}$ & $\begin{array}{l}\text { Percent } \\
44.5\end{array}$ \\
\hline 1890 & & $4,763,145$ & 13. 7 & 23,384 & 203.7 & $1,990,736$ & 41.8 & & \\
\hline 1900 & & $6,268,601$ & 18.0 & 39,237 & 159.8 & $1,880,431$ & 30.0 & & \\
\hline $1910_{-}$ & & $6,260,944$ & 18. 0 & 54,775 & 114.3 & $2,133,081$ & 34.1 & $2,180,796$ & 34.8 \\
\hline $1920 \ldots$ & & $6,223,326$ & 17.9 & 64,592 & 96.3 & $2,386,164$ & 38.3 & $2,226,895$ & 35.8 \\
\hline 1925 & & $6.214,646$ & 17.9 & 78,917 & 78.7 & $2,299,283$ & 37.0 & $2,685,412$ & 43.2 \\
\hline 1930 & & $6,421,233$ & 18.5 & 77,165 & 83.2 & $2,44 i, 502$ & 38.1 & $2,791,580$ & 43. 5 \\
\hline 1935 & & $6,866,127$ & 19. 7 & 95,991 & 71.5 & $2,527,981$ & 36.8 & $2,950,404$ & 43.0 \\
\hline
\end{tabular}

1 Exclusive of Hood River County, which was created in 1908 from part of Wasco County.

Includes cropland and plowable pasture.

Includes woodland pasture and woodland not pastured.

Data from Bureau of the Census. 
The total value of farm products sold, traded, or used by operators' families amounted to 144 million dollars during 1929. The value of field and orchard crops made up approximately half this total, dairy products nearly a quarter, and poultry and eggs about a quarter. The principal field and orchard crops produced were vegetables, berries, apples, cherries, prunes, walnuts, hay, and grain. During 1929, sales of farm-forest products brought in nearly 3 million dollars and, in addition, 21/2 million dollars' worth of fuel wood, fence posts, and other forest products were used on the farms where they originated.

\section{Trends in Agricultural Land Use}

From present indications agricultural use of land has about reached a condition of equilibrium. Relation of present to past conditions is indicated by the 1880-1935 Census Bureau data (table 27) for total acreage in farms, number of farms, average size of farms, acreage of improved land in farms, and acreage of farm woods.

Between 1880 and 1900 farm acreage increased sharply, but for 25 years thereafter the increase was slight. Increase in acreage of farm woods was more gradual, and came mainly after 1920 . The rise in improved land in farms has been slow and fairly steady since 1900. Between 1880 and 1935. the number of farms increased fivefold and average size of farm decreased by more than two-thirds. In the early days of agriculture large farms were the rule and cereals were the principal crops. As population increased and transportation facilities improved, many of the large farms were divided. Grain became less profitable as a crop as land values rose above those in eastern Oregon and Washington, and farming became more intensive and varied.

There are now few blocks of forest land as large as 10,000 acres in the whole region - whether virgin timber, second growth, or cut-over-that could successfully be converted to agriculture, and what potential agricultural land there is lies mainly in Washington, in Lewis, Grays Harbor, Pacific, western Clallam, and western Jefferson counties. ${ }^{13}$

\footnotetext{
${ }^{13}$ In studying possible future conversion of forest land to farm, the forest-survey staff received valuable assistance from agricultural experiment station staff members and county agents of both States.
}

Burrier (3) states that the principal areas in western Oregon suitable for new or more intensive farming are the Willamette Valley and tidelands and wet areas along the Columbia and coastal streams. It has been estimated that drainage would be profitable at this time on 250,000 to 500,000 acres in the Willamette Valley, and preliminary investigations indicate that irrigation could profitably be extended to about 500,000 acres in the valley. Burrier predicts that from 500,000 to 750,000 acres of undeveloped land in western Oregon will eventually be cleared, about half being bottom and valleyfloor lands. A large part of this area is stump pasture or idle forest land, and clearing it will not materially reduce forest crop production.

From present indications there will be little change in the acreage of cultivated land during the next two or three decades. Doubtless some forest land will be cleared and some cleared land now in agricultural use will revert to forest, but the net change will probably be small. Very little of the remaining uncleared forest land would produce sufficient agricultural income to justify the $\$ 100$ to $\$ 250$ per acre required to clear it. What little forest land is cleared will usually be parts of existing farmholds.

\section{Relation of Agriculture to Forests}

The forest is an integral part of the farm economy of this region. Not only do the forests furnish fuel, fence posts, and other products essential to farm management and rural life and a cash crop important in farm economy, but forest industries also afford part-time employment to many farmers. Communities supported by forest industries are important markets, and in some cases the only markets, for local farm produce. Taxation of forests and forest industries helps to build and maintain roads, schools, and other public facilities used chiefly by the rural population.

Of the nearly 3 million acres of woodland in farm ownership in this region in 1934 (table 27), more than two-thirds was grazed. Results of the forest survey indicate that of the total area classed as woodland pasture more than a million acres is so lightly grazed that it is primarily forest land and the remainder is stump land with little forest growth The area of actual farm woods in the region ap- 
proximates 2 million acres, a part of which consists of old-growth stands held for timber speculation and not intended to be operated as part of the farm. The total saw-timber stand in farm woods is estimated at approximately 10 billion board feet. Each year forest products valued at about $\$ 5,000$,000 are removed from farm woods for sale or home use.

Many farmers are employed part time in these neighboring logging operations and in sawmills and other wood-using industries. The periodicity of employment in the forest industries allows them ample time for farm work. No accurate data are available on the amount of employment thus furnished but it is conservatively estimated that 10 to 20 percent get work of this kind. Many have only small farms and practice no more than a subsistence type of agriculture, but they are classified as farmers by the Bureau of the Census.

The proximity of forests gives the farmers a readily available and cheap supply of fuel wood, fencing, building materials, boxes, and other forest products within a reasonable hauling distance, wherever their own woodlands fail to supply their needs. Even the Willamette Valley, the largest agricultural body in this region, is dotted with patches of forest. The low cost of these essential forest products partly offsets the disadvantage of remoteness from the large markets for agricultural goods.

The forest resources of the region pay a large part of the local taxes. In many of the sparsely settled counties they are the principal source of revenue. Many roads used almost exclusively by farmers and many schools attended only by farm children are chiefly supported by the taxes on forest lands. Gerrymandering of school, road, and port-improvement tax districts to include bodies of inaccessible virgin timber is not an uncommon practice. Unquestionably forest resources have reduced the burden of taxation on farm property, especially since virgin forest lands make little demand on the public treasury for services. The expenditures of tax money for the benefit of forest properties are quite disproportionate to the revenues collected therefrom, in comparison with the expenditures for and revenues from farm property.

The availability of cheap cut-over land and other raw land has been responsible for the establishment of many submarginal farms. Burrier (3) estimates that 5,000 to 6,000 farms in western Oregon are problem farms, submarginal as full-time self-sustaining units, chiefly "stump" ranches and farms in "shoestring" valleys. In Oregon they constitute a serious land use problem. Except where continuous supplemental employment can be obtained, the farmers either abandon the farms or depend on public funds for support. These scattered farms in the forest zones unduly increase the cost of local government and greatly raise the fire hazard of adjoining forest land. Not only does the timber owner have to pay more for fire protection but the cost of road and school upkeep falls more heavily upon him. The migration of large-scale logging operations leaves in their wake stump ranchers in distress because of loss of their outside employment. Were sustained-yield management, instead of liquiation, the prevailing policy of private forest-land

TABLE 28.-Stocking classification of cut-over lands in the Douglas-fir region

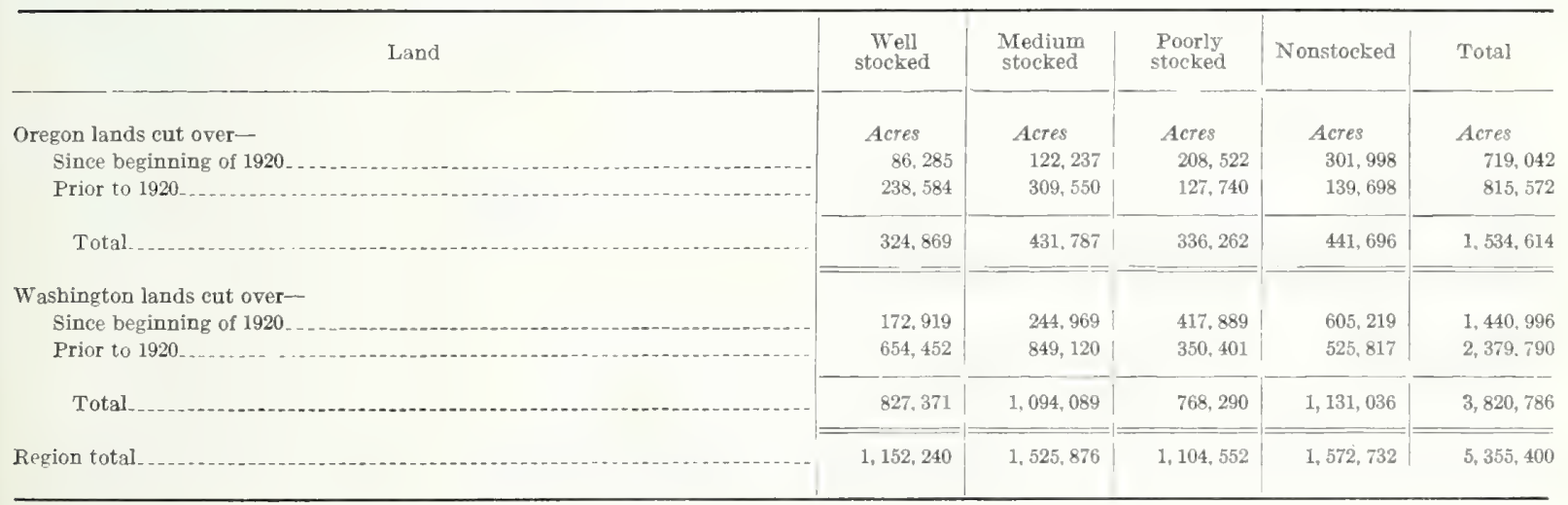


owners, there would be continuing forest employment for a small number of part-time farmers.

\section{Forest Land Use}

The present area of forest land, 29 million acres, will probably remain practically constant for some time to come. This vast area represents a natural resource not only for the production of timber and other commodities, but also for watershed protection, recreational use, wildlife production, and grazing use. Practically every body of forest land can serve efficiently more than one of these uses and in many cases all simultaneously and without conflicting.

Status of Cut-Over Land

As of 1933 the forest-survey data show that 5.36 million acres of forest land in the Douglas-fir region has been cut over and not put to other use (table 28). Of this area about 3.20 million, or 60 percent, was cut over prior to 1920 .

Thirty-six percent of the land cut over prior to 1920 and 71 percent of that cut over later is not restocking satisfactorily, amounting to 50 percent of the total 5.36 million acres. The 2.68 million acres of cut-over land that has restocked satisfactorily is widely scattered. Reforestation has resulted from several combinations of circumstances. The methods of logging and slash disposal practiced varied from early-day light ground logging with no slash burning to clear cutting with complete slash burning. Many tracts were clear cut with no slash burning; still others were clear cut and slash burned, but owing to weather conditions were burned only lightly. Most of the total area, however, was slash burned after logging and thereafter, either by intention or by chance, not reburned.

Fire-protection agencies in the region, in compiling fire statistics, do not record areas on which slash is burned under permit. They attempt to cover all areas reburned, either by accidental fires or in connection with the original slash burning of adjoining areas. Undoubtedly many accidental fires reburning cut-over areas are unreported, although reporting service is much better now than formerly. Fires reported by the protective agencies burned over an annual average of 85,000 acres of recently cut-over land (cut since January 1, 1920) during the 5-year period 1926-30, or more than half the 13-year average of 165,000 acres cut over annually during the period 1920-32. Actually, these reported burns have covered much less than half the cut-over lands, since they undoubtedly included each year substantial acreages of repeated burns. Barely more than one-fourth of the recent cut-overs have restocked satisfactorily, and apparently fire has not been solely responsible. Elsewhere unreported accidental reburning of cutover areas in connection with annual disposal of slash may be to blame. Certainly fire or destructive logging methods must be responsible for the difference in this respect between lands logged before and after 1920. Analysis of data on lands logged prior to 1920 shows that as of 1932 nearly 65 percent were satisfactorily restocked. Much of this area was logged under less destructive conditions than prevailed in later years, and no part of it was subject to the extreme fire hazard of proximity to large areas of recently logged lands. It is a safe assumption that by 1943 not much more than half the lands clear cut in 1920-32 will be satisfactorily restocked if present practices persist, largely because of repeated fires.

This raises the question whether clear-cut areas can be burned in a manner that does not endanger adjacent forest land. Without doubt, vast improvement over past practices and results can be attained, and determined efforts to restrict slash fires to areas cut over during the current year would result in far more reproduction.

The principles and detailed practices involved in slash disposal in this region, after the conventional clear cutting, are covered in a previous report (16) and will not be discussed here.

\section{Timber Production}

In this region 26 million acres, nearly 90 percent, of the forest land was classified as suitable for commercial production of softwood timber and more than half a million acres additional for commercial hardwood timber. Under improved forest management practically all this land, on which timber production will be pre-eminent for many years to come, can perform other functions without interference with its main resource. On the privately 
owned lands other uses will be incidental since these lands are for the most part more valuable for timber production than are the public lands. Of the commercial forest land in public ownership, 696,000 acres generally less suitable for timber production has been set aside for recreation and city water supply protection exclusively.

\section{Production of Commodities Other Than Timber}

Forest products other than timber, from which considerable income is obtained in this region, include Christmas trees, cascara bark, tanbark. swordferns, berries, huckleberry greens, pitch, and Oregon-grape root.

The most important of these is the bark of the cascara buckthorn (Rahmmus purshiana), valuable for its medicinal properties. The gathering of the bark is a seasonal occupation pursued largely by local residents. During the depression this employment has been an important source of income to many people. The price, forced down by a glutted market, has gone up again as unemployment has decreased-from 1 1/2 cents a pound in 1933 to a high of 9 cents a pound in 1936. Despite predictions that the supply of cascara bark would soon be exhausted, it is apparently as large as ever. The dealers state that when the price is around 6 to 8 cents a pound the normal peel is 2,000 tons. The demand is comparatively inelastic, and excess production in 1 year results in a lower price and a smaller peel the next year.

The popularity of Douglas-fir Christmas trees in other parts of the country has resulted in an enormous increase in the annual shipments. In 1936, it is estimated, about $4,000,000$ trees were shipped by rail, truck, and vessel to all sections of the country except the Rocky Mountain and New England States. The majority were consigned to California; other principal destinations were Texas, Kansas, Illinois, Louisiana, Florida, and Oklahoma. A small number were shipped to Hawaii and the Philippine Islands. A large part of the delivered price goes for freight, but the local revenue, including stumpage, labor, etc., undoubtedly totals at least a million dollars annually. Four counties in western Washington, Mason, Kitsap, Thurston, and Pierce, produce the large majority of the annual cut, and in 1936 Mason County alone produced about 25 percent of the regional total. The low-site gravelly soils in this section grow a bushy tree with closely spaced whorls of branches that sells most readily.

On privately owned cut-over land nearly all the young trees are cut for Christmas sale and no attempt is made to manage the land for future crops. Where the land is insufficiently stocked to begin with, as is often the case, the future sawlog productivity of the land is impaired. If the cutter gave thought to making an improvement thinning and to leaving a sufficient stand for proper forest development, the Christmas-tree industry would furnish the landowner some return from his 8- to 20 -year-old stock and yet not diminish production of the major forest crop.

The bark of the tanoak has a high tannin content, and formerly was used in considerable quantities. In recent years the gathering of tanbark has practically ceased, owing to depletion of the available supply and competition of other materials. The latter has so lowered the price that it is at present unprofitable to cut tanoak for bark alone.

Data on ferns, pitch, berries, and the other miscellaneous forest products are nonexistent or unsatisfactory. Harvesting is done almost exclusively by local residents as home industries and no reliable records are kept. These byproducts of the forest, mainly of second-growth stands, are now of very little significance in comparison with the major commodities, but it is safe to predict that there will be a strengthening market for some of them. The gathering of these secondary crops hardly ever conflicts with other forest uses, except in some instances it has increased the risk of forest fires.

\section{Soil and Watershed Protection}

In the Douglas-fir region the great extent of the old-growth forests, the luxuriance of the shrubby vegetation that within 2 or 3 years of logging clothes much of the deforested land, the abundance of water available for farm, home, and industry, and the mildness of the climate render the protective function of the forest cover of much less consequence than in many other parts of the United States. Any vegetative cover does, however, exert an ameliorating influence on flood peaks by retarding run-off and lengthening the time required for 
waters to congregate in streams, and tends to insure continuity of stream flow throughout the dry summer months. Perhaps even more important, it protects the soil against abnormal erosion.

In view of the heavy precipitation, it is fortunate that cut-over areas in this region normally become clothed with a cover of grass, weeds, or shrubs within 2 or 3 years after logging. Such a cover gives watersheds considerable protection from erosion, but is much less effective in retarding runoff and preventing abnormal erosion than a complete forest canopy, is inherently temporary in nature, and is highly inflammable. The area of cut-over land has increased rapidly in the last 20 years and the average quality of the watershed cover has correspondingly lowered. Floods in some 20 to 30 streams west of the summit of the Cascade Range cause damage to lowland property estimated at $\$ 1,000,000$ to $\$ 2,000,000$ or more annually.

In spite of the importance of forests in this region, little positive information is available here concerning the relation of forest cover to stream flow and erosion. The problem is so complex that superficial observation will not answer; detailed studies of different types of forest cover under varying climatic, soil, and topographic conditions are urgently needed.

It is evident, however, that the prevailing practice of clear cutting and slash burning accelerates runoff and that this continues until a new cover is established; considerable soil washing and gullying, started often in the skid trails made by logging machinery, is evident on the steeper freshly logged slopes. Sheet erosion and consequent soil depletion are a natural consequence of heavy rains where the beneficent cover is completely removed and the debris and the humus burned away. As the area of poorly stocked logged-off land grows larger the lack of that run-off regulation and soil conservation which the original forest gave will be more noticeable. More and more, logging and slash-burning operations are reaching the steeper slopes of the mountains, and here the dangers are greater that accelerated run-off and soil deterioration will ensue unless precautionary forest practices are adopted.

The only areas where occupancy and use of the forest are restricted in order to regulate run-off are the watersheds of several streams that supply water for municipalities, aggregating about 200,000 acres. This protection is given to insure the purity of the water supply and the volume and regularity of its flow.

\section{Recreation}

Few other sections of the United States are so fortunate as the Pacific Northwest in its outdoor recreational facilities. The abundant forests, streams, lakes, and snowclad mountains of the Douglasfir region, as well as its seashore, are so accessible that they can be enjoyed with little effort or expense. Good hunting and fishing are still to be had within easy access of the cities and towns. The development of highways and motor transportation in recent years has extended this accessibility until at present most of the forest land is used to some degree for recreation, not only by the local population, but by many tourists from other States. Even areas rendered unsightly by logging or fire are frequented by hunters and fishermen. The recreational resource is thus a very real asset, as this region becomes more and more one of the national playgrounds.

Much of this recreational use conflicts in no way with timber production; only 959,300 acres are reserved from logging to preserve certain distinctive recreational features. Of this area approximately two-thirds is on national forests. The reservations include 472,500 acres of commercial forest land in conifers, but not the 331,600 acres of nonforest land, such as glaciers, rocky barrens, and alpine meadows within the recreational reserves. Among the lands reserved for recreation are such nationally famous areas as Mount Rainier National Park, Crater Lake National Park (which borders this region), Mount Olympus National Park, Mount Hood and Columbia Gorge recreational areas on the Mount Hood National Forest, and the Mount Baker recreational area and North Cascade primitive area on the Mount Baker National Forest. In addition to such reservations, practically all of the remaining national-forest land is available for recreational use. Along the roads on the national forests of this region there are 803 forest camps where facilities are maintained for overnight camping as well as picnicking.

The remarkable increase in popularity of winter sports has been responsible for the recent development of a number of areas for this specific purpose. The subalpine forests on the slopes of the Cascade 
Range are admirably adapted for skiing and other winter sports and are readily accessible to the principal cities and towns. Within $1 \frac{1}{2}$ hours' drive of Portland is the Mount Hood area on the Mount Hood National Forest, and equally accessible to Seattle and Tacoma are the Snoqualmie Falls area on the Snoqualmie National Forest and Paradise Valley in Mount Rainier National Park. Within recent years great progress has been made in the development of State parks, located chiefly on the principal highways; although overnight camping is not permitted in many of the State parks.

The privately owned forest land is not all available for public recreation use; many forest owners forbid trespass on their property near the highways because of the increased fire risk and cost of protection. The trespass laws of Oregon and Washington are not enforceable on unfenced wild land, but the widespread use of closure by State officials under authority of fire laws has resulted in material restriction of public use of forest land during critical fire weather. Nevertheless, there are large areas of private forest land where the public may hunt or fish undisturbed unless they violate State game laws. Farm woods, the most accessible of forest lands, are generally closed to public use, although some farmers add to their income by making a small charge ior the use of their woods for recreation. A definite need exists for small forest picnic and camp grounds, in addition to the existing State parks, on the highways near the larger cities.

\section{Wildlife Production and Use}

This region is well supplied with wildlife. The extensive forests furnish food and shelter for the native fauna and have prevented its depletion. Hunting and fishing have not made the inroads on the game resources here that have been reached in more densely populated regions.

The forests contribute to the maintenance of the fish population by regulating stream flow, moderating water temperature, and keeping the water clear. Other uses of the forests, including recreation, protection, timber production, and grazing, do not seriously disturb wildlife production when properly coordinated. In fact, cutting operations usually result in an increase in shrubby and herbaceous vegetation, which affords more food for game animals.
Fire has undoubtedly been responsible for the destruction of much wildlife. Immediately following a crown fire the deforested area is vegetated by plants affording better feed than the original dense woods, and the game population usually increases by attraction from surrounding forests; but repeated burning results finally in a reduction of feed and consequent lowering of the game population. In some parts of the region it has been a not uncommon practice for local residents to set fire to the forests to improve the hunting. Over a period of years this practice results in impairment of the wildlife resource. The aborigines are generally supposed to have done this, particularly in the Willamette Valley, and the treeless condition of this area when white settlement began is thought to have resulted from this practice. The reclaiming of some of these lands in the foothills of both the Willamette and Umpqua Valleys through fire protection has resulted in some of the most thrifty stands of even-aged immature Douglas-fir now found there.

Game management, including protection of wildlife, has made some progress. The posting of privately owned forests against hunting and fishing, although far from universal, is increasing and is not likely to lessen as the population grows and as better roads bring in more tourists. Hunting and fishing are also forbidden on large areas of both private and public forest land set aside by the State and Federal Governments as wildlife refuges. During critical fire weather other forest areas are closed temporarily for protection against fires that might be started by hunters, fishermen, and other forest users. The national forests, with their traditional policy of multiple land use, guarantee the people of this region large areas on which wildlife management will be correlated with other forest use. Eventually it may be necessary to make provision for wildlife management on all public and private forest lands.

\section{Grazing}

The shrubs and herbaceous species that grow in the shade of the dense forests of the Douglas-fir region proper are usually of low forage value. Woody shrubs, such as Oregon hollygrape, salal, huckleberry, vine maple, and hazel, with little or 


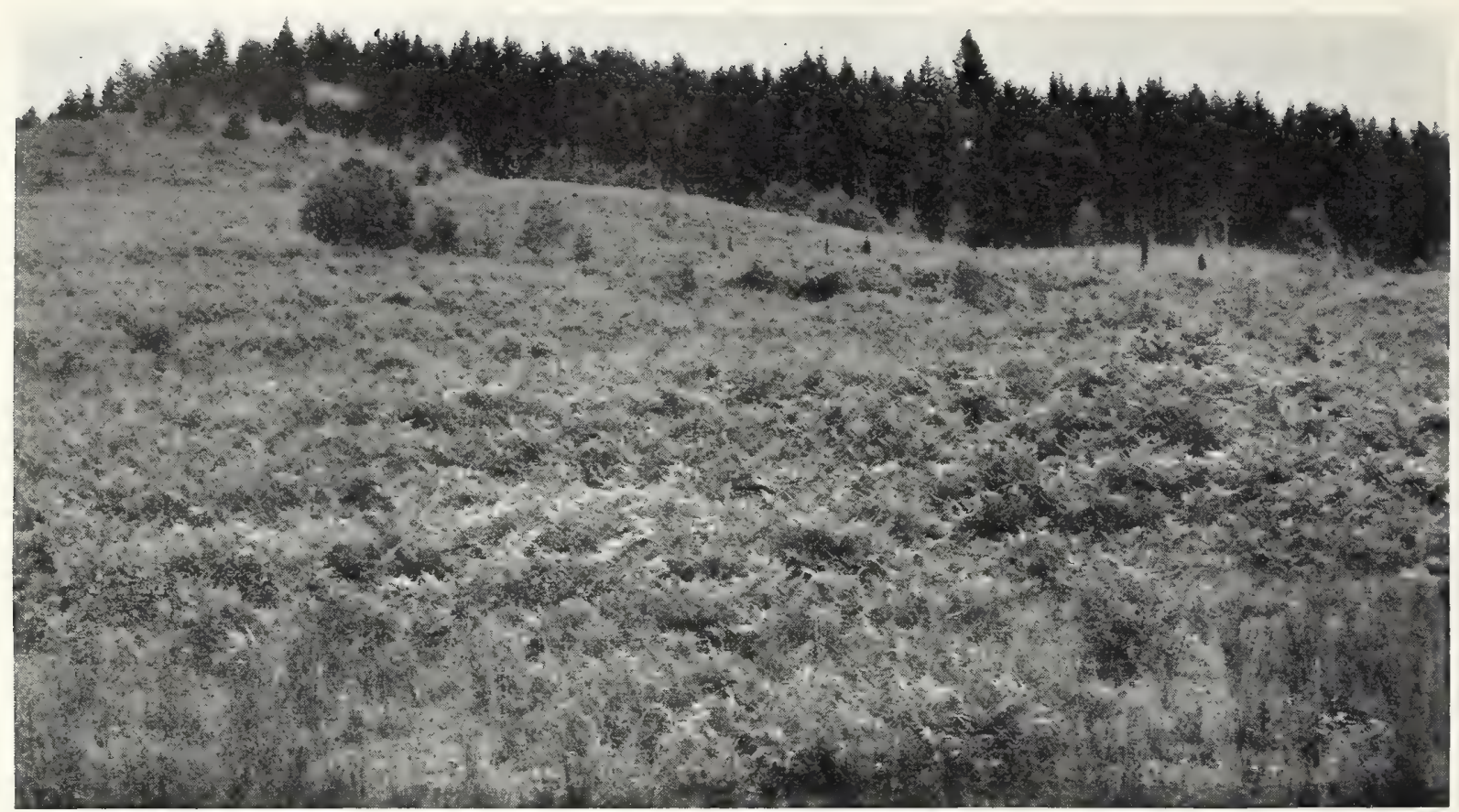

F 348208

FIGURE 19.- This area was cut over years ago, seeded to pasture, and repeatedly burned. It has now been claimed by bracken and is practically worthless for pasture

no palatability to livestock, far outnumber succulent species among the understory plants. On the logged-off land and burns, where there is more of the succulent herbage, the rough topography, large quantities of down timber and other debris, and the rank growth of shrubs make the movement of livestock difficult. Grazing is therefore meager in the virgin and the dense second-growth forests, and very limited on old burns and recently logged land. In the higher mountains, however, chiefly within the national forests, numerous meadows, subalpinetype glades, and grassy hillsides and ridges afford excellent and largely used summer range. During the period 1925-35, approximately 14,000 cattle and 130,000 sheep grazed such areas on the national forests each season, and the grazing fees collected averaged approximately $\$ 20,000$ a year.

A number of attempts to use cut-over Douglas-fir land for livestock range have been temporarily successful, but as a general rule the results have not justified this practice on any considerable scale. The possibility of converting cut-over land to permanent grazing use has been the subject of considerable controversy and study. Certainly much of this land because of failure to restock to conifers and because of unstable ownership is not now filling an economic use. Unquestionably portions of it through seeding can be converted to permanent pasture economically, on other portions grazing can be practiced without seeding for a few years without damaging future use for forestry. The use of fire to convert forest land to grazing should be carefully controlled (9). The guiding principle in determining the future use of cut-over forest lands should be to put them to highest use. There is a dearth of physical and economic facts necessary for an impartial decision between forestry and grazing on much of this land. Some of it obviously suited for one use or the other. Gradually, scientific research by private, State, and Federal agencies and practical experience are supplying the answers to some of the questions; others are unanswered. An early solution to this entire problem of land use is urgent.

If these areas are not reburned for about 3 to 5 years, other shrubby species such as salal, Oregongrape, rose, hazel, oceanspray, willow, and elderberry enter the vegetative type. Broadleaf tree species such as bigleaf maple and red alder appear, and along with conifer seedlings soon dominate the 


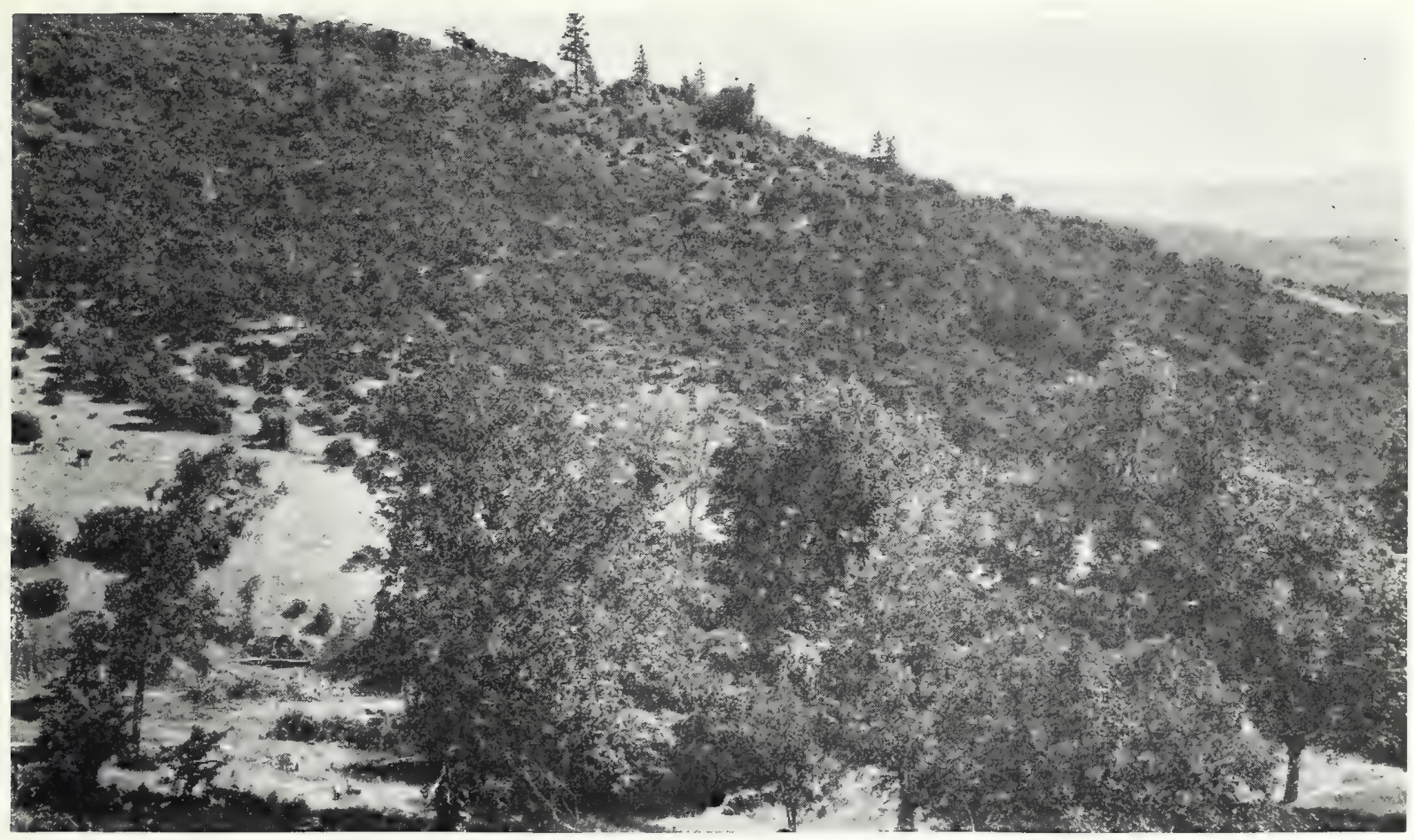

Figure 20.-Oak-madrone forest in southern Oregon, where forests of this type and of ponderosa pine have considerable forage value

other vegetation. Reburning retards the woody species and encourages the bracken (fig. 19), resulting in a vegetation cover not only of little value for grazing but also highly inflammable during dry seasons.

Despite the availability of moderate quantities of forage on recently cut-over land and the possibility of lowering the fire hazard by grazing, use of hthis type of land for stock range as been limited to dairy cattle and a few sheep turned onto it by neighboring farmers and to occasional shipments of sheep from ranches east of the Cascade Range in summers when the home ranges east of the mountains were poor because of drought.

The oak-madrone woodland (fig. 20) and ponderosa pine forests in southern Oregon are less dense and their many grassy openings furnish more range than is found in other forests of the region. Some of these open prairies and hillsides are supposed to have been burned by the Indians to make better hunting, although others are obviously on areas unsuited to forest growth because of soil or climate. In the Siskiyou Mountains of southwestern Oregon, the grazing of cattle on such grasscovered openings began soon after white settlement and was an important industry up to 20 years ago, when heavy grazing had so reduced the forage that the cattle were supplanted by sheep and goats. Periodic burning in the hope of improving grazing has greatly depleted the palatable herbage on these areas, resulting in many instances in a brush cover typically composed of scrub tanoak, Pacific madrone, or any of several species of manzanita or ceanothus, either unpalatable or of such low palatability that only goats will browse it. With the setting up of fire protection, some of the more promising of these areas have been reclaimed by conifers. Others cleared for farming and early abandoned were reclaimed by conifers prior to protection from fire.

Attempts have been made to seed recently cutover lands or burns to forage plants, especially in southwestern Oregon. Seeding by airplane has been tried, with orchard grass, ryegrass, and various mixtures. As a rule a good stand of grass is obtained the first year, but the second year the stand is much less and the third year it is sparse. In order to retain the grass cover it is usually necessary to reseed the grass about every 3 years, and then it is 
often necessary to slash the woody plants that inevitably occupy parts of the area. Alternate grazing of cattle and goats has been tried as a means of keeping out bracken and brush, but without notable success. Repeated burning, as already pointed out, results in increasing the bracken. The expense of seeding is apparently not justified where the land is going to be allowed to revert or will inevitably revert to trees or other woody growth in a few years, and where utilization as permanent pasture is not its highest economic use. Small areas that can economically be converted to pasture by persistent seeding and clearing are usually parts of operating farm units and accordingly are classed as agricultural, not forest land.

\section{Forest Problem Areas}

There are three major areas of idle forest land in the region, which illustrate conditions and problems that occur on many other areas on a smaller scale. The first of these extends along the east side of Puget Sound from near Tacoma to about 25 miles north of Everett and runs inland 15 to 25 miles. Although the soils are chiefly gravelly and of low agricultural value, they once grew valuable forests, a large part of which was logged many years ago. Much of this district, which includes between a third and a half of the population of the Douglas-fir region, has been subdivided, outside urban limits, into 5- and 10-acre lots. Only a small number of these lots have been improved, chiefly for residence by workers in Seattle, Tacoma, and Everett; many of them are tax delinquent; and a considerable number have reverted to the counties through tax forfeiture. Little of the area is actually farmed. Clearing fires escaping to adjoining land have devastated large areas, until in this entire district there is little forest growth. Although this land is fairly densely populated, all but a small part of it is idle. To bring it under management for timber production would be difficult because of instability of ownership and proximity to industrial centers.

The second major problem area is the expanse of recently cut-over land in Grays Harbor, Mason, and western Thurston Counties, Wash. Parts of this area have deep and fertile soil, but the topography is generally unfavorable to agriculture. There is little agricultural settlement in this district, and the only farms are in the narrow shoestring valleys.
This area may restock successfully; but because of its extent, the scarcity of seed trees, and the high fire hazard it probably will not do so for many years, unless remedial measures are applied. If present conditions continue there is a strong possibility that large parts of this area will never restock naturally. The two most difficult problems are fire protection and tax delinquency. The instability of ownership reduces the effectiveness of fire protection. A State forest is now being created in this district, which should alleviate the situation. The area includes some of the most productive forest soil in the region, and if it is nonproductive for long, a serious loss of timber growth will result.

A large part of the third area, covering Columbia, Tillamook, and eastern Clatsop Counties in the northwest corner of Oregon, is cut-over land and deforested burn including the great Tillamook burn of 1933. It is practically all forest land but, like the second area, the topography is so rough as to permit little agriculture. The main bodies of saw timber will be almost entirely gone in about a decade if the present rate of cutting continues. These three counties are already financially distressed, and it is doubtful if they can maintain the present road and school system in the forest zone when tax revenue from timberland decreases, unless sources other than the general property tax are available. The problem of financing fire protection is acute because of the instability of ownership and the large area of county-owned and tax-delinquent land. Much of this area will not restock naturally for many years, since many parts of it are a considerable distance from seed trees.

Practically all of the region's old nonrestocked cut-over lands (type 35), totaling 666,000 acres, occurs in these three problem areas. The economic returns from nonforest use of this land are negligible and from the standpoint of the future timber supply its idleness represents a serious loss. Under good forest management, however, it is easily capable of producing $250,000,000$ board feet of timber annually. It is estimated that an annual production of this amount would give permanent employment to at least 2,000 workers in the forest industries and indirect employment to 2,000 or 3,000 additional workers in dependent industries and service occupations, thus supporting a total population of 10,000 to 12,000 persons. 


\section{Forest Industries}

\section{Conditions in the Industries \\ Development}

$\mathrm{T}$ HE first sawmill in the Douglas-fir region was erected in 1827 near Fort Vancouver on the Columbia River, by John McLoughlin, chief factor of the Hudson's Bay Co. A few years later lumber was exported from this mill to Hawaii. Between 1840 and 1850 a number of mills were established to supply lumber to the increasing local population and for export to the gold fields of California and to the Hawaiian Islands.

From its beginning more than a century ago, lumbering has been one of the leading industries in this region. The present industrial development is based to a very great extent upon the forest resources. The large majority of the population derive their support, directly or indirectly, from either lumbering or agriculture. The only other extractive industries, fishing and mining, are of relatively minor significance. Of the $1,883,650$ population of the Douglas-fir region in 1930 (according to the Bureau of the Census), 815,528 were gainfully employed. Approximately 14.3 percent of those engaged in gainful occupations were directly employed in forestry, lumbering, and other wood-using industries, 12.7 percent in agriculture, 0.9 percent in fishing, and 0.7 percent in the extraction of minerals; altogether, 28.6 percent of the total were employed in natural-resource industries.

In this region the transportation industries, machinery manufacture, ${ }^{14}$ food processing,${ }^{15}$ merchan-

\footnotetext{
1٪ Sawmill and logging machinery and equipment are manufactured here for local use and for shipment to other parts of this country and abroad.

15 This group, next in importance to the forest industries, includes fruit and vegetable canning, fish and other sea-food canning, flour milling, butter and cheese making, condensing and evaporating milk, and meat packing.
}

dising and other service industries, and the professions are all dependent almost entirely upon the natural-resource industries. Another important source of income is tourist travel. It is safe to assume that nearly half the gainfully employed are dependent directly or indirectly upon the forest resources for their livelihood.

Lumbering in the United States has been a migratory industry, and each successive move westward has widened the gap between producer and consumer. In the Douglas-fir region and the other Pacific coast forest regions, the large size of the trees, density of stands, and topography made needful many changes in logging and manufacturing methods as developed in the East and South, and necessitated new techniques. Because of the great distance from markets, distribution is one of the most important problems of the industry here; but in general methods of distribution and business practices have received far less attention from the leaders of the industry than have logging and manufacturing methods.

There is no new frontier to which the industry can turn from here, consequently competitive conditions must soon reach a stage of equilibrium. Lumber from this region competes with lumber produced in the South. Low manufacturing costs, particularly for labor, and much shorter distance to the important domestic markets give the South an advantage over this region that is only partly offset by the latter's cheaper stumpage and high-quality raw material. In foreign markets, and to some extent in domestic markets, lumber from this region is subject to competition from lumber produced in British Columbia and its lower labor and stumpage costs and cargo rates to distant pointsadvantages only partly offset by greater cost of certain equipment and materials used in lumber- 
ing and more difficult physical logging conditions. Both manufacturing and distribution costs must be kept at a minimum if lumber from this region is to continue to compete successfully in eastern and foreign markets.

Data from the Census of Manufactures indicate that in 1929 the forest industries of the region paid in salaries and wages approximately $\$ 125,000,000$ and produced goods valued at more than $\$ 350,000$,000 . For the same year the value of sawlogs, pulpwood, fuel wood, shingle bolts, poles and piling, fence posts, and other timber products was between $\$ 150,000,000$ and $\$ 175,000,000$. During 1929 lumber production was at a peak, wages and prices were high. Since then lumber production, wages, and prices have declined greatly. In 1935 lumber production was but half that of 1929 . However, the relative importance of the forest industries in the economic life of this region has changed but little, as other industries have followed parallel courses.

\section{Integration}

The forest industries throughout the country are not integrated vertically to nearly so great an extent as some other large industries. In the Douglasfir region, in particular, there is little complete vertical integration ${ }^{16}$ in the forest industries. Many of the large lumber manufacturers own standing timber and do their own logging, and some of the larger companies own and operate steamship lines. Some lumber manufacturers produce sash and doors, box shook, and shingles, but a large percentage of the output of these items in this region is produced by independent establishments.

Many of the lumber manufacturers here sell lumber at retail from their plants, but only a few of the larger mills are interested to any great extent in retail lumber companies. Several of the large companies own or control retail line yards in the Middle West. Many of the Douglas-fir manufacturers are affiliated with lumber-manufacturing interests in the Lake States and the South; horizontal integration of this sort is quite common.

\footnotetext{
$16 \mathrm{By}$ "complete vertical integration" is meant performance by the same concern of all processes of manufacture and distribution, from harvesting of the raw material to distribution to the ultimate consumer, including manufacture of byproducts.
}

The pulp industry is dominated by companies not affiliated with lumber manufacturers. The largest wood-pulp manufacturer and its affiliated companies own standing timber, and fill some of their requirements for raw material by logging their own timber. This group is also affiliated with companies that manufacture and distribute many kinds of paper products. A large percentage of the wood-pulp manufacturers make paper.

The plywood and veneer industry is quite independent of other forest industries, and very few of the plywood and veneer manufacturers have any direct connection with timber owners and lumber manufacturers.

\section{Investments}

The total investment in the forest industries of this region at the present time probably exceeds a billion dollars. Of this amount about half is represented by privately owned standing timber and the remainder by logging equipment, manufacturing plants, and working capital. The total investment in logging facilities is estimated at approximately $\$ 85,000,000$, and that in lumber-manufacturing plants at $\$ 140,000,000$ to $\$ 150,000,000$. Not included are common-carrier-railroads, steamship lines, and other shipping facilities that depend mainly on the forest industries for their traffic. The private investment in standing timber and the logging and lumber-manufacturing industries is roughly $\$ 100$ per 1,000 board feet of lumber cut annually. The investment in forest industries, including raw material; is approximately $\$ 4$ per 1,000 feet of privately owned standing timber.

\section{Labor}

Labor is probably the most important single cost element in the forest industries. It is estimated by the West Coast Lumbermen's Association (24) that in 1935 nearly half the return received by the Douglas-fir lumber manufacturer from the sale of his product went for labor. The association states that on an average two 8-hour man-days are required to produce 1,000 board feet of lumber and that in 1935 wages per 1,000 feet averaged $\$ 8.89$. The 40-hour week is established in the lumber industry in this region. Hourly wages in the logging and lumber industries averaged in 1936 about 
65 cents. Wages are much higher than those in the East and South, approximately the same as those in the other Pacific slope States, and as high as those in any other forest region. Hourly wages here are about double those paid in the South.

Wages in the lumber industry in this region declined during the period 1930-32, but not so rapidly as lumber prices, and they have recovered much faster. In 1935 they were approximately at the 1926 level, and at the middle of 1936 they had risen above the 1929 level. Lumber prices had increased, but were still below the 1926 level.

Approximately 75 percent of the 100,000 to 115,000 workers normally employed in the forest industries of this region are skilled. For this and for the consequent high average wage the high degree of mechanization in the logging and lumber industries and the extremely large size of the manufacturing plants are chiefly responsible. Workers, including woods workers, are highly unionized, unlike those in the eastern and southern forest industries.

Employment is nearly yearlong; in normal periods shut-downs are relatively brief. Consequently, a large percentage of the workers employed are resident. Many men in rural communities near the logging centers have had experience in forest work and supplement the yearlong labor during periods of extra activity.

Most of the larger logging operations maintain semiportable or portable logging camps where workers are housed and fed in community fashion. Some of these camps have quarters where married men may house their families, and even provide school facilities. Not a few logging operations, both large and small, are so situated that workers can go to their jobs daily from their homes on nearby farms or in neighboring towns, sometimes in trains run by the company or sometimes in their own automobiles. A large percentage of the labor, which is practically all white, is native born. Many of the remainder, mostly the older forest workers, migrated from the Lake States and the South when operations there folded up or moved to the Pacific Northwest.

\section{Production}

The Douglas-fir region produces approximately 30 percent of the total lumber cut in the United
States. Figure 21, giving lumber production in the United States and in the Douglas-fir region, shows that the ratio of production of this region to the total for the country varied but little during the 11-year period 1925-35. For the first nine years of that period western Oregon's lumber production amounted to about one-third of the regional total, varying from about 32 percent in 1925 to 36 percent in 1929; in the last 2 years the ratio increased slightly, and in 1935 it reached 41 percent.

This region produced 91 percent of the shingles manufactured in the United States in 1935, Washington producing 81 and Oregon 10 percent.

The production of wood pulp was about 23 percent of the total for the country in 1935. The present installed pulp-mill capacity is about 17 percent of the Nation's total. Present indications point to a large increase in pulp-mill capacity within the next few years.

\section{Markets}

This region's wood-using industries depend chiefly upon outside markets. During the period 1926-34 only about one-quarter of the lumber produced in the region was consumed within it. Approximately one-third of the wood pulp produced is shipped to other regions without being manufactured into paper. Only about one-fourth as much paper is consumed in the region as is produced in it. Therefore, local paper consumption accounts for only about 15 to 20 percent of the annual regional pulp production. The situation in the plywood industry is about the same. This dependence upon outside markets apparently will continue for many years if current rates of production are maintained.

With the exception of a very small quantity of hardwood veneer and lumber, no wood products need be brought into this region for a long time to come.

There are four large markets where logs are offered for sale under definite rules of measurement and grading; these are the Puget Sound, Grays Harbor, Willapa Bay, and Columbia River log markets. In each of these, an association has been formed to do the scaling and grading. Many lumber manufacturers depend entirely on these markets for their raw material. 


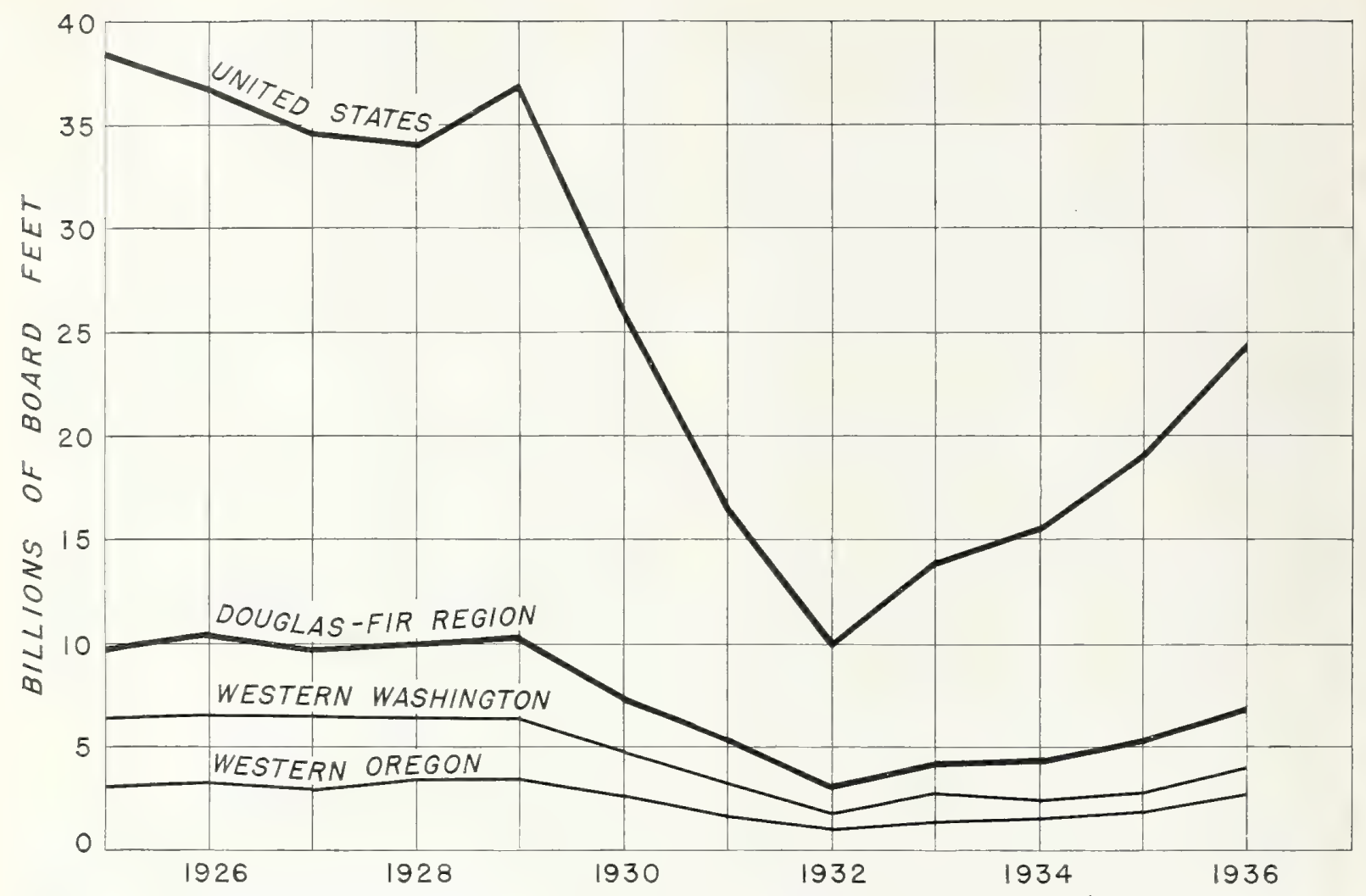

FIGURE 21. -From 1925 to 1936 lumber production of the Douglas-fir region, although fuctuating considerably in volume, remained constant in its relation to national cut, never falling below 25 percent or exceeding 30 percent of lumber production for the United States as a whole

Loggers and manufacturers of this region also buy and sell logs in British Columbia, but compared with the total sawlog consumption, the quantities are not large (table 29). Practically all the imported logs are brought into the Puget Sound district.

The volume of Douglas-fir log exports is comparatively insignificant, amounting to about 0.5 percent of the annual production, and during the

TABLE 29.-Logs imported ${ }^{1}$ from British Columbia to Douglasfir region (Scribner rule), stated years

\begin{tabular}{|c|c|c|c|c|c|}
\hline Species & 1929 & 1931 & 1933 & 1935 & 1937 \\
\hline & $\begin{array}{c}M \text { board } \\
\text { feet }\end{array}$ & $\begin{array}{c}M \text { board } \\
\text { feet }\end{array}$ & $\begin{array}{c}M \text { board } \\
\text { feet }\end{array}$ & $\begin{array}{c}M \text { board } \\
\text { feet }\end{array}$ & $\begin{array}{c}M \text { board } \\
\text { feet }\end{array}$ \\
\hline Douglas-fir & 119,411 & 92,711 & | 77,850 & 40,275 & 18,757 \\
\hline Western redcedar_. & 30,250 & 23,100 & 37,414 & 23,265 & 25,111 \\
\hline Western hemioek & 16,990 & 35,568 & 4,319 & 30,406 & 53,594 \\
\hline All other & 5,560 & 1,223 & 2,483 & 2,736 & 10,214 \\
\hline Total & 172,211 & 152,602 & 122,066 & 96,682 & 107,676 \\
\hline
\end{tabular}

1 Data based on reports from Pacific Northwest Loggers Association. period 1928-37 (table 30), except in three of the years, was more than balanced by imports from British Columbia. A large part of the exports, however, is in "peeler" logs, amounting to a significant part of the total peeler log production. Most of the log exports go to Japan, China, and Australia. From a regional standpoint the quantities exported do not at present materially influence local supplies, except for a few problem species. In addition, considerable quantities of large sawed timbers, "Jap squares," are exported to the Orient for remanufacture (fig. 22).

The quantities of Port Orford white-cedar logs exported, practically all to Japan, are a significant part of the total production of the species. During the 9-year period 1925-33, the total average annual production of Port Orford cedar sawlogs was slightly less than 50 million board feet, log scale. For the last 6 of these years the Port Orford white-cedar log exports averaged about $171 / 2$ million feet annually, or roughly a third of total production. In some 


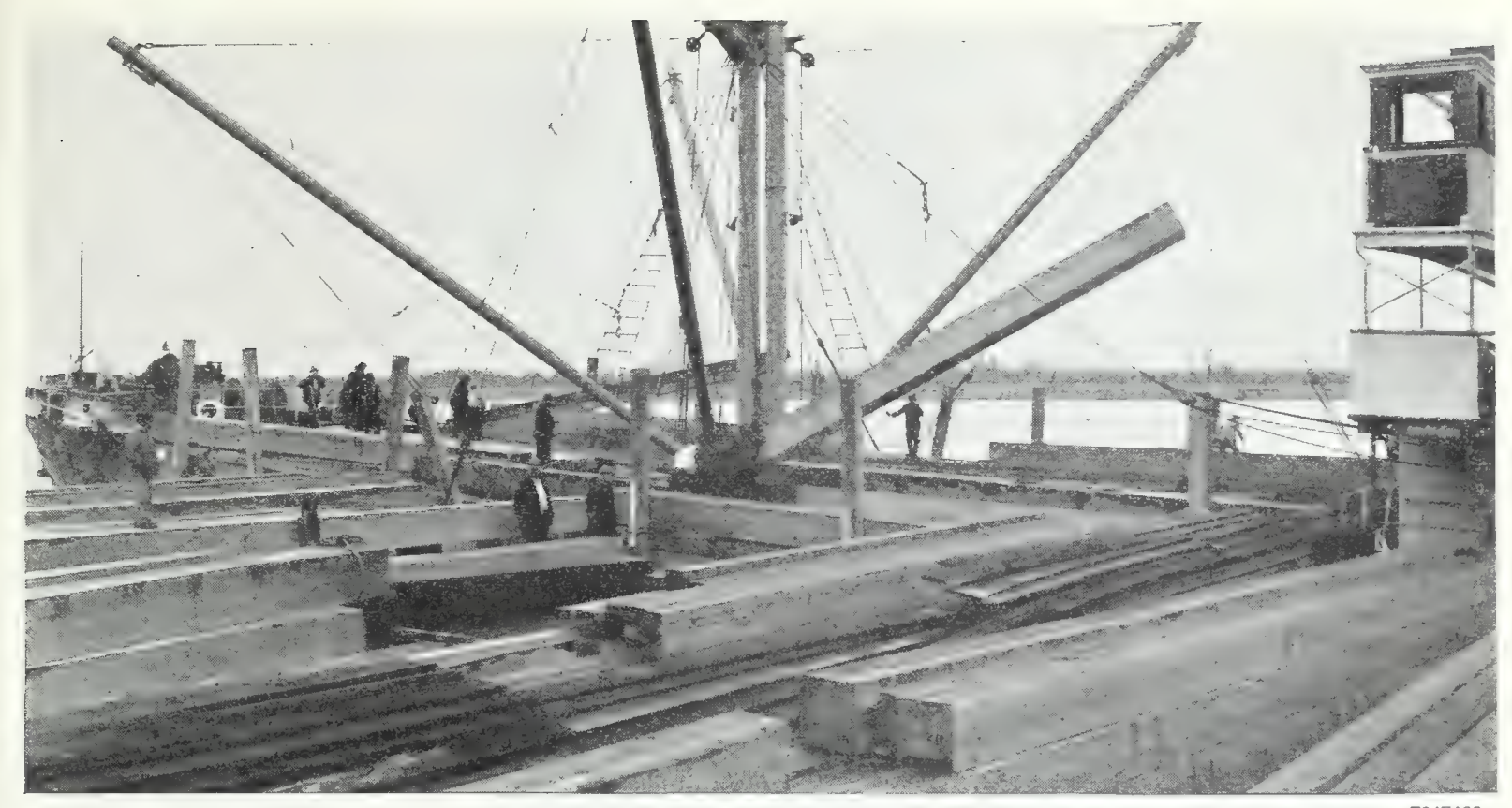

FIGURE 22.-Giant squares being loaded for shipment to Japan, where they will be manufactured into lumber

TABLE 30.-Logs' exported from Douglas-fir region, Scribner rule $2,1928-37$

\begin{tabular}{|c|c|c|c|c|c|}
\hline Species & 1928 & 1929 & ]930 & 1931 & 1932 \\
\hline Douglas-fir......... & $\begin{array}{c}M \text { board } \\
\text { feet } \\
9,388\end{array}$ & $\mid \begin{array}{c}M \text { board } \\
\text { feet } \\
27,225\end{array}$ & $\left|\begin{array}{c}M \text { board } \\
\text { feet } \\
29,939\end{array}\right|$ & $\mid \begin{array}{c}M \text { board } \\
\text { feet } \\
18,385\end{array}$ & $\begin{array}{c}\text { M board } \\
\text { feet } \\
5,509\end{array}$ \\
\hline Western redcedar & 70,938 & 56,897 & 31,373 & \begin{tabular}{|l|}
10, \\
33,826
\end{tabular} & 3,869 \\
\hline Port Orford white-cedar & 35,306 & 28,776 & $14,208$. & 12,658 & 5,298 \\
\hline Western hemlock & 26,468 & 35.119 & 24,633 & 31,215 & 23,797 \\
\hline Balsam firs ${ }^{3}$ & 110 & 489 & 1,955 & 5,707 & 4,889 \\
\hline Northern black cottonwood & 40 & 150 & 1,062 & 7,245 & 4,132 \\
\hline Sitka spruce & 1,846 & 2,380 & 1,982 & I, 309 & 447 \\
\hline All other....... & 332 & 237 & 191 & 1,346 & 269 \\
\hline \multirow[t]{2}{*}{ Total.. } & 144,428 & 151,273 & 105,343 & 111,691 & 48,210 \\
\hline & 1933 & 1834 & 1935 & 1936 & 1937 \\
\hline Douglas-fir .... & | 14,299 & 24,688 & 37,059 & 53,943 & 25,409 \\
\hline Western redced & 5,807 & 8,243 & 10,990 & 7,190 & 1,651 \\
\hline Port Orford white-cedar. & 8,691 & 9,171 & 7,480 & 6,404 & 3,647 \\
\hline Western bemlock ..... & 22,277 & 29,185 & 40,369 & 32,521 & 12,705 \\
\hline Balsam firs ${ }^{3} \ldots \ldots \ldots$ & 4,143 & 1,570 & 2,657 & 4,099 & 1,944 \\
\hline Northern black cottonwood_ & 4,257 & 3,862 & 2,349 & 6,461 & 2,631 \\
\hline Sitka spruce & 580 & 2,805 & 7,083 & 3,245 & 1,497 \\
\hline All other & 175 & 1,611 & 4,290 & 1,965 & 544 \\
\hline Total & 60,229 & 81,135 & 112,277 & 115,828 & 50,028 \\
\hline
\end{tabular}

${ }_{1}$ Data include small quantities of bolts. Source of data, summaries of United States customs records compiled by Seattle and Portland Merchants Exchange.

2 Original Brereton-scale data converted to Seribner by dividing by 2 .

${ }^{3}$ Includes so-called larch, actually noble fir. years exports have been half the total production. In addition to logs, considerable quantities of Port Orford white-cedar lumber and sawn timbers are exported to Japan, and remanufactured there. The supply of Port Orford cedar in private ownership, about three-quarters of a billion board feet, will last only 15 years at the present rate of cutting.

In the vicinity of Coos Bay the manufacture from Port Orford white-cedar of products such as battery separators and venetian blinds has developed into an important and successful industry. This industry employs an unusually large number of laborers for the volume of forest resources used. Exportation of this "cedar" in unmanufactured form deprives this region of considerable income and outlets for labor and hastens the end of this industry.

Western redcedar, the supply of which is limited, is being exported in considerable quantities. However, offsetting the exports, a large volume of this species is imported from British Columbia.

\section{Logging}

\section{Types of Organization}

Logging in the Douglas-fir region is a highly specialized and mechanized operation. This has 
resulted in organization of the industry along lines not commonly found in other forest regions. Many companies and individuals are in the business of logging only, not having any interest in the sawmill industry or other wood-using industries. Some of these concerns are timber holders, others buy timber shortly in advance of cutting, and a few depend almost entirely on Government-owned timber. Their log output is sold on the open market or by contract to manufacturers. Much logging is done by "gyppo" loggers, operators who contract with owners of timber to log it at a stipulated price per 1,000 feet. They usually log on a small scale and are often irresponsible. The timber owner may use the logs in his own sawmill or may sell them on the open market. A number of manu-

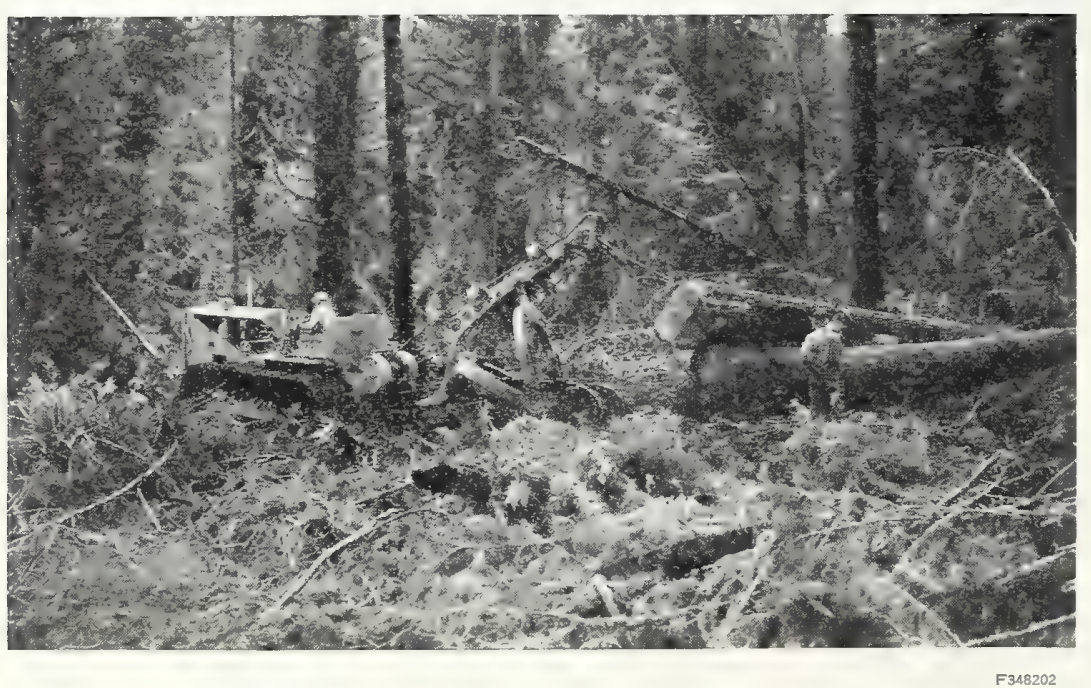

Figure 23.-Logging Douglas fir with tractor and arch in the Oregon Coast Range. Use of this type of equipment is increasing in the spruce-hemlock and Douglas-fir types of western Washington and western Oregon and is causing significant changes in management of these types

facturers, particularly the larger ones, do their own logging, either directly or through logging subsidiaries.

There are many variations and combinations of these types of organization. Some manufacturers supply part of their needs by logging their own timber directly, part by contracting the logging of their timber, and part by purchasing sawlogs on the open market. Sometimes they contract only a part of the logging operation, such as felling and bucking or truck hauling.
Methods

With very few exceptions, forests have been clear cut; that is, the entire merchantable stand has been felled and whatever trees were left as unmerchantantable were usually knocked down in the process of skidding. The large size of the trees, the dense stands, and the rugged topography have been responsible for the development of highly mechanized logging methods. Heavy high-speed machinery powered by steam, gasoline, diesel-oil, or electricity is used to move the logs, by cable, from stump to railroad, highway, or waterway and there load them for final transportation to mill or market. Recently there has been a tendency toward the use of lighter, more flexible, and more mobile machinery like crawler tractors and trucks, not only by small but also by large operators. Where modern tractors or trucks or both can efficiently be used, they are likely to have certain advantages over the conventional steam-donkey and railroad method of logging, chiefly in saving on the investment required per acre logged and in the opportunity to practice selective cutting. Where tractors and trucks are usable their flexibility and mobility enable the operator to select the individual trees or tracts of timber that can most profitably be cut at the time, thus effectively liquidating his investment without needless waste of forest resources or needless operating expenses. The rapid increase in the use of tractors and trucks is actually revolutionizing woods practice in this region and may have a far-reaching effect on both the economics of the industry and the condition of the cut-over areas. The use of tractors for skidding makes practicable the logging of small or remote bodies of timber where the installation of less mobile and more expensive machinery would not be justified. Where a high degree of selectivity is practiced, as when tractors do the skidding (fig. 23), the cut-over land is still partly stocked with trees, in contrast to the denudation 
when clear cut for steam-donkey skidding. Attendant problems of fire protection, silviculture, and forest management vary greatly under the two methods.

\section{Transportation}

Rail hauls of about 50 miles are common and veneer logs are hauled much greater distances. It is not uncommon for logs to be moved by rail and water 150 to 200 miles or more. In the larger operations, standard-gage railroads extend to all parts of the area and the logs are hauled directly to the mill or to waterway. Stream driving, never very common

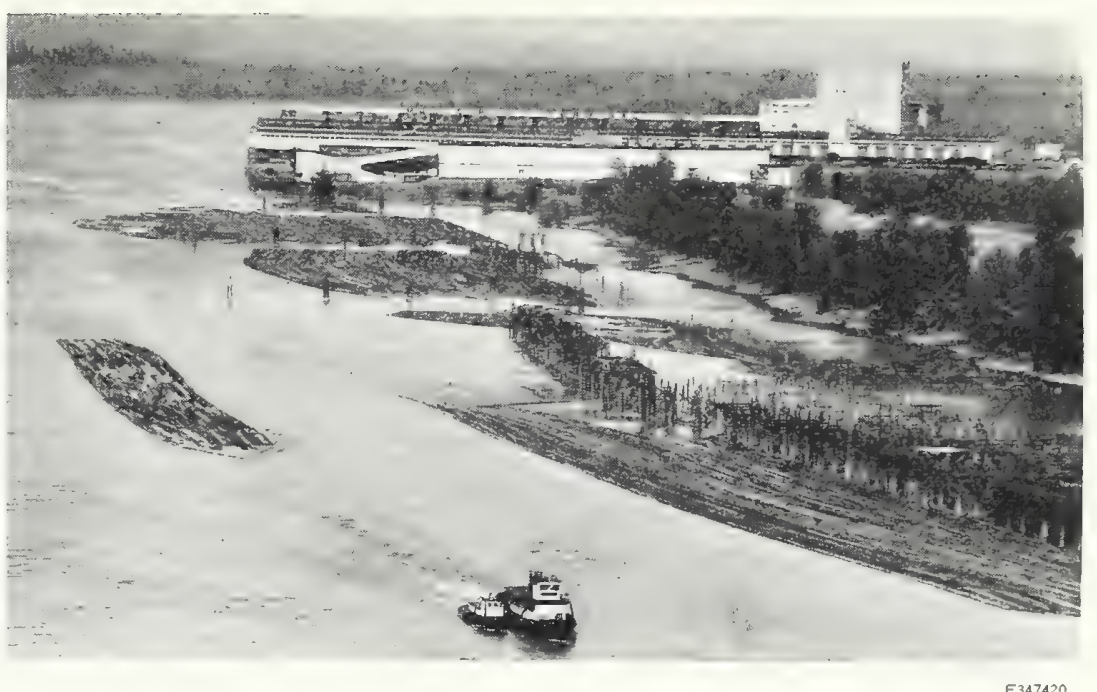
here, is now practiced in only

FIGURE 24. - Log raft being towed up the Willamette River at Portland. At right are storage booms and sorting pond a few places. Puget Sound and the Columbia and Willamette Rivers have made possible cheap transportation of logs. Large flat rafts (fig. 24) are towed considerable distances on these waters and are used to a lesser extent on other waterways. Ocean-going rafts or barges are used to move logs coastwise; cigar-shaped rafts are towed from the Columbia River to San Diego, Calif., a distance of 1,100 miles. Practically all the merchantable timber in western Washington and a large part of that in northwestern Oregon is within 30 or 40 miles of tidewater or navigable streams.
The increased mileage of improved highways in the past few years and the development of efficient and economical motortrucks have extended the use of trucks from small operators to many of the large companies, which are now using them partly or wholly to move logs from woods to mill (fig. 25). The use of trucks, particularly in connection with such mobile and flexible skidding machinery as the modern tractor and arch, makes it practicable to harvest small isolated tracts of timber, or timber at long distances-sometimes 50 miles-from water or railhead, provided there are public highways

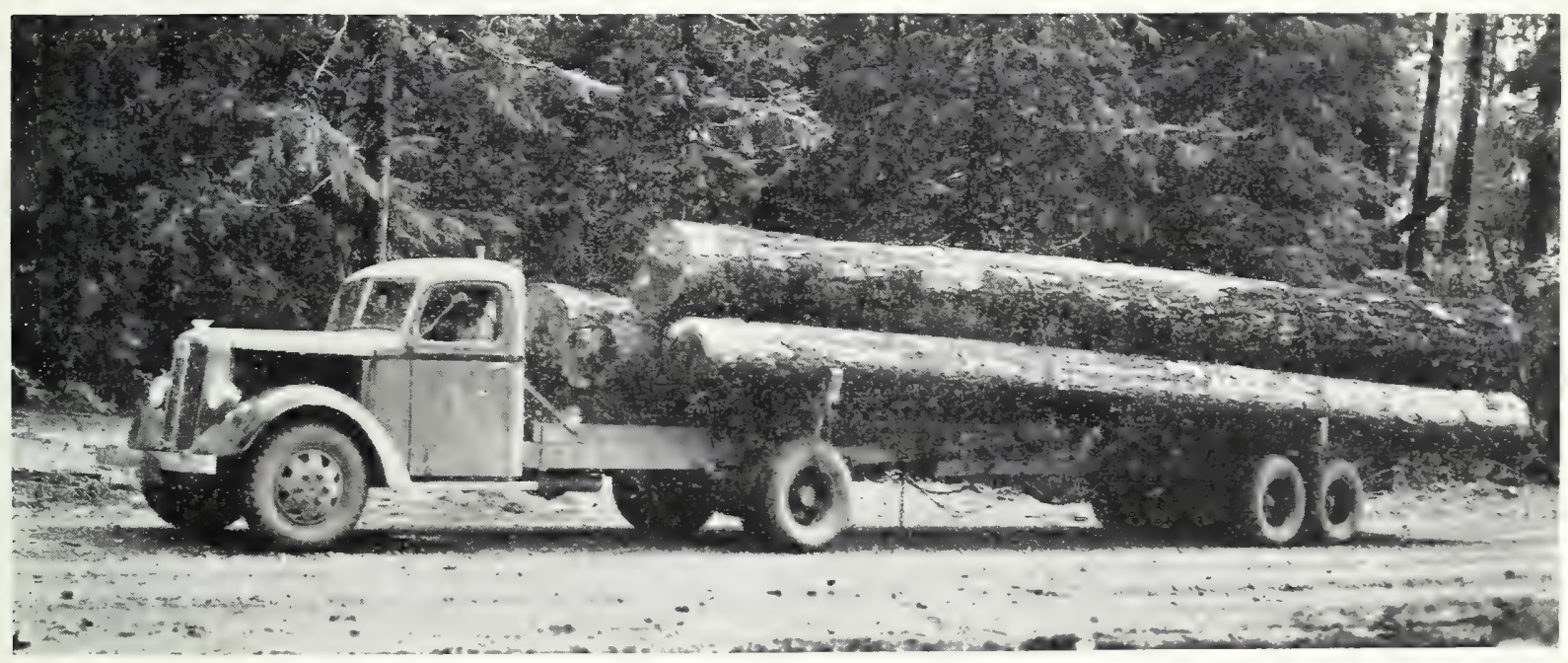

FIGURE 25. - Truck with load of about 4,000 to 6,000 board feet. Larger trucks haul as much as 10,000 board feet 
nearby. This encourages geographic diffusion of logging operations, instead of the former concentration near railroads and waterways. It also encourages selectivity in cutting whereby the very desirable species or the best logs are hauled even from great distances to market, while the less desirable tracts, trees, or logs are passed up for the present. No doubt, trucks will be used more for log transport as investment in logging railroads and expensive rolling stock is liquidated or present equipment is worn out.

Improvement of existing waterways and development of new routes by the construction of canals has been proposed. Two of these proposals, if consummated - the canalization of the Willamette River and the construction of canals connecting Grays Harbor with Puget Sound and the Columbia River-would probably have great influence on log movement, the permanence of manufacturing centers, and logging methods. There is, however, no definite assurance that these projects will be undertaken.

\section{Lumber Manufacture}

The sawmill is the most common type of indusw trial plant in western Oregon and western Washington, and many of the communities have grown up around a sawmill. Longview, Wash., for example, which has grown from nothing in 1920 to a population of over 10,000 , owes its existence to two large sawmills. On the other hand, abandonment or dismantling of sawmills has resulted in the decline of communities dependent on them. Temporary shut-downs immediately result in a noticeable slackening of trade in surrounding communities.

Lumber production is, generally speaking, a more complex manufacturing process than in most other parts of the United States. A large variety of items, grades, and sizes are produced to satisfy many different classes of world-wide trade. The large sawmills produce hundreds of different patterns of molding and interior finish; flooring of many kinds and sizes ranging from 1 - by 4 -inch boards

TABLE 31.- Number and installed capacity ${ }^{1}$ of sawmills in forest-survey units of Douglas-fir region, 1934

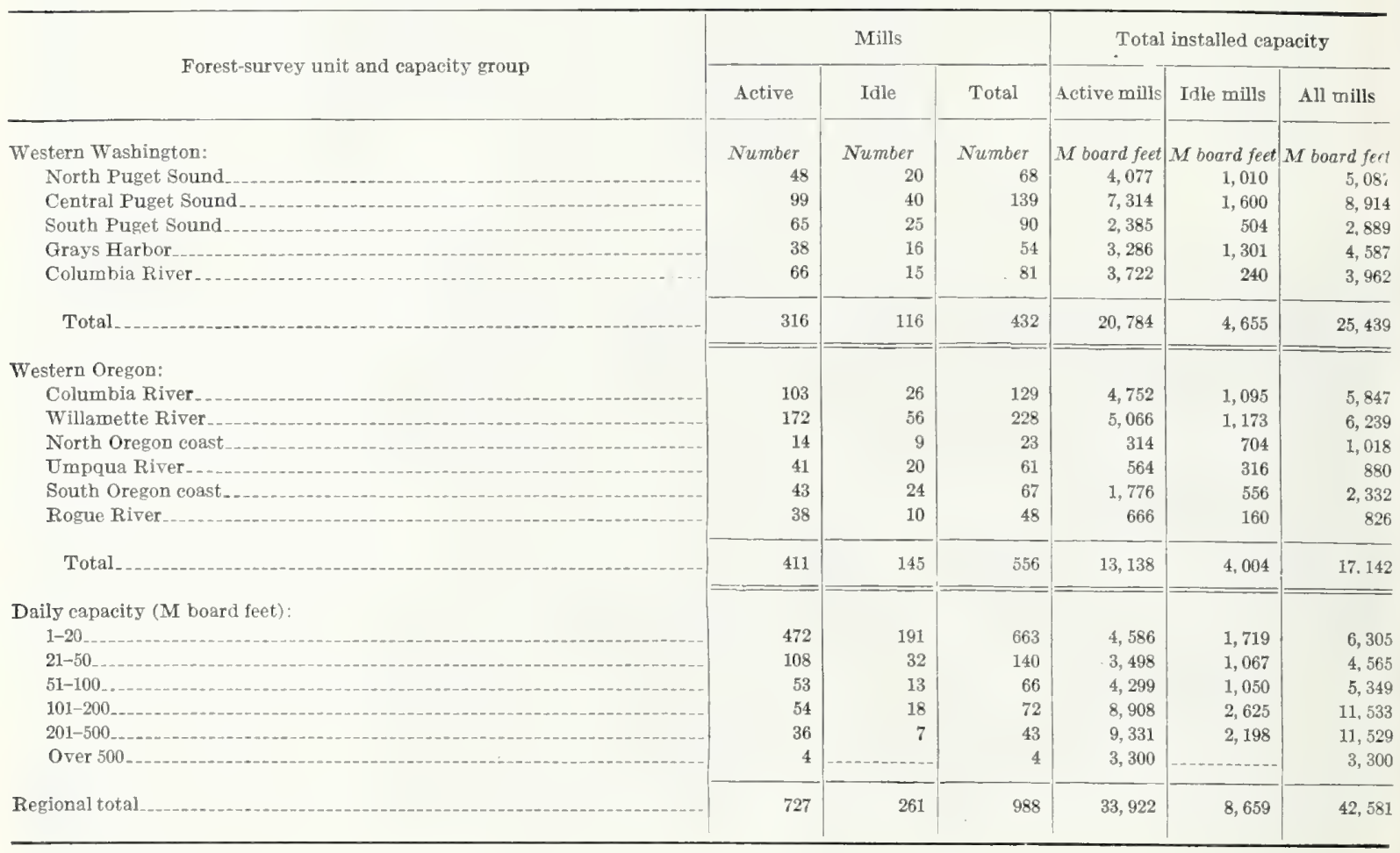

\footnotetext{
1 Per 8-hour shift.
} 


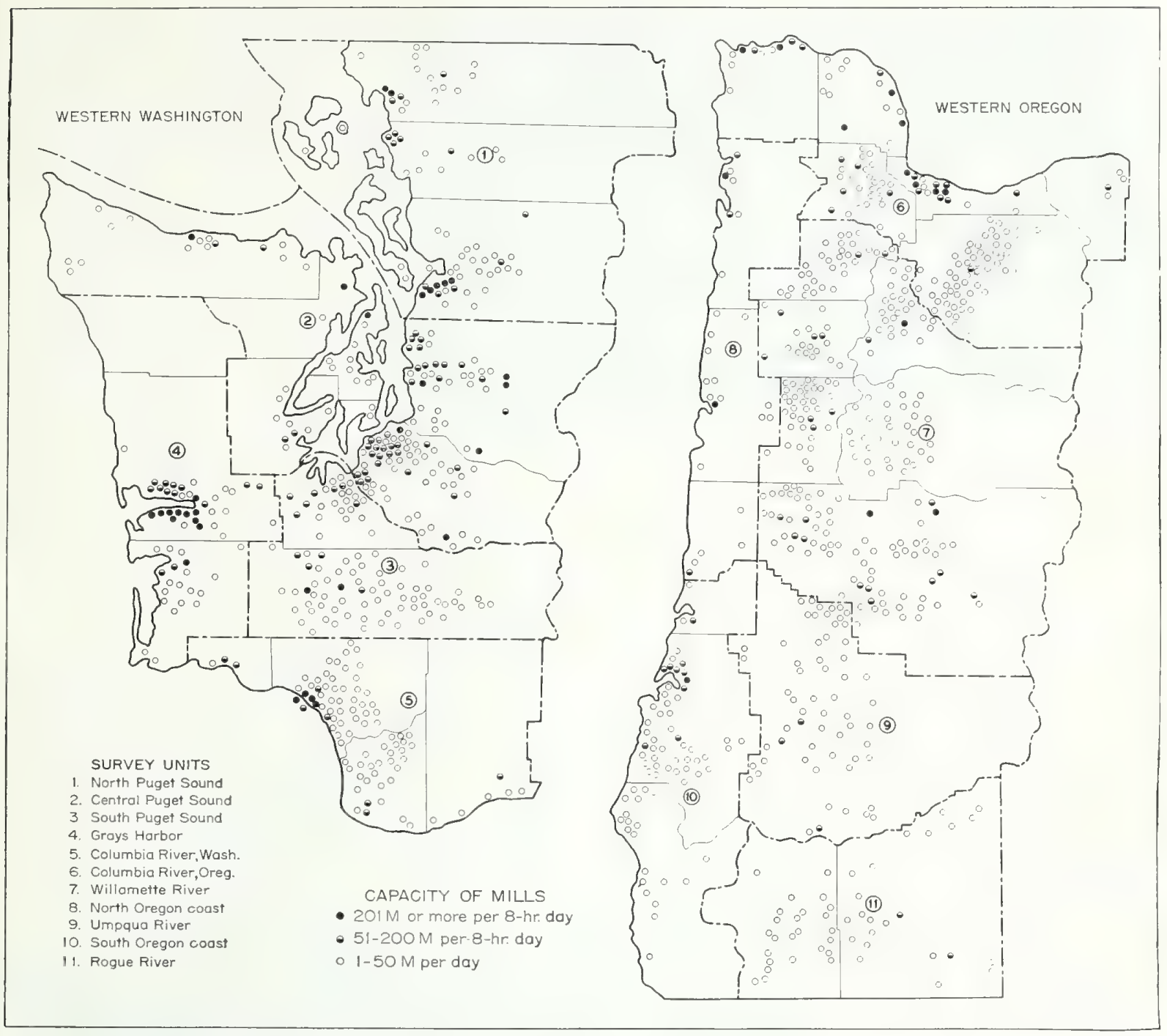

Figure 26.-Location of sawmills in the Douglas-fir region

for ordinary dwellings to ship and bridge decking; ceiling, siding, and boards; dimension lumber of many sizes; large timbers for oil derricks, bridges, and other types of heavy construction; factory lumber; railroad ties; and many other items. The smaller mills produce fewer items, and some manufacture one class of products - ties, for examplealmost exclusively.

\section{Sazomills}

Sawmills range in size from small portable mills operated by a few men to huge plants employing more than 1,000 people each. In 1934, approximately 74 percent of the 988 sawmills in the region were active during at least part of the year (table 31). A significant fact is the relatively large number of small and medium-sized mills that were idle. Western Oregon, with 124 more sawmills than western Washington, had 8 million board feet less installed 8-hour capacity. This is due to the large number of small mills in western Oregon, most of which are in the Willamette Valley. The large mills are concentrated in a few localities (fig. 26) and with some exceptions are located on tide- 


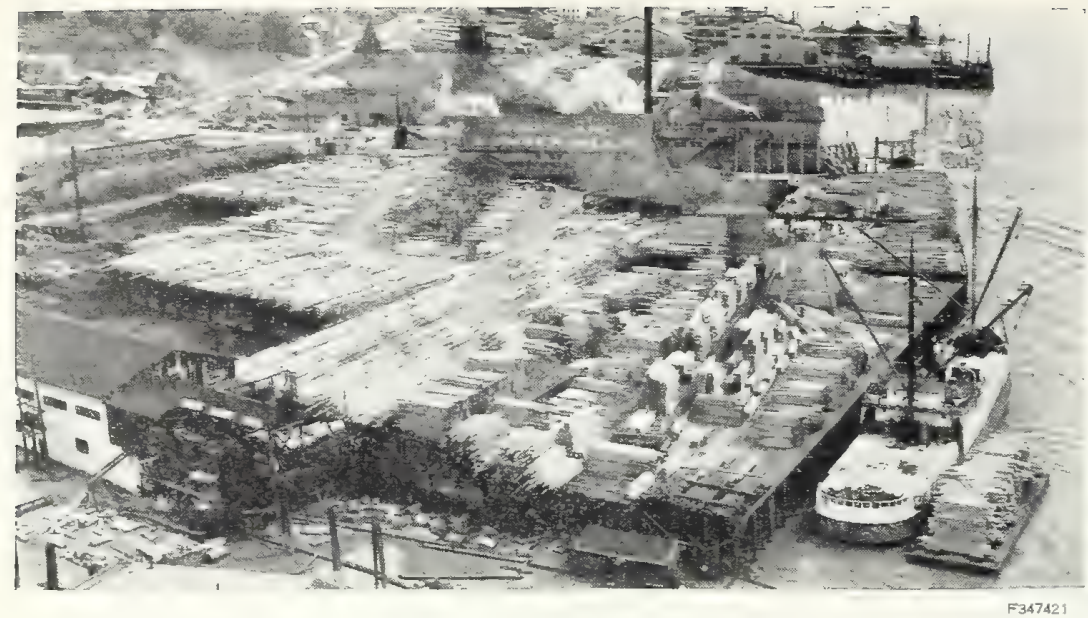

FIGURE 27. - Large sawmill on the Willamette Rizer. In the foreground is a vencer plant; at the extreme left are seen the cores remaining after logs and bolls are peeled and rehabilitation of partly dismantled mills. This condition leads to chronic maladjusment of saw-mill capacity with lumber production.

Retirement of obsolescent sawmills has been advocated as a panacea for the ills of the lumber industry, but no practical method has been suggested for effecting this. Some of the oldest sawmills are among the more successful, proving that age is not necessarily a measure of sawmill obsolescence. Many mills have become obsolete not because of mechani- water or on rivers navigable to transoceanic vessels (fig. 27). In contrast, the small mills are widely scattered throughout the region, mostly in the interior (fig. 28). As cutting progresses the source of raw material becomes more remote from the large mills.

The total annual installed capacity of all existing sawmills in 1934, computed on a basis of 300 working days of 8 hours each, was nearly 12.8 billion board feet (lumber tally), and the annual capacity of the mills active in 1934 was approximately 10.2 billion board feet. Actually, the mills can produce considerably in excess of these totals. Even when production is considerably below normal many of the large mills operate two shifts daily at least part of the year. The lumber production for 1934 was 4.4 billion board feet, only a little more than a third of the total estimated capacity. Evidently, the existing sawmills are mechanically capable of producing at least twice the amount of lumber necessary to fill current demands(1925-33 average annual production). Furthermore, any slight increase in demand and prices is usually followed by erection of new sawmills cal deficiences of the plant but because the accessible timber has all been cut and the mill is too far from the source of raw material to operate successfully. The difficulties of the lumber industry are more deep-seated than excess sawmill capacity. The availability of enormous quantities of standing timber generates a constant pressure to increase production. Timber owners, weary of paying taxes and other carrying charges without return, seek to liquidate at the first opportunity. This trend, coupled with the excess sawmill capacity, has created a chronic overproduction that can be remedied only

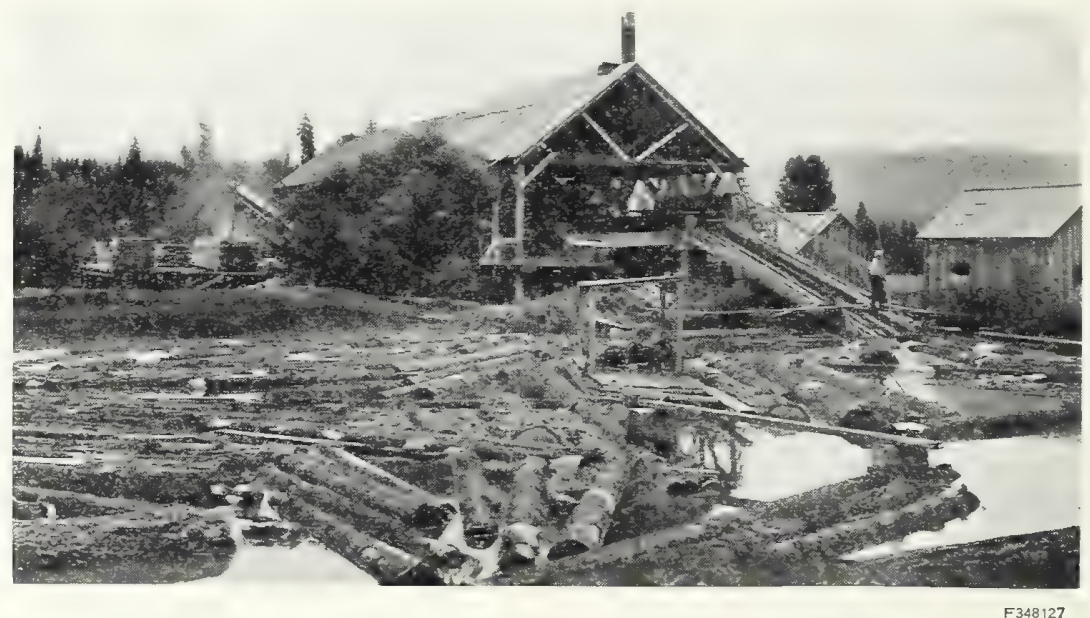

FIGURE 28.-Circular sawmill in western Washington having a capacity of approximately 30,000 board feet per 8-hour shift. The chief products of small mills are railroad ties, planking, timbers, common boards, and dimension. Usually such mills are located in the woods near their $\log$ supply 
by changes in timber ownership or a sharp reduction in the cost of timber holding. General adoption of sustained-yield management would automatically cure most evils of overproduction.

\section{Transportation and Markets}

Lumber from this region is marketed in all parts of the world and forms the principal cargo shipped from its ports in both tonnage and value. Lumber is likewise the leading commodity shipped from the region by rail, in both tonnage and value. Waterborne shipments in 1935 from Oregon and Washington ports amounted to 2.3 billion board feet, according to Pacific Lumber Inspection Bureau data. Practically all the lumber shipped by vessel from Oregon and Washington is produced in the Douglas-fir region; and very little comes from eastern Oregon and eastern Washington or from other States. Domestic shipments picked up from the low points of 1932 and 1934 (table 32 and fig. 29) despite strike conditions in the shipping and lumber industries; but foreign shipments did not respond to improved economic conditions abroad. A large part of the lumber shipments were formerly consigned to Great Britain and possessions, but since the British Empire Trade Agreement of 1932 British Columbia mills are getting more of this business. Partly offsetting this trend, Oregon and Washington mills are getting a larger proportion of the domestic cargo business.

It is estimated that in 1935 approximately 1 billion board feet of lumber produced in the Douglas-fir region was remanufactured or consumed locally, and 1.9 billion board feet was shipped by rail to various parts of the United States. The principal rail markets for forest products from this region are the Lake, Central, and Prairie States. Shipping costs practically prohibit rail shipments to States farther east, although lumber shipped by vessel to the Atlantic coast is reshipped by rail or trucked to interior points within short distances. Freight charges constitute from 35 to 50 percent of the average delivered price of Pacific coast lumber in midwestern and eastern markets. To overcome this handicap there has been increased local use of dry kilns in the last few years.

The rail rate on lumber to Des Moines is 68 cents per hundredweight, to Chicago 72 cents, and to

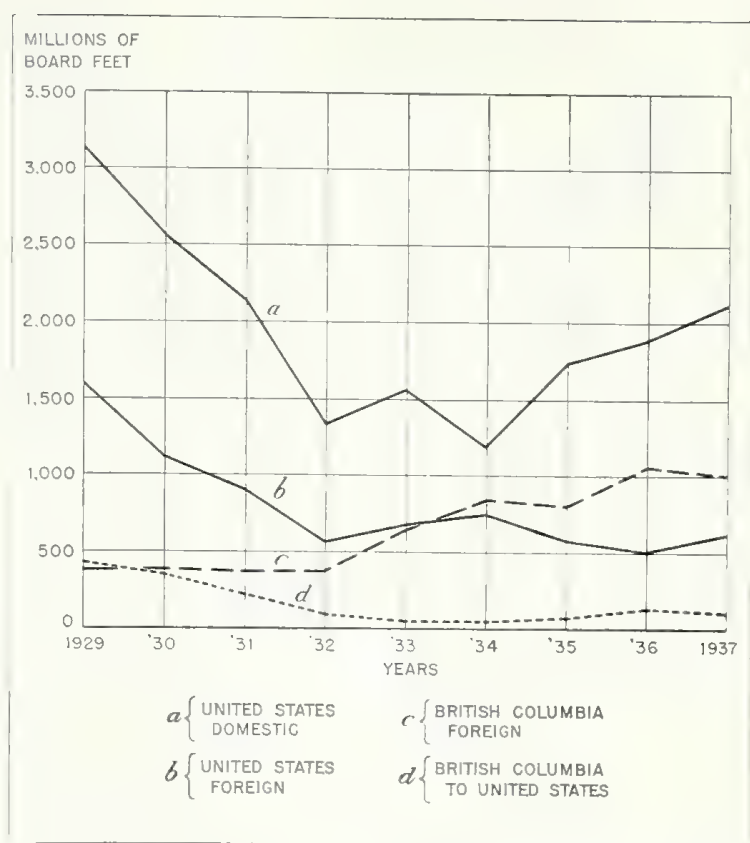

FIGURE 29.-Water-borne lumber shipments from the United States (Oregon and Washington) and from British Columbia to domestic and foreign ports

points eastward to the Atlantic coast 78 cents. Assuming an average shipping weight of 2,500 pounds per $\mathrm{M}$ board feet, these rates amount to charges of $\$ 17, \$ 18$, and $\$ 19.50$ per $M$ feet. The cargo rates per $\mathrm{M}$ board feet from ports in this region to the Atlantic coast averaged $\$ 12$ to $\$ 13$ in the last few years, to California ports $\$ 5$ to $\$ 7$. Back haul costs by rail or truck from Atlantic coast ports mount up rapidly, and at points as distant from the east coast as Buffalo and Pittsburgh cargo rates plus rail back haul exceed the through rail rate. In striking contrast to the domestic cargo rates are the rates to foreign ports; for example, the rate to Japan is about $\$ 7$ per $\mathrm{M}$, to China about the same, and to Australia $\$ 8$ to $\$ 9$. Practically all export shipments are carried in foreign bottoms, with operating costs lower than those of the American vessels that handle coastal and intercoastal trade.

The great distance between mill and market has been a disadvantage in another way; it has been partly responsible for the development of a system of marketing through wholesalers and commission men. It is estimated that 70 percent of the lumber production of this region is sold through wholesale middlemen. This has weakened the control of the 
TABLE 32.-Destination and volume of water-borne lumber shipments ${ }^{1}$ from Oregon and Washington and from British Coiumbia in $1929-35$

OREGON AND WASHINGTON

[Million board feet; i. e., 000,000 omitted]

\begin{tabular}{|c|c|c|c|c|c|c|c|}
\hline Destination & 1929 & 1930 & 1931 & 1932 & 1933 & 1934 & 1935 \\
\hline \multicolumn{8}{|l|}{ Foreign: } \\
\hline Asia- & 817 & 532 & 642 & 367 & 468 & 523 & 375 \\
\hline Continental Europe & 284 & 306 & 73 & 58 & 58 & 63 & 47 \\
\hline Enited Kingdom......... & & 500 & 98 & 43 & 56 & 37 & 31 \\
\hline Testern Hemisphere ${ }^{2} \ldots$ & 260 & 169 & 67 & 47 & 48 & 66 & 75 \\
\hline Australasia_____. & 235 & 91 & 28 & 13 & 8 & 14 & 25 \\
\hline Africa & 14 & 13 & 8 & 9 & 7 & 17 & 11 \\
\hline Total_..... & 1,610 & 1,111 & 916 & 537 & 645 & 720 & 564 \\
\hline \multicolumn{8}{|l|}{ Domestic: } \\
\hline Atlantic coast & 1,594 & 1,342 & 1,236 & 724 & 849 & 601 & 826 \\
\hline 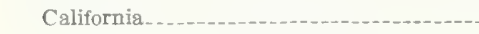 & 1,420 & 1,143 & 824 & 512 & 622 & 500 & 819 \\
\hline United States possessions... & 108 & 82 & 74 & 78 & 83 & 69 & 81 \\
\hline Total ... & 3,122 & 2,567 & 2,134 & 1,314 & 1,554 & 1,170 & 1,726 \\
\hline Grand total ... & 4,732 & 3,678 & 3,050 & 1,851 & 2,199 & 1,890 & 2,290 \\
\hline
\end{tabular}

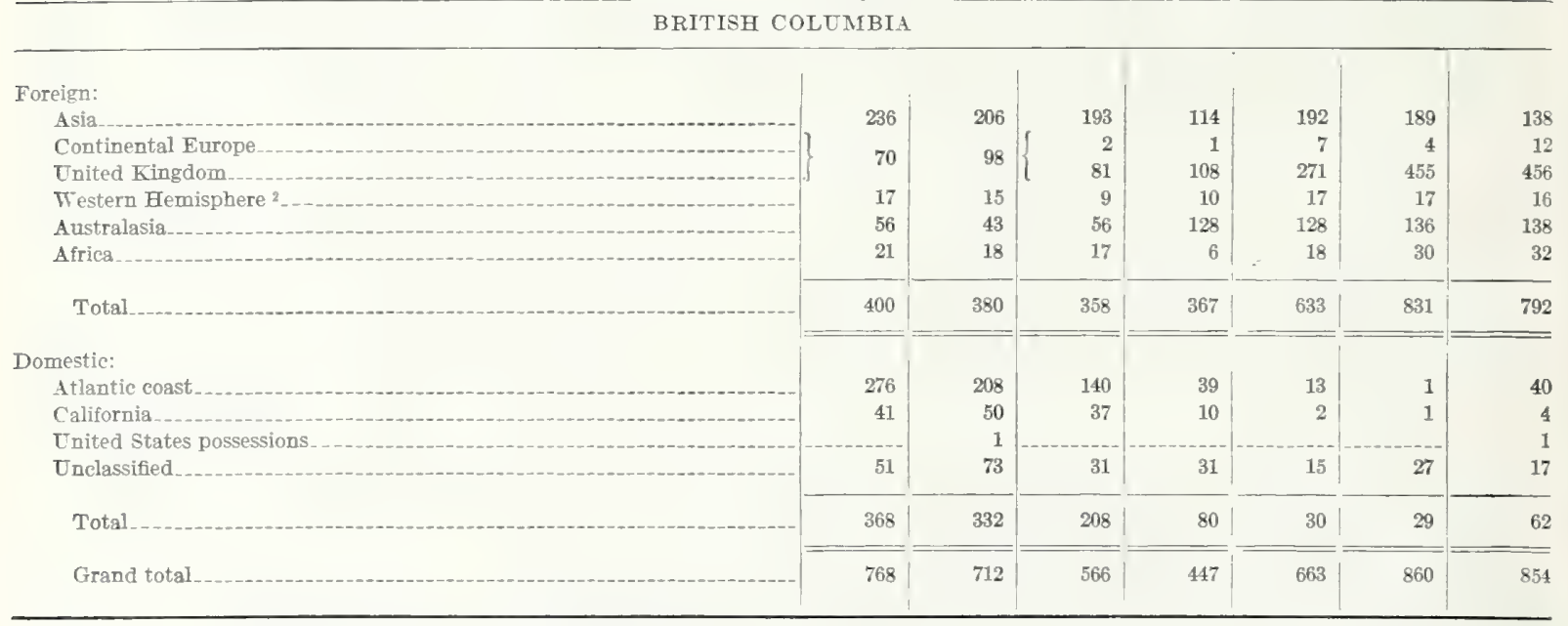

Data from reports of Pacific Lumber Inspection Bureau.

producer over the distribution of his product, and has resulted in reduced prices. The distance from markets was also partly responsible for the practice of shipping transit cars and cargoes, which cost the producers large sums by lowering selling prices and increasing selling costs. The improvement in shipping facilities and the depressed market have been chiefly responsible for the reduction in transit shipments.

\section{Sawmill Byproducts}

In the last 20 years the manufacture of byproducts from what was heretofore waste destroyed in
2 Mexico, West Indies, Central America, and South America

refuse burners at sawmills has increased tremendously. The principal sawmill byproducts are lath, handle squares, shingle bands, pulp chips, fuel wood, hogged fuel, and sawdust. Lath has been manufactured as a byproduct of the sawmills for many years. Nearly half the lath produced in the United States is manufactured in this region.

Slabs, edgings, etc., are used for fuel in homes, apartment houses, schools, and small industrial plants. Hogged fuel is used in sawmills, pulp and paper mills, power plants, other industrial establishments, schools, and office buildings. In recent years the use of clean sawdust as a domestic fuel has 
increased considerably; thousands of homes in Seattle, Portland, and smaller cities have installed sawdust burners. Many schools, apartments, stores and office buildings, also, are heated by sawdustconsuming furnaces.

Hodgson estimated (8) that during 1929 sales of sawmill "waste" fuel wood, hogged fuel, and clean sawdust totaled more than $\$ 4,300,000$ f. o. b. mill.

\section{Other Wood-Using Industries}

\section{Pulp and Paper Manufacture}

The manufacture of wood pulp is fast becoming one of the leading industries in this region. In 1937, 25 active wood-pulp manufacturing plants had a combined capacity of 5,164 tons per 24 hours (table 33) of which more than a third was devoted to the bleached sulphite process. In the last few years production of paper pulp has nearly equalled installed capacity. Production in 1935 represented approximately 225 days' operation at full capacity. The total output for 1937, shown in figure 30 as approximately 1.46 million tons, represents capacity production for about 285 working days. The annual pulpwood consumption of these mills increased sharply from 1936 to 1937 . In 1934-35, as shown in table 34, western hemlock was the predominant species and nearly 70 percent of the total was from sawlogs of this and other species.

In recent years there has been a significant increase in pulp-mill capacity in this region through establishment of new plants and expansion of existing mills. From June 1936 to July 1937 the installed pulp-mill capacity increased more than 1,000 tons per 24 hours, the increase totaling nearly 25 percent. Approximately 750 tons of the increase was in sulphite plants. From present indications such considerable increases will continue. One pulp mill was under construction in 1937 with an expected capacity of 125 tons.

The 17 paper mills active in 1937 had a total 24-hour capacity of 2,600 tons, of which 30 percent was newsprint, nearly 50 percent was fairly evenly divided between sulphites and sulphates and some 16 percent was in boards (table 35). The estimated annual production of paper for 1937 , as shown in figure 30 , amounts to capacity production for 300 working days.

The region has one plant, not listed in table 35, that manufactures wood-fiber insulating board from Douglas-fir exclusively, with a daily capacity of 250,000 square feet.

TABLE 33.-Pulp mills active in Douglas-fir region in 1937 and their capacity, ${ }^{1}$ by survey unit and process of manufacture ${ }^{2}$

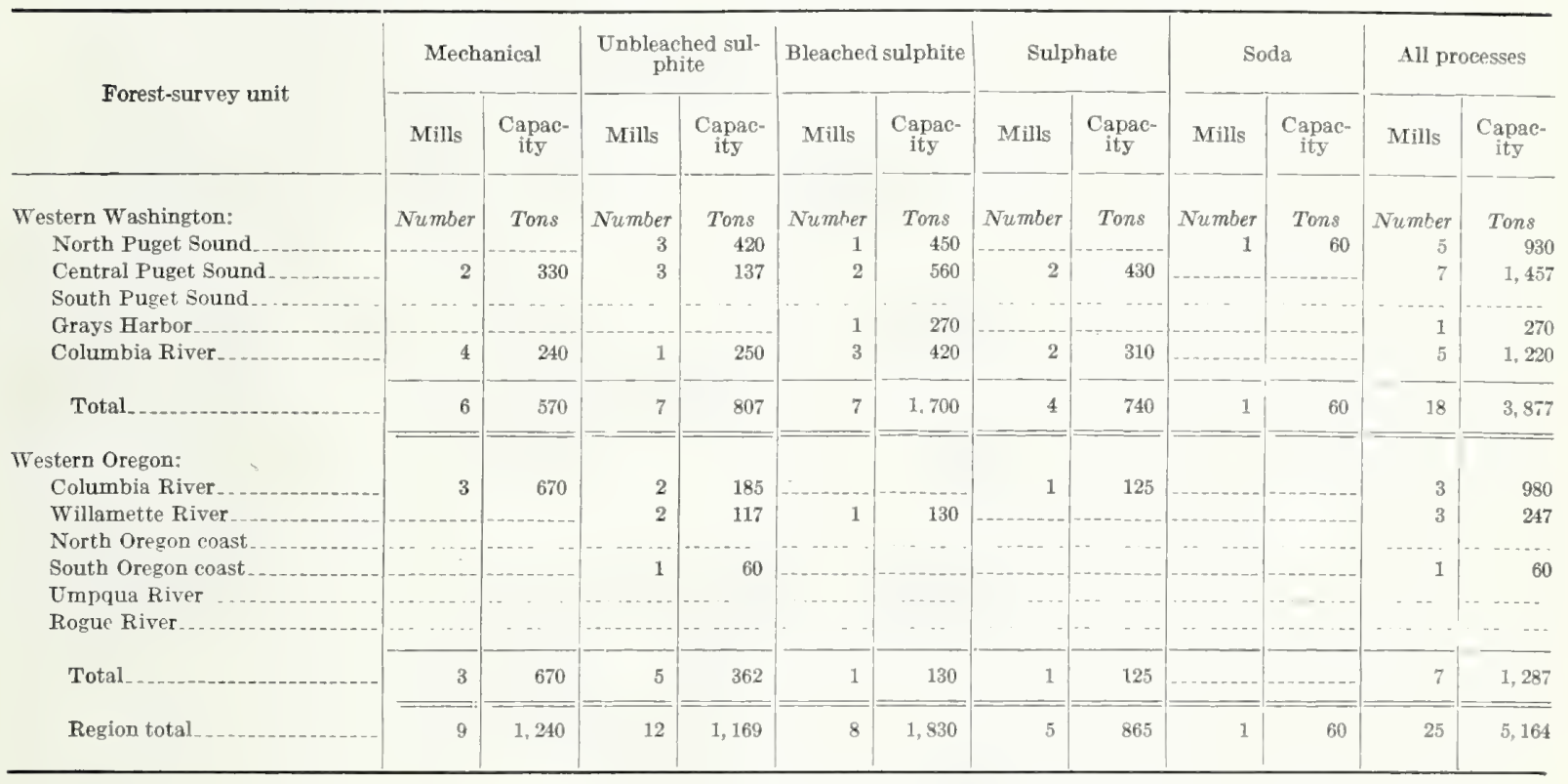

Per 24-hour day.

A mill using more than 1 process of manufacture is enumerated under each. 

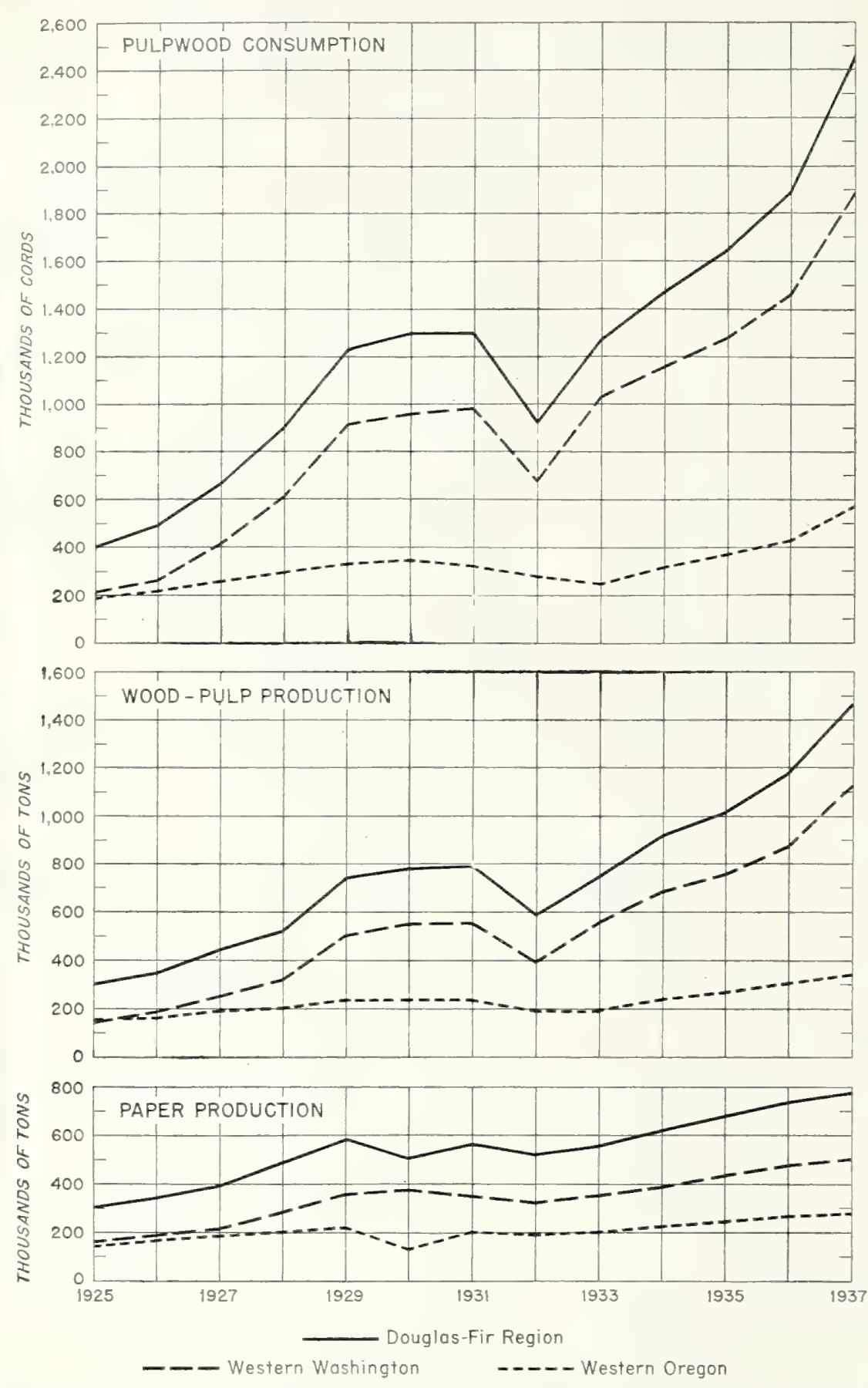

FIGURE 30.-Pulpwood consumption and wrod-pulp and paper production of the Douglas-fir region
The Census of Manufactures for 1929 lists 23 pulp mills and 20 paper mills in the region. It gives the total number of workers as 7,700 , salaries and wages paid as $\$ 12$,000,000 , and value of products for 1929 as $\$ 70$,000,000 . Figure 30 shows clearly an approximate doubling of pulp production between 1929 and 1937 and a 35-percent increase in paper production. The present investment in pulp and paper plants is estimated to exceed $\$ 125,000,000$.

\section{Shingle Manufacture}

Manufacture of "cedar" shingles is among the more important of the other primary wood-using industries. The total production in 1935 was 4 million squares, or about $31 / 4$ billion pieces. During 1934 there were 232 active and 37 idle shingle mills in the region. The active mills had 782 shingle machines and a total installed capacity of $23 \frac{1}{2}$ million pieces, per 8 -hour shift, and the idle mills had 42 machines and a total installed capacity of 965,000 pieces per 8-hour shift. Approximately 85 percent of the installed shinglemill capacity is in western Washington. 


\section{Veneer and Plywood Manufacture}

The veneer and plywood industry has increased steadily in importance in the past decade, and especially in the past few years. Production increased from 200 million square feet in 1932 to 480 million square feet in 1935 and again to 700 million in 1936 (fig. 31). Production lagged behind orders in 1935 owing to longshoremen's and lumber-workers' strikes.

In 1937 there were 19 veneer- and plywoodmanufacturing plants in the region, 17 in western Washington and 2 in western Oregon. The total rated annual capacity of the Washington plants is 790 million square feet, and that of the Oregon plants is 95 million square feet.

The market for plywood and veneer products from this region is principally domestic, only about 9 million square feet being exported in 1935. Of the domestic consumption, about 15 to 20 percent is local.

Douglas-fir is the principal species used in this industry; other species used are Sitka spruce, Port Orford white-cedar, western hemlack, noble fir, red alder, and bigleaf maple.

In recent years there has been a decided change in the type of peeler logs used. Formerly the de-
TABLE 34.- Normal annual pulproood consumption in Douglas-fir region, 1 by species and type of material

\begin{tabular}{|c|c|c|c|c|c|}
\hline Species & $\begin{array}{l}\text { Saw- } \\
\text { logs }\end{array}$ & $\begin{array}{c}\text { Forest } \\
\text { wood }\end{array}$ & $\underset{\text { chips }}{\text { Pulp }}$ & $\begin{array}{c}\text { Mill } \\
\text { waste }\end{array}$ & Total \\
\hline & $M$ cords & $M$ cords & $M$ cords & $M$ cords & $M$ cords \\
\hline Western hemlock & 1,102 & 263 & 81 & 32 & 1,478 \\
\hline Sitka spruce & 130 & 23 & & 4 & 157 \\
\hline White fir........... & 64 & 69 & 27 & & 160 \\
\hline Northern black cottonwood. & 1 & 21 & & & 22 \\
\hline Douglas-fir........ & 38 & 20 & & 61 & 119 \\
\hline Total & 1,335 & 396 & 108 & 97 & 1,936 \\
\hline
\end{tabular}

1 Basis, data for years 1934-35.

2 Factor used to convert log scale to cords, 500 board feet $=1$ cord.

3 Usually measured in 0.8117 -cord units.

mand was almost exclusively for the highest-quality No. 1 grade Douglas-fir logs, 40 inches or more in diameter (fig. 32). Now a large percentage of high-line No. 2 logs, even as small as 30 inches in diameter, are accepted. These developments have been caused chiefly by the increasing scarcity of large No. 1 Douglas-fir logs and by technological improvements. Future expansion of the industry may be curtailed, at least in certain sections, because of the limited quantity of highquality Douglas-fir suitable for veneer faces and

TABLE 35.-Paper mills active in Douglas-fir region in 1937 and their capacity, ${ }^{1}$ by survey unit and kind of material produced ${ }^{2}$

\begin{tabular}{|c|c|c|c|c|c|c|c|c|c|c|c|c|c|c|}
\hline \multirow[b]{2}{*}{ Forest-survey unit } & \multicolumn{2}{|c|}{ News } & \multicolumn{2}{|c|}{ Sulphites } & \multicolumn{2}{|c|}{ Sulphates } & \multicolumn{2}{|c|}{ Book } & \multicolumn{2}{|c|}{ Board } & \multicolumn{2}{|c|}{ Other } & \multicolumn{2}{|c|}{ All materials } \\
\hline & Mills & $\begin{array}{c}\text { Capac- } \\
\text { ity }\end{array}$ & Mills & $\begin{array}{l}\text { Capac- } \\
\text { ity }\end{array}$ & Mills & $\underset{\text { Capac- }}{\text { ity }}$ & Mills & $\begin{array}{c}\text { Capac- } \\
\text { ity }\end{array}$ & Mills & $\begin{array}{c}\text { Capac- } \\
\text { ity }\end{array}$ & Mills & $\begin{array}{c}\text { Capac- } \\
\text { ity }\end{array}$ & Mills & $\underset{\text { ity }}{\text { Capac- }}$ \\
\hline $\begin{array}{l}\text { Western Washington: } \\
\text { North Puget Sound . }\end{array}$ & Number & Tons & $\left|\begin{array}{c}\text { Number } \\
1\end{array}\right|$ & $\begin{array}{r}\text { Tons } \\
15\end{array}$ & Number & Tons & $\begin{array}{c}\text { Number } \\
1\end{array}$ & $\begin{array}{r}\text { Tons } \\
65\end{array}$ & Number & Tons & Number & Tons & Number & $\begin{array}{l}\text { Tons } \\
80\end{array}$ \\
\hline $\begin{array}{l}\text { Central Puget Sound } \\
\text { South Puget Sound }\end{array}$ & 1 & 340 & & & 1 & 235 & 1 & 35 & 2 & 175 & 1 & 8 & 5 & 793 \\
\hline Grays Harbor & & & 1 & 50 & & & & & & & & & 1 & 50 \\
\hline Columbia River....- & & $\ldots$ & 2 & 305 & 2 & 225 & & $\cdots$ & 2 & 252 & & & 4 & 782 \\
\hline Total & 1 & 340 & 4 & 370 & 3 & 460 & 2 & 100 & 4 & 427 & 1 & 8 & 12 & 1,705 \\
\hline $\begin{array}{l}\text { Western Oregon: } \\
\text { Columbia River... } \\
\text { Wiilamette River }\end{array}$ & 2 & 440 & $\begin{array}{l}2 \\
2\end{array}$ & $\begin{array}{l}115 \\
160\end{array}$ & 1 & 135 & & & & & 1 & 45 & $\begin{array}{l}3 \\
2\end{array}$ & $\begin{array}{l}735 \\
160\end{array}$ \\
\hline North Oregon coast & & & 2 & & & & & & & & & & 2 & 160 \\
\hline South Oregon coast & & & & & & & & & & & & & & \\
\hline Umpqua River & & & & & & & & & & & & & & \\
\hline Rogue River & & - & 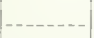 & & & $\ldots$ & & & & & & & & \\
\hline Total & 2 & 440 & 4 & 275 & 1 & 135 & & & & & 1 & 45 & 5 & 895 \\
\hline Region total & 3 & 780 & 8 & 645 & 4 & 595 & 2 & 100 & 4 & 427 & 2 & 53 & 17 & 2,600 \\
\hline
\end{tabular}


the demand for this type of material for other uses. More flexible methods of logging, however, such as those employing tractors and trucks, is now making it possible to reach with partial-cutting methods tracts too inaccessible for the conventional clear-cutting methods; thus a larger volume of potential veneer logs is now brought into the radius of availability. Future expansion, predicated upon a plentiful supply of raw material, will probably be restricted to western Oregon.

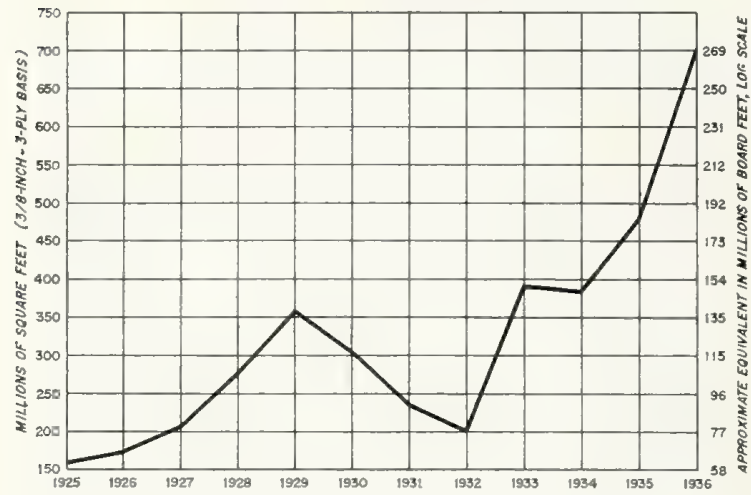

Figure 31.-Plywood production of the Douglas-fir region

\section{Wood Preserving}

The wood-preserving industry - not, strictly speaking, a wood-using industry - is of considerable importance. The prolongation of the life of wood products through treatment with preservatives is an important factor in holding the markets for wood products against the competition of substitutes and in reducing the depletion of the forests of this region. Fifteen plants were in operation in 1935. The principal products treated that year were:

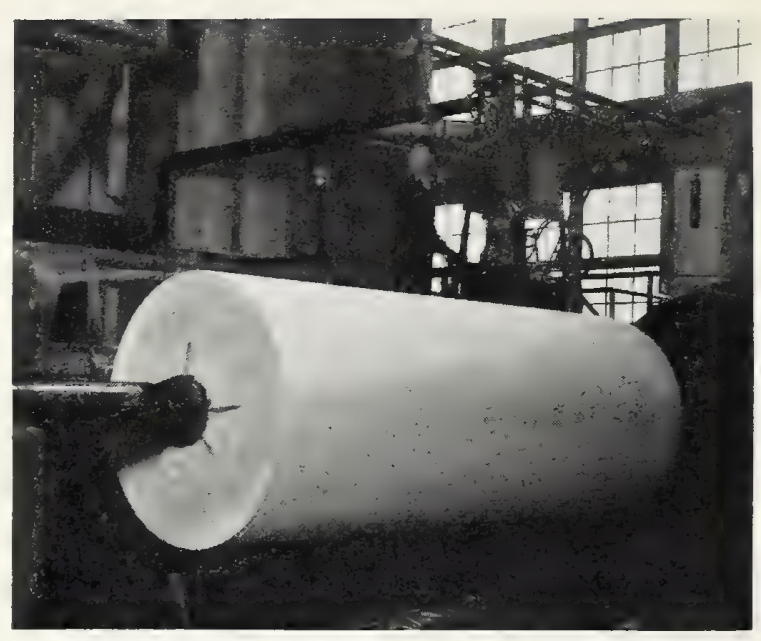

F347405

Figure 32.-Douglas-fir veneer log on lathe. The volume of Douglas-fir veneer produced in the region increased more than 250 percent during the decade 1927-36

Poles (pieces)

71,903

Piles (linear feet) . . . . . . . . . . . . . . . 452, 441

Cross ties (pieces)................ 2, 573, 875

Cross arms (pieces).............. 40, 732

Switch ties, timbers and lumber (board feet). . 50, 000, 000

Secondary Wood-Using Industries

The secondary wood-using industries have increased greatly in the last two decades, although, in comparison with the primary wood-using industries, they are still far from completely developed. Their leading products are sash and doors, millwork, boxes and crates, cross arms, furniture, wood pipes, tanks and silos, handles, caskets, woodenware, and vehicles. The principal woods used in these industries are Douglas-fir, western hemlock, Sitka spruce, western redcedar, red alder, and bigleaf maple. 


\section{Future Timber Supplies in Relation to Industrial Development}

\section{I} $\mathrm{N}$ considering the adequacy of forest resources present and future, it is necessary first to examine the present situation as to forest industries, their requirements, and the supplies of raw material on hand, and then by using the best data available on rates of depletion and growth to project the present situation into the future.

In a century of operation, and 20 to 25 years of heavy cutting, the virgin commercial forests of the Douglas-fir region have been exploited in a very uneven manner, with heavy cutting in the north and central parts of the region and little or no cutting in the southern part. As is shown by the type maps at the back of this publication, vast areas have been cut over on and near Puget Sound, Grays Harbor, and the Columbia River, and large areas of virgin timber remain in southern Oregon. Approximately 75 percent of the present cut-over area (including 84 percent of that in Washington and 59 percent of that in Oregon) was logged to supply tidewater or Columbia River mills.

During the period 1925-33, mills on tidewater and the Columbia River produced 85 percent of the lumber, 95 percent of the pulp, and practically all the veneer manufactured in the region. Such mills have the following advantages over other mills in the region: (1) Access to open log markets in which logs of any grade can be purchased; (2) a wide territory from which to draw logs; (3) access by combinations of rail and water transportation to both foreign and domestic markets for forest products; (4) better opportunity for integration with other wood-using industries, owing to cheap water transportation-for example, several saw- mills on Puget Sound can sell waste material to a pulp mill on the sound, because the waste can be transported cheaply in barges; and (5) better opportunity to sell-as fuel wood, hogged fuel, and sawdust - material that usually goes into the burner at strictly inland mills.

By far the larger part of the remaining timber of economic-availability class 1 in western Washington is tributary to mills on tidewater or the Columbia River. In western Oregon, the class 1 timber in the Columbia River and Oregon coast units is tributary to such mills, but that remaining in the Umpqua and Rogue River units and the southern part of the Willamette River unit cannot, under present conditions, be moved to coast or Columbia River points except at excessive costs. The mills at inland points that are operating in competition with tidewater and Columbia River mills, are doing so in most cases on the basis of special advantages-such as preferred locations and easily accessible timber - that probably will be available to very few additional mills. The production of inland mills, now a very small percentage of the total regional production, is not likely to show any great increase until the timber tributary to tidewater is cut out.

\section{Major Forest Districts}

On the basis of transportation-water, rail, and truck - the region was divided into six major districts (fig. 33) as follows: (1) The Puget Sound district, which includes the north, central, and south Puget Sound forest-survey units, that is, all the territory 
in western Washington tributary to Puget Sound. (2) The Grays Harbor-Willapa Bay district, which is identical with the Grays Harbor unit and includes all the territory in western Washington tributary to Grays Harbor and Willapa Bay harbors. (3) The Columbia River district, which includes the Columbia River unit in Washington and that in Oregon, or all the territory in western Washington and western Oregon tributary to the Columbia River. (4) The Oregon coast district, which includes the north and south Oregon coast units, or all the territory in western Oregon directly tributary to the Pacific Ocean. (5) The Willamette River district, which is identical with the Willamette River unit and includes all territory in the Willamette Valley not tributary to the Columbia River. (6) The south Oregon district, which includes the Umpqua and Rogue River units, or all the remaining territory in southern Oregon.

For the next decade or two, at least, there is not likely to be any great amount of cross haul among these districts so far as the average run of logs is concerned. At some points along the edges of any one of them timber may go either one way or the other, and for high-grade logs there may be a large amount of cross haul, but by far the greater part of the average-grade logs cut in any district will probably be manufactured somewhere within that district. (The district manufacturing the lowest percent of its own log output is the Oregon coast district.) This prediction applies particularly to rail or motortruck transportation; where water transportation is feasible there may be a considerable movement of camp-run logs from one district to another, e. g., from the Oregon coast district

TABLE 36.-Unreserved saw timber of availability class $I$ in the transportation districts of the Douglas-fir region by species group, log scale, Scribner rule

(In millions of board feet, i. e, 000,000 omitted)

\begin{tabular}{|c|c|c|c|c|}
\hline District & $\begin{array}{c}\text { Duuglas- } \\
\text { fir }\end{array}$ & $\begin{array}{l}\text { Pulp } \\
\text { species }\end{array}$ & $\begin{array}{l}\text { All other } \\
\text { species }\end{array}$ & TotaI \\
\hline Puget Sound & 40,922 & 30,972 & 9,100 & 80,994 \\
\hline Grays Harbor-Willapa Bay .- & 8,374 & 22,040 & 4,779 & 35,193 \\
\hline Columbia River. & 27,370 & 11,369 & 2,079 & 40,818 \\
\hline Willamette River & 51,110 & 5,500 & 1,510 & 58,120 \\
\hline Oregon coast & 29,033 & 6,800 & 2,069 & 37,902 \\
\hline South Oregon & 17,987 & 1,398 & 6,256 & 25,641 \\
\hline Total & 174,796 & 78,079 & 25,793 & 278,668 \\
\hline
\end{tabular}

to the Columbia River, Grays Harbor-Willapa Bay, or Puget Sound district and from the Willamette River district to the Columbia River district.

The remaining stand of saw timber of availability class 1 in each of the six districts is shown in table 36.

Territory tributary to tidewater mills may be enlarged and movement of logs between districts facilitated by one or more of the following improvements proposed by various public and private agencies: (1) Improving the Willamette River so as to allow all-year economical towing of logs from Eugene to Portland; (2) cutting a canal across the narrow neck of land separating Willapa Bay from the Columbia River; (3) cutting a canal from Grays Harbor to Puget Sound; (4) connecting the railroad running north from Grays Harbor with that running west and south from Port Angeles. These purposes would be furthered also by other railroad construction, new highway construction, and improvement in trucks.

It is to be expected that the districts having most natural advantages will be exploited first, and that if industry is left to its own course their virgin timber supplies will be exhausted before certain less favored districts are opened up. The Puget Sound, Columbia River, and Grays Harbor-Willapa Bay districts are the most favored, having the advantages of ocean shipping and open log markets. A log fed into the Sound or into the Columbia River at any point is about as available to any one mill on the Sound or on the river, respectively, as to another, so far as the cost of delivery is concerned.

Timber within reasonable distance of these water bodies has the following advantages over other timber: (1) Concentration of sawmills, pulp mills, veneer plants, shingle mills, and other wood-using industries on these water bodies creates specialized markets for logs of many species and varying grades; (2) the log market is not dominated by a few buyers. In many instances these factors may result in rapid liquidation but in some cases they should induce the timber owner to practice continuous forest management.

\section{Puget Sound District}

Of these six major forest districts in the Douglasfir region, the Puget Sound district is the oldest in 
large-scale logging and production of wood products. It has 40 percent of the installed sawmill capacity of the entire region. Prior to the depression a large quantity of logs was put on the Puget Sound log market by independent loggers, but this has fallen off during late years. Puget Sound has excellent harbors and has good shipping service - that is, it has enough volume of other traffic and enough sawmills and pulp mills so that boats plying at regular intervals have an opportunity to get full cargoes. Location of both sawmills and pulp mills on tidewater makes it easy and cheap to move sawmill waste to pulp plants and hogged fuel to points of consumption in the large cities. Logs can easily be imported, also, from British Columbia.

The Sound district is served by three transcontinental railroads to the east and three to the south, and by an excellent highway system. Wood-using plants are scattered up and down the Sound from Bellingham to Olympia, including sawmills, pulp mills, veneer plants, shingle mills, door factories, furniture factories, etc. The diversity of these plants allows maximum integration of industry and full utilization of different timber species and of different grades of logs. The communities on the Sound where most of the woodusing industries are located are modern, progressive cities with good facilities for the welfare of their inhabitants.

\section{Grays Harbor-Willapa Bay District}

The Grays Harbor-Willapa Bay district has some of the advantages of the Puget Sound district, but not to the same degree. Grays Harbor is an excellent port, but the Willapa Bay harbor, to date, is only mediocre. At neither harbor are there other lines of business permitting good watertransportation service for small shipments of lumber or pulp; in fact, forest products constitute practically all the shipping in these two ports. Although the Grays Harbor-Willapa Bay district has sawmills, a pulp plant, veneer plants, shingle mills, box factories, door factories, general remanufacture plants, cabinet works, and other woodusing industries, its wood-using industries are neither so varied nor so extensive as those of the Puget Sound district.

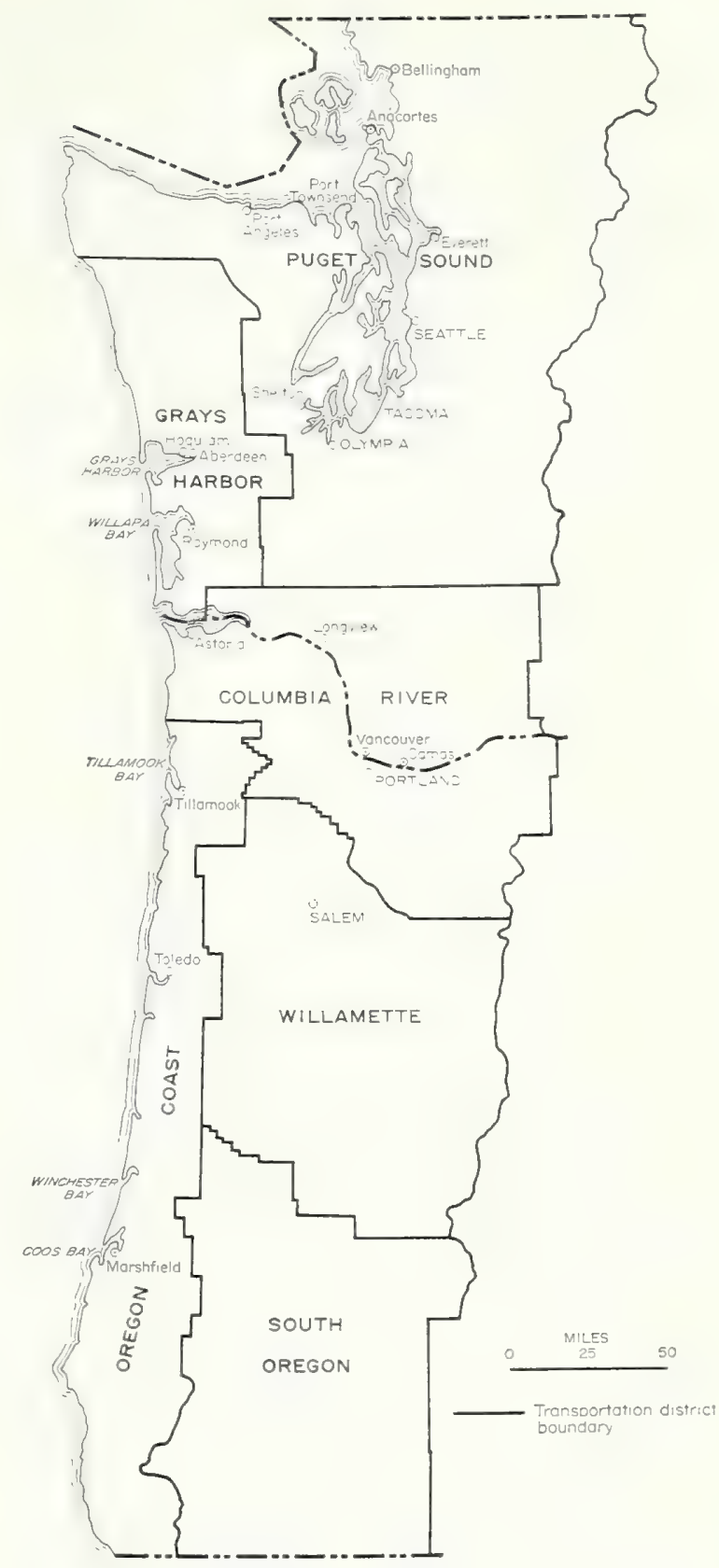

FIGURE 33.-Map showing 6 major transportation districts in the Douglas-fir region

In this district, considering timber in all availability classes, the ratio of board-foot volume of pulp species to that of Douglas-fir is 3 to 1 .

\section{Columbia River District}

The Columbia River district has excellent freshwater harbors that will accommodate transoceanic 
vessels, transcontinental rail facilities, and goodsized cities offering markets for mill byproducts and waste. It has ample fresh-water storage for logs. It contains 25 percent of the active sawmill capacity of the region, 43 percent of the installed pulp-mill capacity, and 18 percent of the installed plywood-mill capacity. It is the center of the furniture-manufacturing industry in the Pacific Northwest, and contains many secondary woodusing plants. Its forest resources have not been exploited to such an extent as those of the Puget Sound district. The existing commercial timber supply of all species immediately tributary to Columbia River mills is less than that tributary to mills on the Sound, but includes almost twice as much Douglas-fir timber as pulp timber.

\section{Willamette River District}

The Willamette River district has more Douglasfir in availability class I than any other district and about 10 times as much Douglas-fir timber as pulp species. It has a greater volume of class I timber of all species than any except the Puget Sound district. It differs widely in industrial development from the three districts already discussed. It has no veneer or plywood industry, only 5 percent of the installed pulp-mill capacity of the region, few minor woodworking industries, and is distinctly a district of small sawmills and small woods operators. In this district 172 sawmills were active in 1934, representing about 15 percent of the regional installed capacity. Of the installed capacity of the district about 30 percent was in 7 mills cutting 100,000 feet or more per day, 44 percent represented mills cutting from 20,000 to 100,000 feet, and 26 percent less than 20,000 . Although a considerable quantity of logs from the Willamette River district are taken into the Columbia River district for manufacture, most of the logs are manufactured locally, and this situation will probably continue for some time. High-grade logs will undoubtedly continue to move north in increasing quantities. A considerable part of the lumber produced is moved to Portland for ocean shipment.

\section{Oregon Coast District}

The Oregon coast district, although cortaining about as much timber of availability class I as either the Grays-Willapa district or the Columbia River district, has lagged behind the districts already discussed in timber cutting and, especially, in forest-products manufacture. In the period 1925-33 it produced about 7 percent of the regional output of sawlogs. Between 20 and 25 percent of these logs were shipped to other districts or other countries for manufacture. This district has only about 8 percent of the installed capacity of active sawmills in the region, no pulp plant except a relatively small one at Empire, and only one veneer plant, newly installed at Coquille. Its sawmills are almost entirely dependent on California for outlets for the part of their cut that is shipped by water; Port Orford white-cedar logs are shipped to the Orient for manufacture, but in smaller quantities now than formerly.

For some time Lincoln and Tillamook Counties have been the source of many of the high-grade logs manufactured in the Columbia River district, and this will undoubtedly continue. Some logs from Lincoln County have been shipped even to Grays Harbor and Puget Sound points. Whether appreciable quantities of logs from the Coos Bay country will in the future be shipped north for manufacture in other districts is somewhat doubtful.

The largest manufacturing center in the Oregon coast district is Coos Bay. Other major industrial points are the Tillamook-Nehalem area, Toledo, and Winchester Bay.

\section{South Oregon District}

The south Oregon district not only lacks facilities for ocean shipping but is more remote from large population centers than any of the other districts. In its southern portions are extensive forests that represent a merging of types characteristic of the Douglas-fir region, the ponderosa-pine region, and the Sierra region of northern California. It is less developed industrially than any other district of the Douglas-fir region. It has no pulp mills, no veneer or plywood mills, and only about 4 percent of the region's installed sawmill capacity. In the period 1925-33 its cut of logs was only 1 percent of that of the region as a whole. Logging and lumber manufacture are chiefly limited to ponderosa pine. In the south Umpqua drainage there is a tremendous volume of Douglas-fir timber, 
but there neither logging nor the manufacture of wood products has been of any consequence up to the present, owing in part to somewhat lower quality of timber but chiefly to lack of water-shipping facilities. In this district as a whole there are relatively few sawmills, and the typical mill and the typical logging operation are small. The one large sawmill is a pine mill with a box factory in connection, located at Medford.

\section{Future Depletion and \\ Inventory}

On the basis of 1933 inventory data and depletion and growth estimates presented previously, forest depletion and growth in the Douglas-fir region have been estimated for each decade of the 30-year period beginning with 1933 and regional forest inventories have been calculated as of 1943 , 1953, and 1963 (table 37 and figure 34). The depletion figures are log scale and do not include the results of any wind or fire catastrophe. Assumption of a specified cut in a given forest-survey unit does not necessarily imply that that quantity of logs will be manu-

factured into lumber, pulp, or other products in that unit. How the assumed future depletion by cutting, fire, etc., would alter type areas is shown in figure 35.

The key element in these estimates and calculations was the assumptions of future cutting. These were based on a continuation of past practices, i. e., that liquidation would take its normal course. This would mean a continuation of past destructive processes. The depletion data as set up, both as to amount and location, are based on conditions which are contrary to conservation principles and which

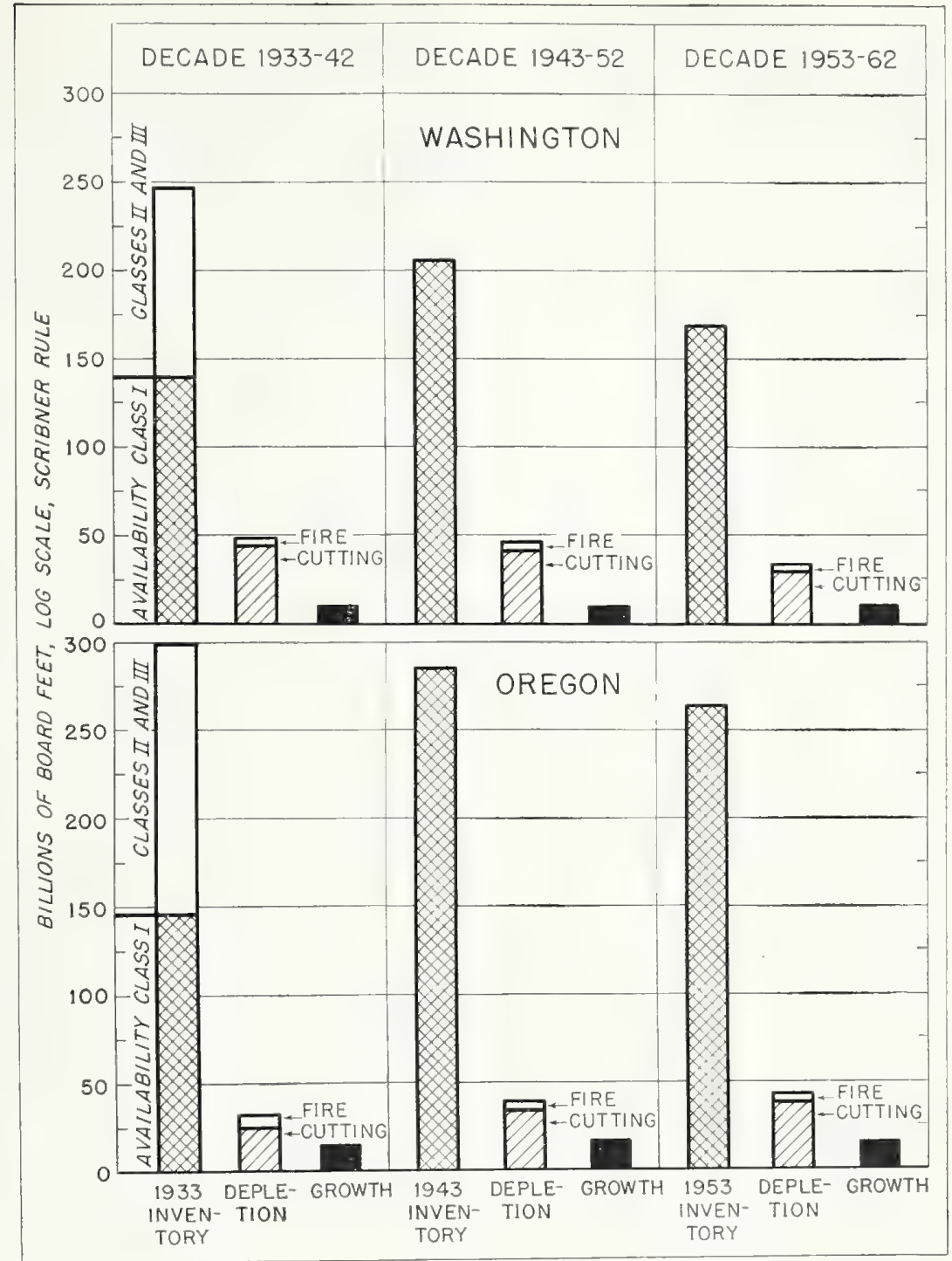

FiguRE 34.-Estimates of forest depletion and growth and periodic timber inventories for the Douglas-fir region

it is to be hoped will change. Nevertheless, it was thought desirable to show what might result if past practices continued. ${ }^{17}$ A constructive program of forestry would alleviate the situation created by this destructive process.

Timber in availability class I alone was considered, on the theory that cutting will shift to class I timber in unexploited localities before any material quantity of class II or class III timber is cut in localities where the class I timber has been

17 See pp. 52 to 53 , inclusive, for further details on assumptions or on estimates of future depletion. 
TABLE 37. - Current and assumed future inventories of forest resources in the Douglas-fir region, by ownership, class, and district 1 INVENTORY OF 1933

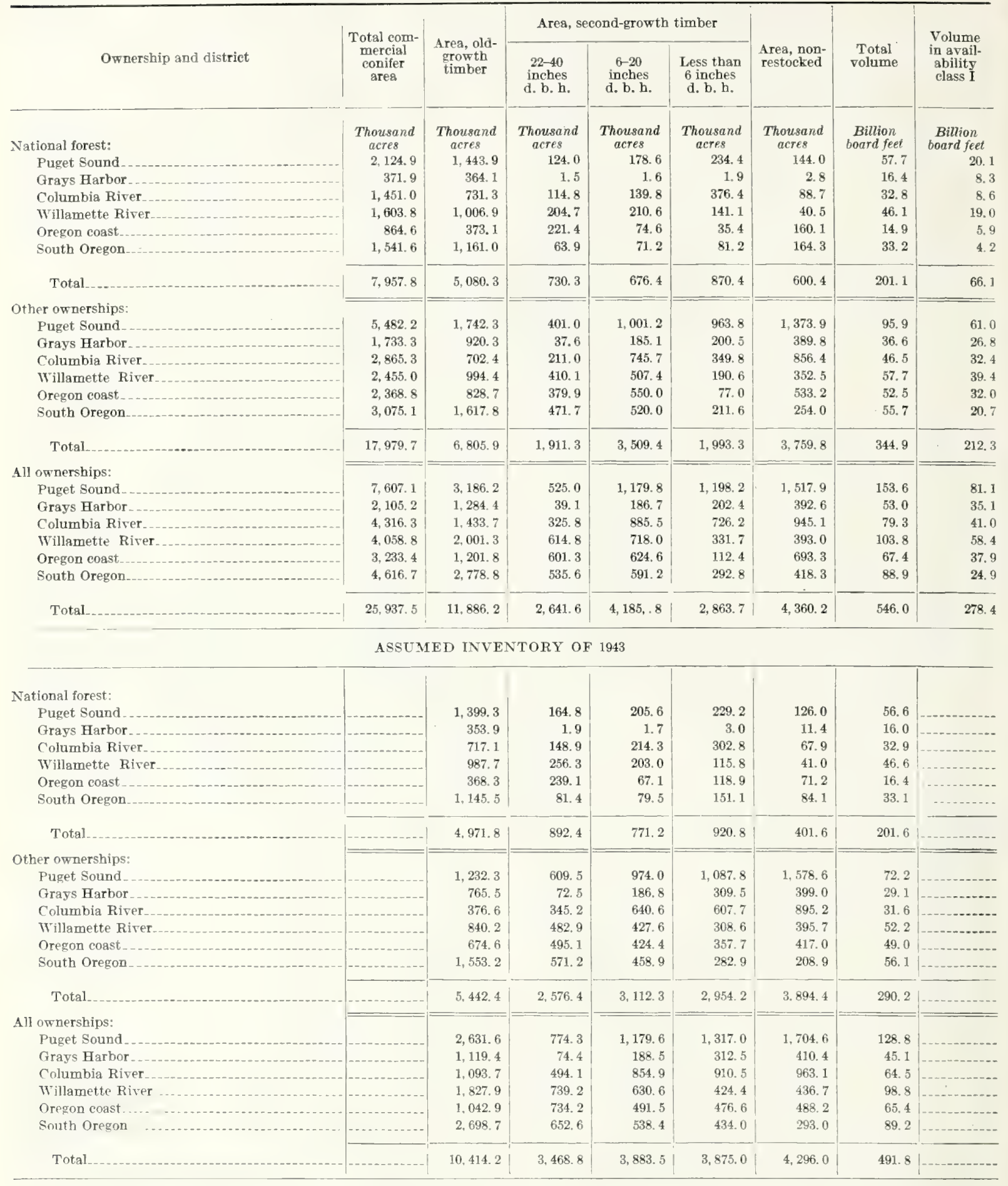

Includes nonreserved lands only. 
TABLE 37.-Current and assumed future inventories of forest resources in the Douglas-fir region, by ownership, class, and district-Continued ASSUMED INVENTORY OF 1953

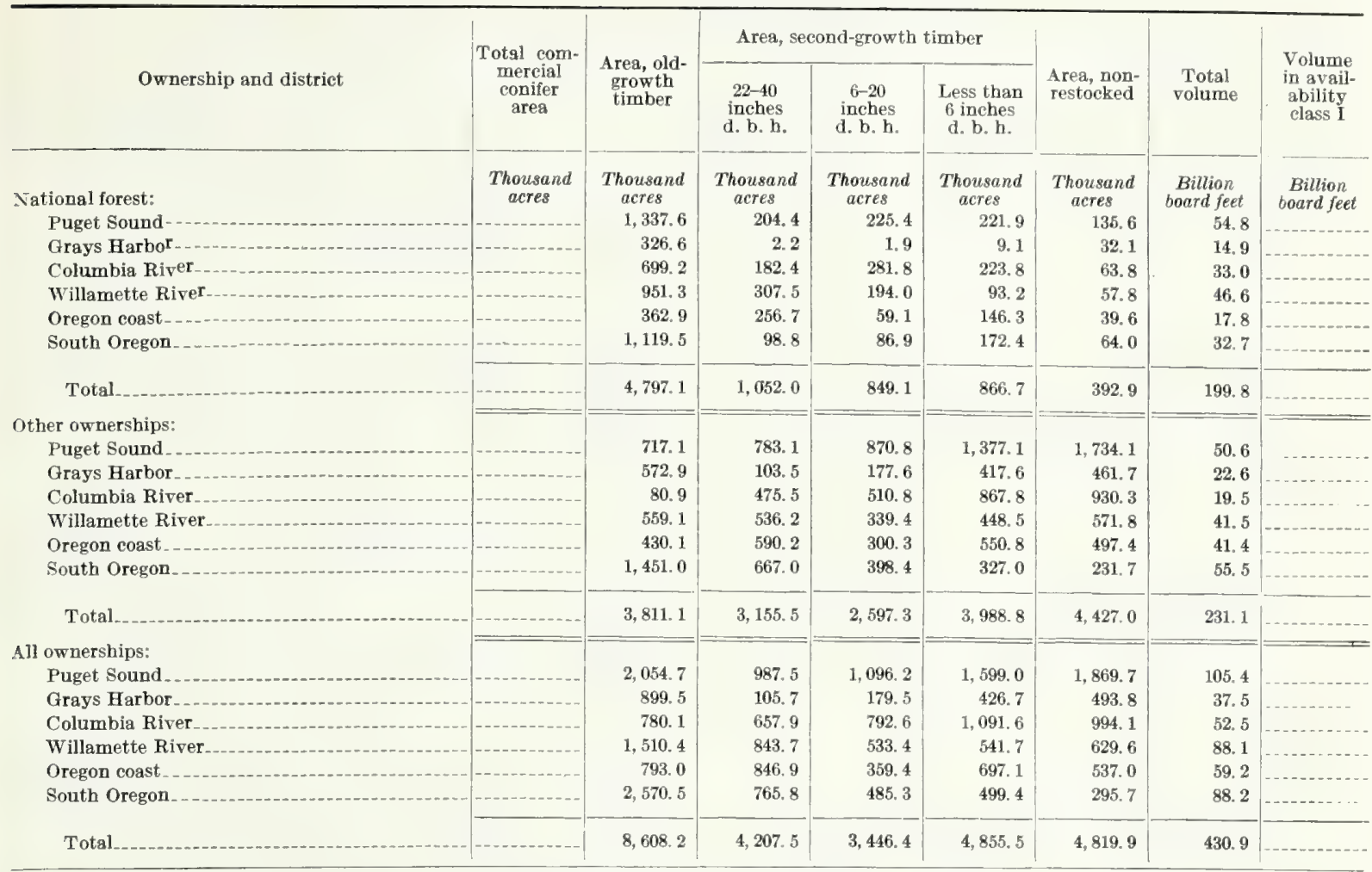

\section{ASSUMED INVENTORY OF 1963}

National forest:

Puget Sound

Grays Harbor.

Columbia River

Willamette River

Oregon coast.

South Oregon.

Total.

Other ownerships:

Puget Sound.

Grays Harbor.

Columbia River.

Willamette River.

Oregon coast -

South Oregon...

Total

All ownerships:

Puget Sound

Grays Harbor.

Columbia River

Willamette River

Oregon coast.

South Oregon.

Total

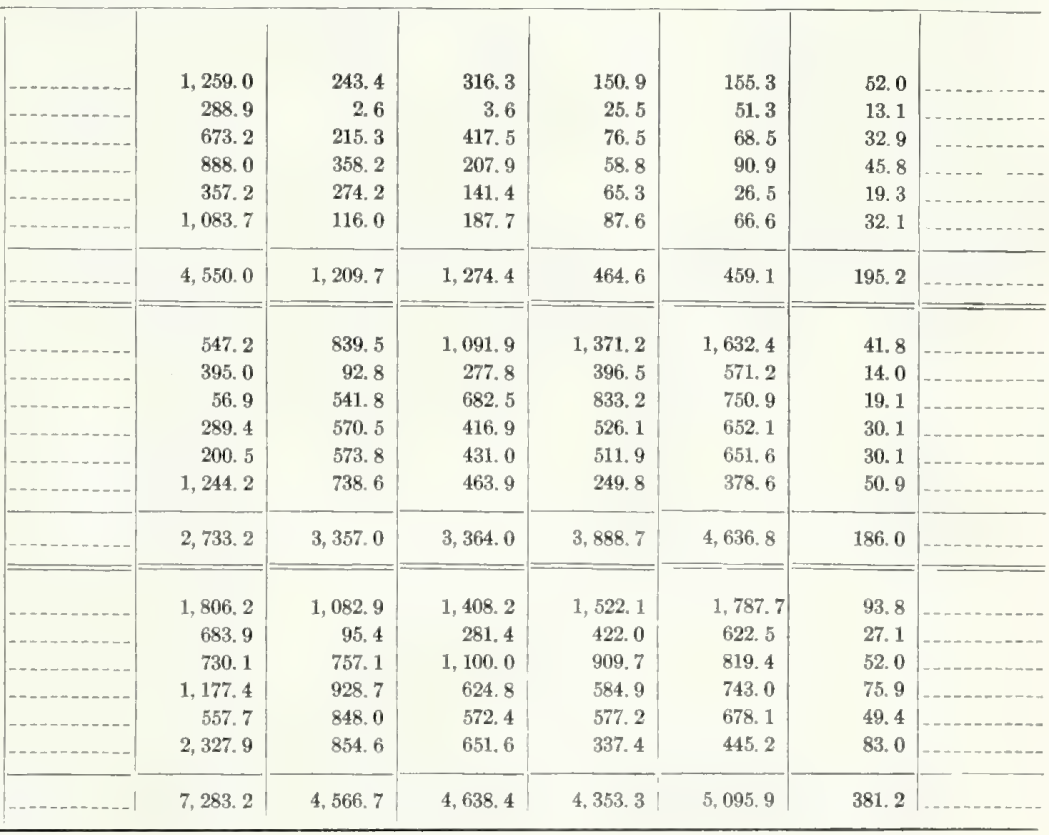


exhausted. In regard to material for lumber manufacture it was assumed that Douglas-fir will be the principal species used during the next two or three decades, and that a certain quantity of Douglas-fir of lower economic availability will be taken before hemlock and other species are used extensively, but that during the second and third decades species other than Douglas-fir will be used in greater quantities than at present. The quantity of pulp manufactured in the region was assumed to increase materially during the 30 years covered by the calculations.

The estimates of depletion in the region and in individual forest-survey units theoretically indicate not only how far the supplies of raw material now available will go but what shifts of logging operations from district to district are likely to take place.

On the 1933 basis, according to the figures given in table 37, by 1963 the region's total volume of all species in all ownership and availability classes would be reduced to about 70 percent and the volumes in the various districts would be reduced as follows: Grays Harbor, to one-half; Puget Sound and Columbia River, to two-thirds each; Willamette River and Oregon coast, to about threequarters each; and south Oregon, to something more than nine-tenths.

According to the estimates the total nationalforest volume in 1963 would be 97 percent of the 1933 figure, but the total volume on other lands in 1963 would be only 54 percent of the 1933 figure; the difference is explained by the fact that in 1933 there was three times as much class I timber on other lands as on the national forests and that the national forests are managed under a sustainedyield policy.

According to estimate, in 1963 the national-forest volume would exceed the volume on all other lands in the Puget Sound, Columbia River, and Willamette River districts, would about equal it in the Grays Harbor-Willapa Bay district, and would fail by a considerable margin to equal it in the Oregon coast and south Oregon districts. The estimates were based on the present ratios of national-forest area to other land area.

Let us consider, with the 1933 inventory data as a basis, how the assumed rates of depletion and growth would affect the supply of raw material for the wood-using industries in each major district of the Douglas-fir region.
Sawlogs

\section{PUGET SOUND DISTRICT}

Douglas-fir saw timber in availability class $I$ is practically cut out in the north and central Puget Sound units. The entire Puget Sound district contains about 154 billion board feet of saw timber of all species in all ownership classes, of which only about 81 billion is in availability class I, including only 40.9 billion feet of Douglas-fir. The depletion assumed for this unit during the decade 1933-42 totals about 30 billion feet. Of the remaining 124 billion feet, 55 to 60 billion would be in class I and only 21 or 22 billion Douglas-fir. During this decade Douglas-fir will continue to form a major part of the cut, most of which will be manufactured somewhere in the Puget Sound district, and undoubtedly some high-grade Douglas-fir logs will be brought in from British Columbia and from Oregon points as far away as the Willamette Valley. So long as there is an open log market on the Sound a supply of raw material for the existing manufacturing plants will be assured, and this situation is likely to continue until 1942 to 1945 ; by that time, although probably there will still be an open log market on Puget Sound for species other than Douglas-fir, it is possible or even probable that a few large operators will control by far the greater part of the Douglas-fir in the district.

Sawlog production in the Puget Sound district in the period 1925-33 averaged about 3 billion feet per year; the 28-billion-foot cut assumed for the decade 1933-42 would allow the industries in the district an annual. supply of that magnitude. About two-thirds of the logs used in 1925-33 were Douglas-fir, and this ratio could continue in 193342. Almost the entire supply of Douglas-fir logs would have to come from the central and south units, since the north unit has only between 7 and 8 billion feet of class I Douglas-fir left.

For the period 1943-52 the total assumed depletion for the Puget Sound district is about $28 \frac{1}{2}$ billion feet, log scale, of which slightly more than 27 billion feet is assigned to cutting. A considerable reduction in cutting is assumed in the north and central units, and a material increase in the south unit. During that decade most of the Douglas-fir timber of sawlog size will be depleted, but local timber resources should be adequate to supply the 


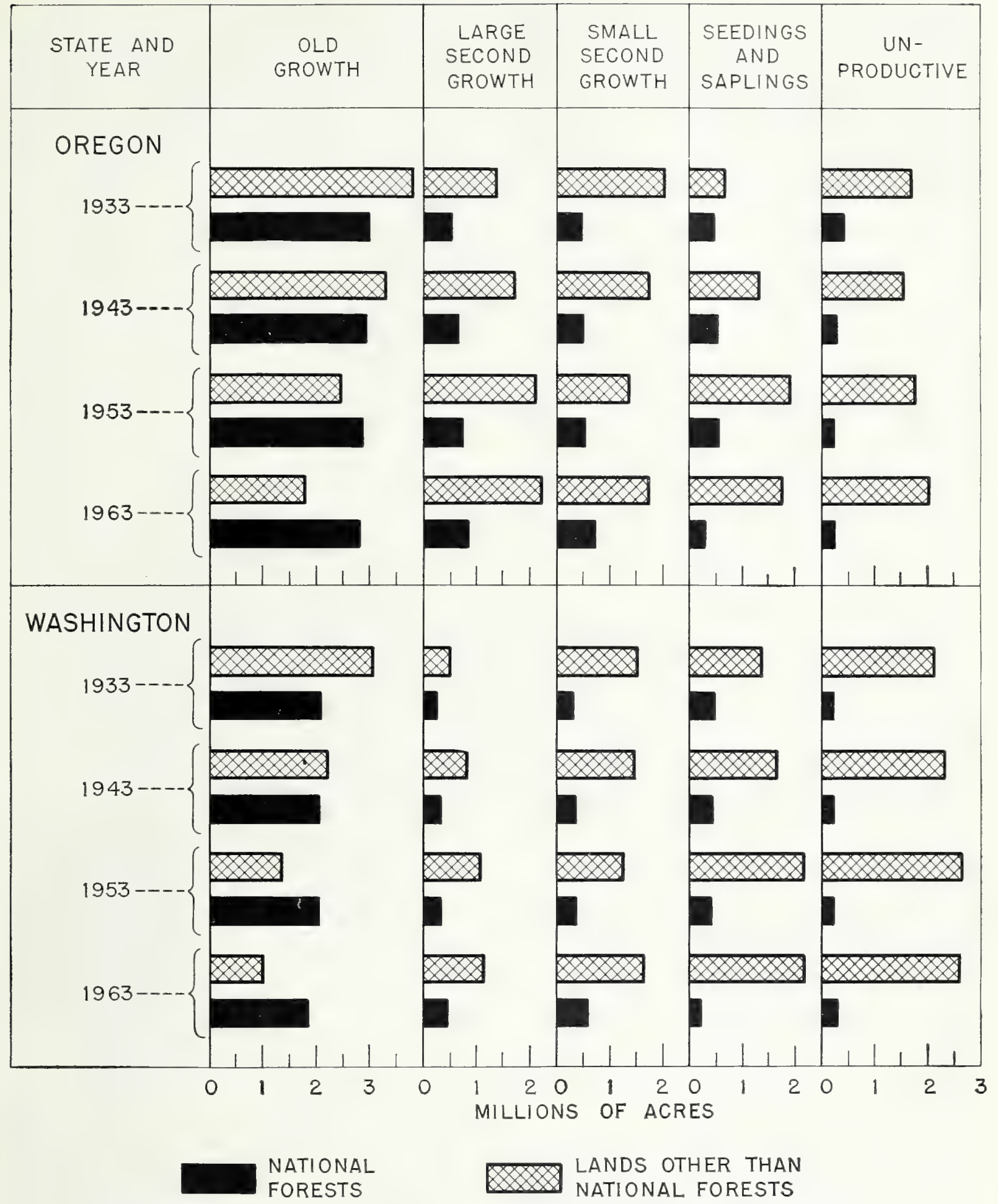

FIGURE 35.-Effect of assumed depletion and calculated growth on timber-type areas in the Douglas-fir region 
sawmills if greater quantities of hemlock and "cedar" are utilized.

For the decade 1953-62 the assumed cut for the district drops to about $15 \% / 2$ billion feet, of which national-forest timber composes about a fifth. In 1963 the Puget Sound district is assumed to have the third largest total log production among the six districts of the region. By that time its total volume of timber on lands other than national forests is assumed to have diminished to about 42 billion feet, and its national-forest timber to have diminished (from 58 billion feet in 1933) to 52 billion feet. A considerable reduction in the quantity of sawlogsparticularly Douglas-fir sawlogs - cut for lumber is expected to occur during this decade. It is assumed that by that period part of the slack in employment caused by the passing of sawmills will be taken up by increase in pulp production.

Under present marketing conditions the existing raw material is sufficient to supply all the existing wood-using industries at present rates of consumption at least until 1943, and is probably sufficient to do so until 1963 if all species are used. However, disappearance of the open log market for Douglasfir would undoubtedly force certain sawmills to cease operation. Owners of sawmills the depreciation of which has been fully accounted for and that are still reasonably efficient can afford to pay about $\$ 1.50$ per 1,000 more for logs than owners of newly built sawmills requiring depreciation, and this $\$ 1.50$ can be applied to the cost of transporting logs from greater distances. This differential is not, however, sufficient to bring in camp-run logs from northern Oregon. Therefore, unless other species are substi. tuted on a large scale for Douglas-fir there is bound to be a reduction in the quantity of lumber sawed in the Puget Sound district during the period 1953-62.

Forced migration of forest industries as a result of raw-material shortage would seriously disrupt the economy of this district which has more than half the population of the entire region. Constructive measures that would help avert this danger are: (1) Conserving the supply of high-quality material through selective logging; (2) better utilization in the woods; and (3) more complete manufacture.

\section{GRAYS HARBOR-WILLAPA BAY DISTRICT}

In the Grays Harbor-Willapa Bay district the annual production of lumber, lath, and shingles for the period 1925-34 averaged about 1.1 billion feet, lumber tally, with a high of 1.8 billion feet in 1926. a low of 0.3 billion feet in 1932, and a 1934 total of about 0.47 billion feet. Annual production of logs (log scale) for 1925-33 averaged slightly more than 1.45 billion feet, with a low of 0.77 billion feet in 1933. The Douglas-fir, spruce, and "cedar" of availability class $I$ in this district is sufficient to maintain the 1933 rate of $\log$ production until about 1948, even if no hemlock or balsam fir trees are cut. This same timber would maintain the 1925-33 annual rate of $\log$ production only until about 1943. The total cut of 9 billion feet assumed for 1933-42 and for 1943-52 includes a considerable proportion of hemlock and other species to be used in pulp mills, 15 to 20 percent in the first decade and 20 to 40 percent in the second. By the end of the second decade the greater part of the Douglas-fir will be gone, and a considerable part of the Sitka spruce and "cedar."

The sawmill industry in the Grays HarborWillapa Bay district will be able to go ahead on a reduced basis for one more decade and probably part of the second, but not much longer unless there is a decided increase in the use of hemlock, "cedar," and balsam firs for lumber. Inventory data and type maps for the district show that the future of this region is bound up in the pulp industry. With raw material enough for greatly increased pulp production, this district needs additional pulp mills if all labor now used in the lumber industry is to be given employment in the future.

Western hemlock lumber is well adapted to most ordinary construction needs, and prior to 1930 a considerable quantity of it was marketed. Prejudice against this wood existed particularly in eastern markets where eastern hemlock, a different species, had only a mediocre rating. Instead of making a determined effort to overcome this prejudice through trade extension and through better manufacturing methods, West Coast manufacturers offered western hemlock at prices lower than those of competing woods. The prejudice persisted; and during the depression, when little building was being done and prices of other woods went to rock bottom, the price-differential sales weapon was eliminated and hemlock lumber sales dropped off in larger proportion than sales of Douglas-fir. It is assumed that good manufacturing procedure, 
including good drying, together with aggressive merchandising, will partly remedy this situation.

The cut of timber in all ownership and economicavailability classes in the period 1933-62 is assumed to total about 30 billion feet. Offset in part by growth, this depletion would reduce the 1933 supply of 36.6 billion feet on lands other than national forests to 14 billion feet and the 16.4 billion feet on the national forests to 13.1 billion feet. During 1953-62 the annual cut of nationalforest timber is assumed to average about 13 percent of the total annual cut.

The industrial development in this district is based almost entirely upon the forest industries. Prompt application of forestry practice that will insure a continuous flow of raw material is of utmost concern to all communities in the district.

\section{COLUMBIA RIVER DISTRICT}

In 1925-34 the Columbia River district produced annually an average of 1.77 billion feet of lumber, with a high of 2.38 billion feet in 1928 and a total of 1.36 billion feet in 1935 . The quantity of logs cut in this district averaged more than 1.82 billion feet in 1925-33, but was only 1.41 billion feet in 1933. The 1925-33 average was about 23 percent of the regional average for that period, and the total in 1933 was 30 percent of the regional total. Production of both logs and lumber fell off less, proportionally, during 1931-33 in this district than in any other district.

The standing timber in this district now in availability class $I$ is not sufficient to maintain the 1925-33 rate of $\log$ production until 1963. During the decade preceding 1935 the sawmills in the district cut $1 \frac{1}{2}$ billion feet or logs per year; if this rate of production continues, and if the pulp mills in the district continue to utilize between 300 and 350 million feet of logs per year, the sawmills and plywood industry will be pinched for raw material sometime between 1943 and 1952. It is assumed here that the annual rate of cutting depletion will be only slightly less in 1933-42 than in the period preceding 1933, that in 1943-52 it will average between 85 and 90 percent of the 1925-1933 rate, and that after about 1952 it will diminish abruptly. A relatively small number of companies own a large part of the timber in this district. It is as- sumed that during 1933-42 these owners, both large and small, will continue cutting at the same rates as in earlier years, but that by the end of that decade most of the present small owners will have cut out and that by 1945-50 there will be few areas where small independent loggers can operate.

The anticipated reduction in cut of timber in the district within the decade 1943-52 would not necessarily result in a proportional reduction in quantity of raw material available to the local woodusing industries; there is every reason to believe that it would be compensated by an increase in the quantities of logs brought into the district from the Oregon coast and Willamette River districts. In the competition with the Puget Sound and Grays Harbor districts for these logs, the Columbia River district should have the geographic advantage enabling it to intercept the flow of logs northward. The lessening of the volume of logs cut within the district would probably have some effect on the volume and quality of logs available on the open log market. This effect would probably be felt first in the plywood industry. General application of selective logging would conserve the supply of peeler logs.

\section{WILLAMETTE RIVER DISTRICT}

The Willamette River district has not played a prominent part in the West Coast lumber industry in the past, but seems destined to do so in the future. In 1934 more than 515 million board feet of lumber was sawed in the district. This was 12 percent of the regional total, and exceeded the output of any of the other districts except the Puget Sound and Columbia River. During 1925-33 the annual cut of trees of sawlog size for all uses averaged about 778 million feet, of which the sawlog cut was about 692 million feet, log scale, including some 120 million feet shipped elsewhere for manufacture. Cutting in the 30 years $1933-62$ is assumed to average higher per year than in 1925-33, but leaving more than 20 billion feet of timber of availability class $I$ in the district, even if none of the timber now in availability class II moves into class I.

Decadal cuts assumed for this district are as follows: 1933-42, 7.6 billion feet; 1943-52, 14.2 billion feet; 1953-62, 16.2 billion feet. The cut on 
the national forests is assumed to amount to about 450 million feet in the first decade and to increase to 2.25 billion in the third. According to these assumptions, by 1963 the 46.1 billion feet of timber on the national forests in 1933 will be reduced to 45.8 billion and the 57.7 billion on other land in 1933 will be reduced to about 30 billion feet, depletion being practically equalled by growth on the national forests but being greatly exceeded by it on other lands.

\section{OREGON COAST DISTRICT}

The average annual cut in the Oregon coast district of trees of sawlog size used for all purposes of 570 million feet in the period 1925-33 was about 7 percent of the total regional cut and fairly evenly divided between the north and south units. Annual lumber production was about 540 million feet (1925-34 average) with a cut of 390 million feet in 1934. By 1933 the production of logs had dropped to 270 million feet, or 6 percent of the regional total.

With the exception of Port Orford white-cedar, there will be no shortage of logs for local industries in this district for at least three decades. The assumed depletion in the district, which increases in each decade to 1963, would leave 15 billion feet of class I timber remaining in that year. The predepression annual cut of Port Orford white-cedar was about 70 million feet. The total stand of this species is not much more than 1.1 billion feet, of which something more than 750 million feet is in private ownership. Resumption of the former rate of cutting would lead to exhaustion of the supply in private hands in the second decade, even if all the remote stands were logged completely. The cut of logs took a tremendous drop in the 1931-33 period, when exports of the logs to Japan were at a very low point, but in 1935-36 it increased materially. Cessation of the exporting of Port Orford whitecedar logs would materially lengthen the life of the local industries dependent on them, since during the period 1928-33 the logs exported amounted to about 30 percent of the total quantity cut.

For the district as a whole the depletion assumed in the survey for the period 1933-62, increasing in each decade, would not exhaust the class I timber. However, as in any other forest district of the region, dividing the remaining supply of class I timber by the past average annual cut of logs does not necessarily give an indication of how long the wood using industries in the district may be assured of a supply of raw material. Even where a considerable volume of timber is at present available, if the mill owner does not own this timber he may have no guarantee of a continuous supply.

The total cut of some 33 billion feet in this district during the period 1933-62 is assumed to include less than 1 percent cut on the national forests. The national-forest timber in the northern part of the district will not mature by 1963, and that in the southern part presumably will still be economically unavailable at that time. While the timber volume on lands other than national forests is calculated to decline from 52.5 billion feet ( $\log$ scale) in 1933 to 30.1 billion feet in 1963, national-forest timber is calculated to increase from about 15 billion feet in 1933 to slightly more than 19 billion feet in 1963 .

The disastrous Tillamook fire of 1933, located mostly in the Oregon coast district, particularly affected the wood-using industries on the Columbia River, since probably at least three-fourths of the 10 billion feet of timber burned would have been manufactured in Columbia River mills. Of the remainder, part would have gone to Oregon coast mills and part to Willamette River mills. Salvage on the burned area has lagged behind expectations, and of the total volume removed to date a considerable part has been green timber. At the end of 1937 only about 5 percent of the timber burned had been salvaged.

Since the fire considerable areas within the boundaries of the burn have become tax delinquent, and even though assessed values have been reduced, the hazards of holding the timber make it doubtful that taxes will be paid on much of the burned area after 1940 or 1945. At current salvage rates the most that present owners can expect to recover befor relinquishing their equities is about 2 billion feet. By about 1945 Tillamook County may own the greater part of the 7 or 8 billion feet that will remain uncut, unless the State or Federal Government takes over the area before that time.

A study of deterioration of fire-killed Douglas-fir (1) showed that by the eighth to tenth year after fire killing, salvage for lumber logs is practical only for large slow-grown trees 50 inches d. b. h. and more. On the Tillamook burn Douglas-fir com- 
posed about 85 percent of the timber burned and 40 percent of this was in trees 50 inches d. b. h. and more. By the time the county may be expected to own most of the burned timber the gross volume of the unsalvaged trees 50 inches d. b. h. and more will probably be less than 3 billion feet.

In an examination ${ }^{18}$ of a large area of the burn in 1935 two-thirds was found to be restocking. A reexamination in 1937 showed serious loss to reproduction from mechanical injuries wherever salvage operations had taken place. Restoring the Tillamook burn to forest productivity represents an acute problem in fire protection and silviculture, and if this is to be accomplished within a reasonable period planting will have to be resorted to on large parts of the burn.

The profits in salvaging this burned timber, even at very low valuation of stumpage, have been small. An operator whose margin of profit is narrow is not likely to do much work to prevent spread of slash fires from the areas logged. As time goes on, salvage operations will probably be conducted only by smaller operators who will spend even less time and money on control of slash fires.

\section{SOUTH OREGON DISTRICT}

The south Oregon district contains about 89 billion feet of standing timber, of which about 25 billion feet is rated in availability class I. In the period 1925-33 the cut of logs in the district amounted to about 1 percent of the regional total, practically all manufactured locally as lumbera few logs cut along the north border being sent to the Willamette River district for manufacture. During the period 1925-34, the average annual production of lumber was only about 85 million feet, of which more than 90 percent was produced in the Rogue River unit, and 70 percent of this was ponderosa pine and sugar pine.

The depletion assumed in the survey for the period 1933-62-even though about six times as great a cut of lumber is assumed for 1953-62 as the 1933-42-would not materially change the quantity of timber available in the district. For

18 IsaAc, L. A., and Meagher, G. S. natural ReproDUCTION ON THE TILLAMOOK BURN TWO YEARS AFTER THE FIRE. Pacific Northwest Forest Expt. Sta. 1936. [Mimeographed.]

$224146^{\circ}-40-8$ some time to come, also, no considerable quantity of logs is likely to be taken from this district for manufacture. ${ }^{19}$ There appears to be sufficient raw material on hand not only for existing wood-using industries but for a considerable addition to them. Several of the small mills may not have enough supplies to continue indefinitely in their present locations, but most could be relocated without difficulty.

\section{Pulpwood}

At the beginning of pulp manufacture on the Pacific Coast, the principal material used by the pulp mills was sawmill waste. In 1929, pulpwood consumption in the region totaled $1 \frac{1}{4}$ million cords, of which logs constituted 48 percent, sawmill waste 40 percent, and forest pulpwood 12 percent. Data obtained by circulating a questionnaire to all pulp manufacturers in the region in 1936 indicated that in a normal year pulpwood consumption would total very nearly 2 million cords and would be divided as follows: Waste, 11 percent; logs, 69 percent; and forest pulpwood, 20 percent. During the last few years the sawmill waste used in pulpwood manufacture has decreased greatly in total quantity, as well as in proportion to other materials used for pulpwood, and the quantities of logs and forest pulpwood used for this purpose have correspondingly increased. This is accounted for in part by the great decrease in hemlock lumber production since 1929. In Puget Sound sawmills, for example, until 1930 hemlock lumber constituted about 20 percent of all the lumber manufactured, in 1932 it was but 7 percent of the total, and in 1934 it was a little more than 8 percent. After 1930, lumber buyers who formerly took a certain quantity of hemlock mixed with Douglas-fir refused to take any hemlock. However, loggers continued to take approximately the same percentage of hemlock out of the woods; in fact, of the logs brought out of the woods in 1931-33 the percent of hemlock was larger than in 1925-29.

Future trends in use of logs as against use of forest pulpwood for pulp manufacture are hard to

\footnotetext{
${ }_{19}$ Some of the pine in the southeast corner of Jackson County will undoubtedly be milled in eastern Oregon, probably at Klamath Falls.
} 
foresee. Unquestionably, the pulp industry in the Pacific Northwest will continue to demand highgrade raw material. Logs yield cleaner pulp than mill waste or forest cordwood and they can be handled at less cost per ton of chips produced. Apparently there is a trend toward use of chipping machines that take larger cants, which further reduces handling charges. In general, cordwood is not likely to supplant logs except where it is available at much lower prices-for example, where it is produced by farmers who are willing to work for wages lower than those paid in the logging industry. However, some of the existing mills are organized to use cordwood, and undoubtedly large quantities of cordwood will be used for pulp manufacture for some time to come. As before stated, the competition of lumber, veneer, and other wood-using industries for hemlock and balsam fir logs may result in higher log prices to the pulp mills when stands in which Douglas-fir predominates become scarce, but this is still likely to be offset by the advantages of using logs. As the lumber industry recovers, more waste will become available, and if independent operators can convert this to chips and sell it at the right price the pulp industry will use it.

Undoubtedly the pulp industry in the Douglas-fir region, as in other parts of the country, will produce various grades of pulp, and consequently will require various grades of raw material.

It is popularly thought that any large sawmill company could be merged with a pulp company and the latter would take all the waste from the mill and utilize all the small logs, leaving only the high-grade logs for the sawmill. As a matter of fact the pulp manufacturers, particularly the producers of high-grade pulp, are likewise looking for better grade logs. There is opportunity for integration of the two industries, however. Until more hemlock is manufactured into lumber, the pulp mills will utilize the hemlock and balsam fir timber occurring in stands logged for Douglas. fir, spruce, and "cedar" to be used in the sawmills, There is very little tendency to date to use small trees for pulpwood, either as small logs or as forest cordwood. Ordinarily only No. 1 and No. 2 hemlock logs are taken from the woods, and in cordwood operations trees less than 14 to 16 inches d. b. h. are not taken. Thus far, attempts to prelog saw-timber stands for the small understory hemlock and to salvage the waste hemlock and balsam firs left on the ground after logging have been unsuccessful. The rapid changes now taking place in logging methods and costs may, however, make production of smail hemlock logs profitable. Also, if the price of hemlock logs rises a greater effort will be made to utilize the waste now left in the woods; but such an increase in price will have to be considerable to result in any appreciable utilization of small understory trees or of logging waste.

In the Puget Sound district pulp manufacture will increase in importance among the forest industries. The supply of pulpwood available in the Puget Sound district is sufficient to maintain the present pulp mills in this district until 1963 and probably much longer. However, in the future (particularly after the first decade) more and more of the logs used for pulpwood will be produced in logging operations intended chiefly to produce pulpwood, rather than as a byproduct of logging for sawlogs. According to present indications, logging will have exhausted most of the stands of the Douglas-fir types by the end of the second decade. In logging stands in which Douglas-fir is a minor species or is lacking, it appears probable that production of sawlogs will usually be incidental to production of pulpwood.

Since 1919 the price of camp-run hemlock in the Puget Sound log markets has with few exceptions been even lower than that of No. 3 Douglas-fir logs. In general, camp-run hemlock logs have been sold on Puget Sound for $\$ 1$ to $\$ 2$ less per 1,000 feet than the actual total cost of production. In 1934 Douglas-fir log prices per 1,000 feet ranged from $\$ 19$ for No. 1 logs to $\$ 10$ for No. 3 logs, and camp-run hemlock sold for about $\$ 9$, although the total cost of delivering those logs to pulp mills, including not only direct cost of logging but overhead, depreciation, etc., was about $\$ 10.50$ per 1,000 feet. As a result of this and of the utilization of sawmill waste, the price per cord of pulpwood delivered at Pacific coast mills has been less than the average for any other forest region of the United States except the South and has been about $\$ 2$ less than the national average. In the past little or no stumpage charge has been made for hemlock, and camp-run hemlock logs (usually only 


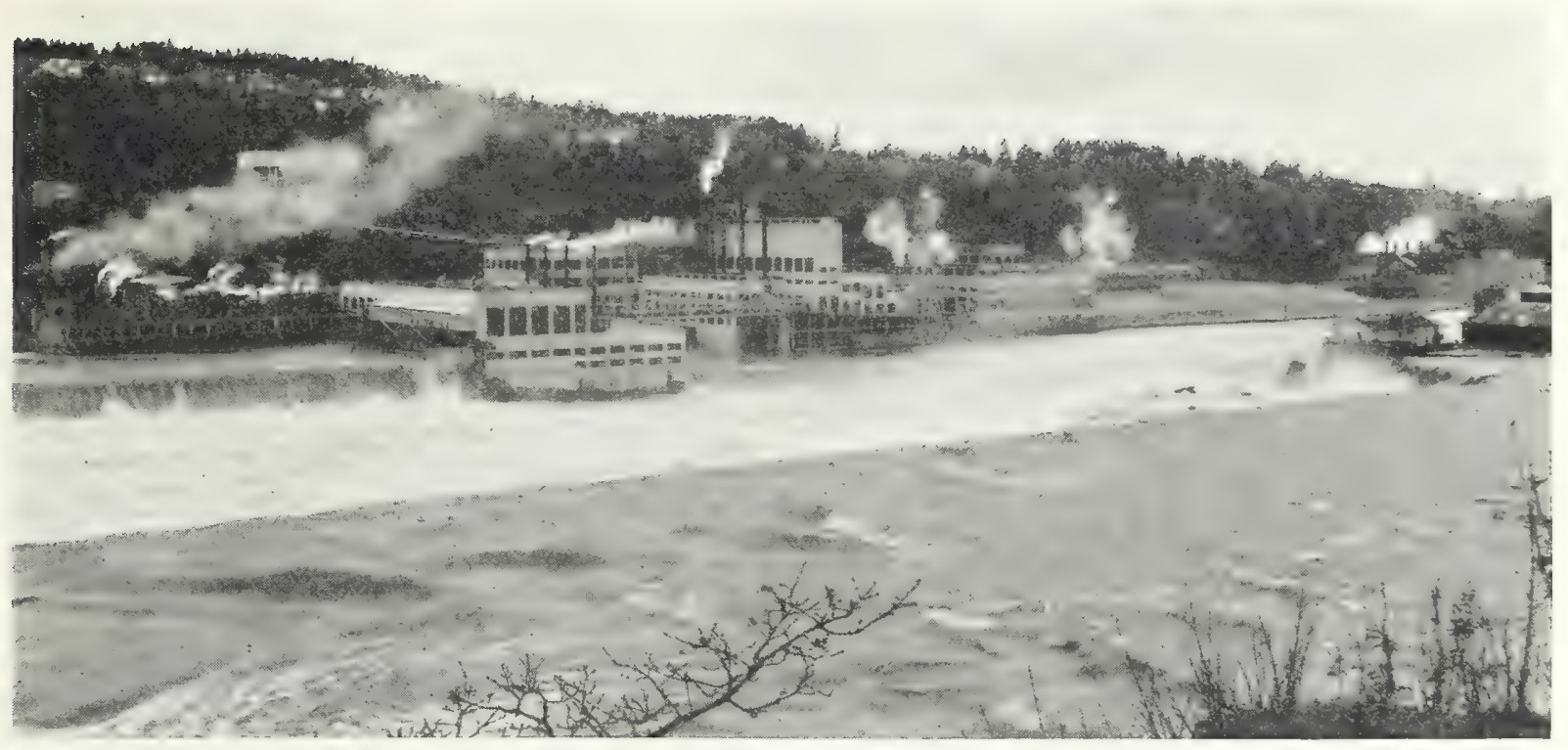

F347418

Figure 36.-Pulp and paper mill on the Willamette River near Oregon City. A plentiful supply of raw material, cheap power, and an abundance of clean water have combined to make pulp and paper manufacture one of the principal industries in the Douglas-fir region

No. 1 and No. 2 grade) were brought in if they would show a profit on the direct cost of logging, all overhead charges being allocated to the Douglasfir, Sitka spruce, and "cedar" logs. This procedure may continue for some time; but by the end of the decade 1943-52, when logging for Douglas-fir, spruce, or even high-quality hemlock will have shifted to stands in which Douglas-fir is only a minor component, western hemlock and balsam firs will have to carry the full cost of logging, which will tend to increase considerably the prices of logs of these species.

Savings under recently developed methods of logging may, however, counteract this tendency to some extent. In the hemlock and balsam fir stands the opportunities for using lighter equipment - tractors and trucks - and for practicing selective logging will be much greater than they have been in stands of large old-growth Douglas-fir. If trees are properly selected for cutting, the supply of high quality logs will meet the needs of the industry, as now constituted, for an indefinite period.

In the Grays Harbor-Willapa Bay district the situation as to future supplies of pulpwood is similar to that in the Puget Sound district. In relation to installed pulp-mill capacity the supply of pulp species is even greater.
In the Columbia River district, pulp mills have heretofore obtained raw material in about the same manner as in the Puget Sound district; but about 43 percent of the region's installed pulpmill capacity (fig. 36) is in this district, and prospective supplies of pulp species are therefore smaller in comparison with plant capacity than in the Puget Sound district. The 1963 stand of 52 billion feet, however, will contain a large volume of pulp species. There is every reason to believe, also, that Columbia River pulp mills will draw some material from the southern part of the Grays Harbor-Willapa Bay district

The capacity of the pulp plants in the Willamette River and Oregon coast districts is so small that the estimated future inventories are more than adequate to supply their needs.

Current annual requirements for pulp total about 190 million cubic feet. ${ }^{20}$ This slightly exceeds the current annual growth of the pulp species (186 million cubic feet) but is considerably less than the potential growth of these species, estimated at 594 million cubic feet. For the region as a whole the assumed future inventories include sufficient raw material for the established pulp mills.

\footnotetext{
${ }^{20}$ See table 9, p. 39 for data concerning present supplies of pulpwood species.
} 
Plywood

The foregoing discussion of future supply of raw material for the lumber industry applies also to the plywood industry, which is chiefly dependent on the lumber industry for its raw material. Plywood manufacture is relatively new here; the region's annual plywood production expanded from 153 million square feet ( $3 / 8$-inch three-ply basis) in 1925 to about 700 million in $1936 .{ }^{21}$ The installed capacity of the region's plywood mills is distributed principally as follows: Puget Sound district, 49 percent; Grays Harbor district, 30 percent; Columbia River district, 18 percent. Concentration of the industry at tidewater and on the Columbia River has been due principally to the ample supply of large high grade logs produced in the course of logging for sawmills and available on the open log markets there. The plywood industry has been in a position to command the market for these logs because it can pay more for them than the sawmills. Owing to the rapid recent increase in plywood manufacture, some combing over of stands of large old growth to get veneer logs in advance of regular logging has been necessary in order to supplement the open-market supply. There is no immediate shortage of peeler-log trees in the woods. Whether or not the supply of high-grade veneer logs obtained in the ordinary course of logging for sawmills will prove adequate for the plywood industry in the future, or whether it will be necessary to continue the present practice of supplementing this supply by combing over old-growth stands, will depend on future trends in the demand for plywood, on progress in using logs of smaller diameter for plywood, and on the extent to which use of lower-grade logs for this purpose can be increased through taping of face stock.

The quantity of high-grade veneer used in making panels is only a small part of the total material needed for panel manufacture.

As yet plywood manufacturers have not owned much timberland, depending mainly on the open market or else on contractual agreements with loggers. This industry is too big and promising to be allowed to decline because of a short-sighted policy towards providing raw material. Through

21269 million board feet of logs is required to produce 700 million square feet of plywood ( $3 / 8$-inch three-ply basis). selective logging and application of simple forestry measures a supply of logs suitable for the manufacture of plywood may be provided indefinitely.

In the Puget Sound district, the supply of raw material for this industry is adequate for the first decade. Puget Sound plants may be faced with a shortage of high-grade Douglas-fir veneer logs during the latter part of the decade 1943-52. Logs of this type can stand a high transportation charge, however, and may be brought in from the Columbia River, Willamette River, and Oregon coast districts; or small veneer plants may be set up in these other districts and veneer shipped from them to plywood mills on the Sound.

In the Grays Harbor-Willapa Bay district the plywood industry will probably have enough raw material to operate for two decades, since a considerable part of the 20-years supply of Douglas-fir and Sitka spruce timber in availability class I will yield logs suitable for veneer manufacture. Even so, veneer logs are now being brought into Grays Harbor from Oregon coast and Willamette River points. If during the next decade or two the plywood industry uses an increased proportion of hemlock, the supply of material for plywood should last well into the third decade.

In the Columbia River district there will undoubtedly be a shortage of peeler logs by the third decade. However, this district has only one-fifth of the region's installed plywood-mill capacity and is close enough to the Willamette River and Oregon coast districts to obtain its supply of veneer logs from them.

\section{Poles and Piling}

The cubic-foot production of poles and piling combined in 1930 contains far more Douglas-fir than "cedar," since the use of Douglas-fir for piling far overshadows that of "cedar" for poles. Western redcedar composed more than 75 percent of the 1930 pole production for the region, more than 90 percent of that in western Washington, and less than 30 percent in western Oregon. Nearly as many "cedar" poles were imported into Washington from British Columbia as were produced locally; at the same time many "cedar" poles growing in Washington were wasted in the process of logging 
for saw timber. Since 1930 the importations have dropped and there has been a very considerable increase in the practice of prelogging old-growth timber stands for "cedar" poles before cutting their saw timber.

The Puget Sound district holds first place in the output of "cedar" poles, which are found mixed with other species, usually as an understory in saw timber along stream bottoms and in other moist sites. Although scattered through Douglas-fir, hemlock, or spruce types, they are most often found in stands that contain enough "cedar" to be classed as a "cedar" type. Large quantities of pole timber are contained in the mature "cedar" stands covering 196,000 acres in the Puget Sound district, 171,000 acres in the Grays Harbor-Willapa Bay district, and 21,000 acres elsewhere in the region. In the small "cedar" type (trees less than 24 inches d. b. h.), which occupies only 26,000 acres in the region, only about 7,500 acres support scattered stands of the pole age of 40 years, in no single instance as large as 100 acres in extent. Therefore, "cedar" poles will unquestionably continue to be produced for the most part by prelogging areas on which the saw timber is to be cut later, since the rate at which commercial logging advances into the particular areas where "cedar" poles are plentiful is not likely to make poles available rapidly enough to meet the market requirements. It is more than probable that future "cedar" pole production will center chiefly in the Puget Sound and Grays Harbor-Willapa Bay districts, where the supply is sufficient to supply the demand for many years.

As for piling, the regional supply of trees of suitable size and quality far exceeds the quantity of material of this kind that is likely to be required for several decades. In contrast with 2.6 million acres of second-growth stands in which most of volume is in trees from 22 to 40 inches d. b. h. and 3.7 million acres of second-growth stands in which most of the volume is in trees from 6 to 20 inches d. b. h., the 1930 regional cut of 135,000 pieces totaling between 25 and 30 million board feet is relatively insignificant. This annual requirement could be supplied by taking on the average one tree from every 4 acres of the large second growth in the Oregon coast district alone. If integrated utilization were effected, no doubt a large part of the annual piling requirements could be obtained in the course of ordinary logging.

\section{Fuei}

In the past forest fuel wood was the chief fuel in western Washington and western Oregon. The use of this type of fuel has decreased, particularly in the large population centers, with increased use of oil, coal, gas, and different forms of mill wasteslabs, trimmings, hogged fuel, and sawdust.

In 1930 the waste from sawmills and other woodworking plants utilized for fuel amounted to 331 million cubic feet of solid wood. In that year trees of saw-timber size aggregating 353 million board feet, log scale, and smaller trees aggregating 60 million cubic feet were cut into forest fuel wood. Portland now uses some 100,000 cords of forest fuel wood annually, in addition to large quantities of mill waste. In Seattle about 10,000 cords of forest fuel wood is burned annually, and considerable quantities of mill waste.

No general statement can be made as to the probable adequacy of future supplies of the various kinds of wood fuel. The timber supply available to the sawmills and other wood-using industries in the larger manufacturing centers of the region is an indication of the quantity of mill waste that may be available to the people in these cities in the future for fuel. Shut-downs in sawmills and other woodusing plants due to cessation of logging in winter, strikes, or other reasons have made the supply of mill waste, particularly hogged fuel and sawdust, somewhat undependable - particularly for residences, in which storage space is limited. However, many people in the wood-manufacturing centers undoubtedly will continue to depend on this type of fuel for a considerable time.

The supply of forest fuel wood that can economically be hauled into Tacoma and Seattle by truck is limited, and will probably be inadequate. On the other hand, lands tributary to Puget Sound include large areas, principally logged areas, supporting trees that are too poor for sawlogs but from which cordwood could be cut and cheaply barged to cities on the Sound. Comparble areas within a reasonable trucking distance of Portland are not extensive enough to permit Portland's present rate of consumption of forest cordwood to continue. 
For most rural communities of the region, future local supplies of forest cordwood apparently will be adequate. Most farms in the region contain some forest land that with but little care and attention could supply farm fuel requirements.

\section{Hardwoods}

More labor is required to $\log 1,000$ board feet of hardwoods than to $\log$ a like quantity of conifers, and the manufacture of hardwoods into the finished product is carried farther. Approximately 90 percent of the hardwood lumber cut in the region is remanufactured locally, practically all being used for furniture. The quantity of hardwood lumber and veneer produced has gradually increased and in 1935 amounted to 50 million board feet, of which 75 percent was alder and practically all the remainder was maple. This annual cut was about 1 percent of the total stand of these two species. Nearly all the hardwood production was in the Puget Sound Columbia River, Willamette River, and Oregon coast districts.

The supply of maple available within reasonable hauling distances of certain hardwood mills is in- adequate, but alder is plentiful in the vicinity of all centers of production. There is between 900 million and 1 billion board feet of alder in the northern part of the Oregon coast district, where alder stands have claimed the old burned-over conifer sites on fertile benches and lower slopes. In this locality conifers are rapidly invading many alder stands and will gradually shade them out, causing the elimination of the present extensive stands except along the principal stream courses and the loss of several hundred million board feet of commercial timber within two or three decades unless the timber is utilized earlier. To utilize this timber before it is lost through the natural process of forest succession, the present rate of cutting will have to be increased and additional markets for alder will have to be developed. Most of the alder trees cut for lumber or veneer are less than 50 years in age, and many are only 25 to 35 years. Considering the short rotation and the large quantity of local labor required in the remanufacture of alder lumber, it would seem desirable to manage certain of the extensive mixed alder-conifer stands in the Oregon coast district for alder production instead of letting nature take its course. 


\title{
Forest-Land Management Problems
}

\begin{abstract}
ix
$\mathrm{F}$ OOREST land is the basic resource of the Douglas-fir region; its products constitute the raw material for the region's leading industries. Past and present unwise treatment of forest land will influence greatly the future economic history of the region. If forest land is not kept continuously productive and protected against deterioration, industry will decline and communities break down. The results of unrestrained forest exploitation are already apparent locally. Depletion of virgin timber within the radius of feasible transportation of several sawmill communities has resulted in serious economic and social loss.

Properly managed, the region's forest land could permanently supply raw material for forest indus-

\section{Uses of Forest Land Other Than for Timber Production}

Effective plans for management for continuous production must in the main be based on areas of forest land that can be expected to produce forest crops continuously. Areas now forested that may in the near future be more valuable for agriculture, or for a type of recreation or wildlife production that allows but little or no cutting, can play little part in sustained-yield plans. It is therefore necessary to consider here the present use and future requirements of forest land for agriculture, recreation, and wildlife production.
\end{abstract} tries of approximately the present magnitude, if these were properly distributed within the region.

Although timber production is the major use of forest land here, other uses are increasing in importance, namely, watershed protection, forage production, recreation, and hunting and fishing. Intelligent forest management involves two major principles: (1) Wood removed from the forest should on the average be limited to a volume approximately equal to the increment, and the growing stock - the forest capital-should be maintained; (2) every forest area should be made to serve as many uses as possible, and these uses should be so correlated as to effect maximum production. The first is called the principle of sustained yield; the second, that of multiple forest-land use. The two are compatible.

One important prerequisite of forest management for continuous production is stability of forest-land tenure. Many of the problems that aggravate the forest situation in this region are inherent in the existing distribution of forest-land ownership.

\section{Future Agricultural Expansion}

As was stated in the section on land use, agricultural use of land has about reached a condition of equilibrium, and any expansion of agricultural production in the next two or three decades will be the result of increasing the productivity of exisiting farmlands and clearing wild land in existing farm holdings. This does not mean that efforts will not be made to convert a considerable area of presentday forest land into farms, much of it in localities where farming probably will not be feasible. Unless adequate zoning laws are enacted, this cannot be prevented. Although the aggregate area of such lands placed under cultivation in the forest zone is small, timber production is endangered by hazards created through careless use of fire in clearing them.

\section{Forage Production}

Future attempts to use large areas of forest land for range may be of greater consequence in limiting 
timber production than future attempts to make arable farmland out of forest land. Logged-off lands and burns, both seeded and unseeded, have been grazed successfully for a few years until tree reproduction and brush crowded out the forage plants; but permanent grazing of cut-over, burnedover, or virgin-timbered areas is incompatible with forest production in this region. Of the landowners who have temporarily gained a livelihood by raising cattle on cut-over and burned forest land, many own and pay taxes on only very small areas, using land either privately owned or county owned as open range. Many people still advocate grazing forest lands, asserting that past failures have been due to improper techniques in seeding after burns and in handling sheep and cattle, and it is true that proper seeding immediately after burns does result in a grass and weed cover that holds for a while. Experience has shown, however, that cutover and burned-over forest land in this region, unless cultivated or otherwise intensively handled, reverts to forest where seed trees are present except where repeated burning results in a permanent brush or bracken cover, which has very little grazing value.

Where burning is practiced to improve grazing, neighboring forest owners who might otherwise have held their land for timber production recognize the fire hazard, liquidate their timber if possible, and let their lands revert to the county.

\section{Recreation}

Because of improved highways and added leisure time, forest lands are now used for recreation to a degree undreamed of 20 years ago. The public apparently has accepted the idea of reservation of certain publicly owned forest lands for recreation. At the same time it assumes that private forest lands are available to it for hunting, fishing, camping, and hiking at no charge, and for the most part does not consider such use of private lands a form of trespass.

The form of forest recreation available to the greatest number of people is that of motoring through forest areas with stops for picnic lunches

TABLE 38. - State and Federal roads in the Douglas-fir region, by class of forest land and ownership of bordering lands 1

\begin{tabular}{|c|c|c|c|c|c|c|c|c|c|c|}
\hline \multirow[b]{2}{*}{ State and class of forest land } & \multicolumn{2}{|c|}{ Private } & \multirow[b]{2}{*}{ State } & \multirow[b]{2}{*}{$\begin{array}{l}\text { County } \\
\text { and } \\
\text { munic- } \\
\text { ipal }\end{array}$} & \multirow[b]{2}{*}{$\begin{array}{l}\text { Indian } \\
\text { reser- } \\
\text { vation }\end{array}$} & \multirow[b]{2}{*}{$\begin{array}{l}\text { Na- } \\
\text { tional } \\
\text { forest }\end{array}$} & \multirow[b]{2}{*}{$\begin{array}{l}\text { Na- } \\
\text { tional } \\
\text { park }\end{array}$} & \multirow{2}{*}{$\begin{array}{l}\text { Oregon } \\
\text { \& Cali- } \\
\text { fornia } \\
\text { Rail- } \\
\text { road }\end{array}$} & \multirow[b]{2}{*}{$\begin{array}{c}\text { Other } \\
\text { Federal }\end{array}$} & \multirow[b]{2}{*}{ Total } \\
\hline & $\begin{array}{c}\text { Outside } \\
\text { national- } \\
\text { forest } \\
\text { boundaries }\end{array}$ & $\begin{array}{c}\text { Inside } \\
\text { national- } \\
\text { forest } \\
\text { boundaries }\end{array}$ & & & & & & & & \\
\hline Western Washington: & Miles & Miles & Miles & Miles & Miles & Miles & Miles & Miles & Miles & Miles \\
\hline Nonforest, including urban areas & 683.8 & 0.4 & 9.2 & 0.7 & 0.3 & 0.3 & -n-n- & & 5. 6 & 700.3 \\
\hline 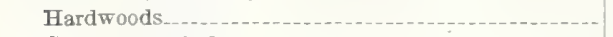 & 49. 6 & $\ldots-$ & 1.7 & .5 & .8 & .5 & 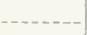 & & & 53.1 \\
\hline Conifer saw timber. & 150.9 & 21.4 & 18.2 & .1 & 20.0 & 24.2 & 10.8 & & 2.0 & 247.6 \\
\hline \multicolumn{11}{|l|}{ Conifer second growth: } \\
\hline 6 to 20 inches $\mathrm{a}, \mathrm{b} . \mathrm{h}$ & 196. 7 & 2.6 & 4. 3 & 2.1 & 1.7 & 9.8 & 2. 2 & & 2.5 & 221.9 \\
\hline Less than 6 inches d. b. h & 127.0 & 7. 6 & 10.0 & .8 & 1.4 & .7 & .5 & & 1.0 & 149.0 \\
\hline Noneommercial .... & 11.5 & 2. 9 & 1.0 & ..... & .2 & $\ldots$ & 1.9 & & 4 & 17.4 \\
\hline Nonrestocked cut-overs and deforested burns & 119.9 & 4. 6 & 4.7 & .8 & .5 & 1.2 & $-\cdots$ & & .5 & 132. 2 \\
\hline Total & $1,339.4$ & 39.5 & 49.1 & 5.0 & 24.9 & 36. 7 & 15.4 & & 12.0 & $1,522.0$ \\
\hline \multicolumn{11}{|l|}{ Western Oregon: } \\
\hline Nonforest, including urban areas... & $1,040.2$ & 27.4 & 3.9 & 2. 1 & .5 & 12.1 & & 3.0 & 1.6 & $1,090.8$ \\
\hline Hardwoods & 32.3 & 5.9 & $-\ldots$ & 1 & .3 & 3.2 & & 5.5 & .4 & 47.7 \\
\hline Conifer saw timber. & 133.9 & 14.1 & 1.4 & .2 & .2 & 58.7 & & 2.0 & 1. 2 & 211.7 \\
\hline \multicolumn{11}{|l|}{ Conifer second growth: } \\
\hline 6 to 20 inches d. b. h. & 170.2 & 6. 6 & 7.9 & .9 & .9 & 21. 1 & & 1.5 & 1.4 & 210.5 \\
\hline Less than 6 inches d. b. h & 37.8 & .5 & ---- & .1 & $\ldots-$ & 6.0 & & .7 & .5 & 45. 6 \\
\hline Noncommercial $\ldots . .$. & 37.7 & 6.4 & . & $\ldots$ & --- & 19.1 & & & & 63.2 \\
\hline Nonrestocked cut-overs and deforested burns & 80.0 & .1 & .4 & .7 & -- & 5.3 & & 1. 0 & .. & 87.5 \\
\hline Total & $1,532.1$ & 61.0 & 13.6 & 4. 1 & 1.9 & 125.5 & & 13.7 & 5.1 & $1,75 \pi .0$ \\
\hline Regional total. - & $2,871.5$ & 100.5 & 62.7 & 9.1 & 26.8 & 162.2 & 15.4 & 13. 7 & 17.1 & $3,279.0$ \\
\hline
\end{tabular}

Both sides of road. 
or overnight camping. Since presumably forest travelers are interested in scenery, particularly that which can be enjoyed from good roads, this form of recreation represents extensive use of large scenic areas plus intensive use of campgrounds and picnic spots. Along forest highways in this region are many beautiful views, but also many miles of unsightly cut-over and burned-over lands.

Old-growth timber occurs along 16 percent of the total mileage of lands bordering State and Federal highways in western Washington and along 12 percent of those in western Oregon (table 38). Less than one-third of the sawlog-size co-

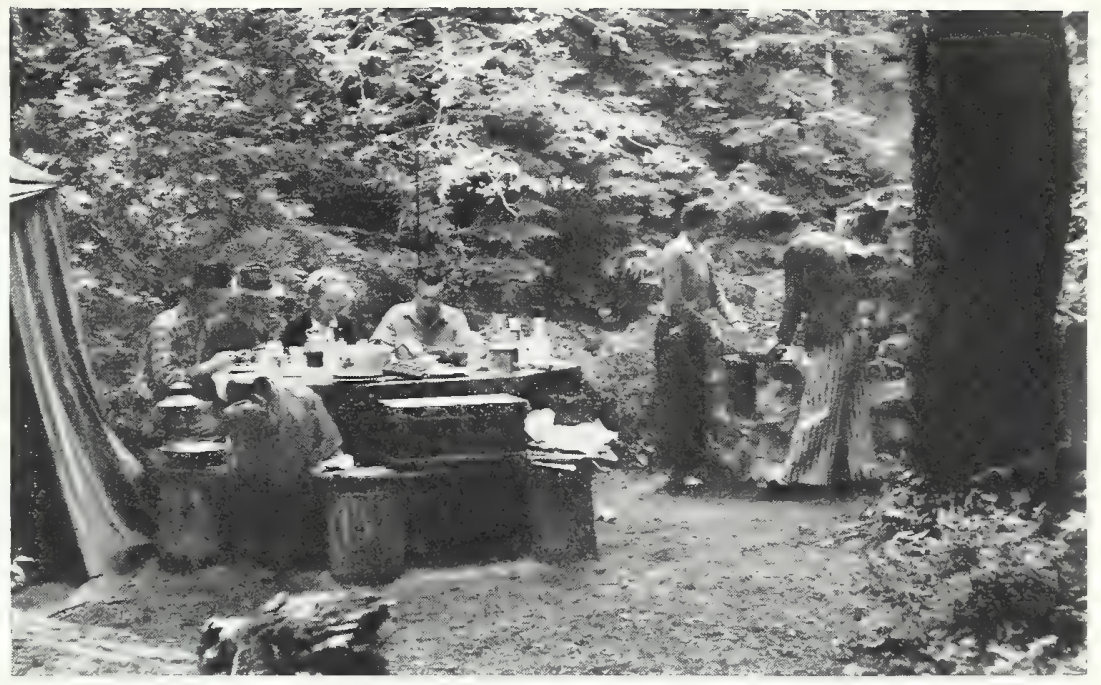

Figure 37.-A forest campground on the Mount Baker National Forest, Wash. During 1937 more than a million visitors entered the national forests of western Oregon and western Washington. Approximately 25 percent of these used the campground facilities provided without charge by the Forest Service

nifer timber bordering 460 miles of main roads in the region is in public ownership. In the last 4 or 5 years the original beauty of three of the recently built scenic highways, the Olympic Peninsula Loop Highway, the Oregon Coast Highway, and the Salmon River cut-off, has been badly marred by roadside logging. The privately owned saw timber along highways, amounting to more than two-thirds of the total saw-timber mileage, is highly accessible, and will probably be logged in the near future unless acquired by the public. Oregon and Washington have been derelict in acquiring adequate strips of virgin timber along roadsides when projecting new highways. Some 31,000 acres would have to be purchased if 400foot strips of the sawlog-size timber now in private ownership were to be saved on each side of the highways. Owing to its location this timber would not be cheap, but its acquisition would probably result in more public satisfaction than acquisition of any other equal area of forest land.

According to table 38, of the 220 miles of cutover and burned-over land adjacent to main highways, 205 miles is privately owned. The public interest in such destruction is manifest. The public responsibility to safeguard roadside beauty, as representing an intensive recreational use of forest land, is being recognized more and more widely, and if the States do not make more progress in acquiring such scenic roadside strips reserving them so far as possible from all cutting other than salvage operations, the Federal Government should step in. When forest land along State highways reverts to the counties for nonpayment of taxes it should immediately be deeded to the States for development of scenic strips. Areas that are not naturally reseeding should promptly be planted with forest trees.

Forest campgrounds have been developed on national forests (fig. 37), and also in many localities on State lands, but there is still a shortage of them close to the larger centers of population. Even a greatly expanded program of forest camp and picnic grounds would not materially decrease the area available for timber production.

So far the discussion has referred to recreational uses that might withdraw from commercial exploitation accessible, high-quality forest land at low altitudes, chiefly in private ownership. Except along streams, lakesides (fig. 38), and highways, the lower-altitude forests of the Douglas-fir region have no great recreational appeal, owing to the density of timber and underbrush. Cross-country progress through these forests is so difficult that recreational use is limited to hiking along trails, fishing, and deer hunting for a short period in the fall. Moreover, a large percentage of the hunting by residents of western Oregon and western Wash- 
ington is done in the eastern parts of the two States. The higher altitude forests, of much lower value for timber production and often of none, have much greater recreational appeal, owing to the fact that they are easily traversed, have openings in the form of mountain meadows, and afford splendid views of vast expanses of country. The national parks and national monuments, the various reserved areas on national forests, and an additional large acreage of national-forest land where no cutting is likely to take place for a long time to come are for the most part located at the higher altitudes.

A large aggregate area of publicly owned forest land in this region is either entirely or partially reserved from timber cutting or other commercial use and dedicated to recreation. Mount Rainier National Park and Mount Olympus National Monument now total 564,000 acres, and have a total stand of 6.4 billion feet of timber all reserved from cutting. ${ }^{22}$ State parks total about 19,000 acres, with a timber stand of about 161 million feet all reserved from cutting.

The Forest Service has dedicated about 11/8 million acres in the Douglas-fir region, chiefly

22 The establishment of the Olympic National Park since these data were compiled will increase these figures by 316,000 acres and 8.6 billion board feet of timber. of noncommercial forest types to recreational use, watershed protection, education, and scientific study, by establishing 5 large recreational areas, 5 large primitive areas, and 4 small natural areas. These 14 areas have a stand of approximately 7.5 billion board feet. The national-forest primitive and recreational areas, and also the national parks and national monuments, contain considerable acreages of large old-growth timber of commercial size and quality but of low economic availability due to location. Table 39 shows the acreages, by forest type, and timber volumes included in the recreational, primitive, and natural areas.

Recreational use of forest land need not always involve a complete ban on cutting. As new types of logging machinery and new logging techniques are developed and as better utilization is attained, many areas of medium or even fairly high recreational value can undoubtedly be cut lightly without loss of recreational value. The total recreation area includes 710,000 acres listed in the survey as "reserved from cutting" and 417,000 acres on which some cutting might presumably be allowed. If economic conditions ever justify logging operations on land of the latter category, the cutting, owing to the general location, will undoubtedly

TABLE 39.-Area, type classification, and timber volume of national-forest primitive, recreational; and natural areas in the Douglas-fir region

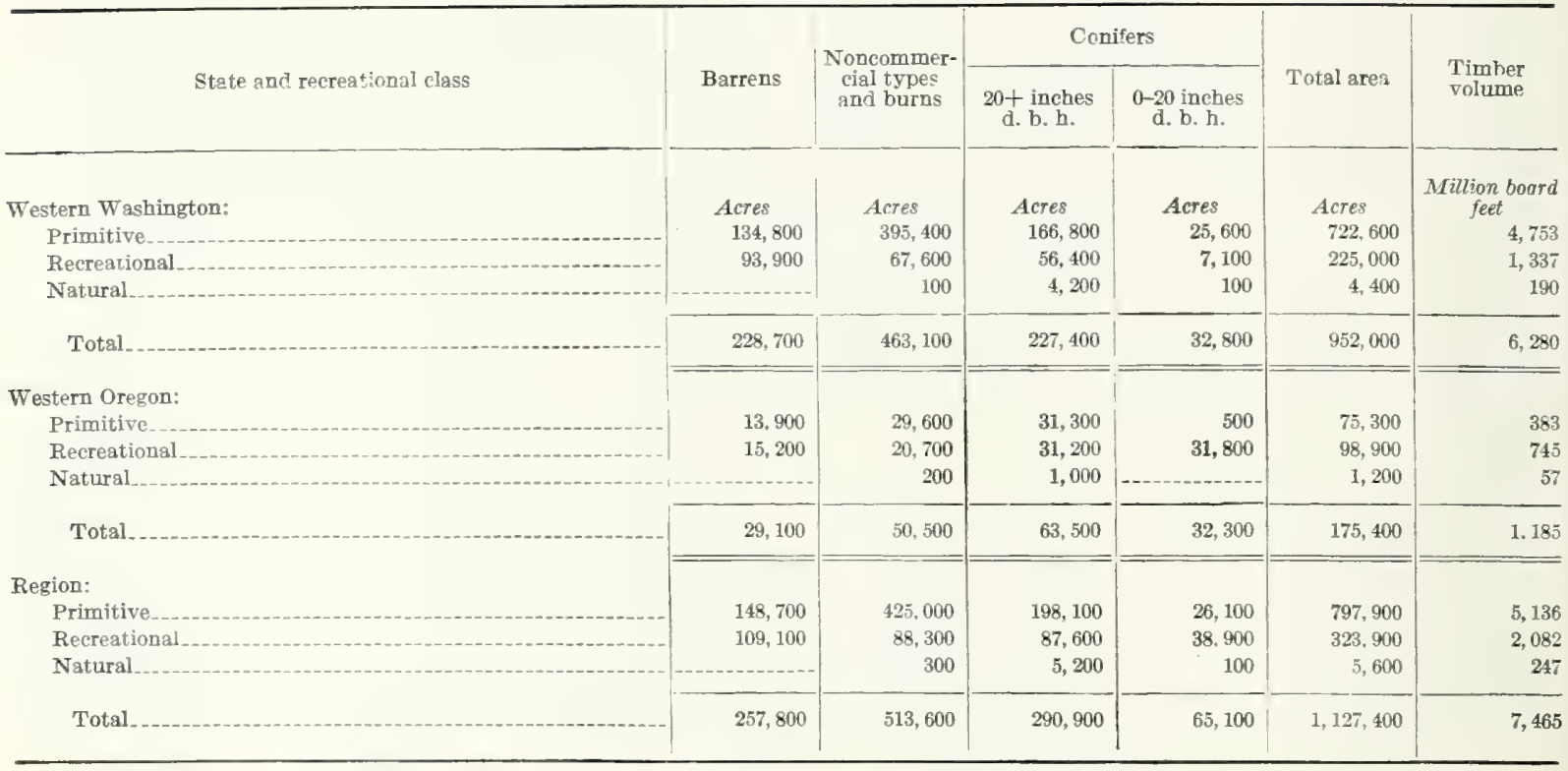




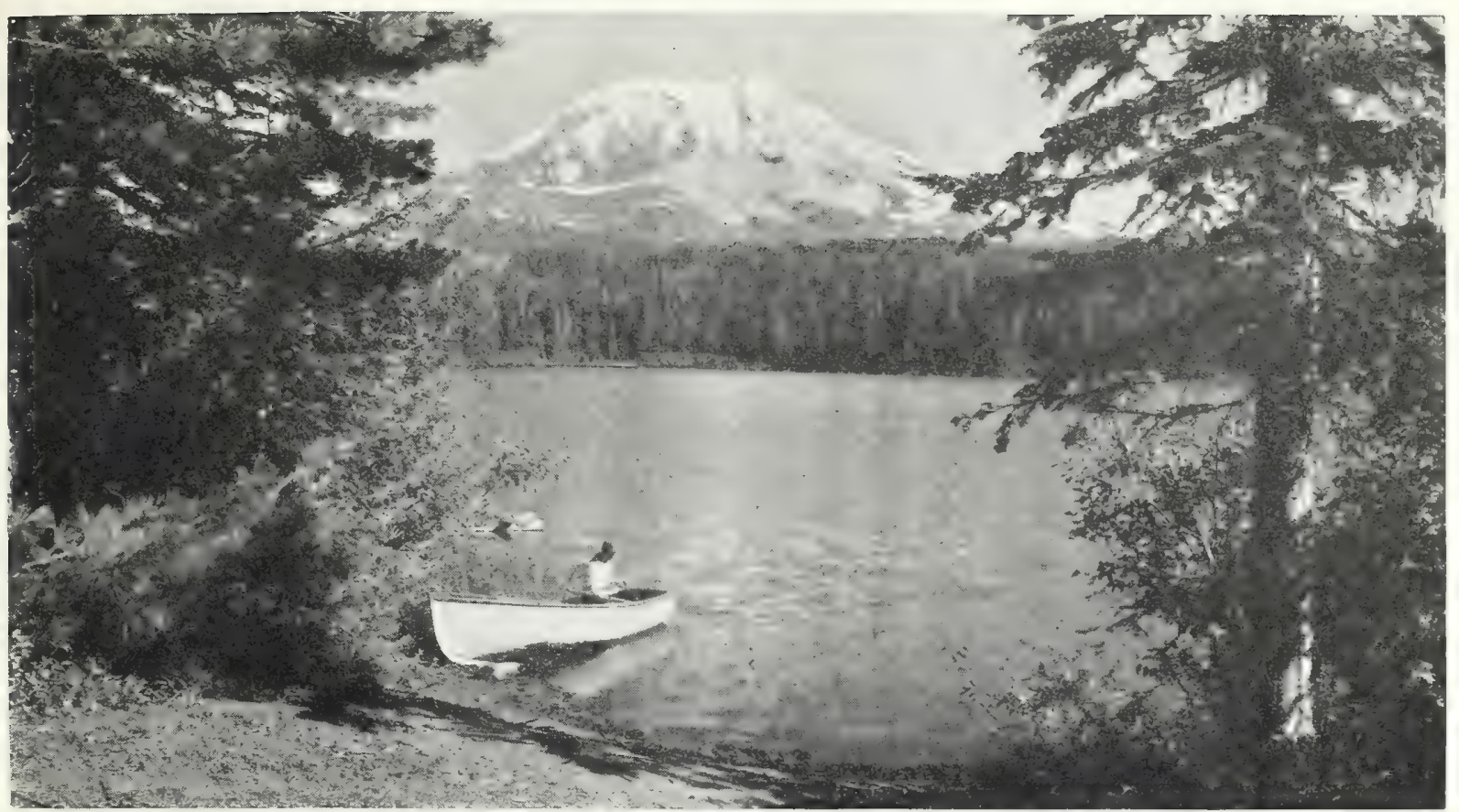

Figure 38. - Takh Lakh Lake, at the foot of Mount Adams, one of the many alpine lakes in the Cascade Range that attract summer recreationists

be of such character as neither to lessen the areas' suitability for recreational use nor to add appreciably to the region's annual production. Reservation of forest land from cutting for recreational use has reduced but little the region's sustained-yield capacity. Under the Forest Service policy of multiple use practically the entire national-forest area is available for recreation.

\section{Wildlife}

In this region the forests support an abundance of wildlife and as a general rule wildlife use does not conflict with timber production or other forest-land uses. The use of forest land for wildlife has had little influence on commercial timber production here, and it is unlikely that any consequential areas of commercial timberland will be withdrawn exclusively for this use in the immediate future.

It is possible to improve wildlife conditions in this region by a slight modification of current forest practice. Most of the streams and lakes are bordered by narrow strips of alder, cottonwood, and maple, with scattered conifers. If these strips were preserved during logging the reduction in quantity of material produced would be small. This practice would greatly improve scenic conditions, result in better fishing conditions, and in addition constitute a first step in a region-wide program of erosion and flood control. Also, the strips of timber would serve as firebreaks and as a source of seed to reforest adjoining cut-over land. On many national-forest timber sales the edges of streams are left in a natural condition after logging; otherwise, there has been little effort on the part of public and private agencies to follow such a course.

Hunting, indirectly, has conflicted with timber production, through the creation of high fire hazard in the fall months by the many hunters in the woods. A large percentage of the fires in this region are caused by hunters, some of them incendiary fires set allegedly to improve hunting conditions.

\section{Sustained-Yield Forest Management}

The preceding discussion of future timber supplies is based on the assumption that liquidation of 
privately owned timber resources and clear cutting will continue, and it applies only to the period ending with 1962, which is as far ahead as most timber operators plan. In discussing the prospective supplies of raw material for that period and particularly for the more remote future, it is necessary to consider the possible effects of sustainedyield forest management.

In this region the term "sustained-yield management" has been used too loosely. Essentially it denotes a plan of procedure which, assuming adequate stocking, will be applicable to an individual property or to a combination of properties under unified control whereby in the long run annual cut will equal annual growth. The cuts on a specified area may be made annually or at intervals of $5,10,20$, or more years, but over a long period cut and growth will balance. At present sustained-yield management is in force on only a small percentage of the world'stotal commercial forest land. It is more prevalent in Germany, the Scandinavian countries, and France than elsewhere. In the Douglas-fir region there is no sustained-yield practice on large areas except on the national forests, and there the annual cut to date has been too small to permit any significant application of the policy.

Leading factors in the present situation in this region as regards sustained yield are about as follows: (1) The forests in any one locality are badly out of adjustment, i. e., in most of them there is either too much old growth in proportion to timber of younger age classes or too little old-growth area in proportion to recently cut-over area, and a paucity of the intermediate size and age classes that would provide the owner a steady income; (2) there is no adequate system of permanent forest-development roads; (3) instead of maintaining a close relation with growers, such as is found in European countries, many manufacturers in the three leading industrial districts depend on open log markets for their supply of raw material - a factor that may, however, be favorable toward attaining sustained yield in the northern part of the region; (4) regional distribution of wood-conversion plants in relation to supplies of standing timber is uneven, with heavy concentration of manufacturing plants in certain heavily cut-over districts and a lack of such facilities in many districts containing extensive stands of virgin timber; (5) vast areas are covered by mature and overmature timber; (6) tax laws do not favor holding timber, and administration of existing tax laws is not uniform; and (7) few private owners are interested in holding forest land for continuous management.

The great extent of the timberland tributary to Puget Sound, Grays Harbor, and the Columbia River and the ease and cheapness of log transportation by water have resulted in the installation of sawmills whose aggregate capacity is far greater than could be supplied by available forests for even a few decades. Many of the mills face a shortage of raw material in the relatively near future which is not only of serious consequence to the companies involved but of even greater gravity to the dependent communities. This shortage is no less real for being at present obscured by the fact that several communities are counting upon the same bodies of privately and publicly owned timber for their sawmills.

Region-wide or large-scale adoption of sustainedyield management must begin in the forest rather than in the mill; wood-using industries must base their operations on what the forest land within their range of economical transportation can produce under such management - and also on their own competitive ability. In a forest region that does not have extensive waterways, the timberland tributary to individual manufacturing centers is usually rather distinctly defined. This is true of some inland portions of the Douglas-fir region. The availability of water transportation in western Washington and northwestern Oregon, however, seriously complicates the distribution of logs and makes it exceedingly difficult to define tributary territories.

Vast expanses of clear-cut areas threaten forest stability. What is needed is a shift from clear cutting to a system, whether individual tree selection or small area selection, which will allow frequent cutting over the same general area of high returns, leaving areas of low return for longer periods.

In connection with plans to institute sustainedyield management on a region-wide basis, decisions as to which of the present mill locations should be retained and what new locations should be chosen would be affected by the facility with which trucks 
and tractors can go over timberlands for the higher quality logs that can stand the expense of long hauls. They will also be influenced by the greatly increased area of operable timberland in the region made available through the low initial investment involved in tractor logging, and by the fact that existing lumber-manufacturing centers on water, such as Seattle, Tacoma, Olympia, Bellingham, Hoquiam, Aberdeen, Longview, and Portland, not only have better facilities for marketing and shipping wood products, including waste, but have an advantage in possibilities for integrating woodusing industries. Many of the present plants have been largely or entirely depreciated. Changes in location involved would in some cases be no greater than those that would result from continuance of present trends under the liquidation policy; for many sawmill owners it has already become a problem whether to mill logs coming from their holdings at existing mills or to establish new mills nearer the source of log supply.

Regardless of whether sustained-yield practices are adopted in the near future, many communities in western Washington and northwestern Oregon will in the future have less saw timber on which to draw than they have had in the past. In considering the region-wide aspects of forest management it would seem expedient to set up sustained-yield units on the basis of allowable annual cut in the future period when the ideal balance constituting sustained yield has been realized, at the same time calculating allowable cut for the intervening period.

If existing laws requiring that publicly-owned timber offered for sale be sold to the highest bidder were modified, sustained yield could be inaugurated in the region through cooperative arrangements whereby the products of specified public and private forest areas would be committed to certain mills. Such arrangements would tend toward constant supplies of raw material for the mills and economic stability for the communities in which the mills are located. In view of the ease of transporting logs by water, however, objections could be raised to freezing into a fixed pattern the distribution of publicly owned timber in the northern part of the region.

Although these cooperative arrangements would not be planned specifically to result in normal age distribution on each individual property involved, some of them might do so, particularly if selective logging were employed. The agreement might then be terminated. Thereafter, each of the individual properties could be managed under an individual sustained-yield plan and its product sold periodically to the highest bidder, and the annual production of the wood-using industry or industries that had been involved in the agreement could be scaled to the raw material obtainable on the basis of free competition. Community stability would then rest on the assurance that a regular supply of raw material would be produced in the various forest units in the region and that this material would be sold in open competition to the mills and communities qualified by virtue of proper location, efficient management, and other economic factors to pay the top price.

Ultimate sustained-yield capacity has been calculated for each of the forest units set up by the Forest Survey, and also the average rates of cutting that, starting with the present areas of old-growth timber, second growth, and cut-over lands, would bring about a balance of cut and growth within a period varying from 90 to 150 years. The calculations were restricted to unreserved commercial conifer forest land. Sustained yield probably will not be put into effect for areas so large as the survey units; but comparison of these figures with past and current rates of cutting depletion show in a general way the extent to which the forest-survey units and the major forest districts are being either overcut or undercut.

Before these allowable rates of cutting could be calculated, however, certain premises had to be set up. Undoubtedly future practice will be better than past and the calculations were based on that assumption, although with no attempt to allow for the inevitable economic changes which will occur in the future. The premises are as follows: That there will be prompt attainment of normal distribution of age classes; that utilization will be reasonably complete in the future; that all timber on commercial conifer land will be marketable; that existing mature stands will be cut first; that there will be an increase in stocking in understocked stands at the rate of about 4 percent per decade; that areas cut over will restock within the next decade; and that future cuttings will restock to approximately 75 percent of normal. 
The rates of cutting calculated for the transition are shown in table 40 in comparison with the record of cutting depletion for the period 1925-33, the cuts in 1933 (which are approximately the lowest of the whole depression period), the assumed depletions for the three decades of 1933-62 as set up in the survey, and the potential ultimate rates of cutting under the sustained-yield plan. The potential ultimate sustained annual cut for the region as a whole of 8.08 billion board feet exceeds slightly the average annual cut during 1925-33 and is nearly three-fourths greater than the 1933 cut. It is noteworthy that the 1925-33 average annual cut of 7.9 billion feet is about 1.66 billion feet in excess of the annual cut estimated to be allowable for the first transitional period of 70 years, but that the cut for 1933 fell short of the estimate by 1.48 billion feet.

It is apparent that the three northern districts, Puget Sound, Grays Harbor, and Columbia River, having river and tidewater facilities and most of the region's wood-using plants, are seriously overcutting, but that the Willamette River, Oregon coast, and south Oregon districts are undercutting (table 40 and fig. 39). The extent of the overcutting in the first three districts is as follows:

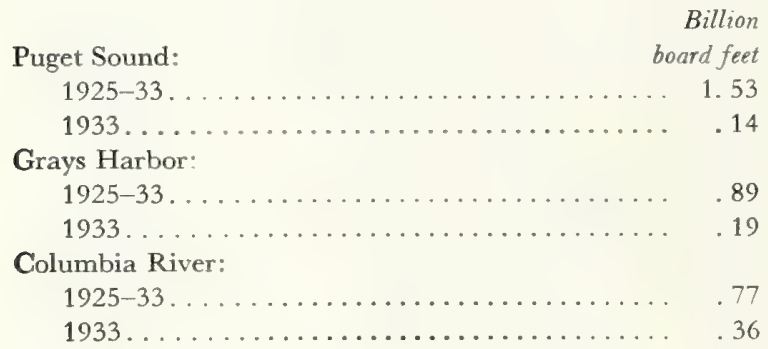

If sustained yield were brought into effect in the Puget Sound, Grays Harbor, and Columbia River districts, the rate of cutting would be reduced to half the 1925-33 average and even below the 1933 figure. In the other districts the annual cut would be double the 1925-33 average and more than three times what it was in 1933. Obviously, any such radical changes are not going to take place in the immediate future.

The Oregon coast and Willamette River districts are now shipping logs of all grades into the Columbia River district and high-grade logs into the Puget Sound and Grays Harbor districts. If sus- tained yield were brought into effect in each of these five districts, the two southern districts could add 1.27 billion board feet to their average annual shipment of logs to the three northern districts as of 1925-33; but this contribution would fail by 0.78 billion feet to meet the shortage in the annual cut of the northern districts as compared with their average for 1925-33.

Overcutting will presumably continue in the Grays Harbor, Puget Sound, and Columbia River districts, in order to keep mills running and men employed, as long as private timber lasts.

A number of sawmills in the three overcutting districts have ceased operations, because of shortage of timber available to these particular mills. Within 20 years more widespread lack of raw material will cause serious dislocation of sawmill employment throughout the overcutting districts. Cutting is already tapering off in the Puget Sound and Grays Harbor districts. Increasing woods and mill operations in Oregon and operation of newly installed pulp mills in Washington will probably employ many of the people deprived of employment by abandonment of sawmills in these two districts. A voluntary further reduction in the rate of cutting logs for sawmills would lessen the shock that will occur if cutting goes ahead at the current rate for a few more years until raw materials suddenly become nonavailable. It would, however, be as difficult to obtain any voluntary reduction of cut in the overcutting districts as to increase production in the undercutting districts, which at present cannot compete with the other three in the principal markets. A regional economy based on maintaining a specified production is so exceedingly rigid that efforts to divert production to undeveloped localities are strongly resisted, until absolute exhaustion of raw material compels such diversion. This is the major unsolved problem of the region.

\section{Forest-Land Ownership}

\section{Stable Owrership Essential to Continuous-Production Management}

Application of the sustained-yield principle would be far easier, other things being equal, on areas where only one ownership was involved. One of the major difficulties in the way of universal adop- 
TABLE 40.- Past and assumed future cutting depletion of saw timber, and allowable transitional and ultimate annual cuts of saw timber under sustained-yield plan, in the Douglas-fir region

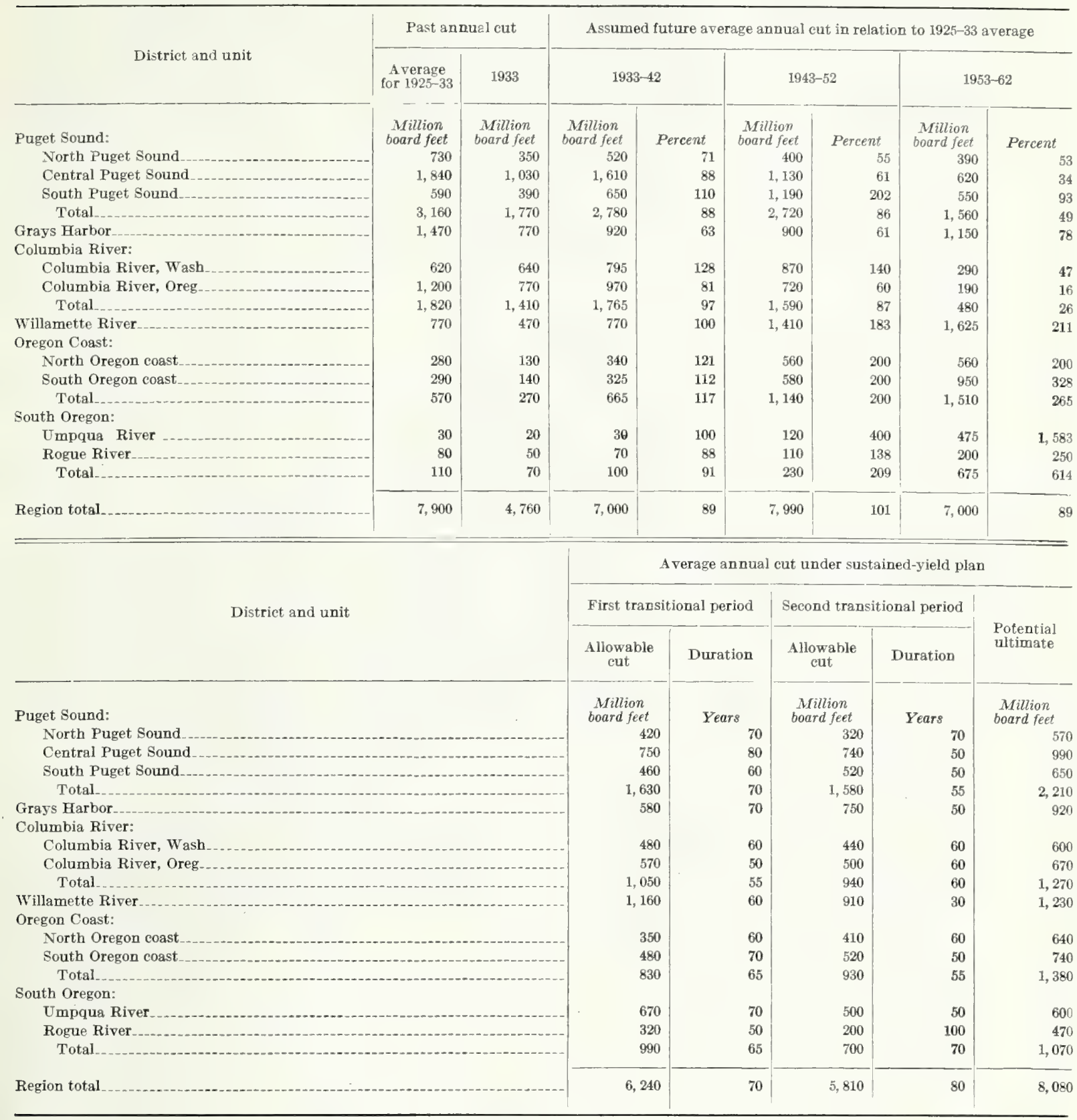

tion of sustained-yield management in the Pacific Northwest is the present division of forest areas among many owners, both public and private whose intentions in regard to management of the areas vary widely. Except for the national forests, the Indian reservations, and the Washington State forests. there are very few large continuous blocks of timber land in one ownership. Even much 


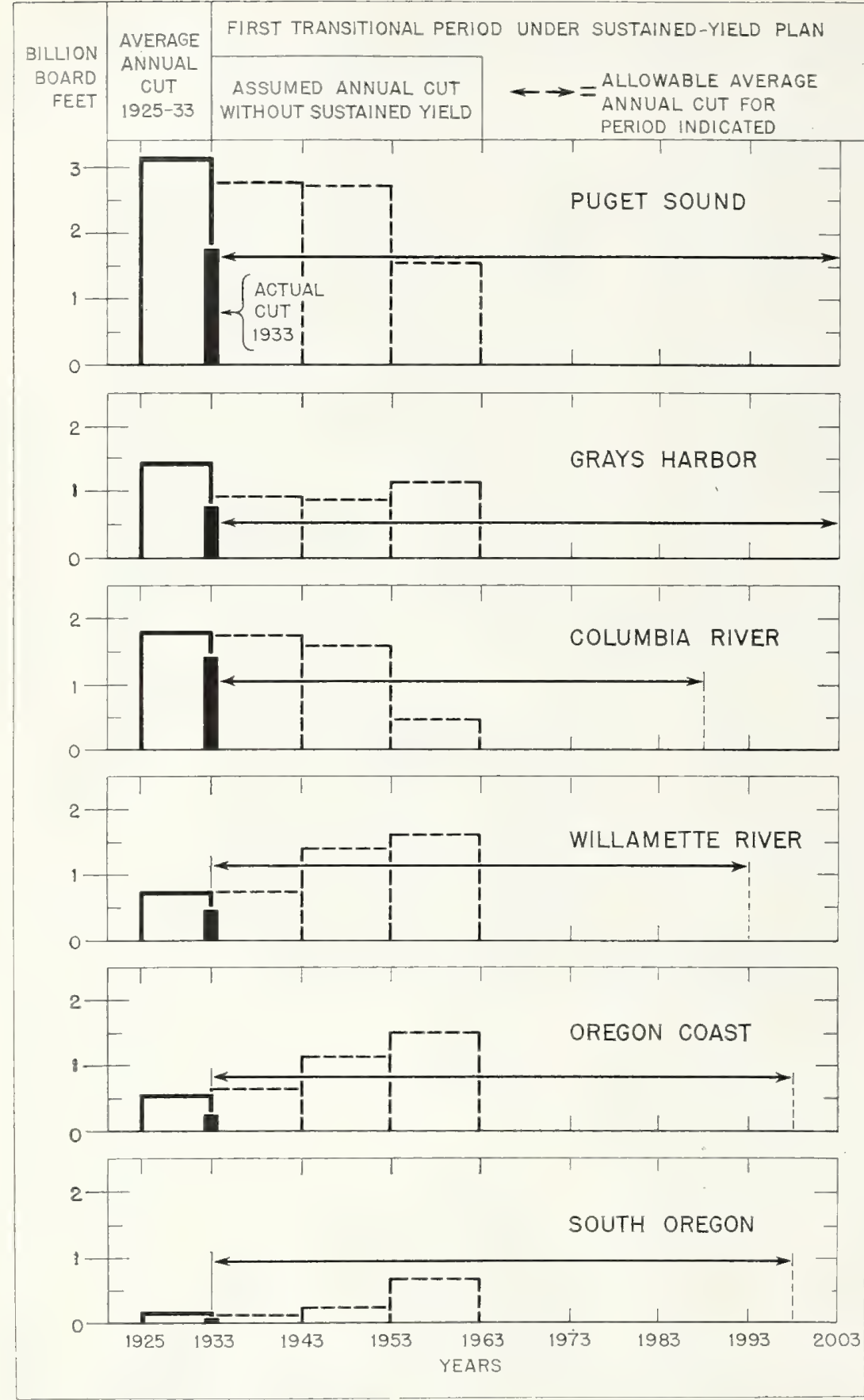

Figure 39.-Past rates and assumed future rates of cutting compared with rates allowable under sustained-yield management

of the publicly owned land is in scattered parcels.

Few timber operators carry more than a 20 year supply; and many owners have scattered their holdings in order to spread the chance of losses from fire and other causes. Private lands are irregularly intermingled with lands in different kinds of public ownership. Moreover, neighboring owners are unlikely to fall into the same general category as to intent in ownership. Some are holding timberland speculatively, intending to sell it to the highest bidder; some own logging equipment and plan to log for the open market or for wood-using industries with which they have contracts; and some operate mills and also do their own logging.

Although it is estimated that the 12 largest owners hold nearly half the privately owned saw-timber area in the region, other owners number about 32,000 . To further complicate the situation, probably nowhere in the region is there a solid block of as much as 30,000 acres owned by one company or individual unalienated by other ownership. Figure 40 shows the complexity of the ownership pattern in a typical forested county, Coos County, Oreg.

In earlier days, particularly in Washington and northern Oregon, mills were set up on the basis of operating only long enough for full depreciation (usually about 20 years), and supplies of standing timber were acquired with the assurance that if the mill owner's supply of timber was exhausted before the plant was depreciated the deficiency could be made up from the open log market. At the same time, much timberland was purchased speculatively by buyers who anticipated that their timber would be needed by mills depend- 
ent on the open log market. Many mills in the region have no raw material of their own to guarantee future production. Of the three major lumbermanufacturing districts, Grays Harbor district has 20 percent of its installed mill capacity dependent on the open log market for raw material, Puget Sound district 50 percent, and Columbia River district 60 percent.

Few private owners are doing much to block up their forest-land properties for continuous timber production. True, some owners have continued to hold timberland after the merchantable timber has been cut, but usually for other reasons than growing and harvesting a second crop of timber. The trends in tax delinquency and in forfeiture of forest land to the counties indicate that no great area of recently cut-over land will remain in private ownership even so long as 20 years. Since the average private forest property in this region contains a much greater area of oldgrowth timber than of second-growth timber, it would be difficult for many owners to put a sustained-yield plan into practice unless they acquired young and middle-aged timber to bridge the gap between the last of their old growth $224146^{\circ}-40-9$

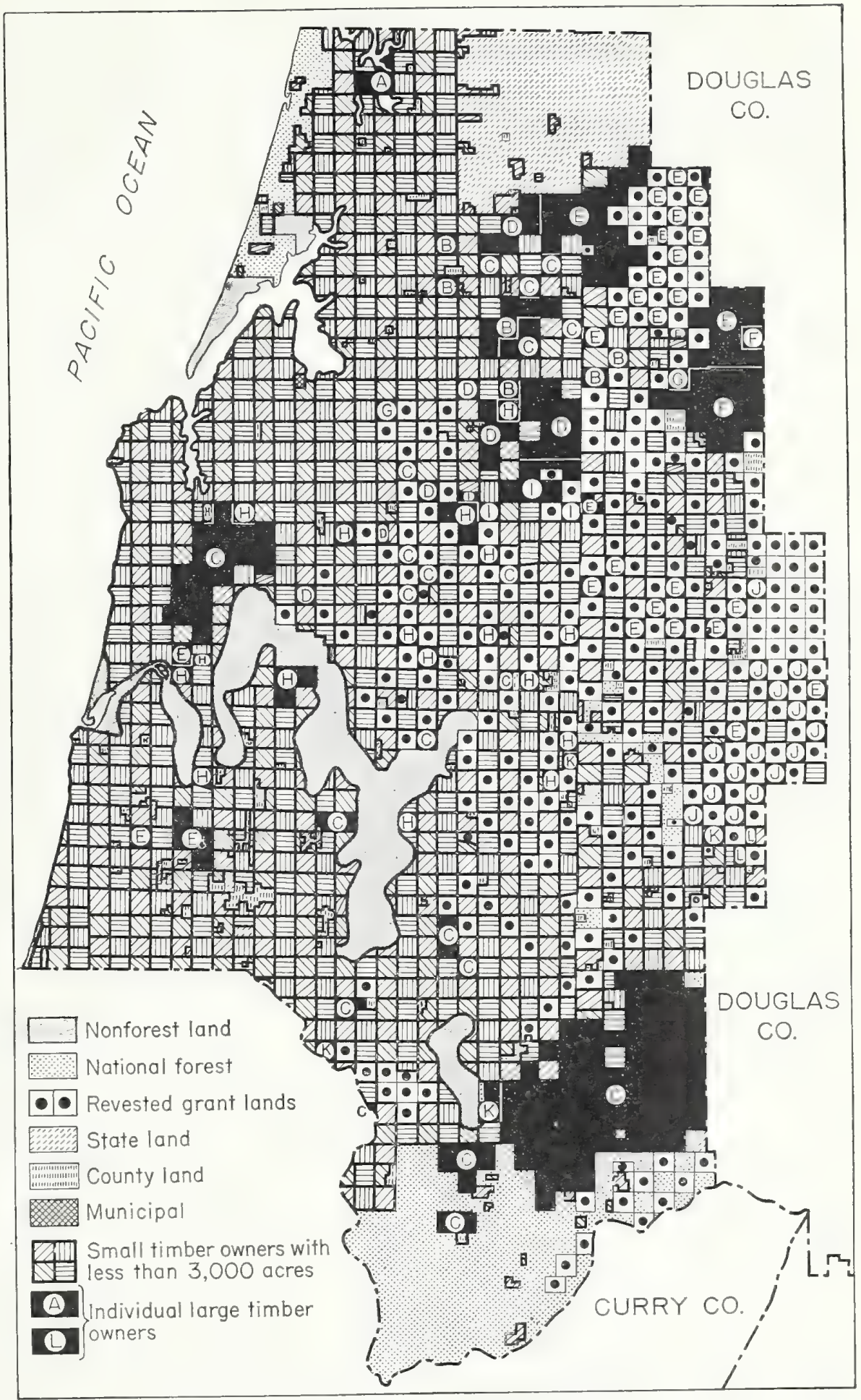

Figure 40.-Forest land ozenership map of Coos County, Oreg. 
and the maturing of the second growth on the lands they now own. Selective logging of the remaining old-growth timber where feasible would greatly assist in the establishment of conditions more favorable to sustained yield. For the region as a whole the forests are far from being in a normal condition, that is, a condition of even representation of the various age classes. Figure 41 shows the very uneven acreage distribution of the four major size classes of timber and figure 9 (p. 24) shows that of 10 -year age classes for the types less than 20 inches d. b. h. In general, progress toward sustained yield on a strictly private-ownership basis would involve blocking up of private properties either through mergers or through direct acquisition.

In a large part of the region the ownership pattern is so complex that the initial step in establishing sustained-yield practice on private lands depends mainly upon the integration of policies and procedures of the various public agencies administering forest land. In the spruce-hemlock coastal districts, and possibly in the Douglas-fir forests in southwestern Washington, public lands are less important and the pattern of private land is such that the integrating of public lands and policies is not of vital concern.

A few private owners of forest land who have serious intentions of owning and operating their lands continuously are selecting the areas of better site and second-growth conditions from their cutover land and dropping the remainder.

\section{Factors Influencing Liquidation of Private Ownership}

The principal reasons given by owners of most timberland other than farm land as to why they are not interested in holding forest property beyond the time when they can liquidate their present stumpage are as follows:

1. Taxes (ad valorem property tax and Federal estate tax).

2. Risk of loss of capital investments through fire, insects, wind throw, and disease.

3. Uncertainty of future markets for wood.

4. Other investment fields more attractive.

5. Difficulty of financing.

6. Extent of public-owned forests

\section{TAXES 23}

The tax problem of forestry in the Douglas-fir region, and elsewhere in the United States for that

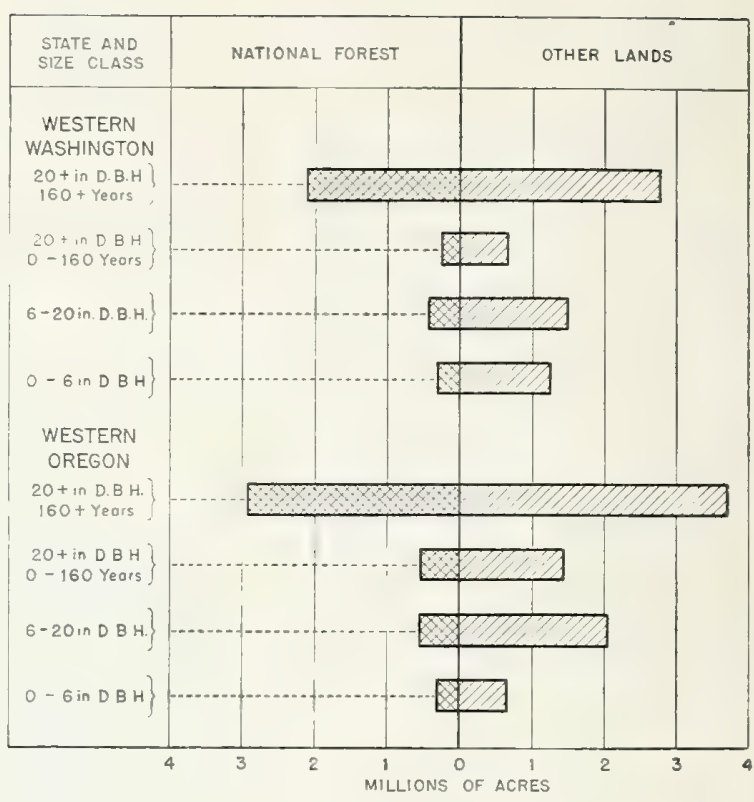

FIGURE 41.-Size-class distribution of timber in the Douglas-fir region

matter, is concerned chiefly with the property tax. The only other taxes which may handicap forestry more than other enterprises are those imposed on transfer of property at death. Under some circumstances, continuity of ownership, which is generally conceded to be favorable to good forestry practices, may be interrupted by the necessity of paying the heavy inheritance and estate taxes levied by the State and Federal Governments. No systematic study has been made of this subject under present conditions, however, and therefore further discussion of the forest-tax problem will be confined to the property tax.

The weight of property taxation is in large measure determined by the extent to which State and local governments rely upon the property tax to meet their revenue requirements, the need for local revenues as affected by organization and functioning of local government, and the manner in which the property-tax burden is distributed among classes of property and among individual owners. What is the present situation in the Douglas-fir region of Oregon and Washington in respect to these factors?

23 For a detailed presentation of the forest tax problem refer to Miscellaneous Publication 218, (4). For a brief treatment, see Circular 358, (6). 
Generally, throughout the country, the ratio of the property tax to the sum of all taxes has for many years tended to decrease. In the decade preceding 1930, however, this decrease was brought about, not by any decrease in property taxes but by increases in other taxes. Subsequent to 1930 there has been a marked decrease in the absolute amount of property taxes in some States. In Oregon the annual property-tax levies, which totaled in the neighborhood of $\$ 50,000,000$ from 1928 to 1931 , receded moderately to about $\$ 40,000,000$ in 1935 and $1936(19, p .20)$. In Washington there was a very marked recession in property-tax levies after 1933, brought about largely by the enactment of over-all limitations of 40 mills on urban and 25 mills on rural property (Iniat. Meas. 64, 1932), so that the total taxes collectible in 1930 of $\$ 81,000,000$ became less than $\$ 54,000,000$ in 1934 , and only a little over $\$ 42,000,000$ in 1936 (23, pp. 10 and 52).

This decrease in property taxes in Washington was accompanied by a large increase in excise taxes. In both Oregon and Washington, local governments now receive practically all the property taxes and the State relies upon other forms of taxation. Many duties performed in the past by the county are now performed by the State, for example, public welfare activities and the construction of primary highways. Moreover the State has taken on new duties such as policing highways and protecting forest lands, including large areas forfeited to the counties for unpaid taxes. Nevertheless, the State is turning over to local governmental agencies an increasingly large percentage of its receipts from various sources, retaining some supervision of their disbursement. Local pressure is increasing upon State and Federal Governments for additional subventions and upon the State for additional services.

In spite of the above-mentioned developments the need for local revenues is an important aspect of the forest-tax problem. The local governments still lean heavily on the property tax. Little has been done to simplify the structure of local government in these States and to adapt it to the needs of the sparsely settled communities where forest lands predominate. As a result, the property-tax burden on forest lands in certain districts is still needlessly high. The most noteworthy recent advance has been the consolidation of certain elementary school districts in Washington which has somewhat reduced costs of administration. On the whole, however, improvements in local government organization and functioning remains a task for the future.

Uncertainty because of irregularities in distribution of the property-tax burden is often more serious than the absolute amount of this burden. Inclusion of forest lands within special jurisdictions, and arbitrary shifting of the boundaries of these jurisdictions to transfer timber values from one district to another, have encouraged extravagance in some districts and in some others have made very high taxes necessary to preservation of the districts' existence. This situation is accentuated by fluctuations in tax rates made necessary in many instances by the narrow tax base.

Another tax hazard to forest growing is the inequality of assessment in many counties. Piecemeal and usually inexpert appraisal of forest properties characterizes existing assessment practice in both Oregon and Washington. Since many properties extend across county lines, the county assessment system at its best can hardly take account of their true economic situation and income capacity as units of operation or management. Failure to choose assessors with proper technical qualifications and lack of State supervision are also important handicaps. While it should be recognized that some county assessors, in spite of great difficulties, have done excellent work, there is no question but that much remains to be done to improve the assessment of forest lands, thus removing another important element of uncertainty in the tax system as now administered. Other steps in tax administration, especially collection, also need strengthening, but assessment is the heart of the property-tax system and the one step in tax administration which has the most direct bearing on equity and certainty in forest taxation.

In January 1937 a report to the Governor and legislative assembly of Oregon (18) recommended reorganization of local government, with consolidation of small rural school districts and State assessment of timberlands under the direct administration of the State Tax Commission. However, legislation recommended in this report was not enacted. 
To date no law has been enacted in this region to adjust the property tax by removing the excess burden (in comparison with that of an ordinary income tax) which it imposes on deferred-yield forest properties. The proof of this excess burden and precise definition of deferred yield have been given in a previous publication (4) of the Forest Service. In 1935, an adaptation of the deferred timber tax, one of the Forest Service proposals to this end, was considered by a committee of the Oregon Legislature, but no legislation resulted.

In the meantime, however, laws were enacted (Oregon in 1929, Washington in 1931) withdrawing cut-over lands suitable for reforestation and not containing timber in merchantable quantities from the ordinary operation of the property-tax system. Lands classified under these laws pay an annual tax on the land (at specific amounts in Oregon and based on fixed assessments in Washington) and a yield tax on the timber products when cut. The purpose was to encourage holding and protecting cut-over and other forest lands suitable chiefly for growing forests and not containing timber in merchantable quantities at the time of classification. The specific tax was originally uniformly 5 cents throughout Oregon but was subsequently reduced to 4 cents east of the Cascades. It is not yet clear how large a portion of the merchantable stand may be left in selective cuttings without making the residual property ineligible for classification under these laws. So far only insignificant amounts of yield tax have been collected. In spite of certain inherent disadvantages (4), these laws have been beneficial in tending to maintain private ownership of cut-over lands and the cooperative fire-protection system. It is too early to pass judgment on their effectiveness in attaining their other objectives.

\section{TAX-REVERTED LANDS}

Unquestionably improved administration of the laws relating to assessment of property and collection of taxes would tend to prevent tax forfeituure. It would not entirely prevent such forfeiture in this region, however, because some of the cut-over land is so devoid of income possibilities that no one is likely to hold it and accept the responsibilities of private ownership no matter how light the carrying charges.
Tax-delinquent lands in Oregon and Washington revert to the county rather than to the State. No adequate plans for the management or other disposition of these lands have been adopted in Oregon. In Washington, county-owned lands may be deeded to the State for State forests. A portion of the county lands have been transferred to the State and are under management. Local opposition to the transfer of tax-forfeited lands to the State has been voiced in parts of Oregon and Washington. Among the reasons given for this opposition are the following: (1) The lands should be restored promptly to the property-tax rolls and local government is in the best position to do this; (2) surrender of this land would be a surrender of home rule; (3) the tax equities of local governments in these lands would be lost or impaired; and (4) any profits in excess of the tax equities derivable from prompt sale after county acquisition should go to local governments. Transfer of these lands to State ownership may become more acceptable locally when it is realized that (1) some of the land is unsuited to private ownership; (2) the State is in better position than local governments to classify, dispose of, and manage such.lands; (3) legal provision can be made for settling the tax equities of local governments and for subsequent contributions in lieu of taxes on lands dedicated to public ownership and use; (4) usually, sale of these lands for immediate profit is followed by early removal of liquidable assets and the land again reverts for unpaid taxes; (5) in general, the amounts recoverable from the State in settlement of tax equities exceed the potential profits from such sales as could be made by the counties in short order.

\section{RISK OF LOSS OF CAPITAL INVESTMENT}

The chances of loss by fire have in the past loomed large to the average owner of forest land in this region. In the section on depletion, it was stated that trees killed directly by fire and not salvaged composed but a small percentage of the annual depletion of saw-timber volume in the region during the 5-year period 1926-30, averag ing about 179 million feet a year on lands other than national forest of which nearly all was privately owned; and that with the more mobile logging equipment now available much of this 
material could be salvaged. The fire records used by the survey did not, however, include any catastrophic fires such as the Tillamook fire of 1933, losses from which have been only slightly reduced through salvage operations. It is undoubtedly fear of such major conflagrations, which can occur in the region at any time, that causes many timberland owners to drop their holdings after liquidating their stumpage and that perpetuates the practice of many timber companies of scattering their holdings over a considerable area.

No insurance company has offered to insure standing timber against loss by fire, but a recent study (20) indicates that forest fire insurance is feasible and could be a profitable undertaking. If forest fire insurance is made available to timber owners it will undoubtedly greatly increase opportunities for timber holding.

Risk of loss by insects, wind throw, etc. is not great in this region, although epidemic losses of considerable magnitude have occurred here at long intervals in the past.

\section{UNCERTAINTY OF FUTURE MARKETS FOR FOREST PRODUCTS}

The uncertainty of the chances of selling timber $10,20,50$, or more years from now naturally bothers the average owner. It appears to him problematical how long the Douglas-fir region will have a Nation-wide market for its large surplus. A large part of the Douglas-fir lumber production is shipped abroad; future possibilities of holding these markets are uncertain. Owners of timberland not tributary to an open $\log$ market are particularly concerned as to their opportunity to sell their timber profitably to operators.

\section{OTHER INVESTMENT FIELDS MORE ATTRACTIVE}

The belief that other forms of investment will bring greater returns than holding timberland to grow a second crop has been one reason for failure to hold such land in this region as in other parts of the United States.

During the era of rapid development in the United States, there was no inducement for a timberland owner to hold his land for a long period in order to grow trees. It was more profitable to liquidate investments in stumpage and buy new stumpage from the Government, timber speculators, or from homesteaders, in a new region. This, therefore, was the usual procedure of private timberland owners in all forest regions in the United States developed prior to those of the Pacific Coast. In the Douglas-fir region as a whole the profits in stumpage, although the initial costs were low, have been dissipated by the heavy carrying charges, as the period of speculative investment was premature by a score or more of years (as measured by the progress of depletion in the East and South).

\section{DIFFICULTY OF FINANCING}

Obtaining low-cost capital in sufficient amounts to carry timber for a sustained-yield operation is a particularly serious problem in this region. The capital required for a manufacturing plant averages larger than elsewhere. Fire-protection costs are high; risk of loss is great. There is no intermediate grazing revenue as in the ponderosa pine region. With rough topography and much inaccessible country heavy expensive equipment is needed for logging including transportation.

Dependence of wood-working industries on markets outside the region results in large production units, the manufacture of high-quality products to offset high cost of transportation, and the carrying of large inventories. All these factors combine to increase the amount of capital necessary to finance operations in this region.

\section{EXTENT OF PUBLIC-OWNED FORESTS}

The proximity of publicly owned forest land may or may not be an obstacle to private owners in setting up sustained-yield plans, depending on type of public ownership and on locality. Neither the cut from the national forests in this region nor that from Oregon \& California Railroad landgrant timberlands has been large enough to influence cutting of private stumpage in the past. In southern Oregon and even in parts of the Willamette River district, private owners forming plans for sustained yield will have to be guided by the policies governing administration of Oregon \& California Railroad timber under the sustainedyield law of 1937. In western Washington future policies as to sale of timber on State school lands 
will be an important factor in the situation. Increasing county ownership not only of cut-over land but, in southern Oregon, of commercial timberland is one of the obstacles to continued holding of land by private individuals. It is impossible to foretell at this time the future timber-sale policies of the 38 counties in the region. Variation in policy among counties is one of the main reasons why tax-delinqeunt forest land should revert to the State rather than to the county. So long as counties continue to sell timberland, whether second growth or old growth, at prices below the average price at which private owners can sell, or even below the assessed value of private timberland, sustained-yield practice by private owners will be hindered.

\section{Areas Favorable for Private Ownership}

As a general rule the opportunities for sustainedyield management of private timberland are greater for the pulpwood-producing areas of the coastal belt of Washington and Oregon than for areas suitable only for growing saw timber. Very probably, much more than half the forest land held by private owners for continuous timber production will be located in the spruce-hemlock zone in western Clallam, western Jefferson, Grays Harbor, and Pacific Counties, Wash., and in western Clatsop, Tillamook, and Lincoln Counties, Oreg. Saw-timber areas equally attractive for the investment of private capital exist, but are limited in extent. Present plans of a few large operators indicate that considerable saw-timber area may be operated on a continuous-production basis. It is likely that much saw-timber-producing land bordering large agricultural areas will be privately operated for continuous production.

The pulpwood-producing areas are practically all of very high site quality, mostly sites I and II. They are now covered with good stands of pulp species. By and large, the topography and ground conditions are such that logging is not difficult, and offer better possibilities for light selection cutting than those of most Douglas-fir areas in other parts of the region. The spruce-hemlock zone has a lower fire hazard, at least from the standpoint of climatic factors, than exists elsewhere in the region. Here the opportunity for integrated management is good, the better grade high value logs going to the saw and veneer mills and the less valuable logs used for pulp.

Until now pulp manufacturers in the Douglas-fir region, with few exceptions, have owned relatively little forest land in proportion to their investments in plants and to their annual wood requirements. On the whole, the pulp industry has ridden along on the back of the lumber industry so far as obtaining supplies of raw material is concerned. In the course of logging for Douglas-fir and "cedar" sawlogs the lumber industry produces more hemlock. logs than are needed for the sawmills, and the pulp industry has depended to a large extent on these openmarket hemlock logs. Relatively small areas of timberland owned by pulp companies have been used as sources of logs with which to depress the open-market price of hemlock logs. When the types in which Douglas-fir and "cedar" occur in quantities sufficient to justify logging for sawlogs are cut out - a condition that will soon be reached in northern Washington-logging for hemlock alone will begin; when this time comes the pulp companies will probably have to obtain their raw material through logging operations of which pulpwood supplies are the main object, and may find it necessary to own and control more timberland than they do now.

Integrated utilization, low fire hazard, high annual growth per acre, not much agricultural development or many public improvements to date and therefore no cause for high-tax rates, make these areas in the spruce-hemlock zone more promising for continuous production and ownership by private capital than any other areas in the region.

\section{Current Trend to County Ownership}

Most of the changes in ownership of forest land now taking place in this region are resulting from county foreclosure of tax-delinquent lands. On January 1, 1934, about 657,000 acres of land was county-owned, of which 630,000 acres was forest land. Since then the area of land foreclosed by Oregon counties has been increasing each year. A comparison of the county-owned-land situation in eight counties of Oregon in 1932-33 and 1935-36 (table 41) shows that in this short period the acreage foreclosed by the counties more than doubled, 
TABLE 41. County-owned areas 1 in selected counties of western Oregon as of 1932-33 and as of 1935-36, by generalized cover type 2

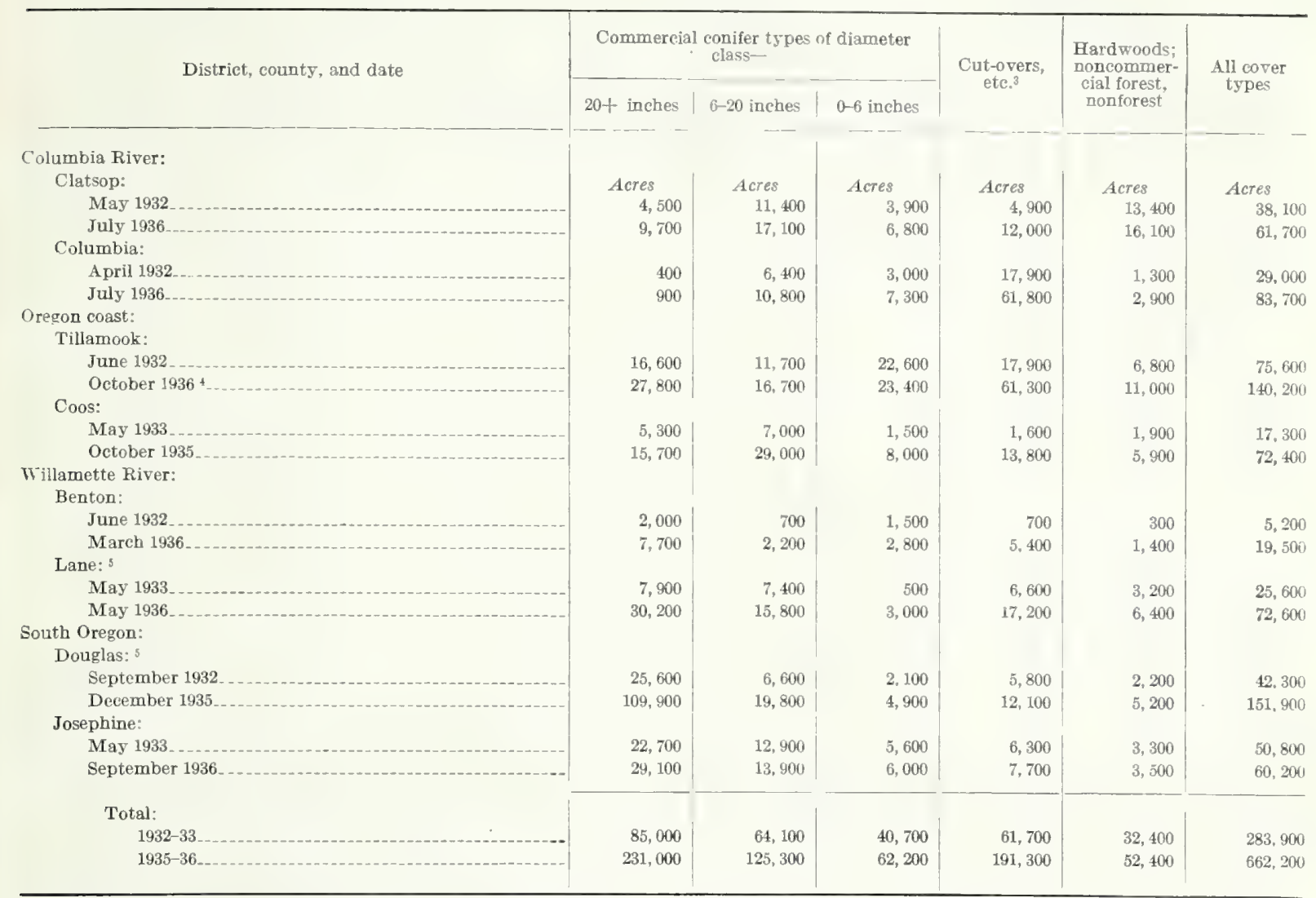

1 Acreages rounded off to nearest hundred. Areas within agricultural zones of Benton, Lane, and Tiliamook Counties not included.

2 For Clatsop and Tillamook Counties, where extensive fres occurred in 1933, new cover-type data were obtained in 1936 for use in the 1936 computations shown here. For other counties, cover-type data taken in 1932-33 were used in the 1935-36 computations, no material changes in cover type having taken place in the interval.

3 Lands cut over since 1920, old cut-overs not restocking, and deforested burns.

- Data include 32,188 acres deeded by owners to Tillamook County to save costs of tax-forfeiture proceedings.

${ }^{5}$ Data include some small areas situated in Oregon coast district.

even without counting in the 32,000 acres of taxdelinquent land deeded directly to Tillamook County by the owners to save the county foreclosure costs. In Washington, there were no foreclosures between 1933 and 1936. Where the cut-over lands are physically unsuited for agriculture the rate of reversion will progressively increase as the oldgrowth timber area is reduced and tax pressure on it increases. Some counties will acquire considerable areas of merchantable timber through tax foreclosure. Unless the States liberalize tax-delinquency laws or county officials drastically reduce assessments on cut-over lands, the acreages of county-owned land will greatly increase in the next two decades.
Washington has adopted legislation whereby forest land acquired by counties through tax reversion can be deeded to the State and managed by it for the benefit of the county, with the provision that the State will be reimbursed for the cost of protection and management from receipts accruing through the sale of products raised on these lands. So far none of the Oregon counties has made any attempt to manage forest land acquired through tax foreclosure, and probably none of them can afford to undertake adequate management. Oregon might well follow the Washington precedent.

If Oregon does nothing to facilitate transfer of reverted lands from county to State ownership and 
Washington continues to acquire only part of the forest lands forfeited to the counties, there will be no reduction in the area of county-owned forest land and in fact it will increase in practically every county in the region. In Washington and northern Oregon the areas reverting to the counties immediately will be principally cut-over lands with or without reproduction, and within the next decade or two these will be supplemented with some remote and low-grade commercial timberland. In southern Oregon the reverting areas will include not only cut-over land and second-growth land but considerable areas of old-growth timber. Extensive public purchases of forest land in the near future would probably retard the reversion of tax-delinquent land to the counties. Countyowned forest lands will consist of scattered areas for many years but in certain counties may eventually be consolidated into blocks. Owing to decreasing tax bases and to the difficulty of administering an irregular patchwork of lands, many counties will undoubtedly sell any or all of their lands at almost any price, seeing only the opportunity for immediate cash return, overlooking the greater future county burdens involved in such sales. Other counties, more far-sighted, may adopt policies designed to hold their lands and keep them off the speculative market. Since much of the tax-reverted land in the southern Oregon counties carries merchantable timber, it is possible that these counties will give more consideration to holding and managing their forest lands than will the northern counties. If the States fail to assume responsibility for the county-owned lands, the individual counties should direct their efforts towards permanent forest management of these lands.

All county revenue in both Oregon and Washington is obtained from the general-property tax. Funds raised by this method have barely sufficed for carrying on the ordinary functions of government, and at present the only statutory method by which counties can substantially increase their income is to raise property-tax rates to points that in many instances would be confiscatory. Under these circumstances it is doubtful that the counties will spend very much for administration of their forest land, particularly in western Washington and in northwestern Oregon where county-owned forest land consists chiefly of areas either recently cut over or occupied by small second growth. So long as counties have to provide road and school services and are limited to the general-property tax for revenue, it will be increasingly difficult for private owners to carry timberland, particularly in the counties where there is but little industry and the farm areas are so small and so poor that the taxes they pay are inadequate to meet the costs of government they create. Under these circumstances county spokesmen will continue to assert that public ownership of large areas of timberland is contributing greatly to county fiscal problems, overlooking the fact that if these same areas of publicly owned land had been turned over to private ownership many years ago they would only have aggravated the problem of oversupply of private timber, and many of them would undoubtedly have reverted to the counties long ago.

\section{Integration of Public Lands and Policies Desirable}

Except in the spruce-hemlock districts just mentioned, and possibly in the Douglas-fir forests in southwestern Washington, sustained-yield practice would be chiefly a matter of integrating policies and procedures of the various public agencies administering forest land.

Although there may be individual instances of sustained-yield practice on private land under the present conditions of unstable private and mixed public ownership, adoption of such practice on a complete region-wide basis is impossible so long as these conditions prevail. Most private owners will find it difficult to practice sustained-yield management unless on the basis of cooperative arrangements with a governmental agency having timber and the authority to enter into long-time agreements.

Under a liquidation program an operator might prefer that the publicly owned timber upon which he partly depends for raw material be controlled by several different public agencies; but under a sustained-yield program the average operator entering into a cooperative agreement involving future supplies for his mill and the handling of his land would prefer to deal with one public agency rather than several. In addition, therefore, to a merging of private properties, some consolidation of 
public forest lands would be desirable in the furtherance of sustained-yield management in this region. Reblocking of federally owned timberland is feasible. A merging of State and county-owned timberland under unified administration is desirable. If the latter is not possible, at least a uniform set of policies, rules, and regulations should be adopted for the handling of all county-owned and Stateowned timberland.

\section{Public Acquisition Programs}

Because of lack of funds, Federal and State acquisitions of forest land in this region have been too small to alter materially the production policy of the lumber industry. Forest Service acquisition has been largely a matter of trading merchantable timber on national forests for cut-over lands in the near vicinity of the national forests, and has been scattered throughout the western part of the two States. Oregon created the Elliott State Forest by exchanging scattered State lands within national forests for a solid block of national-forest land. Washington has blocked up its two major maturetimber areas by the same method, one in Jefferson and one in Snohomish County, and is blocking up an area of cut-over land in the central part of the State. In the latter case the State had purchased about 40,000 acres by the fall of 1936, at a cost of 50 cents per acre, using utility bonds bearing 1 percent interest. It is planned that this particular State forest shall ultimately be extended to include approximately 100,000 acres. Under legislation that provides for transfer of tax-reverted land in Washington from counties to State ownership, about 300,000 acres was transferred as of August 1938 and an additional 50,000 acres later in 1938.

The Federal Government may be considered to have two purposes in acquiring additional forest land, (1) consolidation of Federal ownership within the existing national-forest boundaries and (2) promotion of sustained-yield management on all forest lands. The existing national forests, in the region contain approximately 2 million acres of alienated land, by far the larger part of which is best suited to multiple-use forest management. Acquisition of this land would be logical, for administrative efficiency. The second purpose has greater significance and should receive primary consideration in an acquisition program. In many cases establishment of new national-forest units (both additions to existing national forests and new forests) through acquisition will be necessary to obtain sustained-yield management even on a basis of cooperation with private timber companies, unless outright subsidization is resorted to.

Enlarged public acquisition of second-growth and mature timber is advocated by many lumbermen because it would tend to stabilize stumpage prices, check the liquidation of private timber at excessive rates of cutting, and tend to hold back the cutting of second-growth timber, much of which is now in its period of maximum growth and which will be needed more in the future, when the present oldgrowth stands approach exhaustion. Overproduction because of "distressed" stumpage has been a chronic problem of the West Coast Lumber industry for the last 15 years; timber purchases to establish sustained-yield management will assist in solving it. From the public point of view, emphasis should be placed on purchases that will make industrial developments permanent rather than upon those that will merely reduce the quantity of timber in unstable ownership.

The region contains 173 billion board feet of timber of availability class $I$ in private ownership. If this timber were cut at a rate of about $73 / 2$ billion feet per year, it would last about 23 years. Theoretically it will all be cut before much class II or class III timber is cut. Actually this probably will not happen; but it can be assumed that not much class II and III timber will be cut until nearly all the class I timber is gone, which would mean that timber of classes II and III would have to wait from 20 to 25 years to begin to be marketed. At the present time the pressure to liquidate results for the most part in cutting of class I timber, since that is the only kind for which the return is greater than the cost of operation. The class III timber in private ownership is so limited in extent and so remote from markets that it will have but little influence on liquidation of private stumpage. It is gradually passing into county ownership through tax delinquency, and this trend may be expected to continue. Any purchases by Federal agencies of class III timberland should be for special purposes, such as recreation or stream protection, rather than for management for timber production. 
The 173 billion board feet of privately owned timber in availability class I has a market value probably in the neighborhood of $\$ 400,000,000$. Complete public acquisition is obviously impracticable for fiscal reasons. Moreover, any large Federal timber acquisitions would disturb the counties' tax base. Hence a sound purchase program is one that will make sustainedyield management possible through minimum acquisition.

Maximum effectiveness can be obtained through locating timber purchases (both old-growth and second-growth) on areas where there is no considerable exploitation at present but where major exploitation is in prospect in the near future. First choices for acquisition under a cooperative sustained-yield plan would be in working circles where practically all the timber remaining in private ownership would be committed to such a management plan. Timber purchased could be of either availability class I or class II; class II timber would cost far less. If owners would agree to cut under a sustained-yield management plan, which ordinarily would mean an annual cut smaller than under liquidation, the plan would schedule cutting on their lands first in return for assurance that a stumpage supply would later be available to them from the publicly acquired lands.

In any working circle that might be selected for such acquisition there would probably be some timber owned by mill owners and some owned by nonoperating owners. Persons owning both sawmills and timber would be expected to have a greater interest in a cooperative sustained-yield project than the nonoperating (very often speculative) owners. Nonoperating owners might not be interested at all in such a plan, since under present circumstances there is no such financial inducement in sustained-yield management as is offered by prompt liquidation. Usually their timber would have to be purchased, involving purchase of both class I and class II timber.
The possibilities of purchase under this scheme are greater in Oregon than in Washington. In the remaining old-growth timber stands in western Washington that are primarily valuable for sawlo. production, liquidation has gone so far that the bulk of the remainder could be bought only at high prices including depreciation charges for the facilities already installed to cut and manufacture this timber at rates materially in excess of sustainedyield cutting allowances. This is not true of the large areas of pulp-timber types in the coastal belt in Washington, but the owners of much of this timber may be expected to operate it on a strictly private sustained-yield basis.

Federal timber purchases should be used to convert existing forest enterprises to a sustained-yield basis where this is still possible, and to discourage the installation of new liquidating ventures. Purchases should preferably be made on areas where there are definite possibilities for cooperative sustained-yield management. It is estimated that approximately 30 billion board feet could be purchased to advantage on this basis at the present time. Purchases that would effect complete public ownership of forest resources in a working circle should be undertaken only when cooperative management has been found impracticable and then only if the working circle has particular importance for industrial stability.

Federal timber purchases for the promotion of sustained-yield management are an investment of Federal funds that would result in substantial local benefits in the Douglas fir-region. The counties in which such purchases are made will eventually be in a much sounder financial condition by reason of the industrial stability obtained than if the present liquidation process is permitted to run its course. However, such purchases adversely affect the immediate fiscal position of the counties, by removing mature timber from the tax rolls. Some plan to reimburse the counties, during the adjustment period, for tax losses thus caused is apparently necessary. 


\section{A Regional Forest Program}

$\rightarrow 22$

$\mathrm{P}$

ERMANENT forest management in the Douglas-fir region might be achieved by (1) public regulation, (2) public acquisition of forests, or (3) cooperation between public and private forest agencies to consummate sustainedyield plans. It is extremely unlikely that any one of these methods will be used exclusively; probably two or all three of them will be combined. Past progress toward stable forest-land use has resulted principally from legislation piece-meal, an essentially slow process.

Permanent forest management will not be attained by any of these means until the people of the region thoroughly understand the inevitable consequence of continuing present practices and the results to be expected from sustained-yield management. Therefore, the first step in a regional forest program is to make these facts clear to the public, pointing out the full significance of sustained yield and the problems involved in putting it into effect. This is a task of great magnitude. In view of the economic and social values involved, it should be the function of a technical organization financed by Federal and State forest agencies with the cooperation of private owners' trade associations. Existing inventory, growth, and depletion data gathered in the forest survey are sufficient for all the initial calculations.

Any program for making the forests of the region continuously productive, and thereby assuring to industrial communities a reasonably stable supply of raw material, conflicts with urgent present demands. Some districts are overcutting, others undercutting. The overcutting districts possess natural geographic advantages, established industries, and comparatively large populations; the undercutting districts lack geographic advantages, have few forest industries, are sparsely populated, and have timber supplies large in quantity but, on the average, of poorer quality than the timber now being cut. Owing to the excellent water-transportation facilities, most industrial communities can draw on more adjacent forest territory for raw material than can communities in inland forest regions. This tends toward concentric cuttings around easily accessible and established sawmill communities, and as a result, there is extreme overcutting in this tributary territory and undercutting elsewhere.

Sawmills can be dismantled in a cut-over district and logging equipment moved without too great a sacrifice, but not so community development. When schools, water and sewer systems, and other civic improvements are abandoned because of the approach of timber depletion and industrial disintegration the taxpayers and in fact the entire population suffer a heavy loss.

The immediate need is to shift from liquidation to sustained-yield forest management on areas where forest conditions are favorable, without dislocation of labor and commerce. The woodusing industries of overcutting localities endeavor to maintain existing rates of production even in the face of certain radical curtailment within one or two decades. The reduction of cut involved in immediate application of sustained-yield practices seems too sacrificial of local interests, in spite of the known consequences of failure to do so.

Obviously, stabilization of ownership and other economic readjustments are necessary before sustained-yield management can be generally adopted in the region. Application of a region-wide sustained-yield program would be gradual. Most of the forest land that should be used for continuous production of forest crops could, however, 
through concerted action by industry and government, be put under sustained-yield management during the next 25 to 50 years.

\section{Future Situation If Present Trends Continue}

If present trends continue, it is predicted that sawlog production will decline greatly during the next two or three decades in the Puget Sound, Grays Harbor, and Columbia River districts which are now being overcut, and will increase correspondingly in the Willamette River, Oregon coast, and south Oregon districts. Determined efforts will be made to maintain industries in present locations, by drawing on distant localities for raw material. Well-established wood-using plants will compete sharply for the remaining old-growth timber within economic transportation limits. Logging of large second growth in accessible locations when it is making maximum growth will increase alarmingly. Tax delinquency probably will increase greatly on young second-growth and recently cut-over areas in the northern and central parts of the region and on old-growth areas in the southern part. An increase in regional output of lumber and other sawmill products is expected for a few years, followed by a gradual decrease of such production accompanied by an increase in wood-pulp and plywood production. The transition from railroad and donkey-engine methods of logging to the more flexible truck and tractor methods seems certain to proceed at an accelerated pace. With all its disadvantages clear cutting will undoubtedly continue, but selection cutting of various types will become more prevalent. Cutting out of the old growth on private lands in certain localities may be expected, particularly in north-central Washington and northern Oregon.

Fire protection upon the increasing acreage of highly hazardous cut-over lands will undoubtedly become progressively poorer unless State and Federal appropriations are greatly increased. Fire-protective associations are likely to concentrate on protecting the remaining private commercial saw timber, leaving protection of young second-growth and cut-over land to the States.

The increase of cut-over area will stimulate efforts to convert forest land to grazing use, par- ticularly in southern and western Oregon. This activity may not be confined to deforested lands; misguided attempts may be made to convert areas of second-growth and old-growth timber to grazing land.

Recreational use of public forests, and demands for restricting commercial use of recreational areas, are increasing greatly, and it may be necessary to dedicate additional areas of Federal, State, and county forest land to this use.

Canning and processing of farm products, metallurgical industries stimulated by Federal power projects, pulp and paper manufacture, and other industries will undoubtedly expand within the near future and absorb some of the workers released by the decrease in lumbering in some parts of the region. It is expected that an increase will take place in local remanufacture of lumber, facilitating disposal of the lower grades and giving additional employment.

Considerable forest land now privately owned will pass into public ownership through tax delinquency. Many counties, particularly in Oregon, apparently are reluctant to transfer tax-reverted lands to the State or Federal Government, hoping that these lands, somehow, may be restored to the tax rolls. As time passes and these lands increase in extent, county governments will realize that opportunities for permanently restoring tax-reverted forest to the tax rolls are very limited.

\section{Stabilizing Forest-Land Ownership}

The following program, although not necessarily a complete solution of the problem created by the instability of forest-land ownership, would if adopted vastly improve the situation:

1. All Federal forest land chiefly valuable for commercial timber production should be managed under a uniform policy.

2. Tax-forfeited lands should be promptly classified as to most suitable use and ownership. Forest lands judged suitable for public use and ownership should be transferred to the State forest agency, and those within national-forest boundaries and national-forest exchange limits should then be transferred to the Forest Service in exchange for Federal lands inside State-forest units. 
3. Federal, State, and private holdings should be exchanged and consolidated to improve the extremely patchy pattern of forest-land ownership now common in the region.

4. Private timberland owners, both operating and nonoperating, should be urged to merge their holdings so as to form properties of a size and compactness that will promote sound financing and efficient management for continuous production.

5. Federal loans on private timberlands should be made only to those private owners who agree to adopt and maintain sustained-yield practices; these loans should be made at low interest rates and with long term amortization privileges. The loaning policies of all Federal agencies should be coordinated accordingly. All borrowers should be required to carry forest-fire insurance if it becomes available at equitable rates.

6. Defects and inequities in existing State and Federal tax laws as these affect forest lands should be corrected. With this purpose in view, study should be given by State and county planning boards and by chambers of commerce to recommendations developed by the Forest Taxation Inquiry of the Forest Service (4).

7. As a basis for intelligent land-use planning, classification of rural lands should be undertaken immediately by Federal and State agencies, acting jointly. Following this classification, adequate zoning laws should be enacted, and should be effectively administered.

\section{Public Acquisition of Forest Land}

Because of the instability of private forest-land ownership, it appears that the most direct way to restore and to maintain forest-land productivity in this region is through expanded public ownership. Theoretically, the Federal, State, and county governments should participate in a joint publicacquisition program. The financial inability of the counties to administer forest. Iand adequately shifts their share of the burden to the other agencies. The States of Oregon and Washington have only limited funds for acquiring and administering additional forest land. In view of this region's preeminence in the Nation as regards forest resources, the Federal Government is justified, as a matter of national welfare, in assuming leadership in acquisition of forest land here.

\section{FEDERAL GOVERNMENT}

A guiding policy of Federal acquisition should be to acquire forest land unlikely to remain in private ownership that could advantageously be administered as national-forest sustained-yield units, in cooperation with owners of neighboring land if possible, and for which State acquisition is not in prospect.

The program should be well rounded, including virgin-timber areas, second-growth areas, and deforested land. Choice of areas to be acquired should be governed by the following purposes: Stabilization of ownership and encouragement of sustained-yield management; consolidation of national forests for more effective administration and protection; protection of watersheds; prevention of premature cutting of second-growth forests; rehabilitation of denuded and deteriorated lands; and encouragement of better forest practice on the part of operators who do not intend to hold their lands for continuous production - the last to be accomplished by acquiring only the cut-over lands left in good condition where this is possible, or by discriminating against abused land in the price paid for it.

In planning acquisition, a territorial distribution of areas should be made between the States and the Federal Government, the latter assuming responsibility for areas that cannot be handled effectively by the States.

Any Federal acquisition program would be conditioned on the funds made available. It is highly desirable that sufficient Federal money be made available to attain all the objectives listed. Land now deforested could be obtained very cheaply and a considerable acreage of this type of land is a Federal responsibility. Second-growth timberland would be more expensive, but would be cheap compared with old-growth timberland, and should be acquired in large quantity. For the most part this would involve purchasing lands outside existing national-forest boundaries, leaving acquisition of alienated lands inside national-forest boundaries to be effected through exchange.

If Federal funds sufficient to acquire 25 to 35 billion feet of saw timber within the next 5 to 10 years are made available, a Federal program should be set up to control overproduction in the Douglasfir lumber industry by the methods outlined in the 
preceding section. Up to now there has been only one large-scale Federal purchase of oldgrowth timber; most Federal acquisition has been by exchange. Exchange of national-forest timber for private cut-over land in good condition should be continued and expanded. In the long run it should result in careful cutting of privately owned old-growth timber within the national forests. The boundaries of national forests should be extended so as to enlarge the working area within which properly cut-over private land can be exchanged for Federal timber.

\section{STATE GOVERNMENTS}

An urgent phase of the State forest-land-acquisition program is the acquisition by both States of timber strips along main highways. This should be carried out immediately. Whatever the ultimate plan for handling tax-forfeited forest lands may be, the States should at least insist that such county-owned lands as border highways, are traversed by good fishing streams, or possess other recreational features be transferred from the counties to the States. Both States should acquire more ocean frontage, not only to reserve more beach land for public recreational use but also to control development that would destroy present vegetative cover and result in serious sand-dune encroachment.

The State of Washington should continue to acquire State forests from private owners, by the utility-bond method or otherwise. In western Washington there are several large areas of cutover land of high site quality, both with and without second growth, that could advantageously be blocked into State forests. The State might adopt an exchange system similar to that of the Forest Service and trade the timber on some of its scattered lands for carefully logged land inside the boundaries of existing and proposed State forests This would involve some changes in existing legislation governing disposal of State land. In Oregon there does not seem to be much chance that any considerable amount of State money will be allotted for direct forest-land acquisition in the near future.

The prompt setting up, if only on paper, of several State forest acquisition units in both States is strongly urged. In many places large areas of forest land have reverted to county ownership and additional large areas are almost sure to do so. Most of this land is obviously unsuited to private ownership and use. Scattered among the reverted areas are numerous small parcels of private land that cannot be operated independently on a sustained-yield basis. These parcels are held by persons interested not in managing the land for continuous forest production but in liquidating the forest capital; they include forest operators winding up their affairs in these localities and individuals gainfully employed in nonforest industries. Tentative boundaries could be set up now around groups of such holdings, each group composing an area sufficiently large for an economic administrative unit, say about 100,000 acres. The boundaries need not be extended to include all parcels of land that may soon come into State ownership. Such action would impress upon the people that the State was planning to give these lands a definite management status as soon as finances would permit it, thus stimulating transfer to the State of county lands within such units.

\section{COUNTIES AND MUNICIPALITIES}

No sound reason appears for recommending any county forest-acquisition program other than for small parks needed by rural communities. Counties have not evidenced the consistent policy or the financial ability that would justify such a recommendation. The frequent changes in local officers and policies and the constant struggle to finance existing local public services, owing to dependence upon general-property taxes exclusively, prevent the counties from following a long-term, consistent program of management such as is required for proper forest administration and from undertaking the expense of such administration. In this region natural operating units overlap county boundaries, making it impractical for counties to undertake to protect or manage forests. Administration, particularly protection, is more economical if spread over large areas. In view of these considerations, the counties would be better off in the long run if they conveyed their tax-forfeited forest lands to the State and the State made contributions to the counties in lieu of taxes on lands of this category 
dedicated as State forests. However, if the States will not assume the responsibility of managing the tax-forfeited forest lands the counties will be faced with the job. Any county funds available will be needed more for protecting and managing present and prospective tax-forfeited lands than for purchase of additional forest land.

For the same reasons no broad program of forest acquisition is recommended for municipalities.

\section{Public Regulation of Forest-Land Use}

The necessity for public regulation of forestland use results from the failure of private initiative to check the abuses that follow unrestricted exploitation. For lands that remain hereafter in private ownership there must be some regulation of methods of cutting and fire protection that will protect the public interest.

\section{Methods of Cutting}

Methods of cutting should be employed that provide for prompt and certain reforestation of cutover lands. This involves following the silvicultural practices embodied in the rules adopted under the National Recovery Act and later revised and presented in the Forest Practice Handbook (i1). Adherence of forest owners to the principles embodied in these rules should be made obligatory, as an initial step.

The choice of method should be determined by the physical characteristics of the area and the age, composition, and condition of the stand. In some instances selective cutting would be chosen in others clear cutting.

In selective cutting, a stand of positive value should be reserved.

Areas clear cut in any 1 year should be limited to such size that they can be reseeded by adjoining timber. The potential source of reseeding, whether it be a strip left along creek, ridge, highway, or property line or a body of timber awaiting cutting, should be at least 300 feet wide and should be left standing until the cut-over area has restocked.

\section{Slash Disposal}

Better slash disposal on clear-cut areas is needed. Approved methods (11) should if necessary be required by legislation.
The fire hazard must be controlled on areas logged selectively. Studies are now under way to determine suitable methods of abating the hazard from slashings; the results should be put into practice as soon as available.

\section{Sustained Yield}

The ultimate solution of the forest problem in this region is institution of sustained-yield forest management on all commercial forest land regardless of ownership. It is highly desirable that sustainedyield plans for all the forest areas be formulated at once, because of the possible effect on cutting of public timber, mergers of private properties, establishment of new industrial plants, State legislative action, construction of public improvements, etc.

\section{Restriction of Cutting}

All timber on public forest lands, Federal, State, or county, now reserved or to be reserved exclusively for intensive recreational use should be omitted from sustained-yield calculations and reserved from cutting except for salvage. A comprehensive study of forest-recreation needs is now being conducted by the Forest Service and is expected to indicate future needs for recreation.

Except for thinnings, no second-growth timber in public ownership should be cut and no privately owned second growth that is part of a sustainedyield unit should be cut so long as available oldgrowth timber may be supplied at costs reasonably comparable to costs of operating the second growth.

Integration of any measures taken for (1) stabilization of forest-land ownership, (2) public acquisition of forest land, and (3) enactment of regulatory legislation would assist in the consummation of the sustained-yield plans.

\section{Forest Protection}

With an enlarging acreage of cut-over land and a growing use of the forests by the public for recreation, the Douglas-fir region is facing an increasingly difficult problem of forest-fire protection. Particularly outside the national forests, efforts must be redoubled to keep losses within reasonable bounds. The fire codes of both States are very specific and 
with minor additions would be adequate to meet present conditions, but should be modified as conditions change. The great needs in fire protection are stricter enforcement of the existing laws and more money to finance an adequate protective system.

Some of the specific steps necessary to advance forest protection are as follows:

1. The wild lands outside public forests should be classified to determine the major areas chiefly valuable for forest purposes and requiring protection. Forest-protective agencies should then confine their efforts to these lands, and other agencies such as rural fire departments should be held responsible for the protection of the intervening agricultural and farm-woodland territory.

2. Following land classification, there should be land use legislation to prevent attempts to use forest land for agricultural settlement, since such uneconomic use of submarginal land is sure in this region to increase the fire hazard to adjoining forests.

3. In anticipation that the private timberland owners' contribution toward protection will diminish as the area of virgin forest diminishes, the State should assume a greater share in the protection of county and private lands and ultimately have entire jurisdiction over all forest protection outside Federal holdings. State appropriations should therefore be materially increased, to intensify the present protection and law enforcement.

4. Through educational effort and otherwise, better compliance with the forest-protection laws must be brought about and these laws must be more strictly enforced in the lower courts.

5. Probably the greatest technical weakness of the forest protection on private lands is in the methods of burning slashings and subsequently protecting logged-off lands. There is need for much progress here, particularly in developing methods for abating the hazard, without detriment to forest productivity, on lands that have been selectively cut. A larger force of year-long trained fire wardens is needed to give expert help and supervision in individual slash-burning and land-clearing operations.

6. The Civilian Conservation Corps has been so helpful in fire suppression and prevention and has been so integrated with the regular fire-control organizations during the last few years that a sudden reduction or withdrawal of its help would be upsetting to the protective agencies. This or equivalent assistance should be given.

7. Adetermined effort should be made to have insurance companies offer, and timber owners purchase, insurance for forest lands. The general insuring of forests would give financial security and stability to forest ownership and have a salutary effect on fire prevention.

\section{Reforestation of Denuded Lands}

Large-scale forest planting in this region cannot be justified economically until areas reforesting naturally are better safeguarded. The money that would be required to plant extensive areas where natural reforestation is impossible would bring far greater returns if spent on improving methods of cutting, slash disposal, and fire protection.

A program for permanent C. C. C. work should include planting of deforested burns on national forests and State forests that will not restock naturally in a reasonable period.

\section{Forest Research}

Forest research as now carried on by the Forest Service, the forest schools, and industrial organizations is giving beneficial results and should be continued and expanded. The industry itself should make more intensive studies of its industrial problems, either through its trade associations or otherwise. The States themselves are doing very little research, though there is a field for State activities as a supplement to Federal activities; their research might best be conducted through their forest schools and should be well coordinated with the Federal experiment station's program.

Expansion of the present forest-research program is needed particularly along the following lines:

1. Silvicultural and economic aspects of selective cutting.

2. Improved methods of slash disposal and of protecting logged-off land, particularly areas selectively cut.

3. Further intensification of the Forest Survey to develop basic policies and principles for forest-land use and to determine how forestry fits in with other major types of land use.

4. Basis for distinguishing areas chiefly valuable for forest purposes from areas chiefly valuable for agricultural use or pasturage. 
5. Relation of forest-land management to floods, erosion and quantity and regularity of stream flow.

6. Economics of multiple land use, particularly of stock grazing, game management, and recreation, in relation to timber production.

7. Fconomics of private sustained-yield management of forest lands, especially in relation to public finance and taxation.

8. Improvement of logging equipment and methods to meet requirements of good silviculture and protection.

9. Search for new uses for forest products, new markets, and better methods of conversion, with a view to making highest use of each tree.

10. Principles and plans to meet problems of declining communities that result from overcutting of tributary timber.

The experimental forests, both of the Forest Service and of the forest schools, are serving well as proving grounds and demonstration areas, but there is need for more large-scale trials of new methods and new equipment on representative commercial areas. The scope and importance of the forest problems in this region are such that a great deal more intensive research would well be justified.

\section{Forestry Extension and Forestry Education}

The pre-eminence of the forest resource in this region's economic life makes forest utilization and forest conservation of vital concern to every citizen; but the general public has not been sufficiently impressed with the necessity of keeping forest land permanently productive. The following program of forestry extension and forestry education is recommended:

Despite many years of effort, forest extension activities among both farm and industrial forest owners have failed to convert forest owners from a liquidation philosophy to one of timber growing. Greatly increased activity is needed not only in forest growing extension but also in forest utilization extension. Legislative authority and administrative machinery exists in the Department of Agriculture for extension work in both industrial and farm forestry. Increased appropriations are needed. Legislation supported by adequate appropriations should be provided for extension in the fields of timber utilization and marketing of forest products. The entire responsibility does not rest on the Federal Government; the States of Oregon and Washington, forest owners, and forest industries should greatly increase their own activities.

$224146^{\circ}-40-10$

\section{The Public Responsibility}

\section{Management of Public Forest Land}

All cutting operations on public lands should be on a sustained-yield basis.

All public forest land chiefly valuable for recreation should be reserved from cutting except to salvage timber killed by fire, insects, disease, or wind throw.

All public forest land chiefly valuable for watershed protection should be reserved for that use, conflicting uses being prohibited.

So far as physical conditions permit, strips of timber should be left along all public highways and stream courses.

Full use of forest land under the principle of multiple use advocated by the Forest Service should be the policy wherever practicable.

The present policy of using sales of national-forest timber to encourage the practice of sustained-yield management on private land and refusing to make sales that might add to the established mill capacity or precipitate liquidation of private timber should be continued. All public agencies conducting timber sales should adopt similar policies.

\section{Improvements}

\section{HIGHWAYS}

The remarkable expansion of truck logging in the past few years has greatly complicated transportation planning in this region. The requirements of the forest industries should be considered in planning the location and construction of new highways. Furthermore, future highway development should be integrated with sustained-yield plans wherever possible.

\section{WATERWAYS AND HARBORS}

The bulk of the freight traffic on rivers and harbors of this region consists of forest products. Public development of waterways and harbors is based to a great extent on quantity of tributary timber. Future work should be integrated with sustained-yield plans.

Future exploitation of timber south of the Columbia River district depends chiefly on improvement of shipping facilities. Some projects 
now under consideration by the United States engineers, for example, canalization of the Willamette River and improvements on the lower Umpqua River, would stimulate logging in territory now undeveloped. In time, improvement of certain harbors in southern Oregon will be needed to remove some of the geographic disadvantages now holding back the timber in that territory.

\section{Legislation}

To vitalize the forest program recommended in this report certain State and Federal legislation will be required. Some has recently been enacted, several bills are pending, and on the whole progress is encouraging. It is not within the scope of this report to list specifically the remaining legislation needed.

\section{The Private Owners' Responsibility}

Control of Overproduction

It would be very advantageous both to the public and to industry if overproduction of forest products in this region were controlled by voluntary cooperative action of owners, including mergers, support of trade associations, and better financing. Failing this it may be necessary, in order to protect the public interest, for the Government to step in. The most effective way to control overproduction is curtailment of the log supply, and this should originate in the woods through prompt adoption of sustained-yield practice. Public action to retire obsolescent, inefficient, or excess sawmill capacity would be unnecessary if woods control were effective. At best, it is difficult to determine with exactness what units are obsolete, inefficient, or superfluous.

Installation of additional sawmill capacity in western Washington and northwestern Oregon should be discouraged by associations of timber owners and lumber manufacturers and by banking interests, unless it can be shown that a definite need exists. Any additional plants should be located with consideration of available raw material and marketing facilities, and should be so constructed that successive physical changes to improve operations and meet demands for new products could be made with a minimum of expense.

\section{Logging Practice}

It is the responsibility of the private owner to leave his land in good condition after logging and to discontinue practices that leave larger areas without return cuts for long periods. The method of cutting may be clear cutting, stage cutting, ${ }^{24}$ or selective cutting of some sort, depending on physical and economic conditions. In all cases an adequate seed supply should be provided for restocking, and satisfactory fire-control measures should be taken during and immediately following logging. Detailed recommendations are given in the Forest Practice Handbook (11). Technical advice is available from associations and public agencies. In cases of contract logging the land owner should insist that the logger leave the area in good condition.

A change from power logging to trucks and tractors would permit of flexible cutting methods and automatically leave the forest in better condition for regrowth.

If private owners do not voluntarily adopt such a program, public regulation is invited. Existing laws regulating forest protection should be scrupulously observed.

\section{Utilization of Minor Species}

A definite campaign should be initiated, using the results of research and trade extension, to increase the utilization for lumber and pulp of the so-called minor species, particularly hemlock and the balsam firs, and low-grade material of the major species.

\section{Manufacturing Practice}

Great improvement in manufacturing practice has been made by the lumber industry in the past few years. Further improvement is needed in milling, seasoning, grading, and preparation for shipment. The development of marketable products from sawmill waste should be given greater

${ }^{24}$ A form of cutting which has clear cutting as its final objective. The stand is cut in two or more steps or stages. 
attention by the industry as a whole. In the large centers of production sawmill waste is now used chiefly as fuel. Some of this waste has potentialities for higher uses which would give greater returns and more local employment. Many smaller mills do not market sawmill waste even for fuel. Cooperative action is needed to make available to the small mills facilities for converting their waste to saleable commodities.

The industry should make every effort to reduce the volume of logs and rough lumber shipped out of this region and to increase local remanufacture. Industrial and financial agencies should encourage and support the establishment of local remanufacturing plants for which a definite need and opportunity exist.

\section{Industrial Expansion}

\section{PLYWOOD}

There is some question as to the desirability of further expansion of the plywood industry in its present locations. It has expanded rapidly at tidewater points in the Puget Sound, Grays Harbor, and Columbia River districts, apparently without any definite plans as to future supplies of raw material. There is no shortage of material for core stock and innerplies, but plywood manufacturers are already going far afield for the higher quality of peeler logs needed for outer surfaces of panels. It is a problem to the industry whether to ship in peeler logs from the central and southern parts of the region to augment the supply available on the open log markets or to set up subsidiary veneer plants nearer the source of raw material and then ship veneer to the existing tidewater plants for final fabrication into plywood. This industry, in addition to obtaining supplies from the open log markets, should acquire lands supporting high-quality old-growth timber for a reserve supply, and thereby protect its future. They should also encourage the practice of selective logging.

\section{PULP MIILS}

There is sufficient raw material in the region for additional pulp mills. The available raw material is suitable for the highest quality of pulp, and any new pulp mills installed should be designed for production of the higher grades. This would tend to induce local establishment of remanufacturing industries using pulp for purposes other than paper, such as rayon and other textile materials.

\section{Road Development}

Logging roads should be financed independently by timber owners and logging operators, where there is no public responsibility for the construction of such roads. On some areas supporting extensive undeveloped bodies of virgin timber in mixed ownership there are possibilities of developing main-line truck roads to the nearest public highway through organization of cooperative road districts. The timber owners participating would pay for the construction of the main-line road in proportion to the anticipated benefits and would construct their own spur roads. Some of these roads would eventually be suitable for inclusion in the public highway system. In such cases the State highway departments or county road departments should have some voice in locating the roads and assist in their construction, even though the roads might be closed to general public use for the first few years of logging in the area.

\section{Sustained-Yield Management}

The Douglas-fir region, with its enormous remaining supply of virgin timber, still has the opportunity of adopting sustained-yield management without drastic curtailment of present production for the region as a whole. Other forest regions, in advanced stages of depletion, must greatly reduce cutting if depleted growing stocks are to be built up to normal. It is the private owners' responsibility to support, and to share the leadership of, a coordinated program of private and public action that will make the forests of this region permanently productive and furnish the forest industries a stable supply of raw materials. 


\section{Conclusions}

Progress in accomplishing the program herein presented does not depend upon simultaneous performance of all the recommendations. The program is multilateral, and although overlapping in some particulars it can be approached from several angles at once and thus be attained through a step-by-step process.

Prompt action must be taken on key sections of the program if the disastrous consequences that followed unrestricted exploitation in other forest regions are to be averted. The most critical prob- lems are: Stabilization of ownership, including removal of some of the economic obstacles to private ownership and better distribution of private and public ownership; recognition of the urgency of doing something about the localized overcutting around the Puget Sound, Grays Harbor, and Columbia River districts; adequate protection of all forest land against fire; and provision for a sufficient seed supply on cutover land. Achievement of these objectives will stimulate action on the remainder of the program and contribute greatly to the institution of region-wide forest management. 


\section{Literature Cited}

$\rightarrow 2$ $\lll$

(1) Beal, J. A., Kimmey, J. W., and Rapraeger, E. F. 1935. DETERIORATION OF FIRE-KILlED DOUGLAS FIR. Timberman 37 (2): 13-17, illus.

(2) Boyce, J. S. 1932. DECAY AND OTHER LOSSES IN DOUGLAS FIR IN WESTERN OREGON AND WASHINGTON. U. S. Dept. Agr. Tech. Bul. 286, 60 pp., illus.

(3) BURrter, A. S.

1935. LAND USE PROBLEMS IN OREGON, AND ABRIDGED REPORT. Oreg. State Planning Bd. 64 pp., illus.

(4) Fatrchild, Fred Rogers, and associates. 1935. FOREST TAXATION IN THE UNITED STATES. U. S. Dept. Agr. Misc. Pub. 218, 681 pp., illus.

(5) Ferguson, John W.

1935. TWENTY-FIFTH ANNUAL REPORT OF THE STATE FORESTER OF THE STATE OF OREGON. 86 pp., illus. Salem, Oreg.

(6) Hall, R. Clifford

1935. THE FOREST-TAX PROBLEM AND ITS SOLUTION summarized. U. S. Dept. Agr. Cir. 358, 18 pp.

(7) Hodgson, Allen H.

1929. LOGGING WASTE IN THE DOUGLAS FIR REGION. West Coast Lumberman 56 and 57 (Sup.), 40 pp., illus.

(8)

1931. THE PRESENT UTILIZATION OF SAWMILL WASTE IN THE DOUGLAS FIR REgION. Timberman 32. $(9-12)$, illus

(9) Ingram, Douglas C.

1931. VEgETATIVE GHANGES AND GRAZING USE ON DOUGLAS FIR GUTOVER LAND. Jour. Agr. Res. 43: 387-417, illus.

(10) Johnson, Herman M., Hanzi.tK, Edward J., and Gibbons, William $\mathrm{H}$.

1926. RED ALDER OF THE PACIFIC NORTHWEST: ITS UTILIZATION, WITH NOTES ON GROWTH AND management. U. S. Dept. Agr. Bul. 1437, 46 pp., illus.

(11) Joint Committee on Forest Conservation.

1937. FOREST PRACTICE HANDBOOK ... 31 pp., illus. West Coast Lumbermen Assoc. Seatthe.

(12) McArdel, Richard E., and Meyer, Walter H. 1930. THE YIELD OF DOUGLAS FIR IN THE PACIFIC northwest. U. S. Dept. Agr. Tech. Bul. 201, 64 pp., illus.
(13) Meyer, Walter $H$.

1937. YIELD OF EVEN AGED STANDS OF SITKA SPRUCE and Western hemlock. U. S. Dept. Agr. Tech. Bul. 544, 86 pp., illus.

(14)

1938. XIELD OF EVEN-AGED STANDS OF PONDEROSA PIne. U. S. Dept. Agr. Tech. Bul. 630, 60 pp., illus.

(15) 1930. A STUDY OF THE RELATION BETWEEN ACTUAI AND NORMAL YIELDS OF IMMATURE DOUGLAS FIR FORESTS. Jour. Agr. Res. 41: 635-665, illus.

(16) Munger, Thornton T.

1927. TIMBER GROWING AND LOGGING PRACTICE IN the douglas fir region. U. S. Dept. Agr. BuI. 1493, 42 pp. illus.

(17) Munns, E. N. and Brown, R. M.

1925. VOLUME TABLE FOR THE IMPORTANT TIMBER TREES OF THF: UNITED STATES: I. WESTERN species. U. S. Dept. Agr. Unnum. Pub. $159 \mathrm{pp}$.

(18) Oregon Spegral Committee on Timber Taxation

Appotnted by the Governor.

1937. OREGON TIMBER TAXATION PROBLEMS AND RECOMMENDATIONS TOWARD THEIR SOLUTION. 40 pp., illus. Salem, Oreg.

(19) Oregon State Tax Commission.

1937. THIRTEENTH BIENNIAL REPORT.

(20) Shepard, H. B.

1937. FOREST FIRE INSURANCE IN THE PACIFIC COAST states. U. S. Dept. Agr. Tech. Bul. 551, 168 pp., illus.

(21) Sudworth, George B.

1927. CHECK IIST OF THE FOREST TREES OF THE UNITED STATES: THEIR NAMES AND RANGES. U, S. Dept. Agr. Misc. Circ. 92, 295 pp.

(22) United States Forest Service.

1933. A NATIONAL PLAN FOR AMERICAN FORESTY. [U. S.] Cong. 73d, 1st sess., S. Doc. 12, 2 v., illus.

(23) Washington State Tax Commission.

1936. SIXTH BIENNIAL REPORT.

(24) West Coast Lumbermen's Association.

1937. WEST COAST LUMBer FACTS. 25 pp., illus, Seattle, Wash. 


\section{Appendix}

$\rightarrow \gg$

\section{Inventory Methods and Sources}

\section{Volume Tables}

Several existing Douglas-fir volume tables had given satisfactory results for certain localities, but comparison with measurements of felled timber showed that they could not be used regionally. Accordingly, a form-class table was developed and checked against measured volume of 1.6 million board feet of felled and bucked timber in different sections of the region. In nearly every instance this table checked within 0.5 percent of the actual measurements, and in no case did it deviate more than 2.6 percent.

A western hemlock volume table was constructed in the same way, and was proved to be accurate. For western redcedar a volume table made on the Quinault Indian Reservation by Henry B. Steer, then of the United States Indian Service, was used. For Sitka spruce, table 80 of Volume Tables for the Important Timber Trees of the United States: Part I, Western Species (17), was accepted after adjustment to a 12-inch top diameter. Table 79 from the same publication was adopted for silver fir and white fir, after it had been adjusted to a 12-inch top diameter and extended to include trees as large as 70 inches in diameter.

Table 77 in the publication just mentioned, prepared by R. H. Weidman in 1917, was accepted for noble fir. A table made by Henry B. Steer on the Quinault Indian Reservation was used for western white pine. A form-class table was constructed for ponderosa pine. A table for use in estimating red alder was prepared on the basis of an existing table (10) made by Griffin and Wilcox. The second-growth cottonwood table (table 11) in Volume Tables for the Important Timber Trees of the United States: Part III, Eastern Hardwoods, was found to be suitable for other hardwoods.

\section{Organization of Field Work}

More than 40 percent of the region's total forest-land area is within the boundaries of national forests. This portion, 84 percent of which is in Federal ownership, includes the most mountainous, rugged, and inaccessible lands of the region. When this work was started, national forests either wholly or chiefly within the Douglas-fir region numbered 12; since then, without any significant change in total area, the number has been reduced by consolidations to 10 . These national forests now range in gross area from about 700,000 to $1,850,000$ acres each, averaging approximately $1,200,000$ acres.

A greater part of the national-forest lands than of the other lands had to be covered by field examination. The procedure followed on them was influenced not only by the ruggedness of the many mountain areas but also by scarcity of roads and shortness of field season. It was decided that the work on national-forest areas that had not been intensively cruised should be an intensive reconnaissance. Men familiar with the national forests of the region were selected from the local forest organizations to do this work.

For lands outside the national forests a permanent organization of 5 type mappers and 3 check cruisers was formed. This was augmented by field assistants during the field season and computers during the winter months. In peak periods as many as 40 or 50 men were employed on the survey of these lands.

\section{Collection of Existing Information}

The sources of information already in existence for national-forest areas included intensive timber cruises covering about 15 percent of their total; records of an extensive reconnaissance made in 1909-10 and amended in 1922, of examinations of cut-over land, of planting reconnaissance work, of land-exchange examinations, of appraisals, of settlement cases, of trespass cases, and of fire damage; aerial and panoramic photographs; and miscellaneous other records Of the land outside national foreste about 30 percent had been covered by intensive cruises. Collecting information on areas outside national forests involved investigation of the records of all counties and consultations with lumbermen, public officials, foresters and engineers in private employ, and many other persons. The principal sources of information found were private timber cruises in the hands of timber owners or their agents, county cruises made for taxation purposes, and cruises of State-owned lands, Oregon \& California Railroad revested grant lands, and Indian reservations. In cases in which county cruises were sufficiently complete and appeared to be reliable 
enough to use, no attempt was made to collect private cruises.

Private timberland owners contributed materially to the success of this undertaking. With very few exceptions and reservations they tendered the use of their cruise data, which in the aggregate are estimated to have cost them more than a million dollars. Each cooperator was assured that private cruises given would be kept in strict confidence and that cruise data from private sources would be made public only in such combinations as would safeguard their confidential character. It was emphasized also that the type maps would not indicate density of stand for the mature types.

\section{Field Procedure}

The intensive reconnaissance method applied on national forests consists in mapping areas that are uniform as to type conditions and estimating the average volume per acre for each of these type areas. Type boundaries were determined by working along trails, roads, and ridges, by using high points for lookouts, and by running random strips, and were placed directly on base maps. For each sawtimber-type area, estimates of average volume per acre were made ocularly and were checked by use of data taken on a number of well-distributed sample plots. Sample plots were either quarter-acre circles (58.9-feet radius) or 1 -acre strips ( 66 by 660 feet). For all trees of saw-timber size on these plots species, height, and diameter were recorded and volume was computed. For second-growth areas, that is, areas occupied by stands less than about 150 years of age, averge age of timber and average stocking were recorded. At frequent intervals site observations were taken and recorded; the age of the stand was determined with an increment borer, average height of the dominant and codominant trees was determined with an Abney level, and site values were read from a curve of height over age. In determining site only Douglas-fir trees were measured where the Douglas-fir classification was used, and only ponderosa pines were measured where the ponderosa-pine classification was used.

In the Cascade Range, the Siskiyou Mountains, and the Olympic Mountains, because of the distinctness of the topography it was possible to determine type boundaries largely by observation from vantage points. On the Siuslaw National Forest, in the Coast Range, mapping was seriously impeded by numerous small canyons and short ridges with no definite topographical pattern, by luxuriant brush and tree cover, and by poor weather. Here aerial photography was used as an adjunct to ground work. Oblique rather than vertical pictures were taken, because of lower cost and greater ease of orientation.

For areas outside national-forest boundaries the first step in preparing type maps was to record the collected type data on transparent vellum plats fitted over base maps. Each type mapper visited the county seat in search of additional information and familiarized himself with the county in a general way by driving over the roads. Having selected an area on which to begin work, he mapped as much as he could from the roads and trails. Picking points that would give the best view of the country and using as a control the roads, streams, and other features on the base map and the type areas already entered on the vellum from office records, he oriented himself with a compass and mapped all that could be seen. Each type area was viewed from several vantage points to determine its exterior boundaries. In this region of dense cover and irregular, often rugged topography, once under forest cover it is difficult to see out, and great care was necessary to avoid overlooking any small farms, pasture lands, burns, or small second-growth areas. On areas of mixed types it was customary to map the smaller type areas first, thus fixing the boundaries of the larger types.

For areas not covered by existing data, which were principally second-growth areas, land cut over prior to 1920 , burns, woodland areas, farm woods, agricultural lands, grassland, brush areas, and barrens, the field examiner located, and sketched on the map, the boundaries of each type. For second-growth areas, he determined also the age class of the timber, its species composition, and the degree of stocking. For areas occupied by merchantable timber he estimated the board-foot content of the stand by species. For all coniferous types except lodgepole pine, noncommercial rocky, and subalpine, he made site determinations at frequent intervals.

Several large agricultural areas contain scattered forests and woods that are too small to be shown on the type map but that in the aggregate constitute a forest resource too large to be ignored. These agricultural areas are fairly well defined; an example is the Willamette Valley of Oregon. To get a statistical expression of the extent and character of their forest stands, they were covered by a linear survey. Type and volume data were taken on transects at intervals of 3 miles or less.

Lands shown by county and private records to have been clear cut since the beginning of 1920 (type 36) were not classified in the field but were examined in the field to verify that they had been clear cut. These areas cannot satisfactorily be classified as to restocking, because of the periodicity of adequate seed crops, the practice of slash burning, high fire hazard, and the nature of logging practice in the region. However, a statistical expression was obtained of the condition of those logged prior to the period of general seed-crop failure that began in 1924. A linear survey was made of the areas logged in 1920-23, transects being spaced 2 miles apart or at the rate of 1 mile of strip for every 1,280 acres. At 1-chain intervals on these transects four 13.2-foot quadrats were examined, and each of these was classified as stocked or nonstocked according to whether it contained one well-established seedling (the stockedquadrat method).

The site map was made on a skeleton vellum overlay map of the county, scale one-half inch to the mile. All the site determinations made were plotted on the map and by interpolation site-class boundary lines were sketched in. This of course, gave only a generalized picture, but by referring to 
topographic features and using his knowledge of the country the field examiner was able to make a sufficiently accurate map for an area as large as a county. The site maps were intended to show not the site class of specific small areas but the area of each site class in the county.

The final field job was "adjustment cruising" of contributed cruise data. It was impossible to adjust these data to survey standards without resorting to field work because (1) specifications were often incomplete or lacking and (2) errors made by cruisers might have caused considerable inconsistency in a given cruise. The adjustment cruising consisted in cruising well-distributed sample areas according to the specifications adopted for the forest survey and comparing the results with the original cruise data. The size chosen for the individual sample was 160 acres.

Volume was recorded for quarter-acre circular plots at $21 / 2$-chain intervals, or for 16 such plots on each 40 -acre tract; in other words, a 10-percent cruise was made. The circular-plot system was admirably adapted to the purpose, and speeded up the work. Locations of all doubtful line trees were determined with a tape, all trees apparently more than 60 inches d. b. h. were measured for diameter, and a considerable percentage of the smaller trees were measured. Heights were measured with the Abney level and by taping a number of windfalls each day. Deductions for breakage and defect were calculated for each 40 -acre tract. These deductions were carefully checked, for each tract cruised, by examining felled and bucked timber on neighboring logging operations and by interviewing superintendents, foremen, check scalers, and managers of logging operations in the vicinity.

Per-acre volume of the hardwood stands, usually not included in commercial cruises in the region, had been determined by the type mappers, but information was lacking as to the volume of the hardwood timber occurring as an understory in mature coniferous forests. As a part of the adjustment-cruising project, therefore, data on this hardwood understory were collected.

Each check cruiser compiled his data currently and made frequent comparisons with the original cruise until he was satisfied that the results were consistent and that reliable adjustment factors could be computed. Usually 3 to 4 percent of the area included in the original cruise was check cruised.

\section{Compilation of Data}

In many counties a year or more elapsed between the completion of the original field work and the beginning of compilation. In such cases the status of areas logged and burned in the intervening period had to be investigated. This involved a check of cutting and fire records, and in some cases additional field mapping.

Before type acreages could be computed it was necessary to determine the exact land area of each township, each county, and each national forest. General Land Office plats were used for townships for which they were available.
Areas of unsurveyed townships were determined by planimetering the most accurate maps available.

Information as to ownership was obtained from county records for county-owned and municipal lands, State records for State-owned lands, Department of Interior records for national-park, Indian, and revested grant lands and for unappropriated public domain, and Forest Service records for national forests. All land not shown by public records to be public property was considered private.

Acreage for each of the various types and for divisions of some types by age class and degree of stocking was determined for each section and for each ownership class from the field maps. For each national forest this was done by compartment, block, and working circle and also by county. Acreage was determined by use of the planimeter or by counting squares.

Site-class acreages were compiled for each county and national forest from site maps by planimetering. Percentages of total acreage in each site class represented were determined for each township in the same manner, for use in computing volume of second-growth stands.

Volume data for national forest areas were compiled by applying to type areas the stand-per-acre values determined in the field. Volumes were compiled by compartment and were summarized by block and finally by working circle.

For areas outside national forests, the adjustment factors determined by check cruising were applied to the volume figures taken from existing cruise records and the corrected totals, recorded by section, township, and county. Volumes for areas of merchantable timber, including hardwoods, not covered by previous cruises were compiled by applying to each area the figure for stand per acre shown by the type map. Commercial cruises had omitted a large majority of the second-growth stands in which the average breast-height diameter was below a standard ranging, according to species, from 20 to 24 inches. For uncruised second-growth stands in which the trees averaged 16 inches d. b. h. or more, volumes were obtained from tables adapted from the Douglas-fir yield tables (12). Volume data for second-growth areas were segregated from the others.

\section{Depletion-Study Methods and Sources}

\section{Cutting Depletion}

The data taken on depletion by cutting covered the material removed not only as sawlogs but also as so-called minor timber products. The records used included only wood material actually taken out of the woods, omitting sound material left by operators on the ground as nonutilizable. This sound unused material entered the study only when future depletion was being estimated. Its quantity had been accurately determined in a previous study (7).

The study of annual log depletion was based on the 9-year period 1925-33 because more and better data were available for this period than for any other. It is true that in this period sawlog production reached a peak that it may never reach again, but the period included some years of extremely 
low production; all things considered, the data are believed to be representative.

The log-production data used were taken from several sources but principally from the biennial lumber- and logproduction censuses of Oregon and Washington for the years 1925, 1927, 1929, 1931, and 1933 taken by the Pacific Northwest Forest and Range Experiment Station in cooperation with the Bureau of the Census. Sawlog production as reported by the independent loggers and loggermanufacturers was used in preference to lumber, lath, shingle, veneer, and pulpwood production because in this way the material could be traced to its sources and classified by county and unit. Data for 1926, 1928, 1930, and 1932 were obtained partly from records of the Portland, Oreg., regional office of the Forest Service and partly by interviewing officials of timber companies and lumber associations and other individuals having personal knowledge of lumber operations.

A check of the sawlog data was made by comparing the sum of the county totals with a regional total obtained by combining census and other official figures. The differences found were 3.7 percent for western Washington, 2.1 percent for western Oregon, and 1.9 percent for the region as a whole. The errors for survey-unit totals were estimated to be well within \pm 5 percent.

The study of depletion for minor forest products had to be based on 1930 production alone, as data for previous or subsequent years were either missing or too incomplete for satisfactory use. The basic data were obtained through field investigations and by means of questionnaires circulated to producers and consumers. Information of satisfactory accuracy was obtained by this method for all items except round and split fence posts. Since posts are produced in small quantities and by many individuals, largely by farmers for their own use, it was impossible to canvass the field thoroughly. A figure was obtained by adding to the output reported by the large-scale commercial operators an estimate of annual farm requirements.

\section{Fire Depletion}

The study of depletion of the forest capital by fire was much more complex than the study of depletion by cutting.

The two sources of information available were Forest Service reports covering burned area on the national forests and State foresters' reports covering burned area on all other forest lands. The data were summarized by survey unit, those for national forests being treated separately from those for all other lands.

The basic data used for the analysis of depletion by fire on the national forests were the reports of all class $\mathrm{C}$ fires (fires 10 acres or more in area) on the national forests of the region in the 10-year period 1924-33. Site and type before fire were determined by superimposing on the forest-survey site and type maps the outlines of the areas reported to have been covered by the fires. Each fire was classified and the essential data regarding area, location, type, site, and volume were separately recorded. These were compiled by county and summarized by unit. A field check was made of about 25 percent of the total area reported to have been covered by class C fires, and from the data thus obtained correction factors for both area and volume were computed. No blanket deduction was made for salvage. In the few cases in which material was known to have been salvaged this material was deducted from the loss. When the 10-year totals of area burned and timber killed had been adjusted, they were converted to average annual-loss rates.

Reports made to the State foresters on individual fires in the region in the 5-year period 1926-30, which had been analyzed in connection with the forest fire insurance study (20) recently made by the Pacific Northwest Forest and Range Experiment Station, formed the basic data used in computing fire-depletion rates for land other than national forests. Supplementary reports on nearly all the fires covering 50 acres or more were obtained from the fire wardens, and checked in the field, for all counties except San Juan and Island in Washington and Hood River, Jackson, and Josephine in Oregon. The areas covered by the supplementary fire reports were classified as to site and type by reference to the forest-survey site and type maps, and the volume loss estimated. These data were recorded by county and the totals combined by forest-survey unit. The data were then compared with the State foresters' published reports of total area burned in the same period in the same group of counties and were adjusted to them. They were next converted to an annual loss rate. This procedure automatically included Island, San Juan, and Hood River Counties. Jackson and Josephine Counties were covered by a separate analysis of individual fire reports to the State foresters for the period 1926-32. Finally, annual loss rates were calculated for the entire region by survey unit. Salvage rates for lands outside the national forests were computed on the basis of data obtained in the forest fire insurance study, and were applied to volume-loss totals.

\section{Future Depletion}

No specific formula could be evolved for making estimates of future depletion from cutting. The economic forces that could influence the situation are many and complex. The Douglas-fir region is farther removed than any other forest region of the United States from the large markets of the Midwestern and Eastern States. What quantities of lumber will be shipped from it will depend somewhat on the extent to which the other forest regions can fulfill the requirements of the country's heavily populated sections. On the other hand this region is favorably situated in relation to Asia, Africa, and the antipodes, the world's largest undeveloped markets for softwoods. The depletion estimates are pure assumptions, based on careful analysis of cutting records and of current trends in lumbering, not only regional but national, and all other known influences.

Future depltion from fire, while not subject to so many dynamic economic forces as cutting, was equally difficult of prediction. 


\section{Periodic Saw-Timber Growth}

In order to estimate board-foot timber inventories for the Douglas-fir region as of the years 1943, 1953, and 1963, periodic annual board-foot growth was computed for each of the three decades following 1932. Advance in age and differences in type areas because of depletion were the only changes taken into account; no changes from the 1933 conditions were assumed in either species composition of stands or stand density.

TABLE 42.-Periodic conifer saw-timber growth 1 in the Douglasfir region

\begin{tabular}{|c|c|c|c|}
\hline \multirow{2}{*}{ District and unit } & \multicolumn{3}{|c|}{$\begin{array}{l}\text { Periodic growth of trees } 15.1+\text { inches } \\
\text { d. b. h. }\end{array}$} \\
\hline & $1933-42$ & $1943-52$ & $1953-62$ \\
\hline Puget Sound: & $\begin{array}{c}\text { Million } \\
\text { board feet }\end{array}$ & $\begin{array}{l}\text { Million } \\
\text { board feet }\end{array}$ & $\begin{array}{l}\text { Million } \\
\text { board feet }\end{array}$ \\
\hline North Puget Sound & 1,146 & 1,294 & 1,499 \\
\hline Central Puget Sound & 1,288 & 1,615 & 1,906 \\
\hline South Puget Sound.... & 2,491 & 2,289 & 1,731 \\
\hline Total & 4,925 & 5,198 & 5,136 \\
\hline Grays Harbor... & 1,905 & 1,779 & 1,462 \\
\hline Columbia River: & & & \\
\hline Columbia River Washington & 2,270 & 2,433 & 2,283 \\
\hline Columbia River Oregon & 1,568 & 2,081 & 2,482 \\
\hline Total $\ldots$ & 3,838 & 4,514 & 4,765 \\
\hline Willamette River-. & 4,216 & 4,540 & 4.799 \\
\hline Oregon coast: & & & \\
\hline North Oregon coast ${ }^{3}$. & 2,805 & 2,698 & 2,303 \\
\hline South Oregon coast & 2,946 & 3,256 & 3,435 \\
\hline Total & 5,751 & 5,954 & 5,738 \\
\hline South Oregon: & & & \\
\hline Umpqua River_- & 2,414 & 2,396 & 2,286 \\
\hline Rogue River & 192 & 296 & 462 \\
\hline Total. & 2,606 & 2,692 & 2,748 \\
\hline Region total & 23,241 & 24,677 & 24,648 \\
\hline Summary by distriets: & Percent & Percent & Percent \\
\hline Puget Sound....... & 21. 2 & 21.1 & . 20.9 \\
\hline Grays Harbor. ..... & 8. 2 & 7.2 & 5.9 \\
\hline Columbia River & 16.5 & 18.3 & 19. 3 \\
\hline Willamette River..... & 18.1 & 18.4 & 19.5 \\
\hline Oregon coast......... & 24.8 & 24.1 & 23.3 \\
\hline South Oregon & 11. 2 & 10. 9 & 11.1 \\
\hline Total & 100.0 & 100.0 & 100.0 \\
\hline
\end{tabular}

2. Data are shown only for stands 160 years or less in age, on commercial conifer forest land.

2 Estimated in 32-foot logs to 12 -inch top, Scribner rule.

3 Data exclude growth on 182,060 acres of potential conifer forest land temporarily occupied by hardwoods.

4 Data exclude growth on 14,520 acres of potential conifer forest land temporarily occupied by hardwoods.
This process resulted in the periodic net conifer growth figures shown in table 42. Because relatively little increment is contributed by hardwoods, periodic growth was computed only for the conifer types.

It is estimated that those of the existing conifer stands that survive to 1943 will put on a net growth of 23.2 billion board feet during the decade 1933-42, those that survive to 1953 will grow 24.7 billion board feet during the decade 1943-52, and those that survive to 1963 will grow 24.6 billion board feet during the decade 1953-62. According to the estimates of decadal volume increment and those of depletion (shown in table 20), the 1933 net volume inventory of 546 billion board feet, log scale, for the region will be reduced to 492 billion board feet by 1943, to 431 billion by 1953 , and to 381 billion by 1963 .

\section{Method of Computing Realizable Mean Annual Growth}

For those who are interested in the detail of the technique employed in computing realizable mean annual growth, a sample computation is given in table 43. Calculations for type 6 (Douglas-fir old growth more than 40 inches d. b. h.) appear in the first three lines. Type 6 is assumed to be nongrowing, and accordingly no stocking value is shown for it. The value in line 2, column 13, was calculated on the assumption that 80 percent of the area depleted in 1933-42 will restock by 1948 . The assumed average stocking of this area is indicated in line 2, column 5, and the estimated average age attained by the second-growth stands is shown in line 2 , column 15. The entry in line 2 , column 19 , is 55 percent of normal mean annual growth per acre for Douglas-fir stands to age 85 years. The entry in line 2, column 24, is the product of those in line 2, columns 13 and 19. Since growth is calculated only from the middle of the period 1933-42, half this amount is entered in line 2, column 26. Since it is assumed that the second-growth stands will continue to grow during the whole of the period 1953-62, the total value is given in line 2, column 27. The entries in line 3 were calculated in the same way as those in line 2.

Calculations for type 8 (Douglas-fir second growth, 22 to 40 inches d. b. h.) appear in lines 4, 5, and 6. The growth rate applied for the first decade (line 4, column 16) is the periodic annual growth rate for ages 90 to 94 years, inclusive, of normal Douglas-fir stands on sites of a quality midway between II and III multiplied by 0.60 , the estimated average stocking for type 8 . Growth is assumed only to the middle of the decade 1933-42. The growth rate applied to the type 8 area assumed to be depleted during the decade $1943-52$ is the periodic annual rate for ages 90 to 104 years, similarly adjusted for stocking. Growth is assumed only during three-fourths of the 20-year period 1933-52. In calculating growth on the area assumed to be depleted during the decade 1953-62, the equivalent of 0.833 of the 49,000 acres was assumed to be growing during the entire 30-year period 1933-62 and the normal periodic 
TABLE 43.-Sample computation of realizable mean annual growth

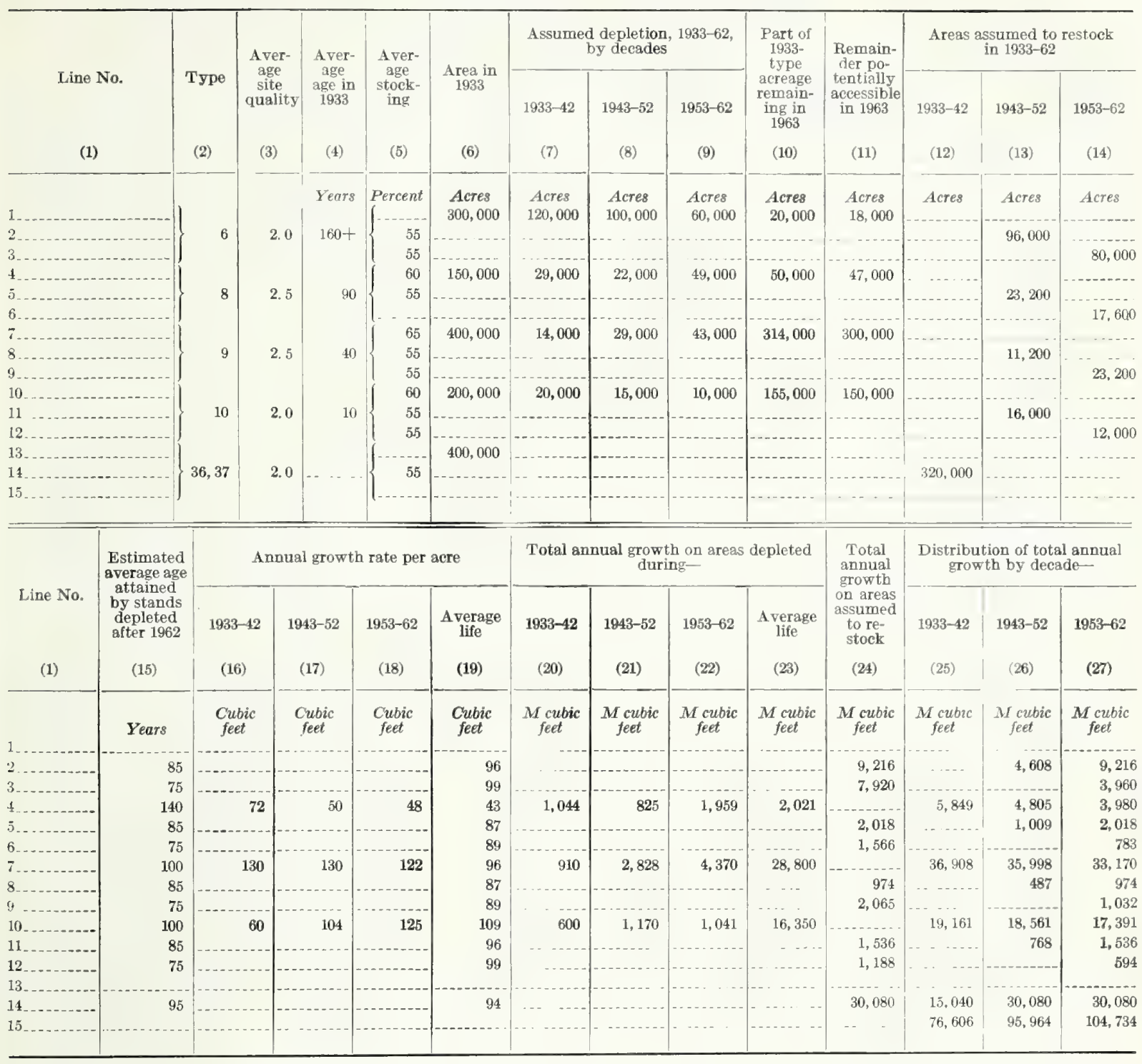

annual growth rate for ages 90 to 119 years, inclusive, was similarly adjusted for stocking.

In line 4 the entry in column 25 is the sum of those in columns $20,21,22$, and 23; the entry in column 26 is the sum of those in columns 21,22, and 23; and the entry in column 27 is the sum of those in columns 22 and 23.

In the calculations for type 8 area as in those for type 6 area, 80 percent of the portion depleted each decade is assumed to restock by the midpoint of the following decade.
The growth figured on the restocking areas is mean annual growth for the period from time of restocking until 2032. Results of this computation are shown in lines 5 and 6 .

The procedure in growth calculations for the other types is essentially similar in detail to that already described.

The sums of columns 25,26, and 27, shown in line 15 , are realizable mean annual growth for the decades 1933-42, 1943-52, and 1953-62, respectively, for the aggregate of type areas in the sample unit. 


\section{Supplemental Tables}

Supplemental estimates of average annual fire damage are shown for the national forests, for other lands, and for all lands in the Douglas-fir region as follows: Forest-land area covered and timber volume, $\log$ scale, lost by fire, by type and site quality, table 44 ; area deforested by fire, by type and survey unit, tables 45,46 , and 47 ; and timber volume, log scale, lost by fire, by type and survey unit, table 48.

Net average annual rate of depletion from causes other than cutting, used in calculating assumed future depletion, is shown by type group in table 49 . Assumed future decadal depletion from all causes is shown by district and ownership class in table 50 .

Rates used in calculating potential annual growth on conifer timber are given in table 51.

Saw-timber data for some forest regions of the United States have been published in lumber tally rather than log scale. In order to facilitate comparison with those data, saw-timber volume for the Douglas-fir region is given in lumber tally in table 52. Lumber-tally values are given for cutting depletion in tables 53 and 54, for fire depletion in table 55, for assumed future depletion in table 56, for current annual growth in table 57 , for potential annual growth in table 58, for realizable mean annual growth in table 59, and for periodic growth in table 60.

TABLE 44.-Estimated annual averages of forest-land area burned over and timber volume ${ }^{1}$ lost by fire in the Douglas-fir region in 1924-33, by type and site quality

ON NATIONAL FORESTS

\begin{tabular}{|c|c|c|c|c|c|c|c|c|c|c|c|}
\hline \multirow{2}{*}{$\frac{\begin{array}{c}\text { Type } \\
\text { No. }\end{array}}{}$} & \multirow[t]{2}{*}{ Type } & \multicolumn{2}{|c|}{ Site $\Pi$} & \multicolumn{2}{|c|}{ Site III } & \multicolumn{2}{|c|}{ Site IV } & \multicolumn{2}{|c|}{ Site V } & \multicolumn{2}{|c|}{ Total } \\
\hline & & $\begin{array}{r}\text { Acres } \\
35\end{array}$ & $\begin{array}{c}M \text { board } \\
\text { feet } \\
1,351\end{array}$ & $\begin{array}{r}\text { Acres } \\
487\end{array}$ & $\begin{array}{c}M \text { board } \\
\text { feet } \\
8,132\end{array}$ & $\begin{array}{r}\text { Acres } \\
215\end{array}$ & $\begin{array}{l}\text { M board } \\
\text { feet } \\
2,784\end{array}$ & $\begin{array}{r}\text { Acres } \\
46\end{array}$ & $\begin{array}{c}M \text { board } \\
\text { feet }\end{array}$ & $\begin{array}{r}\text { Acres } \\
783\end{array}$ & $\begin{array}{c}M \text { board } \\
\text { fect } \\
12,267\end{array}$ \\
\hline $7 \ldots$ & Douglas-fir, small old growth & 9 & 272 & 784 & 13,998 & 3,546 & 38,562 & 232 & 190 & 4,571 & 53,022 \\
\hline 8.-. & Douglas-fir, large second growth & 7 & 181 & 64 & 828 & 14 & 3 & & & 85 & 1.012 \\
\hline $11 \ldots$ & Sitka spruce, large & 8 & 432 & & & & & & & 8 & 432 \\
\hline $14 \ldots$ & Western hemlock, large & 10 & 316 & 269 & 8,097 & 561 & 12,951 & 182 & & 1,022 & 21,364 \\
\hline $17 \ldots$ & Testern redcedar, large & 3 & 10 & 25 & 843 & & ...... & $\ldots$ & & 28 & 853 \\
\hline $18 \ldots$ & Port Orford white-cedar, large & ...- & & & & 16 & 4 & & & 16 & 4 \\
\hline $20 \ldots$ & Ponderosa pine, large & & & 85 & 91 & 63 & 131 & 4 & 5 & 152 & 227 \\
\hline $23 \ldots$ & Fir-mountain hemlock, large & & & 43 & 123 & 397 & $4,0 \overline{1}$ & 238 & 249 & 678 & 4,443 \\
\hline $27 \ldots$ & White fir-larch-Douglas-fir, large... & ... & & $\ldots$ & .. & 8 & 166 & & & 8 & 166 \\
\hline $9 \ldots$. & Douglas-fir, small second growth & 8 & & 442 & $\ldots$. & $2 \pi 4$ & $\ldots$ & 32 & & 756 & .... \\
\hline $10 \ldots$ & Douglas-fir, seedlings and saplings... & 89 & & 2,934 & & 2.637 & & 185 & & 5,845 & -...- \\
\hline $13 \ldots$ & Sitka spruce, seedlings and saplings._. & 2 & & ..... & & & .... & & & 2 & -.... \\
\hline $15 \ldots$ & Western hemlock, small & & & 2 & & & ... & 360 & & 362 & .... \\
\hline 16 & Western hemlock, seedlings and saplings.. & $\ldots$ & & 2 & & 12 & ..... & 4 & & 18 & (n..... \\
\hline 21 & Ponderosa pine, small. . . . . . . . . . & & & & & 2 & -- & -.. - & & 2 & $\ldots$ \\
\hline 22. & Ponderosa pine, seedlings and saplings ... & & & 8 & & 13 & .... & ..... & & 21 & ...... \\
\hline 24. & Fir-mountain hemlock, small ........... & & & 36 & & 878 & $\ldots$ & 43 & & 957 & -... \\
\hline & Lodgepole pine, small. ... ..... & & & 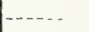 & & & $\cdots$ & ...... & & 281 & \\
\hline 28 & White fir-larch-Douglas-fir, small.. & & & & & 11 & & & & 11 & ....- \\
\hline 32 & 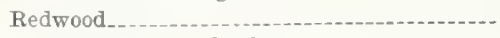 & & & 5 & & ... & ...... & & & 5 & -.... \\
\hline & Oak-madrone woodland.... & & & & & & & & & ${ }^{2} 66$ & \\
\hline 31 & Hardwoods & & & & & & & & & 234 & $\ldots$ \\
\hline 35 & Old cut-overs, nonrestocked.-. & & 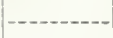 & 12 & & 182 & & & & 194 & \\
\hline 36 & Recent cut-overs & 188 & & 783 & & 68 & & & & 1,039 & \\
\hline 37 & Previously deforested burns........ & 3 & & 1,228 & & 2,544 & & 203 & & 3,978 & \\
\hline $33 \ldots \ldots$ & Subalpine_................... & $\ldots$ & --------. & ........ & 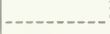 & & 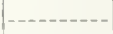 & -...- & & 21,922 & \\
\hline \multirow[t]{2}{*}{$38 \ldots$} & Noncommercial rocky areas.... & & & & & & & & & 21,066 & \\
\hline & Total & 362 & 2,562 & 7,209 & 32,112 & 11,441 & 58,672 & 1,529 & 444 & 23,710 & 93,790 \\
\hline
\end{tabular}

ON LANDS OTHER THAN NATIONAL FORESTS

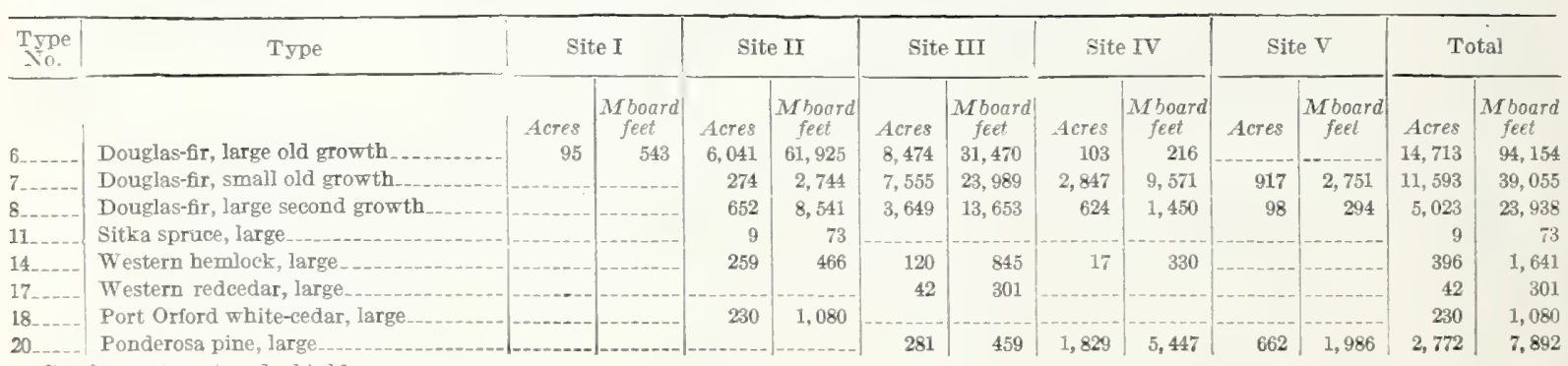


TABLE 44.-Estimated annual averages of forest-land area burned over and timber volume lost by fire in the Douglas-fir region in 1924-33, by type and site quality - Continued

ON LANDS OTHER THAN NATIONAL FORESTS-Continued

\begin{tabular}{|c|c|c|c|c|c|c|c|c|c|c|c|c|c|}
\hline \multirow{2}{*}{$\begin{array}{l}\text { Type } \\
\text { No. }\end{array}$} & \multirow[b]{2}{*}{ Sugar nine large } & \multicolumn{2}{|c|}{ Site I } & \multicolumn{2}{|c|}{ Site IL } & \multicolumn{2}{|c|}{ Site III } & \multicolumn{2}{|c|}{ Site IV } & \multicolumn{2}{|c|}{ Site V } & \multicolumn{2}{|c|}{ Total } \\
\hline & & Acres & $\begin{array}{c}\text { Mboard } \\
\text { fect }\end{array}$ & Acres & $\begin{array}{c}\text { Mboard } \\
\text { feet }\end{array}$ & Acres & $\begin{array}{c}\text { Mboard } \\
\text { feet }\end{array}$ & $\begin{array}{r}\text { Acres } \\
103\end{array}$ & $\begin{array}{c}\text { Mboard } \\
\text { feet } \\
309\end{array}$ & $\begin{array}{r}\text { Acres } \\
80\end{array}$ & $\begin{array}{c}\text { Mboard } \\
\text { feet } \\
240\end{array}$ & $\begin{array}{r}\text { Acres } \\
183\end{array}$ & $\begin{array}{c}M \text { board } \\
\text { feet } \\
544\end{array}$ \\
\hline $23 \ldots$ & Fir-mountain hemlock, large.......... & & & & & & & 670 & Q, 930 & & & 670 & 9.930 \\
\hline $9 \ldots$ & Douglas-fir, small second growth & 32 & & 2,702 & & 11,588 & & 3,718 & & 928 & & 18,968 & \\
\hline $10 \ldots$ & Douglas-fir, seedlings and saplings..--_ & 112 & & 16,632 & & 23,570 & & 8,721 & & 178 & & 49,213 & \\
\hline $12 \ldots$ & Sitka spruce, small & $-\ldots$ & & 61 & & 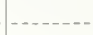 & & 14 & & & & 75 & \\
\hline $13 \ldots$ & Sitka spruce, seedlings and saplings.... & & & 16 & & & & & & & & 16 & \\
\hline $15_{\ldots} \ldots .$. & Western hemlock, small ... & & & 229 & & 11 & & 2 & & & & 242 & ....... \\
\hline $16 \ldots$ & $\begin{array}{l}\text { Western hemlock, seedlings and sap- } \\
\text { lings. }\end{array}$ & 12 & & 253 & & 158 & & 66 & & & & 489 & $\ldots$ \\
\hline $19 . \ldots$ & 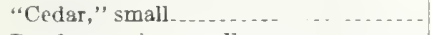 & & & 2 & & 80 & & & & ... & & 82 & \\
\hline $21 \ldots$ & Ponderosa pine, small & & & & & 56 & & 795 & & 21 & & 872 & . . \\
\hline $22 \ldots$ & Ponderosa pine, seedlings and saplings _- & & & 42 & & 330 & & 2,497 & & 1,138 & & 4,007 & \\
\hline $24 \ldots$ & $\begin{array}{l}\text { Fir-mountain hemiock, small } \\
\text { Lodgepole pine, small }\end{array}$ & -. & - & $\ldots . .$. & .... & 45 & & 104 & &.- & & $\begin{array}{r}149 \\
275\end{array}$ & \\
\hline $\begin{array}{l}26 \ldots \ldots \\
51 / 2 \ldots\end{array}$ & Ponderosa pine woodland........... & & & & & & & & & & & 23,452 & \\
\hline $4 \ldots$ & Oak-madrone woodland............. & & & & & & & & & & & 24,081 & \\
\hline 31. & Hardwoods $\ldots \ldots$ & -. &.- & & & & 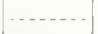 & & & & & 22,203 & $\ldots-\ldots$ \\
\hline $35_{--+}$ & Old cut-overs, nonrestocked.............. & 37 & --- & 3,784 & & 6,567 & & 2,020 & & 32 & & 12,440 & \\
\hline $36 \ldots$ & Recent cut-overs & 1,772 & - & 33,523 & 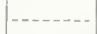 & 37,301 & & 11,045 & & 156 & & 83,797 & \\
\hline $37 . \ldots$ & Previously deforested burns . ........ & ........ & ...... & 1,809 & & 8,490 & $\ldots \ldots$ & 2,498 & & $65 \%$ & & 13,454 & \\
\hline $33 \ldots$ & Subalpine $\ldots \ldots \ldots$. ........ & ....... & -. & ....... & ….... & $\ldots$. & $\ldots \ldots$ & & .. & -.. & & ${ }^{2} 184$ & +2 \\
\hline \multirow[t]{2}{*}{$38 \ldots$} & Noncommercial rocky areas . _ . ...... & …... & $\ldots$ & …..- & $\ldots \ldots$ & $\ldots$ & & & $\ldots \ldots$ & & & ${ }^{2} 16$ & \\
\hline & - & 2,060 & 543 & 66,518 & 74,829 & 108,317 & 70,717 & 37,673 & 27,253 & 4,867 & 5,271 & 229,446 & 178,613 \\
\hline
\end{tabular}

\section{ALL FOREST LANDS}

\begin{tabular}{|c|c|c|c|c|c|c|c|c|c|c|c|c|c|}
\hline & Douglas-fir, large old growth.......... & 95 & 543 & 6,076 & 63,276 & 8.961 & 39,602 & 318 & 3,000 & 46 & & 15,496 & 106,421 \\
\hline & Douglas-fir, small old growth & & & 283 & 3,016 & 8,339 & 37,987 & 6,393 & 48,133 & 1,149 & 2,941 & & 92,077 \\
\hline-1 & Douglas-fir, large second growth... & & & 659 & 8,722 & 3,713 & 14,481 & 638 & 1,453 & 98 & 294 & 5,108 & 24,950 \\
\hline 1 1. & itka spruce, large & & & 17 & 505 & & & & & & & 17 & 505 \\
\hline 4 & 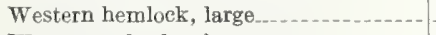 & & & 269 & 782 & 38 & & 578 & & 182 & & & 3,005 \\
\hline 7. & 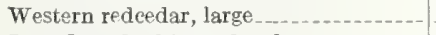 & & & 3 & 10 & 67 & & & & & & & 1,154 \\
\hline 8 . & ort & & & 230 & 1,080 & & & 16 & 4 & & & & \\
\hline $0 \ldots$ & onderos & & & & & 366 & 550 & 1,892 & 5,578 & 666 & 1,991 & 2,9 & 3,119 \\
\hline $20 \mathrm{~A}$ & uga & & & & & & & 103 & & 80 & 240 & & 549 \\
\hline 23 & Fir - & & & & & 43 & 123 & 1,067 & 14,0 & 238 & 249 & & 14,373 \\
\hline 7. & Y & & & & & & & 8 & It & & & & 166 \\
\hline - & & 32 & & 2,710 & & & & 3,992 & & 960 & & & \\
\hline $10 \ldots$ & saplings......- & 112 & & 16,721 & & 26,504 & & 11,358 & & 363 & & & \\
\hline 12. & Sitk & & & 61 & & & & 14 & & .... & & 75 & \\
\hline 13. & Sitk & & & & & & & & & & & & \\
\hline $15 \ldots$ & 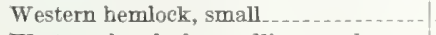 & & & 229 & & 13 & & 2 & & 360 & & 604 & \\
\hline & hemlock, seedlings and sap- & & & & & & & 78 & & 4 & & & \\
\hline 9 & small & & & 2 & & 80 & & & & & & 82 & \\
\hline 1 & Pon & & & & & 56 & & 797 & & 21 & & & \\
\hline $2 \ldots$ & and saplings & & & 42 & & 338 & & 2,510 & & 1,138 & & & \\
\hline 24 . & emlock, small . ... & & & - . . & - - & 81 & & 982 & & 43 & & 1. 176 & \\
\hline 26. & Lodg & & & & & - & & -.... & & & & 2156 & \\
\hline $8 \ldots$ & Wh & & & & & & & 11 & & & & 11 & \\
\hline $2 \ldots$ & 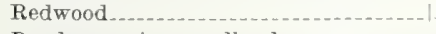 & & & & & 5 & & & & & & & \\
\hline $132 \ldots$ & Pon & & & & & & & & . - & & - & 23,452 & \\
\hline & Oak & & & & & & & & & & & & \\
\hline & F & 3 & & & & & & 2,202 & & 32 & & & \\
\hline $36 . .$. & Rec & 1,772 & & 33,711 & & 38. & & 11,113 & & 156 & & & \\
\hline & Previously deforested burns & & & 1,812 & & 9,718 & & 5,042 & & 860 & & & \\
\hline 33. - . & Subalpine ............... & & & $\ldots . .$. & & & & & & & & & \\
\hline \multirow[t]{2}{*}{$38 \ldots$} & Noncommen̈cial rocky areas _... & & & & & & & $-\ldots$ & & - th- & & 1,082 & \\
\hline & & 2,060 & 543 & 66,880 & 77,391 & 115,526 & 102,829 & 49,114 & 85,925 & 6,396 & 5,715 & 253,156 & 272,403 \\
\hline
\end{tabular}

1 Data for national-forest lands were averages for 1924-33; data for other lands were averages for 1926-30.

3 Unclassified; total of these items: national forests, 3,169 acres; other lands, 10,011 acres, aggregate, 13,180. acres. 
TABLE 45.-Estimated annul averages of area burned over on national forests in the Douglas-fir region in 1924-33, by type and survey unit

\begin{tabular}{|c|c|c|c|c|c|c|c|c|}
\hline \multirow[b]{2}{*}{$\begin{array}{l}\text { Type } \\
\text { No. }\end{array}$} & \multirow[b]{2}{*}{ Type } & \multirow[b]{2}{*}{ fll } & \multicolumn{6}{|c|}{ Western Washington } \\
\hline & & & $\begin{array}{l}\text { North } \\
\text { Puget } \\
\text { Sound }\end{array}$ & $\begin{array}{l}\text { Central } \\
\text { Puget } \\
\text { Sound }\end{array}$ & $\begin{array}{l}\text { South } \\
\text { Puget } \\
\text { Sound }\end{array}$ & $\begin{array}{l}\text { Grays } \\
\text { Harbor }\end{array}$ & $\begin{array}{l}\text { Columbia } \\
\text { River }\end{array}$ & Total \\
\hline $6 \ldots$ & Douglas-fir, large old growth..-- & $\begin{array}{l}\text { Acres } \\
\quad 783\end{array}$ & ${ }^{\text {Acres }}{ }_{54}$ & $\begin{array}{l}\text { Acres } \\
\end{array}$ & ${ }_{14}^{\text {Acres }}$ & Acres & $\begin{array}{l}\text { Acres } \\
\quad 347\end{array}$ & Acres $_{439}$ \\
\hline $7 \ldots \ldots+(-. .-(3)$ & Douglas-fir, small old growth & 4,571 & 1,619 & 733 & & & 84 & 2,436 \\
\hline 8..... & Douglas-fir, large second growth & 85 & 7 & 7 & 1 & & 11 & 26 \\
\hline $11 \ldots$ & Sitka spruce, large & 8 & & & & 8 & & \\
\hline 14 & Western hemlock, large & 1,022 & 711 & 282 & 2 & 11 & 4 & 1,010 \\
\hline $17-\ldots$ & Western redcedar, large & 28 & 25 & 3 & & & & 28 \\
\hline 18 & Port O-ford white-cedar, large & 16 & & & & & & \\
\hline $20 \ldots$ & Pouderosa pine, large & 152 & & & & & & \\
\hline $20 \mathrm{~A}$ & Sugar pine, large & & & & & & & \\
\hline $23 \ldots \ldots-.$. & Fir-mountain hemlock, large & 678 & 211 & 264 & 47 & 2 & 27 & 551 \\
\hline $27 \ldots . .$. & White fir-larch-Dourlas-fir, large.... & 8 & & & & & 8 & 8 \\
\hline 9. --.-- & Douglas-fir, small second growth & 756 & 155 & 46 & 56 & & 20 & 277 \\
\hline 10 & $\begin{array}{l}\text { Douglas-fir, seedlings and saplings_-_.-..- } \\
\text { Sitka spruce, small }\end{array}$ & 5,845 & 258 & 551 & 102 & & 3,294 & 4,205 \\
\hline $12 \ldots$ & $\begin{array}{l}\text { Sitka spruce, small } \\
\text { Sitka spruce, seedlings and saplings }\end{array}$ & 2 & & & & & & \\
\hline $13 \ldots$ & $\begin{array}{l}\text { Sitka spruce, seedlings and saplings } \\
\text { Western hemlock, small }\end{array}$ & 362 & - & 358 & & & & 358 \\
\hline $\begin{array}{l}15 \ldots \\
16\end{array}$ & & 18 & 14 & 1 & & 1 & & $\begin{array}{r}358 \\
16\end{array}$ \\
\hline $19 \ldots$ & "Cedar," small... ... ... & & & & & & & \\
\hline $21 \ldots$ & Ponderosa pine, small & 2 & & & & & & \\
\hline $22 \ldots-$. & Ponderosa pine, seedlings and saplings... & 21 & & & & & & 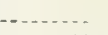 \\
\hline $24 \ldots$ & Fir-mountain hemlock, small $\ldots$ & 957 & 71 & 13 & 1 & & 849 & 934 \\
\hline $26 \ldots$ & Lodgepole nine, small _... & 81 & 63 & & & & & 63 \\
\hline $28 \ldots$ & White fir-larch-Douglas-fir, small & 11 & & & & & & \\
\hline $32 \ldots . .$. & Redwood $\ldots \ldots \ldots$ & 5 & & & & & & \\
\hline $51 / 2 \ldots--$ & Ponderosa pine woodland.... & & & & & & & \\
\hline $4 \ldots-\ldots$ & Oak-madrone woodland........ & 66 & & & & & & \\
\hline $31 \ldots$ & Hardwoods & 34 & & 5 & & & & 5 \\
\hline $35 \ldots . . .$. & old cut-overs, nonrestocked ...... & 194 & & & & & 12 & 12 \\
\hline 36 & Recent cut-overs & 1,039 & 37 & 625 & 15 & 179 & 67 & 923 \\
\hline $37 \ldots \ldots$ & Previously deforested burns & 3,978 & 90 & 144 & 11 & & 1,142 & 1,387 \\
\hline 33_....- & Subalpine & 1,922 & 1,654 & 227 & 9 & & & 1,890 \\
\hline \multirow[t]{2}{*}{ 38_-_-- } & Noncommereial rocky areas. & 1,066 & 331 & 24 & 6 & & 303 & 664 \\
\hline & Total-.. & 23,710 & 5,300 & 3,307 & 264 & 201 & 6,168 & 15,240 \\
\hline
\end{tabular}

\begin{tabular}{|c|c|c|c|c|c|c|c|c|}
\hline \multirow[b]{2}{*}{$\begin{array}{l}\text { Type } \\
\text { No. }\end{array}$} & \multirow[b]{2}{*}{ Type } & \multicolumn{7}{|c|}{ Western Oregon } \\
\hline & & $\begin{array}{l}\text { Columbia } \\
\text { River }\end{array}$ & $\begin{array}{c}\text { Willamette } \\
\text { River }\end{array}$ & $\begin{array}{l}\text { North } \\
\text { Oregon } \\
\text { coast }\end{array}$ & $\begin{array}{l}\text { Umpqua } \\
\text { River }\end{array}$ & $\begin{array}{l}\text { South } \\
\text { Oregon } \\
\text { coast }\end{array}$ & $\begin{array}{l}\text { Rogue } \\
\text { River }\end{array}$ & Total \\
\hline $6 \ldots$ & Douglas-fir, large old growth & ${ }_{26}^{\text {Acres }}$ & $\begin{array}{l}\text { Acre } \\
\quad 254\end{array}$ & ${ }_{3}^{\text {Acres }}$ & $\begin{array}{l}\text { Acres } \\
\\
23\end{array}$ & $\begin{array}{l}\text { Acres } \\
\\
16\end{array}$ & ${ }_{22}^{\text {Acres }}$ & $\begin{array}{l}\text { Acres } \\
344\end{array}$ \\
\hline 7 & Douglas-fir, small old growth & 141 & 53 & & 573 & 1,070 & 298 & 2,135 \\
\hline 8 & Douglas-fir, large second growth & 10 & 19 & 20 & 1 & & 9 & 59 \\
\hline 14 & $\begin{array}{l}\text { Stka spruce, large } \\
\text { Western hemlock, large }\end{array}$ & 9 & 3 & & & & & 12 \\
\hline 17 & Western redcedar, large & & & & & & & \\
\hline $18 \ldots$ & Port Orford white-cedar, large & & & & & 16 & & 16 \\
\hline $20 \ldots$ & Ponderosa pine, large & & & & 22 & 72 & 58 & 152 \\
\hline $20 \mathrm{~A}_{-}$ & Sugar pine, large & & & & & & & \\
\hline $23 \ldots$ & Fir mountain hemlock, large & & 42 & & 9 & & 76 & 127 \\
\hline $27 \ldots$ & White fir-larch-Douglas-fir, large & & & & & & & \\
\hline $9 \ldots$ & Douglas-fir, small second growth_._._...- & 118 & 201 & 22 & 64 & 47 & 27 & 479 \\
\hline 10 & Douglas-fir, seedlings and saplings.... & 70 & 184 & 48 & 169 & 1,089 & 80 & 1,640 \\
\hline 12 & Sitka spruce, small & - & & & & & & \\
\hline $13 \ldots$ & Sitka spruce, seedlings and saplings & 4 & 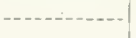 & 2 & & & & 2 \\
\hline $15 \ldots$ & Western hemlock, small $\ldots$ & 4 & & & & & & \\
\hline $16 \ldots$ & Western hemlock, seedlings and saplings & 2 & & & & & & 2 \\
\hline $19 \ldots$ & "Cedar." small & & & & & & & \\
\hline $21 \ldots . .$. & Ponderosa pine, small & & & & & & 2 & 2 \\
\hline $22 \ldots$ & Ponderosa pine, seedlings and saolings.... & & & & 7 & & 14 & 21 \\
\hline
\end{tabular}


TABLE 45.-Estimated annual averages of area burned over on national forests in the Douglas-fir region in 1924-33, by type and survey unitContinued

\begin{tabular}{|c|c|c|c|c|c|c|c|c|}
\hline \multirow[b]{2}{*}{$\begin{array}{l}\text { Type } \\
\text { No. }\end{array}$} & \multirow[b]{2}{*}{ Type } & \multicolumn{7}{|c|}{ Western Oregon } \\
\hline & & $\begin{array}{c}\text { Columbia } \\
\text { River }\end{array}$ & $\begin{array}{l}\text { Willamette } \\
\text { River }\end{array}$ & $\begin{array}{l}\text { North } \\
\text { Oregon } \\
\text { Coast }\end{array}$ & $\begin{array}{l}\text { Umpqua } \\
\text { River }\end{array}$ & $\begin{array}{l}\text { South } \\
\text { Oregon } \\
\text { Coast }\end{array}$ & $\begin{array}{l}\text { Rogue } \\
\text { River }\end{array}$ & Total \\
\hline $24 \ldots$ & Fir-mountain-hemlock, small & ${ }^{\text {Acres }}{ }_{17}$ & ${ }^{\text {Acres }}{ }_{5}$ & Acres & Acres & Acres & Acres & ${ }^{\text {Acres }}{ }_{23}$ \\
\hline $26 \ldots$ & Lodgepole pine, small & & & & 10 & 5 & 3 & 18 \\
\hline $28 \ldots . .$. & White fir-larch-Douglas-fir, small. & 11 & & & & & & 11 \\
\hline $32 \ldots$ & Redwood & & & & & 5 & & 5 \\
\hline $51 / 2 \ldots$ & Ponderosa pine woodland...... & & & & & & & \\
\hline $4 \ldots-$. & Oak-madrone woodland & & & & & & 66 & 66 \\
\hline $31 \ldots$ & Hardwoods .................... & & 23 & 6 & & & & 29 \\
\hline $35 \ldots$ & Old cut-overs, nonrestocked...... & & & & & 182 & & 182 \\
\hline $36 \ldots$ & Recent cut-overs ..................... & 60 & 26 & 2 & & 28 & & 110 \\
\hline 37 --- & Previously deforested burns & 208 & 176 & 188 & 296 & 978 & $7 \pm 5$ & 2,591 \\
\hline $33 \ldots$ & Subalpine $\ldots$... & & 32 & ... & & & & 32 \\
\hline \multirow[t]{2}{*}{$38 \ldots .}$. & Noncommercial rocky areas & -........ & 3 & -.. & 5 & 381 & 13 & 402 \\
\hline & Total_... & 676 & 1,021 & 291 & 1,180 & 3,889 & 1,413 & 8,470 \\
\hline
\end{tabular}

TABLE 46.-Estimated annual averages of area burned over on lands other than national forests in the Douglas-fir region in 1926-30, by type and survey unit

\begin{tabular}{|c|c|c|c|c|c|c|c|c|}
\hline \multirow[b]{2}{*}{$\begin{array}{l}\text { Type } \\
\text { No. }\end{array}$} & \multirow[b]{2}{*}{ Туре } & \multirow[b]{2}{*}{$\begin{array}{c}\text { All } \\
\text { forests }\end{array}$} & \multicolumn{6}{|c|}{ Western W ashington } \\
\hline & & & $\begin{array}{l}\text { North } \\
\text { Puget } \\
\text { Sound }\end{array}$ & $\begin{array}{l}\text { Central } \\
\text { Puget } \\
\text { Sound }\end{array}$ & $\begin{array}{l}\text { South } \\
\text { Puget } \\
\text { Sound }\end{array}$ & $\begin{array}{c}\text { Grays } \\
\text { Harbor }\end{array}$ & $\begin{array}{c}\text { Columbia } \\
\text { River }\end{array}$ & Total \\
\hline 6... & Douglas-fir, large old growth & $\begin{array}{l}\text { Acres } \\
14,713\end{array}$ & $\begin{array}{l}\text { Acres } \\
\quad 216\end{array}$ & $\begin{array}{l}\text { Acres } \\
\quad 794\end{array}$ & $\begin{array}{l}\text { Acres } \\
\quad 887\end{array}$ & $\begin{array}{l}\text { Acres } \\
\quad 187\end{array}$ & $\begin{array}{l}\text { Acres } \\
1,122\end{array}$ & $\begin{array}{l}\text { Acres } \\
\quad 3,206\end{array}$ \\
\hline $7 \ldots$ & Douglas-fir, small old growth...... & 11,593 & & 419 & 2 & $\ldots$ & & 421 \\
\hline 8_..... & Douglas-fir, large second growth & 5,023 & 17 & 415 & 267 & & 207 & 906 \\
\hline $11 \ldots$ & Sitka spruce, large & 9 & & & & & & -. \\
\hline $14 \ldots$ & Western hemlock, large...... & 396 & 114 & 4 & 33 & 12 & 7 & 170 \\
\hline 17. & Western redcedar, large & 42 & 42 & & $\ldots \ldots$ & & & 42 \\
\hline 18 & Port Orford white-cedar, large & 230 & & & - ...... & n....... & & \\
\hline $20 \ldots$ & Ponderosa pine, large & $2, \pi i 2$ & & & $\ldots$ & . n & & \\
\hline $20 \mathrm{~A}$ & Sugar pine, large & 183 & & & & ....... & & \\
\hline $23 \ldots$ & Fir-mountain hemlock, large & 670 & & 670 & $-\ldots$. & ....... & & 670 \\
\hline $27 .-$. & White fir-larch-Douglas-fir, large & -.... & & & & & & \\
\hline 9 & Douglas-fir, small second growth & 18.968 & 350 & 1,718 & 399 & 1.58 & 3,960 & 6,885 \\
\hline $10 \ldots$ & Douglas-fir, seedlings and saplings..... & 49,213 & 2,148 & 8,797 & 4,652 & 1,132 & 26,483 & 43,212 \\
\hline $12 \ldots$ & Sitka spruce, small ..................... & 75 & & & $\ldots$. & .. & ....- - & \\
\hline $13 \ldots \ldots$ & Sitka spruce, seedlings and saplings........ & 16 & & & & 16 & - & 16 \\
\hline $15 \ldots$ & Western hemlock, small _......... & 242 & 11 & 2 & $\ldots$ & 165 & $-\ldots$ & 178 \\
\hline $16 \ldots$ & Western hemolock, seedlings and saplings............ & 489 & 58 & 66 & $\ldots . .$. & 365 & ....... & 489 \\
\hline $19 \ldots$ & "Cedar," small _. . . . & 82 & 73 & & & y & & 82 \\
\hline 21.... & Ponderosa pine, small $\ldots$ & 872 & & & .... & $\ldots$ & & \\
\hline $22 \ldots$ & Ponderosa pine, seedlings and saplings & 4,007 & & & 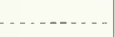 & & -.... & \\
\hline $24 \ldots$ & Fir-mountain bemlock, small $\ldots . . . . .$. & 149 & & 149 & & ...... & & 149 \\
\hline $26 \ldots$ & Lodgepole pine, small . ............ & 75 & & 38 & & 32 & & 70 \\
\hline $28 \ldots$ & White fir-larch-Douglas-fir, small... & (2...... & & & & n....... & & \\
\hline $32 \ldots$ & Redwood & $\ldots$ & & & -...- & & & \\
\hline $51 / 2 \ldots$ & Ponderosa pine woodland ... & 3,452 & & & $\cdots$ & & & \\
\hline $4 \ldots \ldots$ & Oak-madrone woodland....... & 4,081 & & 203 & & $\cdots$ & ....... & $\begin{array}{r}203 \\
2.012\end{array}$ \\
\hline $31 \ldots$ & Hardwoods & 2,203 & 1,335 & 603 & 74 & & & 2,012 \\
\hline $35 \ldots . .$. & Old cut-overs, nonrestocked & 12,440 & 4,028 & 4,048 & 190 & 831 & 1,437 & 10,534 \\
\hline 36 & Recent cut-overs & 83,797 & 10,050 & 18,169 & 8,575 & 9,084 & 6,659 & 52,537 \\
\hline 37 & Previously deforested burns. & 13,454 & & 23 & 10 & & 2,363 & 2,396 \\
\hline $33 \ldots \ldots$ & Subalpine..... & 184 & ..... & 184 & $\ldots$. & & & 184 \\
\hline \multirow[t]{2}{*}{ 38_---- } & Noncommercial rocky areas...-_.-. & 16 & & & & & & \\
\hline & Total _. & 229,446 & 18,442 & 36,302 & 15,089 & 11,991 & 42,238 & 124,062 \\
\hline
\end{tabular}


TABLE 46.-Estimated annual averages of area burned over on lands other than national forests in the Douglas-fir region in 1926-30, by type and survey unit-Continued

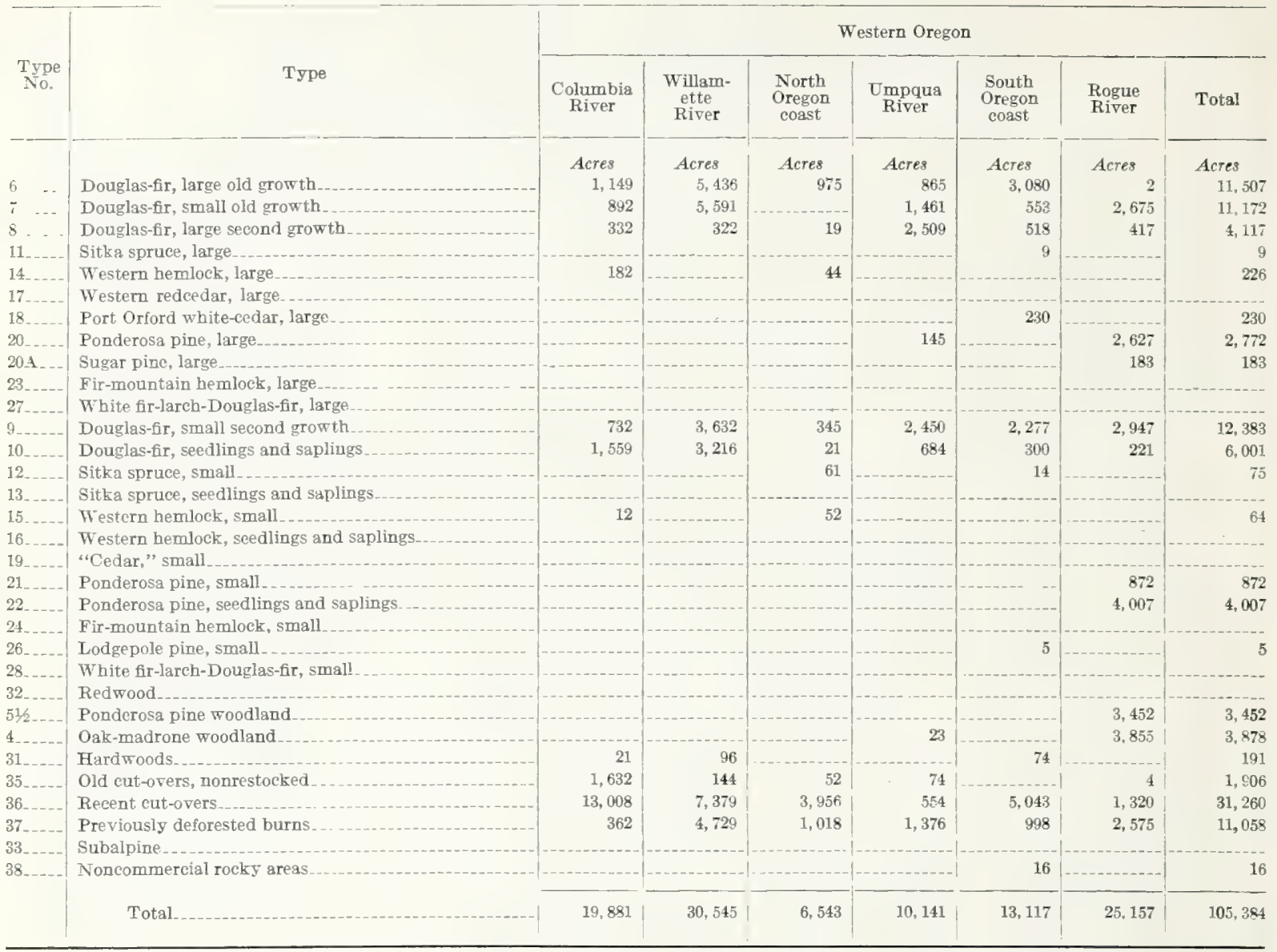

TABLE 47.- Summary of estimated annual averages 1 of area burned over in the Douglas-fir region, by type and survey unit

\begin{tabular}{|c|c|c|c|c|c|c|c|c|}
\hline \multirow[b]{2}{*}{$\begin{array}{l}\text { Type } \\
\text { No. }\end{array}$} & \multirow[b]{2}{*}{ Type } & \multirow[b]{2}{*}{$\underset{\text { forests }}{\text { All }}$} & \multicolumn{6}{|c|}{ Western Washington } \\
\hline & & & $\begin{array}{l}\text { North } \\
\text { Puget } \\
\text { Sound }\end{array}$ & $\begin{array}{l}\text { Central } \\
\text { Puget } \\
\text { Sound }\end{array}$ & $\begin{array}{l}\text { South } \\
\text { Puget } \\
\text { Sound }\end{array}$ & $\begin{array}{c}\text { Grays } \\
\text { Harbor }\end{array}$ & $\begin{array}{l}\text { Columbia } \\
\text { River }\end{array}$ & Total \\
\hline & Donglas-fir, large old growth & $\begin{array}{l}\text { Acres } \\
15,496\end{array}$ & $\begin{array}{l}\text { Acres } \\
270\end{array}$ & $\begin{array}{l}\text { Acres } \\
\quad 818\end{array}$ & $\begin{array}{l}\text { Acres } \\
\quad 901\end{array}$ & $\begin{array}{l}\text { Acres } \\
\quad 187\end{array}$ & $\begin{array}{l}\text { Acres } \\
\quad 1,469\end{array}$ & $\begin{array}{l}\text { Acres } \\
\quad 3,645\end{array}$ \\
\hline 7-...- & Douglas-fir, small old growth & $\begin{array}{l}10,450 \\
16,164\end{array}$ & 1,619 & 1,152 & 2 & 104 & $\begin{array}{r}1, \pm 09 \\
84\end{array}$ & 2.857 \\
\hline $8 \ldots$ & Douglas-fir, large second growth & 5,108 & 24 & 422 & 268 & & 218 & 932 \\
\hline 11 ..... & Sitka spruce, large & 17 & & & & 8 & & \\
\hline $14 \ldots$ & Western hemlock, large & 1,418 & 825 & 286 & 35 & 23 & 11 & 1,180 \\
\hline $17 \ldots$ & Western redcedar, large & 70 & 67 & 3 & & & & 70 \\
\hline $18 \ldots$ & Port Orford white-cedar, large & 246 & & & & & & \\
\hline $20 \ldots$ & Ponderosa pine, large & 2,924 & & - & & & & \\
\hline $20 \mathrm{~A}$ & Sugar pine, large $\ldots \ldots \ldots \ldots$ & 183 & & & & & & ........ \\
\hline $23 \ldots$ & Fir-mountain hemlock, large & 1.348 & 211 & 934 & 47 & 2 & 27 & 1. 221 \\
\hline $27 \ldots$ & White fir-larch-Douglas-fir, large & 8 & & & & & 8 & \\
\hline $9 \ldots \ldots$ & Douglas-fir, small second growth & 19,724 & 505 & 1,764 & 455 & 158 & 3,980 & 6.862 \\
\hline $10 \ldots$ & Douglas-fir, seedlings and saplings...... & 55.058 & 2,406 & 9,348 & 4,754 & 1,132 & 29,777 & 47,417 \\
\hline $12 \ldots$ & Sitka spruce, small $\ldots \ldots \ldots \ldots \ldots$ & 75 & ..... & ........ & ....... & ..... - & & ... ... \\
\hline $13 \ldots$ & Sitka spruce, seedlings and saplings & 18 & - & -. & & 16 & & 16 \\
\hline
\end{tabular}

1 Data for national-forest lands were averages for 1924-33, data for other lands were averages for 1926-30. 
TABLE 47.- Summary of estimated annual averages of area burned over in the Douglas-fir region, by type and survey unit-Continued

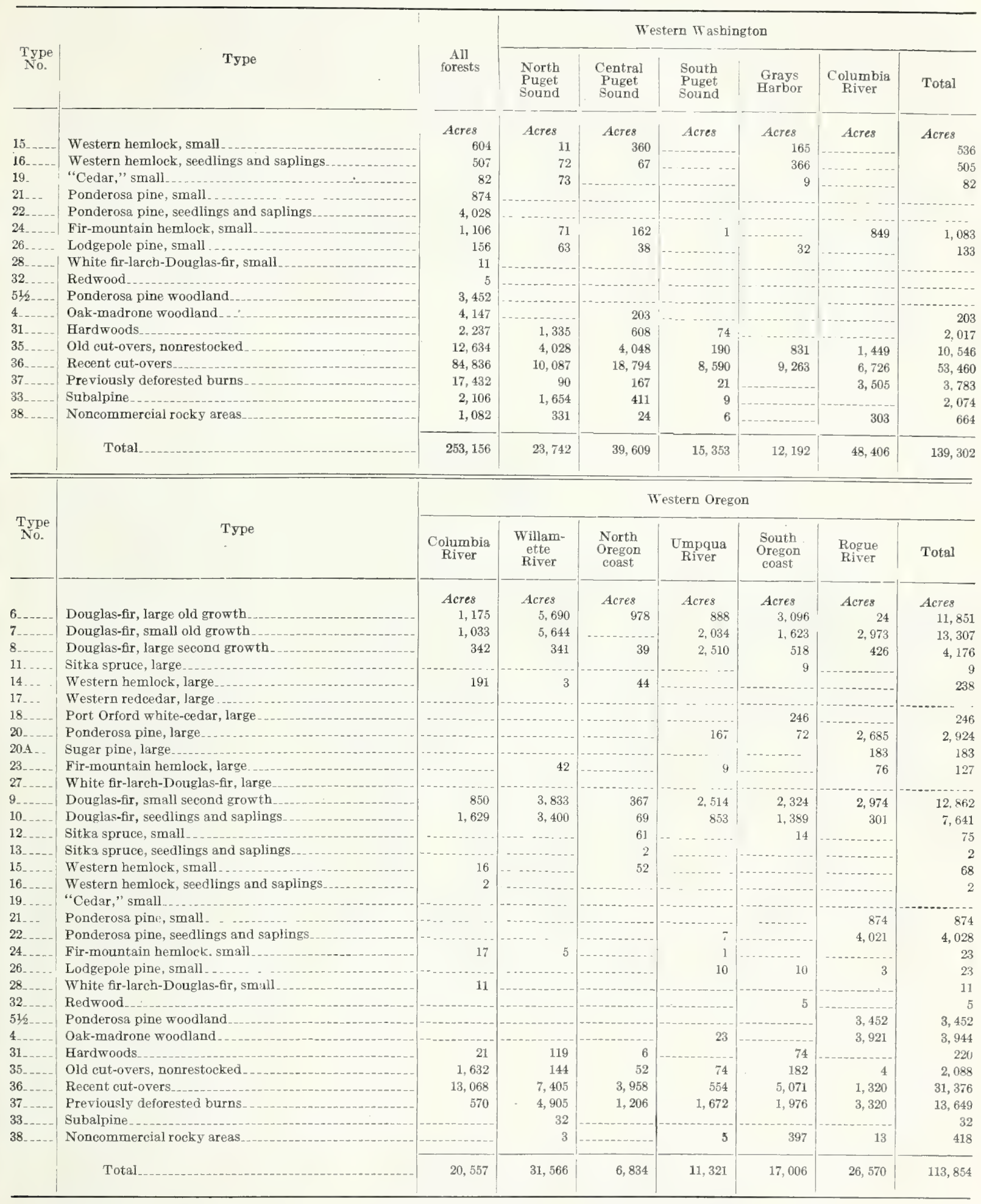


TABLE 48. - Estimated annual averages of timber volume ${ }^{1}$ lost by fire in the Douglas-fir region 2 in 1924-33, by type and survey unit ON NATIONAL FORESTS

\begin{tabular}{|c|c|c|c|c|c|c|c|c|}
\hline \multirow[b]{2}{*}{$\begin{array}{l}\text { Type } \\
\text { No. }\end{array}$} & \multirow[b]{2}{*}{ Type } & \multirow[b]{2}{*}{ All forests } & \multicolumn{6}{|c|}{ Western Washington } \\
\hline & & & $\begin{array}{l}\text { North } \\
\text { Puget } \\
\text { Sound }\end{array}$ & $\begin{array}{l}\text { Central } \\
\text { Puget } \\
\text { Sound }\end{array}$ & $\begin{array}{l}\text { South } \\
\text { Puget } \\
\text { Sound }\end{array}$ & $\begin{array}{l}\text { Grays } \\
\text { Harbor }\end{array}$ & $\begin{array}{l}\text { Columbia } \\
\text { River }\end{array}$ & Total \\
\hline $6 \ldots \ldots$ & Douglas-fir, large old growth... & $\begin{array}{c}M \text { board } \\
\quad \text { feet } \\
\quad 12,267\end{array}$ & $\begin{array}{l}M \text { board } \\
\text { feet } \\
\quad 918\end{array}$ & $\begin{array}{r}M \text { board } \\
\text { feet }{ }_{676}\end{array}$ & $\begin{array}{l}\text { M board } \\
\text { feet } \\
243\end{array}$ & $\begin{array}{l}M \text { board } \\
\text { feet }\end{array}$ & $\begin{array}{c}M \text { board } \\
\text { feet } \\
\quad 3,506\end{array}$ & $\begin{array}{l}M \text { board } \\
\text { feet } \\
\quad 5.343\end{array}$ \\
\hline $7 \ldots$ & Douglas-fir, small old growth..... & 53,022 & 18,419 & 19,869 & & ... & 2,519 & $40,80^{-}$ \\
\hline 8_... & Douglas-fir, large second growth.... & 1,012 & 232 & 98 & 1 & & 71 & \\
\hline $11 .$. & Sitka spruce, large & 432 & & & & 432 & & \\
\hline 14 & Western hemlock, large & 21,364 & 16,395 & 4,360 & 145 & 372 & 40 & 21,312 \\
\hline 17 & Western redcedar, large................ & 853 & 843 & 10 & & & & 853 \\
\hline $18 \ldots$ & Port Orford white-cedar, large & 4 & & & & & & \\
\hline $20 \mathrm{~A}$ & $\begin{array}{l}\text { Ponderosa pine, large } \\
\text { Sugar pine, large }\end{array}$ & 227 & & & & & & \\
\hline $23 \ldots \ldots$ & Fir-mountain bemalock, large & 4,443 & 1,069 & 489 & 1,152 & & $1,4 \pi$ & 4,187 \\
\hline \multirow[t]{2}{*}{27} & White fir-larch-Douglas-fir, large & 166 & & & & & 166 & 166 \\
\hline & 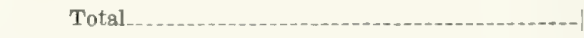 & 93,790 & 37,876 & 25,502 & 1,541 & 804 & 7,779 & 73,502 \\
\hline
\end{tabular}

\begin{tabular}{|c|c|c|c|c|c|c|c|c|}
\hline \multirow[b]{2}{*}{$\begin{array}{l}\text { Type } \\
\text { No. }\end{array}$} & \multirow[b]{2}{*}{ Type } & \multicolumn{7}{|c|}{ Western Oregon } \\
\hline & & $\begin{array}{l}\text { Columbia } \\
\text { River }\end{array}$ & $\begin{array}{l}\text { Willam- } \\
\text { ette River }\end{array}$ & $\begin{array}{l}\text { North } \\
\text { Oregon } \\
\text { coast }\end{array}$ & $\begin{array}{l}\text { Umpqua } \\
\text { River }\end{array}$ & $\begin{array}{l}\text { South } \\
\text { Oregon } \\
\text { coast }\end{array}$ & $\begin{array}{l}\text { Rogue } \\
\text { River }\end{array}$ & Total \\
\hline $6 \ldots$ & Douglas-fir, large old growth & $\begin{array}{l}M \text { board } \\
\quad \text { feet } \\
\quad 793\end{array}$ & $\begin{array}{l}M \text { board } \\
\text { feet } \\
5,800\end{array}$ & $\begin{array}{l}\text { M board } \\
\text { feet } \\
\\
10\end{array}$ & 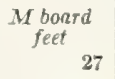 & $\begin{array}{l}\text { M board } \\
\quad \text { feet } \\
\quad 232\end{array}$ & $\begin{array}{l}M \text { board } \\
\quad \text { feet } \\
\quad 62\end{array}$ & $\begin{array}{l}M \text { braard } \\
\quad \text { fiet } \\
\quad 6.924\end{array}$ \\
\hline 7-..... & Douglas-fir, small old growth & 603 & 787 & & 8,163 & 1,105 & 1,557 & 12,215 \\
\hline $8 \ldots$ & $\begin{array}{l}\text { Douglas-fir, large second growth... } \\
\text { Sitka spruce, large }\end{array}$ & |........... & 590 & & & & 20 & 610 \\
\hline 11 & $\begin{array}{l}\text { Sitka spruce, large } \\
\text { Western hemlock, large }\end{array}$ & & 52 & & & & & 52 \\
\hline 17 & Western redcedar, large & & & & & & & \\
\hline $18 \ldots$ & Port Orford white-cedar, large & & & & & 4 & & \\
\hline $20 \ldots$ & Ponderosa pine, large & & ...- & & 61 & & 166 & 227 \\
\hline $20 \mathrm{~A}--$ & $\begin{array}{l}\text { Sugar pine, large } \\
\text { Fir-mountain hemlock, large }\end{array}$ & & & & & & & \\
\hline $23 \ldots$ & $\begin{array}{l}\text { Fir-mountain hemlock, large } \\
\text { White fir-larch-Douglas-fir, large }\end{array}$ & & 249 & & & & 7 & 256 \\
\hline & a & & & & & & & \\
\hline & Total & 1,396 & 7,478 & 10 & 8,251 & 1,341 & 1,812 & 20,288 \\
\hline
\end{tabular}

ON LANDS OTHER THAN NATIONAL FORESTS

\begin{tabular}{|c|c|c|c|c|c|c|c|c|}
\hline \multirow[b]{2}{*}{$\begin{array}{l}\text { Type } \\
\text { No. }\end{array}$} & \multirow[b]{2}{*}{ Type } & \multirow[b]{2}{*}{ All forests } & \multicolumn{6}{|c|}{ Western Washington } \\
\hline & & & $\begin{array}{l}\text { North } \\
\text { Puget } \\
\text { Sound }\end{array}$ & $\begin{array}{l}\text { Central } \\
\text { Puget } \\
\text { Sound }\end{array}$ & $\begin{array}{l}\text { South } \\
\text { Puket } \\
\text { Sound }\end{array}$ & $\begin{array}{c}\text { Grays } \\
\text { Harbor }\end{array}$ & $\begin{array}{l}\text { Columbia } \\
\text { River }\end{array}$ & Total \\
\hline $6 \ldots \ldots$ & Douglas-fir, large old growth... & $\begin{array}{l}M \text { board } \\
\quad \text { feet } \\
\quad 94,154\end{array}$ & $\begin{array}{l}M \text { board } \\
\text { feet } \\
\quad 2,586\end{array}$ & $\begin{array}{l}M \text { board } \\
\quad \text { feet } \\
\quad 1,523\end{array}$ & $\begin{array}{l}M \text { board } \\
\quad \text { feet } \\
\quad 6,386\end{array}$ & $\begin{array}{l}M \text { board } \\
\quad \text { feet } \\
\quad 2,069\end{array}$ & $\begin{array}{l}M \text { board } \\
\text { feet } \\
3,846\end{array}$ & $\begin{array}{l}M \text { board } \\
\text { feet } \\
\quad 16,410\end{array}$ \\
\hline 7 & Douglas-fir, small old growth ...... & 39,055 & & 1,058 & 2 & & & 1,060 \\
\hline 8_-..-- & Douglas-fir, large second growth & 23,938 & 27 & 7,429 & 783 & & 130 & 8,369 \\
\hline 11 . & Sitka spruce, large ... .......... & 73 & & & & & & \\
\hline $14 \ldots$ & Western bemlock, large. & 1,641 & 1,154 & 178 & 228 & 21 & 39 & 1,620 \\
\hline $17 \ldots$ & Western redcedar, large & 301 & 301 & 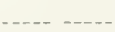 & & & & 301 \\
\hline $18 \ldots$ & Port Oring white-cedar, large... & 1,080 & ........ & $\ldots$ & & & ....... & ..... \\
\hline 20. & Ponderosa pine, large. ...... . . & 7,892 & & & & & & ..... \\
\hline $20 \mathrm{~A} \ldots \mathrm{I}$ & Sugar pine, large & 549 & & & & & & \\
\hline \multirow[t]{2}{*}{$23 \ldots$} & Fir-mountain hemlock, large & 9,930 & -...-- & 9,930 & & & ........ & 9,930 \\
\hline & Total & 178.613 & 4,069 & 20,118 & 7,399 & 2,090 & 4. 015 & 37.690 \\
\hline
\end{tabular}


TABLE 48. - Estimated annual averages of timber volume lost by fire in the Douglas-fir region in 1924-33, by type and survey unit-Con. ON LANDS OTHER THAN NATIONAL FORESTS-Continued

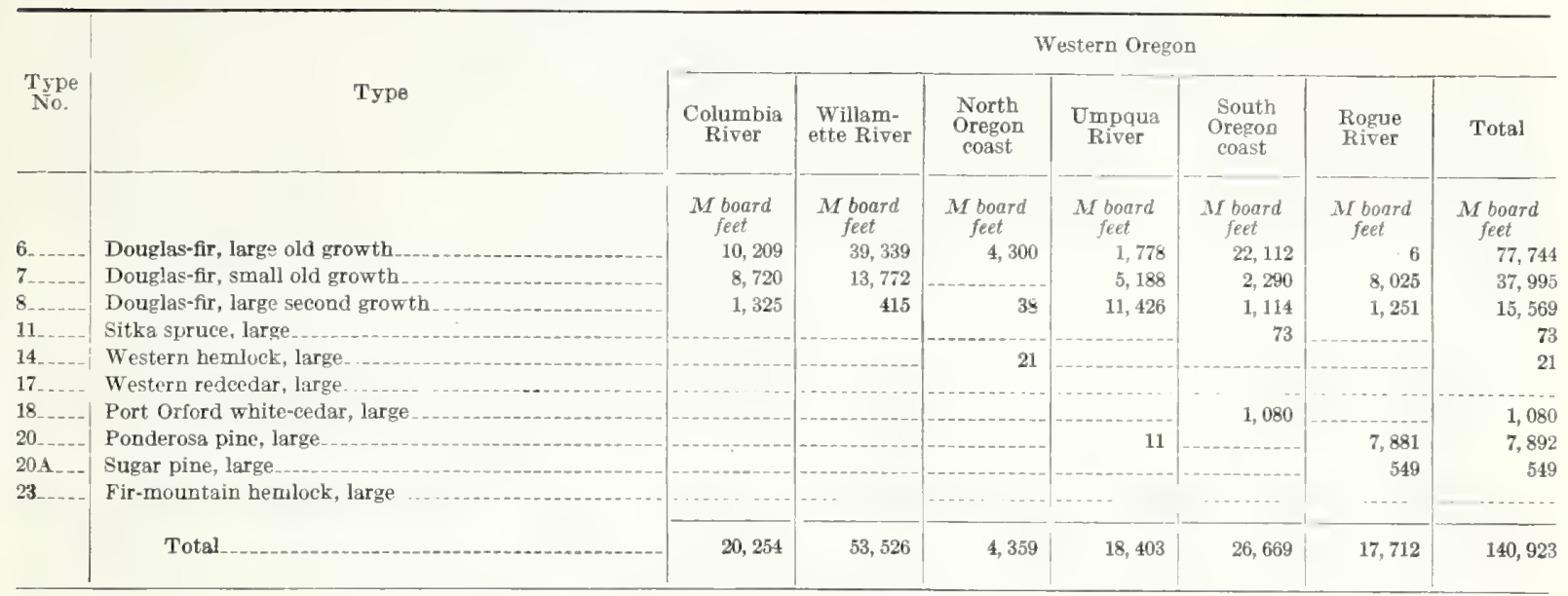

\section{ALL FOREST LANDS}

\begin{tabular}{|c|c|c|c|c|c|c|c|c|}
\hline \multirow[b]{2}{*}{$\begin{array}{l}\text { Type } \\
\text { No. }\end{array}$} & \multirow[b]{2}{*}{ Type } & \multirow[b]{2}{*}{ All forests } & \multicolumn{6}{|c|}{ Western Washington } \\
\hline & & & $\begin{array}{l}\text { North } \\
\text { Puget } \\
\text { Sound }\end{array}$ & $\begin{array}{l}\text { Central } \\
\text { Puget } \\
\text { Sound }\end{array}$ & $\begin{array}{l}\text { South } \\
\text { Puget } \\
\text { Sound }\end{array}$ & $\begin{array}{c}\text { Grays } \\
\text { Harbor }\end{array}$ & $\begin{array}{l}\text { Columbia } \\
\text { River }\end{array}$ & Total \\
\hline 6 & Douglas-fir, large old growth & $\begin{array}{c}M \text { board } \\
\text { feet } \\
106,421\end{array}$ & $\begin{array}{l}M \text { board } \\
\text { feet } \\
\quad 3,504\end{array}$ & $\begin{array}{c}M \text { board } \\
\text { feet } \\
2.199\end{array}$ & $\begin{array}{c}M \text { board } \\
\text { feet } \\
\quad 6,629\end{array}$ & $\begin{array}{l}\text { M board } \\
\text { feet } \\
\quad 2,069\end{array}$ & $\begin{array}{l}M \text { board } \\
\text { feet } \\
7,352\end{array}$ & $\begin{array}{l}M \text { board } \\
\text { feet } \\
21,753\end{array}$ \\
\hline $7 \ldots$ & Douglas-fir, small old growth & 92,077 & 18,419 & 20,927 & 2 & & 2,519 & 41,867 \\
\hline 8-.-- & Douglas-fir, large second growth... & 24,950 & 259 & 7,527 & 784 & (n....... & 201 & 8,771 \\
\hline $11 \ldots$ & Sitka spruce, large & 505 & - n........ & (....... & $-\ldots$. & 432 & - - & 432 \\
\hline 14. & Western hemlock, large & 23,005 & 17,549 & 4,538 & 373 & 393 & 79 & 22,932 \\
\hline $17 \ldots$ & Western redcedar, Jarge & 1,154 & 1,144 & 10 & & & & 1,154 \\
\hline 18 & Port Orford white-cedar, large & 1,084 & & & & & & \\
\hline $20 \ldots$ & Ponderosa pine, large & 8,119 & & & & & & \\
\hline $20 \mathrm{~A}$ & Sugar pine, large & 549 & & & & & & \\
\hline $23 \ldots$ & Fir-mountain hemlock, large & 14,373 & 1,069 & 10,419 & 1,152 & --n--- & 1,477 & 14,117 \\
\hline \multirow[t]{2}{*}{$27 \ldots$} & White fir-lareh-Douglas-fir, large... & 166 & & & & & 166 & 166 \\
\hline & Total & 272.403 & 41,944 & 45,620 & 8,940 & 2,894 & 11,794 & 111,192 \\
\hline \multirow[b]{2}{*}{$\begin{array}{l}\text { Type } \\
\text { No. }\end{array}$} & \multirow[b]{2}{*}{ Tyрө } & \multicolumn{7}{|c|}{ Western Oregon } \\
\hline & & $\begin{array}{l}\text { Columbia } \\
\text { River }\end{array}$ & $\begin{array}{l}\text { Willam- } \\
\text { ette River }\end{array}$ & $\begin{array}{l}\text { North } \\
\text { Oregon } \\
\text { coast }\end{array}$ & $\begin{array}{c}\text { Umpqua } \\
\text { River }\end{array}$ & $\begin{array}{l}\text { South } \\
\text { Oregon } \\
\text { coast }\end{array}$ & $\begin{array}{l}\text { Rogue } \\
\text { Riier }\end{array}$ & Total \\
\hline 6 & Douglas-fir, large old growth...... & $\begin{array}{c}M \text { board } \\
\text { feet } \\
11,002\end{array}$ & $\begin{array}{l}M \text { board } \\
\quad \text { feet } \\
\quad 45,139\end{array}$ & $\begin{array}{l}M \text { board } \\
\quad \text { feet } \\
\quad \mathbf{4}, 310\end{array}$ & $\begin{array}{l}M \text { board } \\
\quad \text { feet } \\
\quad 1,805\end{array}$ & $\begin{array}{c}\text { M board } \\
\text { feet } \\
22,344\end{array}$ & $\begin{array}{r}M \text { board } \\
\text { feet } \\
68\end{array}$ & $\begin{array}{l}M \text { board } \\
\quad \text { fett } \\
\quad 84,668\end{array}$ \\
\hline 7 & Douglas-fir, small old growth & 9,323 & 14,559 & & 13,351 & 3,395 & 9,582 & 50.210 \\
\hline 8 & Douglas-fir, large second growth & 1,325 & 1,005 & 38 & 11,426 & 1,114 & 1,271 & 16,179 \\
\hline $11 \ldots$ & Sitka spruce, large & - $-\ldots+\ldots$ & (n........... & & -......... & 73 & & 73 \\
\hline 14 & 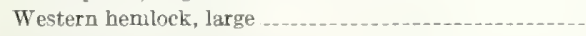 & (-.-n-n & 52 & 21 & 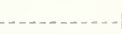 & & & 73 \\
\hline $17 . \ldots$ & Western redeedar, largo $\ldots . .$. & $\ldots \ldots$ & $\ldots$ & -.... & 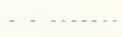 & & .......... & -...... \\
\hline 18 & Port Orford white-cedar, large . . . & ... . . & & $\ldots$ & & 1,084 & & 1,084 \\
\hline $20 \ldots$ & 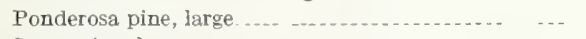 & - & .. & ....... & 72 & $\ldots$ & 8,047 & 8,119 \\
\hline $20 \mathrm{~A}$ & Sugar pine, large … & $\ldots \ldots$. & $\ldots \ldots$ & . & ......... & .... & 549 & 549 \\
\hline $23 \ldots . .$. & Fir-mountain hemlock, large ... . . . . & (............ & 249 & $\ldots \ldots \ldots$ & . $\quad \ldots$ & …… & 7 & 256 \\
\hline \multirow[t]{2}{*}{$27 \ldots$} & White fir-lareh-Douglas-fir, large . . . & - $\quad \cdots . .$. & ..... . & & $\cdot \cdots$ & . - - & - & (1.... \\
\hline & Total _... & 21,650 & 61,004 & 4,369 & 26,654 & 28,010 & 19,524 & 161,211 \\
\hline
\end{tabular}


TABLE 49.-Net average annual rate of depletion from causes other than cutting, by type group

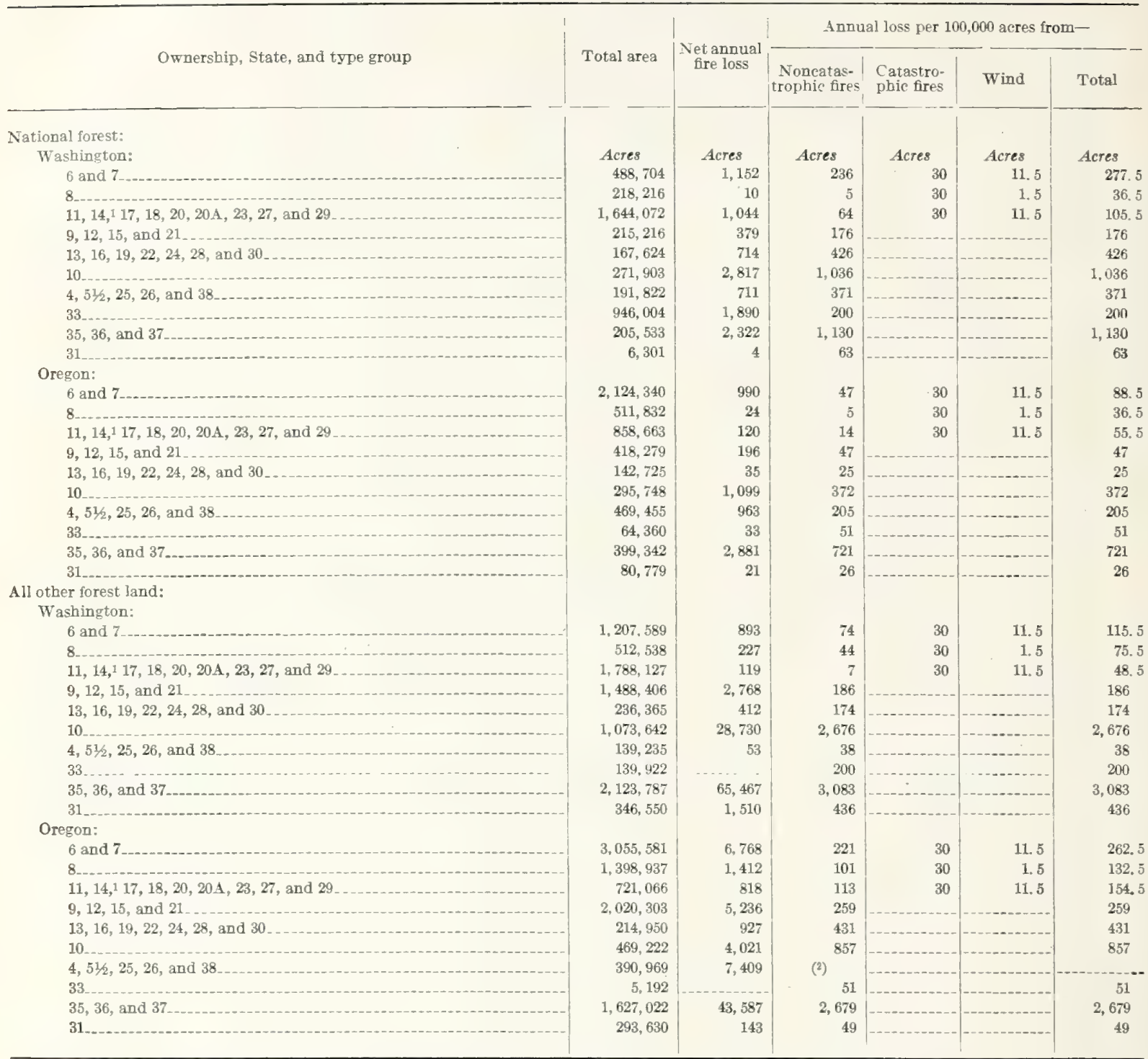

${ }^{1}$ For type 14 the annual looper-damage loss rate per 100,000 acres, not included in the rates tabulated, is 53 acres.

${ }^{2}$ For the Columbia River Oregon, north Oregon coast, Willamette River, and Umpqua River units, 20 acres; for the south Oregon coast unit, 1,100 acres; for the Rogue River unit, 2,700 acres. 
TABLE 50.-Assumed future decadal depletion, ${ }^{1}$ by district and ownership class

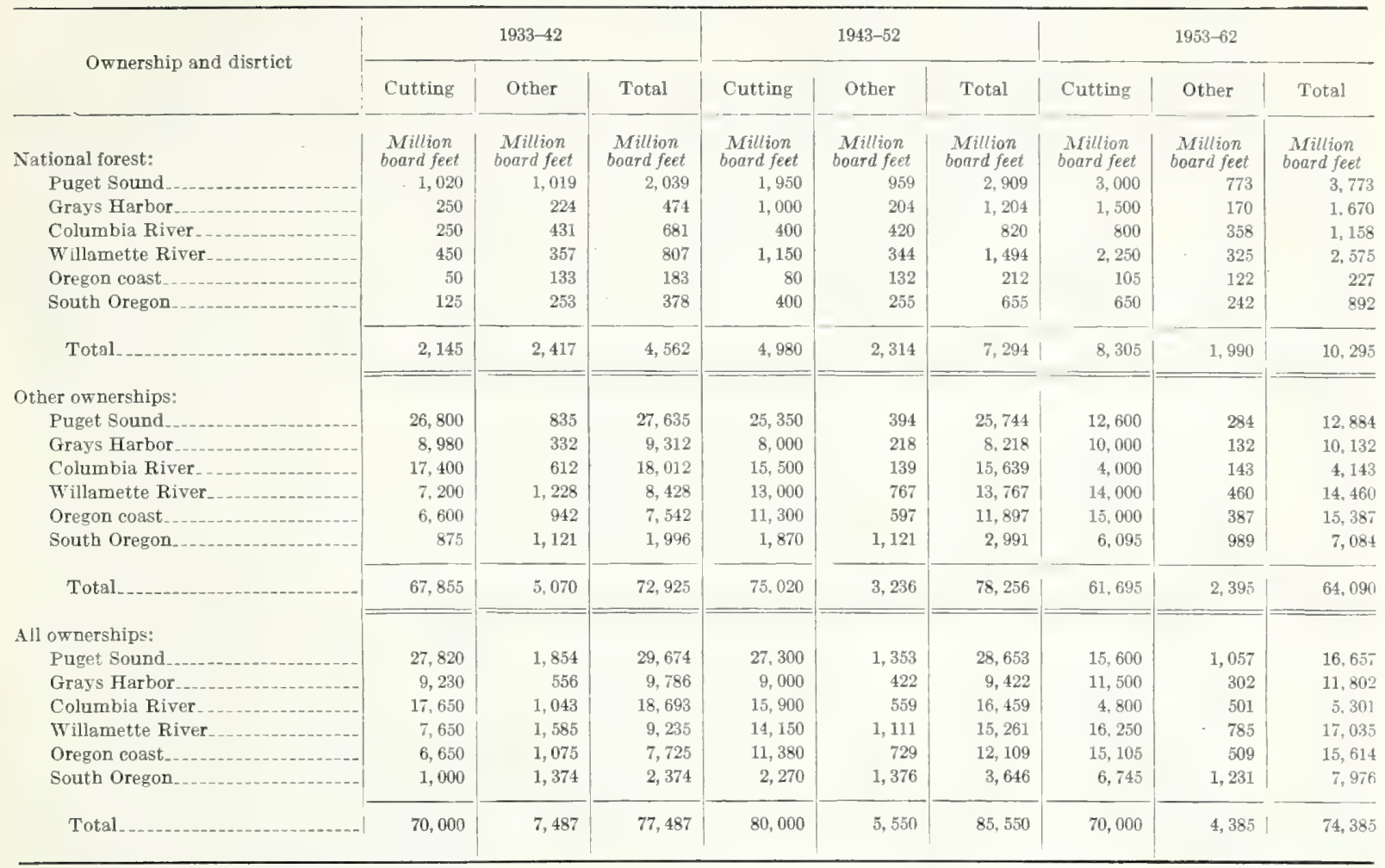

' Figures given are log seale, based on Seribner rule.

TABLE 51.-Rates ${ }^{1}$ used in calculating potential growth of conifer timber, approximate technical rotation ages

\begin{tabular}{|c|c|c|c|c|c|c|}
\hline \multirow{2}{*}{$\begin{array}{l}\text { Site- } \\
\text { quality } \\
\text { class }\end{array}$} & \multicolumn{2}{|c|}{$\begin{array}{c}\text { Trees } 3.1 \text { +inches } \\
\text { d. b. b. }\end{array}$} & \multicolumn{2}{|c|}{$\begin{array}{l}\text { Trees } 15.1+\text { inches } \\
\text { d. b. h. }{ }^{2}\end{array}$} & \multicolumn{2}{|c|}{$\begin{array}{l}\text { Trees } 11.1+\text { inches } \\
\text { d. b. h. }{ }^{3}\end{array}$} \\
\hline & $\begin{array}{l}\text { Mean } \\
\text { annual } \\
\text { growth } \\
\text { per acre }\end{array}$ & $\begin{array}{c}\text { Rota- } \\
\text { tion age }\end{array}$ & $\begin{array}{l}\text { Mean } \\
\text { annual } \\
\text { growth } \\
\text { per acre }\end{array}$ & $\begin{array}{l}\text { Rota- } \\
\text { tion age }\end{array}$ & $\begin{array}{l}\text { Mean } \\
\text { annual } \\
\text { growth } \\
\text { per acre }\end{array}$ & $\begin{array}{l}\text { Rota- } \\
\text { tion age }\end{array}$ \\
\hline & $\begin{array}{l}\text { Cubic } \\
\text { feet }\end{array}$ & Years & $\begin{array}{l}\text { Board } \\
\text { feet }\end{array}$ & Years & $\begin{array}{c}\text { Board } \\
\text { feet }\end{array}$ & Years \\
\hline$I$ & 155 & 60 or 70 & 675 & 100 & 875 & 90 \\
\hline II & 135 & 60 or 70 & 500 & 120 & 675 & 100 \\
\hline III & 105 & 60 or 70 & 300 & 150 & 475 & 110 \\
\hline IV & 75 & 60 or 70 & 125 & 180 & 275 & 130 \\
\hline $\mathrm{V}$ & 45 & 60 or 70 & 30 & +200 & 100 & 150 \\
\hline VI & 20 & 60 or 70 & --- & 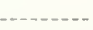 & & \\
\hline
\end{tabular}

1 Approximately 75 percent of mean annual growth rates of normally stocked stands of Douglas-fir in western Oregon and western W ashington. The normal rates for site classes I to $\mathrm{V}$ appear in Technical Bulletic 201 (12). The rate for class VI was derived by extrapolation. No allowance is made for breakage and defect.

${ }^{2}$ Estimated by Scribner rule in 32-foot logs to 12-inch top.

3 Estimated by Scribner rule in 16-foot logs to 8-inch top. 
TABLE 52.-Volume of timber, lumber tally, in the Douglas-fir region, by species, State, and forest-survey unit

\begin{tabular}{|c|c|c|c|c|c|c|c|c|}
\hline \multirow[b]{2}{*}{$\begin{array}{c}\text { Sym- } \\
\text { bol }\end{array}$} & \multirow[b]{2}{*}{ Species } & \multirow[b]{2}{*}{$\begin{array}{l}\text { Total } \\
\text { for } \\
\text { region }\end{array}$} & \multicolumn{6}{|c|}{ Western $W$ ashington } \\
\hline & & & $\begin{array}{l}\text { North } \\
\text { Puget } \\
\text { Sound }\end{array}$ & $\begin{array}{l}\text { Central } \\
\text { Puget } \\
\text { Sound }\end{array}$ & $\begin{array}{l}\text { South } \\
\text { Puget } \\
\text { Sound }\end{array}$ & $\begin{array}{l}\text { Grays } \\
\text { Harbor }\end{array}$ & $\begin{array}{l}\text { Colum- } \\
\text { bia } \\
\text { River, } \\
\text { Wash. }\end{array}$ & Total \\
\hline & & $\begin{array}{l}\text { Million } \\
\text { board } \\
\text { feet }\end{array}$ & $\begin{array}{l}\text { Million } \\
\text { board } \\
\text { feet }\end{array}$ & $\begin{array}{l}\text { Million } \\
\text { board } \\
\text { feet }\end{array}$ & $\begin{array}{l}\text { Million } \\
\text { board } \\
\text { feet }\end{array}$ & $\begin{array}{l}\text { Million } \\
\text { board } \\
\text { feet }\end{array}$ & $\begin{array}{l}\text { Mlliion } \\
\text { board } \\
\text { feet }\end{array}$ & $\begin{array}{l}\text { Million } \\
\text { board } \\
\text { feet }\end{array}$ \\
\hline DA & Large old-growth Douglas-fir-_-_-_. & $166,124.9$ & $5,989.3$ & $16,379.8$ & $14,331.0$ & $10,248.8$ & $15,795.6$ & $62,744.5$ \\
\hline $\mathrm{DB}$ & Small old-growth Douglas-fir_._..... & $116,585.2$ & $2,420.3$ & $11,651.4$ & $4,714.8$ & $1,185.6$ & $2,972.6$ & $22,944.7$ \\
\hline DC & Large second-growth Douglas-fir & $78,512.2$ & $2,460.5$ & $3,718.7$ & $9,233.3$ & $1,282.5$ & $5,351.3$ & $22,046.3$ \\
\hline DD & Small second-growth Douglas-fir & $19,833.7$ & 626.0 & $1,674.4$ & $1,433.3$ & 191.5 & $2,652.5$ & $6,577.7$ \\
\hline $\mathrm{SA}$ & Large Sitka spruce_-_._._......... & $12,453.0$ & 142.8 & $2,125.5$ & 79.0 & $4,530.3$ & 261.8 & $7,139.4$ \\
\hline $\mathrm{SB}$ & Small Sitka spruce_-_-_-_-_-_---_. & 985.4 & 12.7 & 11.3 & & 533.5 & 41.2 & 598.7 \\
\hline $\mathrm{ES}$ & Engelmann spruce & 256.4 & .1 & .6 & 1.6 & & 36.8 & 39.1 \\
\hline НА & Large western hemlock & $105,399.3$ & $14,185.5$ & $28,654.6$ & $6,939.8$ & $22,892.6$ & $7,504.8$ & $80,177.3$ \\
\hline НВ & Small western hemlock & $14,844.4$ & $2,209.7$ & $2,765.1$ & $1,168.8$ & $4,461.4$ & $1,186.2$ & $11,791.2$ \\
\hline $\mathrm{MH}$ & Mountain hemlock .......... & $6,198.9$ & 704.2 & 511.3 & 229.6 & 6.0 & 92.3 & $1,602,4$ \\
\hline $\mathrm{C}$ & Western redcedar, live & $28,358.2$ & $6,105.2$ & $5,983.7$ & $2,494.4$ & $6,516.5$ & $2,006.1$ & $23,105.9$ \\
\hline PC & Port Orford white-cedar, live & $1,350.2$ & & & & & & \\
\hline $\mathrm{YC}$ & Alaska yellow-cedar, live & 629.8 & 173.6 & 298.4 & 98.5 & 24.0 & 21.3 & 615.8 \\
\hline IC & California incense-cedar & $2,056.8$ & & & & & & \\
\hline KPC । & Port Orford white-cedar, dead.- & 28.6 & & & & & ...... & - \\
\hline $\mathrm{KC}$ & Other "cedar", dead & $1,224.6$ & 495.4 & 122.6 & 110.1 & 361.9 & 24.5 & $1,114.5$ \\
\hline YA & Large ponderosa (and Jeffrey) pine & $4,851.2$ & (1) & & & & 106.3 & 106.3 \\
\hline YB & Small ponderosa (and Jeffrey) pine.... & 485.5 & & 2.5 & & & ....... & 2.5 \\
\hline SP & Sugar pine & $3,837.3$ & & & & & & \\
\hline W & Western white (and whitebark) pine_- & $3,045.1$ & 199.5 & 564.9 & 175.0 & 150.6 & 527.5 & $1,617.5$ \\
\hline LP & Lodgepole (and knobcone) pine & 87.7 & .2 & 4.9 & .2 & .4 & .4 & 6.1 \\
\hline WE & White fir and grand fir & $7,343.1$ & 40.0 & 49.7 & 338.6 & 407.4 & 159.5 & 995.2 \\
\hline NF & Noble and Shasta red fir-..--_-.. & $9,978.1$ & 1.0 & $1,093.7$ & 910.5 & 24.7 & $1,143.2$ & $3,173.1$ \\
\hline A & Pacific silver fir & $37,863.0$ & $9,098,4$ & $10,318.0$ & $2,772.1$ & $7,773.2$ & $4,403.9$ & $34,365.6$ \\
\hline $\mathrm{AF}$ & Alpine fir & 113.8 & 4.9 & 28.9 & 4.8 & & (I) & 38.6 \\
\hline WL & Western larch & 145. 7 & & & & & 30.5 & 30.5 \\
\hline $\mathbf{R}$ & Redwood & 66.0 & & & & & & \\
\hline $\mathrm{RA}$ & Red alder & $2,563,1$ & 120.2 & 186.1 & 47.4 & 216.3 & 122.2 & 692.2 \\
\hline 00 & Oregon white oak..... & 110.5 & & & & 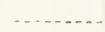 & -.... & ... .. \\
\hline $\mathrm{CO}$ & California black oak & 79.5 & & & & & & \\
\hline CLO & Canyon live oak & 4. 2 & & & & & & \\
\hline TO & Tanoak & 549.3 & & & & .... & & \\
\hline $\mathrm{BC}$ & Northern black cottonwood (and aspen) & 341.9 & 79.3 & 32.7 & 14.3 & 16.4 & 36.2 & 178. 9 \\
\hline OM & Bigleal maple-_... & 919.0 & 55.4 & 41.3 & 151.3 & 48.9 & 11.0 & 307.9 \\
\hline MAD & Madrone & 308.9 & & & & & & \\
\hline ASH & Oregon ash & 56.7 & $: 3$ & 4. 0 & 8.6 & & 1.6 & 14.5 \\
\hline MY & California laurel_. & 73.5 & & & & & & \\
\hline $\mathrm{CH}$ & Chinquapin & 83.6 & & & & & & \\
\hline \multirow[t]{2}{*}{ WPB } & Western and northwestern paper birch.......... & .3 & .3 & & & - -..- & & .3 \\
\hline & Total...... & $627,748.6$ & $45,124.8$ & $86,224.1$ & $45,257,0$ & $60,931.5$ & $44,489.3$ & $282,026.7$ \\
\hline
\end{tabular}

Less than 50,000 board feet. 
TABLE 52.-Volume of timber, lumber tally, in the Douglas-fir region, by species, State, and forest-survey unit-Continued

\begin{tabular}{|c|c|c|c|c|c|c|c|c|}
\hline \multirow[b]{2}{*}{$\begin{array}{c}\text { Sym- } \\
\text { bol }\end{array}$} & \multirow[b]{2}{*}{ Species } & \multicolumn{7}{|c|}{ Western Oregon } \\
\hline & & $\begin{array}{c}\text { Colum- } \\
\text { bia } \\
\text { River, } \\
\text { Oreg. }\end{array}$ & $\begin{array}{l}\text { Willa- } \\
\text { mette } \\
\text { River }\end{array}$ & $\begin{array}{c}\text { North } \\
\text { Oregon } \\
\text { coast }\end{array}$ & $\begin{array}{c}\text { Umpqua } \\
\text { River }\end{array}$ & $\begin{array}{l}\text { South } \\
\text { Oregon } \\
\text { coast }\end{array}$ & $\begin{array}{l}\text { Rogue } \\
\text { River }\end{array}$ & Total \\
\hline DA & Large old-growth Douglas-fir..... & $\begin{array}{l}\text { Million } \\
\text { board } \\
\text { feet } \\
11,929.0\end{array}$ & $\begin{array}{l}\text { Million } \\
\text { board } \\
\text { feet } \\
41,150.5\end{array}$ & $\begin{array}{l}\text { Million } \\
\text { board } \\
\text { feet } \\
9,238.8\end{array}$ & $\begin{array}{l}\text { Million } \\
\text { board } \\
\text { feet } \\
18,676.9\end{array}$ & $\begin{array}{c}\text { Million } \\
\text { board } \\
\text { feet } \\
17,478.3\end{array}$ & $\begin{array}{l}\text { Million } \\
\text { board } \\
\text { feet } \\
4.906 .9\end{array}$ & $\begin{array}{l}\text { Million } \\
\text { board } \\
\text { feet } \\
103,380.4\end{array}$ \\
\hline $\mathrm{DB}$ & Small old-growth Douglas-fir & $11,372.5$ & $34,189.3$ & $1,970.2$ & $25,893.8$ & $9,689.5$ & $10,525,2$ & $93,640.5$ \\
\hline $\mathrm{DC}$ & Large second-growth Douglas-fir & $4,292.5$ & $18,421.4$ & $9,684.5$ & $14,253.3$ & $8,663.8$ & $1,150,4$ & $56,465.9$ \\
\hline DD & Small second-growth Douglas-fir..... & $1,111.7$ & $4,366.0$ & 689.5 & $3,484.3$ & $2,617,9$ & 986.6 & $13,256.0$ \\
\hline $\mathbf{S A}$ & Large Sitka spruce & $1,399.4$ & 7.1 & $2,431.8$ & & $1,475.3$ & ....... & $5,313.6$ \\
\hline SB & Small Sitka spruce & 24.2 & .2 & 300.6 & -...- & 61.7 & -.-- & 386.7 \\
\hline ES & Engelmann spruce & 150.3 & 50.3 & - & .4 & 1.3 & 15. 0 & 217.3 \\
\hline HA & Large western hemlock & $8,407.7$ & $9,626.6$ & $5,127.3$ & 934.8 & $1,041.0$ & 84.6 & $25,222.0$ \\
\hline НВ & Small western hemlock & $1,248.8$ & $1,068.7$ & 535.9 & 104.1 & 86. 3 & 9.4 & $3,053,2$ \\
\hline MH & Mountain hemlock & 796.5 & $2,856.7$ & -...... & 942.7 & & .6 & $4,596.5$ \\
\hline $\mathrm{C}$ & Western redcedar, live & $1,231.4$ & $2,160.9$ & 832.3 & 560.4 & 467.3 & & $5,252.3$ \\
\hline $\mathrm{PC}$ & Port Orford white cedar, live & 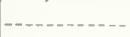 & $-1-. . . .$. & $-\ldots$ & 104.6 & $1,208.1$ & 37.5 & $1,350.2$ \\
\hline $\mathrm{YC}$ & Alaska yellow-cedar, live & 6.4 & 7.2 & $-\ldots-\ldots$ & .4 & ............ & ........ & 14. 0 \\
\hline IC & Caiifornis incense-cedar & -0.1 & 239.4 & & $1,055.4$ & 2.8 & 759.2 & $2,056.8$ \\
\hline KPC & Port Orford white-cedar, dead..... & ---- & -..- & & $-\ldots-\ldots$ & 28.6 & -...-- & 28.6 \\
\hline $\mathrm{KC}$ & Other "cedar," dead & 11.3 & 16. 6 & 37.5 & 21.6 & 22.1 & 1.0 & 110.1 \\
\hline YA & Large ponderosa (and Jeffrey) pine & 60.3 & 73.1 & on & 796.7 & 29.6 & $3,785.2$ & $4,744.9$ \\
\hline YB & Small ponderosa (and Jeffrey) pine & -....... & 2.4 & -.....- & 37.5 & 3.1 & 440.0 & 483.0 \\
\hline SP & Sugar pine & ....... & 181.7 & $-\ldots$ & $1,199.2$ & 158.8 & $2,297.6$ & $3,837.3$ \\
\hline W & Western white (and whitebark) pine & 255.0 & 512.2 & .5 & 385.8 & .5 & 273.6 & $1,427,6$ \\
\hline LP & Lodgepole (and knobcone) pine & 7.0 & 68.4 & .2 & 3.2 & 1.9 & .9 & 81.6 \\
\hline WF & White fir and grand fir & 342.1 & 678.5 & 3.2 & $1,587.3$ & 688.8 & $3,048.0$ & $6,347.9$ \\
\hline NF & Noble and Shasta red fir............. & $1,828.1$ & $1,995.8$ & 400.7 & $1,188.2$ & 30.0 & $1,362.2$ & $6,805.0$ \\
\hline$A$ & Pacific silver fir................... & $1,903.4$ & $1,320.9$ & 156.8 & 116.3 & & & $3,497.4$ \\
\hline$A F$ & Alpine fir. & 44.1 & 31. 0 & $-\ldots$ & .1 & & & 75.2 \\
\hline WL & Western larch & 114. 2 & 1.0 & & -.--- & & $-\ldots$ & 115.2 \\
\hline $\mathrm{R}$ & Redwood & & & & $-\ldots$ & 66.0 & & 66.0 \\
\hline $\mathrm{RA}$ & Red alder & 70.5 & 144. 2 & $1,202.0$ & 71.4 & 382.4 & .4 & $1,870.9$ \\
\hline OO & Oregon white oak & 1.5 & 28.1 & ........... & 57.3 & 3.6 & 20.0 & 110.5 \\
\hline $\mathrm{CO}$ & California black oak & & & & 38.0 & 6. 7 & 34.8 & 79.5 \\
\hline CLO & Canyon live oak & & & & -.....- & .3 & 3.9 & 4. 2 \\
\hline TO & Tanoak & & ---- & & 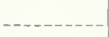 & 541.9 & 7.4 & 549.3 \\
\hline $\mathrm{BC}$ & Northern black cottonwood (and aspen) & 67.1 & 89.4 & ......... & .3 & 1.1 & 5.1 & 163.0 \\
\hline OM & Bigleaf maple & 41.0 & 302.9 & 19. 1 & 94.5 & 153.4 & .2 & 611.1 \\
\hline MAD & 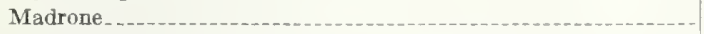 & ........ & $-\ldots$ & ........ & 267.9 & 32.9 & 8.1 & 308.9 \\
\hline ASH & Oregon ash & 6.8 & 32.1 & & 2.1 & 2 & 1.0 & 42.2 \\
\hline MY & California laurel & ...... & ....... & & . . . . . . . & 73.5 & ---- & 73.5 \\
\hline $\mathrm{CH}$ & Chinquapin. & & 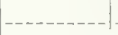 & & 66.8 & 15.9 & .9 & 83. 6 \\
\hline \multirow[t]{2}{*}{ WPB } & Western and northwestern paper birch................. & & $\ldots \ldots$ & & . & $\ldots$ & & $\cdots$ \\
\hline & Total_..... & $46,722.8$ & $119,622.6$ & $32,630.9$ & $71,945.3$ & $45,034.6$ & $29,765.7$ & $345,721.9$ \\
\hline
\end{tabular}


TABLE 53.- Annual output, lumber tally, of timber products cut from irees of saw-timber size in the Douglas-fir region, by State and forest-survey unit 1

\begin{tabular}{|c|c|c|c|c|c|c|c|}
\hline Forest-survey unit & Sawlogs & Fuel wood 2 & Pulpwood 3 & $\begin{array}{l}\text { Veneer } \\
\text { blocks }\end{array}$ & $\begin{array}{l}\text { Shingle } \\
\text { bolts }{ }^{3}\end{array}$ & Posts & Total \\
\hline $\begin{array}{l}\text { Western Washington: } \\
\text { North Puget Sound }\end{array}$ & $\begin{array}{r}M \text { board feet } \\
781,974\end{array}$ & $\begin{array}{r}M \text { board feet } \\
27,111\end{array}$ & $\begin{array}{r}M \text { board feet } \\
18,193\end{array}$ & $\begin{array}{r}M \text { board feet } \\
2,542\end{array}$ & $\begin{array}{r}M \text { board feet } \\
9,200\end{array}$ & $\begin{array}{r}M \text { board feet } \\
521\end{array}$ & $\begin{array}{l}M \text { board feet } \\
\quad 839,541\end{array}$ \\
\hline Central Puget Sound. & $1,973,636$ & 98,900 & 25,110 & 13,812 & 2,012 & 1,188 & $2,114,658$ \\
\hline South Puget Sound _.. & 644,510 & 28,175 & & 11,880 & & 638 & 685,203 \\
\hline Grays Harbor & $1,673,891$ & 6,992 & 3,162 & 1,782 & 288 & 85 & $1,686,200$ \\
\hline Columbia River & 677,524 & 28,635 & 3,968 & & & 294 & 710,421 \\
\hline Total & $5,751,535$ & 189,813 & 50,433 & 30,016 & 11.500 & 2,726 & $6,036,023$ \\
\hline \multicolumn{8}{|l|}{ Western Oregon: } \\
\hline Columbia River_-... & $1,276,764$ & 97,440 & 2,708 & & & 672 & $1,377,584$ \\
\hline Willamette River--. & 795,298 & 73,951 & 17,727 & & & 1,760 & 888,736 \\
\hline North Oregon coast... & 293,505 & 10,752 & 15,122 & & & 162 & 319,541 \\
\hline South Oregon coast.-. & 320,116 & 9,200 & 23 & & & 115 & 329,454 \\
\hline Umpqua River_....... & 25,001 & 11,069 & & & & 293 & 36,363 \\
\hline Rogue River & 78,737 & 13,570 & & & & 170 & 92,477 \\
\hline Total & $2,789,421$ & 215,982 & 35,580 & -... & & 3,172 & $3,044,155$ \\
\hline Region total & $8,540,956$ & 405,795 & 86,013 & 30,016 & 11,500 & 5,898 & $9,080,178$ \\
\hline
\end{tabular}

Data for sawlog production are arerages for the period 1925-33, other data are for 1930 only. fuel.

In addition to the quantities of material shown under this heading, considerable quantities of slabs, edging, mill waste, and sawdust were sold for

${ }^{3}$ In addition to the quantities shown under these headings, some sawlogs were used to manufacture paper pulp, veneers, panels, plywood, and shingles.

TABLE 54.-Average annual sazlog production, lumber tally, in the Douglas-fir region in 1925-33, by State, forest-survey unit, and species

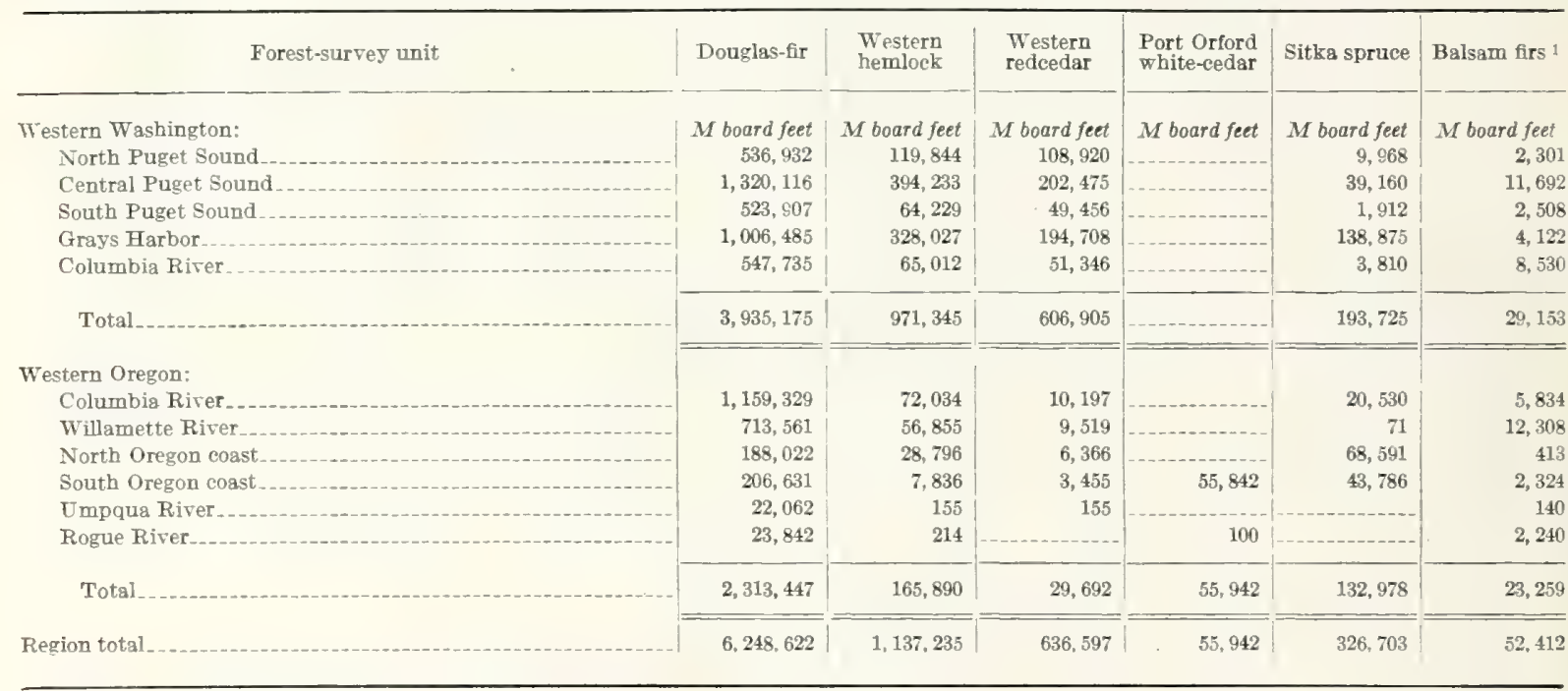

1 Including all species of $A$ bies. 
TABLE 54.- Average annual sawlog production, lumber tally, in the Douglas-fir region in 1925-33, by State, forest-survey unit, and species-Continued

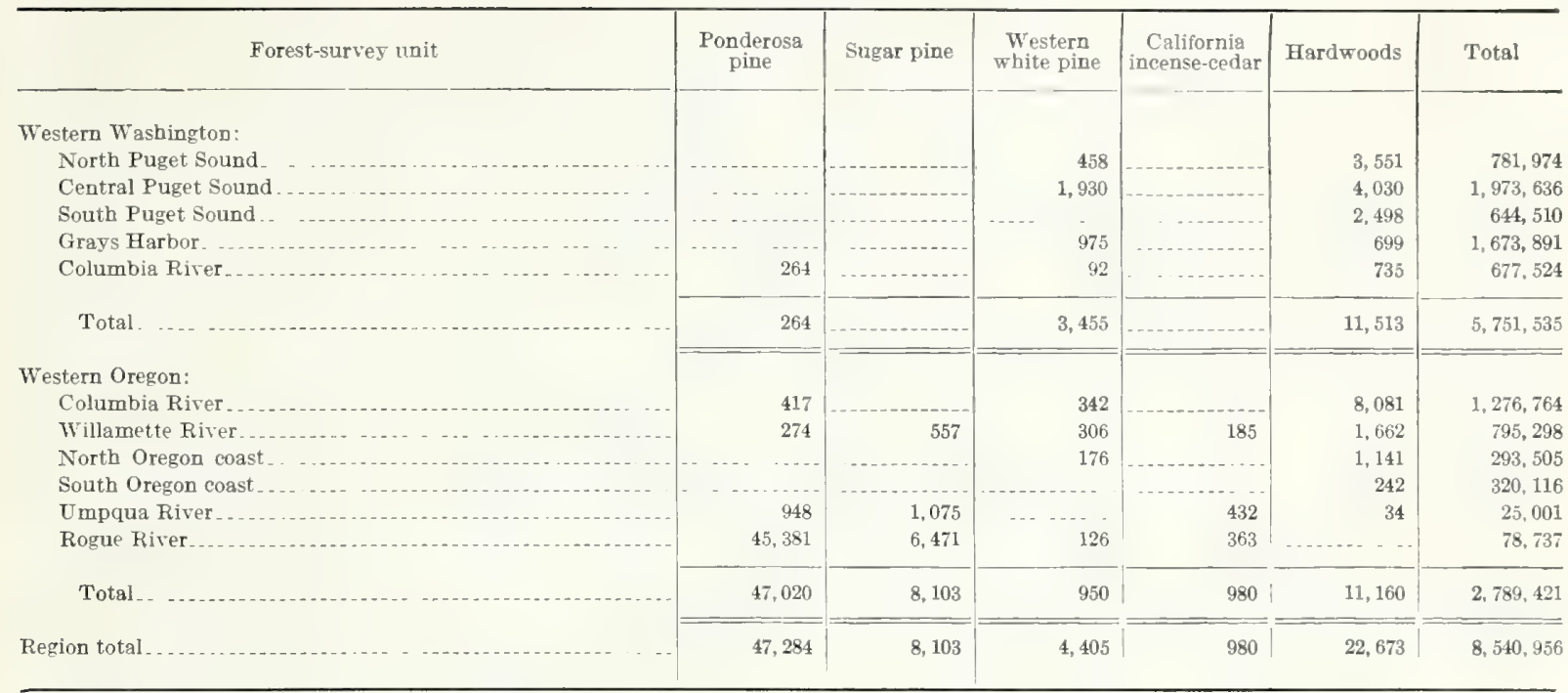

TABLE 55.-Estimated annual averages ${ }^{1}$ of gross forest-land area covered and timber lost by fire in the Douglas-fir region, lumber-tally basis

\begin{tabular}{|c|c|c|c|c|c|c|}
\hline \multirow{2}{*}{ Type group and type No. } & \multicolumn{2}{|c|}{ National forests } & \multicolumn{2}{|c|}{ Other land } & \multicolumn{2}{|c|}{ All land } \\
\hline & Area & Volume & Area & Volume & Area & Volume \\
\hline & Астев & $M$ board feet & Acres & $M$ board feet & Acres & $M$ board feet \\
\hline Conifer saw timber $(6,7,8,11,14,17,18,20,20 \mathrm{~A}, 23,27$, and 32$)$ & 7,356 & 107,858 & 35,631 & 205,405 & 42,987 & 313,26 \\
\hline Conifer second growth, $6-20$ inches d. b. h. $(9,12,15$, and 21) & 1,120 & (a) & 20,157 & (2) & 21,277 & (2) \\
\hline $\begin{array}{l}\text { Conifer seedlings and saplings, } 0-6 \text { inches d. b. h. }(10,13,16 \text {, } \\
\text { and } 22 \text { ) }\end{array}$ & 5,886 & & 53,725 & & 59,611 & \\
\hline Conifer second growth, $0-24$ inches d. b. h. $(19,24$, and 28$)$ & 968 & (2) & 231 & (घ) & 1, 199 & (2) \\
\hline Noncommercial $\left(4,5^{1}, 26,33\right.$, and 38$) \ldots \ldots \ldots$ & 3,135 & & $\tau, 808$ & & 10,943 & \\
\hline Recent cut-orer areas $(36) \ldots$ & 1,039 & & 83,797 & & 84,836 & \\
\hline $\begin{array}{l}\text { Old cut-over areas, nonrestocked, and previously deforested } \\
\text { burns ( } 35 \text { and } 37 \text { ) }\end{array}$ & 4,172 & & 25,894 & & 30,066 & \\
\hline Hardwood timber (31) & 34 & & 2,203 & ..... & 2,237 & ........ \\
\hline Nonforest land ( 2 and 3$)$ & & ..... & & ..... & . & ....... \\
\hline Total & 23,710 & 107,858 & 229,446 & 205,405 & 253,156 & 313,263 \\
\hline
\end{tabular}

1 For national-forest lands, fire-loss data were averaged for the period 1924-33, for other land, data are for 1926-30.

2 Small amounts of saw-timber volume were lost by fire in these types, but fire reports either include them with loss in saw-timber ty pes or ignore them. Quantities involved are negligible.

TABLE 56.-Assumed future average annual forest depletion in the Douglas-fir region, lumber-tally basis

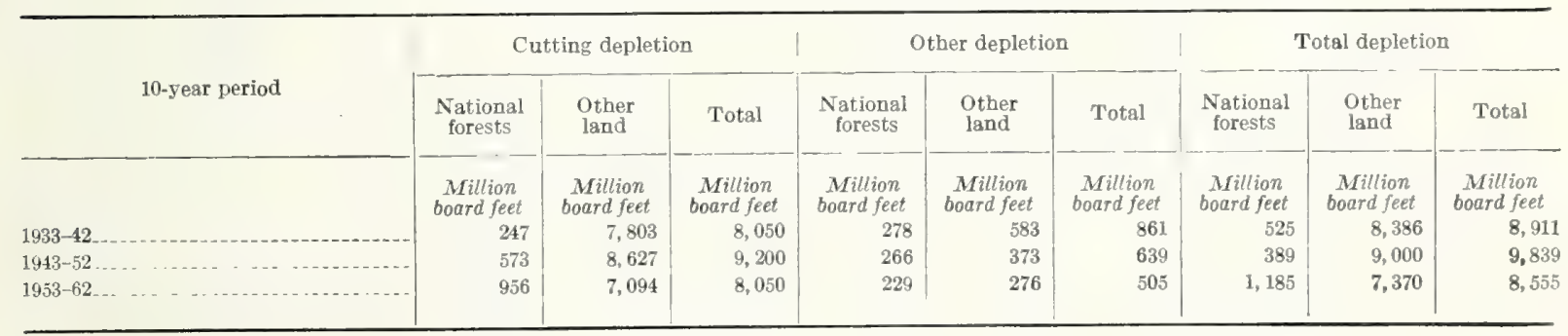


TABIE 57.-Cutrent annual growth 1 in the Douglas-fir region, lumber-tally basis

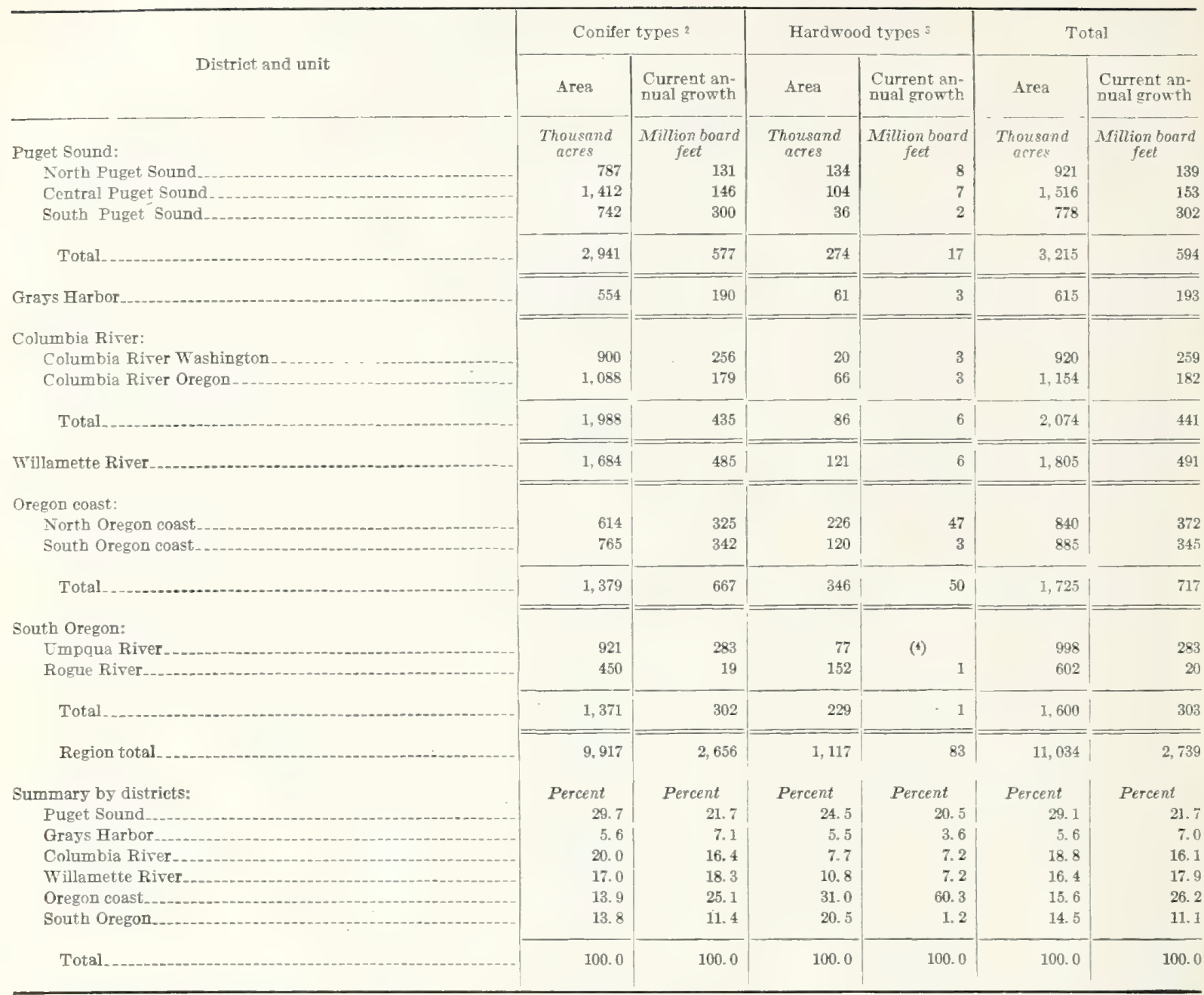

1 Growth in board feet is shown for all conifer trees 15,1 inches $d . b$. h. or more, calculated by estimating volumes in 32 -foot logs to 12 -inch top, by Scribner rule; and for all hardwood trees 11.1 inches d. b. h. or more, calculated by estimating volumes in 8-foot logs to 10 -inch top, by Scribner rule. These values are converted to lumber tally by multiplying by 1.15 .

${ }^{2}$ Data are shown only for stands 160 years or less in age, on commercial conifer forest land.

3 Data shown are totals for hardwood timberland (type 31) and oak-madrone woodland (type 4). Data for north Oregon coast include 182,060 acres of potential conifer forest land temporarily occupied by hardwoods, and those for south Oregon coast include 14,520 acres of such land.

t Less than one-half million board feet. 
TABLE 58.-Potential annual conifer growth ${ }^{1}$ of trees $15.1+$ inches d. b. h. in the Douglas-fir region, lumber-tally basis

\begin{tabular}{|c|c|c|c|c|c|}
\hline Unit & $\begin{array}{l}\text { Annual } \\
\text { growth }\end{array}$ & Unit & $\begin{array}{l}\text { Annual } \\
\text { growth }\end{array}$ & District & $\begin{array}{l}\text { Distribu- } \\
\text { tion of } \\
\text { regional } \\
\text { growth }\end{array}$ \\
\hline $\begin{array}{l}\text { Puget Sound: } \\
\text { North Puget Sound } \\
\text { Central Puget Sound } \\
\text { South Puget Sound } \\
\text { Total ... } \\
\text { Grays Harbor ... } \\
\text { Columbia River: } \\
\text { Columbia River, Wash. } \\
\text { Columbia River, Oreg. } \\
\text { Total................. }\end{array}$ & $\begin{array}{r}\begin{array}{r}\text { Million } \\
\text { board feet } \\
700 \\
1,164 \\
750\end{array} \\
2,614 \\
1,073 \\
695 \\
842 \\
1,537\end{array}$ & $\begin{array}{l}\text { Willamette River. } \\
\text { Oregon coast: } \\
\text { North Oregon coast }{ }^{2} \\
\text { South Oregon coast } \\
\quad \text { Total } \\
\text { South Oregon: } \\
\text { Umpqua River } \\
\text { Rogue River }{ }^{4} \\
\quad \text { Total } \\
\text { Region total }\end{array}$ & $\begin{array}{r}\begin{array}{c}\text { Million } \\
\text { board feet } \\
1,423\end{array} \\
\\
\\
741 \\
852 \\
1,593 \\
\\
6 \\
694 \\
547 \\
1.241\end{array}$ & $\begin{array}{l}\text { Puget Sound } \\
\text { Grays Harbor } \\
\text { Columbia River } \\
\text { Willamette Rirer } \\
\text { Oregon coast } \\
\text { South Oregon } \\
\quad \text { Total }\end{array}$ & $\begin{array}{r}\text { Percent } \\
27.6 \\
11.3 \\
16.2 \\
15.0 \\
16.8 \\
13.1 \\
100.0\end{array}$ \\
\hline
\end{tabular}

1 On commercial conifer forest land. Calculated at annual growth rates given in table 55, and converted to lumber tally by multiplying by 1.15.

2 Data include grow th on 182,060 acres of potential conifer forest land temporarily occupied by hardwoods (type 31 ).

¿ Data include growth on 14,520 acres of potential conifer forest land temporarily occupied by hardwoods (type 31 ).

4 Data exclude growth on 6,510 acres of pine woodland (type 51/2) considered noncommercial forest land. 
TABLE 59.-Realizable mean annual conifer growth ${ }^{1}$ of trees $15.1+$ inches $d . b . h$. in the Douglas-fir region, 1933-62, lumber-tally basis

\begin{tabular}{|c|c|c|c|}
\hline District and unit & $1933-42$ & . $1943-52$ & $1953-62$ \\
\hline Puget Sound: & $\begin{array}{l}\text { Million } \\
\text { board feet }\end{array}$ & $\begin{array}{l}\text { Million } \\
\text { board feet }\end{array}$ & $\begin{array}{l}\text { Million } \\
\text { board.feet }\end{array}$ \\
\hline North Puget Sound & 245 & 292 & 306 \\
\hline Central Puget Sound. & 356 & 461 & 499 \\
\hline South Puget Sound & 361 & 435 & 471 \\
\hline Total & 962 & 1. 188 & 1,276 \\
\hline Grays Harbor... & 300 & 395 & 433 \\
\hline Columhia River: & & & \\
\hline Columbia River, Washington & 378 & 437 & 453 \\
\hline Columbia Rirer, Oregon & 396 & 481 & 498 \\
\hline Total_-. & 774 & 918 & 951 \\
\hline Willamette Rìver.-...... & 642 & 705 & 739 \\
\hline Oregon coast: & & & \\
\hline North Oregon cosst ${ }^{2}$ & 363 & 425 & 435 \\
\hline South Oregon coast ${ }^{3}$... & 394 & 434 & 455 \\
\hline Total & 757 & 859 & 890 \\
\hline South Oregon: & & & \\
\hline Umpqua River & 276 & 285 & 288 \\
\hline Rogue River..... & 91 & 99 & 98 \\
\hline Total & 367 & 384 & 386 \\
\hline Region total & 3,802 & 4,449 & 4,675 \\
\hline Summary by districts: & Percent & Percent & Percent \\
\hline Puget Sound & 25.3 & 26.7 & 27.3 \\
\hline Grays Harbor & 7.9 & 8.9 & 9.3 \\
\hline Columbia River & 20.4 & 20.6 & 20.3 \\
\hline Willamette River..... & 16.9 & 15.9 & 15.8 \\
\hline Oregon coast & 19.9 & 19.3 & 19.0 \\
\hline South Oregon & 9.6 & 8.6 & 8. 3 \\
\hline Total $\ldots$ & 100.0 & 100.0 & 100.0 \\
\hline
\end{tabular}

1 Growth that, according to calculations described in the text, may be expected if growth and depletion trends indicated by the survey continue through the designated period. Growth values shown were calculated by estimating rolumes in 32-foot logs to 12-inch top, by Scribner rule, and converted to lumber tally by multiplying by 1.15 .

2 Data exclude growth on 182,060 acres of potential conifer forest land temporarily oceupied by hardwoods (type 31).

3 Data exclude growth on 14,520 acres of potential conifer forest land temporarily occupied by hardwoods (type 31 ).
TABLE 60.-Periodic conifer growth 1 of trees $15.1+$ inches d. b. h. in the Douglas-fir region, 1933-62, lumber-tally basis

\begin{tabular}{|c|c|c|c|}
\hline District and unit & $1933-42$ & $1943-52$ & $1953-62$ \\
\hline $\begin{array}{l}\text { Puget Sound: } \\
\text { North Puget Sound } \\
\text { Central Puget Sound...-. } \\
\text { South Puget Sound }\end{array}$ & $\begin{array}{r}\text { Million } \\
\text { board feet } \\
1,318 \\
1,481 \\
2,865\end{array}$ & $\begin{array}{r}\text { Million } \\
\text { board feet } \\
1,488 \\
1,857 \\
2,632\end{array}$ & $\begin{array}{c}\text { Million } \\
\text { board feet } \\
1,724 \\
2,191 \\
1,991\end{array}$ \\
\hline Total & 5,664 & 5,977 & 5,906 \\
\hline Grays Harbor & 2,190 & 2,046 & 1,682 \\
\hline $\begin{array}{l}\text { Columbia River: } \\
\text { Columbia River, Washington. } \\
\text { Columhia River, Oregon }\end{array}$ & $\begin{array}{l}2,610 \\
1,803\end{array}$ & $\begin{array}{l}2,798 \\
2,393\end{array}$ & $\begin{array}{l}2,626 \\
2,854\end{array}$ \\
\hline Total & 4,413 & 5,191 & 5.480 \\
\hline Willamette River.......... & 4,849 & 5,221 & 5,519 \\
\hline $\begin{array}{l}\text { Oregon coast: } \\
\text { North Oregon coast }{ }^{2} \\
\text { South Oregon coast }{ }^{3}\end{array}$ & $\begin{array}{l}3,226 \\
3,388\end{array}$ & $\begin{array}{l}3,103 \\
3,744\end{array}$ & $\begin{array}{l}2,648 \\
3,950\end{array}$ \\
\hline Total & 6,614 & 6,847 & 6.598 \\
\hline $\begin{array}{l}\text { South Oregon: } \\
\text { Umpqua River } \\
\text { Rogue River }\end{array}$ & $\begin{array}{r}2,776 \\
221\end{array}$ & $\begin{array}{r}2,756 \\
340\end{array}$ & $\begin{array}{r}2.629 \\
531\end{array}$ \\
\hline Total & 2,997 & 3,096 & 3,160 \\
\hline Region total & 26,727 & 28,378 & 28,345 \\
\hline $\begin{array}{l}\text { Summary by districts: } \\
\text { Puget Sound } \\
\text { Grays Harbor } \\
\text { Columbia River } \\
\text { Willamette River } \\
\text { Oregon coast } \\
\text { South Oregon }\end{array}$ & $\begin{array}{r}\text { Percent } \\
21.2 \\
8.2 \\
16.5 \\
18.1 \\
24.8 \\
11.2\end{array}$ & $\begin{array}{r}\text { Percent } \\
21.1 \\
7.2 \\
18.3 \\
18.4 \\
24.1 \\
10.9\end{array}$ & $\begin{array}{r}\text { Percent } \\
20.9 \\
5.9 \\
19.3 \\
19.5 \\
23.3 \\
11.1\end{array}$ \\
\hline Total & 100.0 & 100.0 & 100.0 \\
\hline
\end{tabular}

1. Data are shown only for stands 160 years or less in age, on commercial conifer forest land. Calculated by estimating volumes in 32 -foot logs to 12-inch top, by Scribner rule, and converted to lumber tally by multiplying by 1.15 .

${ }^{2}$ Data exclude growth on 182,060 acres of potential conifer forest land temporarily occupied by hardwoods.

${ }^{3}$ Data exclude growth on 14,520 acres of potential conifer forest land temporarily occupied by hardwoods. 


\section{ORGANIZATION OF THE UNITED STATES DEPARTMENT OF AGRICULTURE WHEN THIS PUbliCATION WAS LAST PRINTED}

Secretary of Agriculture.

L'nder Secretary.

Assistant Secretary.

Director of Information.

Director of Extension Work

Director of Finance.

Director of Personnel.

Director of Research.

Director of Marketing

Solicitor.

Land Use Coordinator

Office of Plant and Operations.

Office of C.C.C. Activities.

Office of Experiment Stations.

Office of Foreign Agricultural Relations.

Agricultural Adjustment Administration.

Bureau of Agricultural Chemistry and Engineering

Bureau of Agricultural Economics.

Agricultural Marketing Service.

Bureau of Animal Industry.

Commodity Credit Corporation.

Commodity Exchange Administration.

Bureau of Dairy Industry.

Bureau of Entomology and Plant Quarantine.

Farm Credit Administration.

Farm Security Administration.

Federal Crop Insurance Corporation.

Forest Service.

Bureau of Home Economics.

Library.

Bureau of Plant Industry.

Rural Electrification Administration

Soil Conservation Service.

Surplus Marketing Administration.

This publication is a contribution from

Forest Service

Research Divisions.

Division of Forest Economics

$$
\text { Forest Survey. }
$$

Pacific Northwest Forest and Range Experiment Station.
Claude R. Wickard.

paul H. Appleby.

Grover B. Hill.

M. S. Eisenhower.

M. L. WILSON.

W. A. JUMP

ROY F. HENDRICKSON.

JAMES T. JARDine.

Milo R. Perkins.

Mastin G. White.

M. S. EISENHOWER.

Arthur B. Thatcher, Chief.

Fred W. Morrell, Chief.

James T. JARdine, Chief.

Leslie A. Wheeler, Director.

R. M. Evans, Administrator.

Henry G. Knight, Chief.

H. R. Tolley, Chief.

C. W. Kitchen, Chief.

John R. Mohler, Chief.

Carl B. Robins, President.

Josfph M. Mehl, Chief.

O. E. REed, Chief.

Lee A. Strong, Chief.

A. G. BlACK, Governor.

C. B. BALdwin, Administrator.

Leroy K. Smith, Manager.

Earle H. Clapp, Acting Chief.

Louise Stanley, Chief.

Cilaribel R. Barnett, Libratian.

E. C. Auchter, Chief.

Harry Slattery, Administrator.

H. H. Bennett, Chief.

Milo R. Perkins, Administrator.

Earle H. Clapp, Acting Chief.

C. L. Forsling, Assistant Forester, In Charge.

R. E. MARSH, Acting in Charge.

R. D. Garver, Director.

S. N. WyскоғF, Director. 


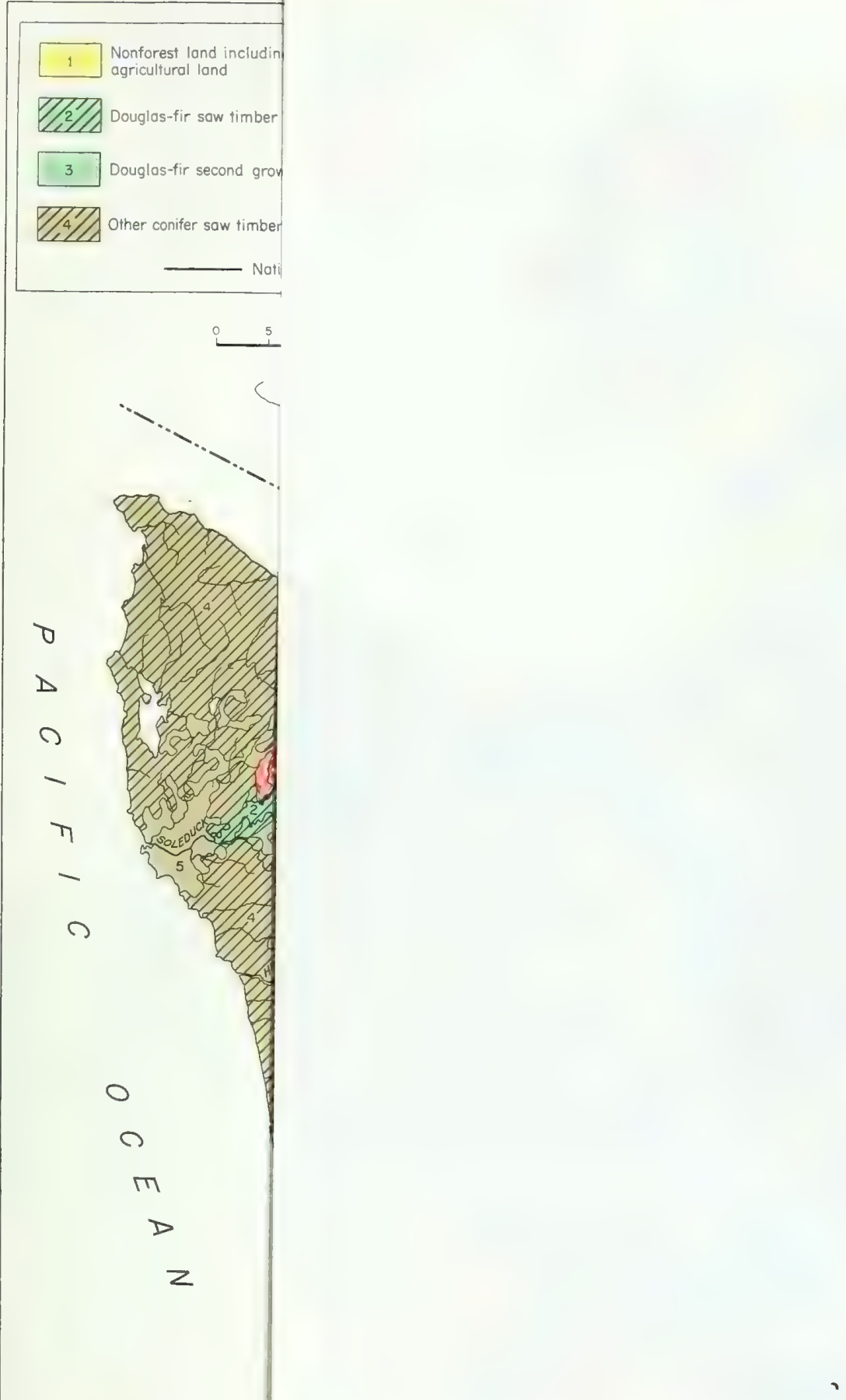





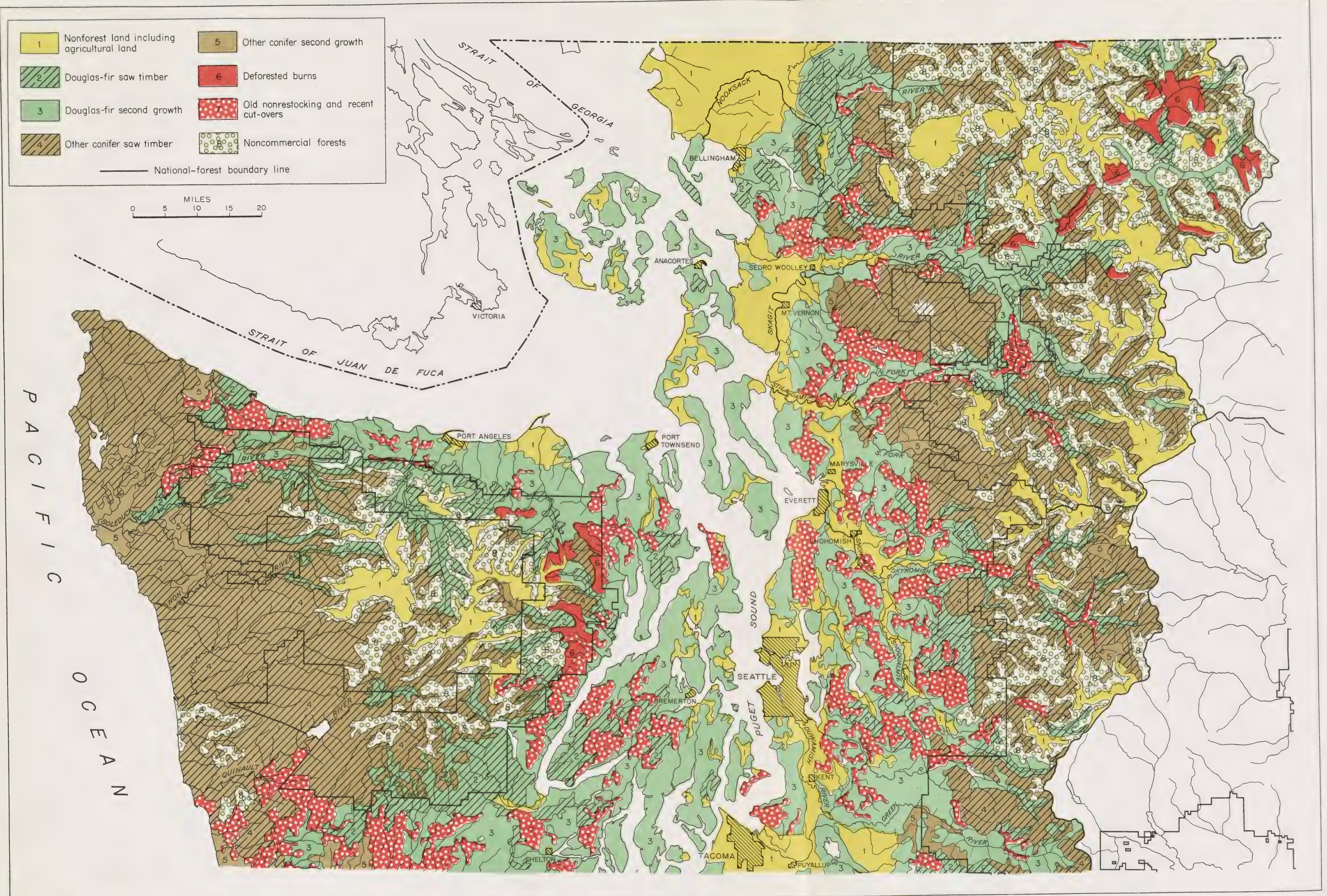

NORTHWESTERN WASHINGTON - FOREST TYPES OF THE DOUGLAS-FIR REGION 
() 


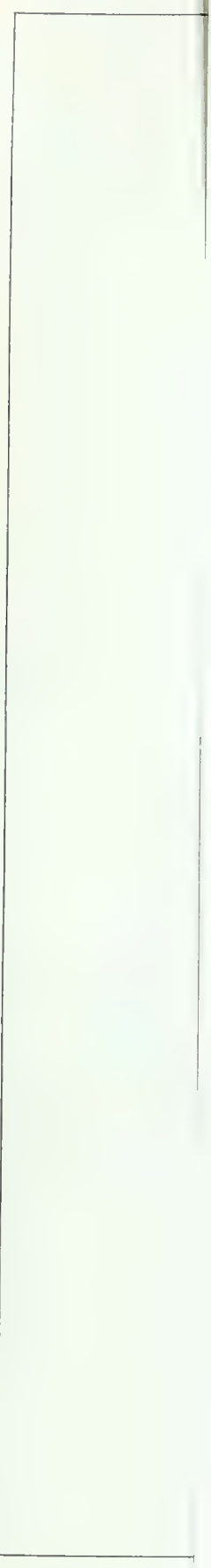




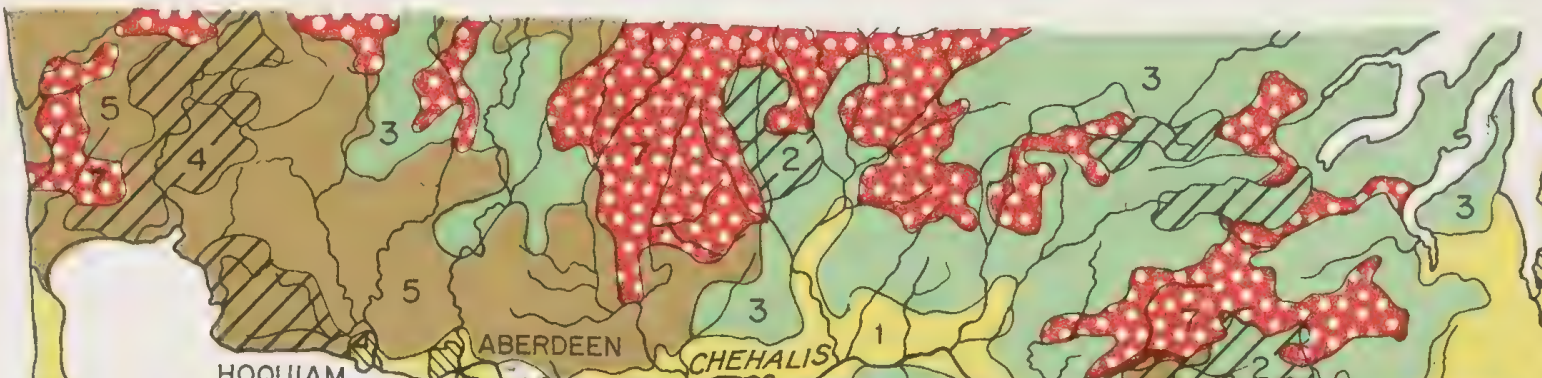

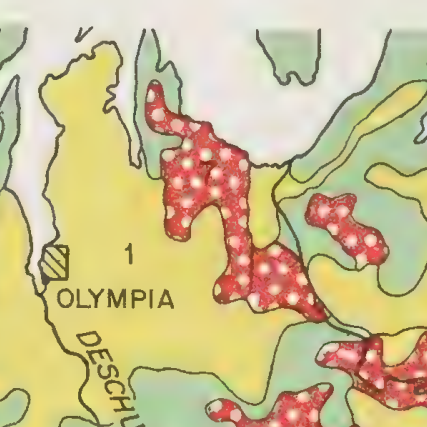

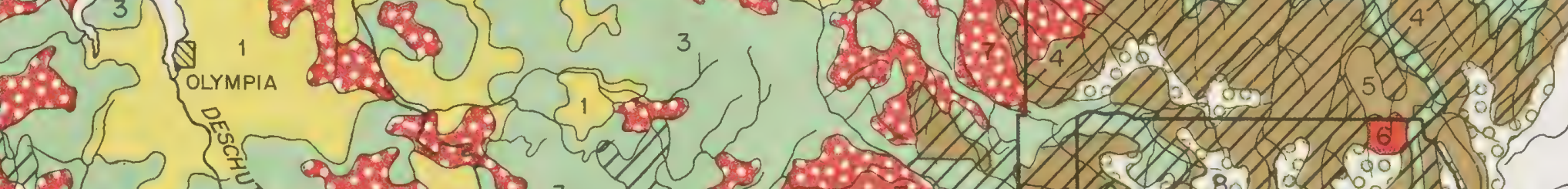

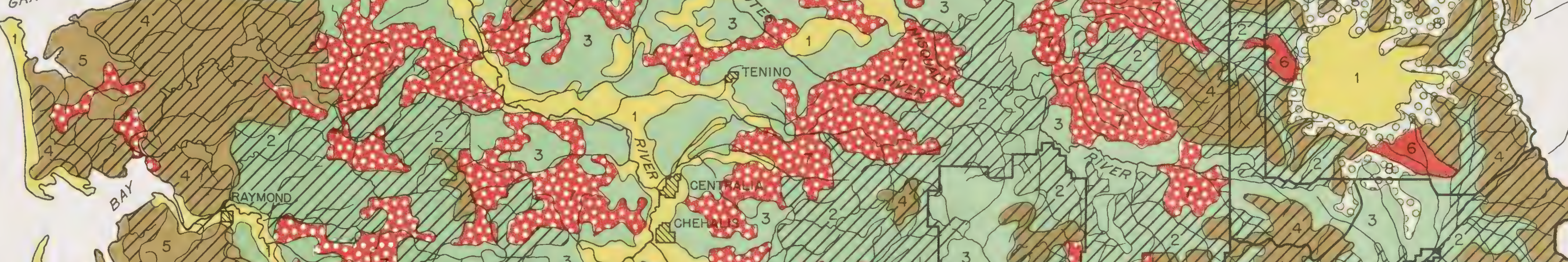

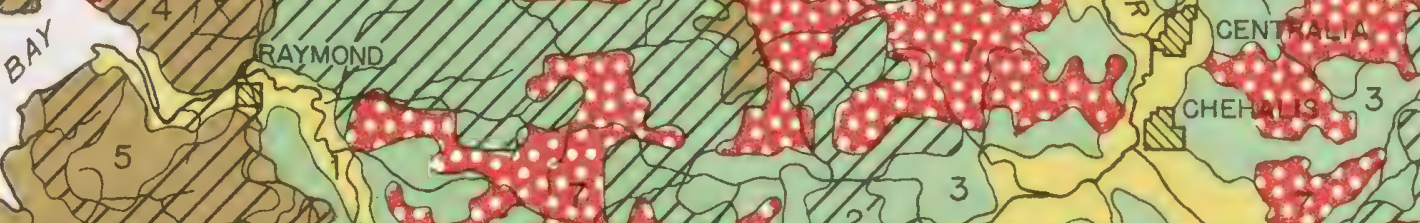

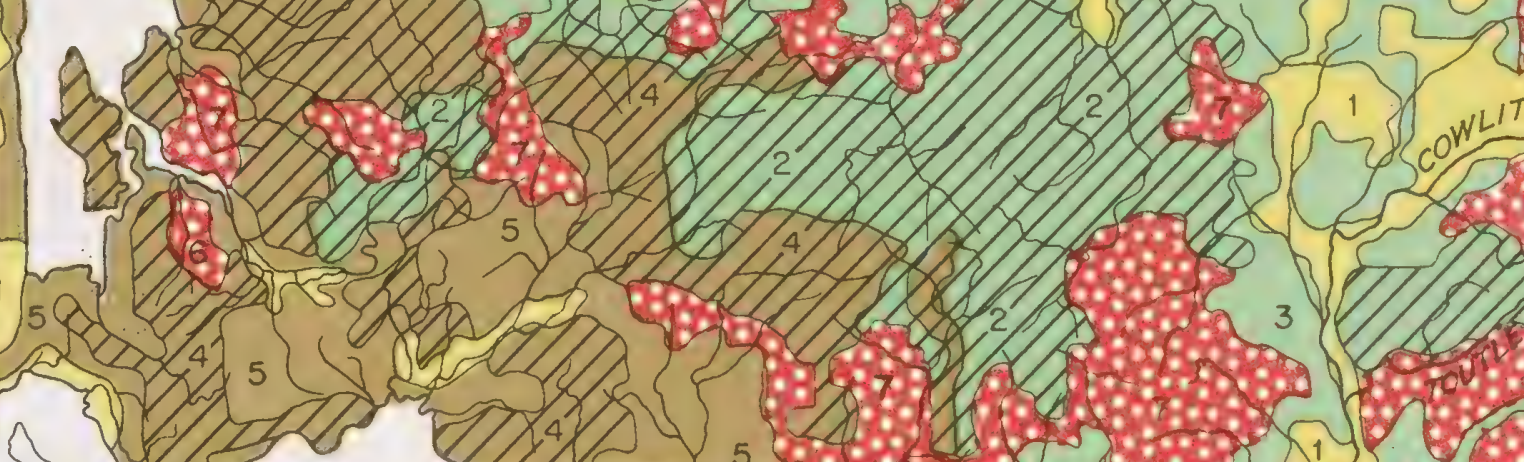

\begin{tabular}{l}
\hline 1 Nonforest land including \\
agricultural land
\end{tabular}

$\frac{1}{3}$

7.

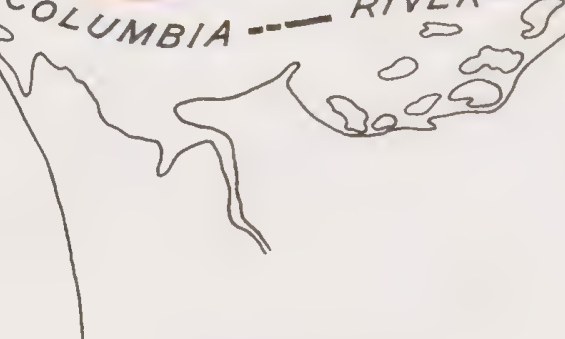

$5 \begin{aligned} & \text { MILES } \\ & 10\end{aligned}$

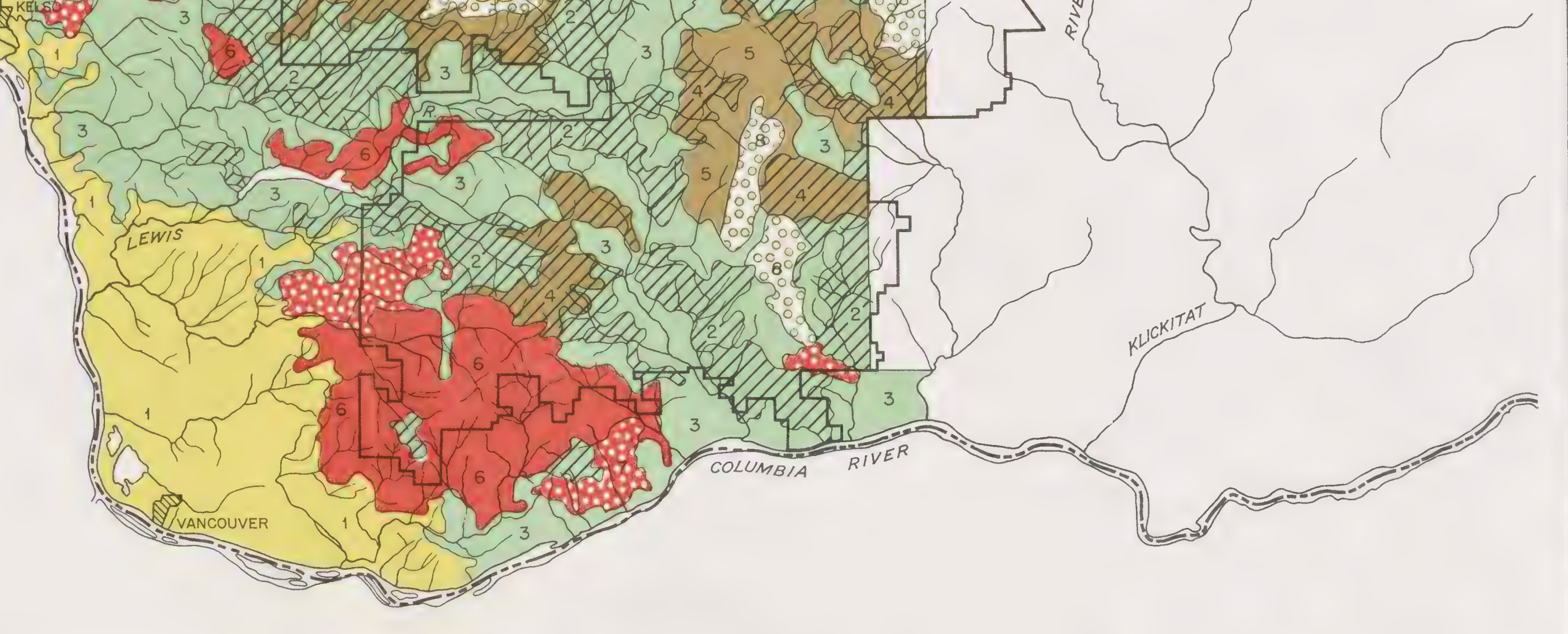

SOUTHWESTERN WASHINGTON - FOREST TYPES OF THE DOUGLAS-FIR REGION 
I 


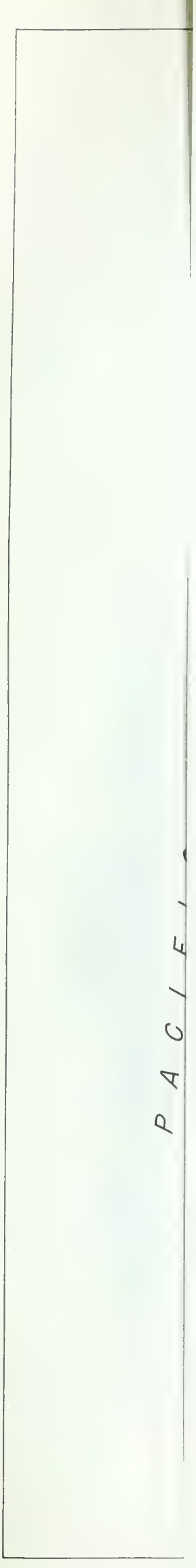





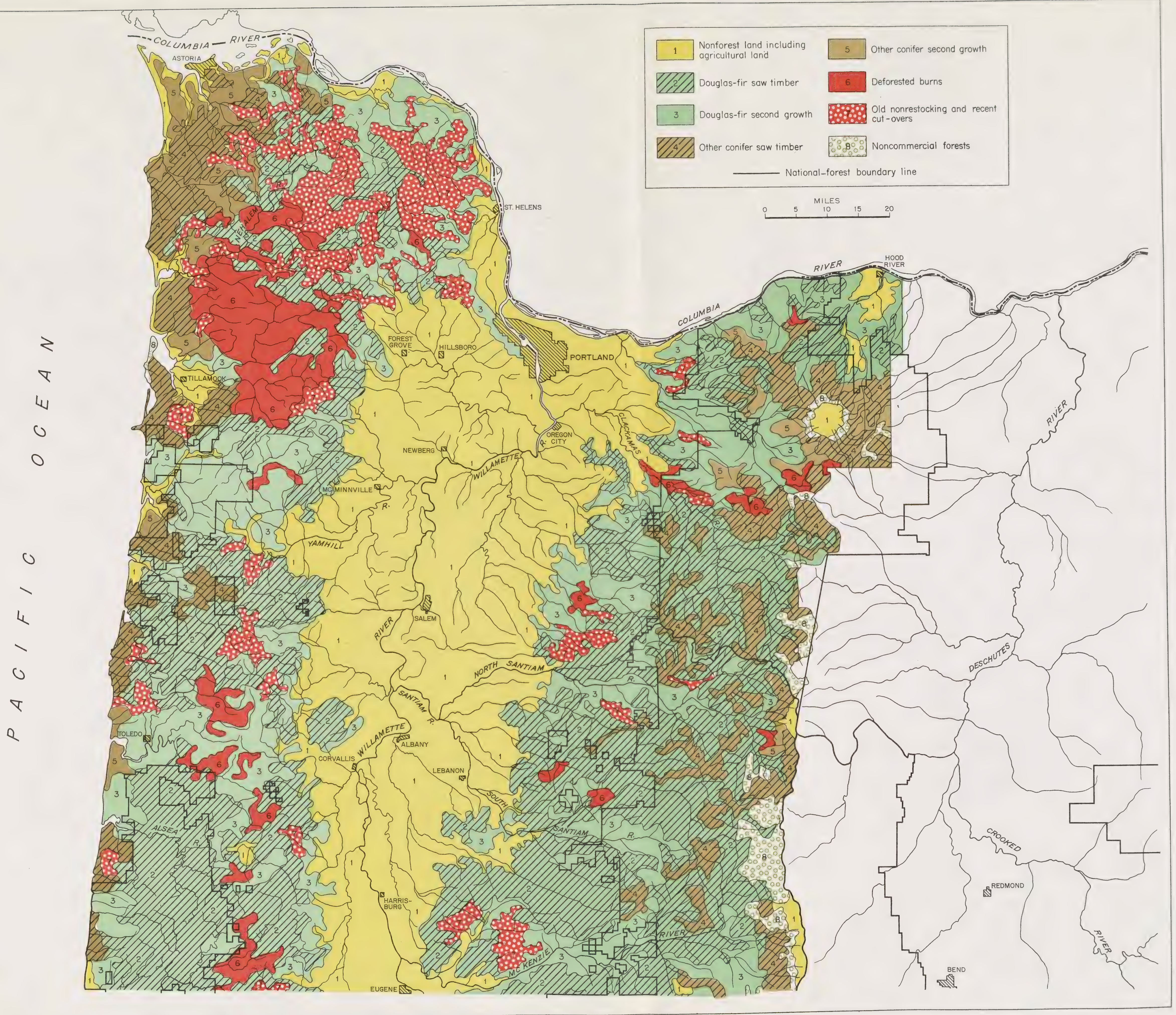

NORTHWESTERN OREGON - FOREST TYPES OF THE DOUGLAS-FIR REGION 




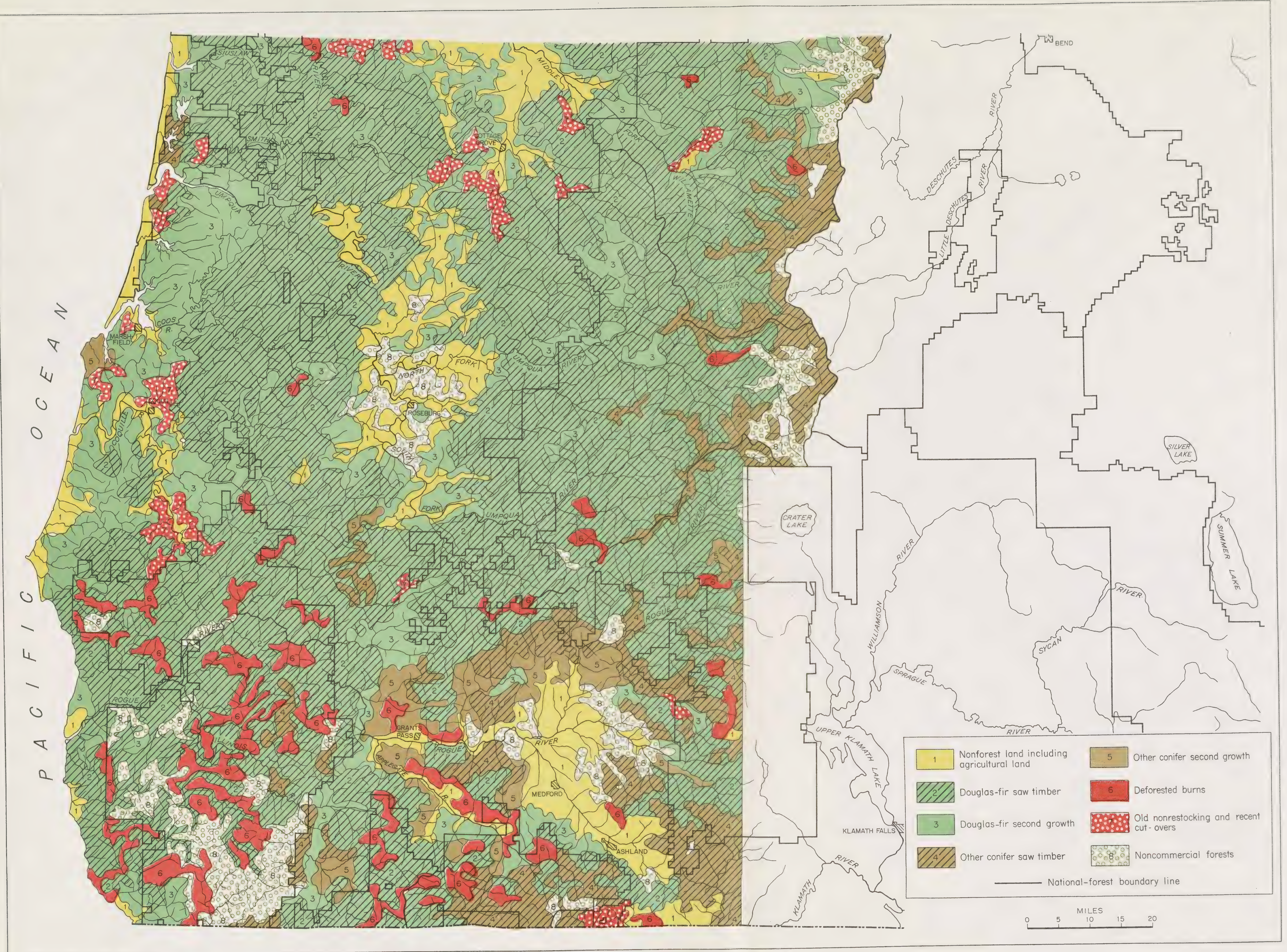


(n) 

$\checkmark$ 
